UNIVERSIDADE DE SÃO PAULO

FACULDADE DE FILOSOFIA, LETRAS E CIÉNCIAS HUMANAS DEPARTAMENTO DE HISTÓRIA

\title{
ALA VERMELHA: REVOLUÇÃO, AUTOCRÍTICA E REPRESSÃO JUDICIAL NO ESTADO DE SÃO PAULO (1967-1974)
}

Tadeu Antonio Dix Silva 


\section{UNIVERSIDADE DE SÃO PAULO \\ FACULDADE DE FILOSOFIA, LETRAS E CIÊNCIAS HUMANAS DEPARTAMENTO DE HISTÓRIA}

\section{ALA VERMELHA: REVOLUÇÃO, AUTOCRÍTICA E REPRESSÃO JUDICIAL NO ESTADO DE SÃO PAULO (1967-1974)}

Tadeu Antonio Dix Silva

Tese apresentada ao Programa de Pós-Graduação em História Social, do Departamento de História da Faculdade de Filosofia, Letras e Ciências Humanas da Universidade de São Paulo, para obtenção do título de Doutor em História Social.

Orientadora: Prof ${ }^{\mathrm{a}}$. Dra ${ }^{\mathrm{a}}$. Maria Aparecida de Aquino 
Dedico esta tese àqueles que fizeram parte da história da Ala Vermelha. 


\section{Agradecimentos}

Essa tese teve a valiosa colaboração de muitas pessoas. Tive a satisfação de trabalhar sob a orientação da Professora Maria Aparecida de Aquino. A ela sou grato pela solidária dedicação durante a orientação. Em momentos de incerteza a sua atuação foi decisiva, ao mostrar compreensão e confiança não só no meu trabalho, como também em minha capacidade de superar os problemas.

Aos colegas do Departamento de História da FFLCH/SP.

Aos Professores Andrei Koerner e Sérgio Salomão Shecaira, agradeço pela sua generosidade. Sempre que necessitei, pude contar com suas prestimosas ajuda.

Ao Walter Cruz Swensson Jr. e Marco Aurélio Vannucchi L. de Mattos, que tive a sorte de tê-los como colegas e pela felicidade por nossa amizade.

Àqueles que através de seus depoimentos possibilitaram a reconstrução da história da Ala Vermelha: Alípio Raimundo Viana Freire, Derly José de Carvalho, Delmar Mattes, Élio Cabral de Souza, Felipe José Lindoso, Gerôncio Albuquerque Rocha, Renato Carvalho Tapajós, Vicente Eduardo Gómez Roig e Tarzan de Castro.

Ao Alberto Silva Franco com quem tenho o privilégio de conviver.

Ao Daniel Aarão Reis Filho pela sua boa vontade em atender aos meus telefonemas e sanar as minhas dúvidas.

Aos amigos que participaram da faceta emocional desta história: Maria Clara Veronesi de Toledo, José Rafael Carpentieri, Alexandre Dantas, Marcos Antonio de Lima, Rosinei Costa Papi Dei Agnoli, Juliano Zappia, Irinéia Ardissom da Silveira Souza, Elaine de Alvarenga Rocha e Gimene Franco.

Aos funcionários do Arquivo Edgar Leuenroth da Universidade Estadual de Campinas por prontamente facilitarem as inúmeras pesquisas realizadas nos processos do "Brasil: Nunca Mais".

Ao Johemir Jannotti Viégas do Arquivo Público do Estado do Rio de Janeiro por sua gentileza em facilitar o acesso ao material de pesquisa.

Fora do mundo acadêmico, agradeço aos amigos e parentes que participaram dessa jornada. 


\section{RESUMO}

O presente trabalho pretende narrar a história da Ala Vermelha, organização que surgiu como dissidência do Partido Comunista do Brasil (PC do B) e se transformou em partido autônomo em 1966, momento em que se inseriu nas lutas sociais brasileiras, chegando, inclusive, a realizar ações armadas de expropriação de fundos e de propaganda revolucionária entre 1968 e 1971. A Ala Vermelha apresenta um aspecto singular, que viria a distingui-la dos demais grupos guerrilheiros que atuavam naquela época no Brasil. $\mathrm{Na}$ plenitude do processo de luta armada, esta organização iniciou um procedimento autocrítico com relação à própria luta armada, procedimento este que se iniciou em 1969 para culminar em 1974, quando avaliou seu equívoco ao optar pelas ações armadas de forma imediata.

PALAVRAS-CHAVE: ALA VERMELHA — LUTA ARMADA — REPRESSÃO — GOLPE DE 64 - AUTOCRÍTICA

\section{ABSTRACT}

The purpose of this work is to tell the story of the Red Wing, an organization that appeared originally as a dissidence inside the Brazilian Communist Party (PC do B) and became an autonomous party in 1966. From 1968 to 1971, it became actively involved in the Brazilian social struggle and even carried out armed actions to expropriate funds and disseminate revolutionary propaganda. The Red Wing had an unique trait that would distinguish it from other guerrilla groups operating at that time: in the heat of the armed struggle, this organization set off a self-criticism procedure focused on the very fight it was engaged on. This procedure was started in 1969 and culminated in 1974, when the organization concluded that its option for immediate armed reaction had been a mistake.

KEYWORDS: RED WING - ARMED STRUGGLE - REPRESSION - 1964 COUP - SELF-CRITICISM 


\section{SUMÁRIO}

INTRODUÇÃO.

I. PRELÚDIO DA ALA VERMELHA. .26

II. CONTRA PONTO. .76

2.1 Os Atingidos. 134

2.2 Indiciados - Resultados Obtidos. 137

2.3 Denunciados - Resultados Obtidos 144

III. CODA (Autocrítica) .155

CONSIDERAÇÕES FINAIS. .258

REFERÊNCIAS BIBLIOGRÁFICAS. .261 


\section{INTRODUÇÃO}

As questões controversas acerca do golpe de 1964 são as mais variadas e de diferentes matizes, que trazem inúmeras dificuldades para a sua avaliação e conseqüentemente, para elaborações interpretativas. Dificuldades estas que são sobrelevadas se considerarmos que ainda persistem ecos das versões legitimadoras propagadas pelos — direta ou indiretamente - envolvidos com o próprio "Putsch".

A problematização que tais questões encerra, pode ser medida pela constatação que a derrubada do presidente constitucional ocorreu quando João Goulart desfrutava de evidente popularidade: $76 \%$ dos brasileiros ${ }^{1}$ apoiavam seu governo. Tal fato, por si, vem a contrapor-se às difundidas versões do esgotamento de Jango frente à população, face à "desordem" e "caos" reinantes no país e ao "repúdio popular" a esta situação — o que teria levado ao golpe, ocorrido em razão desses reclamos. Como, exemplificativamente, nas palavras de Abreu Sodré:

“Após o plebiscito instala-se um clima de agitação permanente (...) Desordens, passeatas, quebra-quebras, bandeiras vermelhas com a foice e o martelo compõem o espetáculo diário dos fins de tarde em todo o país. $O$ agravamento da crise encarregou-se de criar o clima propício à reação popular.(...) Nesse momento, os democratas sentiram que era chegada a hora de mobilização civil (...) No dia 19 de março, sai em São Paulo a Marcha da Família com Deus pela Liberdade. (...) A participação popular superou todas as previsões. Foi uma das maiores manifestações de massa que o Brasil já viu. O movimento que se preparava [o golpe] deixava de ser uma mera quartelada para se tornar uma ação militar nascida do desejo das massas."2

A ruptura da ordem política institucional, em 1964, em realidade, vinha sendo gestada há vários anos, como demarca a produção histórica e político-sociológica contemporânea, convergente nesse aspecto.

\footnotetext{
${ }^{1}$ Pesquisa do IBOPE, realizada entre junho e julho de 1963, apud BANDEIRA, Luiz A. Moniz. O Governo João Goulart. As lutas sociais no Brasil, 1961-1964. Brasília: UnB, 2001, p. 185.

${ }^{2}$ SODRÉ, Roberto de Abreu. No Espelho do Tempo. Meio Século de Política. São Paulo: Best Seller, 1995, p. 121.
} 
No entanto, esses estudos são desarmônicos quando se trata de explicitar as razões que conduziram à deposição do presidente João Goulart, assim como divergem quando da análise do modelo de Estado então implementado.

Privilegiar-se-á aqui a aproximação das análises que dizem respeito ao caráter estatal implantado no Brasil pelo Golpe de 64, por uma questão metodológica, uma vez que lideremos em nosso trabalho com uma determinada acepção para referenciar a natureza do regime instaurado no país por aquele coup d'État. ${ }^{3}$ Numa breve síntese desses escritos iremos indicar os pontos que são mais realçados pelas análises interpretativas que dizem respeito ao caráter estatal.

Uma prática bastante usual é a de denominar o Estado brasileiro após o Golpe de 64 como regime militar ${ }^{4}$, ditadura ${ }^{5}$ ou ambos os termos indiscriminadamente ${ }^{6}$, sem se debruçar sobre o conteúdo e alcance destes vocábulos, como se seu significado bastasse por si mesmo para justificar seu emprego.

A análise de três posturas fundamentais que passamos a examinar, propiciará a determinação da apropriada noção conceitual que se valerá neste trabalho para referir-se ao Estado instaurado no Brasil a partir de 1964.

Guilhermo O’Donnell trabalha com uma análise comparativa que agrupa diversos países nos quais se deu a Estados Autoritários em circunstâncias semelhantes, especialmente na América Latina entre 1960 e 1970. O autor desenvolveu como modelo analítico a família dos regimes autoritários-burocráticos ${ }^{7}$.

David Collier ${ }^{8}$ tece considerações sobre a importância do trabalho de O’Donnel, salientando seus aspectos mais importantes. Aponta para a filiação do modelo às análises do capitalismo dependente, desenvolvido em regiões periféricas do sistema capitalista e que vinculam a emergência de regimes autoritários nessas regiões devido às tensões geradas pela modernização capitalista dependente. Esta traria o colapso ao padrão anterior

\footnotetext{
${ }^{3}$ Para um aprofundado exame das diversas teorias interpretativas das razões que motivaram o Golpe de 64 , ver DELGADO, Lucília de Almeida Neves, 1964: temporalidade e interpretações. Em: REIS, Daniel Aarão; RIDENTI, Marcelo; MOTTA, Rodrigo Patto Sá. (org.). O golpe e a ditadura militar: quarenta anos depois(1964-2004). Bauru, Edusc, 2004, p. 15-28.

${ }^{4}$ Cf., p.ex., a obra de: MATTOS, Marco Aurélio Vannucchi L. de.; SWENSSON JR., Walter Cruz. Contra os inimigos da ordem: a repressão política do regime militar brasileiro (1964-1985). Rio de Janeiro: DP\&A, 2003.

${ }^{5}$ Nesse sentido, exemplificativamente o escrito de: REIS, Daniel Aarão. Ditadura militar, esquerdas e sociedade. Rio de Janeiro: Jorge Zahar, 2000.

${ }^{6}$ Ver, p.ex., o trabalho de: FICO, Carlos. Além do golpe: a tomada do poder em 31 de março de 1964 e a ditadura militar. Rio de Janeiro: Record, 2004.

${ }^{7}$ Entre as várias obras do autor, cf. O' DONNEL, Guillermo. Análise do Autoritarismo Burocrático. Rio de Janeiro: Paz e Terra, 1990.

${ }^{8}$ COLLIER, David. Resumo do Modelo Autoritário-Burocrático. Em: COLLIER, David (org.). Análise do autoritarismo burocrático. Rio de Janeiro: Paz e Terra, 1982, p. 27-39.
} 
de política populista que promovia a participação da classe trabalhadora e da classe média inferior na coalizão da política nacional dominante constituindo-se em importantes beneficiários da política pública. Os governos autoritários que emergem, afastam o setor popular da arena política, impõem uma diminuição de renda para o mesmo na busca de resoluções dessas tensões. O enfoque de O’Donnel ficaria então localizado na mesma dimensão da literatura populista/pós-populista.

Para David Collier, tanto o Brasil (1964) como a Argentina (1966),

"foram governados pelos militares como instituição, em vez de exclusivamente por governantes militares individuais. Além disso, os militares pareceram adotar um enfoque tecnocrático e burocrático na formulação política (ao contrário de um enfoque mais 'político’através do qual as políticas são modeladas pelas exigências econômicas e políticas dos diferentes setores da sociedade, expressas através de canais como eleições, legislaturas, partidos políticos e sindicatos trabalhistas). Este enfoque da formulação política destes regimes levou os estudiosos a juntarem o adjetivo 'burocrático'ao termo 'autoritário' e a chamar estes sistemas de 'autoritário-burocráticos'. 9

Preocupado com a incorporação ou exclusão do setor popular, O'Donnel estabelece três tipos de regime: Oligárquico, Populista e Autoritário-Burocrático. Este se caracteriza pela exclusão do setor popular, pelo caráter não democrático e pelo domínio da coalizão da política de tecnocratas de alto nível (militares e civis) em associação íntima com o capital estrangeiro. Esta elite preocupa-se em promover a industrialização avançada (do setor de bens intermediários e de capital) vista como solução para os problemas de dívida externa e inflação que acredita terem sido gerados pela necessidade de importação desses bens. Esse processo de industrialização se faz com a filiação a corporações multinacionais e associação a agências internacionais de empréstimos. Estes dois elos de ligação trazem como exigência a adoção de medidas econômicas mais ortodoxas que, segundo sua concepção, criam condições de estabilidade econômica. Na dependência da ativação do setor popular, mais ou menos forte, e do grau de aceitação dos empresários nacionais em relação à desnacionalização da economia, reside o sucesso, duração, estabilidade desses regimes.

\footnotetext{
${ }^{9}$ COLLIER, David. Introdução, op. cit., p 12-13.
} 
Guardadas as devidas proporções, estas três análises que representam, cada qual a seu modo, grandes contribuições para o estudo do período, possuem pontos de contato e, especificamente, originam-se de uma mesma raiz. Para tecer considerações acerca do Estado inaugurado em 1964, privilegiam o estado das forças produtivas no momento em que se desencadeou o golpe, em sua relação com o grau de participação/satisfação das necessidades conferido a amplos setores da população (notadamente, as classes trabalhadoras de extração urbana e as vinculadas a setores industriais). Além disso, priorizam a inserção do Brasil no chamado Sistema Capitalista internacional, filiando-se às análises do chamado "capitalismo dependente" que distribui as nações vinculadas ao Sistema em “centrais"e "periféricas e pensa as questões internas aos países "periféricos”à luz de sua relação de dependência com os países "centrais".

Grosso modo, essas análises se originam do pensamento cepalino ${ }^{10}$ que, segundo José Luís Fiori ${ }^{11}$, "privilegiando os fatores externos - como explicadores em 'última instância' - e centrando sua análise na composição, da demanda, fez do político e do Estado meros epifenômenos, quando não 'instrumentos'para a realização dos desígnios estruturais definidos pelas alterações na balança de pagamentos”. Segundo o mesmo autor, esses estudos sobre a dependência retomam a teoria do imperialismo numa releitura em continuidade com a visão definida em 1920 pela III Internacional.

As construções efetuadas por Maria Helena Moreira Alves mostram um novo tipo de entendimento sobre o Estado brasileiro pós-golpe de 64: trata-se do Estado de Segurança Nacional.

A partir da Doutrina de Segurança Nacional e Desenvolvimento (DSND) que foi implementada no entre nós, Alves vem salientar que:

"a tomada do poder de Estado [no Brasil] foi precedida de uma bem orquestrada
política de desestabilização que envolveu corporações multinacionais, o capital
brasileiro associado-dependente, o governo dos Estados Unidos e militares

${ }^{10}$ A Comissão Econômica para a América Latina (CEPAL) foi criada no México em 1951 objetivando a criação de uma política de oposição à Organização dos Estados Americanos (OEA). Por voto e pressão do Brasil, Chile e México, criou-se a CEPAL, organismo voltado para a defesa dos interesses latino-americanos com o objetivo de buscar alternativas para a região no sentido de eliminar a dependência. $\mathrm{O}$ caminho apontado, ao longo dos anos 50, foi o da industrialização, como forma de superar o subdesenvolvimento.

${ }^{11}$ FIORI, José Luis. Para uma crítica da teoria latino-americana de Estado. (I e II). MG, Síntese (nova fase), 50 (XVII): 55-72 e 51 (XVII): 79-103, jul-set e out-dez/1990. 
brasileiros - em especial um grupo de oficiais da Escola Superior de Guerra $(E S G),{ }^{12}$

Estes últimos foram os grandes defensores da DSND, que era utilizada para justificar a imposição de "um sistema de controles e dominação", e efetivamente prevê que o Estado conquistará "certo grau de legitimidade" mercê ao constante desenvolvimento capitalista e seu desempenho como defensor da nação contra "a ameaça dos inimigos internos' e da 'guerra psicológica'." Deste modo, a legitimação do Estado seria dada pelos conceitos de desenvolvimento econômico e segurança interna. ${ }^{13}$

A ênfase que é dada pela DSND à constante ameaça à nação que seria feita por parte dos inimigos internos, produziria entre a população, um clima de "suspeita; o medo (...) permite ao regime levar a cabo campanhas repressivas que de outro modo não seriam toleradas." Por isso, adverte Alves, trata-se de uma "ideologia de dominação de classe, que tem servido para justificar as mais violentas formas de repressão classista." 14

A autora sustenta que

"a natureza do Estado de Segurança Nacional só pode ser avaliada em relação ao processo dinâmico de sua interação com as formas e estruturas dos movimentos de oposição gerados na sociedade civil. Tanto as estruturas do Estado quanto as formas de oposição vão-se permanentemente transformando à mercê das tentativas de cada parte de controlar, conter ou modificar a outra. O relacionamento mútuo é portanto essencialmente dialético." 15

Finalmente, diz Alves que a permanente necessidade de "alterar ou reconstruir as estruturas de coerção" ${ }^{\prime 16}$ do Estado, deram origem a quatro contradições que se tornaram uma característica do Estado de Segurança Nacional. São elas: ${ }^{17}$

1) A tendência a perder o controle do crescimento burocrático, especialmente do aparato repressivo.

\footnotetext{
${ }^{12}$ ALVES, Maria Helena Moreira. Estado e Oposição no Brasil (1964-1984). Petrópolis: Vozes, 1989, p. 23.

${ }^{13}$ ALVES, M. H. M., op. cit., p. 26.

${ }^{14}$ ALVES, M. H. M., op. cit., p. 26.

${ }^{15}$ ALVES, M. H. M., op. cit., p. 27.

${ }^{16}$ ALVES, M. H. M., op. cit., p. 28.

${ }^{17}$ Para o que se segue, cf. ALVES, M. H. M., op. cit., p. 28-29.
} 
2) O Estado de Segurança Nacional é incapaz de eliminar completamente a oposição, e assim, cada campanha repressiva leva o embate até setores ainda não envolvidos, em protesto contra o uso da força.

3) A tentativa de eliminar a oposição pela força ignora as injustiças reais que estão na raiz do conflito.

4) Por esta última razão, o Estado de Segurança Nacional é intrinsecamente instável, tendendo a isolar-se cada vez mais. Em longo prazo, o Estado possui a tendência a tornar-se território exclusivo de uma pequena elite, que mantém a sociedade civil e até mesmo seus integrantes sob controle, mediante o recurso cada vez mais freqüente à força física.

Em trabalho realizado a pedido do Instituto Max-Planck, da Alemanha, Maria Aparecida Aquino ${ }^{18}$ aponta uma outra acepção a respeito do caráter do Estado implementado no Brasil após o golpe de 1964: trata-se do Estado Autoritário.

Inicialmente a autora adverte que apenas pode-se adquirir um maior teor explicativo da complexidade do regime militar inaugurado em 1964: "se atentarmos para fatores externos e internos (dentre os quais o pensamento militar é parte constitutiva) à realidade nacional, bem como o que contém de imponderável e imprevisível a experiência humana". ${ }^{19}$

Após ponderar sobre as dificuldades de definição dos regimes políticos, propõe-se a pensar em tipologias criadas pela ciência política, para entender que "a forma assumida, paulatinamente, pelo Estado brasileiro após o golpe desfechado em 1964 (...) pode ser caracterizada como um Estado Autoritário". ${ }^{20}$ Todavia, adverte, para chegar a essa concepção torna-se necessário que sejam estabelecidas as diferenças existentes entre essa conceituação e as que "tradicionalmente se utilizam para dois outros termos: Ditadura e Totalitarismo". ${ }^{21}$

Preliminarmente, a autora previne que tanto o termo Autoritarismo, como Ditadura e, mesmo, o Totalitarismo estão conceitualmente estabelecidos em oposição à Democracia,

\footnotetext{
${ }^{18}$ AQUINO, Maria Aparecida. Mudanças e permanências: ambigüidades do Estado Autoritário brasileiro pós-64. Em: Elaboração jurídico-penal do passado após mudança do sistema político em diversos países. Relatório Brasil para Instituto Max Planck para o Direito Penal estrangeiro e internacional Freiburg. São Paulo: IBCCrim, 2004, p. 21-65.

${ }^{19}$ AQUINO, M. A., op. cit., p. 29.

${ }^{20}$ AQUINO, M. A., op. cit., p. 30.

${ }^{21}$ AQUINO, M. A., op. cit., p. 30.
} 
ou dito de outra forma, "fazem parte da classe dos regimes considerados nãodemocráticos". ${ }^{22}$

Para a definição de um regime político, a expressão Totalitarismo, surge na década de 1920 e é geralmente atribuída às características do Estado Fascista italiano. Porém, a acepção é revigorada após a II Guerra Mundial, quando, comumente aparece associado aos sintomas da Guerra Fria. Segundo Aquino, isso se deve, especificamente, ao fato de que "as grandes elaborações conceituais do período"23, acostumaram-se a associá-lo, especificamente, a duas experiências-limite: a Alemanha Nazista sob o comando de Adolf Hitler e a URSS sob o comando de Josef Stalin. Desse modo, e de uma forma muito peculiar, associaram-se experiências diversas em seus objetivos e concepções, a uma única conceituação que, inegavelmente, adquire "uma negatividade da qual não mais se desvincularia" ${ }^{24}$. Esse afastamento fez com que o conceito fosse rotulado como parte da estratégia, característica da Guerra Fria, de estigmatizar o comunismo, "como se fosse, de forma indelével, essencialmente dominador, impondo sob o homem - esse o custo da igualdade - uma homogeneização que destrói o indivíduo, sob o estigma da 'classe,.,"25 A autora lembra que com o passar do tempo e, com o próprio “longo e sofrido processo de desestalinização pelo qual passou a URSS, durante décadas, essas questões foram se equacionando de forma mais equilibrada". ${ }^{26}$

A ampla multiplicidade de leituras que o Totalitarismo possibilitou, entretanto, hoje as concepções tão variadas acerca do conceito, ostentam algumas características consensuais que fazem com que o Totalitarismo venha a se distinguir de outros regimes políticos: "entende-se que, para que se instaure a 'estratégia de domínio total' sobre um

\footnotetext{
${ }^{22}$ AQUINO, M. A., op. cit., p. 30.

23 Aquino nota que "a mais elaborada, complexa e completa das teorizações acerca do conceito é a obra de imenso fôlego da pensadora alemã Hannah Arendt (Origens do Totalitarismo. São Paulo: Cia. das Letras, 1989.). Hannah Arendt começa a escrever a sua obra durante a II Guerra Mundial, sob o impacto das perseguições do nazismo e dos campos de concentração. Seu trabalho é publicado depois do término do conflito e é ele que dissemina a comparação fatal entre o terror do Nazismo e o horror do Stalinismo. Para conceber sua elaboração de uma 'novidade' do século XX contida no Totalitarismo, a autora se sustenta em dois pilares básicos, fundamentais, na sua leitura, para que essa 'estratégia de domínio total' se instaure: a ideologia e o terror. Advoga ainda, como idéia central de seu pensamento, a concepção de que a instauração do Totalitarismo destrói o que chama de condição humana: a capacidade do homem se relacionar com outros homens - a dimensão do político propriamente dita - e a capacidade do homem se reconhecer e se relacionar consigo mesmo - a dimensão da identidade e do pensamento (uma atividade central e compreendida de forma muito especial nas reflexões filosóficas de Hannah Arendt)". Cf. AQUINO, M. A., op. cit., p.30.

${ }^{24}$ AQUINO, M. A., op. cit., p. p. 31.

${ }^{25}$ AQUINO, M. A., op. cit., p. 31.

${ }^{26}$ AQUINO, M. A., op. cit., p. 32.
} 
povo é necessário um partido de 'massa' que, por sua vez, promova a penetração e mobilização na e da sociedade". ${ }^{27}$

Com relação à concepção de Ditadura, nota Aquino, "é importante que se estabeleça uma distinção entre o seu uso original que deriva da denominação do órgão criado para ser aplicado excepcionalmente na República romana e o seu uso moderno", uma vez que na República romana:

"a utilização do termo Ditadura ocorria em situações-limite, mas mesmo assim, encontrava-se, de modo rígido, restrita constitucionalmente. Em caso de grave crise interna ou em situação de guerra, o Senado romano poderia propor a sua utilização se julgasse a situação incontornável nos parâmetros da normalidade republicana cabendo aos cônsules - um ou ambos - nomearem um ditador que recebia poderes amplos, mas, mesmo assim, não ilimitados. Havia finalidade definida para a sua nomeação e temporalidade expressa de seu poder: limitado a seis meses. Do conjunto dessas peculiaridades resulta a positividade da concepção quando vista nos moldes da República romana. Era encarado não como ruptura e quebra de regras, mas como parte da normalidade, em períodos de crise e, visto como forma excepcional, mas não ilegítima, de resolução rápida de uma crise incontornável. Contribuía, desse modo, para assegurar a vigência das instituições e preservar as regras políticas definidas de organização da sociedade."28

Já nos dias atuais, a acepção de Ditadura é predominantemente negativa, pois a Ditadura moderna é uma das concepções que "se opõe à Democracia, esta, sempre entendida como forma de exercício e controle do poder 'de baixo para cima"'. A Ditadura em nossos dias é encarada como "ruptura da legalidade e das normas estabelecidas pela e para a organização da sociedade. Daí a sua negatividade inerente". ${ }^{29}$

Da mesma forma que ocorre com o Totalitarismo, a Ditadura moderna vivenciou inúmeras conceituações sobre as quais se debruçaram muitos pensadores ${ }^{30}$. Entretanto,

\footnotetext{
${ }^{27}$ AQUINO, M. A., op. cit., p. 31.

${ }^{28}$ AQUINO, M. A., op. cit., p. 32.

${ }^{29}$ AQUINO, M. A., op. cit., p. 32.

${ }^{30}$ Aquino salienta que "Gostaríamos de destacar os trabalhos de Norberto Bobbio, particularmente as explanações sobre Democrazia e dictatura na Enciclopédia Einaudi (Torino, 1955) e a sugestiva elaboração de Barrington Moore Jr. (As origens sociais da ditadura e da democracia. São Paulo: Martins Fontes, 1983). Além disso, é muito esclarecedor o verbete 'Ditadura', elaborado por Mario Stoppino, no Dicionário de Política (Bobbio, Norberto et al., Brasília, DF:Editora Universidade de Brasília. 1992), p. 368-379." Cf. AQUINO, M. A., op. cit., p. 33.
} 
também para esse conceito, na diversidade de suas acepções, existe a possibilidade de encontrar alguns consensos. Dentre eles, características que definem as Ditaduras modernas e que encerram em si uma contradição essencial. Para que ela se instaure é considerado necessário um momento histórico específico em que se encontre em ascensão a soberania popular e em que largas parcelas da população buscam adentrar, com uma participação ativa na arena política. Porém - e essa é outra de suas características - a Ditadura moderna precisa conviver com o dilema da necessidade de legitimação de seu poder, concentrado e transmitido "do alto para baixo". De maneira geral, para fazer face a essa contradição intrínseca, acreditam os teóricos, que os regimes ditatoriais, podem recorrer a dois expedientes: à figura carismática de um ditador que assemelhe representar a vontade do "povo", ou a um partido que se faça aceitar por parte significativa da sociedade.

Uma vez estabelecidas essas regras gerais da tentativa de definição dos regimes políticos, a autora passa a realizar sua conceituação do regime brasileiro pós-64 como Autoritário, advertindo que "tão complexo, amplo e diversificado quanto o Totalitarismo e a Ditadura, o Autoritarismo possui várias acepções, podendo ser usado para designar o conjunto de todos os regimes contrapostos aos considerados democráticos".

Para Aquino, o conceito de Autoritarismo não se limita por determinadas características presentes no entendimento consensual de Totalitarismo - a necessidade de um partido de "massa" responsável por uma ampla mobilização/penetração da e na sociedade - e no de Ditadura - a premência de recorrer a um ditador carismático ou a um partido que convença parcela significativa da sociedade - e consegue acolher "algumas especificidades do regime brasileiro que podem ser vistas também como suas 'ambigüidades'," 31

Lembra a autora que dos maiores formuladores do conceito de Autoritarismo é Juan $\operatorname{Linz}^{32}$, que recorre a modelos conceituais e a um esquema rígido que prevê a existência de uma tipologia para os regimes autoritários contemporâneos, distinguindo cinco formas principais e duas secundárias de suas manifestações.

\footnotetext{
${ }^{31}$ AQUINO, M. A., op. cit., p. 33.

32 Linz, Juan J. "The Future of an Authoritarian Situation or the Institutionalization of an Authoritarian Regime: The Case of Brazil". In: STEPAN, Alfred C. Authoritarian Brazil: Origins, Policies and Future. New Haven:Yale University Press, 1973; LINZ, Juan J. \& STEPAN, Alfred C. The Breakdown of Democratic Regimes: Latin America. Baltimore:The Johns Hopkins University Press, 1978. Nota Aquino que é "interessante acrescentar que, a respeito especificamente do caso brasileiro, durante a década de 1970, Juan Linz não caracterizava o regime brasileiro como Autoritário, pois, acreditava que ele não havia se institucionalizado, qualificando, portanto, o que vivenciávamos como uma 'situação autoritária"'. Cf. AQUINO, M. A., op. cit., p. 33.
} 
"A que define como a primeira delas denomina de regimes autoritários burocrático-militares, onde reconhece a presença de uma fusão de oficiais $e$ burocratas e o baixo grau de participação política da população. Aponta como características a ausência de uma ideologia e de um partido de massa, geralmente, a tendência à existência de um partido único que restringiria a participação. Admite que, às vezes, pode existir o pluralismo político, mas sem que se estabeleça a disputa eleitoral livre. Segundo ele, essa forma de Autoritarismo foi a mais difundida no século $X X$, apontando como exemplos Brasil e Argentina em momentos históricos determinados". 33

A partir de suas considerações efetivadas sobre uma revisão bibliográfica exaustiva sobre os conceitos aqui resenhados, a autora conclui dizendo que "parece-nos que essas considerações auxiliam-nos a refletir sobre a realidade brasileira", estabelecendo as inevitáveis comparações com outros regimes que se estabeleceram em condições semelhantes e momento próximo, particularmente na América do Sul. Sob muitos aspectos, a realidade "multifacética, móvel e transitória", vivenciada pelo Brasil no longo período entre 1964 e 1985, possui "especificidades e ambigüidades, independentemente de se encontrarem semelhanças" com outros regimes. Essas características, relacionadas diretamente, à conformação histórica da sociedade brasileira, "parecem-nos mais facilmente abrigáveis sob o conceito de Estado Autoritário". ${ }^{34}$

Compartindo as fundamentadas lições de Maria Aparecida de Aquino, partilha-se neste trabalho o conceito desenvolvido por esta professora, para empregar-se, assim, a acepção de Estado Autoritário brasileiro para se fazer referência à forma estatal instalada no Brasil pelo Golpe de 1964.

Golpe este que acarretou, de imediato, a derrocada das forças democráticas e populares portadoras de um projeto nacional-estatista e reformador, que se encontravam em ascensão durante o governo do presidente constitucional deposto, João Goulart. Entretanto, tais forças não ofereceram resistência ativa ao coup d'État promovido por setores político-militares, assim como não o fizeram os comunistas brasileiros - embora houvesse focos isolados e não organizados de insubordinação, que foram prontamente dominados.

\footnotetext{
${ }^{33}$ AQUINO, M. A., op. cit., p. 34.

${ }^{34}$ AQUINO, M. A., op. cit., p. 34.
} 
Esse quadro, contudo, começaria ser paulatinamente alterado. O Partido Comunista Brasileiro (PCB) que havia sido severamente atingido pelos golpistas, após um período de reorganização de suas estruturas, encetou um processo de avaliação da autoproclamada Revolução de 31 de Março. O PCB, então, escolheu os canais institucionais - por mais deteriorados que estivessem ${ }^{35}$ - objetivando conquistar a redemocratização do Brasil, em coerência com sua estratégia geral de transição pacífica ao socialismo.

Em contraposição a estas teses, surgiria a "nova esquerda" ou "esquerda revolucionária", conformada por uma constelação de organizações clandestinas fundamentalmente inspiradas nas vitórias das Revoluções Cubana e Chinesa, e no exemplo da Guerra do Vietnã. Portadora de um projeto socialista para a sociedade brasileira, a "nova esquerda" preconizava a derrubada dos militares e seus aliado civis do governo através de uma ofensiva revolucionária, que aconteceria por meio da luta armada ou insurreições de massa, e posterior implantação de um regime socialista no Brasil. Entre estas organizações se encontrava a Ala Vermelha.

O presente trabalho pretende, em primeiro lugar, narrar a história da Ala Vermelha, organização que surgiu como dissidência do Partido Comunista do Brasil (PC do B) e se transformou em partido autônomo em 1966, momento em que se inseriu nas lutas sociais brasileiras, chegando, inclusive, a realizar ações armadas de expropriação de fundos e de propaganda revolucionária entre 1968 e 1971. Sua presença estendia-se pelos Estados de São Paulo, Rio de Janeiro, Minas Gerais, Rio Grande do Sul, Goiás, Espírito Santo e Maranhão, além de Brasília.

No trabalho será reconstruída a trajetória da Ala Vermelha, percorrendo-a desde seu aparecimento, de modo a propiciar o entendimento de suas divergências com o PC do B que motivaram a ruptura com este partido, ao lado da compreensão de seus pressupostos teóricos, suas propostas programáticas, sua composição social, suas atividades políticas e seus debates internos.

Para atingir este objetivo, serão analisados os documentos fundamentais produzidos pela organização, na sua maior parte sob a guarda do Arquivo Público do Estado do Rio de Janeiro, bem como entrevistas realizadas com pessoas que foram protagonistas do processo de cisão com o PC do B, e com ex-militantes, de um modo

\footnotetext{
${ }^{35}$ No sentido desta afirmação, cf. REIS FILHO, Daniel Aarão. Ditadura e sociedade: as reconstruções da memória. Em: REIS, D. A.; RIDENTI, M.; MOTTA, R. P. S. (org.), op. cit., p. O golpe e a ditadura militar: quarenta anos depois (1964-2004). Bauru, Edusc, 2004, p. 42.
} 
geral, além de dados relevantes para a história da Ala Vermelha contidos em processos do Projeto "Brasil: Nunca Mais". Trata-se, assim, de buscar alcançar a trajetória da Ala Vermelha a partir de dois enfoques: o que é propiciado pela leitura analítica do bloco documental mencionado, e pelo olhar revisitado de seus antigos integrantes, concretizados em depoimentos obtidos na contemporaneidade.

Duas justificativas podem ser apresentadas para esta reconstrução. A primeira delas consiste no aspecto singular da Ala Vermelha, que viria a distingui-la dos demais grupos guerrilheiros que atuavam naquela época no Brasil. Na plenitude do processo de luta armada, do qual participava, esta organização iniciou um procedimento autocrítico com relação à própria luta armada, procedimento este que se iniciou em 1969 para culminar em 1974, quando avaliou seu equívoco ao optar pelas ações armadas de forma imediata. Ao invés disto, a Ala Vermelha apontou que deveria ter privilegiado o trabalho político entre as classes trabalhadoras, de modo a criar as condições necessárias para o futuro desencadeamento da luta revolucionária, entre várias outras considerações críticas. O documento elaborado por esta organização em 1974, intitulado "Autocrítica, 1967-1974", foi considerado pela maioria dos demais grupos guerrilheiros que atuaram naquele interregno histórico, como um documento essencial para o procedimento autocrítico de todo o processo de luta armada no Brasil, e não apenas o da Ala - o que demonstra a relevância desta organização para a História da esquerda armada brasileira.

A segunda justificativa a ser apontada é a inexistência de pesquisas sobre esta organização quer no meio acadêmico, quer em publicações de memórias ou livros que registrem a história da Ala Vermelha, o que confere um cunho inédito ao trabalho que se pretende realizar.

A narrativa histórica da Ala Vermelha delineia um quadro que leva ao segundo objetivo do trabalho: os processos instaurados contra esta organização no Estado de São Paulo, entre 1968 e 1976. Para tanto, analisou-se processos que tramitaram na Justiça Militar de São Paulo contra militantes - e supostos militantes — da Ala Vermelha, através da análise de processos do Projeto "Brasil: Nunca Mais", que se encontram depositados no Arquivo "Edgar Leuenroth", da Universidade Estadual de Campinas (UNICAMP).

Esta delimitação encontra seu fundamento primeiramente na relevância do processo BNM 294, que segundo os autores daquele Projeto, "na verdade representa a unificação de três processos distintos, dois de 1969 e um de 1971, em São Paulo", 
contendo as informações mais importantes "sobre a estrutura, história, atividades $e$ linha política dessa organização" ${ }^{, 36}$. De outro ângulo, se destaca igualmente que todas as ações armadas praticadas pela Ala Vermelha que foram alvo dos processos do Projeto "Brasil: Nunca Mais", aconteceram na Região Metropolitana de São Paulo. A capital paulista, de outro prisma, se mostrou como o local privilegiado de residência dos atingidos pelos organismos de repressão do Regime Autoritário brasileiro pós-64, fossem eles nascidos em São Paulo ou vindos de outras Unidades Federativas, o que vale dizer: São Paulo consistiu a cidade de maior concentração dos militantes da Ala Vermelha naquele período. O Estado de São Paulo, de acordo com o Projeto "Brasil: Nunca Mais", se constituiu no centro das atividades guerrilheiras encetadas pela Ala Vermelha, e, conseqüentemente, no local da maior repressão política estatal contra esta organização.

$\mathrm{Na}$ análise, foram privilegiadas as peças mais importantes dos processos, quais sejam: as denúncias que os instauram, os interrogatórios dos réus nas fases policial e judicial, os depoimentos das testemunhas nas mencionadas fases, as intervenções e alegações da defesa e da acusação e os pareceres do Ministério Público, as sentenças e os acórdãos. Pretende-se, assim, estudar o funcionamento da Justiça Militar, através do papel desempenhado nos processos pelos diversos atores que neles intervieram: réus e seus advogados, delegados, procuradores, juízes e ministros de tribunais.

O período abordado nesse trabalho inicia-se em 1968, ano em que é instaurado o primeiro inquérito contra militantes da Ala Vermelha em São Paulo, e chega a 1974, quando a Ala faz seu documento autocrítico definitivo.

A análise deste material é justificada pelo fato do Regime Autoritário implantado no Brasil em 1964 pautou sua existência por uma preocupação constante em afirmar dentro e fora do país sua legalidade. Visando alcançar tal objetivo, o Regime se caracterizou, no campo do direito, por uma índole fértil de sua produção legislativa. Isto não significa que não tenha se utilizado amplamente de práticas arbitrárias e ilegais. A repressão à esquerda revolucionária demonstra de forma exemplar esta atitude dual do regime, transitando entre a legalidade e a arbitrariedade. Por um lado, o aparato repressivo torturava, assassinava militantes ou promovia seu “desaparecimento", enquanto, de outro lado, preocupava-se em seguir certo formalismo ao confeccionar leis e ao processar judicialmente os militantes.

\footnotetext{
${ }^{36}$ PROJETO "BRASIL: NUNCA MAIS". Perfil dos Atingidos. Projeto "A"- Tomo III. São Paulo: Arquidiocese de São Paulo, 1985, p. 69.
} 
A legislação fundamental com as quais trabalhava a Justiça Militar na repressão dos opositores políticos ao Regime Autoritário, foram as leis de segurança nacional outorgadas pelo próprio regime vigente. A primeira Lei de Segurança Nacional editada data de 1967. Antes de sua vigência, as pessoas acusadas de praticarem crimes contra a segurança do Brasil eram enquadradas na Lei 1.802/53, decretada durante o segundo governo de Getúlio Vargas. O Regime Autoritário criou, ao todo, cinco Leis de Segurança Nacional. No período abrangido por esse trabalho, contudo, vigoraram três delas. A de 1967, que veio a ser substituída pela de março de 1969 (Decreto-lei 510/69), que, por sua vez, deu lugar à de setembro do mesmo ano (Decreto-lei 898/69).

Durante o regime, as Leis de Segurança Nacional foram duramente criticadas pelos opositores, que as acusavam de desrespeitar princípios consagrados do Direito e as próprias liberdades individuais do ser humano.

Esta pesquisa possui igualmente um caráter inédito, considerando-se que não existe registro de qualquer produção científica que aborde a análise de tais processos relativos à Ala Vermelha. O trabalho, neste aspecto, visa, assim, propiciar um instrumento analítico que possa vir a servir como contribuição aos pesquisadores de temáticas que envolvem o Projeto "Brasil: Nunca Mais".

Os dois grandes blocos documentais que dão suporte ao presente trabalho, assim, correspondem aos processos do Projeto "Brasil: Nuca Mais" e aos documentos da Ala Vermelha sob a guarda do Arquivo Público do Estado do Rio de Janeiro (APERJ).

O acervo específico do APERJ com o qual se fundamenta em grande parte este trabalho corresponde à Coleção Particular Daniel Aarão Reis Filho. O conjunto de enformam este patrimônio é, em parte, resultante da Tese de Doutorado em História, defendida por Daniel Aarão Reis Filho nesta Universidade em 1987, intitulada "As organizações comunistas e a luta de classes (1961-1968)".

Daniel Aarão lidou, na elaboração da sua tese, com documentação de praticamente todas as organizações comunistas existentes no Brasil no período que delimitou em seu trabalho. Após a defesa fez a doação deste vasto material ao Arquivo Público do Estado do Rio de Janeiro, onde se encontra depositado e aberto aos pesquisadores.

No caso do acervo referente à Ala Vermelha (AV), o conjunto documental foi entregue para Daniel Aarão por um ex-militante desta organização, e compreende: documentos de discussão interna do partido (de 1966 a 1984); imprensa da AV (de 1968 a 1978); material de educação da Ala Vermelha, contendo texto clássicos do marxismo- 
leninismo e pensamento de Mao Tse-tung, além de material impresso pelos próprios militantes para trabalhar com companheiros e com as massas (de 1969 a 1976).

O bloco documental depositado no Arquivo "Edgar Leuenroth", da UNICAMP, é fruto de um empreendimento que a sociedade brasileira deve a Dom Paulo Evaristo Arns e ao pastor presbiteriano Jaime Wright, por sua inestimável contribuição histórica do ousado projeto clandestino que copiou os cerca de 700 processos que transitaram nas auditorias militares e estavam nos arquivos do STM (Supremo Tribunal Militar), em Brasília.

Esse projeto resultou de uma preocupação com a questão dos direitos humanos depois de decretada a anistia política, em 1979, período em que os militares ainda dirigiam o país ${ }^{37}$. Diante da sensação "de que a qualquer momento o terror pudesse voltar com maior intensidade" ${ }^{38}$, surgiu a idéia de utilizar os processos do STM "como memória viva das atrocidades cometidas pelo regime militar" 39.

"Na verdade, a idéia ocorreu primeiramente a alguns advogados que trabalharam corajosamente pelos prisioneiros políticos durante toda a ditadura militar" ${ }^{40}$, explicou Jaime Wright e ao ser apresentada para Dom Paulo, ele percebeu a importância do projeto e se colocou à disposição do grupo. Mesmo porque, a preocupação maior era que sem esta atitude estariam contribuindo "à aflitiva possibilidade de uma volta à situação anterior" 41 e o esquecimento da história não permitiria qualquer futuro entendimento do que acontecera no Brasil entre 1964 e 1979.

Com o apoio financeiro do Conselho Mundial das Igrejas ${ }^{42}$, organismo internacional ecumênico sediado em Genebra, as equipes de trabalho puderam ser organizadas. "Com o dinheiro em caixa, no início de 1980 a equipe alugou uma sala num prédio de escritórios em Brasília. A sala era pequena, não havia móveis, apenas três máquinas fotocopiadoras, que foram alugadas" ${ }^{43}$.

Os advogados de presos políticos tinham acesso aos processos que podiam ser retirados e devolvidos no prazo de 24 horas. No início, apenas três advogados faziam isso:

\footnotetext{
37 "Na verdade o decreto foi concebido de maneira a impedir até mesmo a possibilidade de qualquer futura investigação oficial do comportamento das forças de segurança entre 1964 e 1979. O passado deveria continuar a ser passado: o livro estava fechado. A abertura podia ir em frente”. WESCHLER, Lawrence. Um milagre, um universo. São Paulo: Companhia das Letras, 1990, p. 22.

38 SIDOW, Evanize; FERRI, Marilda. Dom Paulo Evaristo Arns: um homem amado e perseguido. Petrópolis: Editora Vozes, 1999, p. 319.

${ }^{39}$ Idem.

${ }^{40}$ WESCHLER,., op. cit., p. 24.

${ }^{41}$ Idem, p. 22.

42 O CMI era representado pelo secretário-geral Philip Potter. "O ininterrupto apoio financeiro secreto do CMI ao projeto tornou-se, com o tempo, uma das maiores subvenções individuais de sua história - mais de 350 mil dólares". WESCHLER., op. cit., p. 25.

${ }^{43}$ SIDOW; FERRI.., op. cit., p. 319.
} 
Luis Carlos Sigmaringa Seixas, Luis Eduardo Greenhalgh e Eny Raimundo Moreira, que durante três anos pegaram os processos do STM e para não se exporem muito e arriscar o projeto, contataram outros advogados, apenas para retirar e entregar o processo no dia seguinte, tudo na base da confiança. "Nosso pessoal trabalhava dez horas por dia, sete dias por semana, copiando página por página” ${ }^{44}$, lembra Wright. E durante todo esse tempo o sigilo foi mantido. "Os membros da equipe eram contratados sempre com base no conhecimento pessoal e na confiança, embora a maioria não soubesse em que tipo de projeto estava envolvida" 45.

Por medida de segurança as cópias não permaneceram em Brasília, seguiram para São Paulo. Com a chegada de todas as fotocópias a São Paulo - mais de um milhão de páginas -, o projeto entrou numa outra fase.

As cópias foram microfilmadas e os rolos de filme produzidos foram retirados do Brasil por Jaime Wright e levados para Genebra. O próximo passo era arquivar todos os processos.

"Novos números eram dados às pastas que depois passariam pelo processamento de dados" ${ }^{46}$. Criou-se um programa capaz de armazenar vários dados e confrontá-los em algumas situações. Assim, foi elaborado um questionário com perguntas como "idade, sexo, profissão, atividades, lugares onde esteve preso, nomes de agentes de segurança, investigadores, juízes, promotores e julgamento" ${ }^{47}$. Um novo grupo de pessoas foi contratado para extraírem estas informações dos processos e nenhuma delas sabia exatamente do que se tratava. "O fato de estarem arquivados de forma diferente do STM descaracterizava os documentos, não despertando a atenção daqueles que os manuseavam" ${ }^{48}$. Nesta fase, a questão da tortura foi tratada separadamente e a extração de todos os depoimentos foi realizada por uma única pessoa, durante cinco anos.

Todas as informações obtidas foram intercaladas e agrupadas por tópicos em 12 volumes divididos em seis tomos, num total de quase 7.000 páginas, chamado de projeto A.

O conteúdo dos 12 volumes possui os seguintes títulos: O Regime Militar; A Pesquisa BNM; Os Atingidos; Os Funcionários; Perfil dos Atingidos; As Leis Repressivas; A Tortura; Os Mortos; Índice dos Anexos e Inventário dos Anexos.

\footnotetext{
${ }^{44}$ WESCHLER., op. cit., p. 25.

${ }^{45}$ Idem, p. 45.

${ }^{46}$ SYDOW; FERRI., op. cit., p. 322.

${ }^{47}$ Idem, p. 322.

${ }^{48}$ Ibidem.
} 
Quando parte do material já estava compilado e organizado por tomos, os coordenadores perceberam a necessidade de fazer uma espécie de resumo do projeto A, na forma de livro, com uma linguagem simples e objetiva, direcionada para o grande público, denominado projeto $\mathrm{B}$.

Para esta nova fase foram convidados Ricardo Kotscho e Frei Betto, que durante todo o ano de 1984 trabalharam com os depoimentos extraídos do projeto A e os aspectos históricos necessários para contextualizar a narrativa.

“A Editora Brasiliense foi procurada para publicar o livro. Dom Paulo queria uma editora leiga. O editor Caio Graco Prado disse que era um grande livro, mas recusou a proposta, temendo represálias" 49

Dom Paulo procurou então, pelo diretor da Editora Vozes, Frei Ludovico Gomes de Castro, que após apreciar o projeto levou os manuscritos para o Frei Leonardo Boff que ficou muito entusiasmado. Seus comentários ficaram registrados nas seguintes palavras: “Este não só se transformará em um dos livros mais importantes da história brasileira como também passará a haver uma história antes da publicação e outra depois". 50

Após Dom Paulo ${ }^{51}$ se responsabilizar por qualquer incidente com a publicação, Frei Ludovico aceitou a proposta. Com uma tiragem inicial de 25 mil exemplares, após duas semanas já figurava no primeiro lugar no ranking dos mais vendidos 52 .

Em continuidade aos objetivos do projeto, também foi publicada uma lista com o nome de 444 pessoas denunciadas como torturadores nos processos da Justiça Militar ${ }^{53}$. Esta lista foi colocada à disposição da imprensa em 21 de novembro de 1985 e publicada

\footnotetext{
${ }^{49}$ SYDOW; FERRI., op. cit., p. 326.

${ }^{50}$ SYDOW; FERRI., op. cit., p. 327.

51 "Quando decidimos publicar a obra Brasil Nunca Mais com o relato objetivo das torturas, e conseguimos para tanto, a cópia de quase todos os processos julgados pelo próprio sistema militar, Philip Potter teve a coragem invulgar de escrever comigo o prefácio e de arcar com os custos que a nossa Arquidiocese de São Paulo jamais poderia assumir naquela hora”. ARNS, D. Paulo Evaristo. Da Esperança à Utopia Testemunho de uma vida. Rio de Janeiro: Editora Sextante, 2001, p. 287.

${ }^{52}$ Importante ressaltar que: "de fato, embora mais de trinta pessoas tenham participado em uma ou outra etapa da preparação do livro, apenas duas delas haviam permitido que seus nomes fossem identificados na época da publicação - o cardeal Paulo Evaristo Arns, arcebisbo de São Paulo, e o ministro presbiteriano Jaime Wrigh. (...) as outras pessoas que haviam participado da compilação dos dados para o livro conseguiram manter suas próprias identidades em segredo absoluto por um ano e meio após a publicação do livro". WESCHLER., op. cit., p. 18.

53 "Os nomes são de militares divididos entre Exército, marinha, Aeronáutica, além de integrantes das Polícias Militares estaduais, Polícia Federal e das Secretarias de Segurança Pública e Civis que trabalhavam no DOPS. Muitos deles ainda estavam na vida pública e o fato de seus nomes aparecerem ligados à tortura causou problemas. No Rio de Janeiro o governador Leonel Brizola demitiu aqueles que estavam na lista. Em São Paulo o prefeito Jânio Quadros, que tivera como conselheiro militar o coronel Francisco Antonio Coutinho e Silva, também encontrado na lista, dirigiu declarações irritadas a Dom Paulo através dos jornais. Disse que o cardeal não deveria interferir em suas nomeações”. SYDOW; FERRI., op. cit., p. 328.
} 
por todo o país. O objetivo primeiro era de que a lista integrasse o livro, mas por precaução, decidiram esperar para até depois das eleições de 15 de novembro.

As reações de protesto não tardaram a aparecer, "principalmente naqueles que estavam em sintonia com as forças da ditadura e por isso mesmo não viam com bons olhos a existência do livro e da lista" ${ }^{54}$, se contrapondo ao grito de liberdade das muitas pessoas que foram vítimas da ação militar no país.

Com o objetivo de neutralizar qualquer ação da censura, Jaime Wright, a pedido de Dom Paulo, foi para Nova York tentar a publicação do livro em inglês. Em 1986 o livro foi lançado pela editora de Robert Bernstein com o nome de Torture in Brasil.

A importância do Brasil: nunca mais, como uma das radiografias mais completas sobre o regime militar, "embora não tenha sido o único elemento - outras forças se juntaram para pressionar o presidente José Sarney a assinar, em 1985, a Convenção das Nações Unidas Contra a Tortura -, o livro certamente tem o mérito por oferecer informações fidedignas sobre a violência durante os anos de governo militar" e dessa forma "O Brasil passou a integrar o grupo de 57 países que considera a prática de torturas injustificável” 55 .

Uma vez apresentada uma visão ampla acerca dos variadas contribuições que propiciaram a realização deste trabalho, cabe, finalmente, particulariza-lo, detalhando seus capítulos.

No Capítulo Primeiro contempla-se o início do estudo da Ala Vermelha, a partir de seu surgimento, gerado por um movimento de luta interna no interior do Partido Comunista do Brasil (PC do B), o qual redundou na ruptura desse núcleo divergente com o próprio partido, para originar, inicialmente, a Ala Vermelha do Partido Comunista do Brasil, como uma organização autônoma. Buscaremos fornecer uma visão pormenorizada do processo de luta interna e a reação dos órgãos dirigentes do PC do B contra este movimento, que culminaria na referida cisão.

O Segundo Capítulo trata dos primeiros momentos da Ala Vermelha enquanto organização independente, quando se delineia a orientação de sua linha política, sua visão estratégica e tática, suas diretivas organizacionais e seus primeiros passos em direção ao movimento de massas. A seguir faz-se remissão ao processo de luta armada e é narrada sua primeira reflexão acerca desta forma de luta extremada que exercia, motivada pela prisão de inúmeros de seus quadros, ocorridas desde 1969 até 1971.

\footnotetext{
${ }^{54}$ Idem, p. 328.

${ }^{55}$ SYDOW; FERRI., op. cit., p. 330.
} 
No Terceiro Capítulo analisa-se a culminação desse procedimento autocrítico com relação à luta armada, que ocorreu em 1974. Nesta ocasião, a Ala Vermelha, além de proceder sua autocrítica, indicou o trabalho de massas como prioritário e exclusivo de sua atuação para a organização e luta dos trabalhadores. A Ala Vermelha continua a existir após o período de "transição" do Regime Autoritário brasileiro, vindo, inclusive, a tomar parte nas discussões preliminares do Partido dos Trabalhadores (PT), participando de sua fundação, em 1980 e de suas campanhas eleitorais posteriores. 


\section{I - PRELÚDIO DA ALA VERMELHA}

"No prelúdio se dá a polifonia onde as duas ou até mesmo todas as vozes têm a sua importância.

Há melodias tão bem imaginadas que, entoadas ao mesmo tempo, formam harmonias lindas, sem que uma só voz perca o seu caráter de melodia autônoma..$^{56}$

A Ala Vermelha surgiu em 1966 como dissidência do Partido Comunista do Brasil $\left(\mathrm{PC}\right.$ do $\mathrm{B}^{57}$ ), ano que assistiu ao surgimento de diversas tendências que vieram a compor o fenômeno conhecido posteriormente como "Nova Esquerda",58, cuja característica central era a retomada da revolução enquanto ruptura violenta com a ordem burguesa. Vários são os fatores que contribuíram para esse fenômeno no qual se inseria a Ala Vermelha, como o período de dois anos transcorridos desde a instauração do Regime Autoritário brasileiro pós-64 - o tempo necessário para que uma nova geração, muito jovem por ocasião do Golpe, e outros militantes com mais idade assumissem uma postura de ruptura com as idéias da denominada "velha esquerda" —, a Revolução Cubana, o acirramento da luta de classes no Brasil, uma maior inserção da burguesia nacional no poder político, e, em especial, o XX Congresso do Partido Comunista da União Soviética.

\footnotetext{
${ }^{56}$ SINZIG, Frei Pedro. Os Segredos da Harmonia desvendados singelamente. Petrópolis: Vozes, 1918, p. 11.

${ }^{57}$ Nos dias de hoje o Partido Comunista do Brasil grava a abreviação de seu nome como PCdoB. Na época delimitada nesta pesquisa, entretanto, seus documentos oficiais sintetizam a denominação do partido através da sigla PC do Brasil (Cf., p.ex., PARTIDO COMUNISTA DO BRASIL. A Linha Política Revolucionária do Partido Comunista do Brasil (M-L). Lisboa: Maria da Fonte, 1974, p. 75. Como no referido período histórico e até recentemente tal designação era resumida apenas pelas iniciais PC do B, valeremos desta grafia para fazermos referência ao nome do Partido Comunista do Brasil neste trabalho.

${ }^{58}$ Emprega-se neste trabalho o termo "Nova Esquerda" no sentido que lhe é dado por Daniel Aarão Reis Filho, abrangendo "as organizações e partidos políticos clandestinos" que surgiram no Brasil entre 1961 e 1971 como oposição e alternativa ao Partido Comunista Brasileiro (PCB). A "Nova Esquerda" possuía um propósito comum, o de "dirigir as lutas sociais e políticas do povo brasileiro, encaminhando-as no sentido da liquidação da exploração social, da dominação do capital internacional e da construção de uma sociedade socialista". Com Reis Filho, se compreende também que o vocábulo nova apresenta o significado de diferente e não deve sugerir uma falsa impressão de se pretender designar as forças políticas até aquele momento existentes no país, de arcaicas ou velhas - no aspecto depreciativo destes últimos termos. Cf. apontamentos do mencionado autor em REIS FILHO, Daniel Aarão; SÁ, Jair Ferreira de (org.). Imagens da Revolução. Rio de Janeiro: Marco Zero, 1985, p. 7. Anote-se, contudo, que a expressão "Nova Esquerda" foi cunhada pelo sociólogo norte-americano C. Wright Mills em seu artigo "Letter to the New Left", publicado em 1960. Neste trabalho Mills discutia o que denominou de "ideologia da nova esquerda", que se afastava da "esquerda tradicional", em discussões de temas trabalhistas. Ver MATTSON, Kevin. Intellectuals in Action: The Origins of the New Left and Radical Liberalism, 1945-1970. Filadélfia: Pennsylvania State University, 2002. p. 34 e ss.
} 
O aparecimento da Ala Vermelha, como se vê, perpassa um sinuoso caminho que reclama a compreensão das forças políticas no Brasil em um momento histórico antecedente ao Golpe, ao menos até 1954, ano no qual se realiza o IV Congresso do Partido Comunista do Brasil, matriz da esquerda brasileira. O PC, como então chamado, até a década de 1950 era reconhecido como a única organização política considerada vanguarda da classe operária brasileira.

O referido IV Congresso do PC, que ocorrera clandestinamente em São Paulo no ano de 1954, manifestou os primeiros sinais de mais sérios desacertos no seio do partido. A democracia foi pouco respeitada durante sua convocação, os delegados não foram eleitos livremente pelas bases, mas "manipulados pelo Comitê Nacional" seu secretariado, composto por Luiz Carlos Prestes, João Amazonas, Diógenes Arruda Câmara, Maurício Grabois, Jover Telles, Carlos Marighella e Sérgio Olmos —, e mesmo as intervenções dos delegados presentes "foram preparadas por elementos ligados à direção" $"$. A linha política definida pelo IV Congresso mostra que "a revolução brasileira em sua etapa atual é (...) uma revolução democrática e popular, de cunho antiimperialista e agrária antifeudal”,61. A palavra de ordem fundamental, segundo o Programa, consistia na "derrubada do governo de latifundiários e grandes capitalistas"62.

As práticas carentes de democracia que caracterizaram o IV Congresso podem indicar, porventura, uma postura mais cuidadosa dos dirigentes do $\mathrm{PC}$-o próprio Prestes esteve ausente dos trabalhos por motivos de segurança ${ }^{63}$ - , que anteriormente se haviam visto em uma constrangedora posição. No Projeto de Programa, distribuído em primeiro de janeiro de 1954 para a discussão pelas bases partidárias, a direção caracterizava o governo de Getúlio Vargas como um "governo de traição nacional",64, e conclamava a sua destituição pelas massas populares. Entretanto, quando foi aberta a crise política de agosto de 1954, os comunistas passariam a se confundir com os membros da União Democrática Nacional (UDN) uma vez que se encontravam, todos, em uma "mesma ofensiva pela deposição do Presidente da República",65, e, de acordo com Jacob Gorender, "a direção nacional do PCB custou a "sair da perplexidade ao constatar que se encontrava ao lado

\footnotetext{
${ }^{59}$ SEGATTO, José Antonio et al. PCB 1922-1982. São Paulo: Brasiliense, 1982, p. 106.

${ }^{60}$ Idem, p. 106.

${ }^{61}$ Ibidem, p. 106.

${ }^{62}$ Ibidem, p. 106.

${ }^{63}$ Ibidem, p. 106.

${ }^{64}$ GORENDER, Jacob. Combate nas trevas. A Esquerda brasileira: das ilusões perdidas à luta armada. São Paulo: Ática, 2003, p. 24.

${ }^{65}$ Idem, p. 24.
} 
de setores vinculados ao imperialismo norte-americano." ${ }^{, 66}$ Durante os trabalhos do IV Congresso ocorreu a mudança da proposta de deposição do Governo Vargas - que havia suicidado - para a fórmula "derrubada do atual governo" ${ }^{\text {67 }}$, expressão esta que poderia ser compreendida como o governo de Café Filho ou de qualquer de seu sucessor, inclusive do que seria eleito, Juscelino Kubitschek.

A contradição existente entre as proclamações revolucionárias preconizadas pelo IV Congresso - derrubar o governo - , e as práticas eleitorais do PC, demonstrava uma nítida discrepância entre sua política programática e ação concreta, uma vez que a direção resolveu apoiar em 1955 a candidatura de Juscelino à presidência. Estas incoerências existentes entre o Programa do IV Congresso e a prática dos militantes, entretanto, era "reprimida pelos métodos da vida orgânica"68, que explodiriam na discussão interna aberta por meio do órgão oficial do PC, o Voz Operária, à revelia da direção nacional. O fator decisivo para o acirramento do debate entre os militantes do PC foi o informe confidencial de Nikita Kruchev ${ }^{69}$.

No XX Congresso do Partido Comunista da União Soviética (PCUS), em fevereiro de 1956, Kruchev, primeiro-ministro daquele país, pronunciou o famoso libelo contra Stalin — que havia falecido em 1953 —, acusando-o de haver governado a URSS com métodos brutais, desconhecidos mesmo para os padrões da história russa e soviética, com o cometimento de inúmeros crimes, como torturas e "expurgos" de seus dissidentes políticos. No denominado "Relatório Secreto" que apresentava, Kruchev buscou pôr um termo ao "culto à personalidade de Stalin", desabonando sua imagem, até mesmo sua capacitação militar: Stalin não passaria de "um homem isolado que não levava ninguém em conta" e exigia submissão incondicional às suas idéias; quem ousasse divergir estaria fadado a ser "suprimido da coletividade dirigente e destinado à aniquilação moral e física". Com relação ao papel de Stalin no Exército Vermelho, as críticas eram igualmente ásperas e ferinas: "Mesmo após o começo da guerra, o nervosismo e a histeria manifestados por Stalin causaram ao nosso exército graves perigos;" o antigo líder soviético montaria suas planificações militares com a ajuda de "um globo terrestre", e por tais razões estaria

\footnotetext{
${ }^{66}$ Ibidem, p. 24.

${ }^{67}$ Ibidem, 25.

${ }^{68}$ Gorender diz que tal contradição revelava que "o fiasco da linha política [do PC] como guia da atuação dos comunistas já se tornara clamoroso.” Cf. GORENDER, Jacob, op. cit. p. 25.

${ }^{69}$ Empregamos a escrita do nome deste primeiro-ministro soviético segundo a grafia oficial da época. Cf. DOCUMENTOS Programáticos de Luta pela Paz, a Democracia e o Socialismo. Moscou: Politizdat, 1963.
} 
"longe de compreender a situação real que se desenvolvia na frente" de batalha, o que, para Kruchev, seria "natural porque ele jamais visitou qualquer parte da frente" ${ }^{\text {"70. }}$

O abalo causado pelo "Relatório Secreto" de Kruchev não se restringiu apenas ao PCUS mas atingiu todos os partidos comunistas de todo o mundo, pois a figura de Stalin sempre representou a continuação das idéias de Lênin e da própria Revolução Soviética, referenciais universalmente acolhidos pelos revolucionários marxistas, pois se Lênin dirigiu a Revolução vitoriosa em 1917 e delineou as orientações centrais para a construção do socialismo, foi sob o comando de Stalin que se edificou o socialismo soviético e se impulsionou o movimento comunista por um período de trinta anos.

No ambiente da Guerra Fria, o "Relatório Secreto" se constituiu em um valioso instrumento de propaganda anticomunista, pois a demolição da figura de Stalin efetuada por Kruchev veio a revivificar a política de "guerra ao comunismo" que desde 1945 constituía-se em pauta principal dos países que figuravam no "sistema ocidental" da divisão mundial bipolar.

Os sistemas de propaganda capitalistas, entretanto, ao centrar seu foco na figura de Stalin, estrategicamente omitiram - ou não enfatizaram - a mudança estrutural na linha de política exterior que Kruchev apresentara ao XX Congresso do PCUS, que, assim, passou a ser quase desapercebida para a população, de um modo geral, e dos próprios militantes comunistas, em um primeiro momento. O próprio primeiro ministro soviético contribuiu para essa leitura de sua intervenção no referido Congresso, ao dar relevo especial às denúncias aos crimes e do "culto à personalidade" de Stalin em detrimento do aprofundamento da transformação política que apresentara aos congressistas, e que iria pautar desde então a agenda soviética.

Após apresentar seu "Relatório Secreto" Kruchev proclamou que a democracia leninista e a direção colegiada haviam sido restabelecidas no PCUS, pois "o partido rompeu com noções caducas" ${ }^{71}$. E conclamou de maneira solene sua persuasão íntima de que:

"No curso dos próximos 10 anos a União Soviética, que criou a base material e técnica do comunismo, ultrapassará na produção por habitante o país capitalista mais potente e mais rico, os USA", 72

\footnotetext{
${ }^{70}$ Excertos de: KRUCHEV, Nikita. Rapport au XX ${ }^{\mathbf{e}}$ Congrès. Apud MARTENS, Ludo. Stalin. Um novo olhar. Rio de Janeiro: Revan, 2003, p. 292-296.

${ }^{71}$ Fragmento de KRUCHEV, Nikita, op. cit., p. 338.

${ }^{72}$ Idem, p. 340
} 
A convicção de Kruchev de que o socialismo iria suplantar o capitalismo norteamericano permitia-lhe menoscabar seu inimigo principal até aquele momento, quando a União Soviética permitia-se desejar que "Nós queremos ser amigos dos Estados Unidos."73 Dentro deste ambiente, a revolução socialista ostentaria uma forma pacífica, por meio da qual "A classe operária pode conquistar uma sólida maioria no Parlamento e transformálo em instrumento de uma vontade popular verdadeira" ${ }^{, 74}$.

Assim, de maneira quase desapercebida Kruchev introduzira no XX Congresso uma verdadeira contra-revolução ${ }^{75}$ no campo estratégico socialista, ao estabelecer a linha política que seria tirada naquela instância partidária, que se exprimia na síntese "as três pacíficas e os dois todos”, os quais se traduziam na transição pacífica, coexistência pacífica e emulação pacífica; no "Estado de todo o povo" e no "Partido de todo o povo". Os críticos $^{76}$ de Kruchev anotavam que essa linha política representava uma ruptura total com os preceitos do marxismo-leninismo, pois abandonava o conceito de revolução para substituí-lo pela idéia de transição ao socialismo pela via eleitoral. Capitulava diante da Guerra Fria ao propor que as relações internacionais do mundo socialista teriam de se orientar por um coexistir pacífico com os países capitalistas, no qual se praticaria uma concorrência guiada pela paz fraternal. O Estado agora seria erigido pela manifestação da vontade de todas as pessoas, independente de sua origem de classe, enquanto que o partido comunista, conseqüentemente, exprimiria também esta noção para se transformar em um partido popular, no sentido abrangente do termo. Ao colocar o Estado e o partido comunista amoldados dentro dessas acepções, os dirigentes soviéticos abandonavam, através de um mesmo movimento, as noções de ditadura do proletariado e a do partido da classe operária, conceitos muito caros aos militantes comunistas, de um modo geral, e elementos fundamentais na teoria marxista-leninista.

Os dirigentes do Partido Comunista Chinês (PCCh), todavia, desde quando Kruchev divulgou seu "Relatório Secreto", mostraram-se prudentes e manifestaram, discreta mas claramente, "que eles tinham sobre a obra de Stalin um julgamento um pouco diferente"77,

\footnotetext{
${ }^{73}$ Excerto de KRUCHEV, Nikita, op. cit., p. 339.

${ }_{75}^{74}$ Idem, p. 339.

${ }^{75}$ MARTENS, Ludo, op. cit., p. 338.

${ }^{76}$ Por todos, Jean Baby. Aqui e para o que segue, cf. BABY, Jean. As Grandes Divergências do Mundo Socialista. São Paulo: Senzala, [19- -], p. 10 e ss.

${ }^{77}$ BABY, Jean, op. cit., p. 15.
} 
como expressa o discurso pronunciado por Mao Tsé-tung ${ }^{78}$ em 15 de novembro do mesmo ano da realização do XX Congresso do PCUS:

“Com respeito ao XX Congresso do PCUS, queria dizer algo. A meu juízo, há duas espadas: uma é Lênin e a outra Stalin. A espada que é Stalin, os russos a têm agora jogado por terra. (...) O imperialismo se serve também desta espada para assassinar os povos (...) Esta arma não está emprestada, ela está lançada.

Nós, chineses, não a temos rejeitado. Como primeiro ponto, defendemos Stalin e, como segundo, criticamos seus erros (...) Diferentemente daquelas pessoas que denigrem e liquidam Stalin, nós o tratamos conforme a realidade.

Quando a espada é Lênin, ela não tem sido, também, rejeitada de algum modo pelos dirigentes soviéticos? A meu ver, isso tem ocorrido em grande medida.

A Revolução de Outubro é sempre válida? Pode ainda servir de exemplo para diferentes países?

No informe no XX Congresso do PCUS (...) se afirmou que era possível conquistar o Poder pela via parlamentar, o que significa dizer que para os demais países já não é mais necessário aprender com a Revolução de Outubro.

Uma vez esta grande porta aberta, o leninismo está praticamente rejeitado ${ }^{79}$.

Se nos países socialistas o relatório de Kruchev iria provocar explosões numa dimensão que ameaçava tomar proporções dramáticas ${ }^{80}$, quando a matérias mais debatidas giravam em torno dos crimes e da personalidade de Stalin, o PCCh se constitui em uma exceção $^{81}$, pois desde o início colocou a "questão Stalin" em um segundo plano para discutir mais profundamente a linha política introduzida pelo XX Congresso. O Partido Comunista Chinês desde então passou a defender os postulados marxistas-leninistas contra o que designava de revisionismo contemporâneo - o que deve ser compreendido se considerado especialmente que a China chegou a Marx via Lênin, ou mais precisamente, através do marxismo-leninismo de Stalin, sendo que o marxismo do próprio Mao parece

\footnotetext{
${ }^{78}$ Como a partir de 1979 os nomes chineses passaram a ter uma nova redação no alfabeto ocidental, adotamos neste trabalho a ortografia do período que a pesquisa se delimita (1968-1976), grafando o nome do líder chinês pela escrita em português que era dada por publicação oficial da época, feita pelas Edições em Línguas Estrangeiras de Pequim, ou seja, Mao Tsé-tung. Cf. TSÉ-TUNG, Mao. Escritos Militares Selecionados. Pequim: Línguas Estrangeiras, 1963, passim.

79 TSÉ-TUNG, Mao. Discurso pronuniciado en la II Sesion Plenaria del VIII Comité Central del Partido Comunista de China. Em: Obras Escogidas de Mao Tsetung. Tomo V. Pequim: Lenguas Estrangeras, 1975, p. 359.

${ }^{80}$ BABY, Jean, op. cit., p. 19.

${ }^{81}$ Idem, p. 18.
} 
haver derivado quase inteiramente da obra "História do PCUS (Bolchevique)" ${ }^{\text {, } 22}$, de Joseph Stalin.

Quatro anos depois, em 1960, o Partido dos Trabalhadores da Albânia (PTA), denominação do partido comunista naquele país, também entra em curso de colisão com os dirigentes soviéticos, quando seu dirigente máximo, Enver Hoxha, pronuncia um discurso em Moscou na Reunião do 81 Partidos Comunistas e Operários. Segundo o líder comunista albanês, na ocasião o movimento comunista encontrava-se em face de um ataque contra-revolucionário propagado pela contra corrente revisionista tramada pelos adeptos de Kruchev que haviam concebido a idéia de um marxismo criador, que na realidade visava desviar os partidos comunistas da via do marxismo-leninismo, "para substituir a luta de classes pela reconciliação de classes, e a revolução pelas reformas burguesas", objetivando a submissão de todos os partidos às ordens ditadas por Moscou ${ }^{83}$.

Prosseguia, assim, o PTA no caminho pioneiramente traçado pela China de Mao Tsé-tung, acusando os dirigentes soviéticos de traírem os princípios essenciais do marxismo-leninismo, ao mesmo tempo em que confrontavam a "via pacífica", agregando um elemento analítico mais em sua formulação política, a de que Moscou almejava uma obediência cega dos partidos comunistas em todo o mundo às suas orientações.

O PC brasileiro não ficou imune ao impacto causado pelo "Relatório Secreto", recebendo a existência das denúncias de Kruchev pelo jornal $O$ Estado de São Paulo, que as havia reproduzido do New York Times. Inicialmente negando a existência do "Relatório Secreto", e atribuindo-o ao imperialismo norte-americano e à CIA estado-unidense, a direção do partido comunista do Brasil decidiu enviar Diógenes Arruda Câmara membro do secretariado nacional - para verificar a autenticidade dos informes contidos naquelas publicações, que foi confirmada pelos soviéticos. ${ }^{84}$ A revelação oficial da

\footnotetext{
${ }^{82}$ HOBSBAWN, Eric. Era dos Extremos. O breve século XX. São Paulo: Companhia das Letras, 1998, p. 452.

${ }^{83}$ ALIA, Ramiz. Uma Linha de Luta de Vitória contra o Revisionismo Krutchevista. Em: HOXHA, Enver; ALIA, Ramiz. Uma Linha de Luta de Vitória contra o Revisionismo Krutchevista. Lisboa: Maria da Fonte, 1976, p. 14 e ss.

${ }^{84}$ Clara Charf, militante comunista e viúva de Carlos Marighella, recordando aquela época narrou que: " $O$ Estadão já tinha publicado o relatório denunciando os crimes do stalinismo e o problema do culto à personalidade. Foi o caos. (...) uns diziam para os outros: 'Não, isso não é verdade.' A tendência generalizada de todo mundo, dos dirigentes, dos dirigidos, é de que aquilo não podia ser verdade (...) Nós esperamos que o [Diógenes] Arruda fosse à URSS e trouxesse a verdade", uma vez que a versão difundida no Brasil havia sido publicada "nos jornais que sempre criticamos como jornais que estavam inventando, fazendo campanha, denegrindo o socialismo etc." Cf. CHARF, Clara. Duas histórias de luta, uma história de amor [Entrevista]. Revista Teoria e Debates. São Paulo, nº. 8, out./dez., 1989, p. 37.
} 
veracidade do relatório foi feita por Arruda em 1956 numa reunião do Comitê Central e foi recebida como uma catástrofe pelos dirigentes ${ }^{85}$.

Após a oficialização da autenticidade das resoluções do XX Congresso do PCUS ${ }^{86}$, setores do partido começaram a questionar a validade das teses do IV Congresso, considerando-as incompatíveis em face da nova linha política preconizada por Moscou. Concluíram não ser possível uma mudança radical na orientação política do PC sem que houvesse alterações substanciais no nível da direção partidária. ${ }^{87}$ Particularmente figuras de expressão partidária, como Diógenes Arruda, João Amazonas, Maurício Grabois— que integravam o Comissão Executiva do partido — e Pedro Pomar $^{88}$ —então na suplência do Comitê Central - resistiram em iniciar o processo de discussão interna e opunham-se à modificação dos métodos personalistas e mandonistas ${ }^{89}$ que então caracterizavam a ação de dirigentes do PC, que incluiria a própria figura de Prestes — "tão stalinista quanto seus companheiros de alta direção", segundo Gorender ${ }^{90}$.

Prestes, que era secretário-geral do PC desde 1943, começou a alterar seu posicionamento após efetuar a substituição do segundo homem na hierarquia partidária, Diógenes Arruda — que se caracterizava por métodos mandonistas ${ }^{91}$ — , por Giocondo

${ }^{85}$ Clara Sharf conta que "Quando o Arruda chegou e confirmou os fatos numa reunião do Comitê Central, foi um terremoto. E vou te dizer: Marighella chorou na tribuna (...) Eu também fiquei abaladíssima (...) Ele ficou profundamente comovido, não é que ficou abalado em suas convicções, na luta pelo socialismo, como alguns que depois se mandaram, abandonaram a luta para sempre. Ele não. Ele se levantou contra tudo aquilo e começou a batalhar pela reestruturação do partido com novas formas de direção, botando de lado tudo aquilo que era errado, incorreto, os abusos, o autoritarismo, todos os crimes que eram denunciados, porque nossa tarefa era libertar o povo brasileiro". Cf. CHARF, Clara, op. cit., p. 39.

${ }^{86}$ Os informes do XX Congresso provocaram intensos debates no seio do partido, que culminaram com a expulsão de Agildo Barata, que liderara uma discussão sobre as mesmas, chegando, inclusive a propor a revisão de todos os conceitos marxistas visando sua "humanização". Sobre o tema, ver GORENDER, Jacob, op. cit., p. 28 e ss.

${ }^{87}$ Idem, p. 29 e ss.

${ }^{88}$ Gorender diz que Pomar fora rebaixado da Comissão Executiva do PC brasileiro à suplência do Comitê Central que por "razões desconhecidas" e que após seu rebaixamento, foi ser dirigente do Comitê Distrital do Tatuapé, em São Paulo, ocasião em que "Pomar se portou com dignidade (...) e continuou a cumprir tarefas com a mesma dedicação". Ibidem, p. 37.

${ }^{89}$ CARVAlHO, Péricles de; ALMEIDA, Francisco. PC do B. A sobrevivência de um erro. São Paulo: Novos Rumos, 1985, p. 9.

${ }^{90}$ GORENDER, Jacob, op. cit., p. 30.

91 Quando de sua volta da União Soviética, Diógenes Arruda não apenas confirmou a autenticidade do "Relatório Kruchev" assim como se autoproclamou como "um arauto na luta contra o stalinismo". De acordo com Gorender, tal manobra não frutificou, porque na primeira reunião do Comitê Central após sua volta, "tão repentino anti-stalinismo ficou desmascarado", visto que "ninguém o aceitaria, tratando-se do dirigente que (...) mais se identificou com os chamados 'métodos mandonistas'”. Idem, p. 32. 
Dias, que durante os dez anos de total clandestinidade ${ }^{92}$ de Prestes havia sido o responsável pelos assuntos práticos da secretaria-geral, inclusive pela própria segurança de seu titular. ${ }^{93}$

A partir de então Prestes não apenas se convenceu da necessidade de introduzir alterações na Comissão Executiva que possibilitassem as inovações trazidas pela nova linha política propalada por Moscou, como também julgou inevitável o afastamento das concepções contidas nas teses do IV Congresso. Tais mudanças começaram a ser levadas a cabo em agosto de 1957. Numa reunião plenária do Comitê Central, foram aprovadas as modificações em sua composição, quando saíram da Comissão Executiva Diógenes Arruda, João Amazonas, Maurício Grabois e Sérgio Olmos, e em seu lugar foram introduzidos Giocondo Dias, Mário Alves, Calil Chade e Ramiro Luchesi ${ }^{94}$. Nesta mesma reunião ficou constituída uma comissão encarregada para elaborar um documento acerca das propostas em litígio dentro do partido, pois o Quinto Congresso seria realizado somente dali a dois anos. Prestes se manifestaria na mesma linha de transição pacífica pelo jornal do partido, o Voz Operária, quando escreveu uma autocrítica das posições anteriores do partido, salientando que o PC havia chegado a uma "concepção falsa, de caráter esquerdista, sobre a revolução brasileira", por não divisar a existência de um "processo de democratização da vida política do país" em virtude do qual "se criariam condições para a utilização de meios legais de luta pelas forças nacionalistas e democráticas",95

O artigo de Prestes surgiu concomitantemente com a Declaração Política de Março de 1958, que partiu da mesma premissa do Programa do IV Congresso: a concepção da revolução brasileira em duas etapas ${ }^{96}$. A estratégia definida propunha uma aliança entre o proletariado, os camponeses, a pequena burguesia e a burguesia nacional, para a realização das tarefas revolucionárias, em ambas as etapas. A tática a ser observada derivava de uma perspectiva política que divisava o governo de Juscelino - que obtivera apoio do PC nas

\footnotetext{
${ }^{92}$ De 1948 a 1957 Prestes ficou clandestino "não só para os órgãos de repressão policial como também para seu próprio partido", quando se reunia exclusivamente com os quatro membros do secretariado nacional, e em prazos mais longos, com a Comissão Executiva, integrada por nove membros, incluídos nesta soma os membros pertencentes ao secretariado. A razão para este rígido isolamento era que Prestes não deveria correr o risco de uma nova prisão. GORENDER, Ibidem, p. 30.

${ }^{93}$ GORENDER, Jacob, op. cit., p. 32.

${ }^{94}$ SEGATTO, José Antonio et al., op. cit. p. 117.

${ }^{95}$ PRESTES, Luiz Carlos. São indispensáveis a crítica e a autocrítica de nossa atividade para compreender e aplicar a nova linha. Voz Operária, São Paulo, no. 460, 29.3.1958. In: PCB: Vinte Anos de Política. 19581979 (documentos). São Paulo: Ciências Humanas, 1979, p. 32.

${ }^{96}$ A concepção etapista, como se convencionou denominar, acerca da revolução brasileira, significava que a mesma deveria atravessar duas etapas: a primeira seria de cunho nacional e democrática, de conteúdo antiimperialista e antifeudal. A partir da vitória desta é que se passaria para a segunda etapa, a da revolução socialista. Esta é uma concepção que vem do Sexto Congresso Internacional Comunista, realizado em 1928, como anota Caio Prado Júnior. Ver a respeito do tema: PRADO JÚNIOR, Caio. A Revolução Brasileira. Perspectivas em 1977. São Paulo: Brasiliense, p. 37 e ss.
} 
eleições — como de composição heterogênea, dentro do qual se digladiavam duas alas: a nacionalista e a entreguista. Assim, a tática consistia em apoiar a ala nacionalista e atacar a dos entreguistas. A direção deveria ser o caminho pacífico da revolução, que se viabilizaria pela nova realidade do socialismo internacional advindo das teses do XX Congresso do PCUS, e pela correlação de forças existentes no Brasil: sua concretização aconteceria através das lutas em prol da ampliação das liberdades democráticas e reformas das estruturas. Assim, o caminho pacífico da revolução significava "a atuação de todas as correntes antiimperialistas dentro da legalidade democrática e constitucional, com a utilização de formais legais de luta e de organização de massas" ${ }^{\prime 97}$.

O V Congresso do PC brasileiro foi realizado em agosto de 1960, precedido de um amplo debate que o distinguiu especialmente do seu homônimo anterior, e veio a aprovar, em essência, as teses delineadas na Declaração Política de Março de 1958. Além da aprovação das teses, o Congresso elegeu um novo Comitê Central, eleição esta que marcou a derrota da "corrente stalinista" 98 , com o afastamento de João Amazonas, Maurício Grabois, Diógenes Arruda Câmara daquele órgão dirigente, por uma decisão tomada "pela opinião livre e amplamente majoritária dos militantes. ${ }^{99,}$

Em onze de agosto de 1961, o órgão central do PC, o jornal Novos Rumos publicou o Programa e Estatutos do partido, substituindo a expressão do Brasil, que acompanhava o nome de "Partido Comunista", para substituí-la pelo vocábulo brasileiro. O PC, assim, passava a se autodefinir como Partido Comunista Brasileiro, pretendendo-se com a alteração do nome, não obstaculizar a tão pretendida legalização ${ }^{100}$.

João Amazonas e Maurício Grabois, embora tivessem ficado na defensiva durante os debates do interior do PC ocorridos nos anos 1956-1957, como anota Gorender, "não cederam com relação às posições stalinistas" e as mantiveram após sua exclusão do Comitê Central, ocorrida no V Congresso. Pedro Pomar também mantinha uma posição de severa crítica no primeiro momento do debate interno partidário acerca das teses do $\mathrm{XX}$ Congresso do PCUS. Quando as linhas de discussão ficaram definidas, "prevaleceu nele a formação stalinista”, o que o aproximou de Amazonas e Grabois ${ }^{101}$.

\footnotetext{
${ }^{97}$ Declaração sobre a política do Partido Comunista Brasileiro. Março de 1958. In: PCB: Vinte Anos... p. 22. ${ }^{98}$ GORENDER, Jacob, op. cit., p. 35.

${ }^{99}$ Idem, p. 35.

${ }^{100}$ Recordamos que um dos argumentos centrais para a cassação do registro do PC em 1947 girava em torno da locução "do Brasil" que o partido ostentava, argumentando-se que isso indicaria que não se tratava de um partido brasileiro, mas de uma Seção do Brasil da Internacional Comunista. Sobre o tema ver: BICALHO, Luiz de Carvalho, op. cit.

${ }^{101}$ GORENDER, Jacob, op. cit., p. 38.
} 
Articulados entre si, vieram Amazonas, Pomar e Grabois a lançar um "protesto subscrito por uma centena de militantes", o qual encampava a argumentação preconizada por estes dirigentes de que o Comitê Central do agora Partido Comunista Brasileiro incorrera em infração de princípios, que o Programa e Estatutos encaminhados à Justiça Eleitoral pelo PCB se afastavam do marxismo-leninismo, e que, desta forma, "Prestes $e$ seus companheiros haviam renegado o partido fundado em 1922", e criando um "novo partido revisionista” 102 .

Em defesa do verdadeiro partido comunista do Brasil, em fevereiro de 1962, reuniram-se na Conferência Nacional Extraordinária do Partido Comunista do Brasil (PC do B), e consumaram a cisão ${ }^{103}$ — ou o "racha" — que foi chamada por seus organizadores de "reorganização" do partido nascido em 1922. O país passou a conviver com dois partidos comunistas, o PCB e o Partido Comunista do Brasil (PC do B), o que, como nota Gorender, fere o "dogma stalinista" segundo o qual a classe operária apenas pode ter um único "autêntico partido revolucionário"104.

Existe outra versão para o surgimento do PC do B, a oficial que vem fornecida pelo próprio partido, e difere em alguns aspectos fundamentais da que vimos delineando. De acordo com documentos do próprio PC do B, a origem da "reorganização" ocorre como transcorrência da oposição que o núcleo "reorganizador" deste partido faziam à Declaração de Março de 1958, a qual preconizaria "o caminho pacífico e a colaboração com a burguesia"105. Os opositores teriam assumido "maiores proporções na preparação $e$ no curso do V Congresso do PCB (1960)",106, e nos debates que foram ali travados, "os marxistas-leninistas fazem severa critica da linha oportunista" $" 107$ do PCB e conseguem desmascarar "o caráter reformista das teses apresentadas pelo Comitê Central e propõem uma orientação revolucionária" ${ }^{108}$. Entretanto, o V Congresso vem a aprovar, "manipulado pela direção prestista"109, "as teses oportunistas"110 e ainda, afastar do "quadro de membros efetivos do Comitê Central os que resistem à sua orientação""11.

\footnotetext{
${ }^{102}$ Idem, p. 38, grifamos.

${ }^{103}$ Ibidem, p. 38.

${ }^{104}$ GORENDER, Jacob, op. cit., p. 38.

${ }^{105}$ PARTIDO COMUNISTA DO BRASIL. Meio Século de Existência. Em: PARTIDO COMUNISTA DO BRASIL. Cinquienta anos de Luta. Lisboa: Maria da Fonte, 1975, p. 53.

${ }^{106}$ Idem, p. 53.

${ }^{107}$ Ibidem, p. 53.

${ }^{108}$ Ibidem, p. 53.

${ }^{109}$ Ibidem, p. 53.

${ }^{110}$ Ibidem, p. 53.

${ }^{111}$ Ibidem, p. 53.
} 
Todavia, a luta então travada frutifica, pois "desperta grande número de militantes para o combate às concepções errôneas e aguça o seu espírito crítico" ${ }^{\# 12}$.

Em meados do ano de 1961, o Comitê Central eleito no V Congresso, buscando a legalidade do partido, publica novos Estatutos, dos quais exclui "a afirmação de que o Partido se orienta pelo marxismo-leninismo e pelo internacionalismo proletário" ${ }^{\text {"113 }}$, assim como apresenta um Programa "indefinido, semelhante aos de certos agrupamentos políticos das classes dominantes" $" 114$. O Comitê Central, desta maneira, vem a efetivar a formalização de um "novo partido, de tipo social-democrata, o Partido Comunista Brasileiro, renegando o velho partido da classe operária, o Partido Comunista do Brasil"

Segundo a documentação partidária do $\mathrm{PC}$ do $\mathrm{B}$, "um grande número de militantes não aceita o liquidacionismo do Partido"116, e exige do Comitê Central a anulação de determinadas medidas que havia tomado, ou então a realização de um outro Congresso, sendo que tal reivindicação "é respondida com sanções anti-estatutárias". Os "reorganizadores", convocam então — “em defesa do partido (...) [legitimados por] militantes revolucionários de diferentes Estados"117 — uma Conferência Nacional Extraordinária, que foi realizada em fevereiro de 1962, na qual:

“reorganizam o antigo partido do proletariado - o Partido Comunista do Brasil. Os principais organizadores desta conferência são, entre outros, João Amazonas, Maurício Grabois, Pedro Pomar, Carlos Danielli, Ângelo Arroio, Lincoln Oest, José Duarte, Elza Monerat". ${ }^{118}$

A controvérsia existente entre as versões apresentadas para o surgimento do PC do B é manifesta e não há como se aquilatar a retidão de uma em detrimento de outra, pois cada um dos diferentes modos de interpretar o mesmo fato histórico são excludentes em diversos pontos.

\footnotetext{
${ }^{112}$ Ibidem, p. 54.

${ }^{113}$ Ibidem, p. 54.

${ }^{114}$ PARTIDO COMUNISTA DO BRASIL. Meio Século... p. 54.

${ }^{115}$ Idem, p. 54.

${ }^{116}$ Ibidem, p. 54.

${ }^{117}$ Ibidem, p. 54.

${ }^{118}$ Ibidem, p. 54. Luiz Maklouf, ao escrever a biografia de Pedro Pomar, discorre sinteticamente sobre o processo de "reorganização" do PC do B, ocasião em que aponta como principais organizadores, além dos personagens referidos no documento partidário, também a pessoa de Kalil Chade. Cf. CARVALHO, Luiz Maklouf. Pesquisa biográfica. In: POMAR, Pedro et al. Pedro Pomar. São Paulo: Brasil Debates, 1980, p. 60.
} 
Seja como for, a superação das contradições de qualquer narrativa que se decida abraçar, é alcançada quando se examina os fundamentos programáticos esposados àquela época pelo Partido Comunista do Brasil, onde encontramos a convergência analítica uma vez que a investigação acontece no campo documental.

Vemos, assim, que o PC do B adotou como referencial de seu Manifesto-Programa, aprovado na referida Conferência Extraordinária, as teses do Programa do Quarto Congresso do partido. Sua estratégia consistia na conquista de um governo popular revolucionário ${ }^{119}$ que seria um "inimigo irreconciliável do imperialismo e do latifúndio"120 e também dos "grupos monopolistas" 121 . O novo regime político seria alcançado através da violência revolucionária visto que naquela conjuntura na qual se encontraria o Brasil, "as classes dominantes tornam inviável o caminho pacifico da revolução" ${ }^{22}$, e tão somente " $a$ luta decisiva e enérgica, as ações revolucionárias de envergadura, darão poder ao povo" ${ }^{, 123}$.

O governo de João Goulart era considerado pelo PC do B como um obstáculo que se contrapunha "às aspirações populares e à completa independência nacional", constituía-se, assim, em um "regime reacionário”, que haveria de ser destituído para que fosse possível "a instauração de um novo regime antiimperialista, antilatifundiário $e$ antimonopolista”, pois nem mesmo as reformas de base almejadas por Goulart seriam a solução para o país, uma vez que não seria através de "reformas parciais que o Brasil poderá avançar no caminho de sua libertação"124.

Como a vitória da Revolução Cubana havia sido uma surpresa ${ }^{125}$ para o mundo socialista pós XX Congresso do PCUS - visto que materializava a conquista do regime político pela via não pacífica, contrariando os postulados de Moscou, e que já em 1961 Fidel Castro afirmara o caráter socialista da revolução cubana ${ }^{126}$ —, essa nova realidade

\footnotetext{
119 PARTIDO COMUNISTA DO BRASIL. Manifesto-Programa do Partido Comunista do Brasil. Em: PARTIDO COMUNISTA DO BRASIL. A Linha Política... p. 19.

${ }^{120}$ Idem, p. 19.

${ }^{121}$ Ibidem, p. 15.

122 Ibidem, p. 22.

123 Ibidem, p. 23.

124 Ibidem, p. 19.

${ }^{125}$ Hobsbawn escreve que quando o Regime de Fidel Castro se declarou "de fato oficialmente comunista, para surpresa de todos, a URSS tomou-o sob sua proteção, mas não ao ponto de pôr permanentemente em perigo suas relações com os EUA." HOBSBAWN, Eric., op. cit., p. 423-424, grifos nossos.

${ }^{126}$ Fidel Castro fez esta declaração em primeiro de maio de 1961, após a Invasão da Baía dos Porcos em abril do mesmo ano, o que veio a contribuir para a decisão dos revolucionários cubanos assumirem o socialismo. Ainda no final de 1961, Fidel anunciou um programa marxista-leninista adaptado às condições do país, o que veio a provocar a expulsão de Cuba da Organização dos Estados Americanos e uma frase depreciativa de Fidel sobre o papel deste organismo: "Deixemos que [a OEA] faleça de morte natural". Cf. CASTRO, Fidel.
} 
latino-americana não escapou aos olhos do PC do B, que em seu Manifesto-Programa, saudou esta Revolução ao conclamar que "Cuba é um exemplo de como um povo oprimido, mas decidido a vencer, pode bater seus algozes e conseguir uma nova vida"127.

Esta esperança em obter um novo modelo societário era guiada pela determinação do Partido Comunista do Brasil em se orientar "pelo marxismo-leninismo" 128 objetivando atingir "o socialismo e o comunismo". ${ }^{129}$ A meta estratégica do PC do B, desta forma, consistiria em alcançar uma sociedade socialista como meio de conseguir a plenitude comunista, embora indicasse outro objetivo estratégico "na presente situação" "130, concretizado na obtenção de um "governo popular revolucionário”, que se caracterizaria por ser contra o imperialismo, o latifúndio e os monopólios, sintetizado na fórmula de um "governo de liberdades, cultura e bem-estar para as massas""131.

O PC do B, desta forma, se apresentava como a antítese do PCB, ao se posicionar contra o reformismo ao deixar patente sua opção pela violência revolucionária, e, conseqüentemente, afastar qualquer idéia de transição pacífica como meio de alcançar o socialismo, inclusive propugnando a derrocada do governo de João Goulart.

A postura e linguagem revolucionárias do Partido Comunista do Brasil, bem como seu apoio à Revolução Cubana atraíram militantes de diversos setores sociais que se encontravam descontentes com a linha política de transição pacífica preconizada pelo PCB, entre os quais, integrantes das Ligas Camponesas ${ }^{132}$ e do Movimento Revolucionário Tiradentes (MRT) ${ }^{133}$, que estavam em luta franca contra o governo Goulart pela reforma

Hoy somos un pueblo intero conquistando el porvenir. México: Siglo Veintiuno, 1973. Para a citação ver p. 116.

${ }^{127}$ PARTIDO COMUNISTA DO BRASIL. Manifesto-Programa... p. 23.

${ }^{128}$ Idem, p. 19.

${ }^{129}$ Ibidem, p. 19.

${ }^{130}$ Ibidem, p. 19.

131 Ibidem, p. 19.

${ }^{132}$ As Ligas Camponesas se constituíram em um movimento organizado inicialmente em Pernambuco por Francisco Julião na época do governo de Juscelino Kubitschek e preconizavam a reforma agrária imediata. Os camponeses promoviam invasões de terras que foram se alastrando para os Estados do Maranhão, Paraíba, Bahia, Rio de Janeiro, Rio Grande do Sul e Goiás. Cf. Para as Ligas Camponesas, ver MORAIS, Clodomiro Santos de. História das Ligas Camponesas do Brasil. v. 1. Brasília: Iattermund, , 1997; AZEVEDO, Fernando Antonio. As Ligas Camponesas. Petrópolis: Vozes, 1982. BANDEIRA, Luiz Alberto Moniz. O Governo João Goulart. As lutas sociais no Brasil. 1961-1964. Rio de Janeiro: UnB-Revan, 2001, p. 75 e ss.

${ }^{133}$ O MRT constitui-se em uma tentativa de luta armada visando a conquista do poder para a implantação de um modelo socialista no Brasil, ainda durante o governo João Goulart. Foi um movimento também criado por Francisco Julião - que regressara de Cuba entusiasmado com a experiência da Revolução que ali triunfara em 1959 — , a partir das Ligas Camponesas. O dirigente abandonou a perspectiva legalista que tinha sobre a atuação das Ligas, e começou a pregar uma concepção socialista coletivizante de reforma agrária. Em um congresso realizado em Belo Horizonte (em novembro de 1961) Julião propalou a palavra de ordem “reforma agrária já. Reforma agrária na lei ou na marra”. Em 21 de abril de 1962 lançou em Ouro Preto o Movimento Revolucionário Tiradentes, que adotou uma perspectiva socialista imediata inspirada na 
agrária. Dentre estes se destaca a entrada para o PC do B de três figuras protagônicas desses movimentos, que posteriormente viriam a formar o núcleo em torno do qual se aglutinariam aqueles que viriam constituir a Ala Vermelha: Élio Cabral de Souza, Diniz Cabral Filho e Tarzan de Castro.

Por sua atuação política foram todos convidados para ingressar no PC do B por João Amazonas ${ }^{134}$, no qual entram no final de 1962, principalmente em razão das idéias críticas à linha do XX Congresso do PCUS que o partido propagava, e em virtude do apoio que o mesmo prestava à Revolução Cubana. Passaram a militar no PC do B enquanto partido da classe operária, e continuaram a fazer seus trabalhos nas Ligas e no MRT agora por eles vistos como movimentos sociais — visando, de um lado, continuar a apoiar esse movimento de enfrentamento do governo Goulart, e, de outro, para buscar novos militantes para o PC do B em Goiás ${ }^{135}$. Posteriormente são deslocados pelo partido para a capital federal, onde participariam do "Levante dos Sargentos" "136, de 1963, na denominada "Tomada de Brasília" - cujo plano inicial previa outros levantes, como em Recife, no Rio de Janeiro, Porto Alegre, e outras capitais brasileiras ${ }^{137}$. Élio, Diniz e Tarzan continuavam suas militâncias no PC do B em Goiás, quando aconteceu o golpe de 1964.

A implantação do Regime Autoritário a partir de 1964 significou para parte do movimento comunista do Brasil, o ponto de superação das teses de Kruchev sobre a "transição pacífica", as quais viriam a ser suplantadas pela idéia da revolução, o que permitiria o livre fluxo às elaborações vindas não mais de Moscou, mas da China e Cuba, que passavam a ocupar o espaço deixado em aberto pelo "revisionismo" soviético com referencial revolucionário mundial, e não apenas no Brasil.

Revolução Cubana, e se orientou na preparação da luta armada, com o apoio de Cuba. O MRT comprou fazendas onde foram instalados campos de treinamento guerrilheiro. Cf. GORENDER, Jacob, op. cit., p. 51 e ss. Para o apoio de Cuba às Ligas Camponesas uma vez que a autora não faz distinção entre este movimento e o MRT, cf. ROLLEMBERG, Denise. O Apoio de Cuba à Luta Armada no Brasil: o treinamento guerrilheiro. Rio de Janeiro: Mauad, 2001, p. 21 e ss; MORAES, Denis de. A Esquerda e o golpe de 64. Rio de Janeiro: Espaço e Tempo, 1989, p. 83 e ss.

134 SOUZA, É. C. de.; CASTRO, T. de. Élio Cabral; Tarzan de Castro: depoimento [ago. 2005]. Entrevistador: T. A. D. Silva. Goiânia, 2005. CD 1, faixa 13.

${ }^{135}$ SOUZA, É. C. de.; CASTRO, T. de., cit., CD 1, faixas 14-15.

136 O denominado "Levante dos Sargentos" consistiu em uma rebelião em 12 de setembro de 1963, em Brasília, promovida não apenas por sargentos, mas integrada também por suboficiais e cabos, pertencentes sobretudo da Aeronáutica e da Marinha, comandada pelo sargento da Aeronáutica, Antonio Prestes de Paula. A motivação alegada para a revolta teria sido a recusa do Supremo Tribunal Federal em reconhecer a elegibilidade de alguns sargentos que se candidataram e haviam sido eleitos, mas tiveram seus mandatos cassados. Os rebeldes chegaram a ocupar a Rádio Nacional de Brasília, mas não divulgaram nenhum manifesto. O governo conseguiu, em poucas horas, abafar o movimento, que deixou um saldo de duas pessoas mortas, um militar e um civil. Para o tema, ver: BANDEIRA, Luiz Alberto Moniz, op. cit., p. 124 e ss.

${ }^{137}$ SOUZA, É. C. de.; CASTRO, T. de., cit., CD 1, faixa 28; CD 2, faixa 1. 
Era o momento da "Nova Esquerda" brasileira, que se traduzia no questionamento do revisionismo e da liderança do Partido Comunista Brasileiro e confluía para propostas revolucionárias, como as do $\mathrm{PC}$ do $\mathrm{B}$, cuja proclamação era: “O Partido Comunista do Brasil é o partido da revolução [que] luta para assegurar a hegemonia do proletariado na revolução" ${ }^{138}$. Acrescentava, o PC do B, sua opção explícita pela luta armada, ao consignar "só a luta decidida e enérgica, as ações revolucionárias de envergadura darão poder ao povo"139, e consistia "em tarefa primacial do povo brasileiro" "140 uma vez que "os exitos golpistas são temporários [e apenas] enveredando pelo caminho revolucionário (...) o povo brasileiro acabará triunfando"141

Contudo este partido não se converteu no pólo que catalisaria a adesão total das consideráveis correntes que se desligavam do "Partidão"142, bem como de outras integradas por marxistas independentes ${ }^{143}$, que viriam formar uma variada constelação de

138 PARTIDO COMUNISTA DO BRASIL. Resposta a Kruschov. In: PARTIDO COMUNISTA DO BRASIL. A Linha Política Revolucionária...p. 38.

${ }^{139}$ PARTIDO COMUNISTA DO BRASIL. Manifesto-Programa... p. 15.

140 PARTIDO COMUNISTA DO BRASIL. O Golpe de 1964 e seus Ensinamentos. Em: PARTIDO COMUNISTA DO BRASIL. A Linha Política... p. 79.

${ }^{141}$ PARTIDO COMUNISTA DO BRASIL. O Golpe de $1964 \ldots$ p. 79.

${ }^{142}$ Epíteto atribuído ao Partido Comunista Brasileiro (PCB) por seus próprios militantes e adotado pela esquerda brasileira em geral.

${ }^{143}$ Ressaltamos aqui a existência de duas organizações importantes existentes anteriormente ao Golpe de 64: a Ação Popular (AP) e a Política Operária (POLOP). A AP nasceu em 1962, formada a partir da Juventude Universitária Católica (JUC), que participava do movimento estudantil, onde detinha uma posição hegemônica no período pré-64. A AP contava com uma estreita ligação com o movimento de massa camponês e preocupava-se também com o setor operário, sendo muito próxima sua atuação nesta época à esquerda do PCB. O Golpe de 64 trouxe impactos também para a AP, que em 1965 apresenta uma "Resolução Política", onde fica claro a utilização de um direcionamento marxista. Os tempos de 1966-1967 também vão atingir a Ação Popular, quando seus dirigentes passam a adotar as idéias de Mao Tsé-tung, o que provocou o afastamento dos militantes cristãos, os quais constituíam a maioria da Ação Popular. A partir de 1968 a AP já se apresentava como uma organização revolucionária identificada com a proposta leninista de partido de vanguarda, que embora não tenha formulado uma linha oficial nesse sentido, se inclina pelo mesmo caminho do PC do B e da Ala Vermelha, ao incorporar igualmente o ideário maoísta. As proximidades com o PC do B levam à cisão da AP em 1972, quando a maioria de seus integrantes incorporase a este partido, enquanto os remanescentes vem a reorganizá-la, quando ficou conhecida como "AP Socialista" ou pela sigla APML (Ação Popular Marxista Leninista). A Organização Revolucionária Marxista Política Operária (POLOP) desponta em fevereiro de 1961 pela reunião de grupos provenientes da Liga Socialista de São Paulo (seguidores de Rosa Luxemburgo) e da Mocidade Trabalhista de Minas Gerais (que aceitavam as teses de Trotsky sem rigor dogmático, afora outras teorias de pensadores marxistas), além de dissidentes do PCB e setores trotskistas. Inicialmente atuou como uma "consciência crítica" da esquerda brasileira, dirigida para o estudo e debate doutrinário e teórico, e editava uma publicação, Política Operária, cujas iniciais vêm a originar seu nome. Em torno dessa organização figurariam jovens intelectuais, como Theotônio dos Santos, Vânia Bambirra, Moniz Bandeira, Juarez Guimarães de Brito, Ruy Marini, Eder e Emir Sader, e de uma figura que se destacava dentre eles, a do comunista alemão Eric Sachs, que ficaria conhecido por seu pseudônimo Ernesto Martins. Antes de 1964 não chegou a confeccionar documentos organizacionais, e a partir do Golpe experimentou um fortalecimento, atraindo setores expressivos de militares nacionalistas, envolvidos nas manifestações de sargentos e marinheiros entre 1963-64. A partir de 1967 a POLOP desenvolveu uma fundamentação teórica consubstanciada no "Programa Socialista para o Brasil", e logo vem a adotar o caminho da luta armada. Cf. para a Ação Popular, LIMA, Haroldo; ARANTES, Aldo. História da Ação Popular. Da JUC ao PCdoB. São Paulo: Alfa-Ômega, 1984, p. 13 e ss. 
organizações guerrilheiras dispostas a derrubar, pela força das armas, o Regime brasileiro $^{144}$.

O Partido Comunista do Brasil viria igualmente a receber, entretanto, setores descontentes com a linha política do PCB, entre os quais se destaca Derly José de Carvalho, que também exerceria um papel preponderante nos primeiros momentos de existência da Ala Vermelha. Uma expressiva parcela de militantes oriunda do movimento estudantil em São Paulo, Minas Gerais, Rio de Janeiro, Rio Grande do Sul, Distrito Federal, Ceará e outros Estados do Nordeste veio a ingressar no PC do B após o Golpe de 1964. A maior parte dos novos membros vindos das lutas estudantis não pertencia anteriormente a outras organizações e ingressaram no Partido Comunista do Brasil juntamente como os ex-militantes do "Partidão", tendo em vista a opção revolucionária e, conseqüentemente, a perspectiva de luta armada que o PC do B sintetizava no período.

Os exemplos das Revoluções da China e de Cuba, da Guerra do Vietnã, os movimentos guerrilheiros implantados na Argentina ${ }^{145}$, Colômbia ${ }^{146}$, Venezuela ${ }^{147}$,

Para a POLOP, cf. PROJETO "BRASIL: NUNCA MAIS". Perfil dos Atingidos... p. 33 e ss.; GORENDER, Jacob, op. cit., p. 40-41.

${ }^{144}$ Em São Paulo, a dissidência do PCB se resolverá majoritariamente pela Ação Libertadora Nacional (ALN); no Rio de Janeiro, se reunirá em torno do Partido Comunista Brasileiro Revolucionário (PCBR), que também aglutinaria dissidentes do PCB da Guanabara, Paraná, Pernambuco e outros Estados do Nordeste. $\mathrm{Na}$ Guanabara a dissidência do Partidão irá confluir no Movimento Revolucionário 8 de Outubro (MR-8); em Minas Gerais, na Corrente Revolucionária de Minas Gerais (CORRENTE). A POLOP também não ficou isenta de dissidências, e a quase totalidade do Regional desta organização em Minas Gerais dela se desligaria para vir a fundar os Comandos de Libertação Nacional (COLINA), enquanto que em São Paulo, a ala esquerda da POLOP vem a formar a Vanguarda Popular Revolucionária (VPR), juntamente com militantes dissidentes do PCB e setores remanescentes do Movimento Nacional Revolucionário (MNR). O que restava da POLOP fundiu-se à dissidência do PCB no Rio Grande do Sul, para constituir o Partido Operário Comunista (POC). Estas organizações se constituem matrizes de outras que posteriormente viriam a se formar a partir de dissidências que nelas surgiriam. Assim, sua inserção neste trabalho não possui cunho exaustivo, mas tão somente a indicação das organizações nascidas originariamente de "rachas" com o PCB e da POLOP. Para um exame detalhado destas organizações revolucionárias, ver REIS FILHO, Daniel Aarão. As organizações comunistas e a luta de classes. 1987. 1235 f. Tese (Doutorado em História) - Universidade de São Paulo, São Paulo, 1987; A Revolução faltou ao encontro. Os comunistas no Brasil. São Paulo: Brasiliense, 1990; GORENDER, Jacob, op. cit.; RIDENTI, Marcelo. O Fantasma da Revolução Brasileira. São Paulo: Unesp, 1993; CARVALHO, Apolônio de. Vale a pena sonhar. Rio de Janeiro: Rocco, 1997; REZENDE, José Roberto. Ousar Lutar. Memórias da guerrilha que vivi. São Paulo: Viramundo, 2000; SYRKIS, Alfredo. Os Carbonários. São Paulo: Global, 1980; JOSÉ, Emiliano; MIRANDA, Oldack. Lamarca. O capitão da guerrilha. São Paulo: Global, 1980; CALDAS, Álvaro. Tirando o Capuz. Rio de Janeiro: Codecri, 1981; VARGAS, Índio. Guerra é Guerra, dizia o torturador. Rio de Janeiro: Codecri, PAZ, Carlos Eugênio. Viagem à Luta Armada. Rio de Janeiro: Civilização Brasileira, 1996; PAZ, Carlos Eugênio. Nas Trilhas da ALN. Rio de Janeiro: Bertrand Brasil, 1997; 1981; JOSÉ, Emiliano. Carlos Marighella. O inimigo número um da ditadura militar. São Paulo: Sol \& Chuva, 1997; PALMAR, Aluízio. Onde foi que vocês enterraram nossos mortos? Curitiba: Travessa, 2005; BETTO, Frei. Batismo de Sangue. São Paulo: Casa Amarela, 2001; CAPITANI, Avelino Biden. A Rebelião dos Marinheiros. Porto Alegre: Artes \& Ofícios, 1997; REBELLO, Gilson. A Guerrilha de Caparó. São Paulo: Alfa-Ômega, 1980. Para documentos produzidos por estas organizações, ver REIS FILHO, Daniel Aarão; SÁ, Jair Ferreira de. Imagens da Revolução, cit.

${ }^{145}$ Em 1963, na Argentina, o jornalista Osvaldo Masetti organizou, assessorado por três membros da tropa de elite de Che Guevara, o Exército Guerrilheiro do Povo (EGP), que passou a contar com dissidentes do 


\begin{abstract}
Uruguai $^{148}$, Bolívia ${ }^{149}$, Guatemala ${ }^{150}$, Peru ${ }^{151}$, Paraguai $^{152}$, Nicarágua ${ }^{153}$ e outros países
latino-americanos, pairavam sobre todos, e, especialmente, serviam como referenciais revolucionários.
\end{abstract}

O Partido Comunista do Brasil apesar de significar a alternativa revolucionária pós-

Golpe de 64, não possuía, entretanto, uma tática concreta de luta armada que viabilizasse

Partido Comunista Argentino. Masetti se intitulava Comandante Segundo, o que "indicava a existência de um Comandante Primeiro, ausente momentaneamente. Este não era outro senão Che Guevara”. Cf. ROJO, Ricardo. Meu amigo Che. Rio de Janeiro: Civilização Brasileira, 1968, p. 121 e ss. Em 1968 seria formado na Argentina, o Exército Revolucionário do Povo (ERP), de orientação trotskista, e dois anos depois, surgem os Montoneros, agrupamento que tem por base a esquerda peronista. Cf. BERARDO, João Batista. Guerrilhas e guerrilheiros no drama da América Latina. São Paulo: Edições Populares, 1981, p. 313 e ss.

${ }^{146} \mathrm{Na}$ Colômbia operavam o Exército de Libertação Nacional (ELN), desde 1964, ao qual se incorporaria o padre Camilo Torres, em 1966; as Forças Armadas Revolucionárias da Colômbia (FARC) passariam a atuar a partir de 1965; o Exército Popular de Libertação (EPL) iniciaria suas atividades em 1968. Cf. BERARDO, João Batista, op. cit., p. 141 e ss.

${ }^{147} \mathrm{Na}$ Venezuela combatiam, desde 1962, as Forças Armadas de Libertação Nacional (FALN), sob o comando de Douglas Bravo, que contava inclusive com alguns guerrilheiros cubanos e tinha diversos quadros que haviam treinado na China, na URSS e em Cuba. As FALN incorporaram cerca de sete grupos guerrilheiros que na mesma época atuavam na Venezuela e contaram com mais de mil e quinhentos homens, entre dissidentes do partido comunista, camponeses, jovens universitários e profissionais liberais. Ver BERARDO, João Batista, op. cit., p. 129 e ss.

148 O Movimento de Libertação Nacional, que ficaria conhecido como Tupamaros, surge no Uruguai em 1962, integrado por cerca de dois mil elementos de esquerda de base nacionalista, funcionários públicos, professores, bancários, uns poucos universitários e clérigos. Era considerado um agrupamento de muita eficiência, que realizou pioneiramente ações de seqüestro de diplomatas e autoridades, para exigir altos resgates. BERARDO, João Batista, op. cit., p. 333 e ss.

${ }^{149} \mathrm{Na}$ Bolívia existem dois momentos da atividade guerrilheira: o primeiro é o mais conhecido em face da presença de Ernesto Che Guevara à frente do da coluna guerrilheira e dura até o final de 1967, quando a morte do Che e de diversos outros combatentes fazem arrefecer o movimento. O segundo inicia-se em 1968, sob o comando de um remanescente do grupo do Che, Inti Peredo. Cf. BERARDO, João Batista, op. cit., p. 182 e ss.

${ }^{150}$ O movimento revolucionário na Guatemala iniciou-se em 1959 em torno de ex-militares, que contavam com "um forte apoio da gente dos campos, dos estudantes (...), jovens sacerdotes e com o apoio de um ou dois bispos" e parcela do Partido Comunista daquele país. Posteriormente houve uma cisão na guerrilha, e em 1964 surgiu o Forças Rebeldes Armadas (FRA); uma outra dissidência viria a formar o Movimento Revolucionário 13 (MR-13). Ver BERARDO, João Batista, op. cit., p. 354 e ss.

${ }^{151}$ A Frente de Libertação Nacional começa sua guerrilha, em 1961, no Peru, constituindo-se em uma organização que reunia castristas e maoístas. Em 1962 iniciam suas atividades dois movimentos guerrilheiros: o Partido Operário Revolucionário (POR) - de linha trotskista, sob o comando de Hugo Blanco -, e o Movimento de Esquerda Revolucionário (MIR), integrado por dissidentes de esquerda do mais velho partido peruano. Cf. BERARDO, João Batista, op. cit., p. 161 e ss.

${ }^{152}$ Dois agrupamentos guerrilheiros atuaram entre os anos de 1959 a 1961 no Paraguai: o Movimento 14 de Mayo, que não possuía qualquer definição ideológica a não ser a derrubada do ditador Alfredo Stroessner, no poder desde 1954. A outra guerrilha era formada em torno da Frente Armada de Libertação Nacional (FULINA), ligada a grupos dissidentes do partido comunista paraguaio. BERARDO, João Batista, op. cit., p. 282 e ss.

${ }^{153}$ O movimento guerrilheiro da Nicarágua iniciou sua luta contra a dinastia dos Somoza, em 1962, quando se estabeleceram nas montanhas e trilharam o caminho da luta armada rural até 1967, quando o governo do país declarou oficialmente a extinção da guerrilha. Sua ideologia na época era a "sandinista", que trazia para os nicaragüenses o sentido de patriotismo, elaborado a partir das lutas lideradas por Augusto Cesar Sandino contra a invasão norte-americana acontecida naquele país na década de 1930. A partir de 1970 os guerrilheiros se reagruparam na forma de uma frente única, abrigando diversos segmentos sociais que se denominou Frente Sandinista de Libertação Nacional, e chegaram ao poder em 1979, com a derrubada do regime ditatorial de Anastasio Somoza Debayle. Cf. MAREGA, Marisa. A Nicarágua Sandinista. São Paulo: Brasiliense, 1981. Para o ideário de Sandino, ver SELSER, Gregório. Sandino. General de homens livres. São Paulo: Global, 1979. 
sua estratégia da substituição do governo atual — na formulação herdada das teses de seu IV Congresso - por um governo popular revolucionário. O que se pode deduzir da leitura de seu "Manifesto-Programa" 154 é apenas que se trataria de uma revolução de caráter democrático burguês, embora no contexto de dominação do Brasil pelo imperialismo, teria igualmente uma índole nacional-libertadora - o que vale dizer, uma revolução de caráter nacional-democrática ou democrático-antiimperialista ${ }^{155}$. Isso significava uma concepção "etapista" da revolução brasileira, a implantação de um governo popular revolucionário através de uma "revolução democrático-burguesa (...) organicamente vinculada à luta nacional de libertação (...) [como] etapa de preparação dos pressupostos para a (...) Revolução Socialista"156 — ou seja, prosseguia então o PC do B seguindo os ditames da Internacional Comunista de 1928, em uma tendência que ainda marcaria algumas das organizações revolucionárias ${ }^{157}$ que surgiriam na década de 1960 no Brasil.

A concepção tática sobre a luta armada no Brasil surgiria no Partido Comunista do Brasil em um documento que analisava o Golpe de 1964. A estratégia embora mantivesse o caráter "etapista" foi modificada em coerência com o caráter do Regime Autoritário implantado no país, e passou a se traduzir na "luta contra a ditadura" "158 visando a instauração de um "governo representativo (...) [da] frente única, que abarca desde os operários e camponeses até a burguesia nacional, um governo que, por isso, será automaticamente democrático"159 e teria a natureza "antiimperialista". O governo democrático-burguês antiimperialista seria fruto da conjugação de táticas que abarcariam "todas as formas de luta"160 contra o Regime.

Mantinha o PC do B a concepção delineada no Manifesto-Programa de um governo nacional-democrático ou democrático-antiimperialista, indicava de um modo genérico, porém clarificador, sua opção preferencial pelas lutas do campesinato juntamente com as da classe operária, visto que "o movimento democrático e antiimperialista, sem contar com

\footnotetext{
${ }^{154}$ Cf. PARTIDO COMUNISTA DO BRASIL. Manifesto-Programa... p. 19 e ss.

${ }^{155}$ No sentido do texto, cf. LEVY, Nelson. O PC do B, continuidade e ruptura. Teoria e Política, São Paulo, $\mathrm{n}^{\circ} .1,1980$, p. 25.

${ }^{156}$ El VI Congreso de la Internacional Comunista. Informes y Discusiones, p. 205, grifos originais. Apud ANTUNES, Ricardo. Os comunistas no Brasil: As Repercussões do VI Congresso da Internacional Comunista e a Primeira Inflexão Stalinista no Partido Comunista do Brasil (PCB). Cadernos AEL. Comunistas e Comunismo. Campinas, n. 2, 1995, p. 20.

157 Sobre a ascendência das teses do VI Congresso da Internacional Comunista sobre as táticas destas diversas organizações de guerrilha no Brasil, ver RIDENTI, Marcelo, op. cit., p. 25-61.

${ }^{158}$ PARTIDO COMUNISTA DO BRASIL. O Golpe de $1964 \ldots$ p. 79.

${ }^{159}$ Idem, p. 67.

${ }^{160}$ Ibidem, p. 82.
} 
um sólido apoio no campo é bastante vulnerável e pode ser liquidado pela reação" ${ }^{161}$. Por isto,

\begin{abstract}
"Embora se deva dar bastante atenção às lutas na cidade, porque aí se encontram as grandes massas de operários, de estudantes e a intelectualidade, o trabalho no campo deve constituir uma preocupação central. A aliança entre operários $e$ camponeses é o alicerce sobre o qual deve ser erigida a frente única democrática e antiimperialista" 162
\end{abstract}

O documento do PC do B acrescentava ainda pontos que deixavam mais translúcida sua decisão pela luta armada no campo:

“É no interior que vive a maioria da população (...) [sob] condições de vida (...) piores possíveis (...) Não gozam de mínimos direitos. Trabalham sob regime de feroz exploração. São, potencialmente, uma grande força revolucionária, que começa a despertar”.

“É necessário, pois, empenhar-se ao máximo para organizar e desenvolver o movimento camponês. Tendo em vista que a luta de libertação nacional será dura e prolongada e se travará fundamentalmente no interior do país (...) tudo indica que é no campo onde surgirão os primeiros focos de resistência aos inimigos de nosso povo. (...) a questão camponesa é o problema chave da Revolução Brasileira” ${ }^{\text {163 }}$.

O documento demonstra que o Partido Comunista do Brasil proclamava, sem nada dissimular, sua decisão pela aliança operário-camponesa como tática essencial da revolução brasileira, a qual implicava a condução imediata à luta armada no campo, através da acepção chinesa de guerra popular prolongada ${ }^{164}$. Trata-se da primeira fonte

\footnotetext{
${ }^{161}$ PARTIDO COMUNISTA DO BRASIL. O Golpe de 1964... p. 66.

${ }^{162}$ Idem, p. 66, grifos nossos.

${ }^{163}$ Ibidem, p. 66-67, grifamos.

${ }^{164}$ A partir da inversão feita por Lênin da máxima do general prussiano Von Clausewitz ("a guerra nada mais é do que a continuação das relações políticas por outros meios"), para o postulado "a política é a continuação da guerra por outros meios", Mao Tsé-tung conceitua a guerra como sendo "a política com derramamento de sangue", enquanto que a política consiste na "guerra sem derramamento de sangue" (Mao, p. 102). A práxis política visando à consecução de um projeto político socialista, na visão maoísta do leninismo, conduz à percepção da inexorabilidade da guerra para atingir o objetivo estratégico da conquista do poder do Estado. O processo de luta revolucionária inevitavelmente teria de ser conduzido pelo partido comunista ao qual caberia a ação política de organizar as massas para que viessem a executar as diretrizes partidárias para derrotar o inimigo de classe (Mao, p. 44 e ss). Para cumprir tal missão haveria de ser travada uma guerra duradoura e contínua, a qual que se valeria do cerco das cidades pelo campo, para
} 
documental que revela que as aproximações do PC do B com a China de Mao Tsé-tung, culminaram na adesão do Partido Comunista do Brasil às acepções chinesas e no amparo ideológico e material do Partido Comunista Chinês ao seu homólogo brasileiro.

O apoio do PCCh se manifestaria já antes do Golpe de 1964, durante o governo João Goulart, ocasião em que são enviados à China para treinamento político e militar os dez primeiros quadros ${ }^{165}$ do PC do B, entre os quais se pode precisar os nomes de Dinis Cabral Filho e Osvaldo Orlando da $\operatorname{Costa}^{166}$. No ano seguinte se dirige ao território chinês uma delegação mais ampla com a mesma finalidade de capacitação, que inclui Élio Cabral de Souza e Tarzan de Castro ${ }^{167}$. Em 1966 outro numeroso grupo seria conduzido para ser

alcançar a meta estratégica da aliança proletária-camponesa (Mao, p. 155-156). O conflito a ser deflagrado apresentaria distintas táticas variáveis de acordo com as circunstâncias concretas - conforme fossem "favoráveis para si e desfavoráveis para o inimigo" (Mao, p. 102) -, que inicialmente seriam travadas por movimentos guerrilheiros até surgirem, na luta, as condições para a formação de um exército revolucionário - que a partir de então se incumbiria daquelas tarefas táticas. A guerrilha seria desta forma o embrião do exército revolucionário, e teria de atuar como parte integrante "dessa forma particular da atividade social', que constitui na "experiência da guerra", consistente em uma "experiência especial" e para a qual todos os que dela participassem deveriam "desprender-se dos hábitos correntes e adaptar-se a ela, a fim de poder ganhá-la" (Mao, p. 103) ${ }^{164}$. Em face da superioridade do inimigo frente as debilidades de um movimento guerrilheiro em seu estágio inicial - fragilidade em armas e adestramento, "porém não em moral", como enfatizava Mao (p. 114) - os componentes da guerrilha deveriam cumprir tarefas táticas específicas, assim sistematizadas por Reis Filho: enfraquecer o inimigo com ataques às suas forças que estivessem dispersas e isoladas; concentrar em cada desses combates um nível de força superior ao do inimigo, e, portanto, nunca entrar em combate sem superioridade e conseqüente certeza de vitória; reforçar a guerrilha em homens e armas à custa do inimigo; definir como objetivo principal a aniquilação das forças inimigas; o guerrilheiro deveria ser estimulado a ter um agressivo estilo de luta (caracterizado pela coragem, pelo espírito de sacrifício, disposição para travar combates contínuos); sua luta deveria sempre visando a obtenção da mais perfeita sintonia com aspirações populares. A perspectiva de guerra de longa duração - a guerra popular prolongada - implicaria que os combatentes acumulassem forças em Bases de Apoio Revolucionárias situadas preferencialmente em zonas de difícil acesso do inimigo. Para esta sistematização, cf. REIS FILHO, Daniel Aarão. O maoísmo e a trajetória dos marxistas brasileiros. Em: REIS FILHO, Daniel Aarão et al. História do Marxismo no Brasil. Vol. 1. O impacto das revoluções. São Paulo: Paz e Terra, 1991, p. 116117. Para as referências numeradas feitas à Mao, cf. Sobre la Guerra Prolongada. Em: TSÉ-TUNG, Mao. Obras. Tomo I. Buenos Aires: La Paloma, [196-?]. Com relação à Karl Von Clausewitz, ver sua obra Da Guerra. Mem Martins: Europa-América, 1997, p. 300-301. Para a citação de Lênin, cf. La Bancarrota de la II Internacional; El Socialismo y la Guerra. Em: LÊNIN, Vladmir Ilich Ulianov. Obras Escogidas. Tomo V. 1913-1916. Moscou: Progresso, 1976, p. 219 e ss; p. 283 e ss, respectivamente.

${ }^{165}$ Para o número de militantes enviados na primeira turma de treinamento à China, cf. GORENDER, Jacob, op. cit., p. 117.

${ }^{166}$ SOUZA, É. C. de.; CASTRO, T. de., cit., CD 1, faixas 25. Osvaldo Orlando da Costa, o "Osvaldão", teve importância fundamental na Guerrilha do Araguaia promovida pelo PC do B. Foi um dos primeiros militantes a chegar à região onde se instalaria aquela luta armada (em 1966), e se constituiu em um dos comandantes militares da atividade guerrilheira. "Osvaldão" foi um dos últimos combatentes a ser morto pelas Forças Armadas, em 07 de fevereiro de 1974. Para uma visão deste movimento guerrilheiro, ver, por todos, o trabalho pioneiro de Fernando Portela, que constituiu o primeiro relato da Guerrilha do Araguaia publicado no Brasil, em uma série de sete reportagens divulgadas no Jornal da Tarde, de São Paulo, a partir de 13 de janeiro de 1979. Posteriormente Portela editou seu trabalho pioneiro em um livro acrescido de outras informações. Cf. PORTELA, Fernando. Guerra de Guerrilhas no Brasil. São Paulo: Global, 1979. Para a data da chegada de Osvaldo Orlando da Costa no local da guerrilha, ver p. 164 desta obra. Para o dia de sua morte, cf. MORAIS, Taís; SILVA, Eumano. Operação Araguaia. Os arquivos secretos da guerrilha. São Paulo: Geração, 2005, p. 579.

${ }^{167}$ SOUZA, É. C. de.; CASTRO, T. de., cit., CD 1, faixas 25-28. 
habilitado militar e doutrinariamente na China, integrado, entre outros, por Derly José de Carvalho e Edgard de Souza Martins ${ }^{168}$.

O envio de militantes para treinamento na China, se cercou de sigilo no seio do Partido Comunista do Brasil e nenhum documento oficial partidário veio a tratar do tema na época. A questão da luta armada que estava sendo preparada pelo PC do B constituía um tema que ficava completamente vedado à sua militância, cuja grande maioria possuía, como já se destacou, uma visão de ingressar para o partido para praticar a violência revolucionária contra o Regime Autoritário, com o objetivo de derrubá-lo e substituí-lo por um democrático-burguês antiimperialista, a primeira etapa para a transição ao socialismo - como preconizava o documento "O Golpe de 1964 e seus Ensinamentos".

Esse quadro implicava o questionamento de bases partidárias, particular, mas não exclusivamente, oriundas do movimento estudantil, sobre a questão da luta armada. Como e quando começaria um trabalho efetivo que viabilizasse as ações de violência revolucionária contra o Regime Autoritário brasileiro pós-64 era uma discussão travada entre a militância que não obtinha resposta dos organismos de direção partidária, os quais, por vezes, faziam apenas alusões imprecisas afirmando que o tema era "secreto" e exclusivo do Comitê Central ${ }^{169}$. Insistiam os militantes na argumentação que se embasava na opção feita pelo PC do B pela via revolucionária em contraposição ao reformismo do PCB, principalmente após sua adoção do pensamento de Mao Tsé-tung e de sua noção de guerra popular, que estavam inspirando movimentos de guerrilha na Ásia, América Latina e África.

A negativa peremptória em debater a questão revolucionária com a militância por parte da direção do PC do B, todavia, não era destituída de fundamentação. O Partido Comunista do Brasil havia feito sua opção pela implantação pela da luta armada no país a denominada " 5 . Tarefa" ${ }^{170}$ - e começara paulatinamente a adotar medidas concretas na

\footnotetext{
${ }^{168}$ CARVAlHO, D. J. de. Derly José de Carvalho: depoimento [dez. 2005]. Entrevistador: T. A. D. Silva. São Paulo, 2005. CD 1, faixa 23. Esclarecemos que posteriormente Élio Cabral, Derly Carvalho, Diniz Cabral e Edgard de Souza Martins viriam a ser dirigentes nacionais da Ala Vermelha.

${ }^{169}$ Nesse sentido as afirmações de Renato Tapajós: "a resposta que era dada pelo Lincoln Oest [que dava assistência às bases estudantis], era constante: 'a direção é que está cuidando disso, é uma tarefa secreta dos organismos de direção' e que nós 'não tínhamos de ficar sabendo de nada' sobre o assunto". TAPAJÓS, R. C. Renato Carvalho Tapajós: depoimento [fev. 2005]. Entrevistador: T. A. D. Silva. Campinas, 2005. CD 1 , faixa 3 .

${ }^{170}$ A " 5 a . Tarefa" traduzia-se na efetiva preparação e conseqüente deflagração da luta armada a ser implantada pelo PC do B. Esta tarefa e as demais que a antecediam eram concepções da tática do partido que permitiria atingir sua estratégia, a de "conduzir o povo à conquista dos objetivos da revolução nacional $e$ democrática". Embora todas estas tarefas fossem contempladas em diversos documentos anteriores à VI Conferência, é após a realização desta que todas elas surgiriam de forma sistematizada, em um documento datado de novembro de 1967. Em comprovação a estas assertivas, salientamos que o referido documento
} 
sua preparação. No período compreendido entre final de 1963 e início de 1964, o PC do B já estruturara uma Comissão Militar ${ }^{171}$ cuja tarefa inicial consistiu em determinar a área na qual seria deflagrada a guerrilha. Primeiramente pensou-se na criação de várias frentes de luta para depois fixar-se em três, das quais restaria apenas a do Araguaia ${ }^{172}$.

A luta guerrilheira no Brasil bem como as atividades da Comissão Militar em promover o estabelecimento de áreas para a irrupção da luta armada foram cercadas de um sigilo que Pedro Pomar qualificou posteriormente de conspirativo ${ }^{173}$. Os próprios militantes inicialmente enviados à China não tinham conhecimento do local onde seria realizada a guerrilha que iriam conduzir ${ }^{174}$, e poucos membros do terceiro grupo ${ }^{175}$ apenas souberam da existência de uma área chamada de "prioritária" — denominação esta para se referir à região do Araguaia que perduraria até o ano de 1971, sendo que o próprio conhecimento deste processo guerrilheiro pela militância do PC do B ocorreu somente em 1975 e a verdade sobre a derrota sofrida apenas aconteceria em abril de 1976, embora de maneira esparsa e vaga ${ }^{176}$.

O sigilo acontecia em decorrência da prevalência, dentro da Comissão Executiva do Comitê Central do Partido Comunista do Brasil, da concepção que a " 5 a. Tarefa" exigia

advertia que "todos estes aspectos da tática do Partido (...) constituem parte de um todo, [e] devem ser vistos num conjunto harmônico com a política do Partido em íntima conexão com seu Manifesto-Programa" que era datado de 1962. Assim, no interregno histórico compreendido entre 1962 e 1967, as tarefas do PC do B consistiam em: 1ª . Tarefa: política de "união de todas as forças favoráveis à derrubada da ditadura", visando alcançar a "independência, o progresso e a liberdade". $2^{\mathrm{a}}$. Tarefa: combate ao imperialismo norteamericano e seus aliados, por meio da "concentração dos ataques no imperialismo ianque e na ditadura", a qual expressaria os interesses deste imperialismo e de "seus sustentáculos internos". $3^{\mathrm{a}}$. Tarefa: promover "ações de massas, cada vez maiores, nas cidades e no campo, em todos os aspectos". 4a. Tarefa: privilegiar o trabalho do partido fundamentalmente na área rural, "não só pelo fato de que os homens do campo constituem a força básica da revolução, mas também porque o interior é o cenário mais favorável à luta armada”. 5a. Tarefa: "utilização de todas as formas de luta, tanto abertas quanto clandestinas, [para a] preparação e desencadeamento da luta armada, com o propósito de desenvolver a guerra popular", uma vez que "a luta armada é o único meio de modificar o estado de coisas vigente" e colocava-se "como necessidade imperiosa para todos os que anseiam pôr fim ao odioso sistema político implantado pelos militares". Para as citações realizadas, cf. PARTIDO COMUNISTA DO BRASIL. O Partido Comunista do Brasil na Luta contra a Ditadura Militar. In: PARTIDO COMUNISTA DO BRASIL (M-L). Guerra Popular - Caminho da Luta Armada no Brasil. Lisboa, Maria da Fonte, 1974, p. 36-39.

171 POMAR, Wladimir. O partido e a guerrilha. In: POMAR, Wladimir. Araguaia: o Partido e a guerrilha. São Paulo: Global, 1980, p. 23.

${ }^{172}$ ARROYO, Ângelo. Um grande acontecimento na vida do país e do Partido. In: POMAR, Wladimir, op. cit., p. 275-276. Arroyo informa detalhadamente a respeito das três frentes implantadas pelo PC do B, as quais se situavam "uma em Goiás, outra no Maranhão e a do Araguaia”. A frente de Goiás "desmantelou-se (o responsável, além de erros que cometera, desistiu de desenvolver o trabalho já avançado); a do Maranhão ficou ameaçada de ser denunciada por um elemento que fraquejou e conhecia pistas que podiam afeta-la; ficou apenas a do Araguaia”. Cf. op. cit., p. 276.

${ }_{173}$ POMAR, Pedro. Sobre o Araguaia. (Intervenção no debate do Comitê Central do Partido Comunista do Brasil. Julho de 1976). In: POMAR, Pedro et al., op. cit., p. 203.

${ }^{174}$ SOUZA, É. C. de.; CASTRO, T. de., cit., CD 2, faixa 7.

${ }^{175}$ CARVALHO, D. J. de., cit. CD 1, faixa 25.

${ }^{176}$ POMAR, Pedro. Sobre o Araguaia... p. 200. 
cuidados intensos para não ser descoberta pelos órgãos de repressão. Deveria ser realizada de maneira secreta, sob a responsabilidade de quadros especialmente capazes e especificamente selecionados para tal finalidade. Assim, foram escolhidos militantes com atributos "especiais" e "militares", cujas tarefas somente deveriam ser conhecidas por eles próprios e por um pequeno grupo dentro da já restrita Comissão Executiva (C. E.) do partido.

Imperava, assim, a acepção, dentro desse pequeno grupo da C. E. do PC do B, que o partido e sua atividade política não poderiam, em nome da segurança, estar presentes na área onde se realizaria o trabalho militar. Isto é evidenciado pelas anotações de Ângelo Arroyo: “não existiam organizações do P. [partido] nas áreas periféricas, nem mesmo nos Estados vizinhos [à região do Araguaia]"177. Desta maneira, apenas o pequeno grupo da Comissão Executiva possuía uma visão do que realmente acontecia no processo de preparação da luta armada, ficando excetuados os demais membros da própria C. E., o Comitê Central, as Direções Regionais, Municipais, e, obviamente, os militantes em geral $^{178}$.

O oficial dualismo que se formava então abarcava, de um lado, os procedimentos preliminares para a deflagração da luta armada no campo, e, de outro, a imensa maioria do partido, que conclamava por ela, e obtinha respostas vagas e aparentemente contraditórias com o chamamento para a luta armada, como as elencadas no documento do PC do B sobre o Golpe de 1964:

\footnotetext{
${ }^{177}$ ARROYO, Ângelo. Relatório sobre a Luta no Araguaia. In: POMAR, Wladimir, op. cit., p. 251.

${ }^{178}$ O conjunto do partido apenas conheceria oficialmente a Guerrilha do Araguaia no início de 1975, após, portanto, o término da luta armada naquela região. Entretanto, ao dar esta notícia, o órgão nacional do PC do B, o Classe Operária, noticiou a existência da luta armada no norte do Brasil, ao afirmar que "os guerrilheiros do Araguaia defendem os direitos da gente do interior (...) as Forças Armadas do Araguaia empreendem uma grande campanha patriótica e democrática". Cf. PARTIDO COMUNISTA DO BRASIL. Classe Operária, [S. 1.], nº. 93, jan., 1975, p. 1. Notamos, entretanto, a existência de ao menos dois periódicos, o Brasil Notícias e $O$ Araguaia (cujo objetivo era apoiar e difundir a luta guerrilheira), que noticiaram antes a guerrilha - respectivamente em 14 de fevereiro de 1974 e 1 de julho do mesmo ano. Na grande imprensa, o "furo" foi dado pelo jornal $O$ Estado de São Paulo, que em uma edição de setembro de 1972 publicou matéria sobre o movimento guerrilheiro do Araguaia, escapando miraculosamente da censura existente à época no Brasil. Já a derrota do movimento guerrilheiro na região do Araguaia somente seria reconhecida para o conjunto partidário pela direção do PC do B no ano de 1976, quando o Classe Operária publicou que a luta travada entre guerrilheiros das Forças Armadas foi "tremendamente desigual", e que "apesar da desigualdade material, os guerrilheiros não se submeteram, nem capitularam". Dizia o jornal, que embora "temporariamente a guerrilha tenha retrocedido" continuavam os ideais que a guiavam "bem vivos e atuantes na consciência dos lavradores, do campesinato de todo o país", mesmo porque os guerrilheiros teriam recebido, ao longo de sua luta, "a solidariedade e ajuda mútua, a calorosa simpatia da população". Cf. Classe Operária, [S. 1.], no. 105, abr., 1976, p. 1. Para as referências aos três periódicos do PC do B mencionados, cf. POMAR, Wladimir. O partido... p. 47 e 246-247. Com relação à matéria divulgada pelo "Estadão", ver PORTELA, Fernando, op. cit., p. 27.
} 
"na ação política de massas é necessário atuar sempre tendo em vista a revolução (...) seria incorreto pensar que somente a luta armada é trabalho revolucionário. Essa luta é, sem dúvida, a forma mais alta de atividade revolucionária. Mas não é possível prescindir, ao lado do esforço ininterrupto para fortalecer a vanguarda, da ação política de massas"

O descontentamento que a atuação prática do Partido Comunista do Brasil gerava em meio a seus militantes, ao não discutir com as bases partidárias a questão da opção pela luta armada que o pequeno grupo da Comissão Executiva já fizera, foi acrescido de um outro fator de insatisfação que era manifestado por parcela dos militantes que haviam sido enviados à China.

Ao regressarem de seus estágios nas academias políticas e militares chinesas, Élio Cabral e Tarzan de Castro voltaram questionadores, à vista do embasamento teórico que lá receberam ${ }^{180}$. Haviam deixado as concepções foquistas ${ }^{181}$ que possuíam como fruto de suas convivências no MRT com instrutores e o ideário cubanos ${ }^{182}$, e passaram a ter uma visão mais centrada nas acepções maoístas, como a da guerra popular prolongada. As novas perspectivas que se revelaram para ambos na China levantavam questões acerca da linha política adotada pelo Partido Comunista do Brasil, bem como de sua própria estrutura organizativa.

Dividiram suas inquietações com seu antigo companheiro de MRT, Diniz Cabral, que havia estado antes deles em treinamento na China, e puderam constatar o seu partilhar pelas mesmas incertezas que possuíam. Nas academias chinesas todos haviam apreendido

\footnotetext{
${ }^{179}$ PARTIDO COMUNISTA DO BRASIL. O Golpe de 1964... p. 82-83.

${ }^{180}$ Tarzan de Castro diz que haviam ido para a China "como dóceis instrumentos de uma futura organização revolucionária e voltamos questionadores, com uma base teórica para questionar". SOUZA, É. C. de.; CASTRO, T. de., cit., CD 2, faixa 4.

${ }^{181} \mathrm{O}$ vocábulo foquista é derivado do termo foquismo, expressão que se convencionou para denominar a teoria de Regis Debray, que fez uma leitura das idéias de Che Guevara para formular uma doutrina que exprimia a inversão de um postulado da tradicional teoria leninista segundo o qual a revolução socialista deveria ser conduzida pela vanguarda do proletariado, quando houvesse condições subjetivas para tanto. Na leitura de Debray essa vanguarda política foi substituída por uma vanguarda militar - constituída por um pequeno grupo de pessoas, um "foco" - cujas ações deveriam ser criadores das condições subjetivas para a tomada do poder, dando, assim, esse pequeno "foco", o exemplo para que as massas populares viessem a aderir à luta armada. As teses cubanas, de uma maneira geral, foram denominadas de "foquistas" por partilharem na sua quase totalidade as idéias do pensador francês. Cf. DEBRAY, Regis. ¿Revolución en la revolución? Havana: Casa de las Americas, 1967.

${ }^{182}$ Tarzan de Castro conta: "abandonamos a idéia do foquismo para a idéia da guerra revolucionária prolongada. Nós éramos foquistas, não todos que estavam lá, mas eu, o Élio (...) éramos, nós tínhamos tido aquela experiência com os cubanos e a de Brasília". Cf. SOUZA, É. C. de.; CASTRO, T. de., cit., CD 2, faixa 2.
} 
sobre a necessidade da presença de condições objetivas e subjetivas ${ }^{183}$ para a deflagração da luta armada, sem as quais se tornava inviável qualquer expectativa de ações revolucionárias para a tomada do poder. Estudaram também a importância de um partido comunista forte e democrático, respaldado pela classe operária, pelos camponeses e pela população em geral. Era uma questão essencial para a condução da guerra popular prolongada, a qual deveria ser travada a partir de áreas densamente povoadas, que apresentassem um vigoroso enraizamento partidário entre os camponeses, o qual se refletiria em um considerável grau de politização - o que exigia um elevado nível ideológico dos próprios quadros partidários ${ }^{184}$.

Élio, Diniz e Tarzan iniciaram no Partido Comunista do Brasil um processo de luta interna, uma ampla discussão ideológica com todos os setores do partido, sobre as interrogantes colocadas por estes quadros partidários, visando uma nova fase de reorganização do PC do B, na busca de um conteúdo novo para o mesmo, e se consistia na:

“abertura de discussão de todas as questões fundamentais da revolução brasileira e do Partido, objetivando incentivar o interesse em todos os níveis do Partido acerca daquelas questões, estimulando todos os militantes a pensarem."

Estes quadros partidários aspiravam atingir o ápice da luta interna e dos trabalhos de reorganização do PC do B na VI Conferência do Partido Comunista do Brasil, que seria realizada em agosto de 1967.

As movimentações de Élio Cabral, Tarzan de Castro e Diniz Cabral, entretanto, não passaram despercebidas pela direção partidária. Sem explicação alguma por parte dos dirigentes, Tarzan foi mandado para São José do Rio Preto - local aonde "não havia nada,

\footnotetext{
${ }^{183} \mathrm{O}$ marxismo-leninismo compreende como condições objetivas para a ação revolucionária a crise que atravessa um determinado país, p.ex., como a instauração de uma ditadura que venha a oprimir o povo, e aprofunde seu despotismo cada dia, levando mais e mais as massas operárias e camponesas à miséria e fome. As condições subjetivas necessárias para a revolução se traduzem no fato da vanguarda proletária "estar ideologicamente conquistada (...) Lançar a vanguarda sozinha à batalha decisiva, quando toda a classe, quando as grandes massas ainda não adotaram uma posição de apoio direto a essa vanguarda ou, pelo menos, de neutralidade simpática, e não são totalmente incapazes de apoiar o adversário, seria não só uma estupidez, como um crime. E para que realmente toda a classe, para que realmente as grandes massas dos trabalhadores e dos oprimidos pelo capital cheguem a ocupar essa posição, a propaganda e a agitação, por si, são insuficientes. Para isso necessita-se da própria experiência política das massas. Tal é a lei fundamental de todas as grandes revoluções (...)". LÊNIN, Vladmir Ilich Ulianov. La enfermedad infantil del 'izquierdismo' en el comunismo. Pequim: Lenguas Estranjeras, 1971, p. 99.

${ }^{184}$ SOUZA, É. C. de.; CASTRO, T. de., cit., CD 2, faixa 2

185 A LUTA contra o oportunismo: a origem da luta interna. [S. 1.], ago./set. 1967. Coleção particular Daniel Aarão Reis Filho. SÉRIE: Ala Vermelha. Dossiê 05, doc. 86, Arquivo Público do Estado do Rio de Janeiro, p. 2, grifos nossos.
} 
não existia partido" ${ }^{186}$-, e lá foi preso. Élio é enviado para Mato Grosso, onde não mantém contato com os documentos que estavam sendo elaborados para a VI Conferência, "recebendo apenas informes verbais" 187 a respeito da mesma, por eventuais contatos de outros membros do PC do B que visitavam a região.

Diniz foi deixado pela direção do PC do B em São Paulo, porém veio a ser afastado de sua função de assistente das bases estudantis paulistas ${ }^{188}$. Com a prisão de Tarzan de Castro e o deslocamento de Élio Cabral para longe de São Paulo, Diniz Cabral veio a se transmudar no centro da oposição que aos poucos se formava. Para difundir a luta interna, Diniz mantinha uma série de contatos com as bases partidárias, se aproximando dos militantes "por fora da estrutura orgânica do partido, trazendo uma série de discussões que batiam com as questões da possibilidade da luta interna." ${ }^{189}$ Vicente Roig narra que desde o momento dos contatos de Diniz Cabral com as bases,

"As coisas mudaram radicalmente, porque ele tinha concepções para discutir com a gente, as acepções e as histórias que traz da China. Não ficava aquela coisa de falar mal do partidão. Aí que a gente cresce, começa a se politizar , a pensar, a crescer, caminhar no sentido de ser quadro"190.

Os contatos de Diniz foram multiplicadores: os militantes que contatara, irradiaram as suas preocupações para outros camaradas, num proceder que permitiria a proliferação da idéia de luta interna, agora já incorporada por diversos setores do PC do B, inclusive de outros estados.

Às vésperas da VI Conferência do Partido Comunista do Brasil os integrantes da luta interna (LI) lançam um documento no qual explicitam suas concepções fundamentais

\footnotetext{
${ }^{186}$ SOUZA, É. C. de.; CASTRO, T. de., cit., CD 3, faixa 9.

${ }^{187}$ SOUZA, É. C. de.; CASTRO, T. de., cit., CD 2, faixa 12.

${ }^{188}$ Com a remoção de Diniz Cabral, a função de assistente das bases estudantis veio a ser preenchida por Diógenes de Arruda Câmara, que ingressara no PC do B no início de 1966. Anteriormente esta assistência era dada por Miguel Pereira dos Santos (que foi à China com Élio Cabral e Tarzan de Castro e veio a morrer na Guerrilha do Araguaia, em 20 de setembro de 1972). Miguel foi sucedido por Lincoln Cordeiro Oest (morto pelos órgãos de repressão em 21 de dezembro de 1972). Para a cronologia do cargo de assistente das bases estudantis do PC do B, cf. ROIG, V. E. Vicente Eduardo Roig: depoimento [fev. 2005]. Entrevistador: T. A. D. Silva. Valinhos, 2004. CD 1, faixas 5, 7, 19 e 22. Para a data das mortes, cf. MIRANDA, Nilmário; TIBÚRCIO, Carlos. Dos filhos deste solo. Mortos e desaparecidos políticos durante a ditadura militar: a responsabilidade do Estado. São Paulo: Fundação Perseu Abramo-Boitempo, 1999, p. 176 e 198. Sobre a data da entrada de Diógenes Arruda no PC do B, ver GORENDER, Jacob, op. cit., p. 112.

${ }^{189}$ TAPAJÓS, R. C., cit. CD 1. faixa 3.

${ }^{190}$ ROIG, V. E., CD 1, faixas 18 e 19.
} 
que deveriam servir para "facilitar o esforço conjunto pela reconstrução do P. [Partido], pela formação da frente única e pela preparação da luta armada"191.

No documento inicialmente destacaram a conjuntura internacional, quando identificaram sua característica essencial como sendo, de um lado, "a luta do imperialismo para deter o movimento revolucionário" e o "retrocesso" deste movimento na União Soviética, e, por outro lado, o incremento do "movimento revolucionário na China e nos países subdesenvolvidos", desenvolvimento este que se apresentaria com "características novas' ${ }^{192}$

Passaram então à análise do movimento comunista no Brasil, quando divisaram "perspectivas alvissareiras" para as tarefas de "reconstrução" do Partido Comunista do Brasil, que seriam possibilitadas pelo incremento da fragmentação do movimento comunista no nível internacional, o que veio a colocar de um lado "o Partido Comunista Chinês e os partidos marxistas-lenistas em defesa do marxismo-leninismo e da revolução proletária", e, em um pólo oposto, o PCUS "e seus seguidores, com suas teses de transição pacífica" "193. Os integrantes da LI entendiam que esta situação internacional criara uma nova realidade para os comunistas brasileiros, e o PC do B não conseguira suplantar "algumas debilidades $e$ incompreensões" afloradas já no período que se sucedeu à sua "reorganização" em 1962, as quais não haviam sido discutidas "com a devida profundidade" no interior do partido, em razão do Golpe de 64. Os futuros dissidentes censuravam, assim, a ausência de um necessário balanço autocrítico do movimento comunista brasileiro dentro partido, o que, entendiam, teria possibilitado apontar que estes erros, que viriam do "passado mais remoto", teriam uma estreita relação com os equívocos cometidos "até os nossos dias". Donde, preconizavam, a exigência deste balanço autocrítico que daria um "novo conteúdo ao grande debate teórico que se avizinha", e colocaria à disposição dos "novos quadros um acervo de ricas experiências", desenvolvendo um trabalho de educação de partido, "ensinando-lhes uma tática revolucionária acertada à base de seus próprios erros". ${ }^{194}$ Para tanto, ressaltavam os membros da luta interna, "não há que esquivar-se (...) dos problemas espinhosos (...) nem dissimulá-los e encobri-los, nem tampouco (...) se negar a falar deles", uma vez que tal autocrítica serviria para o "conhecimento das causas dos erros do passado (inclusive do presente)”, o que seria motivo suficiente para que esta tarefa fosse assumida

\footnotetext{
${ }^{191}$ POR UM GRANDE debate revolucionário em nosso Partido. [S. 1.], 1966. Coleção particular Daniel Aarão Reis Filho. SÉRIE: Ala Vermelha. Dossiê 05, doc. 85, p. 1.

${ }^{192}$ Idem, p. 1.

193 Ibidem, p. 2.

${ }^{194}$ POR UM GRANDE debate... p. 3.
} 
prontamente "pelos velhos quadros de direção mais capazes”, pois somente eles possuiriam maiores conhecimentos destes problemas, e, conseqüentemente, teriam "mais condições para sintetizar (...) este trabalho”, o qual “a revolução proletária e o movimento comunista de nosso país não prescinde que seja realizado"195.

Os componentes da luta interna igualmente atacavam a carência de "discussão $e$ estudos profundos” no PC do B que "delineassem a elaboração teórica necessária de tão sérias questões”, como a da luta armada e a da questão camponesa. O que causava surpresa para os integrantes da LI era o fato de existir no Brasil "um movimento comunista com bastante idade para que se tivesse uma concepção mais correta" desses importantes temas. Isto porque se acaso este processo "resultasse do trabalho de pessoas inexperientes”, uma mera explicação de ausência da necessária experiência justificaria o fato de que havíamos deixado de lado "a organização do $P$." na preparação da tarefa militar, subestimando a compreensão que "sem um P. ligado as massas, é muito difícil, quase impossível, preparar conscientemente, sem aventureirismo, a luta armada em nosso país"196.

Mantendo o necessário sigilo, os futuros dissidentes faziam críticas aos dirigentes do Partido Comunista do Brasil pela escolha do Araguaia como "área prioritária" para implantação da guerrilha rural no Brasil, sem que para tanto fosse desacompanhada de um trabalho de massa entre os camponeses e nas cidades. Acrescentavam ainda a existência no PC do B de “concepções errôneas”, as quais “destroçam a organização do partido" e o conduzem a um "ponto de vista exclusivamente militar". Para que fosse sanada esta tendência, se fazia necessário "elevar o nível político do partido por meio da educação, extirpar as raízes teóricas" desta visão; enfim, havia a necessidade de todos os militantes e quadros do partido compreenderem com exatidão "a subordinação do militar ao político ${ }^{197}$.

A questão camponesa era vista pelos integrantes da LI como uma questão pouco debatida entre os marxistas-leninistas brasileiros. Este problema requeria o desenvolvimento de uma compreensão séria e minuciosa do "problema agrário desde as mais simples relações de produção e sociais existentes no campo”, através da criação, pelo partido, "de escolas de quadros camponeses", com a finalidade de "suprir a insuficiência de material humano (...) objetivando o desenvolvimento da luta revolucionária no campo”,

\footnotetext{
${ }^{195}$ Idem, p. 4.

196 Ibidem, p. 4.

${ }^{197}$ POR UM GRANDE debate... p. 5.
} 
a qual se daria através de uma visão do camponês como principal aliado do proletariado, de modo a possibilitar a percepção da questão camponesa "como uma parte do problema geral da ditadura do proletariado" ${ }^{\prime 198}$.

Finalmente aqueles militantes que viriam a se constituir no núcleo da dissidência que formaria a Ala Vermelha, debatiam os métodos e o trabalho dos dirigentes do PC do B:

"não se pode falar em estudar e discutir os problemas da revolução com a frente única, a construção do partido, a luta armada, a questão agrária, a teoria revolucionária, a prática, etc., sem suscitar sobre a necessidade da retificação dos métodos de estudo, trabalho e de direção". 199

Para corrigir estes métodos se fazia necessário "revisar todo o trabalho $e$ movimento comunista deste país”, pois para os integrantes de LI existiria no PC do B um grande volume de métodos "que por sua caducidade, carecem de revisão urgente", os quais se refletiriam no âmbito do trabalho partidário e nas relações entre "dirigentes, quadros e organismos de diferentes níveis". No trabalho, se expressaria pela ausência de estudos, de diretivas, de elaboração e discussão atinentes às questões fundamentais da revolução brasileira, gerando a "debilidade política e ideológica de grande número de militantes e quadros, o desligamento das massas", o que acarreta um resultado prático insuficiente. Tal quadro seria resultante das acepções errôneas existentes no partido e na sua incapacidade de discutir problemas, "envolvendo-os de 'mistérios' para confundir, encobrir os erros e evitar a autocrítica". 200

Nas relações entre dirigentes, quadros e organismos do PC do B, tais métodos se manifestariam, segundo os membros da LI, "no comportamento de falar pelas costas, jogar um camarada contra outro e não levantar problemas claramente nas reunioes". Isto teria constituído uma prática comum no trato entre "quadros dirigentes em contato pessoais com inferiores", que apontavam inúmeros erros para referir-se a uma determinada pessoa para posteriormente "solicitar 'sigilo', pois tal assunto ele menciona porque seu ouvinte merece-lhe grande "confiança", e, por vezes, tratava-se de "problemas graves". Esses dirigentes, visando ter "mais liberdade para continuar com essas atitudes, se prevalecem de normas de segurança e de princípios com o de que 'um revolucionário

\footnotetext{
${ }^{198}$ Idem, p. 6.

${ }^{199}$ Ibidem, p. 7, grifamos.

${ }^{200}$ POR UM GRANDE debate... p. 7-8.
} 
apenas deve saber o que concerne ao seu trabalho' a fim de manipular uma multidão de proibições" ${ }^{201}$.

De acordo com os componentes da LI, tais dirigentes se olvidavam dos ensinamentos de Mao, segundo os quais, quando surgir um problema, "há que celebrar uma reunião, colocar o problema sobre a mesa para discuti-lo e tomar decisões"202. E enfatizavam que quem não reagisse "com tenacidade aos métodos errôneos" poderia “impregnar-se deles. Isto é mal para o partido e gera desconfiança, discórdia e antipatia dentro de seus organismos e entre quadros de diferentes níveis"203.

$\mathrm{O}$ documento apresentado pelos integrantes da luta interna vem a convergir com diversas apreciações formuladas por Pedro Pomar no balanço autocrítico da Guerrilha do Araguaia, realizado dez anos depois ser confeccionada a referida documentação. Os principais afluxos entre ambos ocorrem de maneira particular no que diz respeito à questão da necessidade do trabalho de massas como condição para a deflagração da guerrilha e da exigência da participação do partido como condutor do processo revolucionário.

Em sua intervenção perante o Comitê Central do PC do B, em 1976, Pomar salientou ser fundamental para o desenvolvimento e sobrevivência de uma guerrilha a incorporação das massas à luta armada ${ }^{204}$. Dizia aquele dirigente partidário que havia sido

\footnotetext{
${ }^{201}$ Idem, p. 8.

${ }^{202}$ POR UM GRANDE debate... p. 8.

${ }^{203}$ Idem, p. 8.
}

${ }^{204}$ O PC do B iniciou em 1975 uma avaliação de sua experiência no Araguaia com o Comitê Central do partido, ocasião em que se defrontaram duas correntes básicas oriundas das posições não consensuais da Comissão Executiva. A primeira exprimia a idéia de que a derrota da guerrilha teria sido temporária e propunha a retomada do "caminho do Araguaia"; este enfoque era dado principalmente pelo informe de Ângelo Arroyo e possuía como adeptos, entre outros, João Amazonas. O outro posicionamento - que foi se tornando majoritário - refletia a postura de Pedro Pomar, que expressa uma posição crítica do trabalho desenvolvido no Araguaia, e dava conta da necessidade de empreender um trabalho político de massas e uma reconstrução das bases partidárias antes de promover a preparação da luta armada. Deste modo, Pomar se posicionava contrário à "política blanquista até então predominante na direção", e em torno do qual foram se aglutinando no C. C. "um núcleo de camaradas com disposição para empreender uma crítica em profundidade" a esta linha blanquista. Cf. POMAR, Wladimir. O partido e a guerrilha... p. 48 e ss. Esclarecemos que o vocábulo blanquismo (e conseqüentemente a palavra blanquista) traduz a significação de uma concepção esquerdista e conspirativa de revolução, a qual se daria não como obra das massas guiadas pelo partido marxista-leninista, mas através de uma insurreição que seria feita por pequenos grupos conspirativos, desconectados e independentes dos movimentos sociais. Blanquismo é um termo derivado do nome do revolucionário francês Louis-Auguste Blanqui (1805-1881), que possuiu um papel destacado na Revolução de 1848 na França. Materialista por suas concepções filosóficas gerais, Blanqui entendia que um pequeno grupo de revolucionários bem organizados poderia promover uma sublevação que conduziria as massas a uma revolução vitoriosa. Os clássicos do marxismo-leninismo, apesar de considerarem como muito elevados os méritos revolucionários de Blanqui, criticaram o blanquismo, por negar o papel da luta de classes, desprezar o trabalho de massas, e por substituir o papel do partido do proletariado pela ação de "um punhado de conspiradores" na condução da revolução. Em síntese, Blanqui "não compreendia que o êxito da revolução apenas é possível se dela participam as massas trabalhadoras dirigidas por partidos revolucionários". Para as duas citações, cf. Diccionario Soviético de Filosofía. Montevidéu: Ediciones Pueblos Unidos, 1965, p. 47-48. Para a crítica clássica ao blanquismo, ver MARX, Karl. Las luchas de clases en Francia de 1848 a 1850. Em: MARX, K.; ENGELS, F. Obras Escogidas de Marx y Engels. Tomo I. 
esta a principal dificuldade que se deparava ao tratar da experiência do Araguaia, pois o "número de elementos de massas ganho para a guerrilha foi insignificante" ${ }^{\text {.205 }}$. Na visão de Pedro Pomar a guerrilha havia se iniciado como "um corpo a corpo dos comunistas contra as tropas da ditadura militar", o que consistia "a meu ver, o maior erro" daquela luta $^{206}$. Isto porque, afirmava, "a conquista das massas não pode ser efetuada só depois da formação do grupo guerrilheiro", e que este deva ser constituído "única e exclusivamente (...) apenas de comunistas". ${ }^{207}$ Indicava Pomar a imposição para os comunistas a missão de realizar com antecedência à luta armada "um certo trabalho político de massas" bem como a "organização de um mínimo de P.[partido]"208. A tarefa dos agrupamentos guerrilheiros, assim, deveria ser o de criar na área para o qual fossem enviados, uma "base política através do trabalho entre as massas, de forma que elas decidam por si mesmas a constituição de destacamentos de autodefesa, de milícias, de guerrilhas, etc., e tomem o Poder"; se procedessem de modo inverso, "corremos o risco de cair no militarismo"

Insistia Pedro Pomar que a preparação da luta armada consistia em tarefa "de todo o Partido e não apenas de alguns especialistas", uma vez que o partido "facilita, promove, impulsiona, organiza, sustenta, dirige todo o processo" da luta armada ${ }^{210}$. Seguindo os postulados marxistas-leninistas, preconizava Pomar a submissão das tarefas militares ao controle político, exercido pelo partido comunista, como defendiam os membros da luta interna, os quais salientavam também para os perigos de se alterar essa ordem, caindo em um "ponto de vista exclusivamente militar", ${ }^{211}$ notadamente quando as massas não se encontravam presentes por ausência do trabalho prévio partidário. Ou como dizia Pomar, se o PC do B considerasse que "as massas por si mesmas, espontaneamente” resolvessem "um dia pegar em armas e se defender da violência reacionária", aquele partido estaria, na

Madri: Fundamentos, 1977, p. 135-249. LÊNIN, Vladmir Ilich Ulianov. El Marxismo y la insurrección. Carta al Comité Central del POSD(b) de Rusia. Moscou: Progresso [19- -].

${ }^{205}$ POMAR, Pedro. Sobre o Araguaia... p. 202.

206 Idem, p. 203.

207 Ibidem, p. 203.

${ }^{208}$ Ibidem, p. 204.

209 Ibidem, p. 205. Militarismo era um jargão da esquerda nos anos 1960 e 1970, o qual significava que o aspecto militar em uma determinada organização, que se traduzia nas ações armadas, se sobrepunha à discussão política no interior da mesma, assim como era privilegiado em detrimento do trabalho políticos junto aos trabalhadores, às massas. Daí dizer-se que tais organizações eram militaristas — em contraposição às massistas, as quais privilegiavam o trabalho de massa. No sentido do texto, cf. REIS FILHO, Daniel Aarão. Ditadura e sociedade: a reconstrução da memória. In: REIS FILHO, Daniel Aarão; RIDENTI, Marcelo; MOTTA, Rodrigo Patto Sá. O golpe e a ditadura militar: 40 anos depois (1964-2004). Bauru SP: Edusc, 2004, p. 43, nota 21.

${ }^{210}$ POMAR, Pedro. Sobre o Araguaia... p. 206.

${ }^{211}$ POR UM GRANDE debate... p. 5. 
realidade, adotando "o princípio 'esquerdista', blanquista, foquista, de que são os comunistas que devem pegar em armas em lugar das massas". ${ }^{212}$

A compreensão de que a Guerrilha do Araguaia se tratava de um empreendimento de caráter foquista do PC do B também era um tema que enformava o pensamento do núcleo protagônico da luta interna, pois sua maioria era constituída por antigos militantes das Ligas Camponesas e do MRT e ex-adeptos do foquismo, os quais haviam feito a autocrítica das concepções foquistas a partir das acepções maoístas que introjetaram quando passaram por estágios na China. Possuíam, a partir de então, uma visão clara que a opção do Partido Comunista do Brasil pela região do Araguaia era equivocada, uma vez que não harmonizaria com elementos essenciais da guerra popular da linha chinesa, como a inexistência naquele local de bases de apoio revolucionárias ${ }^{213}$, por se tratar o território uma região de população rarefeita, com baixa densidade demográfica, não possuía um movimento camponês organizado e inexistia "consciência política das massas, a consciência de mudanças [que as tornassem aptas a] enfrentar o inimigo de frente", enfim, "víamos que o PC do B repetia o foquismo, chamando-o de guerra revolucionária". 214

\footnotetext{
${ }^{212}$ POMAR, Pedro. Sobre o Araguaia... p. 205. Anota-se que o processo de avaliação crítica que vinha sendo realizado pelo Comitê Central C. do PC do B sobre a Guerrilha do Araguaia foi interrompido em razão das circunstâncias que culminaram na denominada "Chacina da Lapa", em 16 de dezembro de 1976, Este episódio não resultou tão somente na morte de três de seus dirigentes (Pedro Pomar e Ângelo Arroyo foram executados pelos órgãos de repressão no interior da residência onde se realizava a reunião do $C$. C., e João Batista Franco Drumond, foi morto sob tortura nas dependências do DOI-CODI de São Paulo), mas também com o desbaratamento de parte do C. C., uma vez que os agentes repressivos prenderam diversos integrantes deste organismo partidário à medida em que saíam da reunião e fossem sendo deixados em diversos pontos da capital paulista, antes mesmo do referido ataque, o qual objetivou matar os principais dirigentes do PC do B. João Amazonas sobreviveu àquela operação de aniquilamento, pois viajara, para representar o partido no $12^{\circ}$. Congresso do Partido dos Trabalhadores da Albânia em substituição a Pedro Pomar, que decidiu permanecer no país em face de doença grave de sua esposa, Cf. POMAR, Pedro Estevam da Rocha. Massacre na Lapa. Como o Exército liquidou o Comitê Central do PcdoB. São Paulo: Scritta, 1996, p.19 e ss; p. 35 e ss.; p. 67 e ss.; p. 128. A questão da Guerrilha do Araguaia foi trazida a público novamente em 1979, quando do exílio em que se encontrava, João Amazonas concedeu entrevista ao Jornal Movimento, na qual se contrapôs à posição majoritária do C. C. do PC do B existente antes dos episódios acima mencionados, ao afirmar que: "Em certo sentido, o apoio [dos camponeses] à guerrilha foi bem maior do que se podia esperar. A este respeito talvez não fosse demais repetir aqui uma verdade conhecida: a guerrilha, como uma luta política em geral, não começa quando todos a apóiam. O apoio das grandes massas se verifica no curso da luta, quando esta é justa e corresponde aos anseios populares". Cf. AMAZONAS, João. João Amazonas, Secretário geral do PC do B, analisa o momento político nacional e internacional e promete voltar ao Brasil até o fim do ano. Entrevista concedida a Alberto Villas e Manoel Domingos Neto. Movimento, São Paulo, n. 215, ago. 1979, p. 11-13, grifamos.

${ }^{213}$ Base de apoio revolucionária apresentava para os chineses o significado de uma determinada zona geográfica onde as forças revolucionárias dominam o poder público, e cujo povo se posiciona ao lado dos revolucionários, adesão esta conquistada através de um prolongado trabalho de massas. Cf. CARVALHO, D. J. de., cit. CD 1, faixas 40-44.

${ }^{214}$ SOUZA, É. C. de.; CASTRO, T. de., cit., CD 2, faixas 2 e 5. Para as demais apreciações sobre a região do Araguaia, cf. SOUZA, É. C. de.; CASTRO, T. de., cit., CD 1, faixa 26; CARVALHO, D. J. de., cit., CD 1, faixas 40-45. ROIG, V. E. G., cit., CD 1, faixa 25. TAPAJÓS, R. C., cit., CD 1, faixa 4.
} 
De outro prisma, o olhar que o núcleo dirigente da LI lançava sobre os dirigentes do PC do B refletia um grupo antidemocrático e oportunista. O caráter antidemocrático se manifestaria na extremada verticalidade das relações entre direção em geral e as bases partidárias, o que acarretava a ausência de debates internos no partido; pelo excesso de sigilo em temas que não requereriam tal condição; através da obediência irrestrita e inquestionável a determinações provindas de órgãos superiores; pelos métodos autoritários que seriam empregados pelos dirigentes em suas relações no seio partidário, métodos estes que muitas vezes extrapolavam para ofensas pessoais, afastamento e punição injustificadas de militantes etc. O oportunismo dos dirigentes do PC do B se traduziria em dois aspectos: o primeiro, de natureza objetiva, se relacionava com a recente filiação do partido às teses chinesas. Embora proclamasse haver se reorganizado em 1962 contra o revisionismo encarnado no Brasil pelo PCB, em seu Manifesto-Programa paradoxalmente continuava o PC do B a louvar a URSS, ao afirmar que "A União Soviética marcha para o comunismo" 215 . De outro lado haviam os dirigentes do Partido Comunista do Brasil tentado obter seu reconhecimento por Moscou ${ }^{216}$, o que foi negado pelo dirigente do PCUS e gerou uma dura repreensão pública de Nikita $\mathrm{Kruchev}^{217}$. Todavia, ao procurar responder ao "ataque injustificado do Comitê Central do PCUS",218, os dirigentes do PC do B, no próprio documento de resposta ao primeiro-ministro da URSS - apesar de manifestar seu apoio ao Partido Comunista Chinês e bem como ao Partido dos Trabalhadores da Albânia (PTA) e consignar que "ao apoiar e incentivar a corrente reformista de Prestes, Kruschov e o Comitê Central do PCUS colocaram-se objetivamente contra o movimento revolucionário em nosso país” — argumentaram que "Quaisquer que sejam as injúrias, as distorções da verdade dos atuais dirigentes do PCUS', manifestavam sua “admiração $e$ reconhecimento aos povos da União Soviética que realizaram a Grande Revolução de Outubro, edificaram o socialismo (...) e derrotaram o nazi-facismo"219 — uma declaração típica do indefinido linguajar diplomático.

A direção do PC do B também tentara alcançar uma declaração formal de apoio de Cuba, pedido este habilidosamente não respondido de forma direta pelo regime cubano, que assegurou aos brasileiros que a Revolução Cubana apoiaria qualquer movimento

\footnotetext{
${ }^{215}$ PARTIDO COMUNISTA DO BRASIL. Manifesto-Programa... p. 24.

${ }^{216}$ Cf. GORENDER, Jacob, op. cit. p. 38; ROIG, V. E. G., cit. CD 1, faixa 8 e 29.

${ }^{217}$ A censura foi realizada pelo Comitê Central do Partido Comunista da União Soviética, por meio de Carta Aberta publicada no Pravda, em 14 de julho de 1963. Cf. PARTIDO COMUNISTA DO BRASIL. Resposta a Kruschov... p. 31.

${ }^{218}$ Idem, p. 34.

${ }^{219}$ Ibidem, p. 35.
} 
revolucionário, que lutasse contra o imperialismo ianque e pelo socialismo ${ }^{220}$, sem, contudo, comprometer-se com uma proclamação oficial. Igualmente cursando da linha da diplomacia, a direção do PC do B no mesmo documento de resposta a Kruchev, veio a saudar a Revolução Cubana como exemplo do caminho a ser trilhado na América Latina para a "emancipação para os povos oprimidos deste hemisfério",221.

Bem por isso, os componentes do núcleo dirigente da LI — embora fossem adeptos das teses maoístas - compreendiam que a adesão da direção do PC do B às acepções chinesas, acontecera oportunisticamente e não fora fruto de uma opção construída através de um debate democrático no seio partidário sobre a linha política mais justa e da teoria revolucionária correta para o partido ${ }^{222}$. Acontecera em razão de ser o Partido Comunista Chinês quem reconheceria o Partido Comunista do Brasil como integrante do verdadeiro movimento marxista-leninista internacional, unido em torno da rejeição a Moscou e aos "velhos" partidos comunistas, os quais não seriam "suficientemente revolucionários $e$ leninistas" 223 .

Para os membros da LI, a segunda face do oportunismo dos dirigentes do PC do B se expressaria pelo fato de que a incorporação pelo PC do B das concepções sobre as teses guerra popular de Mao e de Giap ${ }^{224}$ havia ocorrido de forma mecânica e dogmática, sem que os dirigentes partidários atentassem para os fundamentos marxistas-leninistas, o que teria originado "um revolucionarismo de palavras" 225 . Por outro lado, este descompasso havia propiciado uma visão equivocada sobre tais teses, o que conduziu ao subjetivismo

${ }^{220}$ Ver ROIG, V. E. G., cit., CD 1, faixas 9, 12 e 29; SOUZA, É. C. de.; CASTRO, T. de., cit., CD 2, faixa 21.

${ }^{221}$ PARTIDO COMUNISTA DO BRASIL. Resposta a Kruschov... p. 41.

${ }^{222}$ A LUTA contra o oportunismo... p. 1.

${ }^{223}$ HOBSBAWN, Eric., op. cit., p. 81.

${ }^{224}$ Com exceção de Ho Chi Minh, o general Vo Nguyen Giap foi o dirigente mais importante da Forças Revolucionárias Vietnamitas e do Partido Comunista do Vietnã. No final da Segunda Guerra Mundial, Minh nomeou Giap comandante em chefe das forças vietnamitas que combatiam a ocupação daquele país pela França. Giap comandou as ações militares em Dien Bien Phu, em 1954, que precipitou a derrota dos franceses. Nguyen Giap foi nomeado Ministro da Defesa do recém criado Estado independente da República Democrática do Vietnã, e, assim, se tornou o líder militar na subseqüente guerra contra os Estados Unidos, vencida pelo Vietnã, vitória esta em que Giap exerceu um papel fundamental, especialmente pela organização da ofensiva geral do Ano Tet, em janeiro de 1968. Esta ofensiva abalou a opinião publica norteamericana sobre o papel dos Estados Unidos no Vietnã e iniciou efetivamente a derrocada norte-americana naquele país. Giap foi celebrizado como estrategista e teórico militar e publicou diversas obras que influiriam particularmente a esquerda brasileira, como as que abordavam a questão da guerra popular, entre as quais se destacam o livro, prefaciado por Ernesto Che Guevara, Guerra del Pueblo, Ejército del Pueblo. Havana: Política, 1964 e a obra Exército do Povo e Armamento das Massas Revolucionárias. Lisboa: Ulmeiro, 1976. Para a trajetória de Nguyen Giap, ver PARTIDO COMUNISTA VIETNAMITA. História do Partido dos Trabalhadores do Vietname. Lisboa: Maria da Fonte, 1975, p. 35 e ss.

${ }^{225}$ PARTIDO COMUNISTA DO BRASIL - ALA VERMELHA. Crítica ao oportunismo e subjetivismo do documento "União dos Patriotas para livrar o País da Crise, da Ditadura, da Ameaça Neocolonial". [S. 1.], dez., 1967. Coleção particular Daniel Aarão Reis Filho. SÉRIE: Ala Vermelha. Dossiê 05, doc. 90, Arquivo Público do Estado do Rio de Janeiro, p. 45. 
por parte dos dirigentes partidários, ao adotarem uma compreensão exclusivamente "militar" 226 sobre a luta armada, que submetia as questões políticas às acepções militares.

As múltiplas manifestações de oportunismo que caracterizariam a direção do PC do B, segundo os integrantes da LI, encontram sua gênese em um momento histórico bem anterior ao da época da luta interna (1965-1967), e mesmo da própria reorganização do partido, ocorrida em 1962. Wladimir Pomar — filho de Pedro Pomar, e integrante do Comitê Central do Partido Comunista do Brasil até o início da década de 1980 —, detecta que as explicações do surgimento do que denomina de "desvios" ocorridos no PC do B desde 1962 e que perdurariam até a época de seu escrito (1980), são provenientes de uma fase anterior ao combate do prestismo. Nesta última ocasião o Partido Comunista do Brasil limitou-se em desmascarar as teses revisionistas de Prestes, quando na verdade seria indispensável que houvesse se aprofundado na "crítica aos erros e desvios ideológicos $e$ políticos do período anterior, 227 à aceitação, pelo $\mathrm{PCB}$, das idéias trazidas por Kruchev.

Até 1980 continuava atuante e viva no PC do B, a idéia de que os debates em torno de "questões essenciais",228 da linha política do partido, deveriam ficar adstritos "ao âmbito mais estreito da direção”, ou seja, do pequeno grupo do Comitê Central. Apenas quando fossem superadas eventuais divergências ocorridas neste círculo delimitado poderia a discussão vir a ser levada para o Comitê Central e direções intermediárias: da mesma forma em que "na época de Prestes, ao CC [Comitê Central] sobrepunha-se uma outra direção que formalmente a ela deveria estar subordinada". Como anteriormente, continuava a ser inadmissível que um membro do PC do B viesse a comentar uma questão que não houvesse sido previamente considerada resolvida pelo pequeno grupo, pois esta era uma questão tida "como de exclusiva competência daquela direção superior ao CC".

Para Wladimir Pomar,

“Todas essas dificuldades formavam um quadro complexo, que iria determinar o curso posterior da atividade do PC do B e as dificuldades que enfrentaria para corrigir seu rumo político, pese o sentimento revolucionário e proletário da esmagadora maioria de seus militantes" 229 .

\footnotetext{
${ }^{226}$ A LUTA contra o oportunismo... p. 1.

${ }^{227}$ POMAR, Wladimir. O partido e a guerrilha, cit., p. 12.

${ }^{228}$ Idem, p. 12 e ss., grifos nossos.

${ }^{229}$ POMAR, Wladimir. O partido e a guerrilha, cit., p. 12.
} 
O cenário complexo de que nos fala Pomar iria igualmente conduzir o fluxo que tomaria a luta interna dentro do Partido Comunista do Brasil. No início de 1966 acontecera uma cisão do partido na Zona da Mata nordestina, de Alagoas à Paraíba ${ }^{230}$, aglutinando militantes do partido, ex-ativistas das Ligas Camponesas, do MRT, além de setores estudantis e camponeses católicos próximos ao PC do B. Os componentes do "racha" que se corporificariam no Partido Comunista Revolucionário (PCR) - convergiam com os componentes da LI ao apontarem a direção do Partido Comunista do Brasil como "oportunista e mantenedora da mesma linha de trabalho seguida pelo PCB na fase anterior a 1962", ${ }^{231}$ ao mesmo tempo que se afastavam do grupo da luta interna ao se definirem como uma estrutura partidária autônoma ${ }^{232}$.

Em maio de 1966 em São Paulo é realizada uma Conferência Estadual, preparatória da VI Conferência Nacional, que ocorreria no mês seguinte. Naquela Conferência foram levantadas inúmeras questões relativas ao Partido Comunista do Brasil cujos debates serviram aos propósitos reorganizativos dos membros da LI, pois se discutiu o problema militar, a exigência de um balanço autocrítico da história do partido, a adoção de uma política de reconstrução do PC do B, elaboração de uma teoria revolucionária, de uma

\footnotetext{
${ }^{230}$ REIS FILHO, Daniel Aarão; SÁ, Jair Ferreira de. Imagens da Revolução... p. 48.

${ }^{231}$ PROJETO "BRASIL: NUNCA MAIS". Perfil dos Atingidos... p. 88.

${ }^{232}$ Embora o grupo fundador do PCR tenha sido objeto de contatos pelos componentes da LI, particularmente através de Diniz Cabral Filho, e em um primeiro momento tivessem aderido às idéias que propagavam, Amaro Luiz de Carvalho, o "Capivara", Ricardo Zaratini Filho e Manoel Lisboa - que conformavam o citado grupo dirigente - resolveram romper definitivamente com o PC do B no início de 1966, e em maio do mesmo ano lançaram seu documento fundador, denominado "Carta de 12 Pontos". Embora apresentasse a Guerra Popular Prolongada maoísta como tática revolucionária a ser cumprida, se mostrava portador de uma singularidade em relação ao PC do B e mesmo com as outras dissidências que se formariam a partir de então no Brasil, ao caracterizar o Nordeste como campo prioritário do ponto de vista da revolução, por ali se manifestar "de modo mais agudo a contradição entre o imperialismo norte-americano e o povo brasileiro". As particularidades das formulações do PCR eram ainda mais acentuadas ao compreender que na tática advinda do ideário de Mao, de "cerco da cidade pelo campo", a concepção de cidade corresponderia às "grandes cidades e capitais do Nordeste"”. A exceção seriam "área industrial de São Paulo, compreendendo as cidades satélites do ABC, Santos e Rio de Janeiro (...) sendo o restante do país [o] 'campo'”. Cf. PARTIDO COMUNISTA REVOLUCIONÁRIO. Carta de 12 pontos. In: REIS FILHO, Daniel Aarão; SÁ, Jair Ferreira de. Imagens da Revolução... p. 50-51. O PCR desenvolveu um trabalho de propaganda armada, como panfletagens nas portas de fábrica, além de "esporádicas ações para apropriação de armas de militares, atentados e obtenção de recursos financeiros". Em 1969 o PCR sofreu um especial revés com a prisão de um de seus fundadores, Amaro Luis de Carvalho (líder camponês pernambucano), acusado de ser responsável de inúmeros incêndios em canaviais da região. Em 1971 "Capivara" seria morto sob torturas. Cf. BNM 77. Em 1973 o partido foi novamente atingido severamente, quando três de seus principais dirigentes foram presos, torturados e mortos pelos organismos de repressão: Manoel Aleixo da Silva (líder camponês pernambucano conhecido como "Ventania"), Manoel Lisboa de Moura (líder estudantil alagoano) e Emmanuel Bezerra dos Santos (liderança estudantil potiguar). Para as causas das mortes citadas, ver CENTRO CULTURAL MANOEL LISBOA. A Vida e a luta do comunista Manoel Lisboa. Depoimentos. Recife: Centro Cultural Manoel Lisboa, 2000, passim. Após um período de refluxo, o PCR recompôs-se, se constituindo hoje _em uma agremiação partidária legalizada. Ver sua página na Internet: inttp:///pcrbr.sites.uol.com.bì
} 
política de massas e sua ligação com os organismos partidários, ${ }^{233}$ além de outros temas relacionados com a visão da LI.

A discussão das teses que seriam apresentadas na VI Conferência Nacional, todavia, não ocorreu durante a Conferência paulista. O debate acerca de um anteprojeto de tais teses não foi possível em nenhuma instância do PC do B, pois a direção havia negado acesso a tais documentos sob a alegação de que "se houvesse discussões prévias com bases em documentos, a reação tomaria conhecimento da Conferência, ameaçando sua realização" ${ }^{234}$. Essa atitude por parte dos órgãos diretivos do PC do B foi alvo da crítica dos componentes da luta interna: para eles era mais uma demonstração do caráter antidemocrático da direção do partido à vista da “aplicação absoluta do centralismo”, o que levava ao "mandonismo" daqueles dirigentes, que "exageraram as condições de clandestinidade no sentido de usar a arma do centralismo e eliminar a democracia partidária" $^{235}$.

Acontece, então, a VI Conferência Nacional do Partido Comunista do Brasil, em junho de 1966, na cidade de São Paulo. O número de integrantes desta Conferência foi significativamente reduzido, restrito aos dirigentes e a poucos delegados que haviam sido eleitos nas Conferências estaduais ocorridas previamente, pois a direção do PC do B, detectando as incursões de Diniz Cabral entre a militância, tomou a decisão de efetivá-la nestas condições restritivas. Assim, à vista da prisão de Tarzan de Castro, do núcleo dirigente da luta interna, apenas Diniz Cabral Filho e Élio Cabral participariam daquela instância partidária, o que debilitou sensivelmente os integrantes da LI. Este fato foi mais agravado se considerarmos que diversos membros da luta interna que haviam sido eleitos delegados - e, portanto, estariam credenciados a participar da Conferência —, não receberam a convocação ou não conseguiram chegar a tempo de sua realização ${ }^{236}$.

Abertos os trabalhos, após os costumeiros informes, foi lido para os presentes o documento elaborado pela comissão executiva, "União dos Brasileiros para Livrar o País da

\footnotetext{
${ }^{233}$ A LUTA contra o oportunismo... p. 2.

${ }^{234}$ A LUTA contra o oportunismo... p. 3. Tais fatos são corroborados por Élio Cabral, que afirma que: " $O P C$ do B estava preparando a VI Conferência, não recebemos documentos”. Cf. SOUZA, É. C. de.; CASTRO, T. de., cit., CD 2, faixa 12.

${ }^{235}$ A luta contra o oportunismo... p. 3.

${ }^{236}$ Élio Cabral narra um episódio neste sentido, envolvendo o delegado de Goiás para aquela Conferência, Gerson Parreira, salientando que: "Eles [a direção do PC do B] já sabiam do que ia acontecer e colocaram gente deles lá. O Gérson, daqui de Goiás, já estava em luta aberta com o PC do B. Ele precipitou o processo, pois o combinado era a gente se manifestar na IV Conferência (...) eles perceberam antes. $O$ Gerson deu toda a dica, através do Lincoln Cordeiro Oest. O Gerson ia para denunciar. Eles queriam preservar a direção (...) [Então] Eles (...) marcaram um ponto errado" com Gerson, e ele não pôde comparecer à Conferência, cujo local de realização ignorava — por questões de segurança — e seria passado a ele por Lincoln Oest. Cf. SOUZA, É. C. de.; CASTRO, T. de., cit., CD 2, faixa 17 e 23.
} 
Crise, da Ditadura e da Ameaça Neocolonialista”. Segundo os componentes da luta interna, os presentes à VI Conferência foram "surpreendidos com a apresentação daquele documento", que tratava de questões essenciais para o partido - como o problema da tática revolucionária - pois não foi antecedido de qualquer análise das "transformações havidas no seio da sociedade", nem tampouco resultou de uma "discussão intensa travada no Partido a partir de suas experiências concretas", consistindo, conseqüentemente, em "fruto de elucubrações do grupo dirigente, de seu subjetivismo",237.

Não somente com relação ao documento apresentado foram tomados de surpresa os membros da luta interna presentes à VI Conferência. Esta instância partidária não possuía o poder de destituir nem eleger uma nova direção, sendo de sua alçada aprovar documentos importantes, entre um congresso e outro, sujeitos à aceitação posterior por parte de um futuro Congresso do partido.

A direção do PC do B, diziam os membros da LI, "exorbitou suas atribuições" para fazer com que a VI Conferência assumisse "características de Congresso", ao realizar a aprovação de novos estatutos partidários e substituir mais de um quinto dos integrantes do Comitê Central. Na medida em que avocou as formas de um Congresso, a direção deveria seguir "a prevalência das normas [inerentes a] um Congresso", o que absolutamente não veio a acontecer ${ }^{238}$.

Em verdade o que ocorreu com as alterações estatutárias, segundo os integrantes da luta interna, foi a abertura de possibilidade de legalizar a "criação de mecanismos paralelos em diferentes níveis” além dos já existentes. Por tais razões, os novos estatutos do partido, ao invés de tornarem a organização "mais conseqüente para a preparação da luta revolucionária", vieram a possibilitar a criação de condições de "sustentação dos interesses do grupo que ocupa postos de direção”, viabilizando, assim, a dissolução de qualquer organismo partidário que não fosse “dócil a esses interesses”, para substituí-lo por outro do mesmo nível ${ }^{239}$. Um exemplo do proveito para os dirigentes que poderia advir com as mudanças estatutárias era o fato de agora "pessoas notórias" poderiam ser recrutadas pelo Comitê Central, o que anteriormente não era permitido ${ }^{240}$.

A discussão que os componentes da LI efetuaram após a VI Conferência permitiulhes tomar consciência de suas reais características bem como os "interesses por ela

\footnotetext{
${ }^{237}$ A LUTA contra o oportunismo... p. 4.

${ }^{238}$ Idem, p. 3.

${ }^{239}$ A LUTA contra o oportunismo... p. 4-5.

${ }^{240}$ Diógenes Arruda Câmara veio a se beneficiar dessa modificação dos estatutos, pois passou a figurar naquele Comitê sem antes militar nas bases do PC do B. Cf. ROIG, V. E. G., cit., CD 1, faixa 23.
} 
acobertados", e possibilitou-lhes chegar a uma idéia que passaria a ser consensual entre eles: a de que aquela Conferência havia sido "um verdadeiro golpe dentro do Partido"241.

A análise mais aprofundada que posteriormente realizaram acerca do documento aprovado na VI Conferência e o ato da direção do PC do B em firmar posição de aplicar concretamente as teses nele contidas, a compreensão mais acurada dos desvios subjetivistas que a tática do referido documento traçava poderia conduzi-los, as manipulações que teriam sido praticadas pelos dirigentes partidários, foram elementos que, somados, levaram os membros da luta interna a concluírem pela inevitabilidade das contradições no seio do partido, entre as "posições oportunistas (...) do grupo dirigente" e as "concepções revolucionárias das bases do partido" $" 242$. $\mathrm{Na}$ medida em que tais contradições não eram tratadas corretamente pelos órgãos de direção partidários, ponderavam eles que sua resolução apenas poderia se dar através de uma "luta interna ativa, que vá de baixo para cima, atingindo todos os escalões do Partido, sob a forma de revolução cultural"243.

A luta interna ativa então deflagrada levaria ao embate em diversas instâncias partidárias, que se intensificavam por todo o PC do B, em São Paulo e diversos Estados ${ }^{244}$. A partir da instalação da LI ativa estava configurado um novo contexto de enfrentamento com a direção do PC, no qual a disputa ideológica seria acrescida do enfrentamento atuante de organismos partidário contra os órgãos diretivos, particularmente o Comitê Central. O documento dos membros da luta interna adicionava ainda outro componente para esta confrontação, a Revolução Cultural - a busca mais extremada da implantação concreta da idéia de que as massas mobilizadas são capazes de qualquer transformação social ${ }^{245}$.

\footnotetext{
${ }^{241}$ A luta contra o oportunismo... p. 4.

${ }^{242}$ Idem, p. 4.

243 Ibidem, p. 5.

${ }^{244}$ Como exemplo, podemos citar a narrativa de Delmar Mattes e Gerôncio Rocha sobre o XXIX Congresso da UNE, clandestinamente realizado em Belo Horizonte (MG) no ano de 1966. Nesta ocasião estudantes do Rio Grande do Sul, pertencentes ao PC do B, se reuniram com os da base estudantil paulista, que difundiram as críticas propagadas pela luta interna ativa. Os gaúchos identificaram-se com estes pensamentos e levaram o debate para seu Estado. Lá chegando, discutiram as acepções trazidas do Congresso, que foram acatadas pela maioria das bases do PC do B em Porto Alegre e em Santa Maria, e assim passaram a integrar a oposição à direção do partido e suas teses que então se formara — uma situação que igualmente iria se repetir em diversos estados brasileiros. Cf. MATTES, D.; ROCHA, G. A. Delmar Mattes; Gerôncio Albuquerque Rocha: depoimento [fev. 2005]. Entrevistador: T. A. D. Silva. São Paulo, 2005. CD 1, faixa 12. Sobre o tema ver também as declarações prestadas em um dos processos que apura as atividades da Ala Vemelha no Rio Grande do Sul, o BNM 403, por Luiz Fernando Couto Schiavon (fls. 38), Antonio Didoné (fls. 69-v), Luiz Alberto dos Santos Rodrigues (fls. 92, 94), e por Tarso Fernando Herz Genro (fls. 369).

${ }^{245}$ A Revolução Cultural foi instalada na China a partir de 1966 e viria a exercer grande influência no campo do marxismo-leninismo mundial, especialmente nos partidos alinhados, de alguma forma, com as diretrizes do Partido Comunista Chinês e as concepções maoístas. As origens da Revolução Cultural podem ser identificadas em 1964, quando existira na China a suposição de que o poder estaria em mãos dos "seguidores do caminho capitalista" (particularmente pessoas com poder dentro do Partido Comunista Chinês e do
} 
A transmudação do caráter da luta interna travada por militantes do PC do B implicou a adoção de práticas extremadas dirigidas contra a direção partidária, especialmente seu Comitê Central, que adentravam em uma linha de demarcação muito tênue que as distinguiam de ações de ruptura com o partido.

Esse é o sentido de uma primeira manifestação concreta documentalmente comprovada do aprofundamento da luta interna ativa, efetivada pelo Comitê Distrital do $\mathrm{ABC}$, que se constituiu em um dos organismos partidários que efetivamente começou a se insurgir de modo manifesto e frontal contra a direção do PC do B.

Após uma reunião ampliada com todos os comitês de base realizada em 18 de junho de 1967, deliberou o Comitê Distrital do ABC “dirigir séria crítica” a um membro do Comitê Central e não mais aceitar "a assistência [deste] camarada do C.C.[Comitê Central]”, pelo fato de não haver comparecido àquela reunião para “dar explicações referentes às resoluções do C.C.”; por ter ele violado o princípio de segurança partidário

governo) e que para reorientar a linha política interna chinesa seria necessário realizar "Quatro Limpezas" (no plano político, econômico ideológico, organizativo) do PCCh e órgãos governamentais. Deste modo, ganhou força a noção da necessidade de que o alvo do movimento de educação socialista deveriam ser estas pessoas dotadas de poder, o que redundou na colocação "da luta de classes no centro da construção socialista". O Ministro da Defesa, Lin Piao, difundiu então a tese de que "a tomada do poder depende de barris de pólvora e tinteiro", ou seja, poder militar e propaganda. Para obter os "barris", Piao eliminou os graus de oficialato no Exército Popular (visando conseguir maior participação dos soldados e conquistar sua fidelidade), além de afastar comandantes militares para substituí-los por pessoas de sua confiança. Para ter os "tinteiros" lançou uma ampla campanha ideológica, que tinha como cartilha o "Livro Vermelho" de citações de Mao Tsé-tung, organizado e prefaciado por Piao. Kang Shen, membro do birô político do PCCh lança a palavra de ordem de realizar uma revolução política proletária, que fosse a continuação entre a luta de classes havida entre o Kuomitang e o Partido Comunista Chinês. Logo a seguir, em maio de 1966, são publicados os "16 Pontos sobre a Grande Revolução Cultural", que apelavam às massas para 'fazer a revolução, transformar os pensamentos, a cultura, os hábitos e costumes antigos; moldar a fisionomia moral de toda a sociedade conforme os pensamentos, a cultura, os hábitos e costumes do proletariado; derrubar os que ocupavam postos de direção, mas seguiram o caminho capitalista; tomar o poder; opor-se aos ataques da burguesia no domínio ideológico; criticar as autoridades acadêmicas reacionárias; atacar a ideologia burguesa e de todas as outras classes; reformar a estrutura do ensino, a literatura, a arte e todos os demais ramos da superestrutura". Os "16 Pontos" proibiam "que os quadros técnicos e científicos dedicados a atividades estratégicas fossem incomodados" e que a Revolução Cultural "fosse levada às fileiras do Exército Popular de Libertação", além de vedar "que os representantes da burguesia infiltrados no Partido fossem citados nominalmente na imprensa sem a aprovação do comitê ao que pertenciam”. A conseqüência imediata da aplicação dos "16 Pontos" foi que milhões de chineses aderiram à Guarda Vermelha e houve a construção de diversos Comitês Rebeldes Revolucionários, que passaram a aplicar a democracia direta, quando cada agrupamento defendia sua interpretação das citações e instruções do presidente Mao Tsé-tung, o qual fazia uma firme conclamação da idéia de que “as massas não podem ser tuteladas”. Em 1969 o governo e a direção do PCCh ordenaram o desarmamento e a dissolução da Guarda Vermelha, tendo em vista que o perigo de uma guerra civil se materializava na China, em face das reiteradas arbitrariedades, injustiças que eram perpetrados por seus integrantes. Reorganizariam então os organismos estatais, que teriam a participação de membros do PCCh, dos comitês revolucionários e integrantes do Exército, e passaram a dar uma atenção maior à economia do país. A partir desse momento, a ordem passou a ser "fazer a revolução $e$ aumentar a produção”, ocasião esta em que a Revolução Cultural refluiu de suas mobilizações massivas e adentrou em uma "fase de disputa quase exclusivamente palaciana e partidária." Apesar de ter o apoio constante de Mao Tsé-tung até seu final, em 1976, a Revolução Cultural quase não contava mais com apoio popular, e seus defensores foram ficando marginalizados. Para um aprofundamento dos excertos aqui reproduzidos, ver POMAR, Wladimir. A Revolução Chinesa. São Paulo: Unesp, 2003, p. 96 e ss. 
ao "citar o nome legal e a origem" de camaradas que viviam em absoluta clandestinidade; por haver o dirigente criticado militantes ausentes de um outro encontro que com ele mantiveram "usando uma linguagem baixa e difamatória", a qual quebrava o espírito partidário, assim como pelo fato do Comitê Distrital não aceitar o afastamento da pessoa que anteriormente lhe prestava assistência. ${ }^{246}$ Tendo em vista que os integrantes da luta interna ativa pertencentes ao Distrital do $\mathrm{ABC}$ haviam sido acusados pelo membro do Comitê Central de "práticas grupistas", deliberou então àquele órgão partidário "denunciar a acusação de grupismo", a qual teria sido feita "com objetivo claro e desonesto de massacrar camaradas divergentes do Partido" ${ }^{247}$.

Como o Comitê Regional de São Paulo - formado por uma grande maioria de membros da luta interna LI ativa - fora recentemente dissolvido pelo Comitê Central do PC, e substituído por um Birô Regional Provisório, o Comitê Distrital do ABC decidiu exigir da direção partidária a dissolução do "atual Birô" e a "convocação imediata de uma Conferência Estadual". Resolveu também o Distrital "lançar um voto de desconfiança ao C. C." e comunicar "aos demais distritais estas resoluções"248.

A decisão daquele Comitê Distrital se fundamentava no fato de que "as difamações, os métodos incorretos de trabalho e de direção partem de uma orientação geral do C. C." ${ }^{249}$, e na constatação de que "os informes descidos ao Distrital, bem como o documento da VI Conferência e o Boletim de Informações da Classe Operária refletem a orientação política do C. C., e que tal orientação não só trai o Manifesto Programa, como absolutamente não corresponde à linha de nosso Partido"250 .

$\mathrm{O}$ confronto entre a luta interna ativa e o Comitê Central do PC do B, agora franqueado, se espraiou por entre outros organismos dirigentes partidários, em face da divulgação das resoluções do Distrital do ABC. Além de quase todos os comitês distritais de São Paulo haver referendado aquelas resoluções ${ }^{251}$, também o fez o Comitê Estudantil

\footnotetext{
246 PARTIDO COMUNISTA DO BRASIL. COMITÊ DISTRITAL DO ABC. Resolução do Comitê Distrital do ABC. São Bernardo do Campo, jun., 1967. Coleção particular Daniel Aarão Reis Filho. SÉRIE: Ala Vermelha. Dossiê 05, doc. 86, Arquivo Público do Estado do Rio de Janeiro, p. 1. O membro do Comitê Central ao qual o texto do citado documento faz referências, se tratava de Lincoln Cordeiro Oest, de acordo com Derly José de Carvalho. Cf. CARVAlHO, D. J. Derly José de Carvalho: depoimento [jul. 2006]. Entrevistador: T. A. D. Silva. São Paulo, 2006, 1 CD, faixa 2.

${ }^{247}$ PARTIDO COMUNISTA DO BRASIL. Comitê Distrital do ABC. Resolução..., cit., p. 1.

${ }^{248}$ Idem, p. 1, grifos nossos.

${ }^{249}$ Ibidem, p. 1, grifos nossos. .

${ }^{250}$ Ibidem, p. 1, grifos nossos.

${ }^{251}$ PARTIDO COMUNISTA DO BRASIL. COMITÊ ESTUDANTIL DO PARTIDO COMUNISTA DO BRASIL EM SÃO PAULO. Convocação. São Paulo, jul., 1967. Coleção particular Daniel Aarão Reis Filho. SÉRIE: Ala Vermelha. Dossiê 05, doc. 85.2, Arquivo Público do Estado do Rio de Janeiro, p. 1.
} 
Paulista $^{252}$, em sua maior parte igualmente integrado por membros da LI atuante, como Renato Tapajós, Vicente Roig, Paulo Gianinni e Carlos Takaoka.

Entretanto, a discussão e aprovação das referidas resoluções pelo Comitê Estudantil Paulista foi também objeto de represálias drásticas pela direção do PC do B. Na reunião de 25 de junho de 1967, quando foram ratificadas, por maioria de seis votos contra dois, ${ }^{253}$ as resoluções do Distrital do ABC, o "camarada assistente" declarou dissolvido o Comitê Estudantil, "em uma atitude arbitrária e anti-estatutária”, uma vez que "o assunto não tinha sido sequer discutido no organismo superior". O assistente teria ainda se apoiado "na minoria [consistente em duas pessoas $^{254}$ ] que foi voto vencido" naquela ocasião, para iniciar "a formação de um organismo paralelo" ao Comitê Estudantil ${ }^{255}$.

Tal minoria iniciaria um "trabalho fracionista" junto às bases estudantis, que não obteria acolhimento, pois "foi repudiada pela maioria destas". Este solapamento se dava pela divulgação para os militantes em geral que o Comitê Estudantil "tinha sido dissolvido e que a maioria de seus membros foi expulsa do P.", o que consistiria em "fatos mentirosos", uma vez que o Birô Regional Provisório nada teria deliberado sobre o tema. A mesma minoria estaria também divulgando para as bases "os nomes verdadeiros dos participantes do Comitê", bem como "o local em que se deu a reunião anterior", em atitude que implicava uma "flagrante violação das normas de segurança partidárias". Convidada a participar da reunião que o Comitê Estudantil convocou posteriormente, a minoria teria se negado a participar da mesma, "alegando a dissolução" daquele Comitê o que confirmaria "sua participação num organismo paralelo". 256

O Comitê Estudantil Paulista, frente a este quadro, resolveu não acatar e repudiar sua dissolução e "continuar dirigindo as bases estudantis"; "dirigir séria advertência" para aquelas minorias que estariam "realizando trabalho fraccionista" e repudiar suas atitudes de "rompimento das normas de segurança". No encontro de trabalho realizado em $1^{\circ}$. de julho de 1967, deliberou o Comitê por apoiar a "convocação imediata da Conferência Estadual proposta pelo Distrital do $A B C$ ". 257

\footnotetext{
${ }^{252}$ Idem, p. 1.

${ }^{253}$ PARTIDO COMUNISTA DO BRASIL. PRIMEIROS SECRETÁRIOS DO COMITÊ DISTRITAL DO ABC et al. Convocação. [S. 1.], [196-]. Coleção particular Daniel Aarão Reis Filho. SÉRIE: Ala Vermelha. Dossiê 05, doc. 86, p. 1.

${ }^{254}$ Idem, p. 1.

255 Ibidem, p. 1.

${ }^{256}$ PARTIDO COMUNISTA DO BRASIL. COMITÊ ESTUDANTIL DO PARTIDO COMUNISTA DO BRASIL EM SÃO PAULO. Convocação, cit., p. 1.

${ }^{257}$ Idem, p. 1.
} 
A Conferência Estadual para a escolha de um novo Comitê Regional de São Paulo, contudo, não chegaria a se efetivar. A reunião realizada pelo Birô Provisório de São Paulo terminou em um impasse, quando "dois membros se pronunciaram a favor e dois contra" sua realização. A situação então criada geraria a frustração “da quase totalidade do P.”, a qual exigia tal convocação para que fossem solucionados "uma série de problemas de ordem ideológica, política e de organização" que haviam surgido ultimamente no PC do B paulista. ${ }^{258}$

Com o objetivo de superar tais impasses diversos dirigentes de organismos partidários de São Paulo, resolveram, conjuntamente, avocar para si a responsabilidade de convocar uma "Conferência Regional de S. P. do PC do B", que seria realizada na " 2 . quinzena de agosto ou $1^{\text {a }}$. quinzena de setembro" de 1967, com a seguinte ordem do dia: a) discutir as "divergências surgidas no P. e as últimas resoluções do C. C."; b) debater as "resoluções da VI Conferência" Nacional do PC do B, realizada em agosto de 1966, quando seriam discutidos o documento "União dos patriotas...." e os estatutos nela aprovados; c) questões gerais, e, finalmente, as eleições do Comitê Regional. Determinaram também estes dirigentes a formação de uma comissão encarregada de preparar a Conferência que elegeria o novo Comitê Regional, a qual teria igualmente a incumbência de encaminhar para todo o partido as normas que regeriam a mesma ${ }^{259}$.

Por outro lado, tais dirigentes deliberaram por não aceitar a dissolução do Comitê Estudantil Paulista, que seria "legítimo e único representante do Setor Estudantil do P. em $S P$ ”. Resolveram também "não aceitar nenhum organismo" do partido ausente da reunião que realizavam naquele momento, visto que seus componentes "representam a totalidade do P. em $S P^{\prime \prime}{ }^{260}$

Selava-se, neste encontro de dirigentes partidários pertencentes à luta interna ativa, a cisão com os demais órgãos do PC do B, especialmente com os quadros da direção partidária, em atitude peculiar à "revolução cultural" "261 que almejavam instalar para a nova reorganização do Partido Comunista do Brasil.

A resposta do Comitê Central do PC do B não se fez tardar, pois em julho de 1967 viria a publicar no Classe Operária a expulsão de Diniz Cabral Filho, Élio Cabral, Carlos

${ }^{258}$ PARTIDO COMUNISTA DO BRASIL. PRIMEIROS SECRETÁRIOS DO COMITÊ DISTRITAL DO $\mathrm{ABC}$ et al. Convocação, cit., p. 1.

${ }^{259}$ PARTIDO COMUNISTA DO BRASIL. PRIMEIROS SECRETÁRIOS DO COMITÊ DISTRITAL DO $\mathrm{ABC}$ et al. Convocação, cit., p. 1.

${ }^{260}$ Idem, p. 2.

${ }^{261}$ A "revolução cultural" que os integrantes da luta interna desejavam instalar no PC do B após a nova "reorganização" que pretendiam nele realizar será abordada detalhadamente no Segundo Capítulo desta Primeira Parte do trabalho. 
Takaoka, Paulo Gianinni, Renato Tapajós e Vicente Roig ${ }^{262}$ - que já haviam anteriormente deixado espontaneamente o partido ${ }^{263}$ - e de Tarzan de Castro.

Em documento publicado posteriormente, o Partido Comunista do Brasil narrava a história do grupo da LI — o qual chamou de "fracionista" —, relatando que este núcleo de pessoas possuía "maiores pretensões", e escondia, "solertemente seus propósitos e conspirava contra o Partido" ${ }^{264}$. Segundo a direção do PC do B "o principal dirigente deste grupo era Tarzã [sic] de Castro", cujo passado em outras organizações políticas "tinha sido marcado pelo carreirismo e ações divisionistas" ${ }^{265}$. Os dirigentes partidários confessavam que Tarzan se apresentava como "um jovem desejoso de lutar pela revolução” e a direção do partido "esforçou-se por torná-lo um verdadeiro militante comunista", esforço este que se repetiria com relação "a outros elementos que a ele se associaram" "266, numa clara remissão ao envio de Tarzan, Diniz e Élio Cabral à China. Segundo o PC do B, os “mentores" deste núcleo "diziam-se a favor da orientação política" do partido, mas "nos bastidores manifestavam oposição" à mesma. Apresentavam-se estar "de acordo com a direção do Partido, mas não perdiam oportunidade para atacá-la sorrateiramente e sem qualquer motivo" 267. "Insinuavam" estes militantes "contar com o apoio da China, o que não passava de deslavada mentira". 268

Para os dirigentes do PC do B, a "atividade desagregadora" deste grupo tinha como "centro o ataque à direção" do partido, e, ao se aproximar a VI Conferência Nacional, seus membros "intensificaram seu trabalho fracionista" e "manobraram", vindo a aprovar o documento apresentado pelo Comitê Central, contudo, "conspirando contra o Partido"269. O PC do B reconhecia que o grupo, apesar de ser "pequeno, causou certos prejuízos" uma vez que “desviou alguns militantes”; contudo, apontava que, não

\footnotetext{
${ }^{262}$ Ao abordar a expulsão destes sete militantes, Vicente Roig afirma que a direção do PC do B dizia que " $a$ gente estava objetivamente a serviço do imperialismo, de uma maneira geral". O curioso, nota Roig, é que "o Diniz foi expulso por estar a serviço do imperialismo francês. Nunca entendemos isso". Cf. ROIG, V. E. G., cit. CD 1, faixa 34.

${ }^{263}$ TAPAJÓS, R. C., cit. CD 1, faixa 7.

${ }^{264}$ PARTIDO COMUNISTA DO BRASIL. Desenvolver a Luta Ideológica e Fortalecer a Unidade do Partido. Em: PARTIDO COMUNISTA DO BRASIL (M-L). Guerra Popular... p. 11. Ressalta-se que o documento do PC do B não especificava quais seriam as organizações políticas nas quais Tarzan de Castro teria militado.

${ }^{265}$ PARTIDO COMUNISTA DO BRASIL. Desenvolver a Luta..., cit., p. 11.

${ }^{266}$ Idem, p. 11.

267 Ibidem, p. 11.

268 Ibidem, p. 11.

${ }^{269}$ Ibidem, p. 12.
} 
obstante "a maneira astuta e hipócrita de atuar", os membros do grupo haviam sido "repudiados pela totalidade dos militantes". 270

Estava consumada a ruptura do PC do B com os membros da luta interna ${ }^{271}$. Entretanto os componentes da LI ativa que não haviam saído anteriormente do partido, não acataram suas expulsões e prosseguiram nas atividades que denominavam de "reconstrução partidária”, compreendida a partir do prisma da revolução cultural. Tratava-se, em suma, de horizontalizar o partido dando maior participação e autonomia aos organismos e bases partidários contra a verticalização extrema que, no entendimento dos integrantes da luta interna, era aplicada pelo Comitê Central.

A ocorrência de tal estratégia sucedeu em virtude da compreensão que os componentes da LI possuíam acerca de suas atividades. Não traduziriam no rompimento com o PC do $\mathrm{B}^{272}$, mas ao contrário: através da luta interna desejavam reestruturar o partido (indo contra a direção, seus métodos, linha política, etc.) e continuar a reorganizar o PC do B eliminando as concepções que qualificavam como errôneas, assim como os vícios políticos que julgavam possuir o partido. Bem por isso, em um primeiro momento, os integrantes da luta interna ativa mantiveram os organismos partidários que divergiram dos dirigentes do PC do B, como o Comitê Regional de São Paulo e seus Comitês Distritais, além do Comitê Estudantil Paulista ${ }^{273}$; em Minas Gerais o Bureau Estudantil ${ }^{274}$; no Rio Grande do Sul o Comitê Municipal de Porto Alegre ${ }^{275}$ e a Célula Estudantil de Santa Maria ${ }^{276}$ dentre outros.

A existência destes múltiplos organismos partidários que compunham a LI em vários Estados brasileiros implicava, inevitavelmente, a necessidade da criação de um mecanismo que coordenasse as atividades e discussões da luta interna de maneira a centralizá-las e, ao mesmo tempo, interligá-las. Para cumprir estes objetivos, desponta então a Comissão Nacional de Consulta $(\mathrm{CNC})^{277}$, um órgão não deliberativo, cuja função consistiria em organizar de forma metódica o processo da luta interna, conduzindo-o

\footnotetext{
${ }^{270}$ Ibidem, p. 12.

${ }^{271}$ Tarzan de Castro sintetiza a expulsão de componentes da luta interna: "Aplicou-se um stalinismo vertical: ‘já que eles são contra a gente, expulsa esse povo como traidor'. O pessoal aceita essa posição e cada um vai para o seu lado”. Cf. SOUZA, É. C. de.; CASTRO, T. de., cit., CD 3, faixa 1.

${ }^{272}$ SOUZA, É. C. de.; CASTRO, T. de., cit., CD 2, faixa 33.

${ }^{273}$ Cf. PARTIDO COMUNISTA DO BRASIL. PRIMEIROS SECRETÁRIOS DO COMITÊ DISTRITAL DO ABC et al. Convocação, cit., p. 1.

${ }^{274}$ Cf. PARTIDO COMUNISTA DO BRASIL. BUREAU ESTUDANTIL DO PARTIDO COMUNISTA DO BRASIL. Desencadear uma revolução cultural..., cit., p. 3.

${ }^{275}$ Cf. declarações de João Francisco de Pinedo Kasper no DOPS de Porto Alegre. BNM 403, fls. 14.

${ }^{276}$ Cf. interrogatório no DOPS porto-alegrense de Dartangnan Luiz Agostini. BNM 403, fls. 95.

${ }^{277}$ SOUZA, É. C. de.; CASTRO, T. de., cit., CD 2, faixa 32; CD 3, faixa 3.
} 
sincrônica e harmoniosamente. Ficaram a cargo da CNC os precursores luta interna, Diniz Cabral Filho, Élio Cabral de Souza, Derly José de Carvalho ${ }^{278}$, além dos representantes do Rio Grande do Sul, Paulo Cavalcante Brasil ${ }^{279}$, de Minas Gerais, Francisco Sana Pinto ${ }^{280}$, de Goiás, Genésio Borges de Mello ${ }^{281}$, dos Estados da Guanabara e do Rio de Janeiro, Orly Batista Corrêa $^{282}$.

Em um movimento praticamente simultâneo ao início dos trabalhos da CNC, iniciou-se a difusão no seio dos variados grupos que integravam a LI de uma percepção que compreendia os integrantes da luta interna como os verdadeiros representantes do Partido Comunista criado em 1922. Segundo esta acepção era necessário romper com os "oportunistas" - representados pela cúpula do PC do B - ao invés de continuar as tarefas de reconstrução partidária. Desta forma, se fazia imprescindível que a LI desenvolvesse uma identidade própria, a qual não representaria mais uma mera organização como as que surgiam naquela época no Brasil, mas se traduziria no "embrião de um futuro partido comunista" $^{283}$.

A partir destas concepções a LI vai se transmudar em um partido autônomo, a Ala Vermelha do Partido Comunista do Brasil (AV), que seria, de acordo com seus participantes, um núcleo verdadeiramente marxista-leninista, anti-revisionista e antioportunista - em contraposição à direção do PC do B, que representaria sua antítese, uma Ala Branca ${ }^{284}$. A AV, segundo seus membros, representaria a continuidade de uma linha política que vinha desde o Partido Comunista de 1922, passara posteriormente ao PC do B e prosseguiria com a própria Ala Vermelha. No caminho iriam ficando ao largo os

${ }^{278}$ Cf. CARVALHO, D. J. de., cit. CD 2, faixa 11; ver também interrogatório policial de Élio Cabral de Souza. BNM 294, fls. 2330-v.

${ }^{279}$ Em seu depoimento ao DOPS citado na nota anterior, Élio Cabral procurara ocultar a identidade de Paulo Brasil, referindo-se apenas ao seu codinome, "Quirino". Para a menção de ser Paulo Brasil o indivíduo que integrou a Comissão Nacional de Consulta como "Quirino", ver interrogatório no DOPS de Porto Alegre de Luiz Fernando Couto Schiavon. BNM 403, fls. 65.

${ }^{280}$ Igualmente aqui Élio Cabral visa resguardar Fernando Sana Pinto, utilizando-se de seu nome em código, "Mário". Com relação ao registro de ser Fernando a pessoa conhecida na CNC como "Mário", ver seu próprio interrogatório no DOPS paulista constante no BNM 84, fls. 78.

${ }^{281}$ SOUZA, É. C. Élio Cabral de Souza: depoimento [nov. 2006]. Entrevistador: T. A. D. Silva. Goiânia, 2006. CD 1, faixa 3.

282 Idem, faixa 2.

${ }^{283}$ TAPAJÓS, R. C., cit., CD 1, faixa 8.

${ }^{284}$ Élio Cabral narra a origem da escolha da denominação Ala Vermelha: "o nome da Ala Vermelha, como nasceu? (...) Aí tem a forte influência chinesa. Quando estávamos lá foi declarado o movimento da Guarda Vermelha da política do Mao Tsé-tung. Observamos alguma coisa desse movimento lá (...) Então como é que vai chamar? Nós não somos $P C$ do B, porque o PC do B não acolhe [a luta interna], tem a direção. Nós nos considerávamos (...) os legítimos representantes do $P C$ do $B($...), mas não somos reconhecidos como $P C$ do $B$, então surgiu a idéia de que éramos uma ala. Bom, se é uma ala, é uma Ala Vermelha, para contrapor a Ala Branca do PC do B. Aí ficou Ala Vermelha do PC do B". Cf. Idem, CD 2, faixa 30 e 33. 
que chamava de oportunistas e revisionistas; enfim, a Ala representaria, na sua concepção, a herança $^{285}$ e continuação do PC de 1922.

Nesse período ocorreu um debate dentro da AV sobre a questão do nome do partido. Ponderava-se que a denominação "Ala Vermelha do Partido Comunista do Brasil" passava uma falsa impressão que a Ala não constituiria um partido em si, mas uma organização dissidente a mais no espectro da esquerda brasileira. Colocava-se, desta maneira, a discussão sobre o desenvolvimento de uma identidade própria para a $\mathrm{AV}$, que culminou na adoção da designação Partido Comunista do Brasil - Ala Vermelha, que melhor traduziria o seu sentido partidário ${ }^{286}$.

Como conseqüência desses lineamentos ocorridos no seio da AV, a Comissão Nacional de Consulta perdeu seu sentido de ser, deixando de existir para dar lugar à Direção Nacional Provisória, que seria composta, inicialmente, pelos mesmos integrantes da antiga CNC.

A Ala Vermelha, assim, desde seu nascimento vem imbuída de uma visão partidária $^{287}$ moldada nas concepções leninistas, no sentido de consistir o partido no condutor da luta revolucionária do proletariado. O discurso da Ala divisava, a centralidade partidária e a subordinação da luta armada ao partido, o que a distinguiria de outras organizações que participaram do embate revolucionário - como a ALN e a VPR, uma vez que ambas postulavam um privilégio da ação militar em detrimento do papel do partido $^{288}$.

A Ala Vermelha enquanto organização independente no segundo semestre de 1967, assumindo desde então a estrutura tradicional de organização dos partidos comunistas. De baixo para cima, existiam as organizações de base, que eram definidas pela ligação com a

\footnotetext{
${ }^{285}$ TAPAJÓS, R. C., cit. CD 1, faixa 7.

${ }^{286}$ Cf. TAPAJÓS, R. C., cit., CD 1, faixa 7. Élio Cabral esclarece que "o grande defensor do nome 'Ala Vermelha do Partido Comunista do Brasil' era o Diniz [Cabral Filho]". Após os debates internos, alterou-se o nome para "Partido Comunista do Brasil - Ala Vermelha, como nos documentos passou-se a dizer". Cf. SOUZA, É. C. de.; CASTRO, T. de., cit., CD 3, faixa 3.

${ }^{287}$ Nesse sentido os depoimentos de Élio Cabral, Tarzan de Castro, Derly de Carvalho e Renato Tapajós. Cf. SOUZA, É. C. de.; CASTRO, T. de., cit., CD 2, faixas 21-31; CARVALHO, D. J. de. Derly José de Carvalho: depoimento [dez. 2005], cit., CD 2, faixa 20; TAPAJÓS, R. C., cit. CD 1, faixa 5.

${ }^{288}$ Como anota Reis Filho, todas as organizações revolucionárias brasileiras, de maneira mais ou menos ortodoxa, trabalharam com a idéia da imprescindibilidade do partido, donde decorreriam formulações distintas, desde as mais dogmáticas, que seguiam "um padrão mais tradicional, de acordo com o figurino da Internacional Comunista (PCBR, PC do B, POLOP/POC) (...) "até chegar a formulações mais heterodoxas, com base em novos modelos de organização político-militar (ALN, COLINA, VPR)". REIS FILHO, Daniel Aarão. A Revolução..., cit., p. 116. Exemplificativamente, a ALN dizia textualmente que "não há entre nós separação entre o político e o militar. Na guerra revolucionária brasileira não temos comissários políticos que assessoram os quadros militares. Todos os membros da organização são obrigatoriamente as duas coisas ao mesmo tempo". AÇÃO LIBERTADORA NACIONAL. O papel da ação revolucionária na Organização. S. 1, maio, 1969. Em: REIS FILHO, Daniel Aarão; SÁ, Jair Ferreira de. Imagens da Revolução..., cit., p. 217.
} 
produção ou função social. Eram as organizações de base operária, camponesa, estudantil, dos profissionais liberais. Um pouco acima existiam as direções definidas por setores, que por sua vez uniam-se geograficamente; assim, havia a direção do movimento operário, do movimento camponês, do movimento estudantil, etc. Depois apareciam os Comitês Regionais, como os de São Paulo, Rio de Janeiro, Rio Grande do Sul, Minas Gerais e Goiás, os principais locais ${ }^{289}$ onde a Ala atuava naquele período. Acima dos regionais havia a Direção Nacional Provisória.

Como a Revolução Cultural significava para os integrantes da Ala Vermelha o ideal da democracia revolucionária, da democracia socialista, que visava combater os excessos autoritários do próprio partido, a organização comungou desta idéia por completo, para partilhar da noção de que caberia até ao último militante de base do partido, colocar em dúvida a sabedoria da direção, horizontalizando as relações entre os militantes de base e as direções partidárias ${ }^{290}$. A partir desta noção horizontal do partido é que foram criadas as instâncias dirigentes da Ala Vermelha. A Direção Nacional Provisória, como o órgão máximo partidário, era um organismo colegiado no qual todos os seus integrantes tinham igual poder, inexistindo uma Comissão Executiva. O mesmo sucedia nos Comitês Regionais, onde a horizontalização era também estritamente observada e as bases partidárias participavam ativamente das discussões da Ala.

Em outubro de 1967 surge a primeira manifestação do setor de imprensa da AV, com a publicação do jornal Guerra Popular, editado em São Paulo ${ }^{291}$ e um mês depois venha a luz periódico homônimo publicado na Guanabara ${ }^{292}$. A missão desses órgãos era estritamente de caráter interno, e almejavam constituir-se em um instrumento que aliasse "a verdade universal do marxismo-leninismo com a nossa prática concreta". ${ }^{293}$ Para cumprir com tais objetivos o Guerra Popular - coerentemente com a proposta de Revolução Cultural a ser praticada na AV - cederia espaço para "contribuições teóricas, produto de estudos individuais ou coletivos feitos nas OO. BB. [organizações de base]"294, e também para críticas

\footnotetext{
${ }^{289}$ TAPAJÓS, R. C., cit., CD 2, faixa 13.

290 PARTIDO COMUNISTA DO BRASIL - ALA VERMELHA. BIRÔ ESTUDANTIL DO PC DO B ALA VERMELHA. Desencadear uma revolução cultural dentro do partido. [S. 1.], set., 1967. Coleção particular Daniel Aarão Reis Filho. SÉRIE: Ala Vermelha. Dossiê 05, doc. 88, Arquivo Público do Estado do Rio de Janeiro, p. 1.

${ }^{291}$ PARTIDO COMUNISTA DO BRASIL - ALA VERMELHA. Guerra Popular. [S. 1.] ano 1, no $.1,25$ de out., 1967. Coleção particular Daniel Aarão Reis Filho. SÉRIE: Ala Vermelha. Dossiê 09, doc. 238, Arquivo Público do Estado do Rio de Janeiro.

${ }^{292}$ PARTIDO COMUNISTA DO BRASIL - ALA VERMELHA. Guerra Popular. Guanabara, ano I, $\mathrm{n}^{\circ} .1$, nov. 1967. Coleção particular Daniel Aarão Reis Filho. SÉRIE: Ala Vermelha. Dossiê 09, doc. 239, Arquivo Público do Estado do Rio de Janeiro.

${ }^{293}$ PARTIDO COMUNISTA DO BRASIL - ALA VERMELHA. Guerra Popular. [S. 1.] ano 1, $\mathrm{n}^{\circ} .1,25$ out., 1967, cit., p. 1.

${ }^{294}$ PARTIDO COMUNISTA DO BRASIL - ALA VERMELHA. Guerra Popular. Guanabara, cit., p. 1.
} 
que possibilitassem "elevar constantemente seu nível". ${ }^{295}$ O Guerra Popular constituía-se igualmente em um órgão de agitação e propaganda, que almejava ser "um veículo de construção do Partido aonde quer que chegue"296 para que efetivamente viesse a desempenhar seu papel.

${ }^{295}$ PARTIDO COMUNISTA DO BRASIL - ALA VERMELHA. Guerra Popular. Guanabara, cit., p. 1. ${ }^{296}$ Idem. 


\title{
II - CONTRA PONTO
}

\author{
$O$ contraponto e o canto firme \\ ora se encontram em uníssono ou oitava, \\ Ora se afastam ou se procuram em contramovimento, \\ Ora marcham unidos por algum tempo, \\ caso o contraponto não prefira \\ parar na mesma nota \\ para deixar movimentar-se sozinho o canto firme, \\ e vice-versa ${ }^{297}$.
}

Em dezembro de 1967 a Ala Vermelha lançou sua contraposição oficial às teses aprovadas na VI Conferência Nacional do PC do B, intitulada "Crítica ao oportunismo e subjetivismo da 'União dos Brasileiros para Livrar o País da Crise, da Ditadura e da Ameaça Neocolonialista",298 (Doc. de Crítica), quando, sem qualquer meio termo, se contrapunha às teses aprovadas naquela Conferência, criticava abertamente o que denominava de "oportunismo" e "reformismo" do Partido Comunista do Brasil.

Sob o título "Algumas considerações sobre o programa, a estratégia e a tática da revolução brasileira" o Doc. de Crítica diz que a apreensão das necessidades de um programa, bem como das leis da estratégia e da tática da revolução, constitui-se num processo que deve necessariamente partir da análise da contradição principal ${ }^{299}$, "encontra as condições e as formas do relacionamento dialético entre os dois aspectos, do lado das transformações necessárias à substituição do velho pelo novo"300.

\footnotetext{
${ }^{297}$ SINZIG, Frei Pedro, cit., p. 25.

${ }^{298}$ PARTIDO COMUNISTA DO BRASIL - ALA VERMELHA. Crítica ao oportunismo e subjetivismo da 'União dos Brasileiros para Livrar o País da Crise, da Ditadura e da Ameaça Neocolonialista. [S. 1.], dez., 1967. Coleção particular Daniel Aarão Reis Filho. SÉRIE: Ala Vermelha. Dossiê 05, doc. 90.

${ }^{299}$ O Doc. de Crítica entendia que contradição principal é "aquela cujo desenvolvimento determina e influencia o desenvolvimento de outras contradições. A contradição principal determina a qualidade da sociedade, caracteriza a etapa da revolução e sua resolução implica o cumprimento desta etapa. Para se apreender a contradição principal há que examinar os aspectos principais das contradições fundamentais e verificar qual o aspecto principal de uma dessas contradições fundamentais é o fator determinante do desenvolvimento de todo o processo. Este será o aspecto principal da contrição principal". Cf. PARTIDO COMUNISTA DO BRASIL - ALA VERMELHA. Crítica ao oportunismo... p. 30.

${ }^{300}$ PARTIDO COMUNISTA DO BRASIL - ALA VERMELHA. Crítica ao oportunismo... p. 41.
} 
Compreendia o Doc. de Crítica que o processo de conhecimento que permite a elaboração do programa, da estratégia e da tática "se baseia, fundamentalmente, na análise dos aspectos da contradição principal e no conhecimento das contradições fundamentais da sociedade" 301 .

O Doc. de Crítica entende que o Doc. da VI Conferência por não utilizaram o método marxista-leninista, confeccionaram elaboraram seu programa, sua estratégia e sua tática de uma forma que não apenas careceria "de coerência interna, como também resulta inteiramente desligada da realidade". Isto seria motivado pelo fato de "não aplicarem o materialismo dialético, conceberam uma tática que não depende nem se relaciona com sua estratégia e seu programa, além de não ser adequada às condições em que se desenvolve o processo revolucionário brasileiro" ${ }^{, 302}$.

Procurando evitar desvios desta espécie entende o Doc. de Crítica que é imprescindível a aplicação de um método correto de análise da contradição principal e do desenvolvimento do programa, da estratégia e da tática da revolução:

"A proposição que nós fazemos é a de, aplicando o materialismo dialético, apreender alguns aspectos fundamentais de um programa, de uma estratégia e de uma tática para a revolução brasileira. Não nos propomos aqui a esgotar tal assunto, pois, para isto, falta-nos, como a todo o movimento revolucionário brasileiro, um aprofundamento teórico maior das questões do marxismo-leninismo aplicadas a nossa realidade concreta, bem como um conhecimento mais profundo e exaustivo dos dados concretos da realidade do país" ${ }^{303}$.

Preconiza o Doc. de Crítica que a contradição principal da sociedade brasileira consiste na "contradição entre o neocolonialismo e seu suporte social interno, de um lado, e a grande maioria da nação, do outro". A partir desta constatação, entende possível determinar quais aquelas classes e camadas sociais da sociedade brasileira "que estão no campo da revolução e quais são os elementos componentes do campo contrarevolucionário" 304 .

Para o Doc. de Crítica o campo da contra-revolução é integrado por "aquelas forças que compõem o aspecto principal da contradição principal, uma vez que, atualmente, o

\footnotetext{
${ }^{301}$ PARTIDO COMUNISTA DO BRASIL - ALA VERMELHA. Crítica ao oportunismo... p. 41.

${ }^{302}$ PARTIDO COMUNISTA DO BRASIL - ALA VERMELHA. Crítica ao oportunismo... p. 41.

${ }^{303}$ PARTIDO COMUNISTA DO BRASIL - ALA VERMELHA. Crítica ao oportunismo... p. 41

${ }^{304}$ PARTIDO COMUNISTA DO BRASIL - ALA VERMELHA. Crítica ao oportunismo... p. 41.
} 
fator dominante no desenvolvimento da sociedade brasileira e que a caracteriza é a contra-revolução". Assim, é possível definir como sendo "inimigos da revolução o neocolonialismo e seu suporte social interno". O suporte social interno do neocolonialismo seria composto por aquelas classes e camadas sociais que "representam integralmente a dominação e exploração do neocolonialismo, ou a ela se associam”. Estas classes e camadas sociais seriam: "os latifundiários, a burguesia exportadora-importadora, a burguesia financeira e a burguesia integrada". Na medida em que "se confundem com os interesses da dominação neocolonialista”, estas classes representariam a contra-revolução interna, porque, além de "se associarem à dominação neocolonialista, exercem também sua exploração e opressão que as levam a defenderem a manutenção das estruturas sociais atrasadas". Conclui o Doc. de Crítica que "estas são as forças, classes e camadas sociais que se colocam objetivamente no campo da contra-revolução",305.

As classes e camadas sociais que constituem as forças da revolução são, para o Doc. de Crítica, aquelas que "compõem o aspecto secundário da contradição principal, isto é, são aquelas submetidas à dominação, exploração e opressão das forças da contrarevolução". Desta forma, tomam parte do campo da revolução: "o proletariado, $o$ campesinato (principalmente o campesinato pobre), a pequena burguesia, o semiproletariado". A burguesia não integrada — ou nacional —, pelo fato de também estar "submetida à opressão neocolonialista", se constitui "numa força revolucionária na atual etapa". Segundo o Doc. de Crítica seriam esta as classes e camadas sociais que "objetivamente, se colocam no campo da revolução, embora nem todas estejam ganhas subjetivamente para ela".

Reafirma o Doc. de Crítica que a revolução se constitui no "processo de resolução da contradição principal, através da luta entre seus dois aspectos" e, conseqüentemente, “ a superação do aspecto principal pelo aspecto secundário, isto é, a mudança do aspecto principal da contradição principal, ${ }^{, 306}$.

Para que o aspecto secundário possa se sobrepor ao aspecto principal, "através de uma luta" é necessário que as classes que fazem parte do aspecto secundário "se unam e lutem por objetivos comuns, a fim de destruir a dominação, opressão e exploração das classes e camadas que compõem o aspecto principal". Esses objetivos se consubstanciam "na tomada do poder e na constituição de um novo poder que exerça a ditadura dessas

\footnotetext{
${ }^{305}$ PARTIDO COMUNISTA DO BRASIL - ALA VERMELHA. Crítica ao oportunismo... p. 42.

${ }^{306}$ PARTIDO COMUNISTA DO BRASIL - ALA VERMELHA. Crítica ao oportunismo... p. 42.
} 
classes e camadas, hoje exploradas, sobre aquelas que atualmente ocupam o poder $e$ exercem a exploração" ${ }^{\text {307 }}$.

Para alcançar esses objetivos é necessário que exista na "união das classes $e$ camadas sociais que estão no campo da revolução, a hegemonia do proletariado", uma vez que somente sob a direção e liderança do proletariado é que as forças revolucionárias poderão unir-se e conquistar seus objetivos, "bem como serem ganhas subjetivamente aquelas classes e camadas que ainda não o estão",308.

A classe operária tem como objetivo "destruir a propriedade privada dos meios de produção, visando a constituir uma sociedade livre da exploração de classe". Assim, ela é a classe "mais revolucionária da sociedade e, por estas características, é a única que tem condições de levar a revolução até o fim", pois todas as outras classes que fazem parte do campo da revolução exercem ou se interessam "pelo exercício da exploração e têm, em maior ou menor escala, privilégios a defender". Por essas características qualquer uma delas que dispusesse da "hegemonia do poder na revolução utilizá-lo-ia para exercer a exploração sobre as outras e terminaria por permitir novamente a penetração do neocolonialismo", transformando-se, desta maneira, em um "novo suporte social do neocolonialismo". Para o Doc. de Crítica, nas condições do mundo atual, sem que exista a hegemonia do proletariado, "em qualquer revolução, mesmo que as forças revolucionárias atinjam o poder, mais cedo ou mais tarde o país voltará à condição de semicolônia"309.

Diz o Doc. de Crítica que o proletariado visa através da revolução atingir o socialismo e o comunismo, a fim de construir uma sociedade livre da exploração de classe e a eliminação das classes. Entretanto, nota que considerando-se a situação atual, "quando a contradição de nossa sociedade coloca outras classes e camadas sociais ao lado da revolução e dita a necessidade de uni-las para derrotar o inimigo comum, o proletariado",para que seja garantida a união dessas classes e camadas sociais, o proletariado necessita "limitar seus objetivos programáticos, desde que sela assegurada sua hegemonia na revolução". Essa limitação dos objetivos programáticos do proletariado caracteriza, para o Doc. de Crítica a etapa da revolução ${ }^{310}$.

\footnotetext{
${ }^{307}$ PARTIDO COMUNISTA DO BRASIL - ALA VERMELHA. Crítica ao oportunismo... p. 42.

${ }^{308}$ PARTIDO COMUNISTA DO BRASIL - ALA VERMELHA. Crítica ao oportunismo... p. 42.

${ }^{309}$ PARTIDO COMUNISTA DO BRASIL - ALA VERMELHA. Crítica ao oportunismo... p. 42.

${ }^{310}$ PARTIDO COMUNISTA DO BRASIL - ALA VERMELHA. Crítica ao oportunismo... p. 42.
} 
Ressalta o Doc. de Crítica que a revolução brasileira, na sua atual etapa, objetiva "destruir os meios de dominação, opressão e exploração do neocolonialismo e seu suporte social interno" 311 .

Neste aspecto o Doc. de Crítica não se afasta muito do documento da VI Conferência, pois vê que esta dominação, opressão e exploração caracterizariam a sociedade brasileira como sendo uma sociedade "neocolonizada, agrária e de acentuadas relações de produção capitalistas". Aduz ainda o Doc. de Crítica que deste modo, como a revolução brasileira objetiva eliminar a "dominação de classe do neocolonialismo, dos latifundiários, da burguesia importadora-exportadora, da burguesia financeira e da burguesia integrada", caracteriza-se como uma revolução "antineocolonialista, democrática, agrária e de transformações socialistas",312.

Por tais razoes é que o Doc. de Crítica entende que na atual etapa a revolução brasileira objetiva instituir "um regime democrático", porém contrariamente ao Doc. VI Conferência, que esteja "sob a hegemonia do proletariado", a fim de realizar transformações na estrutura da sociedade, correspondentes às necessidades da grande maioria da nação, ou seja: "do povo brasileiro, o que a caracteriza como uma etapa de democracia popular".

A fim de cumprir as tarefas da etapa de democracia popular da revolução brasileira, torna-se necessária a constituição de um "novo poder político que exerça a ditadura sobre aquelas classes e camadas sociais contra-revolucionárias". Este novo poder seria exercido pelas classes e camadas sociais que estão no campo da revolução, sob a hegemonia do proletariado. Devido à sua composição social e às transformações sociais que objetiva introduzir na sociedade, este novo poder seria um "Governo Popular Revolucionário". Este poder, pela necessidade de ser exercido sob a hegemonia do proletariado, "constitui-se como uma forma de ditadura do proletariado"; ou seja, o Governo Popular Revolucionário é a "forma que a ditadura do proletariado assume na atual etapa da revolução"313.

Com a finalidade de "destruir a dominação de classe do neocolonialismo e do seu suporte social interno", preconiza o Doc. de Crítica que o Governo Popular Revolucionário teria como tarefa principal "destroçar os instrumentos de dominação $e$ opressão daquelas classes", bem como expropriar seus meios de exploração, libertar as forças produtivas e construir as bases econômicas e sociais da nova sociedade"314.

\footnotetext{
${ }^{311}$ PARTIDO COMUNISTA DO BRASIL - ALA VERMELHA. Crítica ao oportunismo... p. 42.

${ }^{312}$ PARTIDO COMUNISTA DO BRASIL - ALA VERMELHA. Crítica ao oportunismo... p. 43.

${ }^{313}$ PARTIDO COMUNISTA DO BRASIL - ALA VERMELHA. Crítica ao oportunismo... p. 43.

${ }^{314}$ PARTIDO COMUNISTA DO BRASIL - ALA VERMELHA. Crítica ao oportunismo... p. 43.
} 
Com relação às tarefas a serem executadas por um Governo Popular Revolucionário, o Doc. de Crítica destaca as que considera como medidas essenciais visto que compreende que a elaboração de um programa detalhado e aprofundado dessas medidas seria "conseqüência do próprio aprofundamento do trabalho teórico e do conhecimento minucioso da nossa realidade, imprescindivel à revolução brasileira"315.

Seriam as tarefas essenciais ${ }^{316}$ do Governo Popular Revolucionário:

- "Expropriação e estatização dos capitais, bens e propriedades do neocolonialismo no Brasil. Nisto consiste o conteúdo anti-neocolonialista da revolução brasileira".

- "Expropriação de toda a propriedade latifundiária e reforma agrária radical, constando da distribuição da terra aos camponeses que nela trabalham, propiciando-lhes os meios para desenvolver a produção, bem como a instituição de cooperativas do tipo inferior e superior nas condições em que haja condições para tal. Nisto consiste o conteúdo agrário da revolução brasileira".

- "Expropriação e estatização dos capitais, bens e propriedades da burguesia financeira, da burguesia importadora-exportadora e da burguesia integrada".

Na expropriação e estatização dos capitais e bens do neocolonialismo, da burguesia financeira, da burguesia importadora-exportadora e da burguesia integrada e na instituição de "cooperativas de tipo superior no campo, consiste o caráter de acentuadas transformações socialistas da revolução brasileira",317.

Como condições necessárias para essas transformações, o Governo Popular Revolucionário deveria, segundo o Doc. de Crítica: 1) Aniquilar o aparelho militar da ditadura contra-revolucionária, substituindo-o pelo Exército Popular Revolucionário; 2) Destroçar o aparelho estatal e burocrático da ditadura contra-revolucionária, substituindo-o pelo aparelho de Estado das forças revolucionárias. Tomando tais medidas essenciais, o Governo Popular Revolucionário estaria cumprindo as tarefas da primeira etapa da revolução brasileira. Dessa forma, seria um "governo de transição para a ditadura do proletariado e para a etapa socialista"318.

\footnotetext{
${ }^{315}$ PARTIDO COMUNISTA DO BRASIL - ALA VERMELHA. Crítica ao oportunismo... p. 43.

${ }^{316}$ Aqui e para o que se segue, cf. PARTIDO COMUNISTA DO BRASIL - ALA VERMELHA. Crítica ao oportunismo... p. 43.

${ }^{317}$ PARTIDO COMUNISTA DO BRASIL - ALA VERMELHA. Crítica ao oportunismo... p. 43.

${ }^{318}$ PARTIDO COMUNISTA DO BRASIL - ALA VERMELHA. Crítica ao oportunismo... p. 44.
} 
Apregoa o Doc. de Crítica que do ponto de vista da estratégia da revolução, "é necessário ter conhecimento da situação global da sociedade brasileira", uma vez que de tal conhecimento emanariam "as características fundamentais dessa situação, que correspondem a uma sistematização dos aspectos mais importantes indicados pela análise de nossa sociedade ${ }^{, 319}$.

Seriam as seguintes as características fundamentais da situação atual da sociedade brasileira: 1) A sociedade brasileira estaria submetida à "dominação, opressão $e$ exploração do neocolonialismo e do seu suporte social interno, que as exercem através da contra-revolução armada no poder, sob a forma de ditadura militar neocolonialista”. As classes que comporiam base social da dominação neocolonialista tendem a se amalgamar em torno da ditadura, na medida em que se sintam ameaçadas pela revolução"; 2) o principal instrumento de dominação da contra-revolução armada no poder seria o "exército burguês transformado em força de ocupação interna e tendo como reserva imediata as polícias militar e civil, assessoradas e orientadas pelos especialistas do Pentágono, da CIA e do Ponto IV', as quais procurariam transformar em "reservas do exército as populações civis, através da exigência da prestação de serviços dos civis às Forças Armadas (ex.: Militarização da Medicina)". A ditadura para se manter no poder necessitaria de uma força militar "indivisível e poderosa". Na impossibilidade de conseguir uma unidade monolítica de todo o exército, a ditadura "manipula seus comandos a fim de garantir-lhes a coesão". Este aparelho militar, por ser uma "tropa de ocupação interna do neocolonialismo", contaria com a experiência "internacional da contra-revolução armada". Assim, exerceria uma repressão preventiva contra qualquer "movimento de massa ou armado que assuma ou possa assumir um caráter revolucionário"; 3) a "contrarevolução armada no poder" concentraria a maior parte de seu poderio repressivo nos grandes centros urbanos, onde também se concentrariam seus maiores interesses. Dessa forma, a ditadura seria, segundo o Doc. de Crítica "relativamente fraca nas zonas rurais". No entanto, ela procuraria "neutralizar sua debilidade nas zonas rurais deslocando preventivamente contingentes das Forças Armadas para regiões onde acredita poderem surgir ações revolucionárias, ocupando militarmente essas regiões e tentando "ganhar as populações locais e corromper seus líderes"; 4) O desenvolvimento do capitalismo na sociedade brasileira atual se daria nas "condições de existência de importantes regiões atrasadas", pois embora existisse "uma predominância de relações capitalistas" o Brasil se caracterizaria como um país "predominantemente agrário". No entanto, diz o Doc. de

\footnotetext{
${ }^{319}$ PARTIDO COMUNISTA DO BRASIL — ALA VERMELHA. Crítica ao oportunismo... p. 44.
} 
Crítica, isto se daria ao lado da existência de "fatores fundamentais" para a compreensão da situação atual da sociedade brasileira: a) a maioria da população do país vive no campo, isto é, fora dos centros urbanos, onde se concentra a produção capitalista; b) pelo fato de a economia nacional se fundamentar na "exportação de produtos primários e de a maioria da população ativa viver no campo", a sociedade brasileira se caracterizaria "como predominantemente agrária"; c) as populações que viviam no campo estariam submetidas às formas mais agudas de exploração e opressão, "mesmo nas regiões em que existem relações de produção capitalistas". Portanto tais populações se constituiriam nas "massas mais miseráveis do país e sentem mais diretamente a necessidade social da revolução"; 5) o proletariado, o campesinato, a pequena burguesia e o "semiproletariado colocam-se objetivamente no campo da revolução, devido à opressão e exploração a que estão submetidos pelo neocolonialismo e seu suporte social interno". Pelo fato de a burguesia nacional estar submetida a pressões da dominação neocolonialista, na etapa atual, ela também se colocaria "objetivamente no campo da revolução". Contudo, atualmente, todas essas classes e camadas não estariam ainda "ganhas subjetivamente para o processo revolucionário", pois embora as condições objetivas estivessem "plenamente amadurecidas, existe em relação a elas um atraso das condições subjetivas". Esse desnível ocorreria fundamentalmente porque, no Brasil, não existiria "um conhecimento profundo da teoria do marxismo-leninismo que possibilitasse a combinação de suas verdades universais com a prática concreta da revolução brasileira". Disto resultaria a existência de "múltiplas concepções sobre o processo revolucionário de inúmeras organizações $e$ partidos de esquerda". A ausência de unidade política dificultaria "o desenvolvimento das condições subjetivas". Por outro lado, a "contra-revolução intensifica sua propaganda ideológica visando a confundir as massas, o que concorre ainda mais para dificultar o desenvolvimento das condições subjetivas"; 6) de acordo com o Doc. de Crítica o proletariado, durante um longo processo, ainda não teria logrado "construir a sua verdadeira vanguarda de classe, em virtude da predominância do oportunismo que sempre grassou em suas fileiras". Portanto, a construção do Partido Revolucionário do Proletariado ainda seria uma tarefa a ser cumprida. Entendia o Doc. de Crítica que esta circunstância "impossibilitou também a construção de uma força armada sob a direção do Partido do Proletariado". No desnível das condições subjetivas em relação às objetivas e na ausência de um verdadeiro Partido do Proletariado e de uma força armada sob sua direção "consiste a debilidade do campo da revolução"320.

\footnotetext{
${ }^{320}$ PARTIDO COMUNISTA DO BRASIL — ALA VERMELHA. Crítica ao oportunismo... p. 44-45.
} 
O Doc. de Crítica indica a seguir a direção estratégica do processo revolucionário: para derrotar o "neocolonialismo e seu suporte social interno", o "golpe principal" das forças revolucionárias, sob a direção do proletariado, deveria ser dirigido contra o instrumento de dominação e opressão das forças contra-revolucionárias, isto é, "contra $a$ ditadura militar neocolonialista". A principal tarefa estratégica da revolução seria, pois, " $a$ destruição da ditadura militar neocolonialista e sua substituição por um Governo Popular Revolucionário".

O cumprimento dessa tarefa implicaria a "destruição do principal instrumento de sustentação da ditadura, ou seja, suas forças armadas". Em virtude da distribuição desigual do poderio do inimigo, as forças da revolução deveriam atingi-lo a partir de seus pontos mais débeis: como "o inimigo concentra seu poderio nos grandes centros urbanos $e$ é relativamente débil nas zonas rurais". Por esta razão, as forças revolucionárias deveriam, "a partir das zonas rurais, executar o cerco dos grandes centros urbanos". O cerco das cidades pelo campo seria também indicado pelo fato de a maioria da população do país viver nas zonas rurais e porque esta população estaria "submetida às formas mais violentas de opressão o às mais atrasadas de exploração, o que lhes proporciona um sentimento imediato da necessidade da revolução" ${ }^{\text {321. }}$.

A fim de fazer frente ao "poderio da contra-revolução", o Doc. de Crítica apregoa ser necessário que, no decorrer do processo revolucionário, "unam-se todas as forças suscetíveis de serem unidas". A união somente poderia ser concretizada na medida em que "aquelas classes e camadas sociais que estão objetivamente no campo da revolução forem também ganhas subjetivamente para o processo revolucionário".

Tendo apreciado os traços mais gerais de uma orientação estratégica para o processo revolucionário brasileiro, o Doc. de Crítica procura encontrar as formas e meios de aplicar essa orientação geral à realidade concreta da sociedade brasileira, no item Sobre a tática da Revolução Brasileira.

Naquele ponto o Doc. de Crítica preconiza que para levar a efeito a tarefa principal indicada pela estratégia, ou seja, "a destruição da ditadura militar neocolonialista através do aniquilamento de suas Forças Armadas", seria necessário encontrar a forma de luta adequada: como as Forças Armadas exercem o papel de "força de ocupação interna e realizam a repressão preventiva" e também realizam "a ocupação militar interna do país" estariam elas "capacitadas para reprimir qualquer movimento de massas de caráter pacífico ou armado" uma vez que "já empregam na prática a luta armada contra-

\footnotetext{
${ }^{321}$ PARTIDO COMUNISTA DO BRASIL — ALA VERMELHA. Crítica ao oportunismo... p. 45.
} 
revolucionária". Assim, para que as forças revolucionárias obtivessem êxito, seria necessário o "emprego da luta armada como sua principal forma de ação". Todavia, como na situação atual, como o fator dominante da sociedade brasileira seria "a contrarevolução armada, as forças revolucionárias necessariamente devem empregar as mesmas formas de luta empregadas pelas forças contra-revolucionárias"322.

Em seguida o Doc. de Crítica apresenta sua valoração sobre a experiência da revolução em todo o mundo, onde divisa que esta experiência indicaria a existência de "apenas dois caminhos através dos quais a luta armada pode se desenvolver: a guerra insurrecional e a guerra popular".

A guerra insurrecional tem como base principal a luta nos grandes centros urbanos e realiza-se através de um processo conspirativo de acumulação de forças até que as forças da revolução sejam superiores às do inimigo". Desenvolve-se através de "vigorosos movimentos de massas" - que se ampliam cada vez mais —, e utiliza o "trabalho conspirativo de desintegração do exército do inimigo, ao lado de aprofundar o desmoronamento do poder constituído" ${ }^{323}$. Para o Doc. de Crítica seriam condições básicas para a guerra insurrecional:

"a existência de um exército inimigo desprovido de coesão interna, a necessidade de que o poder constituído esteja num processo de decomposição e desmoralização e a existência de um proletariado em armas que se constitua no contingente principal da revolução, tendo o campesinato como reserva imediata".

Nestas condições, "a greve geral política e os levantes revolucionários nos grandes centros urbanos podem ser combinados com êxito". No entanto o Brasil não ofereceria, atualmente, essas condições pois a "ditadura militar neocolonialista não está em decomposição, os comandos do exército estão coesos e o contingente principal da revolução é o campesinato". Além disso, a concentração do "poderio militar do inimigo nos grandes centros urbanos impede o surgimento de um auge do movimento de massas nas cidades" 324 .

Desta forma, para se derrotar o exército contra-revolucionário seria imprescindível outro exército: como seria "impossível cindir o exército do inimigo", as forças

\footnotetext{
${ }^{322}$ PARTIDO COMUNISTA DO BRASIL - ALA VERMELHA. Crítica ao oportunismo... p. 46.

${ }^{323}$ PARTIDO COMUNISTA DO BRASIL — ALA VERMELHA. Crítica ao oportunismo... p. 46.

${ }^{324}$ PARTIDO COMUNISTA DO BRASIL - ALA VERMELHA. Crítica ao oportunismo... p. 46.
} 
revolucionárias precisariam "construir seu exército o tal tarefa se torna Irrealizável nas condições de trabalho clandestino e conspirativo" 325.

Por outro lado, o Doc. de Crítica entendia que a guerra popular corresponderia "às necessidades impostas pelas condições da sociedade brasileira". Como as forças revolucionárias seriam "taticamente débeis em relação às forças contra-revolucionárias", seria necessário "atingir o inimigo onde ele é mais vulnerável". O Doc. de Crítica dizia que o “inimigo é mais vulnerável nas zonas rurais e, por isto, estas se constituem no palco principal de luta no processo revolucionário". Partindo do campo, a luta armada se desenvolveria em "choque aberto com o inimigo e, nesse processo, ao mesmo tempo em que ganha as grandes massas para a revolução, constrói paulatinamente o Exército Popular Revolucionário" ${ }^{, 326}$.

Frisava o Doc. de Crítica que: "só através da guerra popular é que, nas atuais condições, é possível construir um partido temperado na luta, um exército poderoso, a aliança operário-camponesa e uma frente única revolucionária, que congregue as grandes massas do povo" 327.

Concluía o Doc. de Crítica afirmando que em se utilizando como principal forma de luta a luta armada, "as forças revolucionárias poderão efetuar o cerco dos grandes centros urbanos a partir das zonas rurais", enquanto que aproveitando as "condições favoráveis que as zonas rurais oferecem' e congregando as "grandes massas exploradas do campo no Exército Popular", a guerra popular permitiria "a libertação paulatina de vastas regiões, que se constituirão em bases de apoio estratégicas, de onde partirão os golpes decisivos contra as grandes concentrações do poderio inimigo",328.

As razões que tornariam possível o desenvolvimento desse processo seriam "as características (...) da sociedade brasileira. Características estas que exigiriam — para que o processo revolucionário tivesse êxito —, " a correta combinação entre a luta armada no campo e nas cidades". A luta nas cidades abrangeria uma compreensão que iria "desde a utilização de formas legais até as ações armadas de guerrilhas urbanas". Neste processo se desenvolveria o "movimento de massas e sua combinação com a luta armada no campo permitirá a desintegração das forças do inimigo". Dessa forma, "quando o Exército Popular, a partir de suas bases de apoio, desfechasse o ataque contra os centros urbanos, "as forças revolucionárias nas cidades" desencadeariam "a insurreição urbana para o

\footnotetext{
${ }^{325}$ PARTIDO COMUNISTA DO BRASIL - ALA VERMELHA. Crítica ao oportunismo... p. 46.

${ }^{326}$ PARTIDO COMUNISTA DO BRASIL — ALA VERMELHA. Crítica ao oportunismo... p. 46.

${ }^{327}$ PARTIDO COMUNISTA DO BRASIL — ALA VERMELHA. Crítica ao oportunismo... p. 46.

${ }^{328}$ PARTIDO COMUNISTA DO BRASIL - ALA VERMELHA. Crítica ao oportunismo... p. 47.
} 
aniquilamento total do inimigo". Neste processo, a fim de ganhar subjetivamente as classes e camadas sociais que estariam objetivamente no campo da revolução, o proletariado "dispondo de um partido temperado na luta e de uma força armada sob sua direção, $e$ tendo forjado, na luta, a aliança operário-camponesa" — teria as condições necessárias para a criação de uma "frente única revolucionária sob sua hegemonia"329.

Em continuidade a seu desenvolvimento o Doc. de Crítica nos oferece sua visão da Guerra Popular no Brasil, iniciando por conceituá-la: a "Guerra Popular é forma que a luta armada assume quando, a partir de pequenas ações armadas, se desenvolve paulatinamente até envolver a participação de todo o povo"330.

Ensinava o Doc. de Crítica que o desencadeamento da luta armada poderia ocorrer de várias formas: "no auge do movimento de massas, como resultado de um levante armado camponês, através de uma cisão no exército inimigo ou através da formação de um foco revolucionário"331.

Para o Doc. de Crítica a concepção do desencadeamento da luta armada a partir de um auge do movimento de massas pressuporia "organizar e armar as massas durante um longo processo conspirativo, ao lado da existência de um amplo movimento de massas". Contudo, o Doc. de Crítica afirmava que nas condições brasileiras "este processo é inviável porque a contra-revolução opõe ao movimento de massas a repressão armada antes que a luta de massas possa ser apoiada pela existência de uma força armada revolucionária",332.

Para o Doc. de Crítica o desencadeamento da luta armada a partir de um levante armado de camponeses também seria impossível nas condições brasileira de então, pois para seria necessário para tanto que existisse "um trabalho de agitação política de massas e uma força armada regular a fim de garantir os objetivos do levante e a continuidade dessa luta". Como o trabalho de agitação política de massas estava impossibilitado de se desenvolver, "devido a repressão preventiva contra-revolucionária", o que tornaria igualmente irrealizável esta opção ${ }^{333}$.

A seguir o Doc. de Crítica analisa a hipótese de cisão no exército inimigo, a qual teria como objetivo "contar com uma força armada regular constituída para eclodir a luta armada revolucionária". Tal cisão pressupõe ou uma "decomposição do poder inimigo" ou

\footnotetext{
${ }^{329}$ PARTIDO COMUNISTA DO BRASIL - ALA VERMELHA. Crítica ao oportunismo... p. 47.

${ }^{330}$ PARTIDO COMUNISTA DO BRASIL - ALA VERMELHA. Crítica ao oportunismo... p. 47.

${ }^{331}$ PARTIDO COMUNISTA DO BRASIL - ALA VERMELHA. Crítica ao oportunismo... p. 47.

${ }^{332}$ PARTIDO COMUNISTA DO BRASIL - ALA VERMELHA. Crítica ao oportunismo... p. 47.

${ }^{333}$ PARTIDO COMUNISTA DO BRASIL - ALA VERMELHA. Crítica ao oportunismo... p. 47.
} 
a realização de um "trabalho revolucionário nos comandos das Forças Armadas". O Doc. de Crítica constatava que não existiam no Brasil "condições para concretizar uma cisão no exército contra-revolucionário, pois a ditadura, através da manipulação de seus comandos, garante-lhe a coesão",334.

Finalmente o Doc. de Crítica avalia qual o método que permitiria o desencadeamento e o desenvolvimento da luta armada: "a eclosão da luta armada necessita da existência de uma força armada regular no campo, clandestina, que possa iniciar o choque aberto com o inimigo". Para garantir a sobrevivência desse contingente e permitir a continuidade de sua ação, seria necessário contar com "amplo apoio das massas locais e do país; esse método de eclosão da luta armada se constitui no Foco Revolucionário" ${ }^{335}$.

De acordo com o Doc. de Crítica o foco revolucionário tem como pressuposto " $a$ existência de uma região estrategicamente favorável ao desencadeamento da luta armada, onde um contingente guerrilheiro realiza as primeiras ações armadas do processo revolucionário". Isto porque a partir das ações do contingente guerrilheiro e do apoio das massas camponesas entre as quais se realiza a propaganda armada, seriam criadas as condições necessárias para a "transformação da região numa zona de guerrilhas, permitindo o surgimento de novas guerrilhas e ampliando sua zona de ação". Seriam, assim, dados os primeiros passos para "a construção do Exército Popular Revolucionário e da primeira base de apoio revolucionário". A fim de desenvolver esse processo, o contingente guerrilheiro não apenas deveria executar ações armadas, como também "ganhar o apoio das massas locais e manter contatos com o exterior da zona de guerrilhas, para que todas as outras atividades revolucionárias em curso no país possam ser combinadas com suas ações e em função de suas necessidades" ${ }^{336}$.

Esclarecia o Doc. de Crítica que a criação do foco revolucionário pode ocorrer de diversas maneiras: 1) por meio da "formação do contingente guerrilheiro com elementos da região e baseado num trabalho de agitação local"; 2) através da "implantação clandestina do contingente guerrilheiro e a posterior realização do trabalho de massas na região, a fim de criar, a partir da guerrilha, uma rede de apoio e a organização política"; 3) a inserção clandestina do contingente guerrilheiro que seria realizada por uma organização partidária marxista-leninista, a qual realizaria um trabalho político na região,

\footnotetext{
${ }^{334}$ PARTIDO COMUNISTA DO BRASIL - ALA VERMELHA. Crítica ao oportunismo... p. 48.

${ }^{335}$ PARTIDO COMUNISTA DO BRASIL - ALA VERMELHA. Crítica ao oportunismo... p. 48.

${ }^{336}$ PARTIDO COMUNISTA DO BRASIL - ALA VERMELHA. Crítica ao oportunismo... p. 48.
} 
"para criar não apenas uma rede de apoio concomitantemente com a implantação da guerrilha, como também as condições de sua sustentação" ${ }^{337}$.

Analisava o Doc. de Crítica que as mesmas razões que impossibilitavam o desenvolvimento do movimento de massas no campo - "a repressão preventiva da contra-revolução" —, igualmente "impedem o trabalho de agitação que possibilitaria a formação de um contingente guerrilheiro constituído de elementos da região". Por outro lado, constatava também a inviabilidade da "constituição de um contingente para, a partir dele, realizar o trabalho de massas local e criar a organização partidária”, considerandose que a inexistência anterior da organização partidária implicaria que "os elementos que irão fazer parte do contingente não possuam completa homogeneidade política $e$ ideológica". Isto provocaria "uma falta de unidade capaz de levar o contingente à desintegração". Tal fato colocaria em risco "a necessária clandestinidade no período de preparação anterior à realização de ações abertas". Além disso, a falta de apoio das massas locais no início do processo "contribuiria para dificultar o seu desenvolvimento",338.

O Doc. de Crítica precavia que "para burlar a vigilância da contra-revolução armada, tornava-se necessário que a implantação do contingente seja realizada na mais absoluta clandestinidade". Seria necessário também que esta implantação se realizasse "paralelamente à formação da rede de apoio na região, como resultado de um trabalho político clandestino". Tal trabalho, devido à sua natureza, apenas "poderia ser realizado por uma organização partidária marxista-leninista". A existência dessa organização garantiria também "a homogeneidade política e ideológica do contingente guerrilheiro e os contatos com o exterior da região do foco". Por outro lado, seria necessário que no contingente estivesse a maioria dos "quadros mais responsáveis da organização partidária para que se garanta, desde o início do processo, uma direção político-militar conjunta e presente no palco principal da luta revolucionária”. Como a luta armada é o fator determinante no processo revolucionário, a participação dos principais quadros da organização partidária nessa luta permitiria "a subordinação de todas as outras tarefas à tarefa principal" ${ }^{339}$.

Para impedir o isolamento do foco revolucionário, para dispersar as forças do inimigo e para mobilizar as amplas massas o Doc. de Crítica dizia ser imprescindível que

\footnotetext{
${ }^{337}$ PARTIDO COMUNISTA DO BRASIL - ALA VERMELHA. Crítica ao oportunismo... p. 48.

${ }^{338}$ PARTIDO COMUNISTA DO BRASIL — ALA VERMELHA. Crítica ao oportunismo... p. 48.

${ }^{339}$ PARTIDO COMUNISTA DO BRASIL - ALA VERMELHA. Crítica ao oportunismo... p. 48-49.
} 
se combinassem "as ações de guerrilha, desde seu surgimento, com outras ações e formas de luta no campo e na cidade". Seria necessário, assim, "desenvolver o movimento de massas e desencadear a guerrilha urbana, uma vez que o desenvolvimento do movimento de massas se torna possível se este tem como apoio a luta armada no campo, o seu desenvolvimento e ampliação se darão paralelamente à ampliação e desenvolvimento da luta armada",340.

O Doc. de Crítica ressaltava também a necessidade do Partido do Proletariado, ao dispor que a ação do contingente guerrilheiro na zona de guerrilhas combinada com outras ações e formas de luta revolucionárias possibilitaria "o surgimento de novas guerrilhas e a ampliação da região conflagrada, dando início à construção do Exército Popular Revolucionário" ${ }^{341}$. Para que o desenvolvimento da luta armada e a construção do Exército Popular Revolucionário se dessem sob a hegemonia do proletariado se fazia necessário que,

"paralelamente a este processo, se forje a verdadeira vanguarda do proletariado. Assegurar a hegemonia do proletariado no desenvolvimento da luta armada e na construção do Exército Popular Revolucionário é a condição essencial para garantir a hegemonia do proletariado na Revolução e para o êxito desta" ${ }^{342}$.

Constatava o Doc. de Crítica que após mais de quatro décadas, "o proletariado não logrou forjar sua verdadeira vanguarda de classe". Isto se daria porque desde o surgimento do Partido, "ele esteve marcado pela presença do oportunismo pequenoburguês em suas fileiras". O Partido só se poderia constituir na verdadeira vanguarda do proletariado e se afastar de todas "as gamas do oportunismo em suas fileiras" se o seu surgimento ocorre "na luta, para luta e dirigindo a luta revolucionária". Apenas por meio “da luta revolucionária o Partido se constrói e se tempera como a verdadeira vanguarda do proletariado". Verificava o Doc. de Crítica que:

nas "condições atuais do Brasil, onde nenhuma forma de luta revolucionária tem condições de desenvolvimento sem a luta armada, a cristalização de uma vanguarda do proletariado só se pode dar estreitamente vinculada com a existência concreta da luta armada. No Brasil, o Partido, como destacamento de

\footnotetext{
${ }^{340}$ PARTIDO COMUNISTA DO BRASIL - ALA VERMELHA. Crítica ao oportunismo... p. 49.

${ }^{341}$ PARTIDO COMUNISTA DO BRASIL - ALA VERMELHA. Crítica ao oportunismo... p. 49.

${ }^{342}$ PARTIDO COMUNISTA DO BRASIL - ALA VERMELHA. Crítica ao oportunismo... p. 49.
} 
vanguarda do proletariado, só pode surgir no seio da luta armada, para a luta armada e dirigindo a luta armada" ${ }^{, 343}$.

Partindo da necessidade do Partido do proletariado para dirigir o processo revolucionário e da necessidade da existência de uma organização partidária marxistaleninista para preparar e desencadear a luta armada, o Doc. de Crítica determina as tarefas mais urgentes com relação à luta armada e à construção do Partido. Para o Doc., "a tarefa mais urgente do processo revolucionário brasileiro não consiste na construção de um forte Partido em todo o país, para somente depois preparar e desencadear a luta armada". Não se tratava, assim, de "destacar os melhores quadros para esse trabalho de construção do Partido" 344 .

A partir destas premissas, o Doc. de Crítica conclui que para aquele momento histórico a tarefa mais urgente da revolução brasileira consistira em "destacar os melhores e mais responsáveis quadros da organização partidária para preparar e desencadear a luta armada". A partir da eclosão da luta armada e com base em seu desenvolvimento, " $a$ tarefa da organização partidária será a de intensificar e estreitar suas relações com as massas e assumindo nesse processo o papel de vanguarda do proletariado". Na acepção do Doc. de Crítica a era a partir deste ponto que a tarefa de construção do Partido de vanguarda do proletariado se tornaria possível e adquiriria "seu verdadeiro sentido" 345 .

Advertia o Doc. de Crítica que ao preparar e desencadear a luta armada, a organização partidária "não pode abandonar o trabalho de preparação das condições necessárias para que, após o desencadeamento da luta armada, possa desenvolver a tarefa de se transformar na vanguarda do proletariado e da revolução". Desta maneira, paralelamente ao trabalho de preparação e desencadeamento da luta armada, a organização partidária deveria "desenvolver o trabalho de massas, assentando as bases para seu desenvolvimento posterior ao desencadeamento da luta armada, dando uma nova qualidade ao movimento de massas" $" 346$.

Em continuidade a sua análise o Doc. de Crítica abordava a questão da Frente Única Revolucionária, relembrando que para assegurar que o processo de luta armada assumisse a forma de guerra popular, seria necessário garantir a participação neste processo, "de todas as classes e camadas sociais que estão objetivamente no campo da

\footnotetext{
${ }^{343}$ PARTIDO COMUNISTA DO BRASIL - ALA VERMELHA. Crítica ao oportunismo... p. 49.

${ }^{344}$ PARTIDO COMUNISTA DO BRASIL — ALA VERMELHA. Crítica ao oportunismo... p. 49.

${ }^{345}$ PARTIDO COMUNISTA DO BRASIL - ALA VERMELHA. Crítica ao oportunismo... p. 49-50.

${ }^{346}$ PARTIDO COMUNISTA DO BRASIL — ALA VERMELHA. Crítica ao oportunismo... p. 50.
} 
revolução". Seria, assim, imprescindível "ganhá-las subjetivamente para a revolução e organizá-las para que possam intervir no processo". A Frente Única Revolucionária surge, então como o "instrumento de que se utiliza o proletariado para realizar essas tarefas". Desta maneira, a Frente Única Revolucionária se constituiria em um "instrumento de mobilização das massas para apoiar a luta armada", porque através dela que se daria "o desenvolvimento e a ampliação do movimento de massas e sua combinação com a luta armada"347.

Para que a Frente Única Revolucionária pudesse ser formada exitosamente seria necessário existir a hegemonia do proletariado, pois sem ela "não seria possível manter a coesão da Frente Única Revolucionária e os choques de interesses entre as classes $e$ camadas que a compõem a levaria à desintegração". A hegemonia do proletariado somente seria garantida "pela sua força emanada da existência de um Partido temperado na luta e de uma força armada sob sua direção". Sem esses dois fatores e, conseqüentemente, sem a hegemonia do proletariado, a Frente Única Revolucionária estaria fadada "à desintegração pelas ações das forças contra-revolucionárias" 348 .

O Doc. de Crítica evidencia que "a espinha dorsal da frente única revolucionária é a existência do Partido de vanguarda do proletariado e de uma força armada sob sua direção". Além disso, aduz que a base de massas que o proletariado necessita para realizar a frente única revolucionária "só pode ser fornecida por sua aliança com o campesinato". Por sua vez, "a aliança operário-camponesa só pode ser concretizada com base na existência da força armada do proletariado". Se tanto o Partido de vanguarda do proletariado, como as forças armadas sob sua direção, "só se forjarão com a existência concreta da luta armada", conseqüentemente, a Frente Única Revolucionária só será formada no processo de desenvolvimento da luta armada"349.

Por derradeiro, o Doc. de Crítica faz suas conclusões, onde ressalta que a tarefa mais urgente da revolução brasileira é a "preparação e eclosão da luta armada e que atualmente, no Brasil, a única forma de fazê-lo é pela criação de um foco revolucionário através da formação clandestina de um contingente guerrilheiro". Partindo dessas conclusões, o Doc. de Crítica afirma que "no momento a tarefa principal que nos indica a tática da revolução brasileira para a preparação da luta armada é a da criação do foco revolucionário".

\footnotetext{
${ }^{347}$ PARTIDO COMUNISTA DO BRASIL - ALA VERMELHA. Crítica ao oportunismo... p. 50.

${ }^{348}$ PARTIDO COMUNISTA DO BRASIL — ALA VERMELHA. Crítica ao oportunismo... p. 50.

${ }^{349}$ PARTIDO COMUNISTA DO BRASIL — ALA VERMELHA. Crítica ao oportunismo... p. 50.
} 
Contudo, o Doc. de Crítica ressalta um aspecto: paralelamente a esta tarefa " $e$ sempre subordinada a ela, é necessário desenvolver o trabalho de massas, preparando as condições para que, no momento da eclosão da luta armada, as grandes massas do povo possam apoiá-la". Além disto, destaca questão estreitamente vinculada à criação do foco, alertando que da necessidade de "se desenvolver a tarefa da preparação do trabalho militar nos grandes centros e em várias zonas rurais diversas daquela em que se localiza o foco". Diz o Doc. de Crítica que este trabalho militar, que se combinaria "com as ações realizadas na zona de guerrilhas", teria a finalidade de "confundir e dispersar as forças do inimigo" 350 .

Conclui o Doc. de Crítica dizendo que "realizadas estas tarefas paralelas à criação do foco não se permitirá seu isolamento, garantindo-lhe apoio militar e de massa"351.

Enquanto o Documento de Crítica era discutido pelas bases nos diversos Estados onde a Ala Vermelha existia na época, a partir do final de 1967 a AV executa medidas visando à preparação para ações armadas - coerentemente com as linhas políticas arquitetadas em seu documento fundador.

São enviados militantes para o interior de Goiás, para efetuassem o levantamento de regiões que apresentassem as condições necessárias para a criação de focos guerrilheiros ${ }^{352}$. Concomitantemente a estas diligências são postas em prática medidas para formular a criação de um organismo para realizar ações armadas urbanas.

Por deliberação da Direção Nacional Provisória foi então instituído o Grupo Especial Nacional (GEN), um agrupamento guerrilheiro que teria uma estrutura fixa que responderia diretamente à DNP, sendo que o Comitê Regional de São Paulo ficaria incumbido de manter um contato direto com os guerrilheiros, pois se pensava na realização de ações armadas de forma exclusiva na Grande São Paulo. Ao Regional paulista caberia o levantamento de locais para as atividades guerrilheiras as quais teriam de ter aprovação da DNP para sua efetivação. Ficaram incumbidos de fazer a ligação entre a Direção Nacional e o Regional de São Paulo, dois dos integrantes da DNP, Diniz Cabral Filho e Élio Cabral de Souza ${ }^{353}$.

A Direção Nacional Provisória, conjuntamente com o Comitê Regional de São Paulo, selecionaram militantes para integrar o agrupamento militar, ocasião em que são chamados

\footnotetext{
${ }^{350}$ PARTIDO COMUNISTA DO BRASIL — ALA VERMELHA. Crítica ao oportunismo... p. 51.

${ }^{351}$ PARTIDO COMUNISTA DO BRASIL - ALA VERMELHA. Crítica ao oportunismo... p. 51.

${ }^{352}$ TAPAJÓS, R. C. Renato Carvalho Tapajós: depoimento [dez. 2005]. Entrevistador: T. A. D. Silva. Campinas, 2005. CD 1, faixa 2.

${ }^{353}$ SOUZA, É. C. de. Élio Cabral de Souza: depoimento [nov. 2006]. Entrevistador: T. A. D. Silva. Goiânia, 2006. CD 1, faixa 8.
} 
para integrá-lo os mineiros Devanir José de Carvalho e seus irmãos Daniel e Joel; os goianos James Allen da Luz e Genésio Borges de Mello; os baianos Aderval Alves Coqueiro e José Anselmo da Silva ${ }^{354}$.

Por decisão da DNP foi indicado o dirigente do Regional paulista Renato Tapajós para ser Assistente Político do GEN, que tinha uma dupla função: efetuar discussões acerca das doutrinas marxistas-leninistas à luz do pensamento de Mao Tsé-tung com os membros do Grupo Especial Nacional — partindo do pressuposto "eles vinham do trabalho de base e não possuíam grande formação política" 355 —, e participar na preparação de ações armadas, bem como delas tomar parte de maneira indireta - encarregando-se de realizar o transbordo de veículos dos participantes diretos das atividades guerrilheiras ${ }^{356}$.

Os integrantes do GEN receberam também, desde meados de 1967, Cursos de Capacitação - que foram ministrados por três dirigentes nacionais que haviam feito estágios na China, Derly de Carvalho, Élio Cabral e Diniz Cabral Filho ${ }^{357}$ —, que incluía desde discussões das teorias de Marx, Engels, Lênin e Mao, até o adestramento ou aprimoramento no lidar com revólveres, pistolas automáticas, espingardas, carabinas, metralhadoras, manejo de explosivos em geral, adulteração de veículos e suas placas, confecção de granadas e outros artefatos explosíveis $^{358}$.

Estava a Ala Vermelha, deste modo, preparada para dar início às atividades guerrilheiras urbanas, o que concretamente vai acontecer em fevereiro de 1968 - segundo os processos instaurados contra a AV pelo sistema de repressão do Regime Autoritário brasileiro $^{359}$.

${ }^{354}$ CARVAlhO, D. J. de. Derly José de Carvalho: depoimento [out. 2006]. Entrevistador: T. A. D. Silva. São Paulo, 2006. CD 1, faixa 29; TAPAJÓS, R. C. Renato Carvalho Tapajós: depoimento [nov. 2006]. Entrevistador: T. A. D. Silva. Campinas, 2006. CD 1, faixa 12; SOUZA, É. C. de. Élio Cabral de Souza: depoimento [nov. 2006]. Entrevistador: T. A. D. Silva. Goiânia, 2006. CD 1, faixa 7.

355 TAPAJÓS, R. C. Renato Carvalho Tapajós: depoimento [fev. 2005]. Entrevistador: T. A. D. Silva. Campinas, 2005. CD 1, faixa 24.

${ }^{356}$ TAPAJÓS, R. C., op. cit., CD 2, faixa 1.

${ }^{357}$ Cf. interrogatório prestado no DOPS por Élio Cabral de Souza. BNM 294, fls. 2330-v.

${ }^{358}$ Cf. interrogatório no DOPS de Aderval Alves Coqueiro. BNM 294, fls. 272.

359 A Ala Vermelha praticou mais ações do que as que são objeto de processos contra ela movidos pelos órgãos repressivos. Exemplificativamente, podemos citar a ocupação — por duas vezes — da Rádio Cacique de São Bernardo do Campo, em outubro e dezembro de 1968, para transmitir manifesto contra o Regime Autoritário e sobre a necessidade dos trabalhadores se organizarem; tomada dos transmissores da Rádio Nacional de São Paulo, situados no município de Diadema, em meados de maio de 1969 — igualmente para a transmissão de manifestos de teor semelhante. Nesse sentido, cf. CARVALHO, D. J. de. Derly José de Carvalho: depoimento [out. 2006]. Entrevistador: T. A. D. Silva. São Paulo, 2006. CD 1, faixa 1; 8; 30. Segundo Derly, a Ala Vermelha fez ações "que estão nos processos, foram ações que foram 'abertas' [reveladas pelas pessoas que foram presas] e outras que foram desenvolvidas durante este período após 64 e que não foram abertas, e que por medida de segurança a gente manteve assim". Cf. CARVALHO, D. J. de., op., CD 1, faixa 7. 
Misael Pereira dos Santos era bancário em 1968, e fazia parte do sindicato de sua categoria profissional. Era também dirigente da Ala Vermelha, tomando parte do Comitê Regional de São Paulo.

No princípio de 1968 Misael foi procurado por Élio Cabral de Souza que lhe perguntou "se havia possibilidade de se praticar roubo contra um banco, a fim de se conseguir dinheiro para o Partido" ${ }^{360}$. Como Misael era funcionário do Banco da Lavoura de Minas Gerais, transmitiu a Élio os dados referentes a uma caminhonete que transportava valores, recolhendo numerário "nas estações da Estrada de Ferro Santos/Jundiẫ" que se situavam “desde o Braz até Mauá", fornecendo ainda "a hora da partida e chegada, estações visitadas e número de funcionários que viajavam no carro recolhedor de dinheiro" 361

Uma vez de posse desses dados Élio Cabral contatou os integrantes do Grupo Especial Nacional e Renato Tapajós e lhes transmitiu as instruções de como deveria ocorrer a expropriação do dinheiro transportado pela caminhonete: a ação se daria na Estação de Mauá e ocorreria no dia 08 de fevereiro. Devanir, Aderval e James Allen ficaram incumbidos de efetuarem o levantamento do local e entregar os dados para Élio Cabral, para aprovação. Uma vez de posse do levantamento, Élio autorizou a ação.

A escolha da Estação Mauá não foi aleatória. A opção foi feita a partir de um critério político: o local ficava situado em frente à Companhia "Ultragás", pertencente ao Grupo Ultra, cujo diretor Henning Albert Boilesen - um dinamarquês ${ }^{362}$ naturalizado brasileiro - , contribuía financeiramente dinheiro para os órgãos de repressão e seus agentes $^{363}$.

A camionete objeto da ação da Ala Vermelha recolheria dinheiro dos cofres da Ultragás antes da ação do GEN. Esta era, assim, uma maneira de expropriar diretamente uma companhia - ou ao menos seu diretor - que colaborava ativamente com os setores repressivos do Regime Autoritário brasileiro.

Na data determinada, por volta das 13 horas, Daniel José de Carvalho dirigiu um Aero-Willys - que havia sido tomado de um motorista de táxi e pintado na cor negra pelos integrantes do $\mathrm{GEN}^{364}$ —, até as proximidades da linha férrea e estacionou o veículo,

\footnotetext{
${ }^{360}$ Cf. interrogatório no DOPS de Misael Pereira dos Santos. BNM 294, fls. 562-v.

${ }^{361}$ Cf. interrogatório no DOPS de Misael Pereira dos Santos. BNM 294, fls. 562-v.

362 Élio Gaspari afirma que Boillesen era norueguês. Cf. GASPARI, Élio. A ditadura escancarada. São Paulo: Companhia das Letras, 2002, p. 395.

${ }^{363}$ FON, Antonio Carlos. Tortura. A história da repressão política no Brasil. São Paulo: Comitê Brasileiro pela Anistia, 1979, p. 54-55.

${ }^{364}$ Cf. interrogatório no DOPS de Derly José de Carvalho. BNM 294, fls. 288-v.
} 
no sentido de direção que viria a Kombi do Banco da Lavoura ${ }^{365}$. No mesmo veículo se encontravam seus irmãos Devanir e Joel, além de Aderval Coqueiro e James Allen. Em um outro carro, dirigido por José Anselmo, viajava Genésio Borges - que estavam dando a cobertura (ato de assegurar a proteção) para a ação ${ }^{366}$.

Joel desceu do Aero-Willys com uma bandeira vermelha e postou-se ao lado da ferrovia. No momento em que a Kombi se aproximou, começou ele a agitar a bandeira, sinalizando para que o veículo parasse, enquanto Daniel dava a partida no carro rumou em direção à caminhonete ${ }^{367}$.

No instante em que a Kombi estacionou, Daniel encostou o Aero-Willys atrás da perua do banco, enquanto Devanir, Aderval e James Allen - portando metralhadora, espingarda calibre 12 e pistola automática 7.65 - desceram do veículo e intimaram os quatro funcionários que ocupavam a Kombi a descer. Em seguida, coletaram o dinheiro e o transportaram para o Aero-Willys. No momento da fuga obrigaram os funcionários a se afastarem a pé, enquanto Aderval disparou uma rajada de metralhadora contra o câmbio da perua para inutilizá-1o ${ }^{368}$.

Após empreenderam o abandono do local, na Vila Formosa fizeram o transbordo do dinheiro para o carro de Renato Tapajós, que os aguardava. Abandonaram o AeroWillys $^{369}$ no local e rumaram para seus aparelhos ${ }^{370}$, onde se deram conta que haviam se apoderado de aproximadamente cento e trinta mil reais ${ }^{371}$ — em valores atualizados ${ }^{372}$.

No mês de maio de 1968 de Élio Cabral perguntou a Misael Pereira dos Santos se " $a$ perua do Banco [da Lavoura de Minas Gerias] continuava fazendo o mesmo serviço, ocasião que recebeu resposta afirmativa" ${ }^{373}$. Élio resolveu realizar outra ação no mesmo local anterior — frente à Ultragás — pelas mesmas motivações que o levaram a decidir-se pela Estação de Mauá.

\footnotetext{
365 Idem.

${ }^{366}$ CARVAlHO, D. J. de. Derly José de Carvalho: depoimento [out. 2006]. Entrevistador: T. A. D. Silva. São Paulo, 2006. CD 1, faixas 31.

${ }^{367}$ Cf. interrogatório no DOPS de Derly José de Carvalho. BNM 294, fls. 288-v.

${ }^{368}$ Cf. interrogatório no DOPS de Derly José de Carvalho. BNM 294, fls. 288-v.

${ }^{369}$ Cf. interrogatório no DOPS de Derly José de Carvalho. BNM 294, fls. 288-v.

${ }^{370}$ Utiliza-se o vocábulo aparelho no sentido que era aplicado pela esquerda brasileira desde a década de 1920, designando "imóveis usados clandestinamente para a residencia de militantes" para atividades clandestinas. Cf. FREIRE, Alípio; ALMADA, Izaías; PONCE, J. A. de Granville. (org.). Tiradentes: um presídio da ditadura. São Paulo: Scipione Cultural, 1997, p. 501.

${ }^{371}$ Denúncia do Ministério Público. BNM 294, fls. 1-b.

${ }^{372}$ Atualizou-se os valores referentes a todas as ações que são objeto desta tese, em valores referentes ao dia $1^{\circ}$. dezembro de 2006, através do Índice Geral de Preços-Disponibilidade Interna (IGP-DI) da Fundação Getúlio Vargas. Disponível na Internet: www2.fgv.br/dgd/asp/dsp_IGP.asp Acessado em 17 de dezembro de 2006.

${ }^{373}$ Cf. interrogatório no DOPS de Misael Pereira dos Santos. BNM 294, fls. 562-v.
} 
Como o levantamento efetuado era o mesmo que fora feito anteriormente, Élio Cabral determinou ao GEN que fizesse apenas "uma confirmação do itinerário da perua do Banco, a fim de constatar se havia ou não cobertura policial"374.

Ocorreu apenas uma mudança do local de abordagem da Kombi: foi escolhido o lugar “que dá saída da Companhia Ultragás, uma vez que a perua recolhia numerário daquela companhia e ao retirar-se teria que entrar na Avenida principal, o que era feito com velocidade bem reduzida",375.

No dia três de junho de 1968 Joel José de Carvalho conduziu um Volkswagen sedan — expropriado por Devanir no bairro do Ibirapuera e cujas placas foram alteradas — onde se encontravam seus irmãos Devanir e Daniel, além de James Allen. Em outro "fusca" rumaram José Anselmo e Genésio Borges - para dar cobertura à ação ${ }^{376}$.

Chegaram ao local por volta das duas e meia da tarde, e estacionaram em um lugar próximo à entrada da Liquigás. Daniel desceu do carro e ficou encostado no muro daquela Companhia, portando sob sua japona, uma carabina ${ }^{377}$. Devanir ficou do outro lado da rua, portando uma pistola automática 7.65; James Allen estava com uma espingarda calibre 12 com o cano serrado, enquanto que Aderval estava mais distante, ficando em um local no qual poderia abordar a traseira da Kombi com sua metralhadora; Joel permaneceu no carro, pronto para empreender a fuga ${ }^{378}$.

Ao avistarem a Kombi do banco, se aperceberam que atrás dela vinha um carro Volkswagen, ocupado por funcionários da Ultragás. Quando o veículo bancário aproximou-se do grupo da Ala, Daniel, Aderval e James intimaram os empregados do Banco a descer da perua, enquanto que Devanir intimidou os ocupantes do Volks, ordenando que permanecessem dentro do carro. Pegaram o numerário e o transportaram para o carro onde se encontrava Joel, enquanto Aderval disparava contra o câmbio da Kombi, danificando-o ${ }^{379}$.

A seguir empreenderam a fuga, até encontrem-se com o carro de Renato Tapajós, para o qual se transferiram após abandonarem o Volkswagen ${ }^{380}$. Ao chegar a seus aparelhos puderam notar que haviam feito uma expropriação no valor de quatrocentos e oitenta mil reais $^{381}$ - em valores atualizados.

\footnotetext{
${ }^{374}$ Cf. interrogatório no DOPS de Derly José de Carvalho. BNM 294, fls. 289.

375 Idem.

${ }^{376}$ Cf. interrogatório no DOPS de Derly José de Carvalho. BNM 294, fls. 289.

${ }^{377}$ Cf. interrogatório no DOPS de Derly José de Carvalho. BNM 294, fls. 289.

378 Idem.

${ }^{379}$ Ibidem.

${ }^{380}$ Ibidem.

381 Denúncia do Ministério Público. BNM 294, fls. 1-b.
} 
As ações do GEN motivaram uma discussão no seio da Ala Vermelha sobre a validade política das ações armadas de expropriação de valores e bens móveis. O debate centrava-se no Documento de Crítica, mais particularmente na tática que apresentava para a revolução brasileira, na qual era prevista a necessidade de "desenvolver o movimento de massas $e$ desencadear a guerrilha urbana ${ }^{, 382}$.

A imprecisão do documento era censurada por grande parcela da Direção Nacional, que divisava como contraditória esta afirmação, visto que em outros momentos - como no item em que se apregoava a "A necessidade do Partido do Proletariado"383 o mesmo Documento de Crítica dizia claramente que:

"paralelamente ao trabalho de preparação e desencadeamento da luta armada, a organização partidária deve desenvolver o trabalho de massas, assentando as bases para seu desenvolvimento posterior ao desencadeamento da luta armada, dando uma nova qualidade ao movimento de massas" ${ }^{384}$.

Acrescentavam ainda os críticos à ações de expropriação que o Documento de Crítica ainda ressaltava em suas "Conclusões", de maneira patente que:

"podemos afirmar que no momento a tarefa principal que nos indica a tática da revolução brasileira para a preparação da luta armada é a da criação do foco revolucionário. (...) "estreitamente vinculada à criação do foco, é necessário desenvolver a tarefa da preparação do trabalho militar nos grandes centros e em várias zonas rurais diversas daquela em que se localiza o foco. Este trabalho militar, que se combinará com as ações realizadas na zona de guerrilhas, tem a finalidade de confundir e dispersar as forças do inimigo.

Realizadas estas tarefas paralelas à criação do foco não se permitirá seu isolamento, garantindo-lhe apoio militar e de massa"385.

Argumentavam ainda os detratores do GEN que a questão da luta armada urbana está, no Documento de Crítica, indissoluvelmente conectada à existência de um foco revolucionário - como mostra o texto acima reproduzido —, e em se considerando a não

\footnotetext{
${ }^{382}$ PARTIDO COMUNISTA DO BRASIL - ALA VERMELHA. Crítica ao oportunismo..., cit. p. 49.

${ }^{383}$ PARTIDO COMUNISTA DO BRASIL - ALA VERMELHA. Crítica ao oportunismo..., cit. p. 49.

${ }^{384}$ PARTIDO COMUNISTA DO BRASIL - ALA VERMELHA. Crítica ao oportunismo..., cit. p. 50.

${ }^{385}$ PARTIDO COMUNISTA DO BRASIL - ALA VERMELHA. Crítica ao oportunismo..., cit. p. 51.
} 
implantação ainda de um foco no campo por parte da Ala Vermelha, não teria qualquer sentido as ações de guerrilha urbana no momento.

Outros componentes da AV iam mais além e criticavam a proposta tática do próprio foco guerrilheiro, preconizando sua total substituição pelo estrito cumprimento dos caminhos da Guerra Popular Prolongada.

O debate foi se acirrando de tal maneira que a Direção Nacional houve por suspender transitoriamente ${ }^{386}$ as ações do GEN no decorrer do segundo semestre de 1968.

A resposta a este posicionamento não tardou a surgir. Os integrantes do GEN lançaram críticas à Direção Nacional argumentando que a Ala tinha capacidade operacional para fazer três ou quatro vezes mais ações armadas do que fazíamos. Diziam que a estrutura militar da organização era submetida pela direção a uma ociosidade forçada. Isso, segundo os membros do GEN, estava incorreto "porque as coisas estavam se acirrando, enfim, tinha que se "partir para o pau",387.

A partir deste momento o GEN se transmudou em GENR (Grupo Especial Nacional Revolucionário) e começou a fazer ações por sua própria iniciativa: sua primeira expropriação seria a realizada contra o Banco F. Barreto, em Osasco, em sete de março de 1969. Nesta ocasião os membros do novo agrupamento, apesar de se proclamarem como integrantes da Ala Vermelha, quebrariam uma linha política da própria Ala, a de não assumir publicamente a responsabilidade pelas ações armadas, deixando panfletos no local - como era prática corrente de outras organizações guerrilheiras atuantes no Brasil.

O GENR nesta sua primeira ação deixou um panfleto no local onde ocorreu a atividade, onde não apenas avocou a autoria da expropriação, ao assiná-la como obra do “Grupo Especial Nacional Revolucionário" ${ }^{888}$, mas também cindia-se - na prática - com a Ala Vermelha, ao batizar o ato que fizera como "Ação contra o

\footnotetext{
${ }^{386}$ CARVALHO, D. J. de. Derly José de Carvalho: depoimento [out. 2006]. Entrevistador: T. A. D. Silva. São Paulo, 2006. CD 2, faixa 5.

${ }^{387}$ Cf. TAPAJÓS, R. C. Renato Carvalho Tapajós: depoimento [jan. 2006]. Entrevistador: T. A. D. Silva. Campinas, 2006. CD 1, faixa 12.

${ }^{388}$ GRUPO ESPECIAL NACIONAL REVOLUCIONÁRIO (GENR). Ação contra o oportunismo. BNM 294, anexo 3904, p. 1.
} 
oportunismo" 389 e ao proclamar que "não hesitamos em constituirmo-nos em um grupo armado" disposto a "construir a vanguarda do proletariado no Brasil" 390 .

Posteriormente o GENR assumia seu credo:

"esta ação de requisição tem o fito de criar de imediato as condições necessárias, capazes de desenvolver outras de maior envergadura. É chegada a hora em que os fabricantes de miséria, analfabetismo e todas as injustiças sociais e físicas, prestem conta aos filhos do povo. Não [se] sintam seguros, lacaios do imperialismo, o tribunal da história está deliberando",391.

A Direção Nacional Provisória da Ala Vermelha, ao ter conhecimento da rebeldia dos membros do GEN, em abril de 1969, tomou a decisão de dissolver o grupo, considerando que ele estava desenvolvendo uma atividade independente dentro da AV e sem o controle da direção: como explicita Derly de Carvalho, "nós éramos uma organização marxista-leninista e não poderíamos ter dentro dela um outro grupo independente, que agia em nome do Partido, sem controle da sua direção nacional e da suas políticas ${ }^{\prime 392}$.

Registra-se aqui que o GENR continuou atuando como se fosse ligado organicamente à Ala Vermelha até setembro de 1969, quando em uma reunião realizada em Campos do Jordão vem a se constituir no Movimento Revolucionário Tiradentes $(\mathrm{MRT})^{393}$ — numa clara alusão às origens mais remotas da Ala Vermelha, cujos membros fundadores mais destacados formaram parte do MRT que era oriundo do Movimento das Ligas Camponesas. Seu contingente não se restringia apenas aos antigos membros do GEN, pois adquirira novos integrantes vindos da Ala Vermelha - como Plínio Peterson de Oliveira - um militante veterano da AV que havia realizado treinamento em Cuba -, José Couto Leal, Waldemar Andreu, os irmãos Dimas e Denis Casemiro, Joaquim Alencar Seixas, Antonio André de Camargo Guerra, Domingos Quintino dos Santos, e outros, além

\footnotetext{
389 GRUPO ESPECIAL NACIONAL REVOLUCIONÁRIO (GENR). Ação contra o oportunismo. BNM 294, anexo 3904, p. 1.

390 GRUPO ESPECIAL NACIONAL REVOLUCIONÁRIO (GENR). Ação contra o oportunismo. BNM 294, anexo 3904, p. 1.

${ }^{391}$ GRUPO ESPECIAL NACIONAL REVOLUCIONÁRIO (GENR). Ação contra o oportunismo. BNM 294, anexo 3904, p. 1.

${ }^{392}$ CARVALHO, D. J. de. Derly José de Carvalho: depoimento [out. 2006]. Entrevistador: T. A. D. Silva. São Paulo, 2006. CD 1, faixa 11.

${ }^{393}$ Sobre o tema, cf. BNM 180, processo que apurou simultaneamente atividades do MRT, ALN, VPR, REDE e outras. Ver particularmente fls. 124, 159-v, 177, 212-v, 213, 358 e 496.
} 
de diversos militantes vindos de outras organizações ou que não estavam ligados a nenhuma delas.

Nesta reunião em Campos do Jordão, entretanto, o GENR original viria também a sofrer cisões, quando parte de seus integrantes — como James Allen Luz, Denis Casemiro e outros - decidem incorporar-se à Vanguarda Armada Revolucionária Palmares (VARPALMARES) ${ }^{394}$.

Para melhor enfrentar os debates acerca das dubiedades existentes no Documento de Crítica sobre a questão da luta armada urbana, que foram aguçadas em face da cisão havida como GENR, a Direção Nacional Provisória deliberou a construção de uma linha política sobre o tema - o que indicava de modo tênue ainda, o início de um processo autocrítico.

Ficou estabelecido então que a Ala Vermelha tinha como princípio político que as ações militares nas cidades se dividiam em duas modalidades: as de caráter político e as de captação de recursos ${ }^{395}$. As primeiras possuíam o fim precípuo de possibilitar - e ao mesmo tempo garantir - a propaganda revolucionária, a difusão da própria política da $\mathrm{AV}$ às massas em geral. Eram compreendidas como ações políticas atividades como a cobertura armada propiciada a atos de panfletagem em fábricas, escolas, praças etc., a ocupação de rádios para divulgar manifestos no ar, assim como as atuações com armamentos que visassem assegurar proteção a reuniões de órgãos/entidades clandestinos ou dos que eram — ou potencialmente poderiam ser - alvo de represália dos mecanismos de repressão do Regime Autoritário e/ou de organizações paramilitares que o apoiavam - como reuniões de sindicatos postos na ilegalidade, de comitês contrários ao status quo, de assembléias/congressos estudantis não permitidos, de comícios contrários ao Regime, além de diversas hipóteses semelhantes.

As ações de captação de recursos traduziam-se em expropriações de meios pecuniários — praticadas contra bancos ou carros de transporte de valores —, as de bens materiais como desapropriações de máquinas para impressão de jornais, panfletos e similares —, ou, ainda, as de domínio militar, como nos casos de arrebatamento de armamento de policiais, de soldados, de quartéis, delegacias e congêneres.

A partir desta estruturação principiológica a AV discordava de outras organizações existentes à época, que divisavam nas ações militares de expropriações de recursos como um ato político em si. Para a Ala este tipo de ação não poderia ostentar tal caráter, uma vez que era

\footnotetext{
${ }^{394}$ Esta organização foi criada em meados de 1969, como fusão da VPR e dos COLINA e incorporou também "um grupo do Rio Grande do Sul intitulado União Operária (...) A organização assim nascida reuniu um contingente bastante expressivo de militantes e adquiriu abrangência praticamente nacional". Cf. PROJETO "BRASIL: NUNCA MAIS". Perfil dos Atingidos... p. 62.

${ }^{395}$ CARVALHO, D. J. de. Derly José de Carvalho: depoimento [out. 2006]. Entrevistador: T. A. D. Silva. São Paulo, 2006. CD 1, faixas 7-9.
} 
uma questão imposta pela necessidade de subsistência da própria organização e não uma atividade política.

A AV ainda não descartava este tipo de ação, porém negava à mesma qualquer conteúdo político: eram atividades que a Ala exerceria em razão da imperiosidade de conseguir recursos para sua própria subsistência e a de seus militantes - considerando-se que a Ala se defrontava com problemas como o de manter inumeráveis pessoas que foram obrigadas a optarem pela vida clandestina em função de suas atividades, que já eram objeto dos órgãos de repressão do Regime Autoritário brasileiro.

Após a dissolução do GEN, a Direção Nacional não mais autorizou a criação de organismos fixos de luta armada no partido: ela convocaria militantes para a prática de determinadas e imprescindíveis ações de expropriação, assim como de atividades que envolvessem ações de propaganda revolucionária.

A partir deste quadro é que acontece a primeira ação de expropriação da Ala após Isto obrigou que se procedesse a mais uma expropriação. Para tanto, Derly de Carvalho providenciou o levantamento de informações sobre o Banco Francês e Italiano de São Bernardo do Campo ${ }^{396}$. O número de participantes foi reduzido: em um carro Volkswagen tendo ao volante Élio Cabral, rumaram para o banco Derly, Gilberto Giovanetti e conhecido apenas por seu codinome, "Nilo",397.

Élio estacionou o veículo um pouco antes da agência bancária e Derly, Gilberto e "Nilo" adentraram o banco, portando pistolas automáticas e uma espingarda calibre 12. Renderam os funcionários enquanto Derly ameaçou o gerente para que lhe entregasse o dinheiro, e mediante sua concordância fez a coleta do numerário que encontrou, e saíram rapidamente do local, entrando no carro pilotado por Élio, que rumou para o lugar onde Renato Tapajós $^{398}$ esperava para o transbordo, abandonando o Volks em uma rua de São Caetano do Sul, e posteriormente dirigiram-se para seus aparelhos.

A ação foi muito rápida, demorando cerca de três minutos somente, e rendeu a quantia — atualizada — de setenta e seis mil reais ${ }^{399}$. O inusitado desta ação se deu antes de sua realização: ao tomarem um carro "de um japonês" ${ }^{400}$ na Avenida Brigadeiro Luis Antonio

\footnotetext{
${ }^{396}$ Cf. interrogatório prestado no DOPS por Élio Cabral de Souza. BNM 294, fls. 2331.

397 A pesquisa que se efetivou não pôde apurar o nome real de "Nilo", sabendo-se apenas que o mesmo integrara a Direção Nacional Provisória, sem que nenhuma pessoa entrevistada soubesse fornecer sua verdadeira identidade. Os trabalhos realizados nos processos instaurados contra a Ala Vermelha também não lograram êxito nessa busca.

${ }^{398}$ Cf. TAPAJÓS, R. C. Renato Carvalho Tapajós: depoimento [nov. 2006]. Entrevistador: T. A. D. Silva. Campinas, 2006. CD 1, faixa 12.

${ }^{399}$ Denúncia do Ministério Público. BNM 294, fls. 1-b.

${ }^{400}$ Cf. interrogatório realizado no DOPS de Derly José de Carvalho. BNM 294, fls. 285-v.
} 
para fazer a cobertura da atividade que efetivariam, Derly e Renato Tapajós encontraram dentro do veículo uma maleta contendo trinta e cinco mil reais ${ }^{401}$ - em valores atuais.

Em abril de 1969, os membros da Direção Nacional Provisória deliberaram em fazer uma ação de propaganda relativa à data comemorativa ao Dia do Trabalho. Pensou-se na ocupação de uma emissora de rádio para efetuar a transmissão de um manifesto dirigido aos trabalhadores da região do $\mathrm{ABC}$, quando Derly de Carvalho sugeriu a tomada da Rádio Independência de São Bernardo do Campo. Aprovada a proposta, o mesmo Derly ficou incumbido de fazer os levantamentos necessários, o que foi efetuado com o auxílio do dirigente "Nilo"

Derly elaborou o texto do manifesto que foi aprovado pela DNP e gravou uma parte do documento político enquanto outro trecho ficou a cabo de Élio $\mathrm{Cabral}^{403}$.

No dia primeiro de maio de 1969 rumaram para a Rádio Cacique em um automóvel Volkswagen Derly, Élio, Gilberto Giovanetti e "Nilo". Próximo ao local já aguardavam — em outro Volks — Renato Tapajós e Orly Correia, que faria a cobertura da ação.

Um pouco antes das onze e meia Derly, Élio, Gilberto Giovanetti e "Nilo" entraram na emissora onde se encontravam cerca de vinte pessoas. Incontinenti, ordenaram, sob ameaça das armas que portavam — duas espingardas e pistolas automáticas —, confinaram os presentes em dois sanitários ali existiam e em seguida disseram para o operador da rádio para colocar o aparelho com a gravação que levavam em frente a um microfone para que fosse irradiado o manifesto ${ }^{404}$.

Foi transmitido então uma proclamação da Ala Vermelha na qual saudava "os operários e trabalhadores de todo o Brasil neste dia de conquista e de luta" que, infelizmente, estava sendo vivenciado "sob o jugo da ditadura militar, e dos políticos e dos patrões que servem aos interesses do imperialismo norte-americano". Conclamava o manifesto que os trabalhadores "se organizem em torno de seus sindicatos" visando "combater o regime ditatorial", mesmo porque "somente a união e luta dos trabalhadores conseguirá derrotar a ditadura" e instaurar "um Governo Popular, que irá libertar os trabalhadores e construir as bases de uma nova sociedade" 405 .

\footnotetext{
${ }^{401}$ Cf. TAPAJÓS, R. C. Renato Carvalho Tapajós: depoimento [nov. 2006]. Entrevistador: T. A. D. Silva. Campinas, 2006. CD 1, faixa 12; CARVALHO, D. J. de. Derly José de Carvalho: depoimento [out. 2006]. Entrevistador: T. A. D. Silva. São Paulo, 2006. CD 2, faixa 3.

${ }^{402}$ CARVALHO, D. J. de. Derly José de Carvalho: depoimento [out. 2006]. Entrevistador: T. A. D. Silva. São Paulo, 2006. CD 2, faixa 33.

${ }^{403}$ Cf. interrogatório no DOPS de Derly José de Carvalho. BNM 294, fls. 286.

${ }^{404}$ Cf. interrogatório no DOPS de Derly José de Carvalho. BNM 294, fls. 286.

${ }^{405}$ Fragmentos do manifesto lido na Rádio Independência. BNM 294, anexo 3226.
} 
Não obstante haver sido uma ação de propaganda armada praticada pela Ala, se ressalta que, condizente com sua política de não assinar — ou identificar — suas atividades guerrilheiras, o manifesto foi divulgado não com o nome da $\mathrm{AV}$, mas como se fosse uma obra das "Forças Armadas Revolucionárias Populares" 406 — um criptônimo criado especialmente para a ocasião.

Em meados de marco de 1969 chegou à Direção Nacional Provisória uma informação sobre o fato da indústria Mercedes-Benz também contribuir financeiramente com os órgãos e agentes da repressão. Sindicatos haviam propiciado a documentação interna da fábrica "uma espécie de caixa dois""407 — que comprovaria esta denúncia.

Frente a estes fatos, a DNP decidiu fazer uma expropriação na Mercedes-Benz, visando principalmente desmoralizar a fábrica: seria "uma ação que a cidade inteira, o ABC inteiro iria tomar conhecimento dela. O dinheiro era muito importante, mas o objetivo central da ação não era este", mas sim a propaganda que geraria ${ }^{408}$.

Dada a magnitude da ação que se propunha a realizar, a DNP deliberou na ocasião gerar um novo organismo para efetuar a expropriação: traria militantes de diversos Estados para participar desta ação, e selecionaria integrantes da Ala em São Paulo para que viessem também a tomar parte nela. Derly de Carvalho ficou incumbido de fazer o levantamento do banco situado dentro da fábrica.

As notícias trazidas por Derly à DNP não foram alvissareiras: a Mercedes-Benz possuía um policiamento próprio formado por um grande contingente, e comandado por um militar. A questão de um enfrentamento no momento da ação não era conjectura, mas uma certeza palpável.

Decidiu-se então criar três comandos para esta ação: um responsável pela atividade interna, dentro do banco; outro que responderia pela retenção, pelo enfrentamento que certamente ocorreria; o terceiro ficaria a cargo da retirada dos militantes do local. Para cada um destes comandos foi escolhida uma pessoa: Derly responderia pelo comando interno $^{409}$; Élio Cabral e Orly Correia seriam os responsáveis pela retenção ${ }^{410}$; Renato Tapajós s encarregaria de garantir a saída dos militantes ${ }^{411}$.

\footnotetext{
${ }^{406}$ Cf. Relatório dos investigadores da Delegacia de Polícia de São Bernardo do Campo. BNM 294, fls. 163.

${ }^{407}$ CARVALHO, D. J. de. Derly José de Carvalho: depoimento [out. 2006]. Entrevistador: T. A. D. Silva. São Paulo, 2006. CD 2, faixa 6.

${ }_{408}$ Idem.

${ }^{409}$ CARVAlHO, D. J. de. Derly José de Carvalho: depoimento [out. 2006]. Entrevistador: T. A. D. Silva. São Paulo, 2006. CD 2, faixa 5.

${ }^{410}$ Cf. interrogatório prestado no DOPS por Élio Cabral de Souza. BNM 294, fls. 2331-v.

${ }^{411}$ Cf. interrogatório prestado no DOPS porto-alegrense por João Francisco de Pinedo Kasper. BNM 403, fls. 19.
} 
Mais de trinta pessoas se associariam para a ação que seria realizada no Banco de Crédito Nacional, instalado dentro da Mercedes-Benz. Todas elas se vestiriam com uniformes idênticos aos dos funcionários daquela empresa.

No dia cinco de maio de 1969, por volta das dez horas, “após o carro da Brink's deixar o Banco de Crédito Nacional, quando os funcionários do Banco providenciavam a conferência e transferência do numerário para a caixa forte, foram surpreendidos por seis homens" ${ }^{412}$, dizendo que se tratava de uma expropriação, os quais "prenderam todos os funcionários e clientes (...) no interior de um sanitário, obrigando o gerente (...) a acompanhálos até a caixa forte de onde subtraíram a importância de duzentos e quarenta e oito mil cruzeiro novos" ${ }^{\text {413 }}$, afora o dinheiro que se encontrava em poder dos caixas do banco, o que totalizou "duzentos e cinqüenta e sete mil, trezentos e sessenta cruzeiros novos" $"$ ".

Enquanto Derly, Gilberto Giovanetti, "Nilo",415, "Afonso" e "General" 416 — da Guanabara -, e "Alemão"417 — do Rio Grande do Sul — ainda estavam dentro do banco, "um transeunte avisou a guarda da Mercedes Benz",418, que passou a atirar. Élio Cabral, Orly e os outros componentes da retenção revidaram os disparos, e seguiu-se um intenso tiroteio, de ambas as partes. Como relembra Derly de Carvalho, quando iniciou-se a troca de tiros, "saiu todo mundo para a janela. Você olhava para o prédio da Mercedes só tinha gente em todos os lugares, nas janelas, nas portas... A ação foi assistida 'ao vivo' por todos os operários que estavam trabalhando naquele momento" ${ }^{419}$.

Após apossarem-se do dinheiro os dirigentes e militantes da Ala Vermelha que haviam entrado no banco se retiraram também disparando e rumaram para os carros de retirada. $\mathrm{O}$ major Saturnino Franco, chefe do setor de vigilância da Mercedes-Benz, ao notar que "os carros em que entravam os ladrões empreendiam a fuga, tentou sair em seu encalço" ${ }^{, 420}$ entrando em um Volks que estava estacionado nas imediações. Entretanto, o major apenas

\footnotetext{
${ }^{412}$ Cf. Boletim de Ocorrência da Delegacia de São Bernardo do Campo sobre "Assalto a Banco", tendo como vítima o Banco de Crédito Nacional S. A. BNM 294, fls. 1169-v.

${ }^{413}$ Idem.

414 Ibidem.

${ }^{415}$ Para a citação dos nomes de Derly, Gilberto e "Nilo", cf. interrogatório no DOPS de Misael Pereira dos Santos. BNM 294, fls. 1153.

${ }^{416}$ Para a referência a "Afonso" e "General" — cujos nomes reais não foi possível a identificação —, e sobre o fatos de serem oriundos da Guanabara, cf. interrogatório no DOPS de Renato C. Tapajós. BNM, fls. 1236$\mathrm{V}$.

${ }^{417}$ Para a menção de "Alemão", cuja identificação não se fez possível, e o fato do mesmo ter vindo do Rio Grande do Sul, cf. interrogatório prestado no DOPS por Élio Cabral de Souza. BNM 294, fls. 2331-v.

${ }^{418}$ Cf. interrogatório prestado no DOPS por Élio Cabral de Souza. BNM 294, fls. 2331-v.

${ }^{419}$ CARVALHO, D. J. de. Derly José de Carvalho: depoimento [out. 2006]. Entrevistador: T. A. D. Silva. São Paulo, 2006. CD 2, faixa 6.

${ }_{420}$ Cf. Declarações prestadas pelo major Saturnino Franco na Delegacia de Polícia de São Bernardo do Campo. BNM 294, fls. 1192.
} 
conseguiu "persegui-los por mais ou menos um quarteirão, tendo em vista que o veículo em que se encontrava haver sido baleado no pára-brisa e o mesmo não oferecer condições de visibilidade, 421.

O violento tiroteio acontecido na ação da Mercedes-Benz — de parte da Ala Vermelha gastou-se "de mil e quinhentos a dois mil tiros" —, não obstante sua intensidade, não deixou qualquer vítima fatal, ou ao menos lesionou qualquer pessoa ${ }^{422}$ - fossem componentes da ação, da guarda privada, funcionários do banco ou da indústria, ou meros transeuntes. Esta ação consistiu-se, sim, em um feito memorável para os militantes e dirigentes da Ala Vermelha, pois além de desmerecer a guarda privada da fábrica, ocasionou grande repercussão no seio dos operários e moradores da região do $\mathrm{ABC}$, além do fato de constituir-se na expropriação que teve a mais alta arrecadação do partido, cerca de um milhão, cento e dez mil reais - em valores atualizados.

No final de maio de 1969 a Ala Vermelha é atingida pela primeira vez pelos órgãos repressivos, quando são presos dois dos integrantes da Direção Nacional Provisória, Derly de Carvalho e Genésio Borges de Mello.

Estas prisões foram decorrentes da detenção de antigos componentes do GEN, inicialmente dos irmãos de Derly, Joel e Daniel.

No dia 19 de maio de 1969 Daniel estava dirigindo um carro Volkswagen sedan no município de Osasco, em companhia de Aderval Alves Coqueiro e José Couto Leal ${ }^{423}$ — todos já formavam parte do GENR e estavam fazendo atividades naquele município — como a ação do Banco F. Barreto e o atentado contra a Viação Jurema, ocorrido menos de uma semana antes.

O veículo fora abordado por um policial da Força Pública, que solicitou os documentos do condutor e do automóvel ${ }^{424}$. Como os três companheiros estavam carregando armas em suas valises, Daniel entregou os documentos do carro e sua carteira de habilitação para o guarda, e deu partida no carro, procurando evadir-se do local ${ }^{425}$.

\footnotetext{
${ }^{421}$ Cf. Declarações prestadas pelo major Saturnino Franco na Delegacia de Polícia de São Bernardo do Campo. BNM 294, fls. 1192-v.

${ }^{422}$ No sentido desta afirmação, cf. declarações de testemunhas presentes a ação. BNM 294, fls. 1175/1193-v; 1196/1197. Ver também Laudo Pericial afirmando a inexistência de qualquer lesão ocorrida durante a expropriação. BNM 294, fls. 1194/1194-v.

${ }^{423}$ Cf. interrogatório prestado no DOPS por Aderval Alves Coqueiro. BNM 294, fls. 273-v; 274.

${ }^{424}$ Cf. interrogatório prestado no DOPS por Daniel José de Carvalho. BNM 294, fls. 314-v. Daniel e Aderval referem-se a José Couto Leal através de seu codinome, "Roberto". Para a referência de ser este o nome de guerra pertencente a José Couto, ver interrogatório prestado por Jairo José de Carvalho. BNM 294, fls. 325v. Cf. também Sentença da Segunda Auditoria do Exército. $2^{\mathrm{a}}$. Circunscrição Judiciária Militar. São Paulo. BNM 294, fls. 3429.

${ }^{425}$ Cf. interrogatório prestado no DOPS por Aderval Alves Coqueiro. BNM 294, fls. 273-v; 274.
} 
O soldado da Força Pública, todavia, tomou uma Lambreta e saiu ao encalço do veículo, sendo que em determinado momento o policial logrou alcançar o carro. Neste instante o soldado ordenou que Daniel seguisse para a delegacia de polícia "antes tendo introduzido no veículo um seu colega de farda" ${ }^{426}$ para garantir a ida de Daniel àquela repartição policial.

Após iniciarem o trajeto rumo à delegacia, Aderval e José Couto "conseguiram se apoderar dos revólveres que traziam nas maletas e com os mesmos conseguiram intimidar o soldado que os acompanhava" ${ }^{, 427}$ no interior do carro, e fugiram do policial que estava os seguindo com a Lambreta, pois Daniel "e seus companheiros não poderiam ir à delegacia, uma vez que momentos antes houve um incidente com o outro soldado e estavam armados, podendo pôr a perder o seu grupo" ${ }^{, 428}$.

Daniel e seus camaradas conseguiram êxito em sua fuga, sendo que o policial da Lambreta foi rapidamente para trás. Pararam então "em uma estrada de terra entre Osasco e Taboão da Serra" ${ }^{429}$ e ali deixaram o soldado que fora rendido pelo grupo, "sendo certo que disseram ao mesmo que ali estavam para fazer uma revolução e não tinham nada contra ele nem contra o outro policial que havia ficado com a sua [de Daniel] Habilitação"430.

O soldado que estava em poder da carteira de motorista de Daniel, levou-a para a delegacia mais próxima e narrou o acontecido. $\mathrm{O}$ delegado fez uma conexão com os assaltos a banco e com o atentado à Viação Jurema - locais onde o GENR havia deixado volantes assumindo a responsabilidade pelas ações —, e solicitou que o policial envolvido com Daniel e seus companheiros examinasse as fotos de "terroristas procurados" para tentar identificar entre as pessoas com as quais havia tido o incidente ${ }^{431}$. O soldado ao ver uma fotografia de Carlos Lamarca, imediatamente "identificou" Daniel como sendo aquele ex-capitão do exército. Os jornais do dia seguinte publicaram em manchete: "Lamarca foge da polícia em Osasco usando o nome de Daniel José de Carvalho"432.

Derly José de Carvalho relembra que "os guardas reconheceram o Daniel como sendo o Lamarca, porque Daniel era parecido" ${ }^{\star 33}$. Como a carteira de habilitação de Daniel era de São Bernardo do Campo, os órgãos de repressão - e especialmente o delegado Sérgio

\footnotetext{
${ }^{426}$ Cf. interrogatório prestado no DOPS por Aderval Alves Coqueiro. BNM 294, fls. 274.

${ }^{427}$ Cf. interrogatório prestado no DOPS por Aderval Alves Coqueiro. BNM 294, fls. 274.

${ }^{428}$ Cf. interrogatório prestado no DOPS por Daniel José de Carvalho. BNM 294, fls. 314-v.

${ }^{429}$ Cf. interrogatório prestado no DOPS por Daniel José de Carvalho. BNM 294, fls. 315.

${ }^{430}$ Cf. interrogatório prestado no DOPS por Daniel José de Carvalho. BNM 294, fls. 315.

${ }^{431}$ CARVALHO, D. J. de. Derly José de Carvalho: depoimento [out. 2006]. Entrevistador: T. A. D. Silva. São Paulo, 2006. CD 1, faixa 12.

${ }^{432}$ CARVALHO, D. J. de. Derly José de Carvalho: depoimento [out. 2006]. Entrevistador: T. A. D. Silva. São Paulo, 2006. CD 1, faixa 13.

${ }^{433}$ CARVALHO, D. J. de. Derly José de Carvalho: depoimento [out. 2006]. Entrevistador: T. A. D. Silva. São Paulo, 2006. CD 1, faixa 13.
} 
Paranhos Fleury e sua equipe - fizeram um levantamento na região do $\mathrm{ABC}$, quando "descobriram o cartório onde o Daniel tinha casado"434. Como na época em que havia contraído matrimônio Daniel morava com seus pais, ao localizarem seu endereço, conseqüientemente, conseguiram o endereço dos seus pais.

Os órgãos de repressão naquele momento fizeram a ligação entre os fatos: Daniel deveria estar realmente envolvido com ações "terroristas", considerando-se que havia militado no Sindicato dos Metalúrgicos de São Bernardo, e pelo fato de ser irmão de Derly - que era um conhecido comunista, não apenas por haver viajado para a China, mas por toda sua militância como dirigente do Sindicato dos Metalúrgicos de São Bernardo, ligado ao PCB, e cassado após o Golpe de 64 etc.

Fleury e sua equipe invadiram a casa dos pais de Daniel e ficaram esperando. Os primeiros a aparecer foram Joel e o Jairo, "que eram os dois irmãos menores que moravam em casa, na casa de meus pais e no interrogatório eles abriram tudo" ${ }^{, 435}$ não apenas sobre a Viação Jurema, da qual ambos tinham participado mas também sobre outras ações.

Horas depois Daniel e Devanir chegaram à casa de seus pais. Daniel entrou e foi preso. Devanir, que ainda estava do lado de fora percebeu o que ocorrera, disparou contra a equipe de Fleury, trocou tiros com os policiais, saiu ferido e conseguiu fugir ${ }^{436}$. Derly morava próximo dali, mas sua prisão ocorreu de maneira diferente: "Fleury e seus homens ameaçaram meu cunhado, disseram que iam matar meus irmãos, então ele levou a polícia até a minha casa"437.

A Direção Nacional da Ala Vermelha frente as prisões ocorridas toma uma série de providências. Inicialmente procura resguardar ainda mais seus militantes, tomando medidas mais drásticas em matéria de segurança. A Direção também estava sob forte pressão dos militantes do movimento estudantil para trazê-los para a luta armada, no período em que o AI5 mostrou todo o despotismo e a opressão do Regime brasileiro. Alguns militantes “chegaram a passar para a ALN, pois achavam que esta organização estava fazendo algo, enquanto a Ala nada fazia. Foi o caso do Luis Fogaça Balboni, que acabou sendo morto pela repressão ${ }^{438}$.

\footnotetext{
${ }^{434}$ CARVAlHO, D. J. de. Derly José de Carvalho: depoimento [out. 2006]. Entrevistador: T. A. D. Silva. São Paulo, 2006. CD 1, faixa 13.

${ }^{435}$ CARVAlHO, D. J. de. Derly José de Carvalho: depoimento [out. 2006]. Entrevistador: T. A. D. Silva. São Paulo, 2006. CD 1, faixa 13.

${ }^{436}$ CARVALHO, D. J. de. Derly José de Carvalho: depoimento [out. 2006]. Entrevistador: T. A. D. Silva. São Paulo, 2006. CD 1, faixa 14.

${ }^{437}$ CARVAlHO, D. J. de. Derly José de Carvalho: depoimento [out. 2006]. Entrevistador: T. A. D. Silva. São Paulo, 2006. CD 1, faixa 14.

438438 TAPAJÓS, R. C. Renato Carvalho Tapajós: depoimento [nov. 2006]. Entrevistador: T. A. D. Silva. Campinas, 2006. CD 1, faixa 2. Luiz Fogaça Balboni foi gravemente ferido em emboscada engendrada pelo Delegado Sérgio Paranhos Fleury na Alameda Campinas, em São Paulo. Apesar de seu estado crítico, foi transportado por agentes do DOPS sob o comando de Fleury "até um centro de torturas e interrogado por
} 
Outro fator preponderante na tensão sofrida pela DNP com relação à luta armada foi a recomposição do Comitê Regional de São Paulo, onde os representantes do movimento estudantil detinham mais da metade do grupo dirigente: de seus quatro componentes, Misael Pereira dos Santos era bancário; Renato Tapajós era publicitário, enquanto que José Eli Savoia da Veiga e Carlos Takaoka eram universitários e Nelson Brissac Peixoto era representante do movimento estudantil secundarista ${ }^{439}$.

Em face a este ambiente a Direção Nacional acaba sendo levada a propor a criação de Unidades de Combate (UC), um organismo partidário que abrigaria militantes pertencentes ou oriundos do movimento estudantil, fortalecido por quadros mais experimentados, que se encontravam na clandestinidade. Estas Unidades teriam a missão precípua não a realização de atividades de captação de recursos, mas de realizar ações armadas de caráter político — como dar cobertura a "distribuição de volantes em porta de fábrica, panfletos e a pequenos comícios, enfim tudo o que propiciasse agitação e propaganda no meio operário",440.

As UC ficariam sob o comando de Renato Tapajós e Misael, que decidiriam juntamente com Élio Cabral — representando a DNP — a conveniência da realização de ações armadas, sendo que este dirigente tinha o poder de veto ${ }^{441}$. Estas Unidades de Combate teriam um aparelho próprio para cada uma delas, e seu armamento não ficaria à disposição de seus integrantes, mas do Comitê Regional de São Paulo, que cederia as armas que se fizessem necessárias para ações específicas.

A composição das UC ficou assim estabelecida: Unidade de Combate 1, chefiada por Misael e integrada por Alípio Raimundo Viana Freire, Vicente Eduardo Gomez Roig, Antonio Fernando Bueno Marcelo ${ }^{442}$ e Carlos Takaoka ${ }^{443}$. Unidade de Combate 2, chefiada por Renato Tapajós e composta por Gilberto Giovanetti, "Nilo", Antonio Carlos Lopes Granado e Nelson Brissac Peixoto ${ }^{444}$.

Uma vez instalados em seus aparelhos, os membros das Unidades de Combate - em sua quase totalidade vivendo na clandestinidade - tiveram dificuldades para satisfazer as necessidades de suas novas moradias. Alguns militantes que não levavam vida clandestina

algumas horas antes de ser conduzido ao Hospital das Clínicas" onde faleceu. Cf. MIRANDA, Nilmário; TIBÚRCIO, Carlos, op. cit., p. 37-38.

${ }^{439}$ Cf. interrogatório prestado no DOPS por Misael Pereira dos Santos. BNM 294, fls. 1152-v.

${ }^{440}$ Cf. interrogatório prestado no DOPS por Vicente Eduardo Gómez Roig. BNM 294, fls. 1127-v.

${ }^{441}$ Cf. SOUZA, É. C. de. Élio Cabral de Souza: depoimento [nov. 2006]. Entrevistador: T. A. D. Silva. Goiânia, 2006. CD 1, faixa 11.

${ }^{442}$ Cf. interrogatório prestado no DOPS por Misael Pereira dos Santos. BNM 294, fls. 1152-v.

${ }^{443}$ Cf. Declarações de Nelson Brissac Peixoto à Equipe "B" de Interrogatório Preliminar, em 31 de agosto de 1969. BNM 294, fls. 1374.

${ }^{444}$ Cf. interrogatório prestado no DOPS por Misael Pereira dos Santos. BNM 294, fls. 1152-v. 
contribuíam com "uma caixinha única a fim de satisfazer as despesas do aparelho, bem como terminar de montá-lo com a aquisição de móveis, geladeiras, etc." ${ }^{445}$

As contribuições, todavia, não foram suficientes, uma vez que havia a necessidade das Unidades de Combate adquirirem "mimeógrafo, máquinas off-set, automóvel”, sendo que para isto necessitavam dinheiro, e "diante destas necessidades, partiram para ações de expropriação",446.

Partindo dessas dificuldades é realizada a primeira ação de expropriação de bens das Unidades de Combate, no dia 23 de julho de 1969. Anteriormente Misael Pereira dos Santos e Renato Tapajós ${ }^{447}$ fizeram o levantamento do local, para aquilatar as condições do lugar, a existência das máquinas que pretendiam apoderar-se etc., bem como Misael, Alípio R. Viana Freire e Sérgio Francisco dos $\operatorname{Santos}^{448}$ desapossaram uma perua Kombi no Bairro das Perdizes $^{449}$, para poder cumprir com a atividade que haviam planejado.

No dia da ação, por volta das oito horas da manhã, Alípio ficou vigiando na esquina do estabelecimento comercial, enquanto que Vicente Roig e Misael fizeram cobertura dentro de um automóvel Volkswagen ${ }^{450}$. Renato Tapajós chegou à loja dirigindo a Kombi expropriada, parando na entrada da mesma ${ }^{451}$. Nelson Brissac Peixoto, Antonio Fernando Bueno Marcelo, Gilberto Giovanetti, Antonio Carlos Granado, "Nilo" e "Alves"452 (José Eli Savoia da Veiga ${ }^{453}$ ), entraram na Casa Odeon e sob a ameaça de armas contra o faxineiro do estabelecimento, o imobilizaram levando a seguir para a Kombi seis mimeógrafos e três máquinas de escrever ${ }^{454}$.

Com o sucesso obtido na Casa Odeon os componentes das Unidades de Combate passaram a fazer o levantamento de informações sobre uma outra loja do ramo, a Kelmaq — que foi efetivado por Vicente Roig, Renato Tapajós e Misael ${ }^{455}$, que foram ao estabelecimento comercial indagar — dissimulando suas intenções — sobre os preços das máquinas, verificar o número de funcionários existentes e as dependências do local ${ }^{456}$. Como parte da simulação que

\footnotetext{
${ }^{445}$ Cf. interrogatório prestado no DOPS por Vicente Eduardo Gómez Roig. BNM 294, fls. 1127-v.

${ }^{446} \mathrm{Cf}$. interrogatório prestado no DOPS por Vicente Eduardo Gómez Roig. BNM 294, fls. 1127-v.

${ }^{447}$ Cf. interrogatório prestado no DOPS por Misael Pereira dos Santos. BNM 294, fls. 1152-v.

${ }^{448}$ Cf. interrogatório prestado no DOPS por Alípio Raimundo Viana Freire. BNM 294, fls. 1320.

${ }^{449}$ Cf. interrogatório prestado no DOPS por Misael Pereira dos Santos. BNM 294, fls. 1153.

${ }^{450}$ Cf. interrogatório prestado no DOPS por Alípio Raimundo Viana Freire. BNM 294, fls. 1320-v.

${ }^{451}$ Cf. interrogatório prestado no DOPS por Alípio Raimundo Viana Freire. BNM 294, fls. 1320-v.

${ }^{452}$ Para a citação dos nomes de Nelson, Antonio Fernando, Gilberto e Antonio Carlos, além dos codinomes "Nilo", e "Alves", cf. interrogatório prestado no DOPS por Renato Carvalho Tapajós. BNM 294, fls. 1237.

${ }^{453}$ Para a menção de ser "Alves" a pessoa de José Eli, cf. interrogatório prestado no DOPS por Carlos Yoshikazu Takaoka. BNM 294, fls. 1124-v.

${ }^{454}$ Cf. interrogatório prestado no DOPS por Vicente Eduardo Gómez Roig. BNM 294, fls. 1228.

${ }^{455}$ Cf. interrogatório prestado no DOPS por Carlos Yoshikazu Takaoka. BNM 294, fls. 1124-v.

${ }^{456}$ Cf. interrogatório prestado no DOPS por Renato Carvalho Tapajós. BNM 294, fls. 1237.
} 
levavam a cabo, Vicente Roig alegava que as máquinas que pretensamente desejavam comprar seriam utilizadas para um curso de madureza por correspondência ${ }^{457}$.

Uma vez pesquisado o local, Élio Cabral e Misael planejaram a ação ${ }^{458}$ e determinaram o desapossamento de um carro Volkswagen para servir na atividade, o que foi realizado pelo próprio Misael, Renato Tapajós, José Eli e Antonio Carlos Granado ${ }^{459}$, que se apossaram de um Volks que estava ocupado por um casal na Rua Monte Alegre ${ }^{460}$.

No dia 12 de agosto do mesmo ano, durante a madrugada, utilizando-se da mesma Kombi usada na ação anterior, Misael chegou com o veículo, estacionando-o na porta do estabelecimento. Na cobertura da ação foram utilizados dois automóveis Volkswagen, um ocupado por Élio Cabral ${ }^{461}$ e Antonio Marcelo ${ }^{462}$, outro por José Eli e "Nilo" 463.

Adentraram a loja, armados, Misael, Carlos Takaoka, Alípio, Vicente Roig, Nelson Brissac $^{464}$, Antonio Granado ${ }^{465}$ e de lá expropriaram uma impressora off-set, um mimeógrafo, duas prensas, uma dobradeira de papel ${ }^{466}$ e uma sensibilizadora de estêncil ${ }^{467}$, maquinário este que foi transportado para o aparelho da Unidade de Combate 1 situado à Rua Marcos Arruda $^{468}$.

Sendo necessária ainda a complementar os trabalhos de implantação dos aparelhos das Unidades de Combate de São Paulo, ficou decidido realizar a expropriação de um banco, sendo escolhido o Banco de Minas Gerais de Guarulhos. Para o levantamento do local, participaram Renato Tapajós e Misael ${ }^{469}$. Foram também desapossados dois carros Volkswagen no Bairro de Perdizes, por Vicente Roig, Antonio Marcelo e Misael e Renato Tapajós $^{470}$.

No dia 29 de agosto de 1969, aproximadamente às dez horas da manhã, os membros da Ala Vermelha se dirigiram para Guarulhos em dois carros: o que faria a cobertura da ação

\footnotetext{
457457 Cf. interrogatório prestado no DOPS por Vicente Eduardo Roig. BNM 294, fls. 1228.

${ }^{458}$ Cf. interrogatório prestado no DOPS por Carlos Yoshikazu Takaoka. BNM 294, fls. 1125.

${ }^{459}$ Cf. interrogatório prestado no DOPS por Antonio Carlos Lopes Granado. BNM 294, fls. 2245.

${ }^{460} \mathrm{Cf}$. interrogatório prestado no DOPS por Misael Pereira dos Santos. BNM 294, fls. 1153.

${ }^{461}$ Cf. interrogatório prestado no DOPS por Carlos Yoshikazu Takaoka. BNM 294, fls. 1124-v.

${ }^{462}$ Cf. interrogatório prestado no DOPS por Alípio Raimundo Viana Freire. BNM 294, fls. 1320-v.

${ }^{463}$ Cf. interrogatório prestado no DOPS por Carlos Yoshikazu Takaoka. BNM 294, fls. 1124-v-1125.

${ }^{464}$ Para a menção dos nomes citados, cf. interrogatório prestado no DOPS por Carlos Yoshikazu Takaoka. BNM 294, fls. 1125.

${ }^{465}$ Cf. interrogatório prestado no DOPS por Alípio Raimundo Viana Freire. BNM 294, fls. 1320-v.

${ }^{466}$ Cf. interrogatório prestado no DOPS por Antonio Carlos Lopes Granado. BNM 294, fls. 2245.

${ }^{467}$ Cf. interrogatório prestado no DOPS por Alípio Raimundo Viana Freire. BNM 294, fls. 1320-v.

${ }^{468}$ Cf. interrogatório prestado no DOPS por Antonio Carlos Lopes Granado. BNM 294, fls. 2245.

${ }^{469}$ Cf. interrogatório prestado no DOPS por Renato Carvalho Tapajós. BNM 294, fls. 1237-v.

${ }^{470} \mathrm{Cf}$. interrogatório prestado no DOPS por Renato Carvalho Tapajós. BNM 294, fls. 1237-v.
} 
transportava Orly Correia e Nelson Brissac, enquanto os demais seguiam no veículo dirigido por Misael ${ }^{471}$.

Vicente Roig, Alípio, Antonio Marcelo ${ }^{472}$ adentraram a agência bancária, renderam os funcionários e presentes, e dali retiraram cerca de quatorze mil de trezentos reis ${ }^{473} \mathrm{em}$ valores atualizados. Após evadirem-se do local, realizaram o transbordo de veículos em uma rua de terra próxima à Avenida Guarulhos ${ }^{474}$, e rumaram todos para seus respectivos aparelhos.

A segunda série de prisões que atingiu o Partido Comunista do Brasil - Ala Vermelha tem início quando um grupo de estudantes secundaristas é detido e menciona o nome de Nelson Brissac Peixoto, membro do partido e responsável pelo Setor Estudantil Secundário ${ }^{475}$. Agentes da repressão se dirigiram até a residência de Peixoto e passaram monitorá-lo após um encontro com seu pai.

O militante foi seguido até o aparelho situado no bairro do Caximgui, na Rua Raimundo Testa, 14 e alugada por Alípio Raimundo Viana Freire e Wilson Palhares ${ }^{476}$. Este local funcionava como sede da Unidade de Combate 1 . A casa não foi invadida ${ }^{477}$, pois os agentes preferiram prender os militantes à medida que fossem chegando. Neste local moravam também Renato Carvalho Tapajós e Carlos Takaoka, que foram presos desta forma, ou seja, ao entrar na casa foi surpreendido por agentes do aparato repressivo.

A prisão da Unidade de Combate 1 ocorreu no dia 31 de agosto de 1969, conforme relata Alípio Freire. O grupo foi então conduzido até a OBAN (Operação Bandeirantes), local onde seus integrantes foram submetidos a pesados interrogatórios ${ }^{478}$.

Misael Pereira dos Santos conhecia outra residência do grupo, situado na Rua Marcos Arruda, 62. Neste local foi preso Vicente Eduardo Gomes Roig, por membros do Exército e da Polícia Civil ${ }^{479}$.

Desta forma ocorreu a prisão dos integrantes da Unidade de Combate 1, liderada por Misael $^{480}$ e composta por Alípio, Vicente Eduardo Gomes Roig, Antônio Fernando Bueno Marcelo (que não foi preso nesta ocasião) e da Unidade de Combate 2, liderada por Renato Tapajós e integrada por Gilberto Giovanetti, Nelson Brissac, Antonio Carlos Lopes Granado.

\footnotetext{
${ }^{471}$ Cf. interrogatório prestado no DOPS por Renato Carvalho Tapajós. BNM 294, fls. 1237-v.

${ }^{472}$ Cf. interrogatório prestado no DOPS por Renato Carvalho Tapajós. BNM 294, fls. 1237-v.

${ }^{473}$ Cf. denúncia do Ministério Público. BNM 294, fls. 1013.

${ }^{474}$ Cf. interrogatório prestado no DOPS por Misael Pereira dos Santos. BNM 294, fls. 1153-v.

${ }^{475}$ Cf. interrogatório no DOPS de Misael Pereira dos Santos. BNM 294, fls. 1152-v.

${ }^{476}$ Cf. Denúncia. BNM 294, fls. 1013-v.

${ }^{477}$ Cf. entrevista de Vicente Eduardo Gomes Roig à Tadeu Antônio Dix Silva, CD 2, Faixa 5.

478 Cf. FREIRE, Alípio Raimundo Viana. Relato de prisão. Relatório encaminhado à Comissão.... São Paulo/Campinas, junho/julho de 2002.

${ }^{479}$ Cf. entrevista de Vicente Eduardo Gomes Roig à Tadeu Antônio Dix Silva, CD 2, Faixa 5.

${ }^{480}$ Cf. interrogatório no DOPS de Misael Pereira dos Santos. BNM 294, fls. 1152-v.
} 
Totalmente alheias ao processo de luta armada foram as prisões ocorridas em Guaratinguetá. Jarbas Teobaldo dos Santos — estudante de engenharia em naquela cidade —, João Carlos Antunez Lacaz e Paulo Sérgio Paraíso Cavalcanti — que eram militantes da Ala Vermelha no Rio de Janeiro - efetuavam trabalho de massas, procurando formar um núcleo da AV no município para empreender futuramente ações no meio estudantil e operário da região ${ }^{481}$.

Para tanto realizaram diversas reuniões com estudantes e operários de Guaratinguetá, promovendo a leitura de livros sobre o pensamento de Marx, Engels, Lênin e Mao Tsé-tung e jornais editados pela Ala Vermelha ${ }^{482}$. Esta associação de pessoas, assim, se dedicava ao estudo, e não "perpetrou qualquer ação externa", e nenhum de seus componentes "possuía ou adotou pseudônimo ou 'nome de guerra",483

A Direção Nacional se encontrava sumamente preocupada com as prisões acontecidas particularmente em São Paulo, pois elas foram motivadas — de maneira direta ou indireta - pelas ações armadas ali desenvolvidas.

Diniz Cabral Filho era um dos dirigentes mais apreensivo com a temática da luta armada. Entendia que era necessário suspender imediatamente as ações de expropriação financeiras e de bens ${ }^{484}$. Convocou então uma reunião a ser realizada na Praia Grande, no Estado de São Paulo para que o assunto fosse debatido.

Em meados de novembro de 1969 é realizada a reunião naquela cidade litorânea paulista, da qual participaram ${ }^{485}$ Diniz Cabral Filho, Élio Cabral de Souza, Edgard de Almeida Martins, representando o Birô Político da Ala Vermelha, Felipe Lindoso, Antonio Carlos Granado - por São Paulo —, Orly Batista Correa, Paulo de Tarso Gianinni — pelo Rio de Janeiro - Fernando Sana Pinto - de Minas Gerais -, e Gerôncio Albuquerque Rocha - representando o Rio Grande do Sul —, e Tarzan de Castro, que regressara clandestinamente no Brasil, vindo de seu exílio no Uruguai.

As discussões convergem na orientação de que era necessário uma transformação radical na linha política da Ala Vermelha, vedando, através de um documento oficial as ações armadas de expropriação de bens.

\footnotetext{
${ }^{481}$ Cf. Denúncia do Ministério Público. BNM 436, fls. 1-A.

${ }^{482}$ Cf. BNM 436, fls.

${ }^{483}$ Cf. interrogatório prestado no DOPS de São Paulo por Jarbas Teobaldo dos Santos. BNM 436, fls. 36-v.

${ }^{484}$ Cf. MATTES, D.; ROCHA, G. A. Delmar Mattes; Gerôncio Albuquerque Rocha: depoimento [fev. 2005]. Entrevistador: T. A. D. Silva. São Paulo, 2005. CD 1, faixa 14.

${ }^{485}$ Pela menção aos nomes dos participantes nesta reunião, cf. depoimento no DOPS paulista e o judicial de Edgard de Almeida Martins. BNM 294, fls. 2873, 2949-v.
} 
Nascia neste momento o embrião autocrítico da AV, que seria sintetizado no documento "Os 16 Pontos", datado de novembro de 1969.

Em sua Introdução "Os 16 Pontos" entendia que o documento "Crítica ao oportunismo e subjetivismo do 'União dos Brasileiros para livrar o país da crise, da ditadura e da ameaça neocolonialista"” (Doc. de Crítica), havia marcado "um passo importante em nosso Partido", pois revelara "o oportunismo de direita da tática traçada pelos elementos oportunistas que usurparam o Comitê Central" do PC do B e esboçara uma análise correta da composição social da ditadura, bem como do processo de sua instauração e das classes que poderiam se aliar ao proletariado "na luta pelo Governo Popular Revolucionário", indicando, desta forma, os “corretos objetivos estratégicos para a revolução brasileira" ${ }^{\text {486. }}$.

O documento "Os 16 Pontos" (Doc. 16), todavia, considerava que "erros surgiram na indicação da tática", porque o Doc. de Crítica havia resumido o desencadeamento da luta armada a partir de uma "visão estreita, mecânica e esquemática" do processo ${ }^{487}$.

Salientava também que a prática vivenciada pela Ala Vermelha desde então e o próprio aprofundamento teórico que grande parcela dos militantes experimentou, vieram a mostrar que a maior debilidade da abordagem feita sobre o problema da luta armada foi a de não encará-la a partir de uma linha de massas". Afora esta aspecto, entendia o Doc. 16 que a Ala Vermelha tinha reduzido "todas as tarefas táticas e formas de luta à luta armada, esclerosando politicamente" 488 .

"Os 16 Pontos" indicava de forma precisa o foquismo, ao afirmar que " $A$ concepção do foco não assegura, de forma alguma, o apoio das massas à sua ação, não garantindo sua integração paulatina às ações armadas, permanecendo isolado delas". A acepção de foco, se constituiria no "maior entrave ao desenvolvimento de ações armadas capazes de levar ao estabelecimento concreto da luta armada no país". Isto ocorreria considerando-se que esta concepção impedia que a Ala Vermelha "conduza as massas, onde haja condições favoráveis a se integrarem nas ações armadas", consistindo esta

\footnotetext{
486 PARTIDO COMUnista DO BRASIL - Ala VeRMelHa. Os 16 Pontos. [S. 1.], nov., 1969. Coleção particular Daniel Aarão Reis Filho. SÉRIE: Ala Vermelha. Dossiê 05, doc. 103. Arquivo Público do Estado do Rio de Janeiro, p. 1.

${ }^{487}$ PARTIDO COMUNISTA DO BRASIL - Ala VERMELHA. Os 16 Pontos. [S. 1.], nov., 1969. Coleção particular Daniel Aarão Reis Filho. SÉRIE: Ala Vermelha. Dossiê 05, doc. 103. Arquivo Público do Estado do Rio de Janeiro, p. 1.

${ }^{488}$ PARTIDO COMUNISTA DO BRASIL - ALA VERMELHA. Os 16 Pontos. [S. 1.], nov., 1969. Coleção particular Daniel Aarão Reis Filho. SÉRIE: Ala Vermelha. Dossiê 05, doc. 103. Arquivo Público do Estado do Rio de Janeiro, p. 1.
} 
condição como a única na qual "se generalizará e se estabelecerá de fato a luta armada no Brasil" ${ }^{489}$.

A autocrítica de Ala Vermelha era estimulada no Doc. 16, uma vez que dizia que a AV não havia desenvolvido "as questões táticas e resumimos tudo na tarefa de implantação do foco guerrilheiro", cenário este que abriu terreno para que a Ala se visse despreparada diante da evolução da luta política e fosse acometido de uma grave doença: o reboquisrno à luta espontânea do movimento estudantil"490.

E apresentava críticas à Ala Vermelha por haver permitido o desenvolvimento de duas tendências extremamente nocivas, como o ponto de vista exclusivamente militar e seu desenvolvimento inevitável, o liquidacionismo". A partir da afirmação correta segundo a qual "a principal forma de luta estratégica é a armada", no tático muitos dos companheiros de Ala "quiseram reduzir tudo à luta armada". A ausência de um trabalho político da AV junto às massas básicas, o seu desligamento delas, havia criado condições "para que essa 'luta armada' se limitasse a ações armadas de vanguarda". Daí o desejo de transformar o Partido em "exército", em "unidades de combate", isto é, ao liquidacionismo aberto ou sutil, o passo é pequeno. Isto resultou também da falta de perspectiva para a orientação do trabalho de massas ${ }^{491}$.

Alertava ainda Doc. 16 sobre o fato de termos consciência "de todos esses problemas é metade do caminho andado para superá-los. Todo nosso esforço deve ser dado no sentido de cumprirmos a outra metade". Acrescentava dizendo que por "estarmos penetrados de um espírito autocrítico e determinados a acertar e vencer é que essa tarefa é plenamente realizável, é que ela será realizada" ${ }^{492}$.

Terminava "Os 16 Pontos" assegurando que "esta resolução marca, assim, o início, apenas o início da nova etapa", e cria as condições "para sairmos da situação anterior. A partir dela, outras virão para orientar as atividades cotidianas do Partido". Fazia ainda um apelo a cada militante da Ala, dizendo ser sua a tarefa, assim como de cada organismo — de base ou de direção —, de "travar uma séria e conscienciosa luta pela aplicação dessas diretivas. tarefa de todos os organismos de direção lutarem pelo controle sistematizado destas resoluções". Todo o Partido deveria ser "emulado em sua aplicação,

\footnotetext{
489 PARTIDO COMUNISTA DO BRASIL — ALA VERMELHA. Os 16 Pontos. [S. 1.], nov., 1969. Coleção particular Daniel Aarão Reis Filho. SÉRIE: Ala Vermelha. Dossiê 05, doc. 103. Arquivo Público do Estado do Rio de Janeiro, p. 1.

${ }^{490}$ PARTIDO COMUNISTA DO BRASIL — ALA VERMELHA. Os 16 Pontos, cit. p. 1.

${ }^{491}$ PARTIDO COMUNISTA DO BRASIL - ALA VERMELHA. Os 16 Pontos, cit. p. 1.

${ }^{492}$ PARTIDO COMUNISTA DO BRASIL - ALA VERMELHA. Os 16 Pontos, cit. p. 1.
} 
as experiências colhidas e sintetizadas e, então, corrigidos os erros, desenvolver os aspectos positivos" ${ }^{493}$.

O ponto $\mathrm{n}$. 1 do documento abordava o "golpe contra-revolucionário de abril de 64", que desarticulou o movimento de massas nacionalista burguês e pacífico-reformista que em nosso país se desenvolvia até então e promoveu ma mudança geral na "superestrutura política e jurídica (...) objetivando a consolidação de uma ditadura militar" que garantisse a política de "integração do neocolonialismo e o esmagamento das lutas políticas revolucionárias. Procurando evitar o isolamento total, "a ditadura militar preocupou-se em manter uma fachada democrática com uma oposição consentida e um Congresso aberto" 494 .

O ponto n. 2 dizia respeito ao AI-5, que, segundo o "Os 16 Pontos" "foi decretado no sentido de golpear o movimento estudantil" (...) o movimento operário - que esboçava sua rearticulação e retomava a luta econômica (...) e demais setores populares (clero progressista, intelectualidade) que vinham sendo atraídos pela maré de lutas revolucionárias em curso. A ditadura militar estava preocupada com a realização das "primeiras ações de caráter armado", e quis também "reforçar seus instrumentos de combate às organizações revolucionárias, tentando isolá-las das massas e destruí-las". Além disso o Doc. 16 dizia que o AI-5 foi o instrumento de que se utilizou a ditadura para solucionar as contradições ainda existentes em "setores liberais da burguesia, que vinham à tona devido a própria existência de uma fachada democrática". Tais contradições consistiam um fator de instabilidade política de que a ditadura tenta livrar-se no sentido de cumprir os objetivos definidos no golpe de 64: 'ordem' a qualquer preço e 'progresso' integrado ao neocolonialismo" 495 .

O ponto n. 3 continuava a discorrer sobre o AI-5, assegurando que sua edição revelou e aprofundou o isolamento existente entre "as forças da vanguarda revolucionária e as massas básicas da revolução: o proletariado e o campesinato". As organizações revolucionárias estavam empolgadas pelo ascensão das lutas "antiimperialistas $e$ antiditatoriais do movimento estudantil", de maneira tal que "relegaram a segundo plano o trabalho sistemático de agitação, propaganda e organização daquelas classes". Desta forma não se preparou o proletariado e o campesinato para que diante de "novas formas de organização e luta", começassem a romper os "elos da repressão contra-revolucionária"e 
assumissem seu papel de "mola propulsora e mestra do desenvolvimento da revolução", única condição na qual "esse desenvolvimento será sólido e conseqüente"496.

O ponto n. 4 fala da maior debilidade do campo revolucionário, constatando " $a$ pequena dimensão do movimento da classe proletária", em razão de "seu atual atraso político, à falta de consciência de sua força e à falta de organização sólida e combativa, capaz de romper as barreiras que lhe são impostas pela repressão da ditadura militar". Tal debilidade alcança também o campo, onde inexiste um trabalho suficiente entre as forças mais importantes" - assalariados agrícolas, camponeses pobres — que seja capaz levá-las à luta junto ao proletariado na formação da aliança operário-camponesa e ao desencadeamento da guerrilha rural" ${ }^{497}$.

O ponto n. 5 diz que ao lado dessas debilidades, "amadurecem as condições que permitem prever a energia e a potência com que o movimento operário se desenvolverá". Destacam-se, entre os fatores favoráveis, "a situação da classe operária e do campesinato na estrutura social e econômica e as tendências do desenvolvimento do capitalismo no Brasil". Na medida em que o capitalismo cresce no Brasil — "e esse crescimento se dá com base e em função do capitalismo monopolista, principalmente norte-americano" - a classe proletária vai se tornando cada vez "mais numerosa, os centros operários cada vez mais concentrados". Na agricultura, "os setores fundamentais da economia agrária" são os que apresentam o maior desenvolvimento capitalista no campo, "reunindo em si grandes concentrações do assalariado". Portanto, os centros básicos da economia industrial e agrícola do país reúnem os trabalhadores mais avançados e fortalecidos na concentração. Advertia o ponto n. 5 que o "potencial armazenado nessas concentrações de trabalhadores garantem para o futuro golpes profundos na contra-revolução", que não consegue dispor de meios capazes "de extinguir a raiz de sua existência", mas pelo contrário: "quanto mais a burguesia estender e aumentar sua exploração maiores e mais importantes se tornarão esses centros" ${ }^{498}$.

O ponto 6 fala da exploração da burguesia monopolista, que através do emprego de tecnologia avançada, "reduz a mão-de-obra àquela necessária aos seus grandes lucros. Mostra a utilização da tecnologia e de "um numeroso exército industrial de reserva para submeter a classe operária à superexploração", que atinge também "amplos setores da pequena burguesia". Diante dessa fragilidade que possuem para concorrer com os grandes

\footnotetext{
${ }^{496}$ PARTIDO COMUNISTA DO BRASIL - ALA VERMELHA. Os 16 Pontos, cit., p. 2-3.

${ }^{497}$ PARTIDO COMUNISTA DO BRASIL - ALA VERMELHA. Os 16 Pontos, cit., p. 3.

${ }^{498}$ PARTIDO COMUNISTA DO BRASIL - ALA VERMELHA. Os 16 Pontos, cit., p. 4.
} 
monopólios, as indústrias menores submetem seus operários a uma "ainda maior exploração, procurando compensar sua debilidade competitiva com os monopólios através da exploração de uma taxa alta de mais-valia". Igualmente isto ocorre com os latifundiários que prevalecem-se de "sua força política, das relações de produção existentes e da grande oferta de trabalho, mantêm a superexploração no campo". Decorre desse quadro tanto a "condição de superexplorado dos trabalhadores urbanos e rurais", como também a "pauperização da pequena burguesia e o exército de empregados $e$ subempregados que vão dar origem às favelas e aos mocambos" $" 499$.

O n. 7 aponta para as crises a que está sujeita uma sociedade capitalista integrada como a nossa, considerando-as como aspecto a ser considerado na "análise do futuro revolucionário de nosso país". O fato de que o desenvolvimento econômico nacional esteja baseado na integração ao capital monopolista estrangeiro, "vincula intimamente a situação econômica interna à situação econômica e política do capitalismo mundial". As crises do imperialismo, que são agudizadas pelo "ascenso das lutas revolucionárias em plano mundial repercutirão intensamente na economia interna e na base política do regime". Este debilitamento político "atinge também a ditadura militar neocolonialista, que faz parte do esquema internacional de dominação neocolonialista". Por outro lado, a penetração no campo, que permitiria o aumento necessário do mercado interno, é dificultada "pelo nível de desenvolvimento das relações de produção existentes"

O ponto n. 8 do "Os 16 Pontos" aborda o fato de o capital que domina o país pertencer preponderantemente ao imperialismo norte-americano, o fato de os latifundiários e a grande burguesia exercerem a exploração em aliança com o neocolonialismo e, por fim, "estando a ditadura militar neocolonialista a serviço desse tripé (imperialismo, latifúndio, grande burguesia)", têm o poder de colocar amplos setores da população "ao lado do proletariado na luta pelo poder". Disso resulta a imperiosidade do estabelecimento de uma “justa política de alianças, capaz de ganhar as amplas massas para combater aqueles inimigos e neutralizar os setores impossíveis de serem ganhos". Na sociedade brasileira o proletariado "não tem condições de levar sozinho sua luta", e deve assumir, pela sua condição de classe mais avançada, "o papel dirigente da luta revolucionária" e conduzir "as amplas massas do povo, limitando seus interesses programáticos, momentaneamente,

\footnotetext{
${ }^{499}$ PARTIDO COMUNISTA DO BRASIL - ALA VERMELHA. Os 16 Pontos, cit., p. 5.

${ }^{500}$ PARTIDO COMUNISTA DO BRASIL - ALA VERMELHA. Os 16 Pontos, cit., p. 5.
} 
aos interesses comuns das classes revolucionárias, imprimindo nele sua característica de classe ${ }^{501}$.

O ponto n. 9 do Doc. 16, aborda a violência d regime brasileiro, que através de expedientes de força tenta conter as tensões sociais e políticas "que o processo de desenvolvimento integrado cria". A ditadura procura massacrar essas lutas de classe com o uso da violência militar, desencadeando também "uma ofensiva metodizada nos planos político e ideológico, buscando a consolidação nas cidades como base de apoio contrarevolucionário", estendendo-se ao campo, onde procura "ampliar sua influência, na tentativa de impedir a atividade revolucionária". Esse procedimento, todavia, gera as condições para que se acelere "o amadurecimento da consciência das massas", cria as condições para a "substituição das lutas embrionárias por formas mais elevadas", para fundir as lutas econômicas às lutas políticas e esclarecer a necessidade "de que estas se façam cada vez mais através da luta armada". Por isso, a ditadura, com suas "atitudes desesperadas, na busca de impedir a revolução" nada mais faz "do que preparar $e$ antecipar a sua derrota". Por isso, "as forças da revolução, sob a direção de sua vanguarda, encontram condições favoráveis para acumular forças e desgastar, isolar as forças da contra-revolução",502.

O ponto 10 diz que em decorrência das análises anteriores que, apesar de possuir superioridade estratégica, "a revolução encontra-se presentemente em extrema debilidade tática". A superioridade estratégica da revolução traduz-se tanto na "situação de exploração e dominação a que as massas básicas da sociedade estão submetidas" como no "isolamento em que se debate a ditadura, na sua impossibilidade de solucionar as contradições existentes" no seio de nossa sociedade. Devido à sua extrema debilidade tática, o fundamental é que as forças da revolução saibam "elevar as formas da luta política de massas às formas da luta armada". Diante das "investidas da contrarevolução" as "correntes revolucionárias pequeno-burguesas lançam-se em atividades militares isoladas das massas". Tais correntes estão fadadas ao fracasso, por "desprezarem o potencial de luta das massas", por não reconhecerem nesta o "único recurso seguro para o êxito da revolução". O erro básico das "correntes vanguardistas, militaristas, reside em não aplicar uma linha de massas, em não considerar a revolução como luta de classes". Confundem elas o papel da vanguarda, "que não significa fazer a revolução pelas massas", em seu lugar. Pelo contrário, o papel da vanguarda é o de "ligar-se às massas, impulsionar

\footnotetext{
${ }^{501}$ PARTIDO COMUNISTA DO BRASIL — ALA VERMELHA. Os 16 Pontos, cit., p. 5-6.

${ }^{502}$ PARTIDO COMUNISTA DO BRASIL - ALA VERMELHA. Os 16 Pontos, cit., p. 6.
} 
todas as forças do movimento e dirigi-las na luta". Avançar isolado das massas é "expor a cabeça da revolução aos golpes da contra-revolução", é contribuir para que "não se forme e fortaleça a vanguarda" ${ }^{, 503}$.

O ponto n. 11 alcança o trabalho político entre as massas, salientando que no sentido de superar a "debilidade tática da revolução diante da contra-revolução", tal trabalho visa alcançar os objetivos táticos do Partido: “a combinação das lutas políticas dos trabalhadores urbanos e rurais com a luta armada, basicamente as lutas guerrilheiras no campo". O objetivo do Partido, através das guerrilhas rurais, é "a construção de uma força armada sob sua direção para libertar o povo da ditadura militar neocolonialista". Aponta ainda que na cidade, as lutas mais importantes são as da classe operária, que "atingem formas historicamente comprovadas" - como greves, piquetes — "devem ser elevadas através de sua combinação com as formas armadas - autodefesa, sabotagem etc". Porém, o incentivo e apoio à greve operária deve considerar sempre que "essa forma de luta debilitará o inimigo, educará as massas, aumentará sua força e sua organização", mas não levará à tomada do poder enquanto "não estiver combinada às ações de uma força armada no campo" e às lutas das demais classes e camadas que "são oprimidas pela ditadura". As lutas da classe operária nas cidades necessitam combinar-se às dos trabalhadores rurais: "as lutas guerrilheiras no campo, visando a criação da força armada regular, combinar-se-ão às ações políticas da guerrilha urbana". O conjunto dessas atividades marcará o "rompimento da barreira contra-revolucionária, abrindo o caminho para a tomada do poder pelas forças revolucionárias sob a direção do proletariado".

O ponto n. 12 discorre que o trabalho no seio da classe operária e das massas revolucionárias visa "a educação, a preparação e a organização das massas para a luta política e para a luta armada". Para isso é necessário incentivar ao máximo as lutas da classe operária, tomando como ponto de partida a luta econômica, elevando-a ao nível político, "indicando o caminho da luta violenta e da luta armada e organizando-a para essa luta". Deve-se observar que, nas atuais condições, "a elevação da luta política a nível de luta armada é possível e inevitável”. A Ala Vermelha deve estar preparada para "desenvolver e dirigir essa luta". Além disso, deve-se observar que o "regime ditatorial e policialesco existente" favorece a colocação da "luta política de forma direta", embora as condições das "massas revolucionárias coloquem a luta econômica em geral como ponto de partida". Nesse incentivo deve-se incrementar a luta operária contra "o arrocho salarial, contra o fundo de garantia, contra a lei antigreve, contra a intervenção nos

\footnotetext{
${ }^{503}$ PARTIDO COMUNISTA DO BRASIL — ALA VERMELHA. Os 16 Pontos, cit., p. 6-7.
} 
sindicatos, contra o regime policialesco e de repressão a que estão submetidos os operários". Tais lutas devem ser desencadeadas objetivando transformá-las em "luta pela derrubada da ditadura e instauração de um Governo Popular Revolucionário sob sua hegemonia". Assumem importância também as denúncias acerca dos "agentes da burguesia, dedos-duros, pelegos, agentes policiais". Em nenhum momento se poderá deixar de travar a luta do proletariado contra a burguesia a pretexto de "uma política de frente única com a burguesia não integrada. Não há unidade nenhuma do proletariado com nenhum setor da burguesia que não pressuponha luta". O fundamental é elevar a consciência e combatividade do proletariado, o que não se atingirá "com concessões ao nível da luta por suas reivindicações específicas". As concessões que o proletariado faz são "as concessões táticas do programa mínimo da revolução correspondente à atual etapa". Por outro lado, "em nenhum momento se poderá deixar de indicar quais os inimigos principais do proletariado e de seus aliados na revolução". Os inúmeros problemas existentes dentro das fábricas devem ser levantados "visando ganhar as massas para a luta, educá-las na luta contra a burguesia, desmascarar o imperialismo, a ditadura e os patrões que buscam conter o movimento revolucionário" valendo-se de uma "propaganda demagógica que procura encobrir a verdadeira situação da classe operária". A sistematização dos problemas das fábricas, a denúncia persistente, a conclamação para a luta, "tudo isso fornece matéria-prima básica para a preparação das grandes lutas operárias"

O ponto n. 13 adverte que no estágio atual, "reduzir as formas de luta do proletariado à luta armada é deixar de lado todo um manancial de lutas políticas”. É não considerar que as "suas condições objetivas de super-exploração são a base para um trabalho sistemático de agitação, propaganda e organização, capazes de mobilizar amplos setores da classe para a luta econômica e política". Se, por um lado, esse trabalho é dificultado pelas "condições de clandestinidade impostas pela repressão contrarevolucionária", de outro, "a própria repressão cria um amplo campo para o desenvolvimento de intensa agitação e propaganda revolucionárias, imprescindíveis para a elevação da consciência e da luta de classe". Para travar suas lutas, a Ala Vermelha deve hoje levar em conta a debilidade tática da revolução, "desenvolvendo um paciente $e$ minucioso trabalho de organização, adotando formas de luta de nível inferior" paralisações parciais, operações tartaruga - e "preparando-se minuciosamente para as mais elevadas" - greves, piquetes, como exemplo. Os movimentos desenvolvidos

\footnotetext{
${ }^{504}$ PARTIDO COMUNISTA DO BRASIL — ALA VERMELHA. Os 16 Pontos, cit., p. 7-8.
} 
"precipitadamente podem redundar em derrota, do ponto de vista da participação da massa e desestimularem a luta". Para que tais lutas sejam possíveis, portanto, "é necessário um trabalho persistente, sistemático e minucioso na classe operária",505.

O ponto n. 14 fala que devemos desenvolver a educação da classe operária para o verdadeiro significado da natureza dos sindicatos, "de instrumento de dominação da ditadura e da burguesia". Todavia, não se deve excluir a possibilidade de que as "massas operárias, na medida em que adquirirem consciência e força, possam retomar os sindicatos, utilizando-os como mais um elemento de luta contra a burguesia". A participação dos elementos conscientes nos sindicatos é importante para acompanhar seu trabalho, mas "não se deve colocá-los como forma de organização da massa". Ao contrário, "deve-se incentivar as massas para que elas se organizem através de formas livres para lutar". As organizações internas, por seções e setores de trabalhadores, formação de comitê de luta, comitês de fábricas, "deverão constituir-se, nas condições atuais, nos instrumentos que levarão avante as lutas operárias". Não se deve ser estreito em relação às formas de organização massas: "formas de organização das massas não são inventadas, mas são as próprias massas que as criam" nas horas precisas de lutar. "A autodefesa armada não deve ser criada artificialmente", tampouco incentivada fora das necessidades concretas da luta. "Assim que esta necessidade surgir, entretanto, exige-se decisão em sua criação e preparação cuidadosa para que se cumpra de fato sua finalidade". Outra forma de organização a ser desenvolvida é "de grupos de propaganda armada", dirigidos pelo Partido, com a participação "dos melhores elementos de massa que executam ações mais de propaganda que militares", que visam ampliar a base política e de massa do Partido, "após cuidadosa análise política". Sempre que possível, dependendo do caráter das ações, "os grupos de propaganda armada deverão organizar contingentes de massa para participarem das ações" $"$ "506.

O ponto n. 15 diz respeito ao trabalho do Partido hoje junto ao proletariado industrial e as massas exploradas da cidade objetiva o estabelecimento de "sólidas bases estratégicas", que garantam "a direção da classe operária pelo Partido e o seu fortalecimento político, ideológico e orgânico", capazes de apoiar e coordenar o “desenvolvimento da luta armada no campo com as atividades políticas e armadas nas cidades". O trabalho político do Partido nas cidades hoje cumpre também a tarefa de "criar as condições favoráveis a que se cumpra a tarefa principal de deslocamento para o

\footnotetext{
${ }^{505}$ PARTIDO COMUNISTA DO BRASIL — ALA VERMELHA. Os 16 Pontos, cit., p. 9.

${ }^{506}$ PARTIDO COMUNISTA DO BRASIL - ALA VERMELHA. Os 16 Pontos, cit., p. 10-11.
} 
campo", visando o desenvolvimento de um trabalho político e armado que "resulte na criação de bases de apoio revolucionário". Para isso, coloca-se como "necessidade imediata o início do trabalho de campo, tendo em vista cumprir nossa principal diretiva tática",507.

O último ponto, o de n. 16 - reconhece que o Partido, seguindo estas orientações firmemente, se transformará "de débil em forte, transformará sua fisionomia política e ideológica" irá criar "raízes sólidas entre o proletariado urbano e rural, fortalecer-se-á o suficiente para travar as duras batalhas que a revolução imporá cada vez mais" ${ }^{508}$. Criará condições para se tornar:

“o verdadeiro partido revolucionário do proletariado e dirigir a luta revolucionária de todo o povo. PARA AS FÁBRICAS: AGITAR, EDUCAR, MOBILIZAR E LUTAR PARA O CAMPO: PENETRAR PARA DIRIGIR A ORGANIZAÇÃO E A LUTA",509

Ironicamente pouco tempo se passou desde a divulgação dos "16 Pontos" até ocorrer a prisão de um de seus principais articuladores, Diniz Cabral Filho, em vinte de janeiro de 1970. Este dirigente nacional havia marcado um ponto ${ }^{510}$ com militante da VAR-PALMARES, que, entretanto, havia sido preso horas antes e compareceu ao encontro escoltado por agentes da repressão ${ }^{511}$.

A premência de recursos da Direção Regional de São Paulo ${ }^{512}$ impôs a última ação de expropriação que seria realizada pela Ala Vermelha — não obstante a vedação desta atividade pelo documento dos "16 Pontos".

A atividade consistiria em investir contra um carro comum que transportaria dinheiro para o pagamento de funcionários da fábrica da Chrysler em São Bernardo do Campo. Felipe José Lindoso e Álvaro Lins Cavalcanti Filho ${ }^{513}$ fizeram o levantamento do local, detalhando as condições em que se daria a atividade.

\footnotetext{
${ }^{507}$ PARTIDO COMUNISTA DO BRASIL - ALA VERMELHA. Os 16 Pontos, cit., p. 11.

${ }^{508}$ PARTIDO COMUNISTA DO BRASIL - ALA VERMELHA. Os 16 Pontos, cit., p. 11.

${ }^{509}$ PARTIDO COMUNISTA DO BRASIL — ALA VERMELHA. Os 16 Pontos, cit., p. 11.

${ }^{510} \mathrm{O}$ vocábulo ponto é aqui empregado no sentido que lhe emprestava a esquerda brasileira naquela época, abrangendo o significado de encontro, apontamento.

${ }^{511}$ Cf. interrogatório policial de Diniz Cabral Filho prestado no DOPS paulista. BNM 294, fls. 1808.

${ }^{512}$ Cf. interrogatório prestado no DOPS por Élio Cabral de Souza. BNM 294, fls. 2332-v.

${ }^{513}$ Cf. interrogatório prestado no DOPS por Felipe José Lindoso. BNM 294, fls. 2256.
} 
Em agosto de 1970 Élio Cabral foi comunicado desta decisão, e, relutante, concordou em participar da ação ${ }^{514}$. Inicialmente tomou conhecimento do levantamento do local e em seguida agendou a expropriação para o dia 30 daquele mês. Élio providenciou primeiramente o desapossamento de carros que seriam necessários para a ação: juntamente com Felipe Lindoso e José Gonçalo Nogueira, participou da tomada de um carro Corcel "que se encontrava estacionado próximo ao Clube Paulistano" ${ }^{, 515}$, em São Paulo. Um dia depois Felipe, Élio e Álvaro Lins rumaram para o Mirante do Morumbi, onde se apossaram de outro veículo Corce $^{516}$. Élio determinou ainda que se procedesse a uma simulação da atividade ${ }^{517}$ da qual vieram a tomar parte Felipe, Antonio Granado, Álvaro Lins, José Gonçalo Nogueira e Edgard de Almeida Martins ${ }^{518}$.

Dois dias após este treinamento, em 30 de agosto de 1970, todos os que dele haviam participado, com exceção de Edgard Martins, rumaram para São Bernardo para efetivar a expropriação. Foram nos dois carros Corcel, um dirigido por Élio Cabral e outro por Felipe Lindoso. Chegando no local Élio foi até a agência do Banco Francês e Brasileiro para "seguir o carro que transportava o dinheiro" ${ }^{, 519}$. Felipe ficou aguardando nas proximidades da fábrica da Chrysler.

Vendo que o Volkswagen do banco se aproximava, Felipe dirigiu seu carro em direção àquele veículo, para ajudar Élio a "fechá-lo". Os quatro ocupantes do Volks se viram "obrigados a parar o veículo, uma vez que um carro marca Corcel",520, conduzido por Élio, "que trafegava à frente do veículo [do banco] parou bruscamente (...) e um outro veículo [conduzido por Felipe Lindoso] que estava no cruzamento da rua também parou o carro no meio do cruzamento, fazendo com que parasse todo o tráfego daquela via pública" ${ }^{, 521}$.

Álvaro Lins, Antonio Granado e José Gonçalves abordaram o Volks do banco, e, mostrando suas metralhadora e espingardas "disseram: 'fiquem quietos, saiam do carro e não olhem par nós" ${ }^{322}$, no que foram obedecidos. Ato contínuo Felipe juntou-se aos seus

\footnotetext{
${ }^{514}$ SOUZA, É. C. de. Élio Cabral de Souza: depoimento [nov. 2006]. Entrevistador: T. A. D. Silva. Goiânia, 2006. CD 1, faixa 10.

${ }^{515}$ Cf. interrogatório prestado no DOPS por José Gonçalo Nogueira. BNM 294, fls. 2262-v.

${ }^{516} \mathrm{Cf}$. interrogatório prestado no DOPS por Antonio Carlos Lopes Granado. BNM 294, fls. 2245-v.

${ }^{517}$ Cf. interrogatório prestado no DOPS por Élio Cabral de Souza. BNM 294, fls. 2332-v.

${ }^{518} \mathrm{Cf}$. interrogatório prestado no DOPS por Felipe José Lindoso. BNM 294, fls. 2255-v.

${ }^{519}$ Cf. interrogatório prestado no DOPS por Felipe José Lindoso. BNM 294, fls. 2255-v.

${ }^{520}$ Cf. depoimento do bancário Cláudio Medeiros Venaglia (que se encontrava no interior do Volkswagen abordado na ação), prestado no DOPS. BNM 294, fls. 2348.

${ }^{521}$ Cf. depoimento do bancário Cláudio Medeiros Venaglia (que se encontrava no interior do Volkswagen abordado na ação), prestado no DOPS. BNM 294, fls. 2348-v.

${ }_{522}$ Cf. depoimento da bancária Maria José Gastaldo (que se encontrava no interior do Volkswagen abordado na ação), prestado no DOPS. BNM 294, fls. 2349.
} 
companheiros e se apoderaram de duas sacolas contendo duzentos e trinta e cinco mil reais $^{523}$ numerário e as transferiram para o carro de Élio. Neste ínterim José Gonçalves, “o elemento da metralhadora, desviava o trânsito do local ${ }^{, 524}$ até o momento em que embarcou no carro conduzido por Felipe, que seguia o de Élio.

A derradeira ação da Ala Vermelha que foi objeto dos órgãos repressivos do Regime Autoritário brasileiro consistiu na tomada da Rádio Clube de Santo André, em 14 de novembro de 1970, para lançar um manifesto que apregoava o voto nulo nas eleições que seriam realizadas no dia posterior.

Antonio Marcelo fez o levantamento ${ }^{525}$ das informações necessárias para esta atividade de propaganda guerrilheira, e posteriormente gravou o manifesto ${ }^{526}$ que seria transmitido durante a ocupação da emissora. Enquanto que Élio Cabral e Álvaro Lins ${ }^{527}$ desapropriavam um carro Galaxie de um casal em São Paulo para ser utilizado na ação.

No dia marcado para a atividade, Felipe Lindoso fizera uma reunião em um aparelho de São Bernardo com Antonio Neiva Moreira Netto, Antonio Marcelo, Álvaro Lins e José Gonçalo $^{528}$ onde expôs o esquema elaborado para a tomada da rádio. A seguir rumaram para a emissora no Galaxie, conduzido por Felipe ${ }^{529}$.

Felipe estacionou defronte à radio e permaneceu no carro enquanto que desceram Antonio Neiva Moreira Netto, Antonio Marcelo e José Gonçalo ${ }^{530}$ que entraram na emissora; Álvaro Lins rumou para o carro onde se encontrava Élio Cabral, parado nas proximidades para auxilia-lo na cobertura da ação ${ }^{531}$.

Os três militantes da Ala adentraram a Rádio Clube, e ameaçaram com armas o operador de transmissor daquela emissora determinando-lhe que mostrasse a localização "dos transmissores, pois deveriam colocar uma gravação no ar" ${ }^{2532}$. Antonio Neiva e José Gonçalo ficaram na porta da rádio enquanto que Antonio Marcelo ${ }^{533}$ "tentou ele mesmo colocar a

\footnotetext{
${ }^{523}$ Valores atualizados em $1^{\circ}$. de dezembro de 2006.

${ }^{524}$ Cf. depoimento da bancária Maria José Gastaldo (que se encontrava no interior do Volkswagen abordado na ação), prestado no DOPS. BNM 294, fls. 2349-v.

${ }^{525}$ Cf. interrogatório prestado no DOPS por Antonio Fernando Bueno Marcelo. BNM 294, fls. 2339.

${ }^{526}$ Cf. interrogatório prestado no DOPS por Élio Cabral de Souza. BNM 294, fls. 2333.

${ }^{527}$ Cf. interrogatório prestado no DOPS por Felipe José Lindoso. BNM 294, fls. 2255-v.

${ }^{528}$ Cf. interrogatório prestado no DOPS por Antonio Neiva Moreira Netto. BNM 294, fls. 2459-v.

${ }^{529}$ Cf. interrogatório prestado no DOPS por Antonio Neiva Moreira Netto. BNM 294, fls. 2459-v.

${ }^{530} \mathrm{Cf}$. interrogatório prestado no DOPS por Antonio Neiva Moreira Netto. BNM 294, fls. 2459-v.

${ }^{531}$ Cf. interrogatório prestado no DOPS por Élio Cabral de Souza. BNM 294, fls. 2333.

${ }^{532}$ Cf. depoimento de Francisco de Paulo Rodrigues (operador da Rádio Clube) prestado no DOPS. BNM 294, fls. 2350-v.

${ }^{533}$ Cf. interrogatório prestado no DOPS por Antonio Fernando Bueno Marcelo. BNM 294, fls. 2339.
} 
gravação no ar, não conseguindo" ${ }^{, 534}$, e solicitou que o operador pusesse o manifesto nos transmissores, e uma vez sendo iniciada a propagação da mensagem, colocou aquele trabalhador "trancado no banheiro". 535

O manifesto transmitia à população a mensagem de que "as eleições de quinze de novembro são a mentira mais nova que a ditadura quer contar aos trabalhadores (...) as eleições só servem para desviar nossa atenção de assuntos mais importantes, como o arrocho salarial (...) Anule seu vota amanhã ${ }^{, 536}$

Alguns minutos após o início da transmissão, os militantes da Ala evadiram-se da rádio e se juntaram a Felipe na rua. Logo em seguida foram apanhados pelo Volks de Élio e Álvaro Lins, rumando para São Paulo ${ }^{537}$.

No dia 17 de janeiro de 1971 foram presos dois membros da Direção Nacional da Ala Vermelha. Élio Cabral, quadro egresso das Ligas Camponesas e que esteve na China realizando curso militar junto com Edgar de Almeida Martins, se deparou com uma "operação arrastão" ${ }^{, 338}$, espécie de blitz policial realizado rotineiramente pelos órgãos de repressão. Estava em um Volks do partido e no veículo havia armas e material, utilizados em ação na Rádio Difusora de Santo André. Élio abandonou o veículo na rua e avisou Paulo de Tarso Gianinni.

Dirigiu-se, então, para a casa onde morava com Edgar. Lá, foram cercados por uma veraneio do DOPS. Élio e Edgar trocaram rajadas de metralhadora com os agentes da repressão durante tempo suficiente para chamar a atenção da vizinhança. A estratégia era reunir testemunhas de sua prisão ${ }^{539}$, a fim de evitar eventual desaparecimento forçado.

Ao ser recolhido na viatura policial, Élio encontrou José Felipe Lindoso. Ele conhecia o endereço de Élio e Edgar e fora seguido pela polícia. Posteriormente, Edgar de Almeida Martins se tornou agente de informação do DOI-CODI ${ }^{540}$.

Uma das últimas prisões registradas da Ala Vermelha envolveram o casal Tarzan de Castro e Maria Cristina Uslenghi Rizzi, ocorrida em Recife, no dia 29 de janeiro de 1971.

Tarzan de Castro era uma pessoa com extensa militância política anterior ao Golpe de 1964, que suspendeu seus direitos políticos por dez anos ${ }^{541}$. Ex-militante do PC do B

${ }^{534}$ Cf. depoimento de Francisco de Paulo Rodrigues (operador da Rádio Clube) prestado no DOPS. BNM 294, fls. 2350-v.

${ }^{535}$ Cf. depoimento de Francisco de Paulo Rodrigues (operador da Rádio Clube) prestado no DOPS. BNM 294, fls. 2350-v.

${ }^{536}$ Fragmentos do manifesto lido na Rádio Independência. BNM 294, anexo 4432.

${ }^{537}$ Cf. interrogatório prestado no DOPS por Antonio Fernando Bueno Marcelo. BNM 294, fls. 2339.

${ }^{538}$ Cf. interrogatório no DOPS Élio Cabral. BNM 294, fls. 2333-v.

${ }^{539}$ Cf. SOUZA, É. C. de.; CASTRO, T. de. Élio Cabral; Tarzan de Castro: depoimento [ago. 2005]. Entrevistador: T. A. D. Silva. Goiânia, 2005. CD 1, faixa 21.

${ }_{540}$ PARTIDO COMUNISTA DO BRASIL - ALA VERMELHA. Crítica..., cit. p. 58. 
em Goiás, que o enviou para treinamento na China em 1965. Na sua volta participou da luta interna contra o PC do B, quando foi enviado por aquela agremiação partidária para São José do Rio Preto, onde foi preso e enviado para o Rio de Janeiro, em virtude de ter sido decretada sua prisão em virtude de condenação em um IPM aberto em para apurar as atividades do Partido Comunista do Brasil no Estado de Goiás.

Conseguiu fugir da prisão onde se encontrava encarcerado, no Rio de Janeiro, e solicitado asilo na Embaixada do Uruguai. Concedido seu pedido, viajou para aquele país no final de 1966. Conheceu ali Maria Cristina e passaram a levar uma vida em comum desde 1968. Tarzan voltou clandestinamente para o Brasil em setembro de 1969, ficando inicialmente em São Paulo. Maria Cristina vem logo após, em janeiro de 1970. Mudam-se para Guarulhos; Tarzan vai para Recife em fevereiro de 1970 e Maria Cristina em março do mesmo ano, encarregado pela Direção Nacional daquela organização para manter contatos que possibilitassem a implantação da Ala Vermelha no nordeste ${ }^{542}$.

As últimas prisões de militantes da Ala Vermelha que participaram da luta armada ocorreu quando Antônio Fernando Bueno Marcelo, integrante remanescente da Unidade de Combate 1, foi preso em 21 de abril de 1971. Expropriara, juntamente com Lenos Veríssimo de Souza e Álvaro Lins Cavalcanti Filho ${ }^{543}$, um veículo Opala, que seria utilizado em ação de panfletagem ${ }^{544}$. Os três militantes trocavam a placa do carro, quando, na Marginal Pinheiros, uma viatura policial do DEIC os abordou. Os militantes fugiram, atiraram na C-14 da Polícia e quanto entraram numa rua sem saída, bateram carro. Álvaro Lins Cavalcanti Filho conseguiu fugir $^{545}$, Lenos e Antônio Marcelo foram levados ao DOI-CODI.

As prisões dos integrantes das Unidades de Combate e das detenções relacionadas ao GEN, trouxeram como conseqüência inicial a detenção de outros militantes, que não participavam diretamente da luta armada, constituindo-se em pessoas que faziam trabalho de massas, além de colaboradores ou mero simpatizantes da Ala Vermelha. Assim, das sessenta e quatro prisões que constam dos processos instaurados contra a Ala Vermelha em São Paulo, vinte e nove se referem a militantes que se envolveram com ações armadas enquanto que trinta e cinco delas constituíram-se em detenções de pessoas alheias a esta forma extremada de luta. São elas as prisões de: Aristides da Silva Souza, Bernardino Ribeiro Figueiredo, Cleuzer de Barros, Cid Barbosa Lima Júnior, César Eduardo Moreira Cerqueira, Durval de Lara Filho,

\footnotetext{
${ }^{541}$ Cf. Diário Oficial da União, de 13 de junho de 1964, p. 5050.

${ }^{542}$ PROJETO "BRASIL: NUNCA MAIS". A pesquisa... p. 210-211.

${ }^{543}$ Cf. interrogatório no DOPS Antônio Fernando Bueno Marcelo. BNM 294, fls. 2339.

${ }^{544}$ Cf. interrogatório no DOPS Lenos Veríssimo de Souza. BNM 294, fls. 2454-v.

${ }^{545} \mathrm{Cf}$. interrogatório no DOPS Lenos Veríssimo de Souza. BNM 294, fls. 2455.
} 
Edson Hilário de Freitas, Flávio Antunes Júnior, Geraldo Virgílio Godoy, João Amorim Coutinho, João Carlos Antunez Lacaz, Jarbas Teobaldo dos Santos, Jorge Kurban Abraão, José Fernando dos Santos, José Miguel, Lais Furtado Tapajós, Lucy Tanus Jorge, Letácio Barbosa de Lima, Miriam Bottassi, Margarida Maria do Amaral Lopes, Melchiades Antônio Cervo, Márcia Nely Bernardes, Nobue Ishii, Norimar de Andrade Gomez Roig, Nadir Helú, Osvaldo Bernardino da Silva, Paulo Frateschi, Paulo Sérgio Paraíso Cavalcanti, Sérgio Massaro, Severo de Luca Crudo, Tânia Maria Mendes, William João Bittar e Wilson Palhares.

A segunda consequiência das prisões decorrentes do processo de luta armada foi o desmantelamento de parcela significativa da Direção Nacional — foram detidos Derly José de Carvalho, Diniz Cabral Filho, Edgard de Almeida Martins, Élio Cabral, Felipe José Lindoso, Genésio Borges de Melo, Jair Stoch, além de militantes importantes, como é o caso de Tarzan de Castro.

O terceiro efeito destas prisões relacionadas com ações armadas, além do fato de espraiar seu alcance para outros Estados - como Rio Grande do Sul, Minas Gerais, Rio de Janeiro, Pernambuco, além de Brasília — foi o de trazer danos imponderáveis ao Comitê Regional de São Paulo, pois foram detidos vários de seus integrantes: Carlos Takaoka, Misael Pereira dos Santos, Nelson Brissac Peixoto e Renato Tapajós, o que prejudicou sensivelmente a Ala Vermelha no Estado de São Paulo.

O aparato repressivo atingiu o Partido Comunista do Brasil - Ala Vermelha na quase totalidade dos Estados onde tinha atuação ${ }^{546}$. Foram instaurados dez processos contra esta organização, distribuídos geograficamente entre Minas Gerais (três), Rio de Janeiro (um), Rio Grande do Sul (dois), São Paulo (três) e Distrito Federal (um), permanecendo assim, fora das ações punitivas do Regime Autoritário brasileiro pós-64, os Estados de Goiás e Espírito Santo.

Em nove processos a organização se constituiu em objeto exclusivo de apuração e no único processo do Distrito Federal, a Ala Vermelha foi móvel de investigação e julgamento de suas atividades conjuntamente com as de outras organizações, a Ação

\footnotetext{
546 De acordo com o corpus documental que se examina, o Projeto "Brasil: Nunca Mais", Ala Vermelha "chegou a existir em São Paulo, Rio, Minas, Rio Grande do Sul, Brasília e Espírito Santo, tendo ocorrido também uma tentativa de implantá-la no Nordeste, a partir de Pernambuco". Cf. PROJETO "BRASIL: NUNCA MAIS". Perfil dos Atingidos... p. 66. Jacob Gorender, contudo, além dos Estados mencionados indica também os Estados de Goiás e Maranhão. Cf. GORENDER, Jacob, op. cit., p. 120. Élio Cabral igualmente aponta Goiás como um dos Estados onde a Ala Vermelha se fazia presente: "A divergência abrangeu Rio de Janeiro, São Paulo, Goiás, Brasília, Rio Grande do Sul, Espírito Santo, Minas Gerais”. Cf. SOUZA, É. C. de.; CASTRO, T. de., cit., CD 2, faixa 25.
} 
Libertadora Nacional (ALN), a Ação Popular (AP) e com o Partido Operário Revolucionário (Trotskista) - PORT $^{547}$.

Dentro da delimitação deste trabalho, cabe o exame de três processos instaurados contra a Ala Vermelha em São Paulo, todos pertinentes ao período compreendido em nossa pesquisa, uma vez que se referem aos fatos ocorridos entre 1968 e 1971.

No estudo destes processos conjugaremos o modelo analítico proposto por Maria Aparecida de Aquino como dimensão reflexiva da pesquisa, no qual "é preciso, refletir inicialmente, acerca de duas questões: em que consistem os autos desses processos e qual a importância da análise desse material" ${ }^{, 548}$.

A partir dessa perspectiva, a análise dos autos ${ }^{549}$ percorre os processos, enquanto unidade de análise e se divide metodologicamente, diante dos conjuntos de normas que formam as Leis de Segurança Nacional. Para isto, pode-se apartar o material do Projeto "Brasil: Nunca Mais" em duas fases distintas: a do inquérito policial e a judiciária. Mais precisamente, a primeira fase abrange dois estágios preliminares: o primeiro deles compreende o inquérito policial e a atuação prévia do Ministério Público; a segunda fase compreende o estágio judiciário, onde temos o processo em si.

O estágio do inquérito policial antecedia o processo, pois segundo a tradição processual brasileira, "a função do inquérito é apurar sucintamente um fato delituoso, com intuito de fornecer subsídios para que o Ministério Público possa oferecer denúncia ao Judiciário" ${ }^{, 50}$. Estes subsídios resultavam de vários procedimentos que eram feitos no

\footnotetext{
547 O Partido Operário Revolucionário (Trotskista) - PORT - foi fundado em 1953 sob a orientação do Birô Latino-Americano da IV Internacional (criada em 1938 por Leon Trotski), controlado na época pelo argentino J. Posadas e foi considerado o mais importante grupo trotskista no Brasil. A orientação de Posadas, nos anos 1960, era a de que, já estando os partidos comunistas degenerados, as propostas mais radicais somente poderiam vir da radicalização das correntes nacionalistas de esquerda, o que motivaria a ampla atuação do PORT nas Ligas Camponesas (especialmente em Pernambuco) e nos movimentos dos sargentos e marinheiros. O PORT foi duramente atingido após o Golpe de 1964, mas voltou a atuar no meio estudantil de São Paulo, Brasília e Rio Grande do Sul, e deslocou militantes para os movimentos operários e participou dos meios sindicais até a década de 1970, quando enfrentou diversas cisões. Nessa época Posadas deu "um giro em suas posições, vindo a defender a União Soviética e os partidos comunistas stalinistas", sem prejuízo de suas exóticas teses divulgadas no jornal oficial do partido, o Frente Operária, acerca da existência de sociedades interplanetárias avançadas, cujos porta-vozes seriam os OVNIS. "Os discos voadores iriam desestabilizar o capitalismo e o imperialismo porque demonstrariam a existência de sociedades que, por sua avançada tecnologia, só poderiam ser comunistas". Cf. MAIA, Andréas. O que foi o Partido Operário Revolucionário. Em Tempo, São Paulo, nº 104, 17 a 30 de abril, 1980, p. 16-17.

${ }^{548}$ AQUINO, Maria Aparecida de. Caminhos Cruzados. Imprensa e Estado Autoritário no Brasil (1964-80). 1994. 310 f. Tese (Doutorado em História) - Universidade de São Paulo, 1994, p. 236.

${ }^{549} \mathrm{O}$ vocábulo autos designa as peças (interrogatórios, folhas de antecedentes, depoimento de testemunhas, petições da defesa e do Ministério Público, transcrição de audiências, etc.) produzidas no decorrer de um processo judicial, desde a fase policial até as realizadas na etapa judicial.

${ }_{550}$ MATTOS, Marco Aurélio Vannucchi Leme de. Em nome da segurança nacional: os processos da Justiça Militar contra a Ação Libertadora Nacional (ALN), 1969-1979. 2002. 172 f. Dissertação (Mestrado em História) - Universidade de São Paulo, 2002, p. 51.
} 
transcorrer do inquérito, como interrogatórios, depoimentos de testemunhas, acareações entre declarações conflitantes entre si, buscas, apreensões de objetos e documentos relacionados com o delito, e outras provas técnicas - perícias, vistorias e reconstituição dos eventos considerados criminosos. O delegado - também chamado de autoridade policial encarregado do inquérito apresentava na conclusão das investigações e dos procedimentos, um relatório historiando o que foi apurado, indicando quem deveria ser processado e qual a lei que em sua opinião era de ser aplicada ${ }^{551}$, e remetia todo o conjunto de peças que formavam o inquérito para a apreciação do procurador do Ministério Público.

Em uma etapa igualmente preliminar o representante do Ministério Público (MP) chamado de procurador - examinava os elementos contidos no inquérito policial e formava sua conviç̧ão sobre a existência de crime e sobre a autoria do mesmo. Se possuísse uma opinião segura sobre a ocorrência do delito e de quem foi seu autor, ofereceria então aquele procurador a denúncia ao juiz, consistente em uma peça escrita contendo a exposição do fato considerado como criminoso, a qualificação do indivíduo os dados pessoais daquele que estava sendo acusado -, a classificação legal do delito (o tipo penal ${ }^{552}$ que correspondia à conduta do denunciado), e também apresentava a relação ou rol - de testemunhas que desejava ouvir em juízo. Desta maneira o suspeito de haver cometido o crime passava a ser considerado como um denunciado, ou seja, alguém passível de sofrer um processo penal por haver incorrido na legislação de segurança nacional.

A segunda fase corresponde àquela que se desenvolve no âmbito do Poder Judiciário. Importante reafirmar aqui que a fase judicial dos crimes contra a segurança nacional, acontecia em órgãos da Justiça Militar. No patamar mais baixo da hierarquia da justiça castrense, situavam-se as auditorias, as quais eram divididas em razão de sua inserção no território nacional: o Estado de São Paulo pertencia à Segunda Região Militar $^{553}$, e possuía três auditorias. Estas auditorias eram formadas por um juiz auditor e

\footnotetext{
${ }^{551}$ PROJETO "BRASIL: NUNCA MAIS". A Pesquisa BNM (Os Instrumentos da Pesquisa e a Fonte). Projeto "A"- Tomo II, Volume 1. São Paulo: Arquidiocese de São Paulo, 1985, p. 2.

${ }^{552}$ Pela locução tipo penal compreende-se um algum artigo, parágrafo ou alínea de uma lei criminal ou penal onde se encontram descritos os elementos que irão configurar um determinado crime, bem como a pena para ele prevista.

553 A Circunscrições eram estabelecidas de acordo com a Região Militar onde se situavam, segundo o art. $1^{\circ}$. do Código da Justiça Militar (CJM), de 1938. Cf. BRASIL. Código da Justiça Militar, de 2 de dezembro de 1938. Organizado por Reinaldo Calil. São Paulo: Sugestões Literárias, 1967. Posteriormente o Decreto-lei 1.003, de 21 de outubro de 1969, que instituiu a Lei de Organização Judiciária Militar, veio a dispor em seu art. $1^{\circ}$. sobre a questão das Circunscrições da Justiça Militar, que correspondiam à Região Militar que pertenciam. Cf. BRASIL. Lei de Organização Judiciária Militar. Decreto-lei no . 1.003, de 21 de outubro de 1969. São Paulo: Sugestões Literárias, 1971.
} 
seu substituto, um procurador, um advogado de ofício e substitutos, além de pessoal $\operatorname{auxiliar}^{554}$. O julgamento dos réus não acontecia perante este juiz, mas através do Conselho Permanente de Justiça (CPJ), o qual era integrado pelo juiz auditor - que era civil -, e quatro militares que eram sorteados dentre oficiais da Marinha, do Exército e da Aeronáutica ${ }^{555}$. A presidência deste Conselho ficava a cargo de "um oficial superior, ou de oficial general, de posto mais elevado que o dos demais juízes, ou de maior antiguidade, no caso de igualdade de posto"556.

O juiz auditor era quem decidia se recebia - ou aceitava - a denúncia formulada pelo procurador. Acatando a proposta do Ministério Público, estava iniciada a segunda fase, a judicial ou judiciária. Agora o denunciado passava a figurar como acusado ou réu $u^{557}$ de um processo fundamentado na Lei de Segurança Nacional, processo este que constituía o instrumento por meio do qual os órgãos da Justiça Militar poderiam vir a impor uma pena prevista na LSN à pessoa acusada. Em um primeiro momento, denominado de instrução probatória ${ }^{558}$, o réu seria ouvido em interrogatório, bem como prestariam depoimentos as testemunhas de acusação (indicadas pelo Ministério Público), as de defesa (que fossem apresentadas pelo advogado do réu) e, eventualmente, poderia haver o reconhecimento de pessoas, acareações entre depoimentos díspares, exame de sanidade mental do acusado, além de outros elementos periciais de prova, como laudos necroscópicos (decorrentes de autópsias), de corpo de delito (para averiguar a extensão dos ferimentos recebidos pela vítima), exames de grafia de pessoas acusadas para compará-los com documentos escritos, etc.

Depois de encerrada a instrução probatória o juiz determinava que o Ministério Público e a Defesa - nesta ordem - fizessem suas alegações finais. Nesta ocasião o MP fazia uma apreciação do que foi apurado no decorrer do processo e invocava questões

\footnotetext{
${ }^{554}$ Notamos que esta composição da Auditoria veio dada pela referida Lei de Organização Judiciária Militar (LOJM), em seu artigo 27, uma vez que até o final de outubro de 1969, a estrutura da Auditoria era ditada pelo mencionado Código da Justiça Militar: "Art. $6^{\circ}$ Cada auditoria compor-se-á de um auditor, um promotor, um advogado, um escrivão, dois escreventes, um oficial de justiça e um servente". Esta distinção, contudo, apresenta-se como um registro histórico pois não possui maior relevância para nosso trabalho, uma vez que os primeiros militantes da Ala Vermelha vieram a ser denunciados após a entrada em vigência da LOJM, em 22 de janeiro de 1970. Cf. BRASIL. Lei de Organização Judiciária Militar, cit.

${ }_{555}^{55}$ Ver art. 15 da Lei de Organização Judiciária Militar, referenciada na nota anterior.

${ }_{556} \mathrm{Cf}$. art. $13 \S 1^{\circ}$. da LOJM, citada na nota acima.

557 Se empregam neste trabalho os vocábulos réu e acusado como palavras de igual significado, correspondente a uma pessoa que está sendo criminalmente processada.

${ }^{558}$ Por instrução probatória se entende a fase do processo na qual são produzidas todas as provas (interrogatórios, depoimentos de testemunhas, apresentação de provas técnicas ou periciais, etc.), abrangendo, enfim, todos os atos que são praticados no decorrer do processo até o momento das alegações finais, ou seja, quando a acusação e a defesa apresentam suas razões que justificam o pedido de absolvição ou condenação do réu.
} 
jurídicas visando demonstrar a procedência da acusação feita contra o réu, e, assim, fundamentar um pedido de condenação do acusado. O advogado, por seu turno, procurava esmiuçar as provas produzidas no processo, discuti-las, levantar problemas jurídicos, enfim, analisar o processo sob a luz das provas ${ }^{559}$ nele produzidas para pedir a absolvição do réu.

Uma vez apresentadas as alegações finais do Ministério Público e da Defesa, reunia-se Conselho Permanente de Justiça ${ }^{560}$ para decidir sobre o caso concreto que foi objeto do processo, através de uma sentença escrita, na qual o referido Conselho ${ }^{561}$ exteriorizava o desenvolvimento de seu raciocínio ${ }^{562}$, demonstrando as razões que o levavam a decidir desta ou daquela maneira, ou seja, condenando ou absolvendo o acusado.

Da sentença proferida pelo Conselho Permanente de Justiça poderia caber recursos, tanto por parte do MP quanto da defesa ${ }^{563}$, os quais seriam dirigidos para o Superior Tribunal Militar (STM). Este órgão era composto de quinze ministros, dos quais dez eram militares e cinco civis. Representando o Ministério Público junto ao STM atuava o Procurador-Geral da Justiça Militar.

Das decisões do STM era possível recorrer-se, como derradeiro meio, ao Supremo Tribunal Federal (STF), sediado em Brasília, e composto por onze ministros civis e perante o qual exercia suas funções o Procurador Geral de República, que emitia um parecer sobre os recursos antes do julgamento pelo STF.

Neste contexto geral é que serão analisados os processos referentes à Ala Vermelha no Estado de São Paulo, durante o período que abrange os anos de 1968 - quando aconteceram os primeiros fatos que originaram alguns desses processos -, até 1976, quando é apreciado pelo Supremo Tribunal Federal o último recurso apresentado por seus militantes.

A pesquisa compreenderá, a partir dessa divisão ampla de duas etapas, o exame de cada um dos mencionados processos, no qual se buscará apreender como neles ocorreram as distintas fases do inquérito e do processo, bem como os papéis desemepenhados pelos

\footnotetext{
559 TOURINHO FILHO, Fernando da Costa. Processo Penal - volume 4. São Paulo: Saraiva, 2005, p. 41.

${ }^{560}$ Ver art. 43, I, da LOJM. Cf. BRASIL. Lei de Organização Judiciária Militar, cit.

${ }^{561}$ Neste trabalho se emprega as palavras juiz e magistrado indistintamente, como sinônimas.

${ }^{562}$ TOURINHO FILHO, Fernando da Costa. Processo Penal - volume 4, cit. p. 255.

${ }^{563}$ O Ministério Público poderia apresentar um recurso, p.ex., contra a absolvição do réu para pleitear sua condenação no STM, ou ainda, caso estivesse em desacordo com a pena aplicada pelo juiz, através de um recurso, poderia pedir sua revisão ao mesmo STM, visando aumentar o apenamento recebido pelo réu. A defesa, obviamente, operaria no sentido contrário: caso o acusado fosse condenado, p.ex., entraria com um recurso para pleitear a sua absolvição no STM, ou ainda, em caso de condenação, pedir a diminuição de pena por parte daquele tribunal.
} 
diversos atores intervenientes nestes procedimentos: 1) os integrantes da Ala Vermelha; 2) os delegados; 3) os procuradores do Ministério Público; 4) os juízes e ministros de tribunais; 5) os advogados de defesa.

Apesar de se formular uma aparente estanquização de análise, ressaltamos que a dinâmica que um processo encerra impossibilita compartilhar tal visão, de um nível demarcatório intransponível, no qual cada uma destas etapas deva necessariamente ser examinada apartada das demais. A inter-relação existente entre as diversas fases processuais compele a que tenhamos igualmente um olhar que, se de um lado, privilegia determinada etapa, por outro, faça a oportuna conexão com outros aspectos pertencentes às restantes, almejando, deste modo, atingir uma reflexão ampla sobre a significação do conteúdo e implicações do corpus documental.

É a partir dessa necessária interligação entre as etapas, que iniciamos a análise da primeira fase, examinando primeiramente a totalidade dos atingidos, para determinarmos quem foram as pessoas alcançadas pelas agências de criminalização secundária que iniciavam a repressão estatal, a polícia e o Ministério Público. 


\subsection{Os atingidos}

Elegendo como fonte primária os autos dos processos ${ }^{564}$ do Projeto "Brasil: Nunca Mais" de números BNM 294 ${ }^{565}$, BNM $436^{566}$ e BNM $602^{567}$, procurou-se dar uma visibilidade geral e estatística, compatível à história da Ala Vermelha sob o conjunto de processos formados em São Paulo, objetivando uma comparação entre a caracterização geral dos atingidos efetuada pelo Projeto "Brasil: Nunca Mais" e a individualização das pessoas pertencentes a esta organização que foram alvo dos órgãos repressivos.

Notamos que esta delimitação encontra seu fundamento primeiramente na relevância do processo BNM 294, que segundo os autores daquele Projeto, "na verdade representa a unificação de três processos distintos, dois de 1969 e um de 1971, em São Paulo", contendo as informações mais importantes "sobre a estrutura, história, atividades e linha política dessa organização" igualmente que todas as ações armadas praticadas pela Ala Vermelha que foram alvo dos processos do Projeto "Brasil: Nunca Mais", aconteceram na Região Metropolitana de São Paulo. A capital paulista, de outro prisma, se mostrou como o local privilegiado de residência dos atingidos pelos organismos de repressão do Regime Autoritário brasileiro pós-64, fossem eles nascidos em São Paulo ou vindos de outras Unidades Federativas, o que vale dizer: São Paulo consistiu a cidade de maior concentração dos militantes da Ala Vermelha naquele período. O Estado de São Paulo, deste modo, se constituiu no centro da repressão política estatal e das atividades guerrilheiras encetadas pela Ala Vermelha.

O levantamento pormenorizado da presença e participação dos militantes da Ala Vermelha além de estar inserido no inquérito (etapa policial) através do "auto de qualificação e interrogatório" e do formulário "informações sobre a vida pregressa do indiciado" em que eram registrados os dados sob o ponto de vista individual, familiar e

\footnotetext{
${ }^{564}$ A sigla BNM seguida de um número corresponde à numeração dos processos determinada pelas equipes de análise do Projeto "Brasil: Nunca Mais" e não a sequiência de números original feita pela Justiça Militar.

${ }^{565}$ BNM 294: "Unificação de 3 processos apurando atividades da Ala em São Paulo, desde sua constituição em 67, até início de 71, abordando a composição das direções e organismos da Ala, linha política, reuniões e inúmeras ações armadas". PROJETO "BRASIL: NUNCA MAIS”. A pesquisa BNM... p.164.

566 BNM 436: "Os réus são acusados de integrarem um grupo subversivo que se estruturou em Guaratinguetá (SP), em 1968 e 1969, para estudar textos marxistas, fazer aliciamento, discutir as várias propostas das organizações de esquerda etc. $O$ réu que dava assistência política ao grupo tinha ligações com a Ala e trazia os jornais 'Unidade Operária', desse partido, para leitura e distribuição". Idem, p. 186.

${ }^{567}$ BNM 602: "Os réus (casal) são acusados de pertencerem à Ala e terem residido temporariamente em Guarulhos (SP), mantendo contatos clandestinos e providenciando documentação falsa para a ré, de nacionalidade uruguaia. O inquérito foi aberto em abril de 1971". Ibidem, p. 210-211.

${ }^{568}$ PROJETO “BRASIL: NUNCA MAIS”. Perfil dos Atingidos... p. 69.
} 
social, condição econômica, "sua atitude e estado de ânimo antes, durante e depois do crime, e quaisquer outros elementos que possam contribuir para a apreciação do seu temperamento" ${ }^{\natural 69}$, também está incluído na segunda fase - a judicial -, que ora limita a compreensão dos dados obtidos, ora acresce novas informações que não se revelaram na primeira etapa.

A Pesquisa BNM (PBNM) para extrair os dados necessários dos autos, determinou como instrumento de estratégia de investigação, dois questionários: "o primeiro deles, que se convencionou chamar Q1 (Questionário 1), corresponde à pesquisa de tipo censitário, com questões fechadas para recolher respostas-padrão de todos os processos que compõem o universo documental ${ }^{570}$. Isto permitiu a análise do próprio processo e a focalização de cada indivíduo dentro dele.

O segundo instrumento de análise o Q2 (Questionário 2), “incidiu sobre alguns exemplos intencionalmente selecionados por amostragem ${ }^{571}$ ", resultando num quadro geral sobre o inquérito, sobre o processo, sobre o julgamento e sobre o teor dos discursos de algumas peças do processo.

A partir da coleta dos dados contidos nestes instrumentos, a Pesquisa BNM contabilizou em números absolutos um total de 17.420 atingidos, assim distribuídos:

\begin{tabular}{|l|l|}
\multicolumn{1}{c|}{ Quadro 1 } \\
\hline SITUAÇÃO & $\mathrm{N}^{\mathrm{o}}$. \\
\hline Denunciados & 7.367 \\
\hline Indiciados & 6.385 \\
\hline Testemunhas & 2.183 \\
\hline Declarantes & 1.485 \\
\hline TOTAL & 17.420 \\
\hline \multicolumn{2}{|c}{ Fonte $^{572}$ : BNM }
\end{tabular}

Os indicadores da PBNM compreendem duas espécies distintas de pessoas: primeiramente membros de organizações clandestinas que participaram das lutas sociais e políticas e que se confrontaram com o regime militar e acabaram figurando em um ou mais desses processos, como indiciados e/ou denunciados. Aqui a Pesquisa BNM incluiu "os

\footnotetext{
${ }^{569}$ TOURINHO FILHO, Fernando da Costa. Código de Processo Penal Comentado. Volume 1. São Paulo: Saraiva, 1999, p. 48.

${ }^{570}$ PROJETO “BRASIL: NUNCA MAIS". A pesquisa... p. 08.

${ }^{571}$ Idem, p. 25.

${ }^{572}$ PROJETO "BRASIL: NUNCA MAIS". A pesquisa... p. 338.
} 
militantes mais combativos - provavelmente abrangidos pelas subcategorias dos denunciados e indiciados", de acordo com Reis Filho ${ }^{573}$. Os demais grupos abrangem um "universo mais amplo de todos os que participaram de alguma forma no processo",574, onde se inserem pessoas que testemunharam ou prestaram declarações - nas fases policial ou judicial, ou, ainda, em ambas - nos processos promovidos contra componentes das diversas organizações que vieram a ser alvo dos serviços de repressão do Regime Autoritário brasileiro pós-64.

Com relação aos denunciados, Reis Filho faz toda a análise que realiza em seus trabalhos ${ }^{575}$ com base no Projeto "Brasil: Nunca Mais" a partir do número absoluto contido no quadro acima, de 7.367 pessoas. Marcelo Ridenti realiza suas pesquisas a partir de dois dados: o primeiro que leva em consideração a advertência feita pelo PBNM: "Nos 695 processos pesquisados mediante emprego de computador eletrônico foi possível somar 7.367 nomes de cidadãos denunciados perante a Justiça Militar brasileira", e que uma determinada porcentagem "deste montante aparece de forma repetida, visto que se refere a cidadãos acusados em mais de uma ação penal" ${ }^{, 576}$. Após fazer a exclusão dos nomes repetidos em processos de uma mesma organização, Ridenti ${ }^{577}$ chega a um total de 4.124 denunciados pertencentes às diversas organizações de esquerda no Brasil, que foram processados judicialmente nos anos das décadas de 1960 e 1970. Não obstante utilizar esta contagem, o autor retorna ao total de 7.367 pessoas denunciadas, para lidar com este dado em várias passagens de suas obras ${ }^{578}$.

Neste trabalho, contudo, não iremos nos ater exclusivamente a nenhum desses números totalizadores, visto que com relação aos militantes da Ala Vermelha processados no Estado de São Paulo, o Projeto "Brasil: Nunca Mais" computa 64 pessoas que vieram a ser denunciadas nos três processos instalados contra a organização neste Estado, e 13 indivíduos que vieram a ser indiciados na fase policial. Além desses militantes, o Projeto apresenta ainda uma única testemunha e 27 declarantes, segundo a representação gráfica abaixo.

\footnotetext{
${ }^{573}$ REIS FILHO, Daniel Aarão. A revolução faltou... p. 161.

${ }^{574}$ Idem, p. 161.

${ }^{575}$ Cf. REIS FILHO, Daniel Aarão. As organizações comunistas... Volume 02, p. 614 e ss.; A revolução faltou... p. 160 e ss.

${ }^{576}$ PROJETO “BRASIL: NUNCA MAIS". Perfil dos Atingidos... p. 1.

577 RIDENTI, Marcelo, op. cit., p 204-205.

${ }^{578} \mathrm{O}$ autor se utiliza do número de denunciados do BNM, como sendo de 7.365 para fundamentar outros dados estatísticos. "119 oficiais entre 7.365 denunciados judicialmente (...) "Nos dados gerais do BNM, aparecem 88 'religiosos', correspondentes a 1,2\% do total de 7.365 denunciados pelo regime militar'. RIDENTI, Marcelo., op. cit., p. 150 - 151.
} 


Quadro 2 - Situação da Ala Vermelha nos processos de São Paulo - quanto
ao volume da população atingida, conforme os resultados
\begin{tabular}{|l|l|l|l|}
\hline SITUAÇÃO & BNM 294 & BNM 436 & BNM 602 \\
\hline Denunciados & 59 & 3 & 2 \\
\hline Indiciados & 9 & 4 & - \\
\hline Testemunhas & 1 & - & - \\
\hline Declarantes & 21 & 1 & 5 \\
\hline
\end{tabular}

Por uma questão de análise processual o primeiro levantamento de dados que efetuamos neste trabalho se encontra na etapa preliminar do inquérito policial em que é feita uma leitura do número de indiciados nos três processos que fazem parte de nossa delimitação.

\subsection{Indiciados - Resultados obtidos}

A pesquisa que realizamos alcançou um resultado diferenciado da soma apresentada pelo Projeto "Brasil: Nunca Mais" para essa fase do inquérito relativa ao número de indiciados, como se pode constatar dos quadros abaixo.

\begin{tabular}{|c|c|c|c|}
\hline \multicolumn{4}{|c|}{ Quadro 3 - Pesquisa "Brasil: Nunca Mais" } \\
\hline SITUAÇÃO & BNM 294 & BNM 436 & BNM 602 \\
\hline Indiciados & 9 & 4 & - \\
\hline
\end{tabular}

\begin{tabular}{|c|c|c|c|}
\hline \multicolumn{4}{|c|}{ Quadro 4 - Pesquisa PAV-SP/tads ${ }^{581}$} \\
\hline SITUAÇÃO & BNM 294 & BNM 436 & BNM 602 \\
\hline Indiciados & 65 & 7 & 2 \\
\hline
\end{tabular}

A desconformidade entre os dados que pesquisamos e os resultados atingidos pela PBNM não encontra sua razão de ser na Pesquisa "Brasil: Nunca Mais", que não fornece qualquer indicação de como chegou a tais números, mas apenas apresenta-os, através do quadro reproduzido acima.

Na pesquisa que realizamos partimos da compreensão de que na noção de indiciado situa-se qualquer pessoa que venha a ser alvo de um inquérito policial, segundo o

\footnotetext{
${ }^{579}$ PROJETO “BRASIL: NUNCA MAIS”. A pesquisa... p. 329; 332; 335.

${ }^{580}$ PROJETO “BRASIL: NUNCA MAIS”. A pesquisa... p. 329-335.

${ }^{581}$ A sigla corresponde a: Processos da Ala Vermelha em São Paulo/Tadeu Antônio Dix Silva.

${ }^{582}$ BNM 294, BNM 436 e BNM 602.
} 
entendimento convergente dos juristas. Para que alguém venha a ser considerado indiciado não se exige que a autoridade policial ou militar venha a fazer um ato especial denominado “indiciamento”. O Código de Processo Penal Militar e o Código de Processo Penal comum não fazem qualquer menção ao "ato de indiciamento", e, portanto, entende-se ser suficiente que um delegado inicie contra este indivíduo um inquérito policial para que venha a ocorrer o indiciamento. Em síntese, o indiciado nada mais é do que o "pretenso autor de um crime". 583

Ao investigar sobre um delito, o delegado pode vir a deparar com um suspeito de haver cometido o crime. Havendo indícios ${ }^{584}$ razoáveis que apontam esta determinada pessoa como autora do delito em questão, deverá ela ser indiciada. Aqui não se fala em prova cabal e irrefutável de ser o indivíduo quem cometeu o crime, mesmo porque o inquérito não é um processo ${ }^{585}$, não possui o efeito de condenar ninguém, mas apenas um procedimento destinado a fornecer ao Ministério Público o mínimo de elementos necessários ao oferecimento da denúncia.

Embora não seja regra, normalmente o indiciamento ocorre quando do interrogatório do indiciado, ocasião em que acontece a sua qualificação, ou seja, quando se cita seu nome, filiação, naturalidade, etc., e outras qualidades físicas e sociais que possam auxiliar na sua identificação, como profissão, alcunha, defeitos corporais, sinais visíveis ${ }^{586}$ e assim por diante. O delegado ordenará, nessas circunstâncias, que o suspeito seja identificado, através da colheita de informações sobre sua vida, conduta social, e todos os demais meios necessários a um completo reconhecimento de sua pessoa - inclusive por meio processo de obtenção de impressões digitais, na época dos processos $\mathrm{BNM}^{587}$.

Caso o suspeito não se encontre presente, se não for localizado por estar foragido ou outros motivos que impossibilitem determinar seu paradeiro, será procedida ao denominado indiciamento indireto ${ }^{588}$, quando é feita a colheita de dados de fontes diversas as quais o delegado possa recorrer, como as informações sobre a pessoa suspeita contidas

\footnotetext{
583 TOURINHO FILHO, Fernando da Costa. Prática de Processo Penal. São Paulo: Saraiva, 2002, p. 3.

$584 \mathrm{O}$ termo indiciado encontra suas origens na derivação do vocábulo latino indicium, e significa juridicamente, "uma demonstração provisória e antecipada sobre uma realidade que se quer provar". Por isso é que se diz que o inquérito tem caráter provisório, uma vez que para que o indício seja elevado à categoria de prova, é necessário que passe pela investigação que é levada a cabo no inquérito policial. Cf. BOAS, Marco Antonio Vilas. Processo Penal. Saraiva: São Paulo, 2001, p. 140.

${ }^{585}$ BOSCHI, José Antonio Paganella. Persecução Penal. Rio de Janeiro: Aide, 1987, p. 102.

${ }^{586}$ MIRABETE, Julio Fabbrini. Processo Penal. São Paulo: Atlas, 2001, p. 89.

${ }^{587}$ Atualmente a Constituição Federal aboliu a identificação datiloscópica daqueles que já são identificados civilmente através de certidão de identidade. Cf. art. 5., inciso LVII da C. F. Ver: BRASIL. Constituição (1988) Constituição da República Federativa do Brasil. São Paulo: Saraiva: 2006.

${ }^{588}$ GRECO FILHO, Vicente. Manual de Processo Penal. Saraiva: São Paulo: 1999, p. 95.
} 
em um outro inquérito ou processo ao qual este indivíduo foi submetido, colher dados sobre ele através de familiares, local onde eventualmente tenha trabalhado, estudado, e outros meios que venham a possibilitar não apenas o indiciamento, mas também a qualificação indireta desta pessoa, sem a qual não pode ser iniciado um processo ${ }^{589}$ na Justiça Comum contra ela. Ressaltamos, contudo, que o mesmo não ocorre no âmbito da Justiça Militar ${ }^{590}$, onde correram os processos instaurados para julgamento de crimes contra a segurança nacional.

Apesar desta regra da Justiça castrense, os delegados, certamente habituados com o ritual da Justiça comum, faziam o indiciamento e qualificação indiretos das pessoas que não logravam deter. Um exemplo deste proceder é a qualificação indireta e conseqüente indiciamento de Devanir José de Carvalho ${ }^{591}$, realizados pelo Departamento de Ordem Política e Social, em 23 de outubro de 1969. Devanir somente viria a ser detido pelos órgãos de repressão quando já estava sendo processado - em abril de 1971, ocasião em que foi morto ${ }^{592}$ pelos agentes dos mecanismos repressivos do Regime.

Em síntese, é possível afirmar-se que existia a preocupação dos agentes da repressão em formalizar os seus atos, o que na fase do inquérito, significava em observar

\footnotetext{
${ }^{589}$ Em razão do art. 41 do Código de Processo Penal que diz que a qualificação é elemento indispensável na denúncia feita pelo Ministério Público. Cf., neste sentido, TOURINHO FILHO, Fernando da Costa. Prática..., cit., p. 9.

${ }^{590}$ Segundo o art. 70 do Código de Processo Penal Militar, "A impossibilidade de identificação do acusado com o seu verdadeiro nome ou outros qualificativos não retardará o processo, quando certa sua identidade física. A qualquer tempo, no curso do processo ou da execução da sentença, far-se-á a retificação, por termo, nos autos, sem prejuízo da validade dos atos precedentes". Ver: BRASIL. Código de Processo Penal Militar. São Paulo: Sugestões Literárias, 1970.

${ }^{591} \operatorname{Ver}$ BNM 294, $1^{\circ}$. Volume, fls. 386. Notamos que se emprega a abreviatura fls. para dar-se a referência, ao invés de utilizarmos a abreviação " $p$.". Isto ocorre porque um processo é composto de folhas e não páginas; assim, ao mencionarmos um texto que se econtra, p.ex., na terceira folha de um processo, empregase a abreviatura $f l s .2$ e não $f l s$. 3. Isto porque, consistindo-se de folhas, o processo apresenta a seguinte sequiência: folha 1 , folha 1 verso, folha 2 , follha 2 verso, etc. Portanto, para se referir a uma citação que foi feita no verso da primeira folha de um processo, utiliza-se a seguinte abreviação: fls. 1-v.

592 O militante da ALN Carlos Eugênio Paz narra que Devanir José de Carvalho, o "Henrique", após seu desligamento da Ala Vermelha, em 1969, foi "dirigente máximo do Movimento Revolucionário Tiradentes (MRT), organização revolucionária paulista de extrema combatividade. Valente, solidário, um líder nato, que sempre atuou no sentido da unidade da esquerda armada. Teve atuação importante na Frente Armada que formavam, em 1970, (...) a ALN (...) o MRT (...) a VPR (...) o MR-8 (...) e o PCBR. Como represália à sua morte, a ALN e o MRT justiçaram, em 15 de abril de 1971, Henning Albert Boilensen, presidente da Ultragás, financiador da repressão política e instrutor de torturas". Cf. PAZ, Carlos Eugênio, Viagem..., cit., p. 219. Ivan Seixas esclareceu detalhes sobre a morte de Devanir, afirmando que quando foi preso juntamente com seu pai, Joaquim Alencar Seixas - também dirigente do MRT, os carcereiros lhe contaram que, após a sua prisão, Devanir "mesmo ferido, fora torturado durante dois dias, respondendo apenas seu nome e o da sua organização, xingando e cuspindo sangue na cara de [Sérgio Paranhos] Fleury. Morreu no pau, como prometera o delegado". Fleury "já dissera várias vezes aos irmãos de Devanir que estavam presos: Avisem o Henrique que encomendei nos Estados Unidos um bastão tranqüilizante para poder pegá-lo vivo, e que serei eu, pessoalmente, que o matarei no pau" - segundo registram Nilmário Miranda e Carlos Tibúrcio. Para o depoimento de Ivan Seixas e a alusão às palavras de Fleury, cf. MIRANDA, Nilmário de; TIBÚRCIO, Carlos, op. cit., p. 225-226.
} 
todos os procedimentos formais, entre os quais se situava o indiciamento do acusado como se o cumprimento rigoroso de uma regra fosse capaz de retirar o caráter arbitrário que habitualmente revestia a investigação e prisão de uma pessoa responsabilizada pela prática de um crime contra a segurança nacional.

A partir desta perspectiva é que efetuamos nossa pesquisa, não saindo à busca de um documento específico denominado "auto de indiciamento" ou outro congênere que estivesse contido nos autos do inquérito policial, mas partimos da própria noção do ato de indiciar alguém descrito acima. Assim, consideramos, num primeiro momento, que a mera instauração de um inquérito policial contra determinada pessoa ou pessoas já era mostra suficiente de seu indiciamento. Não obstante esta constatação, cuidamos ainda de buscar nos autos do inquérito referências formais que indicassem que a pessoa estava indiciada, o que normalmente encontramos no relatório final do delegado, destinado ao Ministério Público. Além desses registros formalizados, nos deparamos com diversas alusões igualmente feitas no corpo documental dos inquéritos ao fato de certo indivíduo estar indiciado, contidas em pedidos de prisão preventiva e outros apontamentos efetivados pelo encarregado do inquérito.

Tomando por base esta compreensão se constatou que no BNM 294, um primeiro relatório inicia enumerando 16 “indiciados",593, e no final o delegado afirma: "Após a leitura dos autos, somos obrigados, diante dos fatos e crimes estarrecedores praticados pelos indiciados (...)"594 a pedir a prisão preventiva dos mesmos.

Outro relatório principia do mesmo modo quando são listados e qualificados como "Indiciados"595 28 pessoas, das quais 11 sofreram indiciamento indireto. No final novamente o delegado afirma: "Indiciados para os quais se requer a prisão preventiva"596.

O último relatório obedece ao mesmo padrão, com o termo "Indiciados"597 no início seguido dos nomes de 29 pessoas. Há nos relatórios vários registros da terminologia "indiciado", como mostra o seguinte exemplo: "Diante das provas existentes contra os indiciados(...) $)^{, 598}$.

O total apurado nos relatórios constantes do BNM 294, assim, perfaz um total de 73 pessoas. Todavia, Élio Cabral foi indiciado nos três relatórios. Derly José de Carvalho, Gilberto Giovanetti, Nobue Ishii, e Misael Pereira dos Santos vieram a ser indiciados no

\footnotetext{
${ }^{593}$ BNM 294, $3^{\text {o. }}$. Volume, fls. 598-599.

${ }^{594}$ Idem, $3^{\circ}$. Volume, fls. 603.

${ }^{595}$ BNM 294, $7^{\circ}$. Volume, fls. 1460-1461.

${ }^{596}$ Idem, $7^{\circ}$. Volume, fls. 1471.

${ }^{597}$ Ibidem, $9^{\circ}$ Volume, fls. 2355-2356.

${ }^{598}$ Ibidem, $9^{\circ}$ Volume, fls. 2371.
} 
primeiro e no segundo relatório. Antônio Carlos Lopes Granado e Antônio Fernando Bueno Marcelo foram indiciados no segundo e no terceiro relatórios. Portanto, ao se excluir as pessoas que foram indiciadas mais de uma vez, chegamos ao número final de 65 indiciados, contrariamente aos nove computados na Pesquisa "Brasil: Nunca Mais".

\section{Quadro 5 - Relação alfabética dos indiciados ${ }^{599}$ no processo BMN 294}

1. Aderval Alves Coqueiro (598)

2. Alípio Raimundo Viana Freire (1461)

3. Antônio Caldas Brito (2358)

4. Antônio Carlos Lopes Granado (1456)

5. Antônio Fernando Bueno Marcelo (1464)

6. Antônio Neiva Moreira Netto (2458)

7. Aristides da Silva Souza (2358)

8. $\quad$ Bernardino Ribeiro Figueiredo (1464)

9. Carlos Yoshikazu Takaoka (1460)

10. César Eduardo Moreira Cerqueira (2356)

11. Cid Barbosa Lima Júnior (1462)

12. Cleuzer de Barros (2359)

13. Daniel José de Carvalho (598)

14. Derly José de Carvalho (598)

15. Devanir Jose de Carvalho (603)

16. Diniz Gomes Cabral Filho (1464)

17. Durval de Lara Filho (1462)

18. Edson Hilário de Freitas (2358)

19. Élio Cabral de Souza (599)

20. Felipe José Lindoso (2357)

21. Flávio Antunes Júnior (1464)

22. Genésio Borges de Melo (598)

23. Geraldo Virgílio Godoy (2357)

24. Gilberto Giovanetti (1463)

25. Jair Stoch (2358)

26. Jairo José de Carvalho (598)

27. João Amorim Coutinho (2359)

28. Joel José de Carvalho (598)

29. Jorge Kurban Abraão (2355)

30. José Anselmo da Silva (603)

31. José Couto Leal (603)

32. José Ely Savóia da Veiga (603)

33. José Fernando dos Santos (2359)

34. José Gonçalo Nogueira (2358)

35. José Miguel (2358)

36. José Roberto Michelazzo (2356)

\footnotetext{
${ }^{599}$ O número entre parêntesis na frente do nome indica uma das folhas do auto do processo BNM 294 que fazem referência ao indiciamento desta pessoa.
} 
37. Júlio Cézar Senra Barros (2356)

38. Lais Furtado Tapajós (1461)

39. Lenos Veríssimo de Souza (2453)

40. Letácio Barbosa de Lima (2357)

41. Lincoln Cordeiro Oest (603)

42. Lucy Tanus Jorge (2355)

43. Luiz Antônio Maciel (1461)

44. Márcia Nely Bernardes (2359)

45. Márcio Gonçalves Bentes de Souza (2359)

46. Margarida Maria do Amaral Lopes (1460)

47. Melchiades Antônio Cervo (2356)

48. Miriam Bottassi (1440)

49. Misael Pereira dos Santos (1460)

50. Nadir Helú (2355)

51. Ney Jansen Ferreira Júnior (970)

52. Nobue Ishii (603)

53. Norimar de Andrade Gomez Roig (1463)

54. Osvaldo Bernardino da Silva (2356)

55. Paulo de Tarso Gianini (2357)

56. Paulo Frateschi (1462)

57. Renato Carvalho Tapajós (2357)

58. Sérgio Francisco dos Santos (1461)

59. Sérgio Massaro (598)

60. Severo de Luca Crudo (2355)

61. Tânia Maria Mendes (2359)

62. Vicente Eduardo Gomes Roig (1460)

63. Waldemar Andreo (2360)

64. William João Bittar (1462)

65. Wilson Palhares (1461)

No segundo processo contra os militantes da Ala Vermelha, o BNM 436, o relatório final do delegado apresenta a mesma fórmula empregada no BNM 294, com o termo "Indiciados" $" 600$ escrito no início, seguindo-se a qualificação de sete pessoas. Constam ainda outras menções dessas pessoas haverem sido indiciadas, como, por exemplo: “(...) com solicitação da prisão preventiva para os indiciados" Computamos, assim, neste processo um total de sete pessoas indiciadas, contra quatro registradas na Pesquisa "Brasil: Nunca Mais".

\footnotetext{
${ }^{600}$ BNM 436, fls. 53.
}

${ }^{601}$ Idem, fls. 54. 


\section{Quadro 6 - Relação alfabética dos indiciados no processo BMN 436}

1. Deniol Katsuki Tanaka (fls. 53)

2. Flávio Diniz Fontes (fls. 53)

3. Jarbas Teobaldo dos Santos (fls. 53)

4. João Carlos Antunes Lacaz (fls. 53)

5. José Gaspar Ferraz de Campos (fls. 53)

6. Josebel Rubin de Toledo (fls. 53)

7. Paulo Sérgio Paraíso Cavalcante (fls. 53)

No último processo instaurado contra a Ala Vermelha no Estado de São Paulo, o BNM 602, há dois relatórios. No primeiro existe somente uma referência à falsificação de documentos atribuída à Maria Cristina Uslenghi Rizzi ${ }^{602}$. No segundo relatório, que tem o subtítulo "aditamento", consta a "Qualificação dos indiciados" dados pessoais de Maria Cristina e Tarzan de Castro. Há igualmente no BNM 602 outras menções a situação de indiciados dos réus, como por exemplo: “apesar da indiciada Maria Cristina (...) procurar dificultar a ação policial com evasivas (...)"604. Deste modo, apontamos um número de dois indiciados no inquérito policial, número este que difere do constante na Pesquisa "Brasil: Nunca Mais", a qual não apresenta nenhuma pessoa como indiciada.

\section{Quadro 7 - Relação alfabética dos indiciados no processo BMN 602}

1. Maria Cristina Uslenghi Rizzi (fls. 156)

2. Tarzan de Castro (fls. 156)

Os dados divergentes encontrados por nossa pesquisa com os resultados apresentados pelo Projeto "Brasil: Nunca Mais", não permite que se façam outras análises comparativas entre o corpus documental dos processos BNM, no que diz respeito às considerações que tenham por base o número de indiciados.

Passamos, assim, ao exame dos dados da Pesquisa "Brasil: Nunca Mais" referentes às pessoas que foram denunciadas.

\footnotetext{
${ }^{602}$ Ibidem, fls. 61-62.

${ }^{603}$ BNM 602, fls. 156.

${ }^{604}$ Idem, fls. 157.
} 


\subsection{Denunciados - Resultados obtidos}

Com relação às pessoas denunciadas a pesquisa que efetuamos atingiu um cômputo que se harmoniza com o total apresentado pela Pesquisa "Brasil: Nunca Mais", o que se verifica do exame dos quadros abaixo.

\begin{tabular}{|l|l|l|l|}
\multicolumn{4}{c}{ Quadro 8 - Pesquisa "Brasil: Nunca Mais" } \\
\hline SITUAÇÃO & BNM 294 & BNM 436 & BNM 602 \\
\hline Denunciados & 59 & 3 & 2 \\
\hline
\end{tabular}

\begin{tabular}{|l|l|l|l|}
\cline { 2 - 4 } \multicolumn{1}{c|}{} & Quadro 9-PAV-SP/tads & \\
\hline SITUAÇÃO & BNM 294 & BNM 436 & BNM 602 \\
\hline Denunciados & 59 & 3 & 2 \\
\hline
\end{tabular}

$\mathrm{Na}$ pesquisa que realizamos pudemos constatar que o procurador do Ministério Público deixou de oferecer denúncia contra sete pessoas que estavam indiciadas no BNM 294. Opinou o procurador que quatro delas ${ }^{607}$ - Cid Barbosa Lima Júnior, Durval de Lara Filho, Lais Furtado Tapajós e Margarida Maria do Amaral Lopes não teriam qualquer "participação (...) nos atos da organização"608. Já Paulo Frateschi não foi denunciado porque apesar de haver sido "aliciado pelo menor Nelson Brissac Peixoto, não se ligou à Ala Vermelha, não praticando qualquer ato terrorista". 609 Finalmente o procurador não denunciou William João Bittar pois apesar de também “aliciado por Nelson Brissac, não aceitou as idéias do mesmo, não havendo assim participado também de nenhuma ação"610.

Deste modo, o número de denunciados apontado pela pesquisa que se efetuou no processo BNM 294 aponta um cômputo de 59 pessoas denunciadas.

\footnotetext{
${ }^{605}$ PROJETO “BRASIL: NUNCA MAIS”. A pesquisa... p. 329-335.

${ }^{606}$ BNM 294, BNM 436 e BNM 602.

${ }^{607}$ BNM 294, $7^{\circ}$. Volume, fls. 1513-1514.

${ }^{608}$ Idem, fls. 1513.

${ }^{609}$ Ibidem, fls. 1513.

${ }^{610}$ Ibidem, fls. 1513.
} 
No processo BNM 436, o procurador deixou de oferecer denúncia contra quatro das sete pessoas que haviam sido indiciadas. Assim, Deniol Katsuki Tanaka, Flávio Diniz Fontes, Josebel Rubin de Toledo e José Gaspar Ferraz de Campos não viriam a ser processados. Contudo, o membro do Ministério Público não veio a dar qualquer fundamentação para sua atitude, não existindo nos autos do processo nenhuma ponderação que indique as razões porque assim agiu. De qualquer forma, o número total de denunciados no BNM 436, assim, é de três pessoas ${ }^{611}$.

No processo BNM 602 o Ministério Público denunciou ambos os indiciados ${ }^{612}$, considerando que Tarzan de Castro, "vindo do Uruguai (...) permaneceu em São Paulo fazendo contatos com companheiros de subversão e aguardando o momento de ir ao Nordeste [para] abrir novas frentes da 'Ala",613. Segundo o procurador do MP, Maria Cristina entrou no Brasil com Tarzan de Castro, estabeleceu residência em Guarulhos, e, em momento posterior "transferiu-se para Pernambuco onde [foi] presa"614, acusada de ajudá-lo na tarefa de organizar a Ala Vermelha nos Estados nordestinos.

A sincronia dos números de pessoas denunciadas computados pela Pesquisa "Brasil: Nunca Mais" e os propiciados por nosso exame dos processos, permite que se oriente o trabalho para a investigação acerca dos dados da Ala Vermelha no Estado de São Paulo. Estabelecido, deste modo, o vínculo entre a Pesquisa "Brasil: Nunca Mais" e este pesquisador, torna-se possível uma comparação entre a caracterização geral dos atingidos efetuada pelo PBNM e a individualização das pessoas pertencentes à Ala Vermelha que vieram a ser alcançadas pelos órgãos de repressão na categoria de denunciados.

Quadro 10 - Situação da Ala Vermelha nos processos de São Paulo
\begin{tabular}{|l|l|l|l|l|}
\hline Sexo & quanto ao sexo & BNM 602 & TOTAL \\
\hline Masculino & 53 & 3 & 1 & 57 \\
\hline Feminino & 6 & - & 1 & 7 \\
\hline
\end{tabular}

O quadro 10 mostra um padrão similar com as demais organizações de esquerda analisadas pelo Projeto $\mathrm{BNM}^{615}$, em que $88 \%{ }^{616}$ dos denunciados pertencem ao sexo

\footnotetext{
${ }^{611}$ BNM 436, fls. 1-A e 36.

612 BNM 602, fls. 1-A e 200.

${ }^{613}$ Idem, fls. 200.

${ }^{614}$ Ibidem, fls. 1-A.

${ }^{615}$ Notamos que a investigação do Projeto "Brasil: Nunca Mais" trabalhou neste quadro e nos relativos à faixa etária, e grau de instrução, com um universo mais ampliado, que compreendia não apenas os denunciados, mas igualmente abrangia os indiciados, declarantes e testemunhas. Cf. PROJETO "BRASIL: NUNCA MAIS". A Pesquisa... p. 339, 340 e 345, respectivamente. Pretende-se examinar igualmente os cômputos relativos somente aos denunciados constantes da Pesquisa "Brasil: Nunca Mais", que se encontram disponíveis no
} 
masculino e $12 \%$ ao sexo feminino. O resultado obtido nos três processos da Ala Vermelha indica que $89,1 \%$ eram do sexo masculino e $10,9 \%$ do feminino.

O envolvimento da mulher nos processos judiciais aponta, deste modo, para uma participação minoritária em relação à população masculina atingida. Marcelo Ridenti ${ }^{617}$ faz sua análise deste percentual afirmando que:

"Pode parecer pouco, mas não tanto, se forem levados em conta alguns elementos. Em primeiro lugar, as mulheres ocupavam posições submissas na política e na sociedade brasileira, pelo menos até o final dos anos 60. A norma era a nãoparticipação das mulheres na política, exceto para reafirmar seus lugares de 'mãesesposas-donas-de-casa', como ocorreu com os movimentos femininos que apoiaram o golpe militar de 1964. (...) Em segundo lugar, a opção dos grupos guerrilheiros implicava uma luta militar que, pelas suas características, tendia a afastar a integração feminina, pois, historicamente sempre foi mais difícil converter mulheres em soldados".

Quadro 11 - Situação da Ala Vermelha nos processos de São Paulo quanto à idade
\begin{tabular}{|l|l|l|l|l|}
\hline FAIXA ETÁRIA & BNM 294 & BNM 436 & BNM 602 & TOTAL \\
\hline $19-21$ & 6 & - & & 6 \\
\hline $22-25$ & 26 & 1 & 1 & 28 \\
\hline $26-30$ & 15 & 2 & & 17 \\
\hline $31-35$ & 8 & & 1 & 9 \\
\hline $36-40$ & 3 & & & 3 \\
\hline Acima de 60 & 1 & & & 1 \\
\hline
\end{tabular}

Com relação à idade dos indiciados nos três processos, 9,4\%possuíam idade inferior a 22 anos; $43,7 \%$, ou seja, 28 pessoas estavam localizadas na faixa de 22 a 25 anos; $26,6 \%$ com idade superior a 25 anos e igual ou inferior a 30 anos; 20,3\% com idade igual e superior a 30 anos.

\footnotetext{
“Quadro 99: relação alfabética dos denunciados". Cf. PROJETO "BRASIL: NUNCA MAIS”. Os Atingidos. Projeto “A”- Tomo II, Volume 2. São Paulo: Arquidiocese de São Paulo, 1985, p. 1-140. Entretanto, como tal relação contém 7.367 nomes, muitos dos quais aparecem repetidos, almejamos elaborar uma listagem excluindo as pessoas que aparecem mais de uma vez, para podermos efetuar, posteriormente, os quadros relativos ao sexo, faixa etária, grau de instrução e profissão somente dos denunciados, para incluí-los também em nossa análise. ${ }^{616}$ Efetuou-se em todos os cálculos percentuais deste trabalho a aproximação na casa decimal.

${ }^{617}$ RIDENTI, Marcelo., op. cit., p. 198.
} 
Daniel Aarão Reis Filho ${ }^{618}$ apresenta uma nova abordagem analítica para a população atingida distribuída por faixa etária no BNM relativo ao universo de pessoas envolvidas nos processos da Justiça Militar, em que: "São relacionadas 17.240 pessoas. Abstraindo-se 2.178, sobre as quais não há dados (12,5\%), trabalhamos com um conjunto de 15.242 envolvidos (87,5\%). Reagrupamos os dados em três faixas: até 25 anos, até 30 anos e mais de 30 anos". O resultado obtido foi de 39,5\% até 25 anos, $58,2 \%$ até 30 anos e 41,8\% para aqueles com mais de 30 anos. A soma desses resultados se traduz em $139,5 \%$. Este equívoco foi também conferido junto à sua tese de doutorado ${ }^{619}$, quando, ao adotar o quadro 27 do $\mathrm{BNM}^{620}$, o pesquisador realiza a somatória dos atingidos até 25 anos e agrega ao valor encontrado (5.993 pessoas), a parcela correspondente à faixa etária de 26 até 30 anos (2.881), o que tem como resultado o número de 8.874 atingidos. $\mathrm{O}$ quadro do $\mathrm{BNM}$ aponta para esta mesma faixa etária, 2.881 atingidos, e este é o número que deve ser considerado Assim, encontramos o percentual de 18,90\%, ao invés de 58,2\% localizados por Reis Filho.

Marcelo Ridenti ${ }^{621}$ em sua análise por faixa etária das organizações de esquerda, que a Ala Vermelha, dentro dos dez processos existentes contra ela no PBNM, possuía $59,9 \%$ de militantes com idade de até 25 anos, 33,3\% para os compreendidos na faixa de 26 aos 35 anos e de $6,8 \%$ para quem possuía 36 anos ou mais.

O perfil dos integrantes da Ala Vermelha apresenta uma concentração entre os jovens com idade inferior ou igual aos 25 anos $(58,7 \%)$, de forma superior e destacada ao perfil apresentado pelo resultado do $\mathrm{BNM}(38,9 \%)$ para a mesma faixa etária, o mesmo podendo dizer com relação aos números analisados por Reis Filho, que computa $39,5 \%$ para a população dentro desta margem de idade.

Neste conjunto os padrões sugerem que as características etárias dos integrantes da Ala Vermelha em São Paulo se concentram nos jovens, pois os demais militantes mais velhos correspondem a 20,3\% das pessoas envolvidas nos processos analisados.

\footnotetext{
${ }^{618}$ REIS FILHO, Daniel Aarão, A Revolução... p. 165-166.

${ }^{619}$ REIS FILHO, Daniel Aarão, As Organizações Comunistas... Vol. 02, p. 637-A.

${ }^{620} \mathrm{O}$ quadro 27 trata da caracterização geral da população atingida por faixa etária (denunciados + indiciados + testemunhas + declarantes). PROJETO "BRASIL: NUNCA MAIS". A Pesquisa... p. 340.

${ }^{621}$ RIDENTI, Marcelo, op. cit., p. 123.
} 
Quadro 12 - Situação da Ala Vermelha nos processos de São Paulo quanto à naturalidade

\begin{tabular}{|c|c|c|c|c|c|}
\hline UF & Naturalidade & BNM 294 & BNM 436 & BNM 602 & TOTAL \\
\hline AM & Capital & 2 & & & 2 \\
\hline \multirow[t]{2}{*}{$\mathrm{BA}$} & Capital & 1 & & & 3 \\
\hline & Interior & 2 & & & \\
\hline \multirow[t]{2}{*}{ ES } & Capital & 2 & & & 5 \\
\hline & Interior & 3 & & & \\
\hline \multirow[t]{2}{*}{ GO } & Capital & 1 & & & 2 \\
\hline & Interior & 1 & & & \\
\hline \multirow[t]{2}{*}{ MG } & Capital & 2 & & & 13 \\
\hline & Interior & 10 & 1 & & \\
\hline MT & Interior & 1 & & 1 & 2 \\
\hline $\mathrm{PA}$ & Capital & 2 & & & 2 \\
\hline \multirow[t]{2}{*}{$\mathrm{PE}$} & Capital & 2 & & & 4 \\
\hline & Interior & 2 & & & \\
\hline PI & Interior & 1 & & & 1 \\
\hline PR & Capital & 1 & & & 1 \\
\hline RJ & Capital & 3 & & & 3 \\
\hline $\mathrm{RS}$ & Interior & 3 & & & 3 \\
\hline \multirow[t]{3}{*}{ SP } & Capital & 10 & 1 & & 20 \\
\hline & $\begin{array}{l}\text { Cidade da Grande } \\
\mathrm{SP}^{622}\end{array}$ & 1 & & & \\
\hline & Interior & 8 & & & \\
\hline Exterior $^{623}$ & & 1 & & 1 & 2 \\
\hline $\begin{array}{l}\text { Não } \\
\text { consta }^{624}\end{array}$ & & & 1 & & 1 \\
\hline
\end{tabular}

A interpretação dos dados referentes ao local de nascimento revela uma alta concentração em São Paulo (com 20 militantes), seguido do Estado de Minas Gerais (somando 13 membros da Ala Vermelha). Juntos, estes dois Estados acumulam 51,56\% do total dos envolvidos nos processos pesquisados.

Dentro da análise realizada por Daniel Aarão Reis Filho, o quadro do BNM para a população atingida por naturalidade entre indiciados, testemunhas e declarantes, e do universo de denunciados - que compõem um segundo quadro -, "mostra um índice crescente de concentração. Mais de um terço dos denunciados estão no eixo Rio de Janeiro-São Paulo" ${ }^{625}$ Sua conclusão, assim, diverge com relação aos números computados por nossa pesquisa dos

${ }^{622}$ Consideramos o nascimento de um denunciado, ocorrido em Santo André, como sendo de cidade pertencente à Grande São Paulo. Adotamos para a unidade de federação - São Paulo uma contagem diferenciada e distribuída por capital, grande São Paulo e interior. Isto se justifica inicialmente pela proximidade existente entre tais municípios, que levariam inicialmente à noção de Grande São Paulo. Posteriormente, ocorreu praticamente a unificação da capital com as outras cidades que se viriam formar a complexa Região Metropolitana de São Paulo. ${ }_{223}^{6}$ No processo BNM 294, um dos atingidos nasceu na Espanha e no BNM 602, a ré nasceu em Montevidéu. ${ }^{624}$ Não foi possível determinar a naturalidade de um dos réus do BNM 436, por falta de dados.

${ }^{625}$ REIS FILHO, Daniel Aarão. A revolução... p. 162 
processos instaurados em São Paulo contra a Ala Vermelha, na qual a concentração ocorre, de modo patente, no eixo São Paulo-Minas Gerais.

Com base nos dados examinados, pode-se ainda verificar que $42,2 \%$ da pessoas denunciadas nasceram nas capitais, sendo que 17,2\% na cidade de São Paulo e as restantes (25\%) distribuídas pelas demais capitais de outras unidades federativas. Os militantes provenientes do interior somam 53,1\% dos indivíduos envolvidos nos processos, sendo que a maior concentração se encontra no Estado de Minas Gerais, com 17,2\% de pessoas interioranas.

Dentro da caracterização geral dos denunciados por naturalidade, a distribuição geográfica apontada pela $\mathrm{PBNM}^{626}$ revela uma maior concentração em São Paulo - com 6,38\% nascidos na capital e Grande São Paulo e 13,49\% no interior -, seguido pelo Estado de Minas Gerais, que aponta para 2,85\% para os naturais da capital e 13,39\% para os do interior; na seqüência figura o Estado do Rio de Janeiro, com 10,15\% das pessoas nascidas capital e $4,05 \%$ no interior.

\section{Quadro 13 - Situação da Ala Vermelha nos processos de São Paulo - população atingida por local de residência}

\begin{tabular}{|c|c|c|c|c|c|}
\hline UF & Residência & BNM 294 & BNM 436 & BNM 602 & TOTAL \\
\hline ES & Capital & 5 & & & 5 \\
\hline $\mathrm{PE}$ & Capital & & & 2 & 2 \\
\hline $\mathrm{RJ}$ & Capital & & 2 & & 2 \\
\hline \multirow[t]{2}{*}{$\mathrm{RS}$} & Capital & 3 & & & 4 \\
\hline & Interior & 1 & & & \\
\hline \multirow[t]{3}{*}{ SP } & Capital & 34 & & & 49 \\
\hline & $\begin{array}{ll}\text { Cidades } & \text { da } \\
\text { Grande SP } & \end{array}$ & 2 & & & \\
\hline & Interior & 13 & & & \\
\hline Não consa ${ }^{628}$ & & 2 & & & 2 \\
\hline
\end{tabular}

A análise propiciada pela Pesquisa "Brasil: Nunca Mais" sobre a população atingida segundo o local de residência, é determinante no sentido de conhecer o ambiente no qual os envolvidos desenvolviam sua atuação política, onde efetivamente exerciam suas atividades de militantes, e constituem, portanto, um dos indicadores

\footnotetext{
${ }^{626}$ A pesquisa do BNM computou 7.367 denunciados dos quais foram excluídos os que nasceram no exterior (181) e os que não fizeram contar a naturalidade (1.782). Trabalhamos, deste modo, com um universo de 5.404 denunciados.

${ }^{627}$ Consideramos cidades da Grande São Paulo, os municípios de Santo André e São Bernardo do Campo, onde residiam alguns dos denunciados.

${ }^{628}$ No processo BNM 294 não existe registro referente ao local de moradia de dois denunciados.
} 
"mais significativos para a avaliação do perfil da militância”. ${ }^{629}$ Nesse sentido, o quadro 13 é revelador, ao demonstrar a existência de uma significativa concentração na capital paulista e nas cidades integrantes da grande São Paulo, perfazendo um total de $72,6 \%$, soma esta que se aproxima de $3 / 4$ do total de pessoas envolvidas nos processos analisados.

De outro prisma, a comparação entre os quadros referentes à naturalidade dos denunciados e o do local de sua residência, permite divisar a importância da migração das pessoas envolvidas nos processos de luta uma vez que a capital paulista e as cidades da grande São Paulo foram alvo de intensa movimentação migratória por parte de militantes nascidos em diversas regiões do Brasil. Esta constatação ocorre ao compararmos o número total de denunciados nascidos em São Paulo - 17,2\% - com a somatória alcançada pelos denunciados que viviam na região da Grande São Paulo, que atinge um cômputo de 72,6\%. Este fenômeno pode ser inicialmente interpretado considerando-se que os fluxos migratórios, ocorridos nos anos 1960 e 1970, em direção àquela região, estavam diretamente relacionados à expansão do pólo industrial do $\mathrm{ABC}$, que detinha praticamente a totalidade da produção nacional de veículos e da indústria de autopeças, as quais empregavam grandes contingentes de pessoas. De outro lado, foi igualmente nos municípios situados na área compreendida pela Grande São Paulo que ocorreram a maior parte das ações armadas praticadas pelas organizações clandestinas de esquerda, o que demandou uma movimentação contínua de seus militantes do interior e mesmo de outros Estados para esta região.

A PBNM $^{630}$ aponta que a distinção entre os residentes na capital do Estado de São Paulo (16,31\%) e os que moram no interior $(9,02 \%)$ e os da capital do Estado do Rio de janeiro $(20,41 \%)$ e os do interior $(6,14 \%)$, reúnem mais da metade dos denunciados que residiam nas outras capitais $(48,12 \%)$, demonstrando a concentração existente nestes dois Estados.

\footnotetext{
${ }^{629}$ REIS FILHO, Daniel Aarão. A Revolução... p. 163.

${ }^{630}$ A pesquisa do BNM computou 7.367 denunciados dos quais foram excluídos os que nasceram no exterior (18) e os que não fizeram contar a naturalidade (1.423). Trabalhamos com um universo de 5.926 denunciados.
} 


\section{Quadro 14 - Situação da Ala Vermelha nos processos de São Paulo}

- por profissão

\begin{tabular}{|l|l|l|l|l|}
\hline Profissão & BNM 294 & BNM 436 & BNM 602 & TOTAL \\
\hline Advogado & & 1 & & 1 \\
\hline Artesão & 3 & & 1 & 4 \\
\hline Bancário & 4 & & & 4 \\
\hline Comerciante & 1 & & & 1 \\
\hline Comerciário & 3 & & & 3 \\
\hline Contabilista & 1 & & & 1 \\
\hline Corretor & 1 & & & 1 \\
\hline Economista & 1 & 1 & & 1 \\
\hline Estudante & 9 & & & 10 \\
\hline Estudante/Desenhista & 1 & & & 1 \\
\hline Engenheiro & 1 & & & 1 \\
\hline Funcionário Público & 3 & & 3 \\
\hline Jornalista & 5 & & & 5 \\
\hline Jornalista/Desenhista & 1 & & & 1 \\
\hline Motorista & 1 & & & 1 \\
\hline Operário & 9 & & & 9 \\
\hline Pesquisador Mercado & 1 & & & 1 \\
\hline Prendas Domésticas & 1 & & & 1 \\
\hline Professor & 4 & & & 4 \\
\hline Professor/Estudante & 4 & & & \\
\hline Publicitário & 2 & & & 2 \\
\hline Secretária & 1 & & & 2 \\
\hline Serviços gerais & 1 & & & 1 \\
\hline Nada consta & 1 & & & \\
\hline
\end{tabular}

Em nosso exame deixamos à margem a reunião de profissões em quatro grupos (trabalhadores intelectuais, trabalhadores manuais, técnicos de média qualificação e indefinidos), que visa especificamente avaliar a participação das elites sociais intelectualizadas nas organizações de esquerda ${ }^{631}$. Procuramos, assim, manter as profissões caracterizadas individualmente, atendendo à metodologia adotada pelo PBNM - o indivíduo como unidade de análise -, visando continuar respondendo à indagação formulada por Maria Aparecida de Aquino: “Afinal, quem eram” esses militantes? ${ }^{632}$

\footnotetext{
${ }^{631}$ Este é o método adotado por Reis Filho em sua análise. Cf. REIS FILHO, Daniel Aarão. A Revolução... p.150-151.

${ }^{632}$ AQUINO, Maria Aparecida de. Caminhos cruzados... p. 241.
} 
O único agrupamento que realizamos foi na categoria operário, quando unimos as diversas especializações que formam as atividades do trabalhador na produção industrial na referida categoria ${ }^{633}$.

A relação dos denunciados da Ala Vermelha nos processos analisados revela o conjunto de estudantes como o maior grupo, correspondente a $24,1 \%$. Se considerarmos apenas os militantes que declararam ser somente estudantes, esse percentual cai para 16,1\%. Todavia, com a adição daqueles que se pronunciaram como estudante/desenhista, os dados sobem para $17,7 \%$, e chegam ao total de $24,1 \%$ com a inclusão das pessoas que disseram ser professor/estudante . Não obstante possuir a categoria estudantes como o maior de seus conjuntos por ocupação profissional, a Ala Vermelha é uma das "duas organizações armadas (...) [que] têm número de estudantes inferior à média de 30\%",634, encontrada por Ridenti nos grupos de esquerda armados.

No cômputo dos dados da Ala Vermelha, os operários ocupam uma segunda posição de forma bastante significativa, correspondendo a 14,5\% dos denunciados, ficando pouco abaixo do conjunto de estudantes em si considerado, que atinge um porcentual apenas 1,6\% maior do que o alcançado pelos operários. Os professores ${ }^{635}$ representam 6,5\%, mas ao considerarmos a situação de professor/estudante, esta porcentagem sobe para $13 \%$. Uma outra observação fica em torno dos jornalistas, que alcançam $8,1 \%$ de um total de 62 denunciados com profissão conhecida, mas chegam a $9,7 \%$ ao considerarmos o caso específico de um militante que declarou ser jornalista/desenhista.

As outras profissões conservam as suas participações em 45,2\%, distribuídos em bancários e artesãos (12,9\%); comerciários, funcionários públicos (9,7\%); publicitários e secretárias (6,5\%); advogado, comerciante, contabilista, corretor, economista, engenheiro, motorista, pesquisador de mercado, prendas domésticas e serviços gerais $(16,1 \%)$.

\footnotetext{
${ }^{633}$ São compreendidos na categoria operários os trabalhadores da produção industrial em geral, cujas profissões declaradas foram: torneiros mecânico, mecânico de fábrica, gráfico, montador, mecanógrafo, abastecedor de confecção de pneus.

${ }^{634}$ Como já se ressaltou, Ridenti trabalha com a totalidade dos processos instaurados contra a Ala Vermelha no Brasil, e sua pesquisa, chega ao número de 17,5\% de estudantes. A outra organização referida na citação é a VPR, que apresentava, segundo o autor, um dado de $19,7 \%$ de estudantes entre seus militantes. Cf. RIDENTI, Marcelo, op. cit., p. 117.

${ }^{635}$ Cabe a observação que entre os atingidos na categoria professores, duas das pessoas denunciadas pertenciam ao sexo feminino. Para Marcelo Ridenti em todos os processos sofridos pela Ala Vermelha no país, o número total de professoras que foram processadas judicialmente, nos anos 1960 e 1970, é de oito. Cf. RIDENTI, Marcelo, op. cit., p. 205.
} 
Quadro 15 - Situação da Ala Vermelha nos processos de São Paulo por grau de instrução

\begin{tabular}{|l|l|l|l|l|}
\hline Grau de Instrução & BNM 294 & BNM 436 & BNM 602 & TOTAL \\
\hline Analfabeto & 1 & & & 1 \\
\hline Primário incompleto & 1 & & & 1 \\
\hline Primário & 8 & & & 8 \\
\hline Secundário incompleto & 1 & & & 1 \\
\hline Secundário & 3 & & 3 \\
\hline Colegial incompleto & 3 & & & 3 \\
\hline Colegial & 9 & & 9 \\
\hline Universitário incompleto & 15 & 1 & & 16 \\
\hline Universitário & 9 & 1 & & 10 \\
\hline Nada consta & 9 & 1 & 2 & 12 \\
\hline
\end{tabular}

Para medir o grau de instrução a Pesquisa "Brasil: Nunca Mais" adota uma escala "que compreende os seguintes níveis: analfabeto, primário incompleto, primário, secundário, colegial, universitário incompleto, universitário, escola profissional, escola militar" ${ }^{\prime 636}$. Completando o quadro de resultados apresentado pelo BNM, acrescentamos para análise o secundário incompleto e o colegial incompleto, por representarem as particularidades dos integrantes da Ala Vermelham nos processos analisados. ${ }^{637}$

De um universo de 52 denunciados ${ }^{638}$, o diagnóstico mostra que os atingidos pela repressão são pessoas de variados níveis de escolaridade, mas que faz mais vítimas entre pessoas com mais estudo. $\mathrm{O}$ resultado observado aponta que entre aqueles que informaram a escolaridade, temos os seguintes graus de instrução: analfabetos, 1,9\%; primário incompleto, $1,9 \%$; primário completo, $15,4 \%$; secundário incompleto, $1,9 \%$; secundário completo, 5,8\%; colegial incompleto, 5,8\%; colegial completo, 17,3\%.

Os números computados revelam que afora o percentual de $1,9 \%$ de analfabetos, 17,3\% dos denunciados em processos contra a Ala Vermelha, possuíam o ciclo primário - completo ou não. Os detentores do nível secundário somavam apenas 7,7\% dos militantes processados, enquanto que os que alcançaram o colegial atingiam $23,1 \%$ dos denunciados - compreendidos em ambos os casos cursos terminados ou inconclusos. Considerando estes últimos dados como nível médio, este percentual sobe

\footnotetext{
${ }^{636}$ PROJETO "BRASIL: NUNCA MAIS". A Pesquisa... p. 14.

${ }^{637}$ O Projeto Brasil: Nunca Mais em sua caracterização geral da população atingida por grau de instrução não faz referência ao secundário incompleto e nem ao colegial incompleto. Nas análises dos processos BNM 294, BNM 436 e BNM 602, optou-se pela literalidade destas informações.

${ }^{638}$ No BNM 294 não foi possível constar o grau de instrução para nove dos denunciados e no BNM 436, nada consta sobre uma pessoa. No BNM 602, não há quaisquer informações referentes ao grau de instrução dos denunciados.
} 
para 30,8\% - significando que praticamente 1/3 da composição da Ala Vermelha era formada pelos então denominados estudantes "secundaristas" - em se atendo apenas ao grau de instrução.

Observamos com relação ao grau universitário, os denunciados apresentavam um índice de 30,8\% de pessoas que não haviam completado a universidade, enquanto que 19,2\% já eram diplomados, o que apresenta um total e 50\% de envolvidos que possuíam instrução universitária, completa ou não.

Desta maneira, pode-se concluir que entre os militantes da Ala Vermelha denunciados há uma presença maior de pessoas com nível médio e superior, que totalizam um cômputo de $80,8 \%$.

\begin{tabular}{|c|c|c|c|c|}
\hline \multicolumn{5}{|c|}{ Quadro 16 - Situação da Ala Vermelha nos processos de São Paulo - quanto ao } \\
\hline \multicolumn{5}{|c|}{\begin{tabular}{|l|l|} 
& estado civil \\
\end{tabular}} \\
\hline Estado Civil & BNM 294 & BNM 436 & BNM 602 & TOTAL \\
\hline Casados & 19 & & & 19 \\
\hline Solteiros & 37 & 3 & 1 & 41 \\
\hline Desquitados/Divorciados ${ }^{639}$ & & & 1 & 1 \\
\hline Nada consta ${ }^{640}$ & 3 & & & 3 \\
\hline
\end{tabular}

O quadro 16 não faz parte dos resultados oferecidos pela Pesquisa "Brasil: Nunca Mais". Com base nos autos dos processos pesquisados foi possível elaborar o perfil dos denunciados com relação ao estado civil.

Pela análise $31,66 \%$ já eram casados quando foram atingidos pela repressão, enquanto que $64,1 \%$ permaneciam sem contrair matrimônio. O número maior de solteiros justifica-se pelas características dos integrantes da Ala Vermelha que mostram uma concentração acentuada entre os jovens com idade inferior ou igual aos 30 anos, a qual atinge 79,7\% dos militantes processados judicialmente. Por outro ângulo, é de salientar a mentalidade imperante no seio da esquerda, de um modo geral, mais propícia ao estabelecimento de união entre casais sem a necessidade de contrair casamento, como conseqüência das próprias idéias libertárias que possuía. Além disso temos de considerar também a própria vivência dos militantes das organizações de luta armada que os conduzia quase sempre à clandestinidade total ou parcial, bem como o deslocar rápido e contínuo desses indivíduos para outros locais no Brasil ou mesmo no exterior, o que, em sua somatória, se não impedia, tornava difícil um relacionamento amoroso duradouro por parte de uma pessoa dedicada às atividades de guerrilha urbana.

\footnotetext{
${ }^{639}$ A ré do processo BNM 502 era divorciada em seu país de origem, o Uruguai.

${ }^{640}$ Não foi possível encontrar-se referências na Pesquisa "Brasil: Nunca Mais" ao estado civil de três acusados no processo BNM 294.
} 


\title{
III - CODA - Autocrítica
}

\author{
A coda é a seção conclusiva de uma composição, \\ um prolongamento que serve para facilitar \\ a entrada da resposta da outra voz, \\ que entra em uníssono \\ no começo da melodia ${ }^{641}$.
}

Na prisão Renato Tapajós, Vicente Roig, Alípio Freire e Carlos Takaoka entabularam as primeiras discussões, depois do período de tortura, as quais eram no sentido de tentar salvar a organização e os mecanismos da Ala Vermelha referentes à luta armada. Passado poucos meses, ainda durante 1969, este conjunto de companheiros mudou o enfoque de suas conversas. Agora elas caminhariam "no sentido de perceber que havia algo errado" com a prática que a AV levava a cabo" ${ }^{, 642}$ - não obstante a autocrítica realizada pelo documento "Os 16 Pontos", lançada em novembro de 1969. Derly José de Carvalho, dirigente nacional que estava também preso, adere então ao agrupamento, por partilhar das mesmas preocupações ${ }^{643}$.

Em janeiro de 1970, quando Diniz Cabral é preso, o grupo ficou sabendo que este debate que acontecia entre eles, igualmente ocorria na Ala Vermelha em geral. Como recorda Renato Tapajós, "a gente sabia que o Diniz era uma das cabeças dessa discussão que propunha o refluxo e a ida para o trabalho de massa" ${ }^{\prime 64}$.

Nesta época o grupo já havia elaborado um esboço autocrítico da atuação prática da Ala Vermelha, especialmente com relação à luta armada, com a participação de Renato Tapajós, Carlos Takaoka, Alípio Freire e Vicente Roig. Derly de Carvalho também havia tomado parte na elaboração desta primeiro texto, quando Diniz foi preso e também se juntou ao grupo. Considerando que Derly foi banido do território nacional em janeiro de 1971, e Élio Cabral é preso no final deste mesmo mês e na prisão também veio a fazer parte do agrupamento que confeccionava o pensamento autocrítico, o conjunto de pessoas que cuidou da elaboração da "Autocrítica" durante os anos subseqüentes, até sua divulgação em janeiro de 1974, foi composto por Diniz Cabral, Élio Cabral, Renato Tapajós, Carlos Takaoka, Alípio Freire e Vicente Roig.

\footnotetext{
${ }^{641}$ SINZIG, Frei Pedro, cit., p. 32.

${ }^{642}$ TAPAJÓS, R. C. Renato Carvalho Tapajós: depoimento [nov. 2006]. Entrevistador: T. A. D. Silva. Campinas, 2006. CD 1, faixa 2.

${ }^{643}$ ROIG, V. E. Vicente Eduardo Roig: depoimento [nov. 2006]. Entrevistador: T. A. D. Silva. Valinhos, 2006. CD 1, faixa 1.

${ }^{644}$ TAPAJÓS, R. C. Renato Carvalho Tapajós: depoimento... CD 1, faixa 2.
} 
O documento de Autocrítica foi trazido sete anos após o surgimento da Ala Vermelha enquanto organização independente, como "produto de um processo de retificação ideológica" 645 pelo qual a $\mathrm{AV}$ passou. Consistia "parte integrante desse processo, e ponto de partida para seu aprofundamento e de outro modo não se poderá jamais entender seu verdadeiro sentido e significado" $" 646$.

A Ala Vermelha não pretendia esgotar apenas neste documento todas as questões "colocadas pela revolução" ${ }^{647}$, mas ao contrário: visando a seriedade dos assuntos tratados, procurava abandonar a " "tradição enciclopédica"” da esquerda brasileira.

Notava o documento da $\mathrm{AV}$ que as preocupações e debates que deram origem ao mesmo haviam se inaugurado em 1969 "como resultado do refluxo do movimento revolucionário que se acentua a partir de $1968^{\prime \prime 648}$. As respostas colocadas pela luta de classes naquele momento — como a cessação dos movimentos de massa da pequena burguesia coroando o cenário de desmobilização geral das classes atingidas pelo golpe militar de 1964 e nosso isolamento de qualquer setor social — eram o fundamento que impeliria a Ala à rediscussão das concepções que até então defendia e tentava aplicar à realidade. A intensidade e profundidade dos golpes de repressão que a AV experimentou, "tornaram ainda mais evidente a existência de práticas e concepções errôneas, acentuando a necessidade de suas reformulações"

Para a Ala Vermelha, todavia, não se tratava de apenas constatar os erros, nem de tão somente assumir e proclamar tais erros, "em termos de um 'mea culpa". Tratava-se de localizar os erros, identificar suas causas mais profundas e apontar o caminho para a superação - "o que só é possível quando já se constrói um novo corpo de concepções, no próprio processo de descoberta dos erros" ${ }^{\$ 650}$. Para alcançar estes objetivo a Ala considerava imprescindível que a crítica e a autocrítica fossem "precedidas pela firme decisão de levar avante a revolução, e pelo estudo do marxismo-leninismo" $"$ "551.

Embora o objeto central do trabalho fosse a análise dos erros e desvios da $\mathrm{AV}$, o documento indicava também aqueles mais sérios que atingiram "(e ainda atingem $)$ " toda a esquerda - "na medida em que nossa prática não se constitui (nem se constitui) isolada de outras correntes de pensamento" Centralizando a atenção do estudo nestes aspectos, não se preocupava a Ala Vermelha em destacar acertos, mesmo porque se tratava de autocrítica de uma organização "e não de um balanço geral do movimento". Para o documento de Autocrítica (Doc. Autocr.) ficava implícito o reconhecimento dos esforços, das tentativas de acertar, do custo "em sofrimentos e vidas que tornaram possível o movimento sobreviver e mesmo amadurecer até o ponto em que é possível empreender sua retificação ideológica", os quais tornaram possível a própria existência de Ala Vermelha e criaram condições para que esta organização pudesse esta sua autocrítica. Entretanto, salientava o Doc. Autocr. que ainda não havia chegado o momento de se prestar

${ }^{645}$ PARTIDO COMUNISTA DO BRASIL - ALA VERMELHA. Autocrítica. 1967-1973. [S. 1.], jan., 1974. Coleção particular Daniel Aarão Reis Filho. SÉRIE: Ala Vermelha. Dossiê 05, doc. 150. Arquivo Público do Estado do Rio de Janeiro. Paginação irregular.

${ }^{646}$ PARTIDO COMUNISTA DO BRASIL - ALA VERMELHA. Autocrítica, cit., paginação irregular.

${ }^{647}$ PARTIDO COMUNISTA DO BRASIL — ALA VERMELHA. Autocrítica, cit., paginação irregular.

${ }^{648}$ PARTIDO COMUNISTA DO BRASIL — ALA VERMELHA. Autocrítica, cit., paginação irregular.

${ }^{649}$ PARTIDO COMUNISTA DO BRASIL — ALA VERMELHA. Autocrítica, cit., paginação irregular.

${ }^{650}$ PARTIDO COMUNISTA DO BRASIL - ALA VERMELHA. Autocrítica, cit., paginação irregular.

${ }^{651}$ PARTIDO COMUNISTA DO BRASIL - ALA VERMELHA. Autocrítica, cit., paginação irregular.

${ }^{652}$ PARTIDO COMUNISTA DO BRASIL — ALA VERMELHA. Autocrítica, cit., paginação irregular. 
homenagem aos que tombaram, porque "ainda vivemos um período em que todas as forças se devem dirigir para o reerguimento do movimento, lançando-o no caminho correto da revolução feita pelas massas" $" 653$.

Após estes breves apontamentos introdutórios o documento de Autocrítica adentra na análise do movimento revolucionário no Brasil, que seria caracterizado pela "desorganização da classe operária e das massas, pela inexistência de um partido político revolucionário do proletariado, pelo desmantelamento das organizações e partidos de esquerda", e, conseqüentemente, por um "profundo refluxo da luta revolucionária" ${ }^{, 654}$.

Nesse quadro geral a Ala Vermelha se situava como sendo uma "corrente revolucionária" que além de haver sofrido profundos golpes, não "conseguiu cumprir as tarefas de educar e organizar as massas", não tendo construído ainda os instrumentos que possibilitariam a superação do impasse com o qual se defronta o processo revolucionário brasileiro ${ }^{65}$.

Segundo o Doc. Autocrítica esta situação seria decorrente da existência de "erros e desvios na orientação da atividade revolucionária". Para superar este impasse era necessário localizar cuidadosa e precisamente tais erros e desvios cometidos, investigando suas causas e analisando a situação onde foram gerados, com o propósito de se criar meios eficazes para corrigi-los. Para cumprir estes objetivos entendia a Autocrítica que era "imprescindivel que toda a esquerda organizada assuma a atitude de fazer a autocrítica de seus erros". A Ala Vermelha - como parte desta esquerda organizada - entendia como "tarefa inadiável" reconhecer seus próprios erros, analisar suas causas e discutir os meios que pudessem corrigi-los — o que se propunha a fazer no Doc. Autocrítica.

A Ala Vermelha salientava que a autocrítica não consistia em uma elaboração histórica do partido desde seu surgimento, compreendendo que os dados históricos que necessariamente devem figurar num procedimento autocrítico seriam os essenciais para a análise do conjunto de erros e desvios e da própria prática efetivada pela $\mathrm{AV}$, de modo a buscar as circunstâncias que os originaram.

Em seguida o Doc. Autocrítica salienta que todo o processo revolucionário brasileiro - no qual se integra a Ala Vermelha - foi realizado fundamentalmente pela pequena burguesia ${ }^{656}$ numa realidade em que não existia qualquer movimento da classe operária. Desta maneira o processo revolucionário caiu em um "revolucionarismo ou radicalismo pequeno-burguês" que se traduziria no "voluntarismo e imediatismo" 657.

Os desvios e erros da Ala eram manifestados tanto em suas concepções quanto em sua prática. As concepções fundamentais da AV estavam sintetizadas no Documento de Crítica ${ }^{658}$ enquanto que os aspectos táticos estavam formulados no documento "Organizar um Partido de Novo Tipo em função da Luta Armada $(\text { OPNTEFLA })^{659}$.

\footnotetext{
${ }^{653}$ PARTIDO COMUNISTA DO BRASIL — ALA VERMELHA. Autocrítica, cit., paginação irregular.

${ }^{654}$ PARTIDO COMUNISTA DO BRASIL — ALA VERMELHA. Autocrítica, cit., p. 1.

${ }^{655}$ PARTIDO COMUNISTA DO BRASIL - ALA VERMELHA. Autocrítica, cit., p. 1.

${ }^{656}$ PARTIDO COMUNISTA DO BRASIL - ALA VERMELHA. Autocrítica, cit., p. 2.

${ }^{657}$ PARTIDO COMUNISTA DO BRASIL - ALA VERMELHA. Autocrítica, cit., p. 2.

${ }^{658}$ Cf. PARTIDO COMUNISTA DO BRASIL - ALA VERMELHA.Crítica ao oportunismo e subjetivismo da 'União dos Brasileiros para Livrar o País da Crise, da Ditadura e da Ameaça Neocolonialista, cit.

${ }^{659}$ Cf. PARTIDO COMUNISTA DO BRASIL - ALA VERMELHA. COMITÊ REGIONAL DE SÃO PAULO. Organizar um Partido de Novo Tipo em função da Luta Armada. [S. 1.], mar. 1968. Coleção particular Daniel Aarão Reis Filho. SÉRIE: Ala Vermelha. Dossiê 05, doc. 91, Arquivo Público do Estado do Rio de Janeiro.
} 
Na Ala Vermelha, No P(AV), o voluntarismo e imediatismo irão assumir a forma particular de "uma prática vanguardista". A AV surgida desde seu início desligada das massas, particularmente da classe operaria, não se construiu na luta de classes concreta ${ }^{660} \mathrm{e}$ organizada "quase que exclusivamente elementos provenientes da pequena burguesia" - sobretudo no meio estudantil, "vanguardista por sua incapacidade de ligar-se às massas". Assim, as manifestações mais evidentes dos desvios da Ala seriam: "o desligamento das massas e a prática vanguardista" ${ }^{, 661}$.

Entendemos por vanguardismo a substituição da ação revolucionária das massas pela ação de agrupamentos, partidos, organizações ou indivíduos. Isto é, a atividade vanguardista se realiza em nome e em lugar das massas, deixando-as sem consciência de seu papel revolucionário e sem orientação política conseqüente. Os que se desviem para o vanguardismo, se deformam por não conhecerem as necessidades e interesses das massas e por não compreenderem as exigências políticas e ideológicas do luta de classes. No processo revolucionário brasileiro em seu período recente, o vanquardismo teve sua expressão mais desenvolvida no "esquerdismo" militarista, isto é, na substituição da ação revolucionária das massas pele ação armada de pequenos grupos. $\mathrm{O} \mathrm{P}(\mathrm{AV})$ também incorreu no desvio vanguardista expresso particularmente em sua forma militarista, embora não tenha sido esta a única forma de expressão daquele desvio. Como se ver no curso desta autocrítica, o vanguardismo se manifestou também em diversas outras atividades do $\mathrm{P}(\mathrm{AV})$, uma vez que encontrava fundamento teórico em concepções voluntaristas formuladas em sua linha política.

Desta maneira a Ala Vermelha, sem conseguir laços com as massas que realizam a revolução, "sem educá-las para ação revolucionária, desprovido do instrumental teórico marxista-leninista e realizando atividades práticas isoladas das massas", não representou, como pretendeu, "o papel de destacamento de vanguarda da classe operária" - em razão do "radicalismo pequeno-burguês", que levou a Ala a erros e $\operatorname{desvios}^{662}$.

Desde o seu surgimento, a Ala Vermelha assumiu a posição de ter o marxismo-leninismo como sua teoria, de defender a necessidade do partido do proletariado, a necessidade de um programa, de definições estratégicas e táticas, e de adotar a via armada para a conquista do poder. Entretanto, diz o Doc. Autocrítica, tendo em vista a não assimilação do "conteúdo ideológico proletário que deve se expressar nessas questões", determinou que a compreensão, elaboração e aplicação destas proposições "resultassem deformadas". Tanto não se compreendeu o verdadeiro conteúdo da ideologia proletária que, embora a questão ideológica fosse agitada intensamente em todos os momentos da atividade da Ala, era vista mais como " $a$ 'disponibilidade' para a luta revolucionária, como uma 'ética' e uma 'moral' de comportamento do militante, que como uma concepção científica que corresponde à visão de mundo da classe operária”. É assim que se vai aceitar dentro da AV como "bom nível ideológico" do militante, sua disposição para realizar eficazmente tarefas práticas, sua capacidade de trabalho e dedicação - bem como atitudes de aparente modéstia. O que não se compreendia dentro da Ala era que comportamentos como os mencionado poderiam também ser "posturas assumidas a partir do 'radicalismo' pequeno-burguês" ${ }^{\prime 663}$.

\footnotetext{
${ }^{660} \mathrm{O}$ Doc. Autocrítica entendia por luta de classes concreta, "a luta dos que estão ligados diretamente à produção". Cf. PARTIDO COMUNISTA DO BRASIL - ALA VERMELHA. Autocrítica, cit., p. 4.

${ }^{661}$ Cf. PARTIDO COMUNISTA DO BRASIL - ALA VERMELHA. Autocrítica, cit., p. 3.

${ }^{662}$ PARTIDO COMUNISTA DO BRASIL - ALA VERMELHA. Autocrítica, cit., p. 4.

${ }^{663}$ PARTIDO COMUNISTA DO BRASIL - ALA VERMELHA. Autocrítica, cit., p. 5.
} 
O Doc. Autocrítica afirma que a correta compreensão da questão ideológica parte do "entendimento científico do papel histórico da classe operaria em todo o processo de lutas nas sociedades de classes, até a eliminação destas". As atitudes decorrentes desse entendimento correspondem a uma radical mudança "no mundo subjetivo com a assimilação da visão proletária do mundo", e surgem como exigências necessárias da luta de classes concreta, adquiridas pela "compreensão e domínio da teoria científica do marxismoleninismo" ${ }^{\prime 64}$.

A seguir a Autocrítica passa a contemplar a questão do subjetivismo e do dogmatismo, entendendo que o primeiro ocupa o lugar que deveria ser preenchido pela "ideologia científica do proletariado", o que é determinante para surgimento do dogmatismo - entendendo p Doc. Autocrítica por dogmatismo "o esvaziamento das formulações do marxismo-leninismo de seu conteúdo científico". Resulta pois na utilização de "fórmulas vazias e secas", cujo conteúdo original (o marxismo-leninismo) foi substituído por um outro, fundamentado na ideologia não proletária prevalecente no momento - no caso da $\mathrm{AV}$, "o radicalismo pequeno-burguês". Desse modo, o dogmatismo deforma as concepções do marxismo-leninismo até, convertê-las "na negação do próprio marxismo-leninismo". O dogmatismo teria por base o subjetivismo, na medida em que as mencionadas "fórmulas vazias e secas" têm a função de dar una aparência 'científica' a conclusões cujo funda monto real não é a aplicação do método marxista, mas sim a especulação fundada na vontade". Desta maneira, as formulações do marxismo-leninismo passam a funcionar como "elementos decorativos superponíveis a qualquer estrutura do pensamento". A Ala Vermelha, ao elaborar suas formulações teóricas, embora tentasse se orientar pelo marxismo-leninismo, "dispunha apenas de um conhecimento disperso e superficial dessa ciência, e era influenciado pelo "radicalismo" pequenoburguês". Isto determinou que a AV desembocasse no dogmatismo, o que levou a que "nos ressentíssemos de uma miopia dogmática frente aos fenômeno a que se apresentaram" $" 665$.

Com relação à concepção de partido o Doc. Autocrítica assevera que um dos pontos fundamentais onde se manifesta este desvio é no da compreensão da concepção do partido da classe operária. Desde a constituição a Ala Vermelha, "mantivemos uma visão dogmática a este respeito, que consistia em partir as sua (do partido) necessidade na revolução dirigida pelo proletariado", firmando apenas, no entanto, seu papel de dirigente político, relegando a plano secundário sua função ideológica. Sem dúvida, afirma o Doc. Autocrítica, o partido que dirige o processo revolucionário é "o destacamento de vanguarda da classe operária, Estado-Maior da Revolução". A verdadeira concepção leninista enfatiza como principal seu papel ideológico "despertar, dar consciência através da ideologia científica, educar politicamente e organizar a classe operária - cuja realização consiste na fusão "da ideologia socialista com a luta de classes concreta". Desta forma, faz-se necessário que os intelectuais revolucionários "fundem-se a luta de classes concreta", a fim de levá-la àqueles que realizam objetivamente essa luta. Não basta, entretanto, admitir que a ideologia socialista e introduzida de fora para dentro da classe, mas é preciso "compreender cientificamente como isso se processa, assimilar o papel histórico que joga o proletariado na luta de classes, e imprimir a esta luta o caráter político, do um ponto de vista socialista". Somente agindo assim, o partido da classe operária estará preparado para combater o dogmatismo e qualquer desvio. De outro modo, tentar estabelecer um ponto de vista proletário simplesmente através de definições teóricas em estatutos, linha política e programa etc, "sem

\footnotetext{
${ }^{664}$ PARTIDO COMUNISTA DO BRASIL - ALA VERMELHA. Autocrítica, cit., p. 5. ${ }^{665}$ PARTIDO COMUNISTA DO BRASIL - ALA VERMELHA. Autocrítica, cit., p. 5.
} 
haver assimilado a teoria marxista-leninista aplicada à prática da luta de classes, levará a organização de qualquer partido, menos o partido de vanguarda da classe operária”. Disso decorre a compreensão errônea de que a simples existência formal de um partido que se define e proclama marxista-leninista significa que ele é o partido de vanguarda da classe operária. Para que um partido possa ser caracterizado como vanguarda de uma determinada classe, "é preciso que ela o reconheça como tal". Na Ala Vermelha a visão dogmática acerca da questão do partido se expressava formalmente quando "nos definimos como 'embrião do partido da classe operária' (conforme o documento OPNTEFLA) ou 'como parte revolucionária do partido da classe operária' (Conforme nosso projeto de estatuto de novembro de 1969)". Estas afirmações pretendiam imprimir, por definição formal, o caráter ideológico proletário a uma organização que não reunia condições — ideológicas, políticas e orgânicas — necessárias para se caracterizar enquanto tal. O dogmatismo da $\mathrm{AV}$ deve ao fato de que embora "defendêssemos a necessidade do partido, compreendêssemos seu papel dirigente, reconhecêssemos sua inexistência no nosso país, não dominávamos os processos de sua correta construção". Para corrigir esse desvio, adotando uma visão não dogmática e consentânea com a real situação da revolução em nosso país, a Ala Vermelha "se define hoje como urna organização partidária leninista que se guia pelo marxismo-leninismo, e que luta pela construção do partido da classe operária "

O Doc. Autocrítica enfoca também aborda a questão da elaboração do programa, da estratégia a e da tática da revolução brasileira, que assume ter sido "dogmaticamente vista por nós". A Autocrítica entendia ser correto o entendimento de que o partido da classe operária, para sua atividade revolucionária, necessita ter definidos claramente seu programa, sua estratégia e sua tática. No entanto, para que seja possível dar um tratamento científico a estas definições, é imprescindível "o correto domínio da teoria - e conseqüentemente do método - marxista-leninista e com base nela, conhecer a realidade social em que se atua". Seria preciso ainda que o partido - assimilado o papel histórico da classe operária - "esteja presente na luta de classes concreta, compreendendo, participando e intervindo em cada um de seus momentos". Participando desta forma na luta de classes, que o partido vai conhecer o movimento interno das classes - "determinado por seus interesses nas condições histórico-concretas em que se encontram" - a se munir de um conhecimento rigoroso de toda a sociedade. Só à medida que for dispondo destes conhecimentos é que "o partido poderá ir articulando em programa, estratégia e tática" ${ }^{667}$.

A Autocrítica salienta que quando uma organização ou partido político, não interpreta corretamente a realidade sobre a qual pretende atuar. quando não está inserida na luta de classes concreta, "não participa conseqüentemente nem intervém em qualquer de seus momentos aparentes e portanto não conhece o movimento interno das classes". Quando, por fim, malgrado suas definições, não é em absoluto o partido da classe operária, a tentativa de elaboração acabada do programa, estratégia e tática da revolução, não passará "de um imaginoso exercício de erudição e retórica". Em outras palavras: "elaborar o programa, a estratégia e a tática de uma revolução sem dispor dos elementos que possibilitam o tratamento científico dessas questões" significa incorrer necessariamente no "subjetivismo de uma atividade de gabinete".

$\mathrm{Na}$ medida em que não se possui os meios de elaborar estas questões com base na teoria correta e na atividade prática conseqüente só resta o recurso de tentar resolvê-las manipulando "formulações genéricas do marxismo-leninismo e transpondo-se mecanicamente experiências de revoluções vitoriosas". É exatamente

\footnotetext{
${ }^{666}$ PARTIDO COMUNISTA DO BRASIL - ALA VERMELHA. Autocrítica, cit., p. 6-7.

${ }^{667}$ PARTIDO COMUNISTA DO BRASIL - ALA VERMELHA. Autocrítica, cit., p. 8.
} 
neste proceder que reside o subjetivismo e dogmatismo na elaboração do programa, da estratégia e da tática, porque "esvazia as formulações do marxismo-leninismo de seu conteúdo, destruindo suas possibilidades criadoras", e porque adota as formas assumidas por outras revoluções — que foram realizadas em condições históricas especificas —, sem levar em conta as particularidades e singularidades do próprio processo. Esta manifestação de dogmatismo é "um fenômeno geral da esquerda brasileira, onde são numerosos os programas, as estratégias e táticas revolucionárias propostos". A Ala Vermelha também incorreu nesse dogmatismo ao elaborar uma analise de classes, seu programa, sua estratégia e tática "no Documento de Crítica, e ao sistematizar pormenores dessa tática no documento OPNTFLP”. O tratamento dessas questões se deu sob a influência direta da "Revolução Chinesa mesclada com a da Revolução Cubana". Da experiência Chinesa extraiu-se não só o modelo da análise de classes, como também as formulações de guerra popular e do caminho do cerco das cidades pelo campo, onde o campesinato constitui-se no contingente principal da revolução. A experiência Cubana tem menor influência; reflete-se nas formulações táticas Ala, particularmente na proposição do foco como "detonador da guerra popular, aspecto este sobretudo desenvolvido no documento OPNTEFLA”, no qual, ao lado do foco, propõe-se a formação de toda uma estrutura voltada para a guerrilha nas cidades, o que se chamou de guerrilha urbana ("Grupos Armados Clandestinos de massa" e "Grupos Especiais do Partido”), no campo, as "Guerrilhas de Diversão",668.

A Autocrítica diz que no Documento de Crítica são utilizadas "dogmaticamente formulações genéricas sobre tática e estratégia, extraídas das obras de Mao Tsé-tung e Stalin”. Ainda que transcrevendo as definições corretas contidas nas obras desses autores marxista-leninistas, a Ala Vermelha o fez dogmaticamente porque as "aplicamos a uma realidade que desconhecíamos manipulávamos conforme nosso desejo, sem dispor dos meios que nos permitissem elaborar a tática e a estratégia”. Para que a AV não voltasse a incorrer no dogmatismo em relação estratégia, tática e programa, seria preciso ter clareza "de qual é o nível de definições que a condição atual da luta de classes permite e que ao mesmo tempo, se constitui numa exigência para seu desenvolvimento". Com base no conhecimento do marxismo-leninismo e da realidade do País, com base no grau de sua ligação com as massas e ao nível do seu trabalho concreto, a Ala deve elaborar "diretivas e consignas que orientem toda sua trajetória na atual fase da revolução brasileira". Além disso, deveria também empreender "estudos a pesquisas a respeito da realidade nacional e dos clássicos do marxismo-leninismo", com o objetivo de se capacitar para "definir corretamente as questões programáticas, estratégicas e táticas. que interessam atual etapa da revolução" ${ }^{\circ 69}$.

Na medida em que a Ala Vermelha se constituía em uma organização marxista-leninista que luta pela construção do partido revolucionário da classe operária, tem ela consciência de que "está a necessitar de um programa, uma estratégia e uma tática que unifique a prática de todos os que lutam pela revolução dirigida pelo proletariado”. Para isso, considera uma necessidade a participação de todos os marxistasleninistas "nas tarefas que conduzirão construção do partido revolucionário da classe operária e elaboração do programa da revolução brasileira, da sua estratégia e sua tática”. E, naturalmente, como organização marxista-leninista, a AV “assume para si estas tarefas" $" 670$.

O Doc. Autocrítica incursionava também na ênfase que era dada pela Ala Vermelha na questão da luta armada, dizendo que o radicalismo pequeno-burguês, "tem como uma de suas manifestações mais

\footnotetext{
${ }^{668}$ PARTIDO COMUNISTA DO BRASIL - ALA VERMELHA. Autocrítica, cit., p. 9-10.

${ }^{669}$ PARTIDO COMUNISTA DO BRASIL - ALA VERMELHA. Autocrítica, cit., p. 10.

${ }^{670}$ PARTIDO COMUNISTA DO BRASIL - ALA VERMELHA. Autocrítica, cit., p. 10-11.
} 
características a ênfase exagerada que se deu à luta armada”. Para reagir ao reformismo e à via pacífica da linha revisionista, "a grande maioria da esquerda brasileira passou a preconizar a luta armada como alternativa imediata para a tomada do poder”. No entanto, como não se compreendia o “conteúdo ideológico revisionista expresso no reformismo e como as posições críticas marcadas pelo 'radicalismo' pequeno-burguês”, a contestação foi dirigida quase que exclusivamente às formas de luta e organização, que expressavam a política de transição pacífica. Desse modo, “colocou-se unicamente a luta armada como linha divisória entre a revolução e a reforma, o marxismo o revisionismo" ${ }^{\text {671 }}$.

O Doc. Autocrítica afirma que a posição crítica correta em relação ao revisionismo e sua política “deve partir da identificação da ideologia não proletária que o caracteriza”. Isto significa "identificar a natureza de classe da base social do revisionismo", entender e fazer entender "que ele nega o marxismoleninismo porque representa "interesses contrários aos do proletariado e portanto inconciliáveis com esta teoria”. A doutrina teórica do revisionismo e sua prática têm conteúdo fundamentado "nos interesses de classe da burguesia e a aristocracia operária”. Portanto, a luta contra o revisionismo deveria ter seu fundamento na questão ideológica, na defesa intransigente do marxismo-leninismo o de seus princípios”, e, a partir disso, combater as manifestações políticas do revisionismo como o reformismo, a transação pacífica, etc. $^{672}$

Diz o Doc. Autocrítica que assim procedendo, a questão da luta armada iria se colocar em sua correta dimensão, ou seja, a da "forma de luta mais elevada que o proletariado necessita para atingir os seus objetivos de eliminação da dominação política burguesa”. Como se infere deste contexto, a verdadeira linha divisória entre revolução e reforma, marxismo e revisionismo "é a questão ideológica". Quando se coloca uma forma de luta — no caso luta armada, ou qualquer outra de suas possíveis manifestações —, como sendo "essa linha divisória, não se atinge o cerne do problema", permitindo-se que o "conteúdo ideológico no proletário permaneça em atividades pretensamente marxistas-leninistas porque baseadas na violência das armas" $" 673$.

Na medida em que foi deixada, no curso do processo dos últimos anos, que a questão da luta armada se transformasse no centro das preocupações dos revolucionários, "deu-se campo livre à exacerbação do radicalismo pequeno-burguês”. Como nesse período a esquerda estava desligada das massas, “as ações armadas de pequenos grupos isolados tentaram representar e foram aceitas como sendo a própria luta armada". No entanto, "para o marxista-leninista (operário), a luta armada revolucionária é exercício pelas massas de sua violência de classe em sua forma mais elevada”. ${ }^{674}$

Realizando ações de pequenos grupos isolados, “o 'radicalismo' pequeno-burguês ofereceu apenas urna caricatura de luta armada”. Algumas organizações voltaram-se exclusivamente para as ações armadas - "por exemplo a Ação Libertadora Nacional e a Vanguarda Popular Revolucionária —, constituindo-se como organizações puramente militares”. A Ala Vermelha, embora desse também ênfase exagerada luto armada - "possibilitando que ela se constituísse no aspecto de maior peso de sua linha política —, agregou outras questões em suas concepções sobre a revolução”. Desse modo, a AV constitui-se como uma organização política que "incorreu no desvio militarista, não chegando, entretanto, a convertermo-nos em

\footnotetext{
${ }^{671}$ PARTIDO COMUNISTA DO BRASIL - ALA VERMELHA. Autocrítica, cit., p. 11. ${ }^{672}$ PARTIDO COMUNISTA DO BRASIL - ALA VERMELHA. Autocrítica, cit., p. 11-12.

${ }^{673}$ PARTIDO COMUNISTA DO BRASIL - ALA VERMELHA. Autocrítica, cit., p. 12.

${ }^{674}$ PARTIDO COMUNISTA DO BRASIL - ALA VERMELHA. Autocrítica, cit., p. 12.
} 
uma Organização puramente militar”. Ainda assim, ao admitirmos a luta armada como única linha divisória entre "nosso revolucionarismo e o revisionismo", não criamos as condições para que travasse - e muito menos para que dirigíssemos — "uma luta ideológica conseqüente, permitindo pois que se desenvolvesse e se acentuasse em nossas fileiras o radicalismo pequeno-burguês" ${ }^{\prime 675}$.

Apenas se poderia superar este desvio se a Ala Vermelha empreendesse uma "rigorosa luta ideológica contra "as concepções não proletárias, onde quer que se manifestem (no seio do própria AV ou não), sejam elas geradas pelo revisionismo, pelo “radicalismo pequeno-burguês”. O Doc. Autocrítica entende que estas causas internas são as determinações mais importantes dos desvios, erros, visto que são "os fatores internos a qualquer fenômeno os que determinam as características e o desenvolvimento deste. Os fatores externos dão as condições para o seu desenvolvimento". Entretanto, conhecer estes fatores externos, ou seja, conhecer as circunstâncias em que surgiram os erros, analisar a situação que os originou, é parte integrante do processo de "localizar as múltiplas determinações que constituem, esses mesmo erros". Em outros termos, para podermos entender os erros da Ala Vermelha é necessário estudar que "situação presidiu seu surgimento e sua trajetória”. Não se trata de, com isso, justificar os erros; pelo contrário, "é a forma de localizá-los com maior precisão”. Por tais razões o Doc. Autocrítica passa a esboçar a situação da sociedade brasileira e do movimento revolucionário nos quais a $\mathrm{AV}$ se originou para poder realizar de forma mais sistemática e fundamentada, a crítica das "concepções errôneas contidas no Documento de Crítica"676.

A Ala Vermelha surge num momento em que o movimento revolucionário brasileiro passava por um processo de intenso debate, divergências, cisões e reagrupamentos, em que as massas do proletariado já se encontravam desorganizadas e inertes, "enquanto a pequena burguesia ainda encontrava condições para se mobilizar"; em que a crise econômica e política da sociedade, no bojo da qual ocorrera o golpe militar de 1964, ainda não se havia resolvido ${ }^{677}$.

Naquele período, a classe operária "não contava com seu partido de vanguarda”. O Partido Comunista Brasileiro, em sua longa trajetória, "não foi capaz de se transformar nesse partido de vanguarda". No período mais recente, a partir de fins da década de 50, esse partido já se "transformara definitivamente em um partido revisionista", e, como tal, em um "defensor de interesses alheios aos da classe operária”. Não obstante a importância decisiva do revisionismo no movimento comunista mundial — determinada pela "predominância desta tendência não proletária" no PCUS desde seu XX Congresso —, as causas mais profundas da "deterioração ideológica" do Partido Comunista Brasileiro "já estavam dadas pelas condições internas específicas, próprias a ele". De há muito esse partido trilhava caminhos marcados pela "influência pequeno-burguesa, oscilando entre o 'esquerdismo' de 35 e o reboquismo de 46”, num movimento pendular que nos revela "a inexistência de uma direção proletária ligada às massas" e que interpretasse corretamente a ação da sociedade e definisse um "programa, uma estratégia, uma tática justos para conduzir corretamente a classe operária a seus objetivos" ${ }^{, 678}$.

As condições para a penetração do revisionismo foram reforçadas pela "predominância na sua composição social do elemento pequeno-burguês”. Adotando o revisionismo como teoria o PCB, a partir de seu V Congresso, vê sua política “desarmar ainda mais a classe operária e as massas na luta por seus

\footnotetext{
${ }^{675}$ PARTIDO COMUNISTA DO BRASIL — ALA VERMELHA. Autocrítica, cit., p. 13. 
interesses". Já antes de 1964, a proposição de uma revolução "nacionalista" e "democrática" em aliança com a burguesia nacional, refletia "a incapacidade de analisar e interpretar corretamente a realidade brasileira", mantendo "as ilusões quanto a possibilidade de uma revolução burguesa independente" nas condições em que "predominam os interesses do grande capital imperialista". Essa proposição significava, na prática, "o abandono da concepção da hegemonia do proletariado na revolução"679.

Tal política levou à "subordinação dos interesses da classe operária aos da burguesia e manteve o PCB e o proletariado sob a influência da ideologia burguesa”. Mesmo quando pensa participar de forma decisiva no processo imediatamente anterior a 64, о PCB "não compreende o que ocorre na sociedade brasileira". Aliás, não vem a compreendê-lo nem posteriormente - como de resto toda a esquerda", inclusive a Ala Vermelha ${ }^{680}$.

Desde a entrada maciça de capitais estrangeiros no nosso país, a partir da segunda metade da década de 50, a economia brasileira caminhava rapidamente para uma "monopolização capitalista 'precoce"”. A superposição de um setor industrial avançado a uma economia ainda atrasada, em suas linhas gerais, criava tensões significativas. O setor da burguesia industrial associado ao capital estrangeiro não se interessava pela manutenção da democracia burguesia ou pelo populismo como formas de dominação política, na medida em que para o grande capital monopolista, nas condições de monopolização precoce baseada no capital estrangeiro, "servem melhor as formas abertamente autoritárias" 681.

Em contrapartida, a burguesia nacional encontrava justamente no populismo o caminho adequado a seus interesses: "não só vinha se servindo dele há perto de 3 décadas, como via em sua intensificação um instrumento para atingir ainda naquele momento seus objetivos”. As opções econômicas da burguesia nacional estavam "condicionadas estruturalmente a mercados de baixas rendas (aos quais dirigia sua produção), interessando-lhe uma expansão desses”. Quando a crise econômica se desencadeia nesse período, deixa-a as voltas com uma “crise de realização, na medida em que a inflação, corroendo os salários reais limitou a expansão de seu mercado”. Interessando-se, assim, pela inclusão das massas rurais na economia de mercado, e por elas pressionada, punha-se a favor da reforma agrária. Contra tais pretensões que se alinhavam "os setores agrárias, temerosos de qualquer medida que afetasse a estrutura da propriedade rural". Por sua vez, a grande burguesia industrial e financeira ligada ao capital imperialista "via na crise a possibilidade de impor uma solução que lhe fosse favorável”. A crise pela qual passava o capitalismo no Brasil tinha, desta vez, a peculiaridade de - ao contrário de outras pelas quais já passara anteriormente o sistema — “ser gerada pelos mecanismos internos do desenvolvimento da própria economia do país"682.

A situação levara a um acirramento da luta de classes com a participação do proletariado das classes rurais em intensas mobilizações. Entretanto, essas mobilizações se faziam dentro do "quadro limitativo do populismo", com todas as características negativas que acarretava. A classe operária não dispunha — como continua sem dispor — de “independência ideológica, política e organizativa”. Sua própria formação e as peculiaridades da revolução burguesa no Brasil determinavam essas características ${ }^{683}$.

\footnotetext{
${ }^{679}$ PARTIDO COMUNISTA DO BRASIL - ALA VERMELHA. Autocrítica, cit., p. 15.

${ }^{680}$ PARTIDO COMUNISTA DO BRASIL - ALA VERMELHA. Autocrítica, cit., p. 15.

${ }^{681}$ PARTIDO COMUNISTA DO BRASIL - ALA VERMELHA. Autocrítica, cit., p. 15.

${ }^{682}$ PARTIDO COMUNISTA DO BRASIL - ALA VERMELHA. Autocrítica, cit., p. 15-16

${ }^{683}$ PARTIDO COMUNISTA DO BRASIL - ALA VERMELHA. Autocrítica, cit., p. 16.
} 
Desde a década de 30, o Estado que representava a coalizão entre a burguesia industrial e os setores agrários, levou adiante uma política, conhecida como "populismo", que visava "não só utilizar o potencial de luta das massas para sua sustentação", como também criar "condições favoráveis a industrialização do país, favorecendo a burguesia industrial”. É nesse processo que a burguesia vai antecipar de forma paternalista a concessão de direitos trabalhistas (Consolidação das Leis do Trabalho, Salário mínimo etc.) vinculando, ao mesmo tempo, a organização dos trabalhadores ao Estado. Dessa forma, os sindicatos foram subordinados ao Ministério do Trabalho e criaram-se estruturas organizativas que retiravam da classe operária suas perspectivas de independência. Abafando as lutas espontâneas com concessões paternalistas e subordinando a organização da classe aos interesses oficiais, o fator de amortecimento político do populismo transformou o proletariado "de sujeito da ação política em simples instrumento de pressão - em função dessa fração da burguesia - marginalizando-o em relação aos centros de decisão"684.

Essas características da classe operária brasileira — dadas por sua trajetória — são de importância fundamental para "compreendermos a fragilidade de seu movimento e o baixo grau de consciência, que não chega a ser nem mesmo revisionista ou sindicalista. O Partido Comunista Brasileiro além de não compreender os processos reais pelos quais passava nossa sociedade, "tampouco compreendeu a situação da classe operária",pelo contrário, "enquadrou-se no jogo do populismo, aceitou o sindicalismo oficial, e não lutou pela independência da classe operária". Nesse sentido "é flagrante sua falência como vanguarda da classe do proletariado e sua solidarização com os interesses da burguesia" ${ }^{\text {685 }}$.

O Partido Comunista do Brasil (PC do B) vai surgir da cisão de um partido com estas características e história. Entretanto, a ruptura do PC do B com o PCB não foi a identificação dos desvios que apontamos anteriormente que levaram à luta interna; ainda que houvesse manifestações contra a "política direitista do Congresso", estas foram "tímidas e pouco significativas". As causas do rompimento foram muito mais "questões de política interna - luta pela influência e controle de postos de direção - e tiveram por base o 'radicalismo' pequeno-burguês (revisionismo). O alinhamento do PC do B ao Partido Comunista Chinês e ao Partido do Trabalho da Albânia na condenação ao revisionismo é muito mais devido "à necessidade de sobrevivência política e ao oportunismo que ao entendimento do conteúdo ideológico do revisionismo". Isto se torna mais claro se atentarmos para "a inexistência até hoje (passados 12 anos) de qualquer autocrítica dos dirigentes do PC do B com relação à sua prática anterior", e a permanência nessa organização "de métodos e estilo de trabalho vigentes no $P C B$ ". Não conseguindo em sua ruptura empolgar as bases ou setores do velho PCB, a "nova" organização se construiu "sobre militantes dispersos ou abandonados do antigo partido". As ligações operárias do PCB, ainda a mais importante e numerosa da esquerda brasileira, “não são atraídas pelos divergentes". Os poucos operários que arrebanha não são sequer ativistas sindicais, indo sua composição "primar pela presença de elementos oriundos da pequena burguesia", dispersos e desligados do movimento de massas. Assim, "logo ao se desligar do PCB, o PC do B ao invés de se vincular a luta de classes concreta, dela irá se afastar, construindo-se, pois, fora da classe operária”. Mesmo quando, antes de 1964, as condições para uma vinculação às massas eram favoráveis, "optou por uma política sectária, isolacionista e 'radical' pequeno-burguesa, baseada na pregação messiânica da luta

\footnotetext{
${ }^{684}$ PARTIDO COMUNISTA DO BRASIL - ALA VERMELHA. Autocrítica, cit., p. 16-17.

${ }^{685}$ PARTIDO COMUNISTA DO BRASIL - ALA VERMELHA. Autocrítica, cit., p. 17.
} 
armada e por tentativas delirantes de sua deflagração através de pequenos grupos agindo no campo, isolados das massas" $" 686$.

A apreciação desfavorável do Doc. Autocrítica com relação do PCB e PC do B se manifesta de forma patente na avaliação que faz dos mesmos com relação ao Golpe de 64: "a falência das políticas desses partidosse revela plenamente com o golpe de 64, e em sua incapacidade de reação no período subseqüente". Revela-se também na incapacidade de realizar a autocrítica de sua política e de oferecer perspectivas ao movimento revolucionário brasileiro" ${ }^{\circ 87}$.

A seguir a Autocrítica passa à análise do próprio Golpe de 64, assegurando que este representou um rompimento com "as formas de dominação política que se haviam desenvolvido após 1930 - redefinindo a coalizão de poder e estabelecendo uma nova hegemonia — “ e teve sua motivação "imediata na crise pela qual passava a sociedade". As contradições que já se haviam historicamente definido "são levadas peIa crise a ponto de rompimento". As massas urbanas e rurais se movimentavam pelas reformas: levadas pelo populismo e pelo revisionismo a se alinharem com os interesses da burguesia nacional — "que julgava, assim como o PCB, ainda possível completar sua revolução em condições de independência”. O acirramento da luta de classes leva "as massas mais longe do que pode pretender o populismo da burguesia nacional, $e$ esta vacila, como é de sua natureza”. Os setores agrários rompem a coalizão de poder ate então existente e "se aliam ostensivamente a grande burguesia industrial e financeira integrada ao capitalismo imperialista". Abre-se assim a oportunidade para esse setor assumir a hegemonia de um golpe que empolgaria " $a$ classe media assustada pelo ascenso de massas e terá as Forças Armadas não apenas como instrumento militar, mas também como testa-de-ferro político" ${ }^{\circ 88}$.

As Forças Armadas representam a única força organizada nacionalmente capaz de intervir — “posto que no Brasil, devido as características de sua revolução burguesa, não existe tradição organizativa das classes dominantes (nem das dominadas)" - e já estavam "ganhas ao nível de parcelas consideráveis de seus altos escalões", para a perspectiva do golpe. Ganhas tanto "ideologicamente quanto no sentido de um envolvimento com os interesses do grande capital", o que irá permitir que, nos anos seguintes, as Forças Armadas "assumam o papel de partido da classe hegemônica no poder". Evidentemente tal hegemonia "é assumida pela grande burguesia industrial e financeira integrada", uma vez que esse setor de classe "já dominava os setores dinâmicos da economia" ${ }^{689}$.

O Doc. Autocrítica diz que a vacilação da burguesia nacional (arrastando a seu reboque o PCB) permite que o golpe seja desferido sem resistência, já que as classes eram mobilizadas pelo populismo". A nova classe hegemônica afasta a burguesia nacional dos centros de decisão e "desencadeia a repressão em larga escala para se implantar e se manter, assim como a sua política econômica". Esta vai se caracterizar pelo aumento das facilidades para a entrada do capital estrangeiros, controle da inflação, submissão da classe operária à super-exploraçao de sua força de trabalho (arrocho), incentivo ã concentração de renda reforçando um mercado consumidor de elite - e tentativa de saída representada pelo incentivo à exportação de manufaturados. Tal política, "beneficiando diretamente à grande burguesia industrial e financeira abrelhe a perspectiva para um posterior crescimento acelerado da economia". Ao mesmo tempo, ela representa ainda um imediato "alijamento da burguesia nacional, uma paulatina perda de poder (e importância) dos setores agrários e, sobretudo, uma grande intensificação da exploração das massas". Sua aplicação exige

\footnotetext{
${ }^{686}$ PARTIDO COMUNISTA DO BRASIL - ALA VERMELHA. Autocrítica, cit., p. 17-18.

${ }^{687}$ PARTIDO COMUNISTA DO BRASIL - ALA VERMELHA. Autocrítica, cit., p. 17-18.

${ }^{688}$ PARTIDO COMUNISTA DO BRASIL — ALA VERMELHA. Autocrítica, cit., p. 19.

${ }^{689}$ PARTIDO COMUNISTA DO BRASIL - ALA VERMELHA. Autocrítica, cit., p. 19.
} 
um "regime ditatorial que marginaliza setores das classes dominantes e reprime violentamente todas as manifestações de oposição, dirigindo-se especialmente contra as massas" $" 690$.

A Autocrítica compreende que se as classes dominantes são atingidas pela dissolução dos partidos políticos, cassações de mandatos, perda do poder legislativo e restrições ao judiciário, "as massas, sobretudo a classe operária, vêem suas organizações implacavelmente desmanteladas". Mesmo as estruturas oficiais “criadas pelo populismo são reduzidas à inoperância”. Mais que nunca a classe operária fica "desprovida de seus instrumentos de luta, rigidamente controlada e vigiada - enquanto as massas rurais, que apenas começavam a se organizar, perdem rapidamente suas poucas e recém atingidas conquistas"691.

A política econômica “da ditadura aprofunda, num primeiro momento, a crise que originara o golpe", resultando um grande numero de falências, uma acentuada pauperização da pequena burguesia e considerável deterioração do nível de vida das massas. Isso vai criar "resistências à ditadura no seio da pequena burguesia, bem como crescente oposição por parte dos setores marginalizados das próprias classes dominantes" ${ }^{\prime 692}$.

O Doc. Autocrítica passa então a analisar a fragmentação da esquerda, após o Golpe de 64, divisando que nessa situação "de repressão e crise, de diminuição da base social da ditadura e tentativa de resistência que a esquerda começa a se fragmentar, em busca de uma saída revolucionária”. O PCB e o PC do B não ofereciam respostas ou apresentavam alternativas. Suas dissidências e lutas internas refletiam esse estado de coisas, e se manifestam e principalmente nos setores estudantis. Isso se deveu sobretudo ao fato de que, por um lado, a "ação repressiva da ditadura ainda não havia arrebentado" — àquela época —, as organizações do movimento estudantil - que, de resto, sempre haviam desfrutado de maior independência com relação ao Estado que os sindicatos "como o fizera com as do movimento operário" 693 ; por outro lado, a pequena burguesia, estudantes e intelectuais se radicalizavam principalmente pelo fato de disporem de consciência política desenvolvida. Como destaca o Doc. Autocrítica,

"Este fato é de importância fundamental para que possamos compreender corretamente a radicalização desta classe naquele momento e também entendermos a importância para as classes de possuírem elementos que, por terem acesso à cultura, são capazes de interpretar seus interesses sejam políticos, económicos ou ideológicos)" ${ }^{694}$.

Será no movimento estudantil que todas as tendências emergentes vão se confrontar no debate político. Além da derrota, "a contra-revolução que tornou clara a bancarrota da política revisionista”, as novas tendências recebem a "influência da Revolução Cubana (com sua exaltação da tomada do poder pelas armas) e das divergências sino-soviéticas”. A riqueza do debate que então só trava, está justamente no fato de se colocar na mesa questões nunca discutidas dentro dos "velhos partidos": concepção do partido, caráter da Revolução, Frente Única, programa e tática, bem como discussões colocadas pelo movimento comunista internacional. Entretanto, “o despreparo teórico elou a assimilação dogmatizada do marxismo-leninismo (que na realidade não é sua assimilação)" levou os revolucionários a aprenderem "apenas os aspectos particulares de toda a problemática colocada”. Deste modo, do debate sino-soviético absorveu-se principalmente a condenação à transição pacífica e se erigiu, na prática, "a luta armada como única linha divisória entre o revisionismo e o marxismo-leninismo". Não se chegou, assim, a compreender "a natureza ideológica do revisionismo". A dogmatização da experiência cubana, ao invés de destacar as especificidades de seu processo histórico, reduziu-as "à negação da necessidade do Partido, substituindo-o pelo foco

\footnotetext{
${ }^{690}$ PARTIDO COMUNISTA DO BRASIL - ALA VERMELHA. Autocrítica, cit., p. 20.

${ }^{691}$ PARTIDO COMUNISTA DO BRASIL - ALA VERMELHA. Autocrítica, cit., p. 20.

${ }^{692}$ PARTIDO COMUNISTA DO BRASIL - ALA VERMELHA. Autocrítica, cit., p. 21.

${ }^{693}$ PARTIDO COMUNISTA DO BRASIL - ALA VERMELHA. Autocrítica, cit., p. 21.

${ }^{694}$ PARTIDO COMUNISTA DO BRASIL - ALA VERMELHA. Autocrítica, cit., p. 21.
} 
guerrilheiro, ao mesmo tempo em que reduzia ao foco a via violenta de tomada do poder". Paralelamente, a Revolução Cultural Proletária que se desenvolvia na China neste período, foi compreendida apenas como exemplo e estímulo para "a aliança dos quadros intermediários com as bases revolucionárias na luta contra as direções esclerosadas". Todo este debate se fez em meio as intensas mobilizações de massas do movimento estudantil, no período 66-68, e no curso dessa prática que se forjam as primeiras organizações decorrentes das “lutas internas nos velhos 'partidos comunistas"'. Resultado deste processo é também a Ala Vermelha ${ }^{695}$.

Se esta situação permitiu uma aproximação com o marxismo-leninismo na busca de novos caminhos — e "é este o elemento que permitirá o salto da algumas organizações no período subseqüente à derrocada do militarismo" —, não é menos verdade que "o conteúdo ideológico radical pequeno-burguês do conjunto da esquerda exigiu a passagem imediata à prática". Sem fôlego para levar mais adiante o debate, "as novas organizações recebem de Debray a sistematização da teoria do foco". As teses foquistas marcam profundamente a maioria das organizações — algumas (como a Ação Libertadora Nacional e a Vanguarda Popular Revolucionária) "negam pura e simplesmente a necessidade do Partido de vanguarda do proletariado, substituindo-o peIa ação de pequenos grupos"; outras como a Ala Vermelha e o Movimento Revolucionário 8 de Outubro, "tentam harmonizar foco e Partido"; e há ainda, as que - como a Organização Partidária Marxista-Leninista, Política Operária e o Partido Operário Comunista — "assimilam a idéia de foco a uma orientação absolutamente contraditória a ela" ${ }^{\text {, }}$.

A seguir o Doc. Autocrítica passa a analisar o AI-5, dando inicialmente sua contextualização: a classe operária, com exceção feita a Osasco e Contagem, praticamente não é atingida pela mobilização de massas desse período; a "radicalização" da pequena burguesia que culmina com a passeata dos 100 mil define a composição das organizações que emergiam. A ideologia "radical" pequeno-burguesa se teve como matriz o desconhecimento e a não assimilação correta do marxismo-leninismo pelos revolucionários, encontrou no "movimento concreto das classes naquele momento um campo extremamente favorável para se desenvolver". A oposição dos setores das próprias classes dominantes descontentes com os rumos da ditadura, criou melhores condições para que "as manifestações da pequena-burguesia se ampliassem $e$ fortalecessem”. Os setores agrários e a burguesia nacional, com seus interesses prejudicados pela nova política econômica e "afastados dos centros de decisão à medida em que se consolidavam os interesses da grande burguesia industriais e financeira" — que detinha a hegemonia do poder político — "passam a conspirar". Contando ainda com uma parcela razoável de poder político —como alguns governos estaduais e o Congresso - , as aspirações destes descontentes vão se cristalizar na Frente Ampla, "favorecendo a que a pequena burguesia se radicalize e saia às ruas" ${ }^{\prime 697}$.

O Ato Institucional n $\mathrm{n}^{\circ} 5$ surge, então, como o instrumento que permitirá “deter a agitação de massa, as investidas da Frente Ampla e consolidar efetivamente a hegemonia da grande burguesia industrial $e$ financeira no poder político". Garantindo sua estabilidade, o AI-5 assegura a plena aplicação da política econômica que favorece ao desenvolvimento do grande capital, especialmente do grande capital imperialista. O esmagamento das organizações de massa que ainda haviam sobrevivido a 64, ou se rearticulado, a expansão, a intensificação da repressão policial, o esvaziamento político do Congresso, a censura mais

${ }^{695}$ PARTIDO COMUNISTA DO BRASIL - ALA VERMELHA. Autocrítica, cit., p. 21-22.

${ }^{696}$ PARTIDO COMUNISTA DO BRASIL - ALA VERMELHA. Autocrítica, cit., p. 22.

${ }^{697}$ PARTIDO COMUNISTA DO BRASIL - ALA VERMELHA. Autocrítica, cit., p. 23. 
rigorosa a imprensa — todas essas medidas são necessárias para dar "plena eficácia ao modelo de desenvolvimento econômico dependente do imperialismo, vindo completar o conjunto cuja base já fora anteriormente assentada, com o arrocho salarial e a repressão ao movimento operário". A política da "ditadura do grande capital industrial e financeiro integrado, exercida através dos militares", instrumentada desde 1964 e complementa da em 1968 pelo Ato Institucional n 5, permite ao capitalismo no Brasil "superar a crise em que vinha se debatendo, dentro dos próprios marcos do sistema, passando para uma fase de crescimento econômico acelerado" 698 .

A repressão posterior ao AI-5 limita a área social onde as organizações de esquerda ainda realizavam algum trabalho de massa, isolando-as. Sua reação e a passagem à ação armada de grupos isolados — atividade que já vinha sendo levada à prática por algumas organizações — “dominam então o cenário da esquerda, e mais que nunca os revolucionários se distanciam da classe operária"699.

O Doc. Autocrítica passa a analisar o surgimento da própria Ala Vermelha, discorrendo que a Ala, enquanto organização independente do PC do B, origina-se no processo de "confusão e debate da esquerda, em busca da um caminho para a revolução brasileira". Como parte que foi neste debate, "refletirá suas insuficiências e descaminhos". Embora sem chegar a compreender em profundidade a origem das deformações do PC do B - pois eram portadores do mesmo ecletismo ideológico alguns quadros intermediários se opuseram a elas, basicamente ao oportunismo e mandonismo no estilo de trabalho e de direção, ao isolamento e não participação dos militantes nas decisões políticas, ao "tratamento policialesco" das divergências internas e a não preparação da luta armada. Os quadros que desta forma iniciaram o processo de luta interna não tinham sua origem no PC do B, provinham das Ligas Camponesas ou do movimento estudantil, atraídos, para o PC do B pela perspectiva de "luta armada imediata". Os quadros originários das Ligas Camponesas, além de não se haverem formado na adoração mítica e servilismo próprio de ambos os "partidos comunistas", vinham de um processo de ruptura com Francisco Julião e estavam “afeitos a critica mais do que ao seguidismo". Os originários do movimento estudantil viviam o processo de fragmentação da esquerda e o início do debate que colocava na mesa uma serie de questões básicas do marxismo-leninismo. Embora tanto um quanto outro fosse portador da uma ideologia predominantemente pequeno-burguesa, não haviam sofrido "as deformações e castração teóricas próprias dos militantes tradicionais". São os originários das Ligas que, entusiasmados pelo estudo da Revolução Chinesa, lançam as primeiras criticas e é basicamente no setor estudantil que elas vão encontrar eco. Das primeiras críticas à ruptura há um processo rico da discussões que vai marcar positivamente seus participantes ${ }^{700}$.

Surgida "do debate e do exercício da crítica" a Ala Vermelha alcançou uma "qualidade diversa da organização onde se originou", no que diz respeito ao estilo de trabalho que incentiva e promove a discussão interna e a prática da crítica e da autocrítica. No entanto, às suas "críticas justas somava-se sua incompreensão da questão ideológica e a não assimilação do marxismo-leninismo, o que ira marcá-la e ser o responsável por seus descaminhos futuros”. Quando ocorre a cisão, a Ala empolga a maioria das bases do PC do B, trazendo pois consigo o mesmo contingente social disperso, desligado da classe operária e ideologicamente eclético existente naquela organização, e envereda ainda mais no "radicalismo" pequenoburguês. A cisão decorre da atitude do Comitê Central do PC do B que, assumindo a postura de "legítimo

${ }^{698}$ PARTIDO COMUNISTA DO BRASIL - ALA VERMELHA. Autocrítica, cit., p. 23-24.

${ }^{699}$ PARTIDO COMUNISTA DO BRASIL — ALA VERMELHA. Autocrítica, cit., p. 24.

${ }^{700}$ PARTIDO COMUNISTA DO BRASIL - ALA VERMELHA. Autocrítica, cit., p. 25. 
herdeiro do PCB", interrompe a luta interna, "expulsando os quadros que a dirigem utilizando-se não só do mandonismo como lançando mão de velhos chavões do gênero 'agentes da CIA' e epítetos similares" ${ }^{\text {"701. }}$.

A Ala Vermelha, uma corrente política dentro do PC do B, se vê obrigada a se organizar independentemente, com os recursos humanos originários daquele organização, com uma serie de quadros "profissionalizados" sem a "suficiente clareza e experiência política e de organização para tal". Dá-se então uma quebra abrupta no processo de discussão, e todos os quadros se voltam para a manutenção da organização. Obrigados a sair prematuramente do "terreno da critica para os das definições que orientassem a organização", não são capazes de dar continuidade ao debate, e , como conseqüência, "não se processa a necessária depuração ideológica". Nessas condições, pressionados pelas exigências do momento, o documento "Crítica ao Oportunismo..." que fora planejado inicialmente apenas como crítica à "União dos Patriotas", ganha, no "próprio curso de sua elaboração, o propósito de definir uma linha política". As posições que alguns quadros elaboravam dispersamente no curso da luta interna cristalizam-se no documento. Justamente por tudo isso o documento vai se constituir num apanhado de "concepções radicais 'pequenoburguesas', transpondo mecanicamente experiências de outras revoluções, além de pretender estar respondendo a questões que a luta de classes não colocara". Na medida em que respondia aos anseios da maioria dos militantes (que participavam da luta interna imbuídos do espírito de "fazer" a luta armada a curto prazo), "o documento obtém fraca aceitação". Aceitas suas concepções como linha da Ala Vermelha, o documento vai se tornar a "influência dominante dentro do nosso partido desde sua publicação até hoje". É portanto nele é que estão "calcados os principais desvios de concepções" da Ala. É "ele que reflete com mais clareza a fidelidade a tendência ideológica 'radical" pequeno-burguesa que caracteriza nossa teoria e nossa prática". Realizado nas condições assinaladas reflete naturalmente essas "concepções errôneas acerca da realidade brasileira, a começar pela avaliação incorreta da crise pela qual passava a sociedade $" 702$.

A não compreensão de que a crise era gerada pelas contradições internas à sociedade brasileira e de que a economia já era dominada em seus setores básicos pelo capital monopolista, principalmente americano; a não compreensão de que era possível superá-la nos marcos do sistema sem modificações profundas em sua estrutura e sem a abertura para a participação política popular ou mesmo das forças política burguesas levou a Ala Vermelha a uma supervalorização do papel do imperialismo no Golpe e na crise, e a idéia, de que esta "se aguçaria cada vez mais, abrindo caminho para a saída revolucionária a curto prazo" "703.

A correta constatação da "diminuição da base social da ditadura militar devido à sua política despótica a serviço da grande burguesia industrial e financeira em detrimento das demais classes dominantes", e, sobretudo, "em prejuízo das amplas massas, e à conseqüente ampliação conjuntural do campo da revolução", é interpretado pela Ala como "condição favorável à saída revolucionária imediata". Outra circunstância que propiciava uma visão imediata era a constatação correta da necessidade de "reação contra a política revisionista da via pacífica, já desmoralizada pelo golpe". Entretanto, da constatação de que a "base social da ditadura diminuía e de que era necessário reagir à bancarrota do revisionismo", ${ }^{704} \mathrm{a}$ Ala Vermelha extraiu

\footnotetext{
${ }^{701}$ PARTIDO COMUNISTA DO BRASIL - ALA VERMELHA. Autocrítica, cit., p. 25.

${ }^{702}$ PARTIDO COMUNISTA DO BRASIL - ALA VERMELHA. Autocrítica, cit., p. 26.

${ }^{703}$ PARTIDO COMUNISTA DO BRASIL - ALA VERMELHA. Autocrítica, cit., p. 26.

${ }^{704}$ PARTIDO COMUNISTA DO BRASIL - ALA VERMELHA. Autocrítica, cit., p. 26-27.
} 
"conclusões equivocadas que levaram a proposição da luta armada imediata, ao invés de propor uma política que assegurasse a participação de setores marginalizados pela ditadura (conjunturalmente situados no campo da revolução) de compreender que o revisionismo deve ser desmascarado teórica, política e ideologicamente, e não apenas em suas proposições pacifistas",705.

A inexistência do movimento operário após o golpe era explicada pela "ação eficiente da ditadura" que exercia sobre a classe operária vigilância e repressão preventivas; pela intervenção e dissolução de suas organizações, pela perseguição e encarceramento de seus dirigentes e, mais, pela influência revisionista. "Nisso via-se uma resposta ao invés de uma pergunta". Em vez de se questionar as causas mais profundas da inexistência do movimento operário em vez de compreender que a classe operária mesmo antes de 64 não dispunha de organização sindical independente nem estava organizada na base, mobilizando-se apenas através da manipulação das cúpulas ligadas ao Ministério do Trabalho; de compreender que os direitos de trabalhistas eram resultado de populismo e não frutos conquistados pela luta da classe operária; enfim, " $a$ o invés de se dedicar a pesquisa da formação e composição da classe operária brasileira e de seu movimento, ficava-se na superfície da constatação das dificuldades objetivas que a política da ditadura impunha", assim, a Ala Vermelha como quase toda a esquerda brasileira nesse período, apresentava "a luta armada imediata como alternativa que levaria a classe operária à mobilização e à ação revolucionárias" ${ }^{\text {"706 }}$.

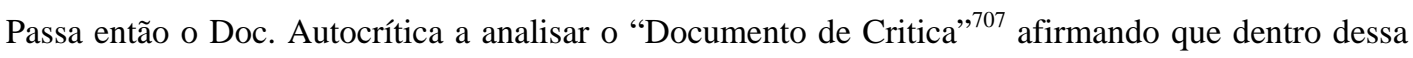
situação, tal Documento vai girar em torno da afirmação "enfática e exagerada da luta armada, colocando-a como única linha divisória entre marxismo e revisionismo",708. Isso se torna nítido na crítica às concepções de luta armada do PC do B feita no "Documento de Crítica":

\footnotetext{
"Ao imaginar que a luta armada será o resultado natural de um auge do movimento de massas, os redatores do documento da VI incorrem num acentuado desvio de direito, manifestando claramente tendências revisionistas. Nas condições atuais da sociedade brasileira, é idealismo pensar que o movimento de massas possa desenvolver-se sem a existência concreta e simultânea na luta armada' $(p .37)^{, 709}$.
}

O Doc. Autocrítica anota que a Ala identificava como tendência revisionista era justamente a "não colocação da luta armada como ponto de partida para toda atividade revolucionária". E mais: "os verdadeiros revolucionários se distinguiriam dos oportunistas na medida em que reafirmassem sua adesão à luta armada, de forma incondicional e a absoluta" ${ }^{\text {,710: }}$

\footnotetext{
${ }^{705}$ PARTIDO COMUNISTA DO BRASIL - ALA VERMELHA. Autocrítica, cit., p. 27.

${ }^{706}$ PARTIDO COMUNISTA DO BRASIL - ALA VERMELHA. Autocrítica, cit., p. 27.

${ }^{707}$ Relembra-se que o "Documento de Crítica" é a referência que se faz ao longo nome dado ao documento fundador da Ala Vermelha, o Crítica ao oportunismo e subjetivismo do documento "União dos Patriotas para livrar o País da Crise, da Ditadura, da Ameaça Neocolonial, cit.

${ }_{708}$ PARTIDO COMUNISTA DO BRASIL - ALA VERMELHA. Autocrítica, cit., p. 28.

${ }_{710}^{709}$ PARTIDO COMUNISTA DO BRASIL — ALA VERMELHA. Autocrítica, cit., p. 29.
} 
“'De qualquer forma, comprova-se sempre a assertiva de que essa evolução do movimento de massas, nas condições atuais, só pode se dar com a existência da luta armada, em função da luta armada e apoiado na luta armada' (p. 38) (...) No Brasil, o Partido, como destacamento de vanguarda do proletariado, só pode surgir no seio da luta armada, para a luta armada e dirigido à luta armada' (p.47) (...) 'Já constatamos que a tarefa mais urgente da revolução brasileira é a preparação e a eclosão da luta armada' (p. 48)"

Diz a Autocrítica que se verifica claramente que toda a argumentação do Documento de Crítica tem como objetivo justificar essa adesão à luta armada, "assumida aprioristicamente". "Relegávamos o movimento de massas (que é expressão mesma da luta de classes em sua manifestação concreta e mais abrangente) a um total segundo plano, em face de uma forma específica de luta, a luta armada. "Aberrações teóricas tornaram-se necessárias para obter esse resultado" "111.

"Se seu inimigo adota como forma de luta principal a violência armada, não é possível que as forças revolucionárias adotem, como forma de luta principal, uma de nível inferior, como o movimento de massas' (p.38)”

A Autocrítica nota que além de "reduzirmos o movimento de massas à categoria de forma de luta, entendíamos que a revolução deve sempre responder ao inimigo no mesmo nível", sem levar em conta a relação de forças entre revolução e contra-revolução. Ou, o que é ainda pior, "propúnhamos esse enfrentamento direto no mesmo nível, mesmo constatando que":

'No desnível das condições subjetivas às objetivas e na ausência de um verdadeiro partido do proletariado e de uma força armada sob sua direção, consiste a debilidade no campo da revolução' $(\mathrm{p} .42)^{, 712}$

O Doc. Autocrítica marca que esta visão de luta armada que buscava superar o desnível de forças entre a revolução e seus inimigos através de enfrentamento imediato, abriu caminho para a proposição de ações armadas de grupos isolados e, mais particularmente, para o foco revolucionário. Todo esse pensamento "pretendia se justificar por uma visão de acumulação de forças revolucionárias resultante do choque armado com o inimigo do qual não só se desgastariam as forças contra-revolucionárias, como também "criar-se-iam as condições para a adesão das massas à luta armada e já em andamento". O ponto de partida era a idéia de atacar o inimigo onde ele é mais fraco:

'Como as forças revolucionárias são taticamente débeis em relação às forças contrarevolucionárias, torna-se necessário atingir o inimigo onde ele é mais vulnerável. O inimigo é mais vulnerável nas zonas rurais (...) Partido do campo a luta armada se desenvolve em choque aberto

\footnotetext{
${ }^{711}$ PARTIDO COMUNISTA DO BRASIL - ALA VERMELHA. Autocrítica, cit., p. 29.

${ }^{712}$ PARTIDO COMUNISTA DO BRASIL - ALA VERMELHA. Autocrítica, cit., p. 30.
} 
com o inimigo e, nesse processo, ao mesmo tempo em que ganha as grandes massas para a revolução, constrói paulatinamente o Exército Popular Revolucionário' (p. 44),"713

A Autocrítica destaca que até mesmo na tentativa de transposição mecânica da experiência chinesa da guerra popular, o documento se equivocou, na medida em que "nossa visão 'Radical' pequeno-burguesa deformava o conceito" que procurávamos $\operatorname{copiar}^{714}$ :

'A guerra popular é a forma que a luta armada assume quando a partir de pequenas ações armadas, se desenvolve paulatinamente até envolver a participação de todo o povo' (p. 45 - grifos dos autores da Autocrítica), ${ }^{, 715}$

Nota o Doc. Autocrítica que essa deformação "permitia-nos 'harmonizar' a idéia de guerra popular com a do foco revolucionário. É justamente aí que o desvio de esquerda do Documento de Crítica sob a influência das teses de Debray, atinge sua expressão teórica mais extremada. O foco que "propúnhamos obedecia, em suas características fundamentais, ao modelo debraysta". Entretanto, como ele se inseria numa visão estratégica transposta da Revolução Chinesa, apresentava alguns acréscimos particulares ${ }^{716}$.

Mas a essa visão "'ortodoxa' de foco, agregáramos o conceito necessidade do partido e da hegemonia do proletariado, o da criação de áreas libertadas e de cerco das cidades pelo campos":

'Para que o desenvolvimento da luta armada e construção do Exército Popular Revolucionário se dêem sob a hegemonia do proletariado, e necessário que, paralelamente a esse processo se forje a verdadeira vanguarda do proletariado (pag.46)(...) a Frente Única Revolucionária e um instrumento de mobilização das massas para apoiar a luta armada (pag.47) (...) utilizando principal forma de luta a luta armada, as forças revolucionárias poderão efetuar o cerco dos grandes centros urbanos a partir das zonas rurais" (pag.44). ${ }^{717}$

De modo que, no Documento de Crítica, o foco não é a única tarefa dos revolucionários, ainda que seja a principal:

“'Paralelamente a esta tarefa de preparação do foco, e sempre subordinado a ela é necessário desenvolver o trabalho de massas, preparando as condições para que, no momento da eclosão da luta armada, as grandes massas do povo possam apoiá-la. Além disso, e estreitamente vinculado a criação do foco, e necessário desen-volver a preparação do trabalho militar nos grandes centros $e$ em várias zonas rurais diversas daquela em que se localiza o foco. Este trabalho militar, que se

\footnotetext{
${ }^{713}$ PARTIDO COMUNISTA DO BRASIL - ALA VERMELHA. Autocrítica, cit., p. 30.

${ }^{714}$ PARTIDO COMUNISTA DO BRASIL - ALA VERMELHA. Autocrítica, cit., p. 30.

${ }^{715}$ PARTIDO COMUNISTA DO BRASIL - ALA VERMELHA. Autocrítica, cit., p. 30.

${ }^{716}$ PARTIDO COMUNISTA DO BRASIL - ALA VERMELHA. Autocrítica, cit., p. 30.

${ }^{717}$ PARTIDO COMUNISTA DO BRASIL - ALA VERMELHA. Autocrítica, cit., p. 31.
} 
combinará com as ações realizadas nas zonas de guerrilhas, tem à finalidade de confundir $e$ dispersar as forças do inimigo' (pág. 48)", ${ }^{718}$

A Autocrítica assevera que embora por essas citações feitas à concepção de foco no Documento de Crítica procurasse abranger um processo complexo (envolvendo a luta armada nas cidades e no campo, o movimento de massas, o Partido e se desdobrando no Exercito Popular Revolucionário, nas áreas libertadas e no cerco das cidades pelo campo), ela não consegue disfarçar sua origem, nem se livrar dos desvios decorrentes de sua própria natureza. $\mathrm{O}$ foco é a sistematização mais elaborada da ação isolada de um pequeno grupo em confronto direto com o inimigo. Trata-se de uma atividade totalmente desvinculada das massas, particularmente do proletariado; sua "implantação clandestina" demonstra a pressa dos que são incapazes de esperar pelos frutos do trabalho revolucionário entre as massas e a falta de confiança nestas, em nome das quais proclama ser feita a luta revolucionária. É aí que o vanguardismo se manifesta de modo mais enfático: o grupo de quadros "contingente guerrilheiro" iria "eclodir" a luta armada em nome do povo, e ao povo, as massas, caberia apoiar essa luta, aderir a ela ou imitá-la. A luta de classes e substituída pela luta de um pequeno grupo que se substitui as classes revolucionárias. Não obstante as tentativas de amenizar este conteúdo através da defesa da necessidade do partido e das referências vagas ao movimento de massas, o Doc. Autocrítica não consegue mudar a natureza ideológica da concepção de foco na medida em que e o "radicalismo" pequeno-burguês que informa toda essa articulação teórica. Já se tornou óbvio, através da prática, o fracasso previsível de tal teoria. Isoladas das massas, os contingentes da guerrilha rural se tornam presa fácil do aparelho repressivo inimigo e, mesmo quando sobrevivem, deslocam os revolucionários de seu trabalho principal, causando assim entraves ao processo revolucionário ${ }^{719}$.

Entretanto, no que diz respeito `a Ala Vermelha, o foco "não chegou a passar da teoria para a prova prática". Mas esta mesma teoria, o mesmo fundamento ideológico deu origem a novas formulações que interferiram mais diretamente em nossa prática. Assim é que o documento OPNTEFLA ${ }^{720}$ não passa de um desenvolvimento das idéias contidas na última citação reproduzida acima. $\mathrm{E}$ as teses deste documento vão ter uma influência mais direta nas atividades da AV - ações armadas urbanas, grupos especiais do Partido e grupos armadas de massa ${ }^{721}$.

Embora a Ala não tenha chagado a "eclodir" um foco, a AV baseou o fundamental de sua prática na visão "vanguardista, militarista e isolada das massas que caracteriza aquela concepção" 722.

Ainda que apresentando concepções vanguardistas e ideologicamente não proletárias, o "Documento de Crítica" guarda certa coerência interna. Isto é, as conclusões a respeito da luta armada, foco e outras "não foram extraídas do ar, não foram afirmações jogadas": elas decorriam de uma analisa errônea da realidade do país a da realidade internacional. Dizendo de outro modo, elas fazem parte de uma "visão geral deformada do país, do mundo e da própria teoria marxismo-leninismo". Um exemplo claro disso está na forma pela qual o documento "demonstra" que a revolução brasileira percorrerá o caminho do cerco das cidades pelo campo. Tal tese não é afirmada gratuitamente: o Doc. Autocrítica pretendia que ela decorresse

\footnotetext{
${ }^{718}$ PARTIDO COMUNISTA DO BRASIL - ALA VERMELHA. Autocrítica, cit., p. 32.

${ }^{719}$ PARTIDO COMUNISTA DO BRASIL - ALA VERMELHA. Autocrítica, cit., p. 33.

${ }^{720}$ Se recorda que esta sigla é referente ao documento, de 1968, da Ala Vermelha intitulado Organizar um Partido de Novo Tipo em função da Luta Armada, cit.

${ }^{721}$ PARTIDO COMUNISTA DO BRASIL - ALA VERMELHA. Autocrítica, cit., p. 32.

${ }^{722}$ PARTIDO COMUNISTA DO BRASIL - ALA VERMELHA. Autocrítica, cit., p. 33.
} 
de determinadas características da realidade brasileira. Assim a que, expondo as "características fundamentais da situação atual da sociedade brasileira”, tem-se: ${ }^{723}$

“O desenvolvimento do capitalismo na sociedade brasileira atual se da nas condições de existência de importantes regiões atrasadas. Embora haja uma predominância de relações capitalistas, o Brasil se caracteriza como um país predominantemente agrário. No entanto isto se da ao lado de fatores fundamentais da compreensão situação atual da sociedade brasileira: a) A maioria da população do pais vive no campo, isto é, fora dos centros urbanos onde se encontra a produção capitalista; b) Pelo fato da economia nacional se fundamentar na exportação de produtos primários e da maioria da população ativa viver no campo, a sociedade brasileira se caracteriza por ser predominantemente agrária’ (pág. 42).,724

De tal análise o Doc. Autocrítica conclui não somente que a revolução brasileira seria entre outras coisas "agrária" (pág.40 do "Documento de Crítica"), mas também que o campesinato seria seu contingente principal e, logicamente, que o processo de guerra popular levaria "ao cerco das cidades pelo campo",725

'O cerco das cidades pelo campo é também indicado pelo fato da maioria da população do país viver no campo e porque esta população esta submetida as formas mais violentas de opressão e às mais atrasadas de exploração, o que lhes proporciona um sentimento imediato da necessidade da revolução' (pág. 43).”

Segundo o Doc. Autocrítica no penúltimo trecho citado verifica-se diversos erros e distorções. De início, o critério de declarar o país predominantemente agrário baseado na distribuição da população e composição da pauta de exportações, é um "erro manifesto". O que caracteriza uma sociedade são as relações de produção dominantes, isto e, aquelas que se fazem presentes nos setores mais dinâmicos e significativos da economia. Sob este ponto de vista, "não resta dúvida que o Brasil é um país capitalista", sem contar, é claro, que se era verdade em 1967 que pouco mais da metade da população viva no campo, hoje em dia esta proporção se inverteu. E não foi isso, seguramente, que determinou qualquer mudança no caráter .da sociedade brasileira. Em seguida, no trecho citado, afirma-se expressamente que no Brasil "há uma predominância de relações capitalistas", e não obstante, se trata de um país "predominantemente agrário". Conforme o que já se demonstrou, essa afirmativa se constituí numa "contradição em termos, na verdade, de uma hesitação em extrair a conclusão da "predominância de relações capitalistas", o que levou ao emprego deslocado do conceito de "país agrário", por querer afirmar, sem segurança para dizê-lo, que se tratava de uma sociedade pré-capitalista. A confusão teórica que isso permite abriu caminho para as conclusões que levam ao cerco das cidades pelo campo. Entretanto, aclarando tais confusões, reconhecendo que o país é capitalista, eliminando o artifício do "predominantemente agrário", "o cerco das cidades pelo campo cai no

\footnotetext{
${ }^{723}$ PARTIDO COMUNISTA DO BRASIL — ALA VERMELHA. Autocrítica, cit., p. 33.

${ }^{724}$ PARTIDO COMUNISTA DO BRASIL — ALA VERMELHA. Autocrítica, cit., p. 33.

${ }^{725}$ PARTIDO COMUNISTA DO BRASIL - ALA VERMELHA. Autocrítica, cit., p. 33.
} 
vazio". Isto é, sem base para sustentá-lo, sua afirmação pura e simples deixa de ser resultado de uma análise para permanecer apenas como "um palpite ao gosto da futurologia",726.

A insistência na necessidade do partido do proletariado, presente na $\mathrm{AV}$, desde sua formação e conseqüentemente no Documento de Crítica, tende a afastar as concepções do ponto de vista puramente militar. Após definir-se o foco revolucionário como tarefa principal, argumentava-se:

"Para que o desenvolvimento da luta armada e do Exercito Popular Revolucionário se dêem sob a hegemonia do proletariado, é necessário que paralelamente a asse processo se forje a verdadeira vanguarda do proletariado. Assegurar a hegemonia do proletariado no desenvolvimento da luta armada e na construção do Exercito Popular Revolucionário e condição essencial para garantir a hegemonia do proletariado na revolução e para o êxito desta (pág.40) (...) Partindo da necessidade do partido do proletariado para dirigir o processo revolucionário (...) a hegemonia do proletariado é garantida pela sua força, emanada da existência de um partido temperado na luta e de uma força armada sob sua direção’ (pág.47)”727.

Tanto nestes trechos como em todos os outros em que no documento o Doc. Autocrítica se refere ao partido, ficava clara a visão de sua necessidade como instrumento para dirigir a luta armada e para garantir a hegemonia do proletariado. Ainda que estes sejam aspectos corretos da concepção de partidos, eles representam apenas um lado da questão. Não há em todo o documento referência ao papel ideológico do partido, a sua função primeira de educador das massas proletárias. Essa "visão unilateral que reconhecia apenas o papel de dirigente político do partido é produto do dogmatismo". No entanto, não é apenas este aspecto de uma visão errônea da concepção de partido que o Documento de Crítica revela: o "radicalismo" pequeno-burguês que fundamenta todo o documento "atrelava o partido e sua construção a luta armada". 728 Deslocando esta última para o primeiro plano, transformava o partido do proletariado num elemento subordinado a ela: “"No Brasil, o partido como destacamento de vanguarda do proletariado só pode surgir no seio da luta armada, para a luta armada e dirigindo a luta armada' (pág.47),"729.

Desse ponto de vista, a "forma de luta limita o partido, condiciona sua existência e, na verdade, se sobrepõe a ele". O que naturalmente decorria de uma visão do processo revolucionário onde a forma de luta era o elemento determinante, relegando a outro plano a dinâmica da luta de classes e o movimento de massas despido de suas verdadeiras funções, o partido se traduzia a uma espécie "de Estado-Maior, de Comando Supremo das operações militares da guerra popular". Tal empobrecimento da concepção de partido vai se refletir logicamente no entendimento do processo de sua construção ${ }^{730}$.

De início, ainda uma vez, ele é relegado a um segundo plano:

"No momento atual, a tarefa mais urgente do processo revolucionário não consiste na construção de um forte partido em todo o país, para somente depois preparar o desencadeamento da luta armada. Não se trata de destacar os melhores quadros para esse trabalho de construção do partido" (pág.47) ${ }^{731}$.

\footnotetext{
${ }^{726}$ PARTIDO COMUNISTA DO BRASIL - ALA VERMELHA. Autocrítica, cit., p. 34.

${ }^{727}$ PARTIDO COMUNISTA DO BRASIL - ALA VERMELHA. Autocrítica, cit., p. 34.

${ }^{728}$ PARTIDO COMUNISTA DO BRASIL - ALA VERMELHA. Autocrítica, cit., p. 34.

${ }^{729}$ PARTIDO COMUNISTA DO BRASIL - ALA VERMELHA. Autocrítica, cit., p. 34-35.

${ }^{730}$ PARTIDO COMUNISTA DO BRASIL - ALA VERMELHA. Autocrítica, cit., p. 35.

${ }^{731}$ PARTIDO COMUNISTA DO BRASIL - ALA VERMELHA. Autocrítica, cit., p. 35.
} 
Justamente, quando se verifica que um dos principais elementos de atraso da revolução brasileira e a inexistência do partido, afirma-se que sua construção não é a tarefa mais urgente. Reagindo à visão do Partido Comunista do Brasil de construir uma imensa e pouco ágil máquina partidária como tarefa anterior a todas as outras e delas desligadas, o "Documento de Crítica" caiu no desvio oposto. Traçava-se um processo em que a organização partidária "destaca seus -melhores quadros" para preparar e eclodir a luta armada e, posteriormente, "a partir da eclosão da luta armada" e com base em seu desenvolvimento, a tarefa da organização partidária será a de dar "uma nova qualidade ao movimento de massas, assumindo nesse processo o papel de vanguarda do proletariado" ${ }^{732}$ A Ala Vermelha eclodiria a luta armada e, no bojo desta se transformaria no partido:

“ ‘...a organização partidária ao se preparar para desencadear a luta armada não pode abandonar o trabalho da preparação das condições necessárias para que, após o desencadeamento da luta armada, possa desenvolver a tarefa da se transformar na vanguarda do proletariado e da revolução" (pág.47) ${ }^{733}$.

Em outras palavras, se entendia que a organização partidária então existente precisava, basicamente, da luta armada para se transformar no partido; na medida em que não são colocadas questões referentes as "condições ideológicas, políticas e orgânicas necessárias à construção do partido", torna-se claro o entendimento de que a Ala Vermelha já reunia essas condições, faltando apenas o "caldo de cultura" da luta armada. O que nos leva de volta ao dogmatismo: a AV por definição, já reunia aquelas condições, já era uma espécie de partido do proletariado em ponto pequeno, uma "maquete" de partido. Com isso , obviamente, afastavam-se todas as necessidades de retificação política e ideológica da organização, para que fosse possível lançá-la da forma como existia na preparação da luta armada. Tal concepção retardou, dentro da Ala Vermelha, a compreensão da necessidade da autocrítica, de um profundo processo de retificação ${ }^{734}$.

De um modo geral, é perceptível nas colocações da AV naquele documento, sobre a luta armada, uma pressuposição dogmática; sem dizê-lo, os elementos estratégicos e táticos que a Ala apresentava se referiam a uma situação hipotética em que a luta armada já existia. Com a provável exceção do foco — que afinal era entendido como elemento desencadeador - , todas as outras colocações seriam válidas, se propostas por um partido já envolvido em uma situação real de guerra: o partido dirigindo a luta armada como forma principal de luta, subordinando todas as outras, etc. Trata-se aqui de um claro exemplo de dogmatismo na medida em que todas essas teses (com exceção ainda uma vez do foco), foram tomadas "de empréstimo a Revolução Chinesa, na qual a guerra já era um dado concreto e dominante da realidade". Denota isto o fato de se haver escolhido como citação ilustrativa, na página final do documento, um texto de Mao Tsé-tung extraído de "A tática da luta contra o Imperialismo Japonês", correta para um momento de pleno desenvolvimento da luta armada, mas que se demonstra deslocada na situação da sociedade brasileira. Nesse sentido, "o dogmatismo da Ala Vermelha não era menor, que o do Partido Comunista do Brasil", na medida em que, para validar sua tática de "União dos Patriotas", só não existia o dado concreto de uma

\footnotetext{
${ }^{732}$ PARTIDO COMUNISTA DO BRASIL — ALA VERMELHA. Autocrítica, cit., p. 35.

${ }^{733}$ PARTIDO COMUNISTA DO BRASIL - ALA VERMELHA. Autocrítica, cit., p. 35.

${ }^{734}$ PARTIDO COMUNISTA DO BRASIL — ALA VERMELHA. Autocrítica, cit., p. 37.
} 
invasão japonesa. Da mesma forma, o dogmatismo da $\mathrm{AV}$ vai estar presente no que o documento de Crítica coloca sobre a estratégia, tática e programa ${ }^{735}$. O dogmatismo se revela de imediato na própria definição metodológica para abordar tais problemas:

“'É necessário, em primeiro lugar, ter o conhecimento das contradiçoes fundamentais, e, da contradição principal da sociedade brasileira. Tendo-se esse conhecimento, e possível, entao, definir o programa e traçar a tática com base em tal conhecimento' (pag.29),736.

O ponto de partida para uma colocação desse tipo, diz o Doc. Autocrítica, foi uma leitura mal assimilada do texto teórico "Sobre a Contradição" de Mao Tsé-tung. Entendendo mecanicamente a questão das contradições na sociedade, ela se despiu de qualquer dialética, de qualquer movimento. Criou-se um modelo "rígido, linear, que via a sociedade num corte estrutural, onde as classes se enfrentavam estaticamente, dispostas em campos antagônicos bem definidos". Estabelecia-se na verdade uma fórmula segundo a qual um dado ordenamento de contradições hierarquizadas produzia diretamente o programa, a estratégia e a tática da revolução. O que vale dizer que, de posse da fórmula, qualquer pessoa, independente de sua prática política, de sua militância e de seu conhecimento teórico, poderia definir estratégia, tática e programa. Estava, é claro, pressuposto que o conhecimento das contradições fundamentais e da contradição principal era o resultado de uma análise de classes anteriormente feita. Esta tentava surpreender a "estrutura" da sociedade como que congelada diante do observador, "a-histórica, sem levar em conta seus desdobramentos no tempo",737.

De posse desta fórmula, a AV estabelecia os pólos da contradição principal entre, de um lado, o povo, e, de outro, o neocolonialismo e seu suporte social interno. A revolução vinha a ser o choque entre os dois aspectos da contradição, e a superação do aspecto principal (neocolonialismo e seu suporte) pelo aspecto secundário. Desse enfrentamento decorriam todas as características da revolução. Esse "esquematismo" nada mais é que o "empobrecimento sistemático de Mao Tsé-tung em Sobra a Contradição". Nele se pode perceber como uma teoria correta, empregada dogmaticamente, se transforma exatamente no seu contrário ${ }^{738}$.

Assim é que se afirma que na atual etapa da revolução "objetiva destruir os meios de exploração e opressão do neocolonialismo e de seu suporte social interno". Essa exploração e opressão caracterizam a sociedade brasileira como: "Uma sociedade neocolonizada, agrária, de acentuadas relações de produção capitalistas" (pág.40) ${ }^{739}$.

Dessa forma tortuosa e insegura, o "Documento de Crítica" chegava à etapa da democracia popular. A afirmação correta do caráter da revolução brasileira era, portanto, sustentada por "uma análise e por argumentações absolutamente errôneas". Se hoje a AV continua definindo a revolução como uma revolução de democracia popular, a fundamentação dessa assertiva é bem outra. Ela parte do reconhecimento de que a sociedade brasileira é uma sociedade capitalista, na qual, entretanto, as particularidades da revolução burguesa lha determinam um caráter não democrático, e que está inserida numa situação dependência ao imperialismo.

\footnotetext{
${ }^{735}$ PARTIDO COMUNISTA DO BRASIL - ALA VERMELHA. Autocrítica, cit., p. 38.

${ }^{736}$ PARTIDO COMUNISTA DO BRASIL - ALA VERMELHA. Autocrítica, cit., p. 38.

${ }^{737}$ PARTIDO COMUNISTA DO BRASIL - ALA VERMELHA. Autocrítica, cit., p. 39.

${ }^{738}$ PARTIDO COMUNISTA DO BRASIL - ALA VERMELHA. Autocrítica, cit., p. 39.

${ }^{739}$ PARTIDO COMUNISTA DO BRASIL - ALA VERMELHA. Autocrítica, cit., p. 39.
} 
Em seguida, no Documento de Crítica, extrai-se a conclusão de que a etapa corresponde um poder "exercido pelas classes e camadas que estão no campo da revolução, sob a hegemonia do proletariado", ou Governo Popular Revolucionário.

Ao abordar a estratégia, o Documento de Crítica realiza, no seu grau mais desenvolvido, o exercício subjetivista: a partir de uma série de contradições fundamentais da sociedade brasileira, projetava-se a luta armada surgindo no campo e seu desenvolvimento paulatino ate chegar-se ao cerco das cidades. Em um momento em que o processo revolucionário brasileiro ainda não revelou as lindas gerais de seu encaminhamento, tais afirmações "soam como uma divagação visionária". 740.

No Documento de Crítica o neocolonialismo era entendido como sendo uma nova fase do imperialismo, assim como este foi em relação ao capitalismo não monopolista. Sua caracterização, que constitui a parte fundamental da análise internacional do documento, se prende à existência das empresas "multinacionais", à substituição de "exportação de capitais" pelo "investimento direto", à fusão entre o capital financeiro e o capital estatal - e o que é mais importante, ao papel hegemônico desempenhado pelos Estados Unidos da América no mundo capitalista depois da II Guerra mundial. "O neocolonialismo iria além do imperialismo na dominação das economias atrasadas", pois utilizaria formas similares de "dominação colonial", substituindo a administração colonial por governos títeres (ditaduras militares neocolonialistas), substituindo a ocupação realizada por tropas da metrópole pela ocupação por tropas nativas educadas ideologicamente pelo Pentágono ${ }^{741}$.

Tal ocupação representa o produto da tentativa de realizar uma análise que esgotasse as características do imperialismo contemporâneo posterior à II Guerra mundial, "sem dispor de base teórica e do conhecimento da realidade necessários". Algumas características novas assumidas pelo imperialismo foram transformadas no próprio conteúdo da "nova fase". Uma determinada forma de dominação que pode ser identificada em algumas nações africanas do passado colonial recente, foi transformada na forma "típica" de dominação do capital monopolista atual. No "Documento de Crítica" "se generalizava o que era particular no imperialismo contemporâneo" ${ }^{\text {"742 }}$.

Devido às concepções políticas errôneas que orientavam a Ala Vermelha, não se compreendeu corretamente as situações conjunturais da sociedade e de suas mudanças. A existência artificial da organização e, conseqüentemente, sua atuação marginal ao processo social, o convencimento de que a preparação da luta armada no campo dependia exclusivamente das iniciativas da própria AV, determinavam um profundo desconhecimento - e mesmo a desnecessidade de conhecer - das mudanças nas relações de poder e das conjunturas dai decorrentes. Desse modo, quando ocorre uma significativa mudança na conjuntura política como a decretação da AI-5, não só "fomos incapazes de definir uma posição sobre seu significado", como também "enveredamos de forma ainda mais acentuada no desvio de atuarmos apenas com nossas limitadas forças, reforçando a tendência de esquerda", particularmente "o militarismo",743.

A reação diante do AI-5 representou a reafirmação das concepções vanguardistas do Documento de Crítica à sua exacerbação. A repressão que se segue ao AI-5 atinge de imediato os setores da pequena burguesia, particularmente o movimento estudantil, e esmaga suas organizações. Isso atemoriza e limita a

\footnotetext{
${ }^{740}$ PARTIDO COMUNISTA DO BRASIL - ALA VERMELHA. Autocrítica, cit., p. 39.

${ }^{741}$ PARTIDO COMUNISTA DO BRASIL - ALA VERMELHA. Autocrítica, cit., p. 43.

${ }^{742}$ PARTIDO COMUNISTA DO BRASIL - ALA VERMELHA. Autocrítica, cit., p. 43.

${ }^{743}$ PARTIDO COMUNISTA DO BRASIL - ALA VERMELHA. Autocrítica, cit., p. 51.
} 
área social onde as organizações de esquerda ainda realizavam algum trabalho de massa, isolando-as. A reação da esquerda é uma radicalização cada vez maior inaugurando, assim, "o período de apogeu das ações armadas de grupos isolados". A Ala Vermelha é atingida pelo mesmo fenômeno. "Sem compreendermos o significado e a dimensão desse instrumento do qual lançava mão a ditadura", não entendendo que o momento determinava recuo e um "trabalho paciente e camuflado" de ligação com as massas, para evitar o isolamento, a AV tentou continuar a avançar apenas com nossos próprios recursos internos, preparando-nos para a luta armada através de "uma prática militarista",744.

Como medida para romper o isolamento em que a Ala se encontrava passou-se a aceitar a ação armada como instrumento de propaganda e não mais apenas como forma de obter recursos financeiros. Praticamente foi abandonado o trabalho no meio estudantil e tentou-se deslocar o centro de gravidade de nossa atuação no sentido de estabelecer laços com o proletariado, intensificando a agitação vanguardista através de panfletagens e do que se chamou "de propaganda armada"745.

Esse aguçamento do vanguardismo da Ala encontrou sua expressão mais acentuada em São Paulo. No período imediatamente posterior ao AI-5, desenvolveu-se nesse Regional uma intensa discussão que tinha por base concepções do Documento de Crítica e do OPNTEFLA. Uma orientação política foi elaborada e posta em prática com relativa autonomia em relação à Direção Nacional Provisória. A diretiva básica era a de ligação com a classe operária: pretendia-se, entretanto, realizá-la através de um trabalho que aliava o trabalho de organização na fábrica com "a propaganda armada”. O trabalho na fábrica era entendido como sendo de "dentro para fora", isto é, vinculado da classe ao partido, enquanto que a "propaganda armada" era a de intensa distribuição de material impresso — basicamente panfletagens — apoiada por ações que iriam desde comícios relâmpagos com cobertura militar, até tomadas de estações de rádio ${ }^{746}$.

Pretendia-se que esta "propaganda" elevasse o nível de consciência da massa para que ela se organizasse "espontaneamente", ampliando os contatos do trabalho de "dentro para fora", além da construção do Partido nas fábricas. Entendia-se que, na medida em que o movimento operário se encontrava estagnado, a "propaganda armada" teria a virtude de desencadear a luta "espontânea" do proletariado. Na realidade, a “propaganda armada" nada tinha de propaganda, posto que não era instrumento de educação, não realizava um papel pedagógico. Não passava de "agitação vanguardista por não se basear nas reais condições subjetivas das massas, além de se dirigir de forma dispersa e fragmentária". A própria idéia de criar lutas "espontâneas" a partir de um estímulo de fora traduz uma visão distorcida do que seja luta "espontânea", ratificava a "teoria do exemplo" (a massa deve imitar o que a vanguarda já está fazendo), e nada mais é, enfim, que uma vestimenta nova da velha idéia do "terror excitativo" que Lênin combateu em "Que fazer?"747.

Está claro que a prática dessas concepções, efetivadas através da criação de organismos especializados, as "Unidades de Combate", não contribuiu para levar consciência as massas e organizá-las, nem para incentivar sua movimentação, e muito menos ainda para ligar a AV à classe operária ou ampliar sua influência. Pelo contrário, esse é o período em que "vamos nos encontrar mais agudamente isolados, perdendo até mesmo a área de apoio de que anteriormente dispúnhamos". Constatado esse isolamento, a

\footnotetext{
${ }^{744}$ PARTIDO COMUNISTA DO BRASIL - ALA VERMELHA. Autocrítica, cit., p. 51-52.

${ }^{745}$ PARTIDO COMUNISTA DO BRASIL - ALA VERMELHA. Autocrítica, cit., p. 52.

${ }^{746}$ PARTIDO COMUNISTA DO BRASIL - ALA VERMELHA. Autocrítica, cit., p. 52.

${ }^{747}$ PARTIDO COMUNISTA DO BRASIL - ALA VERMELHA. Autocrítica, cit., p. 52-53.
} 
curta experiência das Unidades de Combate, interrompidas com as prisões de agosto de 69, não será posteriormente retomada.

Neste período, além dos desacertos políticos em nossa prática junto à sociedade, cabe ainda destacar alguns aspectos da política de organização da AV. Em vários momentos fez-se referência a uma estrutura pesada, rígida, construída artificialmente. Se por um lado ficou localizado sua determinação por havermos aprendido dogmaticamente (no campo teórico) a concepção leninista do Partido e por havermos surgido enquanto partido da cisão de uma organização já isolada das massas — “das quais nossa prática vanguardista veio a nos afastar cada vez mais" — falta, no entanto, precisar como se manifestou este artificialismo e o que significou concretamente ${ }^{748}$.

Estruturados fora do contexto social, os organismos da AV — assim como o conjunto de sua estrutura orgânica — não correspondem às necessidades do desenvolvimento da luta social. Formam-se como "estruturas paralelas à luta e à classe ou setor social a que se referem, estruturas formais cujas existências não determinam nem são formadoras de função educadora elou dirigente”. A título de exemplo, o comitê estudantil não organizava os elementos mais ativos e que dirigiam as lutas de seu setor, mas elementos que regra geral “comportavam-se como massa no movimento”. Em outras palavras: não se tratava de “um núcleo de comunistas que desenvolvia um trabalho no movimento estudantil, mas de um punhado de estudantes que se organizava no interior da AV”.

Artificiais e ineficientes, cada organismo em particular é depositário da concepção que os engendrou, infundiram os traços de sua natureza a todas as suas atividades. Montou-se, deste modo, uma aparelhagem que não correspondia às verdadeiras necessidades do trabalho que se desenvolvia e que nela não se assentava: profissionalizam-se desnecessariamente quadros, exigem-se recursos superiores aos que um trabalho correto determinaria. Exige-se, assim, recursos artificiais como os de destacar quadros ou militantes para montar um aparelho assumindo um papel de disfarce clandestino, quando uma aparelhagem montada a partir do trabalho correto utilizaria os recursos materiais e humanos criados por este.

A alternativa correta exigiria menor numero de profissionais e recursos nitidamente inferiores. Esta dinâmica artificial leva a que "não consigamos atuar além dos marcos de nossa própria organização". Com isso, a atividade do conjunto da organização e, sobretudo a de seus principais responsáveis, vai ser consumida quase que exclusivamente com os problemas internos que irão absorver todas as suas potencialidades. Esse fechamento da organização sobre si mesma tende "a transformar sua vida interna numa existência de seita ${ }^{749}$.

A causa mais profunda da inexistência de uma direção política na época reside, porém, no fato de nossa linha nos tornar impermeáveis às questões conjunturais. A análise estática contida no Documento de Crítica, bem como a estratégia e a tática ali definidas, “'resolveriam' todos os problemas políticos da revolução ${ }^{, 750}$.

$\mathrm{O}$ P(AV) não necessita de dirigentes políticos acompanhando e analisando os acontecimentos e mudanças que se desenvolvem na sociedade como na maioria das organizações; necessita de "executores da política traçada e ‘administradores' do aparelho da organização”. Daí decorre abstração teórica e política

\footnotetext{
${ }^{748}$ PARTIDO COMUNISTA DO BRASIL - ALA VERMELHA. Autocrítica, cit., p. 54.

${ }^{749}$ PARTIDO COMUNISTA DO BRASIL — ALA VERMELHA. Autocrítica, cit., p. 54.

${ }^{750}$ PARTIDO COMUNISTA DO BRASIL - ALA VERMELHA. Autocrítica, cit., p. 55.
} 
dos quadros e dirigentes; desestimulados do estudo e da pesquisa, "permanecem com o mesmo conhecimento deformado da teoria marxista-leninista e da situação do país”.

O artificialismo também se refletiu na política de recrutamento e de promoção de quadros. Não estando fundido a luta de classes concreta, a AV assimilou elementos "despreparados, sem qualquer experiência de luta e, portanto, sem as mínimas condições de militância”. O recrutamento era feito entre as pessoas disponíveis conhecidas pelos militantes, e não entre aquelas cuja eficiência concreta, "mesmo quando atuávamos no seio de determinados movimentos". Dessa forma, os militantes, além de não terem a devida formação ideológica proletária, não eram o que deve ser qualquer militante de base de um partido sério: “dirigentes políticos de massa, capazes de levar a política do partido, educá-las, organizá-las e dirigi-las em suas lutas". Este fenômeno, naturalmente, se estendeu ao processo de formação das direções e da promoção de quadros sem o critério da prática, sem terem sido forjados na luta de classes, os quadros acabavam por ser promovidos com base em critério tais como a um conhecimento teórico, facilidade de expressão, certa agudeza política. Isso permite, fatalmente, "a formação de direções com quadros ideologicamente débeis, inexperientes e fracos possibilitando o arrivismo". A experiência iniciada na AV demonstrou o prejuízo que podem causar quadros desse gênero, "quando dos golpes infligidos pela contrarevolução" ${ }^{, 751}$.

O Doc. Autocrítica sugere então uma política conseqüente de construção do partido, apoiada na sua fusão com a luta de classes concreta, a qual deve determinar rigorosas exigências para a assimilação e promoção de quadros. Abandonando o artificialismo, só devem ser recrutados aqueles elementos que se revelam no trabalho concreto da luta de classes, que já assimilaram pelo menos rudimentos da ideologia socialista, e que trazem atrás de si um trabalho real, traduzido na influência que tenham num círculo de elementos da massa. Somente assim "o militante de base será um dirigente político de massas" e somente assim a organização pode ter critérios corretos para promover os mais capazes e ideologicamente mais $\operatorname{preparados}^{752}$.

A Autocrítica ressalta, contudo que neste período, "nossa própria unidade política foi artificial, se refletindo e refletida pelos próprios métodos de direção nacional que aplicávamos". O que de inicio mantivera a unidade da organização fora da luta contra o Comitê Central do Partido Comunista do Brasil; como organização independente, tentamos estabelecer, através do Documento de Crítica, uma linha política que representasse o conjunto da organização. Entretanto, devido sua própria inaplicabilidade, o documento não obteve êxito neste terreno. A unidade da AV existiu, então, apenas formalmente: na verdade, sua direção central se demonstrou inoperante e os diversos Comitês Regionais desenvolveram orientações praticamente independentes. Esse "autonomismo" dos Comitês Regionais criou um risco real de fragmentação da AV, que só veio a ser superado após a adoção do Documento dos "16 Pontos". O "autonomismo" mais um sintoma da existência artificial da organização naquele período. Um verdadeiro partido proletário tem, como um de seus aspectos essenciais, a unidade política garantida por uma direção central conseqüente ${ }^{753}$.

Nesse processo, como direção central, a AV dispôs, de início, de uma Comissão Nacional de Consultas, órgão composto por representação dos Regionais, sem poderes executivos. Posteriormente, criada a Direção Nacional Provisória. Este organismo ainda que dispondo formalmente das características de uma

${ }^{751}$ PARTIDO COMUNISTA DO BRASIL - ALA VERMELHA. Autocrítica, cit., p. 55.

${ }^{752}$ PARTIDO COMUNISTA DO BRASIL — ALA VERMELHA. Autocrítica, cit., p. 56.

${ }^{753}$ PARTIDO COMUNISTA DO BRASIL - ALA VERMELHA. Autocrítica, cit., p. 56-57. 
direção central, "não conseguiu, num primeiro momento, superar o "autonomismo" dos Comitês Regionais". Passamos então por uma aguda crise interna, como resultado da prática incorreta decorrente das concepções do "Documento de Crítica e no OPNTEFLA. Por um lado, a inaplicabilidade destas concepções levou ao espontaneísmo (como no movimento estudantil) ou ao ativismo Interno, em substituição de atividade que se deveria realizar entre as massas. Por outro, a tentativa de sua aplicação, sobretudo no período posterior ao ato Institucional $\mathrm{n}^{\circ} 5$, levou a AV ao "momento mais agudo de seu desvio vanguardista - particularmente sob a forma de militarismo - e ao mais profundo isolamento das massas". Situação que nos deixou com o "flanco aberto aos golpes da repressão" — resultando em diversas e profundas quedas ${ }^{754}$.

Mas, durante mesmo esse período, já se verificava, no interior da $\mathrm{AV}$, resistência à sua prática vanguardista e ao militarismo. "Particularmente a concepção de foco era contestada por alguns quadros e militantes". Devido, principalmente, ao seu afastamento dos centros mais importantes e da direção nacional, em alguns locais a prática militarista não preponderava. Dedicavam-se a conseguir certo grau de ligação com as massas, revelando alguns conflitos com a política nacional da organização. Esses conflitos entretanto, devido à falta de nível teórico e político, manifestavam-se em questões práticas e secundárias da atividade, atingindo claramente a essência da política vanguardista da $\mathrm{AV}^{755}$.

Os rumos cada vez mais extremistas que o vanguardismo passa a assumir na organização, notadamente o caso do "Grupo Especial” e a atividade do Regional de São Paulo, cria um clima de dúvida e insegurança na direção nacional e nos quadros, mostrando que algo estava errado com a política e a prática da $\mathrm{AV}^{756}$.

A reflexão sobre estes fatos, "e não uma compreensão madura da teoria marxista-leninista”, que vai produzir a necessidade de uma mudança na "fisionomia política" da organização ${ }^{757}$.

A Autocrítica passa a abordar o documento dos "16 Pontos", afirmando que ele "propôs de fato, uma profunda mudança na orientação do trabalho da $A V$ ”, mas, na medida em que ele não identificava os verdadeiros desvios de nossas concepções, nem põe a nu suas causas, conserva as mesmas características ideológicas não proletárias do Documento de Crítica. Isto é, na medida em que não identifica autocriticamente o dogmatismo, o subjetivismo e o voluntarismo de nossas concepções ele representa uma continuidade do "radicalismo" pequeno-burguês que orienta nossa organização. Na verdade, "a autocrítica dos "16 Pontos" se centra no militarismo" — e apenas nele — "sem chegar a localizar as determinações ideológicas das quais o militarismo é simples manifestação”, sem conseguir romper radicalmente com essa concepção vanguardista extremada. Assim que, embora chegue a falar em vanguardismo, ainda o faz com uma visão nitidamente unilateral ${ }^{758}$.

Segundo o Doc. Autocrítica o "16 Pontos" passou “de leve pela apreensão correta de que vanguardismo, continuamos a não apreender o papel ideológico da vanguarda, destacando apenas o seu papel dirigente". Mesmo em se considerando essa limitação básica, mesmo levando em conta que os "16 Pontos" ainda é "o documento radical pequeno-burguês, necessário é constatar a importância da transformação que ele inaugura” na AV. Em seus aspectos essenciais, tal importância está em que ele

\footnotetext{
${ }^{754}$ PARTIDO COMUNISTA DO BRASIL - ALA VERMELHA. Autocrítica, cit., p. 57.

${ }^{755}$ PARTIDO COMUNISTA DO BRASIL - ALA VERMELHA. Autocrítica, cit., p. 57.

${ }^{756}$ PARTIDO COMUNISTA DO BRASIL - ALA VERMELHA. Autocrítica, cit., p. 58.

${ }^{757}$ PARTIDO COMUNISTA DO BRASIL - ALA VERMELHA. Autocrítica, cit., p. 58.

${ }^{758}$ PARTIDO COMUNISTA DO BRASIL - ALA VERMELHA. Autocrítica, cit., p. 59.
} 
compreende que "a revolução é feita pelas massas e não pela vanguarda - e que a prática isolada das massas só levaria derrota”. Nesse sentido, já fez uma crítica enérgica à concepção de foco, ao desligamento das massas e aquilo que chama de "ações armadas de vanguarda". Reconhecendo a importância de um trabalho sistemático de agitação, propaganda e organização das "massas básicas" (proletariado e campesinato), "ressaltou a necessidade da ligação com o proletariado nas grandes concentrações da cidade e do campo"759.

Em resumo, os "16 pontos", na medida em que conserva os desvios fundamentais das concepções anteriores, salienta "a necessidade de uma linha de massas que leve à luta armada a curto prazo". A partir dessa compreensão, a reformulação básica consistia em definir onde realizar o investimento das forças partidárias, "onde concentrar o trabalho". Como resposta a estas questões surgem as "diretivas e resoluções" que acompanham o documento - são elas que dão indicações práticas que deveriam guiar a reestruturação interna da AV e a orientação básica das tarefas junto às massas. São elas, portanto, as responsáveis no plano da ação concreta pela mudança da "fisionomia política" da organização ${ }^{760}$.

Como se tratam de orientações extremamente elementares — na verdade, indicações genéricas de como ligar às massas uma organização que até aquele momento estivera delas isolada —, as "diretivas e resoluções" contêm diversas verdades, válidas ainda hoje — na mesma medida em que "ainda hoje continua a existir uma situação de isolamento em relação às massas”. Entretanto, como o pensamento no qual elas estão inseridas continuava a ser um pensamento "radical" pequeno-burguês, sua visão geral revela uma orientação errônea $^{761}$.

Assim é que elas definem a necessidade de concentrar as principais forças da AV junto à classe operária, nos principais centros industriais, lançando nessa tarefa o maior número possível de militantes; insistem na necessidade de lutar pelo soerguimento da luta de classe operária, destacando a importância da agitação e propaganda das lutas econômicas; por fim preconizam uma reformulação interna que visa dar unidade à organização e fortalecer o órgão dirigente, bem como reorientar a política de finanças, transformando-a num instrumento de educação e numa resultante do trabalho político entre as massas ${ }^{762}$.

As principais manifestações de permanência dos desvios encontram-se nas "constantes referências à luta armada imediata": "tomar como ponto de partida (...) e mostrar o caminho armado" (diretriz 2, ponto 2); "greves, piquetes, auto-defesa, sabotagens, grupos de propaganda armada" (diretriz 2, ponto 4); "Deslocar quadros (...) objetivando a guerrilha rural “ (diretriz 3, ponto 1). Mesmo em orientações que não fazem referência direta à luta armada, "os ecos do nosso voluntarismo e vanguardismo continuam soando",763.

Para aplicação dos "16 Pontos"- e de acordo com uma de suas resoluções — a AV se submeteu a uma reestruturação orgânica, buscando uma estrutura partidária leninista. Empreendemos a reorganização de cima para baixo, fortalecendo a direção central. A unidade política conseguida em torno dos "16 Pontos" e a reestruturação orgânica puseram fim, no fundamental, ao "autonomismo" dos Regionais. Porém, essa

\footnotetext{
${ }^{759}$ PARTIDO COMUNISTA DO BRASIL - ALA VERMELHA. Autocrítica, cit., p. 59-60.

${ }^{760}$ PARTIDO COMUNISTA DO BRASIL — ALA VERMELHA. Autocrítica, cit., p. 63.

${ }^{761}$ PARTIDO COMUNISTA DO BRASIL - ALA VERMELHA. Autocrítica, cit., p. 63-64.

${ }^{762}$ PARTIDO COMUNISTA DO BRASIL - ALA VERMELHA. Autocrítica, cit., p. 64.

${ }^{763}$ PARTIDO COMUNISTA DO BRASIL - ALA VERMELHA. Autocrítica, cit., p. 64.
} 
reestruturação aplicada ainda nos marcos do vanguardismo fez com que "se criassem organismos $e$ comissões artificiais", sem apoio nas reais necessidades do trabalho de massas ${ }^{764}$.

O Doc. Autocrítica enfoca neste ponto as conseqüências de "Nossa Prática", quando afirma que "não foi fácil, porém - e nem se completou —, a passagem de uma prática política isolada para a de ligação com as massas, dada a permanência de concepções voluntaristas e de práticas vanguardistas". Sobretudo nas condições de uma organização cujos militantes estavam em grande parte na clandestinidade ou profissionalizados, alguns em decorrência da repressão conseqüente o AI-5, mas principalmente por causa da política anterior da AV, "voltada para a preparação da infra-estrutura como base de apoio à ação de grupos isolados". Além das dificuldades naturais impostas pelas condições objetivas — vigilância e repressão da ditadura - a "desprofissionalização" e a conseqüente ligação à produção "se dá de modo lento e encontra resistências, algumas por oposição às diretivas”, a maioria pela falta de consciência em relação ao seu significado. Deformados pela prática anterior em que os recursos da organização não eram frutos do trabalho e da influência política entre as massas, "muitos perduraram por longo tempo dependendo materialmente da organização" ${ }^{, 765}$.

As principais dificuldades vão surgir, entretanto, "da própria limitação e visão errônea dos ' 16 Pontos"'.Ao se lançar no trabalho entre as massas, a AV vai com uma visão estreita sobre as formas de organização das massas, não compreendendo a necessidade de aproveitar todas as formas de organização legais existentes, como ponto de apoio para o trabalho clandestino e para as organizações ilegais. Conseqüentemente, se propunha como forma principal a organização em grupos de "Unidade Operária", isto é, uma organização clandestina em torno deste jornal. A idéia que estava por trás de tal proposta era a de fazer a "Unidade Operária" representar o mesmo papel que na Rússia fora desempenhado pelo "Iskra" idéia essa que decorria de uma leitura mal assimilada de uma transposição mecânica da obra de Lênin "Por onde começar”. Confundíamos, pois, a organização parapartidária com as organizações amplas das massas por isso mesmo, não sabíamos aproveitar as organizações legais e nelas fazer um trabalho paciente de elevação de consciência de classe. Não atuávamos no sentido do soerguimento do movimento de massas: limitávamo-nos a organizar os elementos próximos da AV (com perspectivas de recrutamento), não sabendo o que fazer em termos da organização das massas não partidárias. Em suma, não compreendíamos a relação que existe entre o movimento de massas e a construção do Partido ${ }^{766}$.

As quedas em dois Regionais no final de 1970 e as de 1971, na direção nacional, revelam toda a debilidade orgânica e ideológica que ainda persiste na organização, a concepção vanguardista de ligação com as massas e o conteúdo claro da política da época iniciada com a aplicação dos '16 Pontos",,767.

Essa política conduziu à instalação de uma aparelhagem voltada para a realização de "grandes" tarefas de apoio ao trabalho de ligação com as massas e de divulgação da organização. Essa aparelhagem, centralizada e vulnerável, era desproporcional às forças da organização e em desacordo com o volume de nosso trabalho e de nossa penetração nas massas. Não só foi desmantelada rapidamente pela repressão, como multiplicou os seus golpes, permitindo atingir através dessa estrutura (aparelhagem de direção nacional) os

\footnotetext{
${ }^{764}$ PARTIDO COMUNISTA DO BRASIL - ALA VERMELHA. Autocrítica, cit., p. 64-65.

${ }^{765}$ PARTIDO COMUNISTA DO BRASIL - ALA VERMELHA. Autocrítica, cit., p. 65.

${ }^{766}$ PARTIDO COMUNISTA DO BRASIL - ALA VERMELHA. Autocrítica, cit., p. 66.

${ }^{767}$ PARTIDO COMUNISTA DO BRASIL - ALA VERMELHA. Autocrítica, cit., p. 67.
} 
Regionais e o trabalho de base do Partido. Deixou claro, ainda, de forma brutal, a insuficiência ideológica da organização, que se refletiu em diversos comportamentos débeis, chegando alguns ao nível da traição.

O balanço dessa trajetória da AV indica que, até então, suas ligações com as massas permaneciam precárias, sua composição social não se modificara e o artificialismo na sua política de organização ainda se refletia numa aparelhagem não assentada na fusão com a luta de classe concreta. É necessário destacar que, devido a todos esses fatores e devido ao reduzido tamanho da organização, a AV "não desempenhou um papel significativo ao processo político do período". Sua importância na sociedade foi — e ainda é — extremamente reduzida, uma vez que é praticamente nula sua influência na política entre as massas, e muito pequena sua capacidade de manter estreitos laços com a classe operária. O reconhecimento dessa debilidade deve servir de estímulo para que todos os quadros e militantes da organização ${ }^{768}$.

Autocrítica passa agora a enfocar a situação da Ala Vermelha em 1974 e suas tarefas, inicialmente salientando que com os golpes sofridos em 71, a organização teve "seus principais dirigentes presos, todos os seus segredos desvendados, sua infra-estrutura destruída e seus organismos desmantelados"769.

A principal tarefa de então era "impedir o colapso total, resguardando e rearticulando o restante da organização". Todas as medidas tomadas na época visam este objetivo, o que "obrigou a um recuo no trabalho revolucionário" ${ }^{, 770}$.

No entanto, a própria sobrevivência política da organização não dependia somente dessas medidas, mas sim de uma "profunda transformação política e ideológica que retificasse o conjunto de erros e desvios que eram a base” dos reveses sofridos.

O cumprimento desta tarefa pesada teria de ser feito a partir de uma "organização extremamente enfraquecida". O contingente da AV, reduziu-se mais ainda caracterizando-se "por apresentar um despreparo político e ideológico muito grande”, mais claramente revelado em condições adversas. Soma-se a isto a perda de apoio da maioria dos aliados e simpatizantes que, devidos aos acontecimentos, "mostravamse receosos e sem confiança na organização”. Essa situação gera uma confusão político-ideológica interna, onde se desenvolvem posições errôneas diversas: negação da necessidade do partido — desde o liquidacionismo até o obreirismo praticista - e o "teoricismo" — que nega a possibilidade da realização do trabalho entre as massas sem uma linha política acabada - o que implicava em parar a atividade prática para aprofundar o conhecimento teórico ${ }^{771}$.

Segue-se um período de desagregação com o afastamento de militantes e aliados. A direção, por sua vez, denotando fraqueza política em condições precárias de funcionamento coletivo, foi incapaz de sustar em tempo mais curto este processo de desagregação interna ${ }^{772}$.

Não obstante tudo isto, a AV sobreviveu não só pela compreensão global adquirida da origem dos erros e desvios mas principalmente pelas medidas práticas que tomou: "orientação de integração nas fábricas e bairros proletários, mudança da política de infraestrutura, abandono dos métodos vanguardistas na ligação com as massas"

\footnotetext{
${ }^{768}$ PARTIDO COMUNISTA DO BRASIL - ALA VERMELHA. Autocrítica, cit., p. 67.

${ }^{769}$ PARTIDO COMUNISTA DO BRASIL - ALA VERMELHA. Autocrítica, cit., p. 68.

${ }^{770}$ PARTIDO COMUNISTA DO BRASIL - ALA VERMELHA. Autocrítica, cit., p. 68.

${ }^{771}$ PARTIDO COMUNISTA DO BRASIL - ALA VERMELHA. Autocrítica, cit., p. 68.

${ }^{772}$ PARTIDO COMUNISTA DO BRASIL - ALA VERMELHA. Autocrítica, cit., p. 68.

${ }^{773}$ PARTIDO COMUNISTA DO BRASIL - ALA VERMELHA. Autocrítica, cit., p. 69.
} 
Já se processa um encaminhamento — por meio das "circulares" de diretivas centrais e na discussão em toda a organização — através da qual se "abandona, efetivamente, no plano teórico, as concepções vanguardistas e espontaneístas, bom como o dogmatismo, as pretensões futurológicas” de definir cabalmente um programa, uma estratégia e uma tática que correspondem, hoje, "a todos os problemas da revolução, além da visão dogmática sobre a própria questão do partido" ${ }^{\text {,774 }}$.

A mudança do modo pelo qual a AV enfoca o movimento revolucionário tem base na "mudança de visão em relação à sociedade brasileira". Anteriormente se deslocava o centro de interesse da organização para a questão do campo, uma vez que este era considerado o palco principal da luta e o campesinato o contingente principal da revolução.Hoje, entretanto, a análise da sociedade brasileira — livre das transposições mecânicas - nos indica o papel preponderante do movimento operário em nossa revolução. Preponderante não apenas devido ao peso que esta classe adquire na "sociedade brasileira enquanto sociedade capitalista” — mas também devido à compreensão da necessidade ideológica de um partido enraizado na classe. Em outras palavras: compreende-se que o proletariado não é apenas o fator dirigente do processo. Além do dirigente, ele desempenha papel decisivo como participante da luta revolucionária.

Nos “16 Pontos” já ocorre uma mudança na orientação da AV nesse sentido, mas sem ir ao fundo do problema nem fazer uma autocrítica da posição anterior. Agora completamos a reformulação de nossa visão, colocando de fato - na teoria e na prática - a classe operária e o movimento operário como o centro de nossas preocupações e atividades. No entanto, essas mudanças são apenas o primeiro passo para que nos situemos corretamente diante da sociedade, do movimento revolucionário e das massas, e para que definamos as tarefas que, na situação atual, o que permitirá superar o impasse em que se encontra a revolução brasileira. Para traçar as indicações gerais dessas tarefas, dizia o Doc. Autocrítica, torna-se necessário apreciar a conjuntura atual da sociedade e do movimento revolucionário no Brasil ${ }^{775}$.

A conjuntura atual - fruto de um desenvolvimento capitalista acelerado e dependente (sob a condição política de intenso acirramento da ditadura) —, se caracteriza pela "inexistência de lutas significativas das massas e pelo esfacelamento das organizações de esquerda"776.

$\mathrm{O}$ aspecto conjuntural que nos interessa mais de perto e como elemento central de nossas preocupações é a situação da classe operária e de seu movimento - "uma vez que este é o aspecto decisivo para a definição das tarefas que se impõem ao movimento revolucionário”. Atualmente o movimento operário se encontra num estado de acentuada apatia. Os últimos movimentos de algum vulto data de 1968 — as greves de Osasco e Contagem —, compondo um quadro de "profundo refluxo que vem desde 1964". Particularmente nos últimos anos, a inexistência de mobilizações é a regra - observam-se apenas esporádicos e reduzidos movimentos tolerados e legais, “nos quadros permitidos pela legislação da ditadura”. Mais recentemente têm surgido erupções em alguns centros de grandes concentração industrial, lutas espontâneas e isoladas umas das outras, de pequena envergadura (paralisações parciais, operações tartaruga) que "buscam formas que não se enquadram na legislação repressiva da ditadura”. Essas lutas, de significado restrito, não mudam o quadro geral da apatia da classe refletindo entretanto, o alto grau de exploração a que ela está submetida e uma situação particular do desenvolvimento capitalista do país. O quadro geral é de uma classe operária inerte, incapaz de movimentos mais vigorosos, ainda que ao nível da luta econômica. Os motivos

${ }^{774}$ PARTIDO COMUNISTA DO BRASIL — ALA VERMELHA. Autocrítica, cit., p. 69.

${ }^{775}$ PARTIDO COMUNISTA DO BRASIL — ALA VERMELHA. Autocrítica, cit., p. 69.

${ }^{776}$ PARTIDO COMUNISTA DO BRASIL - ALA VERMELHA. Autocrítica, cit., p. 70. 
mais imediatos dessa situação encontram-se no baixíssimo nível de consciência e organização da classe, ao lado da eficiente política repressiva da ditadura. A classe operária no Brasil hoje em dia, não dispõe sequer de uma consciência sindicalista; e isto está relacionado com a inexistência prática de qualquer nível de organização independente desta classe. Os próprios "sindicatos oficiais, controlados pela ditadura" — e naturalmente a serviço da burguesia —, têm pouca penetração na classe operária, o que se reflete no baixo grau de sindicalização. Tudo isto nos dá a visão de uma classe, na prática, quase totalmente desorganizada ${ }^{777}$.

A fraqueza do movimento operário no Brasil tem causas inerentes a seu próprio processo de formação. Cabe destacar nesse sentido, como aspectos mais marcantes, a estrutura organizativa do sindicalismo populista, a correspondente orientação "nacional-desenvolvimentista” e a incorreta atuação do PCB. O sindicalismo oficial afirmou-se como principal forma de organização da classe operária. Sua estrutura vertical tende a dificultar as trocas de experiência e a unidade entre as várias categorias profissionais. A existência do imposto sindical representa a pedra de toque da dependência dos sindicatos oficiais do Estado - e explica em parte a falta de dinamismo desses próprios sindicatos. Na medida em que recebem verbas referentes a toda sua categoria profissional, independentemente do número de sindicalizados, os sindicatos oficiais tendem a se mostrar mais solidários ao Estado — via Ministério do Trabalho — , que a seus associados, desinteressando-se mesmo em incentivar a sindicalização. Por outro lado, a orientação "nacional desenvolvimentista" que prevaleceu até 64 imprimiu ao movimento operário uma forte tendência a se solidarizar com os interesses da burguesia nacional, entravando a formação de uma consciência de classe $^{778}$.

Motivados de cima para baixo pelos sindicatos oficiais em torno de interesses alheios aos de sua classe, lutando também por reivindicações econômicas, mas "sem com isso identificar nos sindicatos oficiais os instrumentos de defesa de seus interesses” — os operários não chegam sequer a desenvolver uma consciência "sindicalista" consistente ${ }^{779}$.

É necessário observar que estas características do movimento operário encontram plenas condições para se desenvolver entre uma classe operária jovem, isto é, cuja composição se renova rapidamente, devido ao aumento de seu contingente, provocado pela industrialização acelerada, e também jovem pelo pouco tempo de industrialização no país. Além disso, há a questão da "origem camponesa que contribui para rarefazer a possibilidade do desenvolvimento de uma consciência de classe”. Esses fatores objetivos favorecem a fluidez do mundo subjetivo do proletariado, criando um terreno fértil para a penetração das deformações da ideologia burguesa, particularmente aquelas instrumentadas por um sindicalismo oficial que atende aos interesses das classes dominantes. Por outro lado, o fator que poderia se contrapor a essas tendências — uma educação ideológica realizada pela intelectualidade socialista militante — simplesmente não existe. $\mathrm{O}$ PCB, através de suas políticas concretas, reforçou efeitos negativos do populismo. Não levou à classe a ideologia socialista - e pior que isso, nem mesmo combateu o sindicalismo oficial, buscando criar um movimento operário independente. Mesmo que em certos momentos possa ter conseguido alguma penetração na massa operária, o PCB falhou ao longo de toda sua história como vanguarda da classe, não conseguindo subtraí-la à influência da burguesia.Tentativas pouco conseqüentes, como a dos "sindicatos paralelos" não forneceram alternativas de organização autônoma para o proletariado. O que nos permite

${ }^{777}$ PARTIDO COMUNISTA DO BRASIL - ALA VERMELHA. Autocrítica, cit., p. 71.

${ }^{778}$ PARTIDO COMUNISTA DO BRASIL - ALA VERMELHA. Autocrítica, cit., p. 71-72.

${ }^{779}$ PARTIDO COMUNISTA DO BRASIL - ALA VERMELHA. Autocrítica, cit., p. 72. 
afirmar que, falando como educador ideológico e como dirigente político, o PCB não foi — nem é — o partido de vanguarda da classe operária. Como nenhuma outra tendência de esquerda, até hoje, se aproximou do cumprimento desse papel, podemos registrar como um dos fatores fundamentais para a situação atual de atraso do movimento operário, justamente a inexistência do partido de vanguarda da classe operária em nosso país ${ }^{780}$.

O surgimento de outras organizações de esquerda além do PCB, através da fragmentação iniciada já antes de 64, não mudou a situação. Em certo sentido, agravou-a, pois além de não dar origem a qualquer partido que assumisse o papel de vanguarda da classe operária, deu surgimento a tendências que se afastaram ainda mais daquela classe: as que negaram a necessidade do Partido, como a "Ação Libertadora Nacional" e a "Vanguarda Popular Revolucionária", substituindo-o pela ação isolada de pequenos grupos mantiveram-se voluntariamente distantes das massas. Outras como o Partido Comunista do Brasil, vendo no campesinato o verdadeiro sujeito da revolução, não exerceram influência política na classe da qual, curiosamente, se proclamavam vanguardas; e, ainda, as que se voltam para o proletariado mas, devido aos desvios de suas orientações, falham em se aproximar dele. A “Ação Popular”, por exemplo, levou uma política voluntarista, agitando questões que resultaram muitas vezes em erupções imediatas e momentâneas, mas que nunca chegaram a modificar a consciência da massa que atingiam e não organizaram, e por fim, acabou perdendo cada um dos vínculos que conseguira estabelecer. A organização Partidária Marxista-Leninista Política Operária, por sua vez, tentou realizar uma propaganda socialista calcada apenas no doutrinarismo teórico. Esse voluntarismo teoricista não logra, é claro, estabelecer laços com a massa; ele só tem condições de ser razoavelmente aceito entre os setores intelectualizados da pequena-burguesia. Por fim a AV "que oscila entre o militarismo e o agitacionismo vanguardista”, permanecendo distante das massas ${ }^{781}$.

Assim, desligadas das massas, as organizações de esquerda não combateram as tendências ideológicas burguesas do populismo e do revisionismo, deixando as massas proletárias sob a influência dessas tendências. Além disso, nos anos mais recentes, "a esquerda foi profundamente golpeada pela repressão": várias organizações foram aniquiladas, outras sofreram golpes bastante sérios para, na prática, perderem sua capacidade de atuação. Os marxistas-leninistas e outros revolucionários encontram-se hoje isolados com poucos laços organizativos entre si e mergulhados em profunda confusão relativamente aos passos que devem ser dados para retirar o processo revolucionário de seu refluxo. Registram-se tão somente algumas tentativas de rearticulação, bem como o surgimento de círculos independentes que buscam estudar o marxismo-leninismo e/ou realizar algum trabalho de ligação com a massa ${ }^{782}$.

É fácil definir, a partir da análise precedente, os principais elementos que comprovam o baixo nível das condições subjetivas da classe operária: "desorganização, falta de uma consciência de classe, inexistência de seu partido de vanguarda" — e, paralelamente — "desligamento dos marxistas-leninistas em relação às massas e a presença de diversas tendências ideológicas não proletárias no seio da esquerda”. Observando os entraves que o sindicalismo oficial, a repressão e o bombardeio ideológico da burguesia colocam para o desenvolvimento do movimento operário torna-se clara a necessidade, para os revolucionários, da realização de tarefas que auxiliem no soerguimento do movimento operário e a ele imprimam uma orientação revolucionária. Com isso não se quer cair no voluntarismo de afirmar que o

\footnotetext{
${ }^{780}$ PARTIDO COMUNISTA DO BRASIL — ALA VERMELHA. Autocrítica, cit., p. 72.

${ }^{781}$ PARTIDO COMUNISTA DO BRASIL - ALA VERMELHA. Autocrítica, cit., p. 73.

${ }^{782}$ PARTIDO COMUNISTA DO BRASIL - ALA VERMELHA. Autocrítica, cit., p. 73-74.
} 
movimento operário dependa exclusivamente da ação dos revolucionários de vanguarda para realizar quaisquer movimentos. O agravamento das condições objetivas deverá levar à intensificação da luta espontânea. Trata-se, isto sim, de não cair no espontaneísmo de esperar o surgimento de movimentos, para então atuar, praticamente a reboque deles. As tarefas que cabem, hoje, aos revolucionários, são aquelas que acelerando a formação das condições subjetivas das massas, permitirão romper os entraves contrarevolucionários e preparar o surgimento de um movimento "verdadeiramente de massas e verdadeiramente revolucionário" - Lênin em "Doença Infantil". Nesse sentido, salta à vista que uma das tarefas é " $a d a$ ligação dos marxistas-leninistas às massas, particularmente à classe operária, sua fusão com a luta de classes concreta”. Ligação que visa educá-las política e ideologicamente e junto a elas e com elas descobrir as formas de luta e de organização capazes de superar o atual refluxo ${ }^{783}$.

No curso desse processo e na medida em que os marxistas-leninistas se fundam à luta de classes concreta, coloca-se "a tarefa de construir o partido de vanguarda do proletariado" — garantia de que todo o movimento se orientará no sentido do cumprimento do papel histórico da classe operária. Finalmente, para que estas tarefas possam ser levadas a bom termo torna-se imprescindível empreender uma "vigorosa luta ideológica contra todas as tendências não proletária existentes não só na própria classe operária, como no seio da esquerda" ${ }^{, 784}$.

A partir deste ponto a Autocrítica passa a analisaro Desenvolvimento Capitalista Acelerado e as condições objetivas da classe operária, registrando inicialmente que o "grande atraso das condições subjetivas da classe operária" coloca como principal tarefa hoje o trabalho de organização e educação das grandes massas proletárias. A realização desse trabalho encontra condições objetivas favoráveis — superexploração e deterioramento das condições de vida dos trabalhadores - decorrentes da política de desenvolvimento capitalista acelerado adotada pela burguesia integrada como solução para a crise que afetou o sistema na primeira metade da década de 60.

Os aspectos exteriores dessa nova orientação traduzem-se nas altas taxas de crescimento do Produto Nacional Bruto nos últimos cinco anos e no relativo controle da inflação. Esse crescimento da economia se tornou possível, a partir de opções tomadas desde 64, dirigindo-a para um mercado consumidor de altas rendas e para a exportação. A presença crescente do capital imperialista e de sua tecnologia avançada aplicada em setores já voltados para um mercado de altas rendas - condicionava tais opções, na mesma medida em que tornava a economia brasileira mais dependente em relação aos monopólios estrangeiros. A penetração do capital imperialista garantiu-lhe o controle dos setores fundamentais da produção, inclusive através do capitalismo de Estado - empresas estatais —, na medida em que este é colocado a serviço da classe que detém a hegemonia do poder. Esse processo de desenvolvimento não só se dirige para um mercado consumidor de altas rendas já existente, mas também o cria - amplia - e reforça. A tendência de concentração de rendas já existia na economia brasileira desde há muito, particularmente devido à estrutura de propriedade rural. A partir de 64, tal tendência é reforçada por uma política dirigida expressamente nesse sentido. A política de reconcentração de rendas determina, ao mesmo tempo, um reforço do processo de monopolização da economia e o fortalecimento de um mercado interno de alto poder aquisitivo, ainda que restrito como área social. Dele vão participar, além da própria grande burguesia e dos outros setores

\footnotetext{
${ }^{783}$ PARTIDO COMUNISTA DO BRASIL - ALA VERMELHA. Autocrítica, cit., p. 74-75.

${ }^{784}$ PARTIDO COMUNISTA DO BRASIL - ALA VERMELHA. Autocrítica, cit., p. 75.
} 
burgueses, as camadas superiores e ascendentes da classe média —que somam aproximadamente $10 \%$ da população —, cujo poder aquisitivo é artificialmente ampliado por mecanismos de crédito direto ${ }^{785}$.

Ao voltar-se para a exportação, a política econômica visa não apenas encontrar novos mercados para os produtos manufaturados — garantindo a colocação de uma produção em crescimento—, como também a “obtenção de divisas que garantam a capacidade de importar" — sobretudo bens de produção e matérias prima $^{786}$.

Para que a economia crescesse de forma acelerada, ampliou-se a capacidade de investir. A entrada do capital imperialista não bastaria — na verdade, de acordo com os interesses do imperialismo, essa entrada de capitais objetiva fundamentalmente controlar a economia. No que diz respeito à capacidade de investir, o capital imperialista, além de contribuir decisivamente — enquanto investimento direto — para a "arrancada inicial" de importantes setores do atual desenvolvimento, participa, sob a forma de empréstimos, da formação do capital necessário à expansão, como "poupança externa” complementar "a "poupança interna” considerada insuficiente para manter sozinha taxas de crescimento de 9 a $10 \%$ anuais. Como ocorre nas economias de desenvolvimento capitalista acelerado (a exemplo da Alemanha Ocidental e Japão), “a base da acumulação necessária de capital - a “poupança interna - é a superexploração do proletariado”, isto é, trata-se de extrair da classe operária altas taxas de mais valia super-dimensionadas, muito além da exploração capitalista "normal". A base evidentemente é a compressão salarial, o "arrocho". Mas a ele se somam inúmeras outras formas de aumentar a parcela de trabalho não pago. A inflação é uma delas, e a inflação se torna necessária num processo de desenvolvimento acelerado: o propalado controle da inflação, fora a evidente carga demagógica que o acompanha, visa tão somente mantê-la em níveis previsíveis, que possam ser computados nos cálculos empresariais, mas nunca a acabar com ela ${ }^{787}$.

Outros recursos como o Programa de Integração Social e o Fundo de Garantia por Tempo de Serviço realizam uma poupança aplicável como investimento pelo grande capital. Ainda que de forma indireta, os incentivos fiscais operam no mesmo sentido. Se ainda acrescermos a tudo isto o aumento da produtividade não acompanhado pelo aumento do salário, a extensão real da jornada do trabalho através do recurso às horas extras e o aumento da intensidade do trabalho (técnicas de racionalização), teremos uma idéia aproximada do volume de trabalho não pago extraído do operário brasileiro e localizaremos a verdadeira fonte da capacidade de investir que permitiu à grande burguesia industrial impulsionar o desenvolvimento acelerado ${ }^{788}$.

A superexploração do operário é acompanhada, também, por um emprego mais intenso de mão-de-obra feminina e do menor (sub-remuneradas) e por péssimas condições de trabalho: as empresas, visando baixar custos de produção, não instalam equipamentos de proteção ao trabalhador; não cumprem a legislação e estimulam, através dos chamados prêmios de produção, o desrespeito, pelos próprios operários, das normas mais elementares de segurança pessoal em função de minguados aumentos de salário. Daí o índice de acidentes de trabalho e doenças profissionais no Brasil estar entre os mais altos. Por outro lado, devido ao baixo nível de consciência e organização, as empresas agem discricionariamente em relação aos operários: mudanças no ritmo de trabalho, dispensas, etc. são questões resolvidas pelas direções das empresas sem a

\footnotetext{
${ }^{785}$ PARTIDO COMUNISTA DO BRASIL — ALA VERMELHA. Autocrítica, cit., p. 76.

${ }^{786}$ PARTIDO COMUNISTA DO BRASIL - ALA VERMELHA. Autocrítica, cit., p. 77.

${ }^{787}$ PARTIDO COMUNISTA DO BRASIL - ALA VERMELHA. Autocrítica, cit., p. 77.

${ }^{788}$ PARTIDO COMUNISTA DO BRASIL - ALA VERMELHA. Autocrítica, cit., p. 78.
} 
mínima possibilidade de interferência dos trabalhadores. Além disso, "o próprio crescimento industrial, aumentando seu contingente de operários, sua concentração e seu poder de barganha" — sobretudo devido à demanda crescente de operários especializados —, cria continuamente melhores condições objetivas para o desencadeamento de lutas ${ }^{789}$.

Finaliza seu apanhado o Doc. Autocrítica salientando que todas as condições expostas agem nesse sentido na medida em que criam tensões cada vez maiores. A manutenção da situação só é possível através da permanente vigilância repressiva, que interfere nas manifestações mais elementares de descontentamento dos operários, e devido à falta de condições subjetivas da classe. O que nos traz de volta à questão da falta de consciência e organização que permitam aproveitar as condições objetivas existentes. O proletariado necessita partir das reivindicações mais elementares, com as formas de luta e de organização que estiverem de acordo com o seu próprio nível, a cada momento; é necessário que os revolucionários saibam aproveitar cada situação dessas para educar as massas, passando pela experiência concreta da luta para os níveis mais elevados" $" 790$.

Neste ponto o Doc. Autocrítica passa examinar criticamente a situação no campo sob o desenvolvimento capitalista acelarado, ressaltando que ele também implementa a rápida penetração do capitalismo no campo. A grande burguesia industrial e financeira realiza grandes investimentos na agricultura e na pecuária. Configuram-se "empresas capitalistas no campo" que, tanto pela racionalização da produção quanto pelas relações de produção que estabelecem, modificam a estrutura agrária tradicional. A oligarquia latifundiária, nas regiões onde se registra este desenvolvimento, associa-se ao grande capital, "perdendo expressão como classe social diferenciada". Os novos empreendimentos se dirigem tanto para o abastecimento do mercado interno quanto para a exportação, e a presença do capital estrangeiro é significativa. Importa assinalar que esse fenômeno determina o deslocamento do controle da economia rural para a área do grande capital monopolista, tornando paulatinamente de menor importância, no conjunto da economia, o capital da burguesia agro-exportadora "tradicional"791.

Diz a Autocrítica que a penetração das grandes empresas capitalistas no campo "aumenta a concentração de assalariados agrícolas", ao mesmo tempo em que determina um "crescimento impressionante do contingente de camponeses sem terra e sem trabalho certo". O Doc. Autocrítica destaca que as principais modificações introduzidas pela penetração capitalista no campo, que cria, por outro lado, concentrações de proletariado rural e outros assalariados agrícolas e, por outro lado, expulsa os camponeses da terra me ritmo mais acelerado do que o faziam os setores agrários "tradicionais". Os camponeses sem terra geralmente vão aumentar o número de marginalizados que gravitam na periferia de alguns centros urbanos sem se integrarem à economia urbana, constituem uma massa flutuante de assalariados temporários de empreendimentos agrícolas — os trabalhadores volantes ou "bóias frias". Todos esses fenômenos no campo dão origem a tensões sociais que, com relativa freqüência, explodem em conflitos isolados e espontâneos. Entretanto, as condições subjetivas das massas rurais encontram-se num nível ainda mais baixo que os da classe operária. No campo, nem mesmo a experiência sindical-populista adquiriu significância. As massas rurais sempre estiveram marginalizadas dos processos políticos da sociedade brasileira. Todas as

\footnotetext{
${ }^{789}$ PARTIDO COMUNISTA DO BRASIL - ALA VERMELHA. Autocrítica, cit., p. 78.

${ }^{791}$ PARTIDO COMUNISTA DO BRASIL — ALA VERMELHA. Autocrítica, cit., p. 79.
} 
transformações que caracterizaram o desenvolvimento capitalista e a revolução burguesa no país não contavam com sua participação. A reação espontânea às condições da miséria, opressão e exploração não encontrou no campo formas políticas de expressão, manifestando-se muitas vezes no terreno do banditismo e do misticismo. A isso corresponde uma igual incapacidade do PCB para organizar e dirigir as lutas rurais. Embora falasse, em seus programas, do campesinato desde a época de sua fundação, só na década de 50 é que alguma atividade prática vai se dirigir nesse sentido. Mesmo assim o PCB não conseguiu ligar a luta dos camponeses ao conjunto da luta revolucionária. O único período em que há um início de incorporação dessas massas no processo político é aquela que vai dos últimos anos da década de 50 até 64. por um lado, a burguesia nacional começava a se interessar em atrair as massas rurais para a economia do mercado, por outro, a agitação no campo contava com um mínimo de organização construída tanto pelo PCB quanto pelas Ligas. A experiência das Ligas e as tentativas de sindicalização rural vão constituir o único momento significativo da política revolucionária no campo. Mesmo sem levar em conta os erros ideológicos e políticos que caracterizaram estas experiências, sua vida foi "demasiado curta criar condições subjetivas necessárias ao desenvolvimento da luta revolucionária”.

$\mathrm{O}$ golpe de 64 "reprime radicalmente a agitação rural e leva as massas camponesas a retornarem a uma situação de apatia e desorganização — choques que posteriormente ainda se verificam até hoje — "são o produto espontâneo de condições de exploração e opressão insuportáveis". Muito embora a grande maioria das organizações de esquerda surgidas das cisões do velho partido tenham colocado o campo — a guerrilha rural — como eixo de seus programas —inclusive a AV, praticamente nenhuma delas consegue sequer dar os primeiros passos nesse sentido. Quase única e lamentável exceção é o PC do B: "o desencadeamento da guerrilha na região do Araguaia leva à prática uma concepção voluntarista similar à do foco ainda que disfarçada verbalmente de 'guerra popular'”. A ação armada numa “região de população extremamente rarefeita, distante de qualquer zona agrária econômica ou socialmente vital”, além de permitir seu isolamento estratégico pela repressão, não tem o menor efeito sobre a consciência e a organização das massas rurais. Acresça-se a tudo isso o fato de o surgimento dessa guerrilha se dar extemporaneamente, em condições de refluxo da revolução ${ }^{792}$.

Hoje em dia se torna claro que o trabalho dos marxistas-leninistas no campo se deve dirigir para as regiões onde existem "grandes concentrações de camponeses elou assalariados rurais, determinadas pelo desenvolvimento capitalista do campo e áreas de tensão social” e não como preconizam as orientações militaristas, para as regiões "estrategicamente" favoráveis do ponto de vista militar. Em cada região específica, em face das condições objetivas existentes, os marxistas-leninistas devem lutar pela organização dos camponeses e assalariados rurais —assumindo particular importância a questão dos sindicatos rurais. A questão do campo exige particular atenção dos marxistas-leninistas porque lá, mais que em qualquer outro lugar, o abismo entre a rápida maturação das condições subjetivas pode levar a aventuras espontaneístas, trazendo situações prejudiciais para a revolução dirigida pelo proletariado ${ }^{793}$.

O Doc. Autocrítica se lança agora para realçar a importância e a necessidade da luta pelas liberdades políticas, destacando que mesmo considerando a difícil situação das suas camadas inferiores, não se pode falar hoje — como se poderia em 1967 ou 1968 — de pauperização da pequena burguesia, ao menos nas

${ }^{792}$ PARTIDO COMUNISTA DO BRASIL - ALA VERMELHA. Autocrítica, cit., p. 80-81.

${ }^{793}$ PARTIDO COMUNISTA DO BRASIL — ALA VERMELHA. Autocrítica, cit., p. 81. 
camadas médias e superiores. Entretanto, existem tensões latentes: setores prejudicados pela monopolização buscam ter voz política para protestar, os setores ascendentes também o fazem, na medida em que toda camada que passa a desempenhar um certo papel econômico, procura influir politicamente nos centros de decisão ${ }^{794}$.

É necessário destacar, no caso das camadas médias, o aspecto determinado pelo acesso à cultura que, criando certa consciência política, cria igualmente uma tendência à participação. Intelectuais e estudantes assumem, quase sempre, "a postura de oposição à ditadura”, principalmente por motivos políticos, "em face das restrições às liberdades democráticas”. O movimento estudantil, além de lutar por suas reivindicações específicas, "tende a assumir a luta contra a ditadura, pelas liberdades políticas"795.

O proletariado, por sua vez, tem necessidade vital de liberdade política que lhe garanta melhores condições de expressão, organização e mobilização. Embora as grandes massas proletárias não tenham ainda consciência dessa necessidade, e por isso mesmo, cabe aos revolucionários despertá-las para isso, "tornando a luta por liberdade política parte integrante de suas reivindicações imediatas e concretas",796.

Somente quando o proletariado "assumir sua liderança é que a luta por liberdades políticas tornar-se-á um amplo e sólido movimento de todos os setores oprimidos contra a ditadura” ${ }^{\text {797. }}$.

Embora reconhecendo a tendência dominante no momento - capitalismo acelerado e manutenção da ditadura -, "é necessário aos marxistas-leninistas observar o movimento das forças que ocorre no interior da sociedade" - inclusive entre as classes dominantes — , para empreender as perspectivas de mudanças ${ }^{798}$.

Nesse sentido é possível que "os atritos entre as classes dominantes levem a um 'afrouxamento das tensões políticas' circunstancial”. Mais remota é a "possibilidade de uma 'redemocratização', de uma volta à democracia burguesa, com a revogação dos instrumentos de exceção”, mesmo sem afastar a grande burguesia integrada de sua posição hegemônica. Tal possibilidade estaria relacionada com a ocorrência de fatores tais como a configuração de uma crise na situação internacional, que levaria o capital imperialista a pressionar a ditadura no sentido de 'aberturas democráticas",". Entretanto, ainda que atritos entre as classes dominantes ou abalos internacionais possa, eventualmente, imprimir mudanças no sentido de “"abrandamento" da ditadura", somente a mobilização e lutas das massas pode manter e elevar as liberdades políticas alcançadas numa situação desse tipo ${ }^{799}$.

Após a vasta investigação que efetuou, o Doc. Autocrítica trata, finalmente, das tarefas atuais que se colocavam para superar o atraso político das massas e o distanciamento dos revolucionários da luta de classes concreta. Caberia aos marxistas-leninistas construir as forças da revolução, ou seja, realizar as tarefas já determinadas no curso desta autocrítica: "ligar-se à luta de classes concreta, construir o partido de vanguarda do proletariado e travar a luta ideológica”. A ordem em que enunciamos, no entanto, não implica em "qualquer hierarquia de uma sobre as outras". Pelo contrário, "estas três tarefas são absolutamente interdependentes", o que significa que "a realização de cada uma implica a realização das demais e é por elas determinada" ${ }^{\circ 00}$.

\footnotetext{
${ }^{794}$ PARTIDO COMUNISTA DO BRASIL - ALA VERMELHA. Autocrítica, cit., p. 82.

${ }^{795}$ PARTIDO COMUNISTA DO BRASIL - ALA VERMELHA. Autocrítica, cit., p. 82.

${ }^{796}$ PARTIDO COMUNISTA DO BRASIL - ALA VERMELHA. Autocrítica, cit., p. 82-83.

${ }^{797}$ PARTIDO COMUNISTA DO BRASIL - ALA VERMELHA. Autocrítica, cit., p. 83.

${ }^{798}$ PARTIDO COMUNISTA DO BRASIL — ALA VERMELHA. Autocrítica, cit., p. 83.

${ }^{799}$ PARTIDO COMUNISTA DO BRASIL — ALA VERMELHA. Autocrítica, cit., p. 83.

${ }^{800}$ PARTIDO COMUNISTA DO BRASIL - ALA VERMELHA. Autocrítica, cit., p. 84.
} 
Os marxistas-leninistas, organizados em seus partidos, organizações, agrupamentos ou círculos, devem "buscar a ligação com as massas a fim de levar a elas a ideologia socialista". Dessa forma, e somente dessa forma, será possível fazer com que o proletariado e as massas saiam da atual situação de refluxo e desencadeiem movimentos significativos ${ }^{801}$.

Objetivando a criação desse "movimento verdadeiramente de massas e verdadeiramente revolucionário", mas tendo a clareza das limitações impostas pela conjuntura atual e pela situação da esquerda, os marxistas leninistas precisam entender que a tarefa de ligação com as massas, particularmente com o proletariado, "implica num trabalho miúdo e paciente". Nesse trabalho é preciso "apoiar-se nas atividades legais para camuflar a atividade clandestina"; "aproveitar todas as formas de luta", desde as mais atrasadas, mais simples e elementares, e descobrir, criar e adaptar as formas de organização; localizar a liderança espontânea da classe, seja na fábrica, nas escolas, nos sindicatos e nos bairros, para educá-las na ideologia socialista, aplicando o princípio da linha de massas de "organizar os mais avançados, apoiar-se nos intermediários, para dirigir os mais atrasados". O movimento verdadeiramente revolucionário de massas será resultado da educação ideológica de sua liderança e da organização da classe, dialeticamente relacionada com o próprio movimento e com as condições objetivas existentes. Cabe ainda ressaltar que, no trabalho de ligação com as massas não se pode cair no desvio vanguardista de provocar movimentações imediatas, não sustentadas pela educação e organização de pelo menos, uma parcela da massa. Esse tipo de atuação realizada em diversas oportunidades pela Ação Popular e, em menor escala pela AV, provoca uma erupção momentânea, mas que esvazia em seguida sem deixar saldo em termos de consciência e organização da $\operatorname{massa}^{802}$.

No seio de um "movimento verdadeiramente de massas e verdadeiramente revolucionário" é que se torna possível construir o Partido da classe operária, através da fusão da ideologia socialista com a luta de classes. Por isso além de estar ligado à luta de classes concreta é preciso ter a compreensão da necessidade histórica do Partido, particularmente no que diz respeito a seu conteúdo ideológico, o que precede suas demais caracterizações e tarefas. Historicamente, o Partido é necessário porque nenhuma outra forma menos avançada de organização tem condições de levar a consciência de classe à classe e dirigi-la conseqüentemente. O ponto de partida para esse entendimento é a compreensão do papel histórico da classe operária, como a única capaz de levar a revolução até as últimas consequiências, isto é, até seu próprio desaparecimento como classe na sociedade sem classes. Dito de outro modo, o proletariado é a única classe cuja libertação implica na libertação de todas as outras, através da extinção de todas elas. Entretanto, a compreensão desse papel histórico, como se sabe, não surge espontaneamente da própria classe. A ideologia socialista, que o define cientificamente, surge fora da classe, elaborada pela intelectualidade socialista capaz de acesso à ciência. A consciência espontânea da classe operária só atinge o "trade-unionismo", a luta pela melhoria das condições em que vende a força de trabalho, sem questionar o sistema que a submete a esta venda. Torna-se pois, necessário levar a consciência socialista à classe e isso é tarefa dos marxistas-leninistas organizados em seus partidos, organizações, agrupamentos ou círculos - quando ainda não existe o Partido da classe operária, como é o caso de nosso país. Essa tarefa de educação, entretanto, tem duplo significado: os intelectuais socialistas vão às massas para educá-las no conhecimento do marxismo-leninismo e, ao

\footnotetext{
${ }^{801}$ PARTIDO COMUNISTA DO BRASIL — ALA VERMELHA. Autocrítica, cit., p. 84.

${ }^{802}$ PARTIDO COMUNISTA DO BRASIL - ALA VERMELHA. Autocrítica, cit., p. 84-85.
} 
mesmo tempo, para se educarem na luta de classes concreta. No momento em que a organização, orientada pela ideologia socialista, influa sobre as massas operárias, educando seus elementos mais avançados no conhecimento do marxismo-leninismo, permite e cria as condições para seu próprio crescimento e transformação. Só com a assimilação dos melhores e mais combativos elementos, será possível mudar o conteúdo da organização e capacitá-la a atuar de forma mais direta e proveitosa, ou seja, como partido proletário. Percebe-se que o partido só pode se construir na luta de classes concreta e que, inversamente, a luta de massas, particularmente a do proletariado, só ganha conseqüência com a existência do Partido. Isto é, "só com Partido é que se dará conseqüência à construção das forças da revolução, conduzindo-as para as lutas futuras pela tomada do poder político e pelo socialismo"

Por outro lado, essas tarefas só serão possíveis através de uma "intensa luta ideológica que faça prevalecer a ideologia proletária" sobre as outras ideologias que desviam a classe de seus objetivos ${ }^{804}$.

A luta ideológica se dirige contra as principais tendências que entrava o desenvolvimento da revolução. Atualmente, no Brasil, essas tendências são: entre as massas do proletariado, o populismo, a visão "nacional desenvolvimentista", o reboquismo em relação à burguesia, ainda uma vez o revisionismo, o "radicalismo" pequeno burguês, o voluntarismo, e nos últimos tempos o economicismo — em sua forma obreirista —, negando a necessidade da luta política e, em última instância, do Partido. Deve ficar claro que a luta ideológica não é um simples debate esotérico entre organizações de esquerda: ela é "um processo complexo, permanente", que implica na luta entre as massas contra todas as tendências não proletárias, na luta contra as diversas correntes que se pretendem marxistas-leninistas e na luta dentro de cada uma destas. Tanto ao nível de ligação com as massas quanto da construção do Partido será a luta ideológica que garantirá aos marxistas-leninistas fazer prevalecer a ideologia proletária na realização daquelas tarefas ${ }^{805}$.

Nas condições atuais da revolução brasileira, "tais tarefas cabem a tosos os marxistas-leninistas agrupados em suas organizações, partidos ou círculos: é imprescindível a organização para obter a ligação com as massas $" 806$.

Salienta o Doc. Autocrítica que deve ficar claro que nas circunstâncias atuais a tarefa de construção do Partido não as embasará na fusão orgânica (reorganização) das organizações, grupos ou círculos existentes, mas sim no encontro no trabalho de base (no seio das massas) das diversas tendências, na luta ideológica na base, na construção de novas forças ideologicamente proletárias no interior da classe, enfim, na aproximação pela base dentro do movimento de massas onde se manifestam essas tendências. O que vale dizer que a luta ideológica deve ser entre as organizações, grupos ou círculos, principalmente através da imprensa. Assim, "qualquer fusão de organizações que não derive da fusão com base ideológica e promovida no trabalho revolucionário concreto é artificial" e tende a formar grupos internamente fracionados em tendências inconciliáveis ${ }^{807}$.

\footnotetext{
${ }^{803}$ PARTIDO COMUNISTA DO BRASIL - ALA VERMELHA. Autocrítica, cit., p. 85-86.

${ }^{804}$ PARTIDO COMUNISTA DO BRASIL - ALA VERMELHA. Autocrítica, cit., p. 86.

${ }^{805}$ PARTIDO COMUNISTA DO BRASIL - ALA VERMELHA. Autocrítica, cit., p. 86.

${ }^{806}$ PARTIDO COMUNISTA DO BRASIL - ALA VERMELHA. Autocrítica, cit., p. 86-87.

${ }^{807}$ PARTIDO COMUNISTA DO BRASIL - ALA VERMELHA. Autocrítica, cit., p. 87.
} 
A AV se insere no quadro de esquerda e a ela cabe também como aos demais, marxistas-leninistas, desenvolver as três tarefas fundamentais. Para isso deve levar em conta "sua situação particular atual, suas limitações e suas potencialidades ${ }^{\prime 808}$.

Definindo-se como uma organização partidária leninista, que se orienta pelo marxismo-leninismo e luta pela construção do partido de vanguarda de classe operária, a AV necessita, antes de mais nada, "superar suas próprias limitações, retificar sua orientação, eliminando os erros e desvios apontados nesta autocrítica". Trata-se portanto de se voltar decisivamente par as massas e se lançar na tarefa de educá-las e organizá-las, tomando como base a necessidade de eliminar o "radicalismo" pequeno burguês, o voluntarismo, o vanguardismo, o dogmatismo e o subjetivismo de suas concepções e de sua prática, através de uma intensa luta ideológica interna. Não se trata apenas de substituir determinadas orientações por outras, mas sim de instrumentar um profundo debate capaz de chegar à raiz ideológica dos desvios de cada militante e do conjunto da organização. Partindo daí, elaborar e adotar diretivas que lhe permitam realizar corretamente as tarefas que hoje São apresentadas como tarefas de todos os marxistas-leninistas. Cabe-lhe ainda para chegar a isso, instrumentar sua própria transformação numa organização sólida e eficaz, através da retificação e aperfeiçoamento dos métodos de direção, de formação de quadros, dando um caráter científico à militância, transformando cada militante num educador, organizador e dirigente político das massas ${ }^{809}$.

Objetivando a realização das três tarefas e buscando a unidade de todos os marxistas-leninistas do país, o PC do B - AV “apresenta sua autocrítica ao conjunto do movimento revolucionário”. Espera que como primeiro passo de uma luta ideológica conseqüente, "as demais organizações, agrupamentos e partidos assumam também uma atitude autocrítica, além de criticar as concepções expostas neste trabalho" ${ }^{\text {" }} 10$.

\footnotetext{
${ }^{808}$ PARTIDO COMUNISTA DO BRASIL - ALA VERMELHA. Autocrítica, cit., p. 87.

${ }^{809}$ PARTIDO COMUNISTA DO BRASIL - ALA VERMELHA. Autocrítica, cit., p. 87-88.

${ }^{810}$ PARTIDO COMUNISTA DO BRASIL - ALA VERMELHA. Autocrítica, cit., p. 88.
} 


\section{III - CODA - Autocrítica}

A coda é a seção conclusiva de uma composição, um prolongamento que serve para facilitar a entrada da resposta da outra voz, que entra em uníssono no começo da melodia ${ }^{811}$.

Na prisão Renato Tapajós, Vicente Roig, Alípio Freire e Carlos Takaoka entabularam as primeiras discussões, depois do período de tortura, as quais eram no sentido de tentar salvar a organização e os mecanismos da Ala Vermelha referentes à luta armada. Passado poucos meses, ainda durante 1969, este conjunto de companheiros mudou o enfoque de suas conversas. Agora elas caminhariam "no sentido de perceber que havia algo errado"

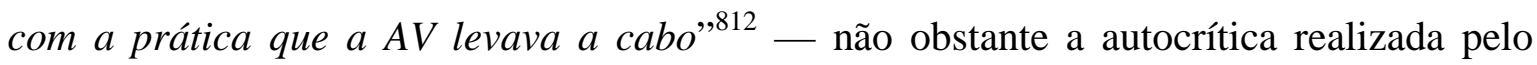
documento "Os 16 Pontos", lançada em novembro de 1969. Derly José de Carvalho, dirigente nacional que estava também preso, adere então ao agrupamento, por partilhar das mesmas preocupações ${ }^{813}$.

Em janeiro de 1970, quando Diniz Cabral é preso, o grupo ficou sabendo que este debate que acontecia entre eles, igualmente ocorria na Ala Vermelha em geral. Como recorda Renato Tapajós, “a gente sabia que o Diniz era uma das cabeças dessa discussão que propunha o refluxo e a ida para o trabalho de massa" ${ }^{814}$.

Nesta época o grupo já havia elaborado um esboço autocrítico da atuação prática da Ala Vermelha, especialmente com relação à luta armada, com a participação de Renato Tapajós, Carlos Takaoka, Alípio Freire e Vicente Roig. Derly de Carvalho também havia

\footnotetext{
${ }^{811}$ SINZIG, Frei Pedro, cit., p. 32.

${ }^{812}$ TAPAJÓS, R. C. Renato Carvalho Tapajós: depoimento [nov. 2006]. Entrevistador: T. A. D. Silva. Campinas, 2006. CD 1, faixa 2.

${ }^{813}$ ROIG, V. E. Vicente Eduardo Roig: depoimento [nov. 2006]. Entrevistador: T. A. D. Silva. Valinhos, 2006. CD 1, faixa 1.

${ }^{814}$ TAPAJÓS, R. C. Renato Carvalho Tapajós: depoimento... CD 1, faixa 2.
} 
tomado parte na elaboração desta primeiro texto, quando Diniz foi preso e também se juntou ao grupo. Considerando que Derly foi banido do território nacional em janeiro de 1971, e Élio Cabral é preso no final deste mesmo mês e na prisão também veio a fazer parte do agrupamento que confeccionava o pensamento autocrítico, o conjunto de pessoas que cuidou da elaboração da "Autocrítica" durante os anos subseqüentes, até sua divulgação em janeiro de 1974, foi composto por Diniz Cabral, Élio Cabral, Renato Tapajós, Carlos Takaoka, Alípio Freire e Vicente Roig.

O documento de Autocrítica foi trazido sete anos após o surgimento da Ala Vermelha enquanto organização independente, como "produto de um processo de retificação ideológica" ${ }^{\prime 15}$ pelo qual a AV passou. Consistia "parte integrante desse processo, e ponto de partida para seu aprofundamento e de outro modo não se poderá jamais entender seu verdadeiro sentido e significado" ${ }^{, 816}$.

A Ala Vermelha não pretendia esgotar apenas neste documento todas as questões "colocadas pela revolução" "817, mas ao contrário: visando a seriedade dos assuntos tratados, procurava abandonar a " "tradição enciclopédica"” da esquerda brasileira.

Notava o documento da AV que as preocupações e debates que deram origem ao mesmo haviam se inaugurado em 1969 "como resultado do refluxo do movimento revolucionário que se acentua a partir de 1968"818. As respostas colocadas pela luta de classes naquele momento - como a cessação dos movimentos de massa da pequena burguesia coroando o cenário de desmobilização geral das classes atingidas pelo golpe militar de 1964 e nosso isolamento de qualquer setor social - eram o fundamento que impeliria a Ala à rediscussão das concepções que até então defendia e tentava aplicar à realidade. A intensidade e profundidade dos golpes de repressão que a AV experimentou, "tornaram ainda mais evidente a existência de práticas e concepções errôneas, acentuando a necessidade de suas reformulações" 819 .

Para a Ala Vermelha, todavia, não se tratava de apenas constatar os erros, nem de tão somente assumir e proclamar tais erros, "em termos de um 'mea culpa". Tratava-se de localizar os erros, identificar suas causas mais profundas e apontar o caminho para a superação — "o que só é possível quando já se constrói um novo corpo de concepções, no

\footnotetext{
${ }^{815}$ PARTIDO COMUNISTA DO BRASIL - ALA VERMELHA. Autocrítica. 1967-1973. [S. 1.], jan., 1974. Coleção particular Daniel Aarão Reis Filho. SÉRIE: Ala Vermelha. Dossiê 05, doc. 150. Arquivo Público do Estado do Rio de Janeiro. Paginação irregular.

${ }^{816}$ PARTIDO COMUNISTA DO BRASIL — ALA VERMELHA. Autocrítica, cit., paginação irregular.

${ }^{817}$ PARTIDO COMUNISTA DO BRASIL - ALA VERMELHA. Autocrítica, cit., paginação irregular.

${ }^{818}$ PARTIDO COMUNISTA DO BRASIL - ALA VERMELHA. Autocrítica, cit., paginação irregular.

${ }^{819}$ PARTIDO COMUNISTA DO BRASIL — ALA VERMELHA. Autocrítica, cit., paginação irregular.
} 
próprio processo de descoberta dos erros" ${ }^{\$ 20}$. Para alcançar estes objetivo a Ala considerava imprescindível que a crítica e a autocrítica fossem "precedidas pela firme decisão de levar avante a revolução, e pelo estudo do marxismo-leninismo" ${ }^{\text {821. }}$.

Embora o objeto central do trabalho fosse a análise dos erros e desvios da AV, o documento indicava também aqueles mais sérios que atingiram "(e ainda atingem)" toda a esquerda - "na medida em que nossa prática não se constitui (nem se constitui) isolada de outras correntes de pensamento" ${ }^{\prime 822}$. Centralizando a atenção do estudo nestes aspectos, não se preocupava a Ala Vermelha em destacar acertos, mesmo porque se tratava de autocrítica de uma organização "e não de um balanço geral do movimento". Para o documento de Autocrítica (Doc. Autocr.) ficava implícito o reconhecimento dos esforços, das tentativas de acertar, do custo "em sofrimentos e vidas que tornaram possível o movimento sobreviver e mesmo amadurecer até o ponto em que é possível empreender sua retificação ideológica", os quais tornaram possível a própria existência de Ala Vermelha e criaram condições para que esta organização pudesse esta sua autocrítica. Entretanto, salientava o Doc. Autocr. que ainda não havia chegado o momento de se prestar homenagem aos que tombaram, porque "ainda vivemos um período em que todas as forças se devem dirigir para o reerguimento do movimento, lançando-o no caminho correto da revolução feita pelas massas" ${ }^{\prime 23}$.

Após estes breves apontamentos introdutórios o documento de Autocrítica adentra na análise do movimento revolucionário no Brasil, que seria caracterizado pela “desorganização da classe operária e das massas, pela inexistência de um partido político revolucionário do proletariado, pelo desmantelamento das organizações e partidos de esquerda", e, conseqüentemente, por um "profundo refluxo da luta revolucionária" 824.

Nesse quadro geral a Ala Vermelha se situava como sendo uma "corrente revolucionária" que além de haver sofrido profundos golpes, não "conseguiu cumprir as tarefas de educar e organizar as massas", não tendo construído ainda os instrumentos que possibilitariam a superação do impasse com o qual se defronta o processo revolucionário brasileiro $^{825}$.

Segundo o Doc. Autocrítica esta situação seria decorrente da existência de "erros $e$ desvios na orientação da atividade revolucionária”. Para superar este impasse era

\footnotetext{
${ }^{820}$ PARTIDO COMUNISTA DO BRASIL — ALA VERMELHA. Autocrítica, cit., paginação irregular. ${ }^{821}$ PARTIDO COMUNISTA DO BRASIL - ALA VERMELHA. Autocrítica, cit., paginação irregular.

${ }^{822}$ PARTIDO COMUNISTA DO BRASIL - ALA VERMELHA. Autocrítica, cit., paginação irregular.

${ }^{823}$ PARTIDO COMUNISTA DO BRASIL — ALA VERMELHA. Autocrítica, cit., paginação irregular.

${ }^{824}$ PARTIDO COMUNISTA DO BRASIL - ALA VERMELHA. Autocrítica, cit., p. 1.

${ }^{825}$ PARTIDO COMUNISTA DO BRASIL - ALA VERMELHA. Autocrítica, cit., p. 1.
} 
necessário localizar cuidadosa e precisamente tais erros e desvios cometidos, investigando suas causas e analisando a situação onde foram gerados, com o propósito de se criar meios eficazes para corrigi-los. Para cumprir estes objetivos entendia a Autocrítica que era "imprescindível que toda a esquerda organizada assuma a atitude de fazer a autocrítica de seus erros". A Ala Vermelha - como parte desta esquerda organizada - entendia como "tarefa inadiável" reconhecer seus próprios erros, analisar suas causas e discutir os meios que pudessem corrigi-los — o que se propunha a fazer no Doc. Autocrítica.

A Ala Vermelha salientava que a autocrítica não consistia em uma elaboração histórica do partido desde seu surgimento, compreendendo que os dados históricos que necessariamente devem figurar num procedimento autocrítico seriam os essenciais para a análise do conjunto de erros e desvios e da própria prática efetivada pela $\mathrm{AV}$, de modo a buscar as circunstâncias que os originaram.

Em seguida o Doc. Autocrítica salienta que todo o processo revolucionário brasileiro - no qual se integra a Ala Vermelha - foi realizado fundamentalmente pela pequena burguesia ${ }^{826}$ numa realidade em que não existia qualquer movimento da classe operária. Desta maneira o processo revolucionário caiu em um "revolucionarismo ou radicalismo pequeno-burguês" que se traduziria no "voluntarismo e imediatismo" 827.

Os desvios e erros da Ala eram manifestados tanto em suas concepções quanto em sua prática. As concepções fundamentais da AV estavam sintetizadas no Documento de Crítica $^{828}$ enquanto que os aspectos táticos estavam formulados no documento "Organizar um Partido de Novo Tipo em função da Luta Armada (OPNTEFLA) ${ }^{829}$.

$\mathrm{Na}$ Ala Vermelha, No P(AV), o voluntarismo e imediatismo irão assumir a forma particular de "uma prática vanguardista". A AV surgida desde seu início desligada das massas, particularmente da classe operaria, não se construiu na luta de classes concreta ${ }^{830} \mathrm{e}$ organizada "quase que exclusivamente elementos provenientes da pequena burguesia" sobretudo no meio estudantil, "vanguardista por sua incapacidade de ligar-se às massas”.

\footnotetext{
${ }^{826}$ PARTIDO COMUNISTA DO BRASIL - ALA VERMELHA. Autocrítica, cit., p. 2.

${ }^{827}$ PARTIDO COMUNISTA DO BRASIL - ALA VERMELHA. Autocrítica, cit., p. 2.

${ }^{828}$ Cf. PARTIDO COMUNISTA DO BRASIL - ALA VERMELHA.Crítica ao oportunismo e subjetivismo da 'União dos Brasileiros para Livrar o País da Crise, da Ditadura e da Ameaça Neocolonialista, cit.

${ }^{829}$ Cf. PARTIDO COMUNISTA DO BRASIL - ALA VERMELHA. COMITÊ REGIONAL DE SÃO PAUlO. Organizar um Partido de Novo Tipo em função da Luta Armada. [S. 1.], mar. 1968. Coleção particular Daniel Aarão Reis Filho. SÉRIE: Ala Vermelha. Dossiê 05, doc. 91, Arquivo Público do Estado do Rio de Janeiro.

${ }^{830}$ O Doc. Autocrítica entendia por luta de classes concreta, "a luta dos que estão ligados diretamente à produção". Cf. PARTIDO COMUNISTA DO BRASIL — ALA VERMELHA. Autocrítica, cit., p. 4.
} 
Assim, as manifestações mais evidentes dos desvios da Ala seriam: "o desligamento das massas e a prática vanguardista" ${ }^{\prime \prime 31}$.

Entendemos por vanguardismo a substituição da ação revolucionária das massas pela ação de agrupamentos, partidos, organizações ou indivíduos. Isto é, a atividade vanguardista se realiza em nome e em lugar das massas, deixando-as sem consciência de seu papel revolucionário e sem orientação política conseqüente. Os que se desviem para o vanguardismo, se deformam por não conhecerem as necessidades e interesses das massas e por não compreenderem as exigências políticas e ideológicas do luta de classes. No processo revolucionário brasileiro em seu período recente, o vanquardismo teve sua expressão mais desenvolvida no "esquerdismo" militarista, isto é, na substituição da ação revolucionária das massas pele ação armada de pequenos grupos. O P(AV) também incorreu no desvio vanguardista expresso particularmente em sua forma militarista, embora não tenha sido esta a única forma de expressão daquele desvio. Como se ver no curso desta autocrítica, o vanguardismo se manifestou também em diversas outras atividades do $\mathrm{P}(\mathrm{AV})$, uma vez que encontrava fundamento teórico em concepções voluntaristas formuladas em sua linha política.

Desta maneira a Ala Vermelha, sem conseguir laços com as massas que realizam a revolução, "sem educá-las para ação revolucionária, desprovido do instrumental teórico marxista-leninista e realizando atividades práticas isoladas das massas", não representou, como pretendeu, "o papel de destacamento de vanguarda da classe operária” — em razão do "radicalismo pequeno-burguês", que levou a Ala a erros e desvios ${ }^{832}$.

Desde o seu surgimento, a Ala Vermelha assumiu a posição de ter o marxismoleninismo como sua teoria, de defender a necessidade do partido do proletariado, a necessidade de um programa, de definições estratégicas e táticas, e de adotar a via armada para a conquista do poder. Entretanto, diz o Doc. Autocrítica, tendo em vista a não assimilação do "conteúdo ideológico proletário que deve se expressar nessas questões", determinou que a compreensão, elaboração e aplicação destas proposições "resultassem deformadas". Tanto não se compreendeu o verdadeiro conteúdo da ideologia proletária que, embora a questão ideológica fosse agitada intensamente em todos os momentos da atividade da Ala, era vista mais como “a 'disponibilidade’ para a luta revolucionária, como uma 'ética' e uma 'moral' de comportamento do militante, que como uma concepção científica que corresponde à visão de mundo da classe operária”. É assim que se vai

\footnotetext{
${ }_{831}$ Cf. PARTIDO COMUNISTA DO BRASIL - ALA VERMELHA. Autocrítica, cit., p. 3.

${ }^{832}$ PARTIDO COMUNISTA DO BRASIL - ALA VERMELHA. Autocrítica, cit., p. 4.
} 
aceitar dentro da AV como "bom nível ideológico" do militante, sua disposição para realizar eficazmente tarefas práticas, sua capacidade de trabalho e dedicação - bem como atitudes de aparente modéstia. O que não se compreendia dentro da Ala era que comportamentos como os mencionado poderiam também ser "posturas assumidas a partir do 'radicalismo' pequeno-burguês",833.

O Doc. Autocrítica afirma que a correta compreensão da questão ideológica parte do "entendimento científico do papel histórico da classe operaria em todo o processo de lutas nas sociedades de classes, até a eliminação destas". As atitudes decorrentes desse entendimento correspondem a uma radical mudança "no mundo subjetivo com a assimilação da visão proletária do mundo", e surgem como exigências necessárias da luta de classes concreta, adquiridas pela "compreensão e domínio da teoria científica do marxismo-leninismo" ${ }^{, 834}$.

A seguir a Autocrítica passa a contemplar a questão do subjetivismo e do dogmatismo, entendendo que o primeiro ocupa o lugar que deveria ser preenchido pela "ideologia científica do proletariado", o que é determinante para surgimento do dogmatismo - entendendo p Doc. Autocrítica por dogmatismo "o esvaziamento das formulações do marxismo-leninismo de seu conteúdo científico". Resulta pois na utilização de "fórmulas vazias e secas", cujo conteúdo original (o marxismo-leninismo) foi substituído por um outro, fundamentado na ideologia não proletária prevalecente no momento - no caso da $\mathrm{AV}$, "o radicalismo pequeno-burguês". Desse modo, o dogmatismo deforma as concepções do marxismo-leninismo até, convertê-las "na negação do próprio marxismo-leninismo". O dogmatismo teria por base o subjetivismo, na medida em que as mencionadas "fórmulas vazias e secas" têm a função de dar una aparência 'científica' a conclusões cujo funda monto real não é a aplicação do método marxista, mas sim a especulação fundada na vontade". Desta maneira, as formulações do marxismoleninismo passam a funcionar como "elementos decorativos superponíveis a qualquer estrutura do pensamento". A Ala Vermelha, ao elaborar suas formulações teóricas, embora tentasse se orientar pelo marxismo-leninismo, "dispunha apenas de um conhecimento disperso e superficial dessa ciência, e era influenciado pelo "radicalismo" pequenoburguês". Isto determinou que a AV desembocasse no dogmatismo, o que levou a que

\footnotetext{
${ }_{833}^{833}$ PARTIDO COMUNISTA DO BRASIL — ALA VERMELHA. Autocrítica, cit., p. 5.

${ }^{834}$ PARTIDO COMUNISTA DO BRASIL - ALA VERMELHA. Autocrítica, cit., p. 5.
} 
"nos ressentíssemos de uma miopia dogmática frente aos fenômeno a que se apresentaram" $" 835$.

Com relação à concepção de partido o Doc. Autocrítica assevera que um dos pontos fundamentais onde se manifesta este desvio é no da compreensão da concepção do partido da classe operária. Desde a constituição a Ala Vermelha, "mantivemos uma visão dogmática a este respeito, que consistia em partir as sua (do partido) necessidade na revolução dirigida pelo proletariado", firmando apenas, no entanto, seu papel de dirigente político, relegando a plano secundário sua função ideológica. Sem dúvida, afirma o Doc. Autocrítica, o partido que dirige o processo revolucionário é "o destacamento de vanguarda da classe operária, Estado-Maior da Revolução". A verdadeira concepção leninista enfatiza como principal seu papel ideológico "despertar, dar consciência através da ideologia científica, educar politicamente e organizar a classe operária - cuja realização consiste na fusão "da ideologia socialista com a luta de classes concreta". Desta forma, faz-se necessário que os intelectuais revolucionários "fundem-se a luta de classes concreta”, a fim de levá-la àqueles que realizam objetivamente essa luta. Não basta, entretanto, admitir que a ideologia socialista e introduzida de fora para dentro da classe, mas é preciso "compreender cientificamente como isso se processa, assimilar o papel histórico que joga o proletariado na luta de classes, e imprimir a esta luta o caráter político, do um ponto de vista socialista". Somente agindo assim, o partido da classe operária estará preparado para combater o dogmatismo e qualquer desvio. De outro modo, tentar estabelecer um ponto de vista proletário simplesmente através de definiçõos teóricas em estatutos, linha política e programa etc, "sem haver assimilado a teoria marxistaleninista aplicada à prática da luta de classes, levará a organização de qualquer partido, menos o partido de vanguarda da classe operária”. Disso decorre a compreensão errônea de que a simples existência formal de um partido que se define e proclama marxistaleninista significa que ele é o partido de vanguarda da classe operária. Para que um partido possa ser caracterizado como vanguarda de uma determinada classe, "é preciso que ela o reconheça como tal”. Na Ala Vermelha a visão dogmática acerca da questão do partido se expressava formalmente quando "nos definimos como 'embrião do partido da classe operária' (conforme o documento OPNTEFLA) ou 'como parte revolucionária do partido da classe operária' (Conforme nosso projeto de estatuto de novembro de 1969)". Estas afirmações pretendiam imprimir, por definição formal, o caráter ideológico proletário a uma organização que não reunia condições — ideológicas, políticas e orgânicas —

\footnotetext{
${ }^{835}$ PARTIDO COMUNISTA DO BRASIL — ALA VERMELHA. Autocrítica, cit., p. 5.
} 
necessárias para se caracterizar enquanto tal. O dogmatismo da AV deve ao fato de que embora "defendêssemos a necessidade do partido, compreendêssemos seu papel dirigente, reconhecêssemos sua inexistência no nosso país, não dominávamos os processos de sua correta construção". Para corrigir esse desvio, adotando uma visão não dogmática e consentânea com a real situação da revolução em nosso país, a Ala Vermelha "se define hoje como urna organização partidária leninista que se guia pelo marxismo-leninismo, e que luta pela construção do partido da classe operária" ${ }^{836}$.

O Doc. Autocrítica enfoca também aborda a questão da elaboração do programa, da estratégia a e da tática da revolução brasileira, que assume ter sido "dogmaticamente vista por nós”. A Autocrítica entendia ser correto o entendimento de que o partido da classe operária, para sua atividade revolucionária, necessita ter definidos claramente seu programa, sua estratégia e sua tática. No entanto, para que seja possível dar um tratamento científico a estas definições, é imprescindível "o correto domínio da teoria $-e$ conseqüentemente do método - marxista-leninista e com base nela, conhecer a realidade social em que se atua". Seria preciso ainda que o partido - assimilado o papel histórico da classe operária - "esteja presente na luta de classes concreta, compreendendo, participando e intervindo em cada um de seus momentos". Participando desta forma na luta de classes, que o partido vai conhecer o movimento interno das classes "determinado por seus interesses nas condições histórico-concretas em que se encontram" - a se munir de um conhecimento rigoroso de toda a sociedade. Só à medida que for dispondo destes conhecimentos é que "o partido poderá ir articulando em programa, estratégia e tática” ${ }^{837}$.

A Autocrítica salienta que quando uma organização ou partido político, não interpreta corretamente a realidade sobre a qual pretende atuar. quando não está inserida na luta de classes concreta, "não participa conseqüentemente nem intervém em qualquer de seus momentos aparentes e portanto não conhece o movimento interno das classes". Quando, por fim, malgrado suas definições, não é em absoluto o partido da classe operária, a tentativa de elaboração acabada do programa, estratégia e tática da revolução, não passará "de um imaginoso exercício de erudição e retórica”. Em outras palavras: "elaborar o programa, a estratégia e a tática de uma revolução sem dispor dos elementos que possibilitam o tratamento científico dessas questões" significa incorrer necessariamente no "subjetivismo de uma atividade de gabinete".

\footnotetext{
${ }^{836}$ PARTIDO COMUNISTA DO BRASIL - ALA VERMELHA. Autocrítica, cit., p. 6-7.

${ }^{837}$ PARTIDO COMUNISTA DO BRASIL - ALA VERMELHA. Autocrítica, cit., p. 8.
} 
Na medida em que não se possui os meios de elaborar estas questões com base na teoria correta e na atividade prática conseqüente só resta o recurso de tentar resolvê-las manipulando "formulações genéricas do marxismo-leninismo e transpondo-se mecanicamente experiências de revoluções vitoriosas". É exatamente neste proceder que reside o subjetivismo e dogmatismo na elaboração do programa, da estratégia e da tática, porque "esvazia as formulações do marxismo-leninismo de seu conteúdo, destruindo suas possibilidades criadoras", e porque adota as formas assumidas por outras revoluções que foram realizadas em condições históricas especificas —, sem levar em conta as particularidades e singularidades do próprio processo. Esta manifestação de dogmatismo é "um fenômeno geral da esquerda brasileira, onde são numerosos os programas, as estratégias e táticas revolucionárias propostos". A Ala Vermelha também incorreu nesse dogmatismo ao elaborar uma analise de classes, seu programa, sua estratégia e tática "no Documento de Crítica, e ao sistematizar pormenores dessa tática no documento OPNTFLP". O tratamento dessas questões se deu sob a influência direta da "Revolução Chinesa mesclada com a da Revolução Cubana”. Da experiência Chinesa extraiu-se não só o modelo da análise de classes, como também as formulações de guerra popular e do caminho do cerco das cidades pelo campo, onde o campesinato constitui-se no contingente principal da revolução. A experiência Cubana tem menor influência; reflete-se nas formulações táticas Ala, particularmente na proposição do foco como "detonador da guerra popular, aspecto este sobretudo desenvolvido no documento OPNTEFLA”, no qual, ao lado do foco, propõe-se a formação de toda uma estrutura voltada para a guerrilha nas cidades, o que se chamou de guerrilha urbana ("Grupos Armados Clandestinos de massa" e "Grupos Especiais do Partido"), no campo, as "Guerrilhas de Diversão" 838 .

A Autocrítica diz que no Documento de Crítica são utilizadas "dogmaticamente formulações genéricas sobre tática e estratégia, extraídas das obras de Mao Tsé-tung e Stalin”. Ainda que transcrevendo as definições corretas contidas nas obras desses autores marxista-leninistas, a Ala Vermelha o fez dogmaticamente porque as "aplicamos a uma realidade que desconhecíamos manipulávamos conforme nosso desejo, sem dispor dos meios que nos permitissem elaborar a tática e a estratégia”. Para que a AV não voltasse a incorrer no dogmatismo em relação estratégia, tática e programa, seria preciso ter clareza "de qual é o nível de definições que a condição atual da luta de classes permite e que ao mesmo tempo, se constitui numa exigência para seu desenvolvimento”. Com base no conhecimento do marxismo-leninismo e da realidade do País, com base no grau de sua

\footnotetext{
${ }^{838}$ PARTIDO COMUNISTA DO BRASIL — ALA VERMELHA. Autocrítica, cit., p. 9-10.
} 
ligação com as massas e ao nível do seu trabalho concreto, a Ala deve elaborar "diretivas e consignas que orientem toda sua trajetória na atual fase da revolução brasileira”. Além disso, deveria também empreender "estudos a pesquisas a respeito da realidade nacional e dos clássicos do marxismo-leninismo", com o objetivo de se capacitar para "definir corretamente as questões programáticas, estratégicas e táticas. que interessam atual etapa da revolução" ${ }^{839}$.

Na medida em que a Ala Vermelha se constituía em uma organização marxistaleninista que luta pela construção do partido revolucionário da classe operária, tem ela consciência de que "está a necessitar de um programa, uma estratégia e uma tática que unifique a prática de todos os que lutam pela revolução dirigida pelo proletariado”. Para isso, considera uma necessidade a participação de todos os marxistas-leninistas "nas tarefas que conduzirão construção do partido revolucionário da classe operária $e$ elaboração do programa da revolução brasileira, da sua estratégia e sua tática”. E, naturalmente, como organização marxista-leninista, a AV "assume para si estas tarefas" ${ }^{, 840}$.

O Doc. Autocrítica incursionava também na ênfase que era dada pela Ala Vermelha na questão da luta armada, dizendo que o radicalismo pequeno-burguês, "tem como uma de suas manifestações mais características a ênfase exagerada que se deu à luta armada". Para reagir ao reformismo e à via pacífica da linha revisionista, "a grande maioria da esquerda brasileira passou a preconizar a luta armada como alternativa imediata para a tomada do poder". No entanto, como não se compreendia o "conteúdo ideológico revisionista expresso no reformismo e como as posições críticas marcadas pelo 'radicalismo' pequeno-burguês”, a contestação foi dirigida quase que exclusivamente às formas de luta e organização, que expressavam a política de transição pacífica. Desse modo, "colocou-se unicamente a luta armada como linha divisória entre a revolução e a reforma, o marxismo o revisionismo" ${ }^{, 841}$.

O Doc. Autocrítica afirma que a posição crítica correta em relação ao revisionismo e sua política "deve partir da identificação da ideologia não proletária que o caracteriza”. Isto significa "identificar a natureza de classe da base social do revisionismo", entender e fazer entender "que ele nega o marxismo-leninismo porque representa "interesses contrários aos do proletariado e portanto inconciliáveis com esta teoria”. A doutrina

\footnotetext{
${ }^{839}$ PARTIDO COMUNISTA DO BRASIL - ALA VERMELHA. Autocrítica, cit., p. 10.

${ }^{840}$ PARTIDO COMUNISTA DO BRASIL - ALA VERMELHA. Autocrítica, cit., p. 10-11.

${ }^{841}$ PARTIDO COMUNISTA DO BRASIL - ALA VERMELHA. Autocrítica, cit., p. 11.
} 
teórica do revisionismo e sua prática têm conteúdo fundamentado "nos interesses de classe da burguesia e a aristocracia operária”. Portanto, a luta contra o revisionismo deveria ter seu fundamento na questão ideológica, na defesa intransigente do marxismo-leninismo o de seus princípios”, e, a partir disso, combater as manifestações políticas do revisionismo como o reformismo, a transação pacífica, etc. ${ }^{842}$

Diz o Doc. Autocrítica que assim procedendo, a questão da luta armada iria se colocar em sua correta dimensão, ou seja, a da "forma de luta mais elevada que o proletariado necessita para atingir os seus objetivos de eliminação da dominação política burguesa”. Como se infere deste contexto, a verdadeira linha divisória entre revolução e reforma, marxismo e revisionismo "é a questão ideológica". Quando se coloca uma forma de luta - no caso luta armada, ou qualquer outra de suas possíveis manifestações —, como sendo "essa linha divisória, não se atinge o cerne do problema", permitindo-se que o "conteúdo ideológico no proletário permaneça em atividades pretensamente marxistasleninistas porque baseadas na violência das armas"

$\mathrm{Na}$ medida em que foi deixada, no curso do processo dos últimos anos, que a questão da luta armada se transformasse no centro das preocupações dos revolucionários, "deu-se campo livre à exacerbação do radicalismo pequeno-burguês". Como nesse período a esquerda estava desligada das massas, "as ações armadas de pequenos grupos isolados tentaram representar e foram aceitas como sendo a própria luta armada". No entanto, "para o marxista-leninista (operário), a luta armada revolucionária é exercício pelas massas de sua violência de classe em sua forma mais elevada”. 844

Realizando ações de pequenos grupos isolados, "o 'radicalismo' pequeno-burguês ofereceu apenas urna caricatura de luta armada”. Algumas organizações voltaram-se exclusivamente para as ações armadas — "por exemplo a Ação Libertadora Nacional e a Vanguarda Popular Revolucionária —, constituindo-se como organizações puramente militares". A Ala Vermelha, embora desse também ênfase exagerada luto armada "possibilitando que ela se constituísse no aspecto de maior peso de sua linha política —, agregou outras questões em suas concepções sobre a revolução”. Desse modo, a AV constitui-se como uma organização política que "incorreu no desvio militarista, não chegando, entretanto, a convertermo-nos em uma Organização puramente militar”. Ainda assim, ao admitirmos a luta armada como única linha divisória entre "nosso

\footnotetext{
${ }^{842}$ PARTIDO COMUNISTA DO BRASIL - ALA VERMELHA. Autocrítica, cit., p. 11-12.

${ }^{843}$ PARTIDO COMUNISTA DO BRASIL - ALA VERMELHA. Autocrítica, cit., p. 12.

${ }^{844}$ PARTIDO COMUNISTA DO BRASIL - ALA VERMELHA. Autocrítica, cit., p. 12.
} 
revolucionarismo e o revisionismo", não criamos as condições para que travasse - e muito menos para que dirigíssemos — "uma luta ideológica conseqüente, permitindo pois que se desenvolvesse e se acentuasse em nossas fileiras o radicalismo pequenoburguês" ${ }^{\prime 845}$.

Apenas se poderia superar este desvio se a Ala Vermelha empreendesse uma "rigorosa luta ideológica contra "as concepções não proletárias, onde quer que se manifestem (no seio do própria $A V$ ou não), sejam elas geradas pelo revisionismo, pelo “radicalismo pequeno-burguês”. O Doc. Autocrítica entende que estas causas internas são as determinações mais importantes dos desvios, erros, visto que são "os fatores internos a qualquer fenômeno os que determinam as características e o desenvolvimento deste. Os fatores externos dão as condições para o seu desenvolvimento". Entretanto, conhecer estes fatores externos, ou seja, conhecer as circunstâncias em que surgiram os erros, analisar a situação que os originou, é parte integrante do processo de "localizar as múltiplas determinações que constituem, esses mesmo erros". Em outros termos, para podermos entender os erros da Ala Vermelha é necessário estudar que "situação presidiu seu surgimento e sua trajetória”. Não se trata de, com isso, justificar os erros; pelo contrário, "é a forma de localizá-los com maior precisão". Por tais razões o Doc. Autocrítica passa a esboçar a situação da sociedade brasileira e do movimento revolucionário nos quais a AV se originou para poder realizar de forma mais sistemática e fundamentada, a crítica das “concepções errôneas contidas no Documento de Crítica" ${ }^{846}$.

A Ala Vermelha surge num momento em que o movimento revolucionário brasileiro passava por um processo de intenso debate, divergências, cisões e reagrupamentos, em que as massas do proletariado já se encontravam desorganizadas e inertes, "enquanto a pequena burguesia ainda encontrava condições para se mobilizar"; em que a crise econômica e política da sociedade, no bojo da qual ocorrera o golpe militar de 1964 , ainda não se havia resolvido ${ }^{847}$.

Naquele período, a classe operária "não contava com seu partido de vanguarda”. $\mathrm{O}$ Partido Comunista Brasileiro, em sua longa trajetória, "não foi capaz de se transformar nesse partido de vanguarda". No período mais recente, a partir de fins da década de 50, esse partido já se "transformara definitivamente em um partido revisionista", e, como tal, em um "defensor de interesses alheios aos da classe operária". Não obstante a

\footnotetext{
${ }^{845}$ PARTIDO COMUNISTA DO BRASIL - ALA VERMELHA. Autocrítica, cit., p. 13.

${ }^{846}$ PARTIDO COMUNISTA DO BRASIL - ALA VERMELHA. Autocrítica, cit., p. 13

${ }^{847}$ PARTIDO COMUNISTA DO BRASIL - ALA VERMELHA. Autocrítica, cit., p. 14.
} 
importância decisiva do revisionismo no movimento comunista mundial — determinada pela "predominância desta tendência não proletária" no PCUS desde seu XX Congresso —, as causas mais profundas da "deterioração ideológica" do Partido Comunista Brasileiro “já estavam dadas pelas condições internas específicas, próprias a ele”. De há muito esse partido trilhava caminhos marcados pela "influência pequeno-burguesa, oscilando entre o 'esquerdismo' de 35 e o reboquismo de 46", num movimento pendular que nos revela "a inexistência de uma direção proletária ligada às massas" e que interpretasse corretamente a ação da sociedade e definisse um "programa, uma estratégia, uma tática justos para conduzir corretamente a classe operária a seus objetivos" ${ }^{848}$.

As condições para a penetração do revisionismo foram reforçadas pela "predominância na sua composição social do elemento pequeno-burguês”. Adotando o revisionismo como teoria o PCB, a partir de seu V Congresso, vê sua política "desarmar ainda mais a classe operária e as massas na luta por seus interesses". Já antes de 1964, a proposição de uma revolução "nacionalista" e "democrática" em aliança com a burguesia nacional, refletia " $a$ incapacidade de analisar $e$ interpretar corretamente a realidade brasileira", mantendo "as ilusões quanto a possibilidade de uma revolução burguesa independente" nas condições em que "predominam os interesses do grande capital imperialista". Essa proposição significava, na prática, "o abandono da concepção da hegemonia do proletariado na revolução" ${ }^{, 49}$.

Tal política levou à "subordinação dos interesses da classe operária aos da burguesia e manteve o PCB e o proletariado sob a influência da ideologia burguesa”. Mesmo quando pensa participar de forma decisiva no processo imediatamente anterior a 64, o PCB "não compreende o que ocorre na sociedade brasileira". Aliás, não vem a compreendê-lo nem posteriormente - como de resto toda a esquerda", inclusive a Ala Vermelha $^{850}$.

Desde a entrada maciça de capitais estrangeiros no nosso país, a partir da segunda metade da década de 50, a economia brasileira caminhava rapidamente para uma “monopolização capitalista 'precoce,”. A superposição de um setor industrial avançado a uma economia ainda atrasada, em suas linhas gerais, criava tensões significativas. $\mathrm{O}$ setor da burguesia industrial associado ao capital estrangeiro não se interessava pela manutenção da democracia burguesia ou pelo populismo como formas de dominação política, na

\footnotetext{
${ }^{848}$ PARTIDO COMUNISTA DO BRASIL - ALA VERMELHA. Autocrítica, cit., p. 14.

${ }^{849}$ PARTIDO COMUNISTA DO BRASIL - ALA VERMELHA. Autocrítica, cit., p. 15.

${ }^{850}$ PARTIDO COMUNISTA DO BRASIL - ALA VERMELHA. Autocrítica, cit., p. 15.
} 
medida em que para o grande capital monopolista, nas condições de monopolização precoce baseada no capital estrangeiro, "servem melhor as formas abertamente autoritárias", 851 .

Em contrapartida, a burguesia nacional encontrava justamente no populismo o caminho adequado a seus interesses: "não só vinha se servindo dele há perto de 3 décadas, como via em sua intensificação um instrumento para atingir ainda naquele momento seus objetivos". As opções econômicas da burguesia nacional estavam "condicionadas estruturalmente a mercados de baixas rendas (aos quais dirigia sua produção), interessando-lhe uma expansão desses". Quando a crise econômica se desencadeia nesse período, deixa-a as voltas com uma "crise de realização, na medida em que a inflação, corroendo os salários reais limitou a expansão de seu mercado”. Interessando-se, assim, pela inclusão das massas rurais na economia de mercado, e por elas pressionada, punha-se a favor da reforma agrária. Contra tais pretensões que se alinhavam "os setores agrárias, temerosos de qualquer medida que afetasse a estrutura da propriedade rural". Por sua vez, a grande burguesia industrial e financeira ligada ao capital imperialista "via na crise a possibilidade de impor uma solução que lhe fosse favorável". A crise pela qual passava o capitalismo no Brasil tinha, desta vez, a peculiaridade de - ao contrário de outras pelas quais já passara anteriormente o sistema - "ser gerada pelos mecanismos internos do desenvolvimento da própria economia do país"

A situação levara a um acirramento da luta de classes com a participação do proletariado das classes rurais em intensas mobilizações. Entretanto, essas mobilizações se faziam dentro do "quadro limitativo do populismo", com todas as características negativas que acarretava. A classe operária não dispunha - como continua sem dispor — de “independência ideológica, política e organizativa”. Sua própria formação e as peculiaridades da revolução burguesa no Brasil determinavam essas características ${ }^{853}$.

Desde a década de 30, o Estado que representava a coalizão entre a burguesia industrial e os setores agrários, levou adiante uma política, conhecida como "populismo", que visava "não só utilizar o potencial de luta das massas para sua sustentação", como também criar “condições favoráveis a industrialização do país, favorecendo a burguesia industrial”. É nesse processo que a burguesia vai antecipar de forma paternalista a concessão de direitos trabalhistas (Consolidação das Leis do Trabalho, Salário mínimo

\footnotetext{
${ }^{851}$ PARTIDO COMUNISTA DO BRASIL - ALA VERMELHA. Autocrítica, cit., p. 15.

${ }^{852}$ PARTIDO COMUNISTA DO BRASIL - ALA VERMELHA. Autocrítica, cit., p. 15-16

${ }^{853}$ PARTIDO COMUNISTA DO BRASIL - ALA VERMELHA. Autocrítica, cit., p. 16.
} 
etc.) vinculando, ao mesmo tempo, a organização dos trabalhadores ao Estado. Dessa forma, os sindicatos foram subordinados ao Ministério do Trabalho e criaram-se estruturas organizativas que retiravam da classe operária suas perspectivas de independência. Abafando as lutas espontâneas com concessões paternalistas e subordinando a organização da classe aos interesses oficiais, o fator de amortecimento político do populismo transformou o proletariado "de sujeito da ação política em simples instrumento de pressão — em função dessa fração da burguesia - marginalizando-o em relação aos centros de decisão" ${ }^{, 854}$.

Essas características da classe operária brasileira — dadas por sua trajetória — são de importância fundamental para "compreendermos a fragilidade de seu movimento e o baixo grau de consciência, que não chega a ser nem mesmo revisionista ou sindicalista. $\mathrm{O}$ Partido Comunista Brasileiro além de não compreender os processos reais pelos quais passava nossa sociedade, "tampouco compreendeu a situação da classe operária",pelo contrário, "enquadrou-se no jogo do populismo, aceitou o sindicalismo oficial, e não lutou pela independência da classe operária". Nesse sentido "é flagrante sua falência como vanguarda da classe do proletariado e sua solidarização com os interesses da burguesia" ${ }^{855}$.

O Partido Comunista do Brasil (PC do B) vai surgir da cisão de um partido com estas características e história. Entretanto, a ruptura do PC do B com o PCB não foi a identificação dos desvios que apontamos anteriormente que levaram à luta interna; ainda que houvesse manifestações contra a "política direitista do Congresso", estas foram "tímidas e pouco significativas". As causas do rompimento foram muito mais "questões de política interna - luta pela influência e controle de postos de direção - e tiveram por base o 'radicalismo' pequeno-burguês (revisionismo). O alinhamento do PC do B ao Partido Comunista Chinês e ao Partido do Trabalho da Albânia na condenação ao revisionismo é muito mais devido "à necessidade de sobrevivência política e ao oportunismo que ao entendimento do conteúdo ideológico do revisionismo". Isto se torna mais claro se atentarmos para "a inexistência até hoje (passados 12 anos) de qualquer autocrítica dos dirigentes do PC do B com relação à sua prática anterior", e a permanência nessa organização "de métodos e estilo de trabalho vigentes no PCB”. Não conseguindo em sua ruptura empolgar as bases ou setores do velho PCB, a "nova” organização se construiu "sobre militantes dispersos ou abandonados do antigo partido". As ligações operárias do

\footnotetext{
${ }^{854}$ PARTIDO COMUNISTA DO BRASIL — ALA VERMELHA. Autocrítica, cit., p. 16-17.

${ }^{855}$ PARTIDO COMUNISTA DO BRASIL - ALA VERMELHA. Autocrítica, cit., p. 17.
} 
PCB, ainda a mais importante e numerosa da esquerda brasileira, "não são atraídas pelos divergentes". Os poucos operários que arrebanha não são sequer ativistas sindicais, indo sua composição "primar pela presença de elementos oriundos da pequena burguesia", dispersos e desligados do movimento de massas. Assim, "logo ao se desligar do PCB, o PC do B ao invés de se vincular a luta de classes concreta, dela irá se afastar, construindo-se, pois, fora da classe operária”. Mesmo quando, antes de 1964, as condições para uma vinculação às massas eram favoráveis, "optou por uma política sectária, isolacionista e 'radical' pequeno-burguesa, baseada na pregação messiânica da luta armada e por tentativas delirantes de sua deflagração através de pequenos grupos agindo no campo, isolados das massas" ${ }^{\prime 856}$.

A apreciação desfavorável do Doc. Autocrítica com relação do PCB e PC do B se manifesta de forma patente na avaliação que faz dos mesmos com relação ao Golpe de 64: "a falência das políticas desses partidosse revela plenamente com o golpe de 64, e em sua incapacidade de reação no período subseqüente". Revela-se também na incapacidade de realizar a autocrítica de sua política e de oferecer perspectivas ao movimento revolucionário brasileiro" ${ }^{, 857}$.

A seguir a Autocrítica passa à análise do próprio Golpe de 64, assegurando que este representou um rompimento com "as formas de dominação política que se haviam desenvolvido após 1930 - redefinindo a coalizão de poder e estabelecendo uma nova hegemonia — “ e teve sua motivação "imediata na crise pela qual passava a sociedade”. As contradições que já se haviam historicamente definido "são levadas peIa crise a ponto de rompimento". As massas urbanas e rurais se movimentavam pelas reformas: levadas pelo populismo e pelo revisionismo a se alinharem com os interesses da burguesia nacional — "que julgava, assim como o PCB, ainda possível completar sua revolução em condições de independência”. O acirramento da luta de classes leva "as massas mais longe do que pode pretender o populismo da burguesia nacional, e esta vacila, como é de sua natureza". Os setores agrários rompem a coalizão de poder ate então existente e "se aliam ostensivamente a grande burguesia industrial e financeira integrada ao capitalismo imperialista". Abre-se assim a oportunidade para esse setor assumir a hegemonia de um golpe que empolgaria "a classe media assustada pelo ascenso de massas e terá as Forças

\footnotetext{
${ }^{856}$ PARTIDO COMUNISTA DO BRASIL - ALA VERMELHA. Autocrítica, cit., p. 17-18.

${ }^{857}$ PARTIDO COMUNISTA DO BRASIL - ALA VERMELHA. Autocrítica, cit., p. 17-18.
} 
Armadas não apenas como instrumento militar, mas também como testa-de-ferro político", 858 .

As Forças Armadas representam a única força organizada nacionalmente capaz de intervir - "posto que no Brasil, devido as características de sua revolução burguesa, não existe tradição organizativa das classes dominantes (nem das dominadas)" — e já estavam “ganhas ao nível de parcelas consideráveis de seus altos escalões”, para a perspectiva do golpe. Ganhas tanto "ideologicamente quanto no sentido de um envolvimento com os interesses do grande capital", o que irá permitir que, nos anos seguintes, as Forças Armadas “assumam o papel de partido da classe hegemônica no poder". Evidentemente tal hegemonia "é assumida pela grande burguesia industrial e financeira integrada", uma vez que esse setor de classe "já dominava os setores dinâmicos da economia"

O Doc. Autocrítica diz que a vacilação da burguesia nacional (arrastando a seu reboque o $\mathrm{PCB}$ ) permite que o golpe seja desferido sem resistência, já que as classes eram mobilizadas pelo populismo". A nova classe hegemônica afasta a burguesia nacional dos centros de decisão e "desencadeia a repressão em larga escala para se implantar e se manter, assim como a sua política econômica”. Esta vai se caracterizar pelo aumento das facilidades para a entrada do capital estrangeiros, controle da inflação, submissão da classe operária à super-exploraçao de sua força de trabalho (arrocho), incentivo ã concentração de renda - reforçando um mercado consumidor de elite - e tentativa de saída representada pelo incentivo à exportação de manufaturados. Tal política, "beneficiando diretamente à grande burguesia industrial e financeira abre-lhe a perspectiva para um posterior crescimento acelerado da economia”. Ao mesmo tempo, ela representa ainda um imediato “alijamento da burguesia nacional, uma paulatina perda de poder (e importância) dos setores agrários e, sobretudo, uma grande intensificação da exploração das massas". Sua aplicação exige um "regime ditatorial que marginaliza setores das classes dominantes $e$ reprime violentamente todas as manifestações de oposição, dirigindo-se especialmente contra as massas" $" 860$.

A Autocrítica compreende que se as classes dominantes são atingidas pela dissolução dos partidos políticos, cassações de mandatos, perda do poder legislativo e restrições ao judiciário, “as massas, sobretudo a classe operária, vêem suas organizações implacavelmente desmanteladas". Mesmo as estruturas oficiais "criadas pelo populismo

\footnotetext{
${ }^{858}$ PARTIDO COMUNISTA DO BRASIL - ALA VERMELHA. Autocrítica, cit., p. 19.

${ }^{859}$ PARTIDO COMUNISTA DO BRASIL - ALA VERMELHA. Autocrítica, cit., p. 19.

${ }^{860}$ PARTIDO COMUNISTA DO BRASIL - ALA VERMELHA. Autocrítica, cit., p. 20.
} 
são reduzidas à inoperância”. Mais que nunca a classe operária fica "desprovida de seus instrumentos de luta, rigidamente controlada e vigiada - enquanto as massas rurais, que apenas começavam a se organizar, perdem rapidamente suas poucas e recém atingidas conquistas" ${ }^{\prime 861}$.

A política econômica "da ditadura aprofunda, num primeiro momento, a crise que originara o golpe", resultando um grande numero de falências, uma acentuada pauperização da pequena burguesia e considerável deterioração do nível de vida das massas. Isso vai criar "resistências à ditadura no seio da pequena burguesia, bem como crescente oposição por parte dos setores marginalizados das próprias classes dominantes" $" 862$.

O Doc. Autocrítica passa então a analisar a fragmentação da esquerda, após o Golpe de 64, divisando que nessa situação "de repressão e crise, de diminuição da base social da ditadura e tentativa de resistência que a esquerda começa a se fragmentar, em busca de uma saída revolucionária". O PCB e o PC do B não ofereciam respostas ou apresentavam alternativas. Suas dissidências e lutas internas refletiam esse estado de coisas, e se manifestam e principalmente nos setores estudantis. Isso se deveu sobretudo ao fato de que, por um lado, a "ação repressiva da ditadura ainda não havia arrebentado" àquela época —, as organizações do movimento estudantil - que, de resto, sempre haviam desfrutado de maior independência com relação ao Estado que os sindicatos "como o fizera com as do movimento operário" 863 ; por outro lado, a pequena burguesia, estudantes e intelectuais se radicalizavam principalmente pelo fato de disporem de consciência política desenvolvida. Como destaca o Doc. Autocrítica,

"Este fato é de importância fundamental para que possamos compreender corretamente a radicalização desta classe naquele momento e também entendermos a importância para as classes de possuírem elementos que, por terem acesso à cultura, são capazes de interpretar seus interesses - sejam políticos, económicos ou ideológicos)" ${ }^{\text {864. }}$.

Será no movimento estudantil que todas as tendências emergentes vão se confrontar no debate político. Além da derrota, "a contra-revolução que tornou clara a bancarrota da

\footnotetext{
${ }^{861}$ PARTIDO COMUNISTA DO BRASIL - ALA VERMELHA. Autocrítica, cit., p. 20.

${ }^{862}$ PARTIDO COMUNISTA DO BRASIL - ALA VERMELHA. Autocrítica, cit., p. 21.

${ }^{863}$ PARTIDO COMUNISTA DO BRASIL - ALA VERMELHA. Autocrítica, cit., p. 21.

${ }^{864}$ PARTIDO COMUNISTA DO BRASIL - ALA VERMELHA. Autocrítica, cit., p. 21.
} 
política revisionista", as novas tendências recebem a "influência da Revolução Cubana (com sua exaltação da tomada do poder pelas armas) e das divergências sino-soviéticas”. A riqueza do debate que então só trava, está justamente no fato de se colocar na mesa questões nunca discutidas dentro dos "velhos partidos": concepção do partido, caráter da Revolução, Frente Única, programa e tática, bem como discussões colocadas pelo movimento comunista internacional. Entretanto, "o despreparo teórico elou a assimilação dogmatizada do marxismo-leninismo (que na realidade não é sua assimilação)" levou os revolucionários a aprenderem "apenas os aspectos particulares de toda a problemática colocada". Deste modo, do debate sino-soviético absorveu-se principalmente a condenação à transição pacífica e se erigiu, na prática, "a luta armada como única linha divisória entre o revisionismo e o marxismo-leninismo". Não se chegou, assim, a compreender "a natureza ideológica do revisionismo". A dogmatização da experiência cubana, ao invés de destacar as especificidades de seu processo histórico, reduziu-as " $a ̀$ negação da necessidade do Partido, substituindo-o pelo foco guerrilheiro, ao mesmo tempo em que reduzia ao foco a via violenta de tomada do poder". Paralelamente, a Revolução Cultural Proletária que se desenvolvia na China neste período, foi compreendida apenas como exemplo e estímulo para "a aliança dos quadros intermediários com as bases revolucionárias na luta contra as direções esclerosadas". Todo este debate se fez em meio as intensas mobilizações de massas do movimento estudantil, no período 66-68, e no curso dessa prática que se forjam as primeiras organizações decorrentes das "lutas internas nos velhos "partidos comunistas". Resultado deste processo é também a Ala Vermelha ${ }^{865}$.

Se esta situação permitiu uma aproximação com o marxismo-leninismo na busca de novos caminhos - e "é este o elemento que permitirá o salto da algumas organizações no período subseqüente à derrocada do militarismo" —, não é menos verdade que "o conteúdo ideológico radical pequeno-burguês do conjunto da esquerda exigiu a passagem imediata à prática". Sem fôlego para levar mais adiante o debate, "as novas organizações recebem de Debray a sistematização da teoria do foco". As teses foquistas marcam profundamente a maioria das organizações - algumas (como a Ação Libertadora Nacional e a Vanguarda Popular Revolucionária) "negam pura e simplesmente a necessidade do Partido de vanguarda do proletariado, substituindo-o peIa ação de pequenos grupos"; outras como a Ala Vermelha e o Movimento Revolucionário 8 de Outubro, "tentam harmonizar foco e Partido"; e há ainda, as que —como a Organização

\footnotetext{
${ }^{865}$ PARTIDO COMUNISTA DO BRASIL — ALA VERMELHA. Autocrítica, cit., p. 21-22.
} 
Partidária Marxista-Leninista, Política Operária e o Partido Operário Comunista “assimilam a idéia de foco a uma orientação absolutamente contraditória a ela"

A seguir o Doc. Autocrítica passa a analisar o AI-5, dando inicialmente sua contextualização: a classe operária, com exceção feita a Osasco e Contagem, praticamente não é atingida pela mobilização de massas desse período; a "radicalização" da pequena burguesia que culmina com a passeata dos 100 mil define a composição das organizações que emergiam. A ideologia "radical" pequeno-burguesa se teve como matriz o desconhecimento e a não assimilação correta do marxismo-leninismo pelos revolucionários, encontrou no "movimento concreto das classes naquele momento um campo extremamente favorável para se desenvolver". A oposição dos setores das próprias classes dominantes descontentes com os rumos da ditadura, criou melhores condições para que "as manifestações da pequena-burguesia se ampliassem e fortalecessem”. Os setores agrários e a burguesia nacional, com seus interesses prejudicados pela nova política econômica e "afastados dos centros de decisão à medida em que se consolidavam os interesses da grande burguesia industriais e financeira" - que detinha a hegemonia do poder político - "passam a conspirar". Contando ainda com uma parcela razoável de poder político — como alguns governos estaduais e o Congresso —, as aspirações destes descontentes vão se cristalizar na Frente Ampla, "favorecendo a que a pequena burguesia se radicalize e saia às ruas" $" 867$.

O Ato Institucional $n^{\circ} 5$ surge, então, como o instrumento que permitirá “deter $a$ agitação de massa, as investidas da Frente Ampla e consolidar efetivamente a hegemonia da grande burguesia industrial e financeira no poder político". Garantindo sua estabilidade, o AI-5 assegura a plena aplicação da política econômica que favorece ao desenvolvimento do grande capital, especialmente do grande capital imperialista. O esmagamento das organizações de massa que ainda haviam sobrevivido a 64, ou se rearticulado, a expansão, a intensificação da repressão policial, o esvaziamento político do Congresso, a censura mais rigorosa a imprensa — todas essas medidas são necessárias para dar "plena eficácia ao modelo de desenvolvimento econômico dependente do imperialismo, vindo completar o conjunto cuja base já fora anteriormente assentada, com o arrocho salarial e a repressão ao movimento operário". A política da "ditadura do grande capital industrial e financeiro integrado, exercida através dos militares", instrumentada desde 1964 e complementa da em 1968 pelo Ato Institucional no 5, permite ao capitalismo no

\footnotetext{
${ }^{866}$ PARTIDO COMUNISTA DO BRASIL - ALA VERMELHA. Autocrítica, cit., p. 22.

${ }^{867}$ PARTIDO COMUNISTA DO BRASIL - ALA VERMELHA. Autocrítica, cit., p. 23.
} 
Brasil "superar a crise em que vinha se debatendo, dentro dos próprios marcos do sistema, passando para uma fase de crescimento econômico acelerado" ${ }^{\text {"868. }}$.

A repressão posterior ao AI-5 limita a área social onde as organizações de esquerda ainda realizavam algum trabalho de massa, isolando-as. Sua reação e a passagem à ação armada de grupos isolados — atividade que já vinha sendo levada à prática por algumas organizações - “dominam então o cenário da esquerda, e mais que nunca os revolucionários se distanciam da classe operária" ${ }^{869}$.

O Doc. Autocrítica passa a analisar o surgimento da própria Ala Vermelha, discorrendo que a Ala, enquanto organização independente do PC do B, origina-se no processo de "confusão e debate da esquerda, em busca da um caminho para a revolução brasileira". Como parte que foi neste debate, "refletirá suas insuficiências e descaminhos". Embora sem chegar a compreender em profundidade a origem das deformações do PC do B - pois eram portadores do mesmo ecletismo ideológico alguns quadros intermediários se opuseram a elas, basicamente ao oportunismo e mandonismo no estilo de trabalho e de direção, ao isolamento e não participação dos militantes nas decisões políticas, ao "tratamento policialesco" das divergências internas e a não preparação da luta armada. Os quadros que desta forma iniciaram o processo de luta interna não tinham sua origem no PC do B, provinham das Ligas Camponesas ou do movimento estudantil, atraídos, para o PC do B pela perspectiva de "luta armada imediata". Os quadros originários das Ligas Camponesas, além de não se haverem formado na adoração mítica e servilismo próprio de ambos os "partidos comunistas", vinham de um processo de ruptura com Francisco Julião e estavam "afeitos a critica mais do que ao seguidismo". Os originários do movimento estudantil viviam o processo de fragmentação da esquerda e o início do debate que colocava na mesa uma serie de questões básicas do marxismo-leninismo. Embora tanto um quanto outro fosse portador da uma ideologia predominantemente pequeno-burguesa, não haviam sofrido "as deformações e castração teóricas próprias dos militantes tradicionais". São os originários das Ligas que, entusiasmados pelo estudo da Revolução Chinesa, lançam as primeiras criticas e é basicamente no setor estudantil que elas vão encontrar eco. Das primeiras críticas à ruptura há um processo rico da discussões que vai marcar positivamente seus participantes ${ }^{870}$.

\footnotetext{
${ }^{868}$ PARTIDO COMUNISTA DO BRASIL - ALA VERMELHA. Autocrítica, cit., p. 23-24.

${ }^{869}$ PARTIDO COMUNISTA DO BRASIL - ALA VERMELHA. Autocrítica, cit., p. 24.

${ }^{870}$ PARTIDO COMUNISTA DO BRASIL - ALA VERMELHA. Autocrítica, cit., p. 25.
} 
Surgida "do debate e do exercício da crítica" a Ala Vermelha alcançou uma "qualidade diversa da organização onde se originou", no que diz respeito ao estilo de trabalho que incentiva e promove a discussão interna e a prática da crítica e da autocrítica. No entanto, às suas “críticas justas somava-se sua incompreensão da questão ideológica e a não assimilação do marxismo-leninismo, o que ira marcá-la e ser o responsável por seus descaminhos futuros". Quando ocorre a cisão, a Ala empolga a maioria das bases do PC do B, trazendo pois consigo o mesmo contingente social disperso, desligado da classe operária e ideologicamente eclético existente naquela organização, e envereda ainda mais no "radicalismo" pequeno-burguês. A cisão decorre da atitude do Comitê Central do PC do $\mathrm{B}$ que, assumindo a postura de "legítimo herdeiro do $P C B$ ”, interrompe a luta interna, "expulsando os quadros que a dirigem utilizando-se não só do mandonismo como lançando mão de velhos chavões do gênero 'agentes da CIA' e epítetos similares" ${ }^{\wedge 71}$.

A Ala Vermelha, uma corrente política dentro do PC do B, se vê obrigada a se organizar independentemente, com os recursos humanos originários daquele organização, com uma serie de quadros "profissionalizados" sem a "suficiente clareza e experiência política e de organização para tal'. Dá-se então uma quebra abrupta no processo de discussão, e todos os quadros se voltam para a manutenção da organização. Obrigados a sair prematuramente do "terreno da critica para os das definições que orientassem a organização", não são capazes de dar continuidade ao debate, e, como conseqüência, "não se processa a necessária depuração ideológica". Nessas condições, pressionados pelas exigências do momento, o documento "Crítica ao Oportunismo..." que fora planejado inicialmente apenas como crítica à "União dos Patriotas", ganha, no "próprio curso de sua elaboração, o propósito de definir uma linha política". As posições que alguns quadros elaboravam dispersamente no curso da luta interna cristalizam-se no documento. Justamente por tudo isso o documento vai se constituir num apanhado de "concepções radicais 'pequeno-burguesas', transpondo mecanicamente experiências de outras revoluções, além de pretender estar respondendo a questões que a luta de classes não colocara". Na medida em que respondia aos anseios da maioria dos militantes (que participavam da luta interna imbuídos do espírito de "fazer" a luta armada a curto prazo), "o documento obtém fraca aceitação". Aceitas suas concepções como linha da Ala Vermelha, o documento vai se tornar a "influência dominante dentro do nosso partido desde sua publicação até hoje". É portanto nele é que estão "calcados os principais desvios de concepções" da Ala. É "ele que reflete com mais clareza a fidelidade a

\footnotetext{
${ }^{871}$ PARTIDO COMUNISTA DO BRASIL — ALA VERMELHA. Autocrítica, cit., p. 25.
} 
tendência ideológica 'radical" pequeno-burguesa que caracteriza nossa teoria e nossa prática". Realizado nas condições assinaladas reflete naturalmente essas "concepções errôneas acerca da realidade brasileira, a começar pela avaliação incorreta da crise pela qual passava a sociedade ${ }^{, 872}$.

A não compreensão de que a crise era gerada pelas contradições internas à sociedade brasileira e de que a economia já era dominada em seus setores básicos pelo capital monopolista, principalmente americano; a não compreensão de que era possível superá-la nos marcos do sistema sem modificações profundas em sua estrutura e sem a abertura para a participação política popular ou mesmo das forças política burguesas levou a Ala Vermelha a uma supervalorização do papel do imperialismo no Golpe e na crise, e a idéia, de que esta "se aguçaria cada vez mais, abrindo caminho para a saída revolucionária a curto prazo" ${ }^{, 873}$.

A correta constatação da "diminuição da base social da ditadura militar devido à sua política despótica a serviço da grande burguesia industrial e financeira em detrimento das demais classes dominantes", e, sobretudo, "em prejuízo das amplas massas, e à conseqüente ampliação conjuntural do campo da revolução", é interpretado pela Ala como "condição favorável à saída revolucionária imediata". Outra circunstância que propiciava uma visão imediata era a constatação correta da necessidade de "reação contra a política revisionista da via pacífica, já desmoralizada pelo golpe”. Entretanto, da constatação de que a "base social da ditadura diminuía e de que era necessário reagir à bancarrota do revisionismo", ${ }^{874}$ a Ala Vermelha extraiu

“conclusões equivocadas que levaram a proposição da luta armada imediata, ao invés de propor uma política que assegurasse a participação de setores marginalizados pela ditadura (conjunturalmente situados no campo da revolução) de compreender que o revisionismo deve ser desmascarado teórica, política e ideologicamente, e não apenas em suas proposições pacifistas ${ }^{\text {,875. }}$.

A inexistência do movimento operário após o golpe era explicada pela "ação eficiente da ditadura" que exercia sobre a classe operária vigilância e repressão preventivas; pela intervenção e dissolução de suas organizações, pela perseguição e

\footnotetext{
${ }^{872}$ PARTIDO COMUNISTA DO BRASIL - ALA VERMELHA. Autocrítica, cit., p. 26.

${ }^{873}$ PARTIDO COMUNISTA DO BRASIL - ALA VERMELHA. Autocrítica, cit., p. 26.

${ }^{874}$ PARTIDO COMUNISTA DO BRASIL - ALA VERMELHA. Autocrítica, cit., p. 26-27.

${ }^{875}$ PARTIDO COMUNISTA DO BRASIL - ALA VERMELHA. Autocrítica, cit., p. 27.
} 
encarceramento de seus dirigentes e, mais, pela influência revisionista. "Nisso via-se uma resposta ao invés de uma pergunta". Em vez de se questionar as causas mais profundas da inexistência do movimento operário em vez de compreender que a classe operária mesmo antes de 64 não dispunha de organização sindical independente nem estava organizada na base, mobilizando-se apenas através da manipulação das cúpulas ligadas ao Ministério do Trabalho; de compreender que os direitos de trabalhistas eram resultado de populismo e não frutos conquistados pela luta da classe operária; enfim, "ao invés de se dedicar a pesquisa da formação e composição da classe operária brasileira e de seu movimento, ficava-se na superfície da constatação das dificuldades objetivas que a política da ditadura impunha”, assim, a Ala Vermelha como quase toda a esquerda brasileira nesse período, apresentava "a luta armada imediata como alternativa que levaria a classe operária à mobilização e à ação revolucionárias" ${ }^{876}$.

Passa então o Doc. Autocrítica a analisar o "Documento de Critica",877 afirmando que dentro dessa situação, tal Documento vai girar em torno da afirmação "enfática $e$ exagerada da luta armada, colocando-a como única linha divisória entre marxismo e revisionismo" ${ }^{\$ 78}$. Isso se torna nítido na crítica às concepções de luta armada do PC do B feita no "Documento de Crítica":

“Ao imaginar que a luta armada será o resultado natural de um auge do movimento de massas, os redatores do documento da VI incorrem num acentuado desvio de direito, manifestando claramente tendências revisionistas. Nas condições atuais da sociedade brasileira, é idealismo pensar que o movimento de massas possa desenvolver-se sem a existência concreta e simultânea na luta armada' $(p .37)^{\text {}} 879$.

O Doc. Autocrítica anota que a Ala identificava como tendência revisionista era justamente a "não colocação da luta armada como ponto de partida para toda atividade revolucionária". E mais: "os verdadeiros revolucionários se distinguiriam dos

\footnotetext{
${ }^{876}$ PARTIDO COMUNISTA DO BRASIL - ALA VERMELHA. Autocrítica, cit., p. 27.

${ }^{877}$ Relembra-se que o "Documento de Crítica" é a referência que se faz ao longo nome dado ao documento fundador da Ala Vermelha, o Crítica ao oportunismo e subjetivismo do documento "União dos Patriotas para livrar o País da Crise, da Ditadura, da Ameaça Neocolonial, cit.

${ }_{878}$ PARTIDO COMUNISTA DO BRASIL - ALA VERMELHA. Autocrítica, cit., p. 28.

${ }^{879}$ PARTIDO COMUNISTA DO BRASIL - ALA VERMELHA. Autocrítica, cit., p. 29.
} 
oportunistas na medida em que reafirmassem sua adesão à luta armada, de forma incondicional e a absoluta" ${ }^{, 800}$.

“'De qualquer forma, comprova-se sempre a assertiva de que essa evolução do movimento de massas, nas condições atuais, só pode se dar com a existência da luta armada, em função da luta armada e apoiado na luta armada' (p. 38) (...) No Brasil, o Partido, como destacamento de vanguarda do proletariado, só pode surgir no seio da luta armada, para a luta armada e dirigido à luta armada' (p.47) (...) 'Já constatamos que a tarefa mais urgente da revolução brasileira é a preparação e a eclosão da luta armada' (p. 48)”

Diz a Autocrítica que se verifica claramente que toda a argumentação do Documento de Crítica tem como objetivo justificar essa adesão à luta armada, "assumida aprioristicamente". "Relegávamos o movimento de massas (que é expressão mesma da luta de classes em sua manifestação concreta e mais abrangente) a um total segundo plano, em face de uma forma específica de luta, a luta armada. "Aberrações teóricas tornaram-se necessárias para obter esse resultado" ${ }^{881}$ :

"Se seu inimigo adota como forma de luta principal a violência armada, não é possível que as forças revolucionárias adotem, como forma de luta principal, uma de nível inferior, como o movimento de massas' (p.38)”

A Autocrítica nota que além de "reduzirmos o movimento de massas à categoria de forma de luta, entendíamos que a revolução deve sempre responder ao inimigo no mesmo nível', sem levar em conta a relação de forças entre revolução e contra-revolução. Ou, o que é ainda pior, "propúnhamos esse enfrentamento direto no mesmo nível, mesmo constatando que":

'No desnível das condições subjetivas às objetivas e na ausência de um verdadeiro partido do proletariado e de uma força armada sob sua direção, consiste a debilidade no campo da revolução' (p.42)"882

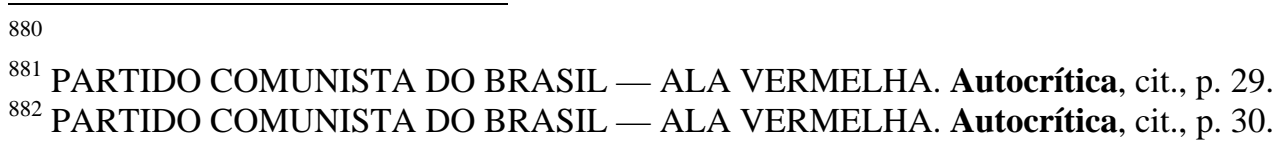


O Doc. Autocrítica marca que esta visão de luta armada que buscava superar o desnível de forças entre a revolução e seus inimigos através de enfrentamento imediato, abriu caminho para a proposição de ações armadas de grupos isolados e, mais particularmente, para o foco revolucionário. Todo esse pensamento "pretendia se justificar por uma visão de acumulação de forças revolucionárias resultante do choque armado com o inimigo do qual não só se desgastariam as forças contra-revolucionárias, como também “criar-se-iam as condições para a adesão das massas à luta armada e já em andamento". O ponto de partida era a idéia de atacar o inimigo onde ele é mais fraco:

'Como as forças revolucionárias são taticamente débeis em relação às forças contra-revolucionárias, torna-se necessário atingir o inimigo onde ele é mais vulnerável. O inimigo é mais vulnerável nas zonas rurais (...) Partido do campo a luta armada se desenvolve em choque aberto com o inimigo e, nesse processo, ao mesmo tempo em que ganha as grandes massas para a revolução, constrói paulatinamente o Exército Popular Revolucionário' (p. 44)",883

A Autocrítica destaca que até mesmo na tentativa de transposição mecânica da experiência chinesa da guerra popular, o documento se equivocou, na medida em que "nossa visão 'Radical' pequeno-burguesa deformava o conceito" que procurávamos $\operatorname{copiar}^{884}$ :

'A guerra popular é a forma que a luta armada assume quando a partir de pequenas ações armadas, se desenvolve paulatinamente até envolver a participação de todo o povo' (p. 45 - grifos dos autores da Autocrítica) ${ }^{\text {\$85 }}$

Nota o Doc. Autocrítica que essa deformação “permitia-nos 'harmonizar' a idéia de guerra popular com a do foco revolucionário. É justamente aí que o desvio de esquerda do Documento de Crítica sob a influência das teses de Debray, atinge sua expressão teórica mais extremada. O foco que "propúnhamos obedecia, em suas características fundamentais, ao modelo debraysta". Entretanto, como ele se inseria numa visão

\footnotetext{
${ }^{883}$ PARTIDO COMUNISTA DO BRASIL - ALA VERMELHA. Autocrítica, cit., p. 30.

${ }^{884}$ PARTIDO COMUNISTA DO BRASIL - ALA VERMELHA. Autocrítica, cit., p. 30.

${ }^{885}$ PARTIDO COMUNISTA DO BRASIL - ALA VERMELHA. Autocrítica, cit., p. 30.
} 
estratégica transposta da Revolução Chinesa, apresentava alguns acréscimos particulares $^{886}$.

Mas a essa visão “'ortodoxa' de foco, agregáramos o conceito necessidade do partido e da hegemonia do proletariado, o da criação de áreas libertadas e de cerco das cidades pelo campos":

'Para que o desenvolvimento da luta armada e construção do Exército Popular Revolucionário se dêem sob a hegemonia do proletariado, e necessário que, paralelamente a esse processo se forje a verdadeira vanguarda do proletariado (pag.46)(...) a Frente Única Revolucionária e um instrumento de mobilização das massas para apoiar a luta armada (pag.47) (...) utilizando principal forma de luta a luta armada, as forças revolucionárias poderão efetuar o cerco dos grandes centros urbanos a partir das zonas rurais" (pag.44). ${ }^{887}$

De modo que, no Documento de Crítica, o foco não é a única tarefa dos revolucionários, ainda que seja a principal:

“'Paralelamente a esta tarefa de preparação do foco, e sempre subordinado a ela é necessário desenvolver o trabalho de massas, preparando as condições para que, no momento da eclosão da luta armada, as grandes massas do povo possam apoiála. Além disso, e estreitamente vinculado a criação do foco, e necessário desenvolver a preparação do trabalho militar nos grandes centros e em várias zonas rurais diversas daquela em que se localiza o foco. Este trabalho militar, que se combinará com as ações realizadas nas zonas de guerrilhas, tem à finalidade de confundir e dispersar as forças do inimigo' (pág. 48)”, 888

A Autocrítica assevera que embora por essas citações feitas à concepção de foco no Documento de Crítica procurasse abranger um processo complexo (envolvendo a luta armada nas cidades e no campo, o movimento de massas, o Partido e se desdobrando no Exercito Popular Revolucionário, nas áreas libertadas e no cerco das cidades pelo campo), ela não consegue disfarçar sua origem, nem se livrar dos desvios decorrentes de sua

\footnotetext{
${ }^{886}$ PARTIDO COMUNISTA DO BRASIL - ALA VERMELHA. Autocrítica, cit., p. 30.

${ }^{887}$ PARTIDO COMUNISTA DO BRASIL - ALA VERMELHA. Autocrítica, cit., p. 31.

${ }^{888}$ PARTIDO COMUNISTA DO BRASIL - ALA VERMELHA. Autocrítica, cit., p. 32.
} 
própria natureza. O foco é a sistematização mais elaborada da ação isolada de um pequeno grupo em confronto direto com o inimigo. Trata-se de uma atividade totalmente desvinculada das massas, particularmente do proletariado; sua "implantação clandestina" demonstra a pressa dos que são incapazes de esperar pelos frutos do trabalho revolucionário entre as massas e a falta de confiança nestas, em nome das quais proclama ser feita a luta revolucionária. É aí que o vanguardismo se manifesta de modo mais enfático: o grupo de quadros "contingente guerrilheiro" iria "eclodir" a luta armada em nome do povo, e ao povo, as massas, caberia apoiar essa luta, aderir a ela ou imitá-la. A luta de classes e substituída pela luta de um pequeno grupo que se substitui as classes revolucionárias. Não obstante as tentativas de amenizar este conteúdo através da defesa da necessidade do partido e das referências vagas ao movimento de massas, o Doc. Autocrítica não consegue mudar a natureza ideológica da concepção de foco na medida em que e o "radicalismo" pequeno-burguês que informa toda essa articulação teórica. Já se tornou óbvio, através da prática, o fracasso previsível de tal teoria. Isoladas das massas, os contingentes da guerrilha rural se tornam presa fácil do aparelho repressivo inimigo e, mesmo quando sobrevivem, deslocam os revolucionários de seu trabalho principal, causando assim entraves ao processo revolucionário ${ }^{889}$.

Entretanto, no que diz respeito `a Ala Vermelha, o foco "não chegou a passar da teoria para a prova prática". Mas esta mesma teoria, o mesmo fundamento ideológico deu origem a novas formulações que interferiram mais diretamente em nossa prática. Assim é que o documento OPNTEFLA ${ }^{890}$ não passa de um desenvolvimento das idéias contidas na última citação reproduzida acima. $E$ as teses deste documento vão ter uma influência mais direta nas atividades da AV - ações armadas urbanas, grupos especiais do Partido e grupos armadas de massa ${ }^{891}$.

Embora a Ala não tenha chagado a "eclodir" um foco, a AV baseou o fundamental de sua prática na visão "vanguardista, militarista e isolada das massas que caracteriza aquela concepção" ${ }^{\text {s92 }}$.

Ainda que apresentando concepções vanguardistas e ideologicamente não proletárias, o "Documento de Crítica" guarda certa coerência interna. Isto é, as conclusões a respeito da luta armada, foco e outras "não foram extraídas do ar, não foram afirmações

\footnotetext{
${ }^{889}$ PARTIDO COMUNISTA DO BRASIL - ALA VERMELHA. Autocrítica, cit., p. 33.

${ }^{890}$ Se recorda que esta sigla é referente ao documento, de 1968, da Ala Vermelha intitulado Organizar um Partido de Novo Tipo em função da Luta Armada, cit.

${ }^{891}$ PARTIDO COMUNISTA DO BRASIL - ALA VERMELHA. Autocrítica, cit., p. 32.

${ }^{892}$ PARTIDO COMUNISTA DO BRASIL - ALA VERMELHA. Autocrítica, cit., p. 33.
} 
jogadas": elas decorriam de uma analisa errônea da realidade do país a da realidade internacional. Dizendo de outro modo, elas fazem parte de uma "visão geral deformada do país, do mundo e da própria teoria marxismo-leninismo". Um exemplo claro disso está na forma pela qual o documento "demonstra" que a revolução brasileira percorrerá o caminho do cerco das cidades pelo campo. Tal tese não é afirmada gratuitamente: o Doc. Autocrítica pretendia que ela decorresse de determinadas características da realidade brasileira. Assim a que, expondo as "características fundamentais da situação atual da sociedade brasileira”, tem-se: ${ }^{893}$

"O desenvolvimento do capitalismo na sociedade brasileira atual se da nas condições de existência de importantes regiões atrasadas. Embora haja uma predominância de relações capitalistas, o Brasil se caracteriza como um país predominantemente agrário. No entanto isto se da ao lado de fatores fundamentais da compreensão situação atual da sociedade brasileira: a) A maioria da população do pais vive no campo, isto é, fora dos centros urbanos onde se encontra a produção capitalista; b) Pelo fato da economia nacional se fundamentar na exportação de produtos primários e da maioria da população ativa viver no campo, a sociedade brasileira se caracteriza por ser predominantemente agrária' (pág. 42)." 894

De tal análise o Doc. Autocrítica conclui não somente que a revolução brasileira seria entre outras coisas "agrária" (pág.40 do "Documento de Crítica"), mas também que o campesinato seria seu contingente principal e, logicamente, que o processo de guerra popular levaria "ao cerco das cidades pelo campo" 895

'O cerco das cidades pelo campo é também indicado pelo fato da maioria da população do país viver no campo e porque esta população esta submetida as formas mais violentas de opressão e às mais atrasadas de exploração, o que lhes proporciona um sentimento imediato da necessidade da revolução' (pág. 43).”

\footnotetext{
${ }^{893}$ PARTIDO COMUNISTA DO BRASIL - ALA VERMELHA. Autocrítica, cit., p. 33.

${ }^{894}$ PARTIDO COMUNISTA DO BRASIL - ALA VERMELHA. Autocrítica, cit., p. 33.

${ }^{895}$ PARTIDO COMUNISTA DO BRASIL - ALA VERMELHA. Autocrítica, cit., p. 33.
} 
Segundo o Doc. Autocrítica no penúltimo trecho citado verifica-se diversos erros e distorções. De início, o critério de declarar o país predominantemente agrário baseado na distribuição da população e composição da pauta de exportações, é um “erro manifesto". O que caracteriza uma sociedade são as relações de produção dominantes, isto e, aquelas que se fazem presentes nos setores mais dinâmicos e significativos da economia. Sob este ponto de vista, "não resta dúvida que o Brasil é um país capitalista", sem contar, é claro, que se era verdade em 1967 que pouco mais da metade da população viva no campo, hoje em dia esta proporção se inverteu. E não foi isso, seguramente, que determinou qualquer mudança no caráter .da sociedade brasileira. Em seguida, no trecho citado, afirma-se expressamente que no Brasil "há uma predominância de relações capitalistas", e não obstante, se trata de um país "predominantemente agrário". Conforme o que já se demonstrou, essa afirmativa se constituí numa "contradição em termos, na verdade, de uma hesitação em extrair a conclusão da "predominância de relações capitalistas", o que levou ao emprego deslocado do conceito de "país agrário", por querer afirmar, sem segurança para dizê-lo, que se tratava de uma sociedade pré-capitalista. A confusão teórica que isso permite abriu caminho para as conclusões que levam ao cerco das cidades pelo campo. Entretanto, aclarando tais confusões, reconhecendo que o país é capitalista, eliminando o artifício do "predominantemente agrário", "o cerco das cidades pelo campo cai no vazio". Isto é, sem base para sustentá-lo, sua afirmação pura e simples deixa de ser resultado de uma análise para permanecer apenas como "um palpite ao gosto da futurologia"896.

A insistência na necessidade do partido do proletariado, presente na AV, desde sua formação e conseqüentemente no Documento de Crítica, tende a afastar as concepções do ponto de vista puramente militar. Após definir-se o foco revolucionário como tarefa principal, argumentava-se:

"Para que o desenvolvimento da luta armada e do Exercito Popular Revolucionário se dêem sob a hegemonia do proletariado, é necessário que paralelamente a asse processo se forje a verdadeira vanguarda do proletariado. Assegurar a hegemonia do proletariado no desenvolvimento da luta armada e na construção do Exercito Popular Revolucionário e condição essencial para garantir a hegemonia do proletariado na revolução e para o êxito desta (pág.40) (...) Partindo da necessidade do partido do proletariado para dirigir o processo revolucionário (...) a hegemonia do proletariado é garantida pela sua força,

\footnotetext{
${ }^{896}$ PARTIDO COMUNISTA DO BRASIL — ALA VERMELHA. Autocrítica, cit., p. 34.
} 
emanada da existência de um partido temperado na luta e de uma força armada sob sua direção' (pág.47)" ${ }^{897}$.

Tanto nestes trechos como em todos os outros em que no documento o Doc. Autocrítica se refere ao partido, ficava clara a visão de sua necessidade como instrumento para dirigir a luta armada e para garantir a hegemonia do proletariado. Ainda que estes sejam aspectos corretos da concepção de partidos, eles representam apenas um lado da questão. Não há em todo o documento referência ao papel ideológico do partido, a sua função primeira de educador das massas proletárias. Essa "visão unilateral que reconhecia apenas o papel de dirigente político do partido é produto do dogmatismo". No entanto, não é apenas este aspecto de uma visão errônea da concepção de partido que o Documento de Crítica revela: o "radicalismo" pequeno-burguês que fundamenta todo o documento "atrelava o partido e sua construção a luta armada" ${ }^{898}$ Deslocando esta última para o primeiro plano, transformava o partido do proletariado num elemento subordinado a ela: “"No Brasil, o partido como destacamento de vanguarda do proletariado só pode surgir no seio da luta armada, para a luta armada e dirigindo a luta armada' (pág.47)”899.

Desse ponto de vista, a "forma de luta limita o partido, condiciona sua existência e, na verdade, se sobrepõe a ele". O que naturalmente decorria de uma visão do processo revolucionário onde a forma de luta era o elemento determinante, relegando a outro plano a dinâmica da luta de classes e o movimento de massas despido de suas verdadeiras funções, o partido se traduzia a uma espécie "de Estado-Maior, de Comando Supremo das operações militares da guerra popular". Tal empobrecimento da concepção de partido vai se refletir logicamente no entendimento do processo de sua construção ${ }^{900}$.

De início, ainda uma vez, ele é relegado a um segundo plano:

“No momento atual, a tarefa mais urgente do processo revolucionário não consiste na construção de um forte partido em todo o país, para somente depois preparar o desencadeamento da luta armada. Não se trata de destacar os melhores quadros para esse trabalho de construção do partido" (pág.47) ${ }^{901}$.

\footnotetext{
${ }^{897}$ PARTIDO COMUNISTA DO BRASIL - ALA VERMELHA. Autocrítica, cit., p. 34.

${ }^{898}$ PARTIDO COMUNISTA DO BRASIL - ALA VERMELHA. Autocrítica, cit., p. 34.

${ }^{899}$ PARTIDO COMUNISTA DO BRASIL - ALA VERMELHA. Autocrítica, cit., p. 34-35.

${ }^{900}$ PARTIDO COMUNISTA DO BRASIL - ALA VERMELHA. Autocrítica, cit., p. 35.

${ }^{901}$ PARTIDO COMUNISTA DO BRASIL - ALA VERMELHA. Autocrítica, cit., p. 35.
} 
Justamente, quando se verifica que um dos principais elementos de atraso da revolução brasileira e a inexistência do partido, afirma-se que sua construção não é a tarefa mais urgente. Reagindo à visão do Partido Comunista do Brasil de construir uma imensa e pouco ágil máquina partidária como tarefa anterior a todas as outras e delas desligadas, o "Documento de Crítica" caiu no desvio oposto. Traçava-se um processo em que a organização partidária “destaca seus -melhores quadros” para preparar e eclodir a luta armada e, posteriormente, "a partir da eclosão da luta armada" e com base em seu desenvolvimento, a tarefa da organização partidária será a de dar "uma nova qualidade ao movimento de massas, assumindo nesse processo o papel de vanguarda do proletariado". ${ }^{902}$ A Ala Vermelha eclodiria a luta armada e, no bojo desta se transformaria no partido:

“ ‘...a organização partidária ao se preparar para desencadear a luta armada não pode abandonar o trabalho da preparação das condições necessárias para que, após o desencadeamento da luta armada, possa desenvolver a tarefa da se transformar na vanguarda do proletariado e da revolução" (pág.47) ${ }^{903}$.

Em outras palavras, se entendia que a organização partidária então existente precisava, basicamente, da luta armada para se transformar no partido; na medida em que não são colocadas questões referentes as "condições ideológicas, políticas e orgânicas necessárias à construção do partido", torna-se claro o entendimento de que a Ala Vermelha já reunia essas condições, faltando apenas o "caldo de cultura" da luta armada. O que nos leva de volta ao dogmatismo: a AV por definição, já reunia aquelas condições, já era uma espécie de partido do proletariado em ponto pequeno, uma "maquete" de partido. Com isso , obviamente, afastavam-se todas as necessidades de retificação política e ideológica da organização, para que fosse possível lançá-la da forma como existia na preparação da luta armada. Tal concepção retardou, dentro da Ala Vermelha, a compreensão da necessidade da autocrítica, de um profundo processo de retificação ${ }^{904}$.

De um modo geral, é perceptível nas colocações da AV naquele documento, sobre a luta armada, uma pressuposição dogmática; sem dizê-lo, os elementos estratégicos e táticos que a Ala apresentava se referiam a uma situação hipotética em que a luta armada já

\footnotetext{
${ }^{902}$ PARTIDO COMUNISTA DO BRASIL - ALA VERMELHA. Autocrítica, cit., p. 35.

${ }^{903}$ PARTIDO COMUNISTA DO BRASIL - ALA VERMELHA. Autocrítica, cit., p. 35

${ }^{904}$ PARTIDO COMUNISTA DO BRASIL - ALA VERMELHA. Autocrítica, cit., p. 37.
} 
existia. Com a provável exceção do foco - que afinal era entendido como elemento desencadeador —, todas as outras colocações seriam válidas, se propostas por um partido já envolvido em uma situação real de guerra: o partido dirigindo a luta armada como forma principal de luta, subordinando todas as outras, etc. Trata-se aqui de um claro exemplo de dogmatismo na medida em que todas essas teses (com exceção ainda uma vez do foco), foram tomadas "de empréstimo a Revolução Chinesa, na qual a guerra já era um dado concreto e dominante da realidade". Denota isto o fato de se haver escolhido como citação ilustrativa, na página final do documento, um texto de Mao Tsé-tung extraído de "A tática da luta contra o Imperialismo Japonês", correta para um momento de pleno desenvolvimento da luta armada, mas que se demonstra deslocada na situação da sociedade brasileira. Nesse sentido, "o dogmatismo da Ala Vermelha não era menor, que o do Partido Comunista do Brasil", na medida em que, para validar sua tática de "União dos Patriotas”, só não existia o dado concreto de uma invasão japonesa. Da mesma forma, o dogmatismo da AV vai estar presente no que o documento de Crítica coloca sobre a estratégia, tática e programa ${ }^{905}$. O dogmatismo se revela de imediato na própria definição metodológica para abordar tais problemas:

“"É necessário, em primeiro lugar, ter o conhecimento das contradiçoes fundamentais, e, da contradição principal da sociedade brasileira. Tendo-se esse conhecimento, e possível, entao, definir o programa e traçar a tática com base em tal conhecimento' (pag.29)"906.

O ponto de partida para uma colocação desse tipo, diz o Doc. Autocrítica, foi uma leitura mal assimilada do texto teórico "Sobre a Contradição" de Mao Tsé-tung. Entendendo mecanicamente a questão das contradições na sociedade, ela se despiu de qualquer dialética, de qualquer movimento. Criou-se um modelo "rígido, linear, que via a sociedade num corte estrutural, onde as classes se enfrentavam estaticamente, dispostas em campos antagônicos bem definidos". Estabelecia-se na verdade uma fórmula segundo a qual um dado ordenamento de contradições hierarquizadas produzia diretamente o programa, a estratégia e a tática da revolução. O que vale dizer que, de posse da fórmula, qualquer pessoa, independente de sua prática política, de sua militância e de seu conhecimento teórico, poderia definir estratégia, tática e programa. Estava, é claro,

\footnotetext{
${ }^{905}$ PARTIDO COMUNISTA DO BRASIL - ALA VERMELHA. Autocrítica, cit., p. 38.

${ }^{906}$ PARTIDO COMUNISTA DO BRASIL - ALA VERMELHA. Autocrítica, cit., p. 38.
} 
pressuposto que o conhecimento das contradições fundamentais e da contradição principal era o resultado de uma análise de classes anteriormente feita. Esta tentava surpreender a "estrutura" da sociedade como que congelada diante do observador, "a-histórica, sem levar em conta seus desdobramentos no tempo"907.

De posse desta fórmula, a AV estabelecia os pólos da contradição principal entre, de um lado, o povo, e, de outro, o neocolonialismo e seu suporte social interno. A revolução vinha a ser o choque entre os dois aspectos da contradição, e a superação do aspecto principal (neocolonialismo e seu suporte) pelo aspecto secundário. Desse enfrentamento decorriam todas as características da revolução. Esse "esquematismo" nada mais é que o "empobrecimento sistemático de Mao Tsé-tung em Sobra a Contradição". Nele se pode perceber como uma teoria correta, empregada dogmaticamente, se transforma exatamente no seu contrário ${ }^{908}$.

Assim é que se afirma que na atual etapa da revolução "objetiva destruir os meios de exploração e opressão do neocolonialismo e de seu suporte social interno". Essa exploração e opressão caracterizam a sociedade brasileira como: "Uma sociedade neocolonizada, agrária, de acentuadas relações de produção capitalistas" (pág.40) ${ }^{909}$.

Dessa forma tortuosa e insegura, o "Documento de Crítica" chegava à etapa da democracia popular. A afirmação correta do caráter da revolução brasileira era, portanto, sustentada por "uma análise e por argumentações absolutamente errôneas". Se hoje a AV continua definindo a revolução como uma revolução de democracia popular, a fundamentação dessa assertiva é bem outra. Ela parte do reconhecimento de que a sociedade brasileira é uma sociedade capitalista, na qual, entretanto, as particularidades da revolução burguesa lha determinam um caráter não democrático, e que está inserida numa situação dependência ao imperialismo.

Em seguida, no Documento de Crítica, extrai-se a conclusão de que a etapa corresponde um poder "exercido pelas classes e camadas que estão no campo da revolução, sob a hegemonia do proletariado”, ou Governo Popular Revolucionário.

Ao abordar a estratégia, o Documento de Crítica realiza, no seu grau mais desenvolvido, o exercício subjetivista: a partir de uma série de contradições fundamentais da sociedade brasileira, projetava-se a luta armada surgindo no campo e seu desenvolvimento paulatino ate chegar-se ao cerco das cidades. Em um momento em que o

\footnotetext{
${ }^{907}$ PARTIDO COMUNISTA DO BRASIL - ALA VERMELHA. Autocrítica, cit., p. 39.

${ }^{908}$ PARTIDO COMUNISTA DO BRASIL - ALA VERMELHA. Autocrítica, cit., p. 39.

${ }^{909}$ PARTIDO COMUNISTA DO BRASIL - ALA VERMELHA. Autocrítica, cit., p. 39.
} 
processo revolucionário brasileiro ainda não revelou as lindas gerais de seu encaminhamento, tais afirmações "soam como uma divagação visionária". ${ }^{910}$.

No Documento de Crítica o neocolonialismo era entendido como sendo uma nova fase do imperialismo, assim como este foi em relação ao capitalismo não monopolista. Sua caracterização, que constitui a parte fundamental da análise internacional do documento, se prende à existência das empresas "multinacionais", à substituição de "exportação de capitais" pelo "investimento direto", à fusão entre o capital financeiro e o capital estatal — e o que é mais importante, ao papel hegemônico desempenhado pelos Estados Unidos da América no mundo capitalista depois da II Guerra mundial. "O neocolonialismo iria além do imperialismo na dominação das economias atrasadas", pois utilizaria formas similares de "dominação colonial”, substituindo a administração colonial por governos títeres (ditaduras militares neocolonialistas), substituindo a ocupação realizada por tropas da metrópole pela ocupação por tropas nativas educadas ideologicamente pelo Pentágono ${ }^{911}$.

Tal ocupação representa o produto da tentativa de realizar uma análise que esgotasse as características do imperialismo contemporâneo posterior à II Guerra mundial, "sem dispor de base teórica e do conhecimento da realidade necessários". Algumas características novas assumidas pelo imperialismo foram transformadas no próprio conteúdo da "nova fase". Uma determinada forma de dominação que pode ser identificada em algumas nações africanas do passado colonial recente, foi transformada na forma "típica" de dominação do capital monopolista atual. No "Documento de Crítica" "se generalizava o que era particular no imperialismo contemporâneo",912.

Devido às concepções políticas errôneas que orientavam a Ala Vermelha, não se compreendeu corretamente as situações conjunturais da sociedade e de suas mudanças. A existência artificial da organização e, conseqüentemente, sua atuação marginal ao processo social, o convencimento de que a preparação da luta armada no campo dependia exclusivamente das iniciativas da própria AV, determinavam um profundo desconhecimento - e mesmo a desnecessidade de conhecer — das mudanças nas relações de poder e das conjunturas dai decorrentes. Desse modo, quando ocorre uma significativa mudança na conjuntura política como a decretação da AI-5, não só "fomos incapazes de definir uma posição sobre seu significado", como também "enveredamos de forma ainda

\footnotetext{
${ }^{910}$ PARTIDO COMUNISTA DO BRASIL - ALA VERMELHA. Autocrítica, cit., p. 39.

${ }^{911}$ PARTIDO COMUNISTA DO BRASIL - ALA VERMELHA. Autocrítica, cit., p. 43.

${ }^{912}$ PARTIDO COMUNISTA DO BRASIL - ALA VERMELHA. Autocrítica, cit., p. 43.
} 
mais acentuada no desvio de atuarmos apenas com nossas limitadas forças, reforçando a tendência de esquerda", particularmente "o militarismo"913.

A reação diante do AI-5 representou a reafirmação das concepções vanguardistas do Documento de Crítica à sua exacerbação. A repressão que se segue ao AI-5 atinge de imediato os setores da pequena burguesia, particularmente o movimento estudantil, e esmaga suas organizações. Isso atemoriza e limita a área social onde as organizações de esquerda ainda realizavam algum trabalho de massa, isolando-as. A reação da esquerda é uma radicalização cada vez maior inaugurando, assim, "o período de apogeu das ações armadas de grupos isolados". A Ala Vermelha é atingida pelo mesmo fenômeno. "Sem compreendermos o significado e a dimensão desse instrumento do qual lançava mão a ditadura", não entendendo que o momento determinava recuo e um "trabalho paciente $e$ camuflado" de ligação com as massas, para evitar o isolamento, a AV tentou continuar a avançar apenas com nossos próprios recursos internos, preparando-nos para a luta armada através de "uma prática militarista" 914.

Como medida para romper o isolamento em que a Ala se encontrava passou-se a aceitar a ação armada como instrumento de propaganda e não mais apenas como forma de obter recursos financeiros. Praticamente foi abandonado o trabalho no meio estudantil e tentou-se deslocar o centro de gravidade de nossa atuação no sentido de estabelecer laços com o proletariado, intensificando a agitação vanguardista através de panfletagens e do que se chamou "de propaganda armada" 915.

Esse aguçamento do vanguardismo da Ala encontrou sua expressão mais acentuada em São Paulo. No período imediatamente posterior ao AI-5, desenvolveu-se nesse Regional uma intensa discussão que tinha por base concepções do Documento de Crítica e do OPNTEFLA. Uma orientação política foi elaborada e posta em prática com relativa autonomia em relação à Direção Nacional Provisória. A diretiva básica era a de ligação com a classe operária: pretendia-se, entretanto, realizá-la através de um trabalho que aliava o trabalho de organização na fábrica com "a propaganda armada”. O trabalho na fábrica era entendido como sendo de "dentro para fora", isto é, vinculado da classe ao partido, enquanto que a "propaganda armada" era a de intensa distribuição de material impresso basicamente panfletagens — apoiada por ações que iriam desde comícios relâmpagos com cobertura militar, até tomadas de estações de rádio ${ }^{916}$.

\footnotetext{
${ }^{913}$ PARTIDO COMUNISTA DO BRASIL - ALA VERMELHA. Autocrítica, cit., p. 51.

${ }^{914}$ PARTIDO COMUNISTA DO BRASIL — ALA VERMELHA. Autocrítica, cit., p. 51-52.

${ }^{915}$ PARTIDO COMUNISTA DO BRASIL — ALA VERMELHA. Autocrítica, cit., p. 52.

${ }^{916}$ PARTIDO COMUNISTA DO BRASIL - ALA VERMELHA. Autocrítica, cit., p. 52.
} 
Pretendia-se que esta "propaganda" elevasse o nível de consciência da massa para que ela se organizasse "espontaneamente", ampliando os contatos do trabalho de "dentro para fora", além da construção do Partido nas fábricas. Entendia-se que, na medida em que o movimento operário se encontrava estagnado, a "propaganda armada" teria a virtude de desencadear a luta "espontânea" do proletariado. Na realidade, a "propaganda armada" nada tinha de propaganda, posto que não era instrumento de educação, não realizava um papel pedagógico. Não passava de "agitação vanguardista por não se basear nas reais condições subjetivas das massas, além de se dirigir de forma dispersa e fragmentária". A própria idéia de criar lutas "espontâneas" a partir de um estímulo de fora traduz uma visão distorcida do que seja luta "espontânea", ratificava a "teoria do exemplo" (a massa deve imitar o que a vanguarda já está fazendo), e nada mais é, enfim, que uma vestimenta nova da velha idéia do "terror excitativo" que Lênin combateu em "Que fazer?"917.

Está claro que a prática dessas concepções, efetivadas através da criação de organismos especializados, as "Unidades de Combate", não contribuiu para levar consciência as massas e organizá-las, nem para incentivar sua movimentação, e muito menos ainda para ligar a AV à classe operária ou ampliar sua influência. Pelo contrário, esse é o período em que "vamos nos encontrar mais agudamente isolados, perdendo até mesmo a área de apoio de que anteriormente dispúnhamos". Constatado esse isolamento, a curta experiência das Unidades de Combate, interrompidas com as prisões de agosto de 69, não será posteriormente retomada.

Neste período, além dos desacertos políticos em nossa prática junto à sociedade, cabe ainda destacar alguns aspectos da política de organização da AV. Em vários momentos fez-se referência a uma estrutura pesada, rígida, construída artificialmente. Se por um lado ficou localizado sua determinação por havermos aprendido dogmaticamente (no campo teórico) a concepção leninista do Partido e por havermos surgido enquanto partido da cisão de uma organização já isolada das massas — "das quais nossa prática vanguardista veio a nos afastar cada vez mais" - falta, no entanto, precisar como se manifestou este artificialismo e o que significou concretamente ${ }^{918}$.

Estruturados fora do contexto social, os organismos da AV - assim como o conjunto de sua estrutura orgânica - não correspondem às necessidades do desenvolvimento da luta social. Formam-se como "estruturas paralelas à luta e à classe ou setor social a que se referem, estruturas formais cujas existências não determinam nem

\footnotetext{
${ }^{917}$ PARTIDO COMUNISTA DO BRASIL - ALA VERMELHA. Autocrítica, cit., p. 52-53.

${ }^{918}$ PARTIDO COMUNISTA DO BRASIL - ALA VERMELHA. Autocrítica, cit., p. 54.
} 
são formadoras de função educadora elou dirigente”. A título de exemplo, o comitê estudantil não organizava os elementos mais ativos e que dirigiam as lutas de seu setor, mas elementos que regra geral “comportavam-se como massa no movimento”. Em outras palavras: não se tratava de "um núcleo de comunistas que desenvolvia um trabalho no movimento estudantil, mas de um punhado de estudantes que se organizava no interior da $A V^{\prime}$.

Artificiais e ineficientes, cada organismo em particular é depositário da concepção que os engendrou, infundiram os traços de sua natureza a todas as suas atividades. Montouse, deste modo, uma aparelhagem que não correspondia às verdadeiras necessidades do trabalho que se desenvolvia e que nela não se assentava: profissionalizam-se desnecessariamente quadros, exigem-se recursos superiores aos que um trabalho correto determinaria. Exige-se, assim, recursos artificiais como os de destacar quadros ou militantes para montar um aparelho assumindo um papel de disfarce clandestino, quando uma aparelhagem montada a partir do trabalho correto utilizaria os recursos materiais e humanos criados por este.

A alternativa correta exigiria menor numero de profissionais e recursos nitidamente inferiores. Esta dinâmica artificial leva a que "não consigamos atuar além dos marcos de nossa própria organização". Com isso, a atividade do conjunto da organização e, sobretudo a de seus principais responsáveis, vai ser consumida quase que exclusivamente com os problemas internos que irão absorver todas as suas potencialidades. Esse fechamento da organização sobre si mesma tende "a transformar sua vida interna numa existência de seita $^{919}$.

A causa mais profunda da inexistência de uma direção política na época reside, porém, no fato de nossa linha nos tornar impermeáveis às questões conjunturais. A análise estática contida no Documento de Crítica, bem como a estratégia e a tática ali definidas, “'resolveriam' todos os problemas políticos da revolução"920.

$\mathrm{O}$ P(AV) não necessita de dirigentes políticos acompanhando e analisando os acontecimentos e mudanças que se desenvolvem na sociedade como na maioria das organizações; necessita de “executores da política traçada e 'administradores' do aparelho da organização". Daí decorre abstração teórica e política dos quadros e dirigentes; desestimulados do estudo e da pesquisa, "permanecem com o mesmo conhecimento deformado da teoria marxista-leninista e da situação do país”.

\footnotetext{
${ }^{919}$ PARTIDO COMUNISTA DO BRASIL - ALA VERMELHA. Autocrítica, cit., p. 54.

${ }^{920}$ PARTIDO COMUNISTA DO BRASIL - ALA VERMELHA. Autocrítica, cit., p. 55.
} 
$\mathrm{O}$ artificialismo também se refletiu na política de recrutamento e de promoção de quadros. Não estando fundido a luta de classes concreta, a AV assimilou elementos “despreparados, sem qualquer experiência de luta e, portanto, sem as mínimas condições de militância". O recrutamento era feito entre as pessoas disponíveis conhecidas pelos militantes, e não entre aquelas cuja eficiência concreta, "mesmo quando atuávamos no seio de determinados movimentos". Dessa forma, os militantes, além de não terem a devida formação ideológica proletária, não eram o que deve ser qualquer militante de base de um partido sério: “dirigentes políticos de massa, capazes de levar a política do partido, educá-las, organizá-las e dirigi-las em suas lutas". Este fenômeno, naturalmente, se estendeu ao processo de formação das direções e da promoção de quadros sem o critério da prática, sem terem sido forjados na luta de classes, os quadros acabavam por ser promovidos com base em critério tais como a um conhecimento teórico, facilidade de expressão, certa agudeza política. Isso permite, fatalmente, "a formação de direções com quadros ideologicamente débeis, inexperientes e fracos possibilitando o arrivismo". A experiência iniciada na AV demonstrou o prejuízo que podem causar quadros desse gênero, "quando dos golpes infligidos pela contra-revolução" 921 .

O Doc. Autocrítica sugere então uma política conseqüente de construção do partido, apoiada na sua fusão com a luta de classes concreta, a qual deve determinar rigorosas exigências para a assimilação e promoção de quadros. Abandonando o artificialismo, só devem ser recrutados aqueles elementos que se revelam no trabalho concreto da luta de classes, que já assimilaram pelo menos rudimentos da ideologia socialista, e que trazem atrás de si um trabalho real, traduzido na influência que tenham num círculo de elementos da massa. Somente assim "o militante de base será um dirigente político de massas" e somente assim a organização pode ter critérios corretos para promover os mais capazes e ideologicamente mais preparados ${ }^{922}$.

A Autocrítica ressalta, contudo que neste período, "nossa própria unidade política foi artificial, se refletindo e refletida pelos próprios métodos de direção nacional que aplicávamos". O que de inicio mantivera a unidade da organização fora da luta contra o Comitê Central do Partido Comunista do Brasil; como organização independente, tentamos estabelecer, através do Documento de Crítica, uma linha política que representasse o conjunto da organização. Entretanto, devido sua própria inaplicabilidade, o documento não obteve êxito neste terreno. A unidade da AV existiu, então, apenas

\footnotetext{
${ }^{921}$ PARTIDO COMUNISTA DO BRASIL — ALA VERMELHA. Autocrítica, cit., p. 55.

${ }^{922}$ PARTIDO COMUNISTA DO BRASIL - ALA VERMELHA. Autocrítica, cit., p. 56.
} 
formalmente: na verdade, sua direção central se demonstrou inoperante e os diversos Comitês Regionais desenvolveram orientações praticamente independentes. Esse "autonomismo" dos Comitês Regionais criou um risco real de fragmentação da AV, que só veio a ser superado após a adoção do Documento dos "16 Pontos". O "autonomismo" mais um sintoma da existência artificial da organização naquele período. Um verdadeiro partido proletário tem, como um de seus aspectos essenciais, a unidade política garantida por uma direção central conseqüente ${ }^{923}$.

Nesse processo, como direção central, a AV dispôs, de início, de uma Comissão Nacional de Consultas, órgão composto por representação dos Regionais, sem poderes executivos. Posteriormente, criada a Direção Nacional Provisória. Este organismo ainda que dispondo formalmente das características de uma direção central, "não conseguiu, num primeiro momento, superar o “autonomismo" dos Comitês Regionais". Passamos então por uma aguda crise interna, como resultado da prática incorreta decorrente das concepções do "Documento de Crítica e no OPNTEFLA. Por um lado, a inaplicabilidade destas concepções levou ao espontaneísmo (como no movimento estudantil) ou ao ativismo Interno, em substituição de atividade que se deveria realizar entre as massas. Por outro, a tentativa de sua aplicação, sobretudo no período posterior ao ato Institucional $\mathrm{n}^{\mathrm{o}} 5$, levou a AV ao "momento mais agudo de seu desvio vanguardista — particularmente sob a forma de militarismo - e ao mais profundo isolamento das massas". Situação que nos deixou com o "flanco aberto aos golpes da repressão" — resultando em diversas e profundas quedas $^{924}$.

Mas, durante mesmo esse período, já se verificava, no interior da $\mathrm{AV}$, resistência à sua prática vanguardista e ao militarismo. "Particularmente a concepção de foco era contestada por alguns quadros e militantes". Devido, principalmente, ao seu afastamento dos centros mais importantes e da direção nacional, em alguns locais a prática militarista não preponderava. Dedicavam-se a conseguir certo grau de ligação com as massas, revelando alguns conflitos com a política nacional da organização. Esses conflitos entretanto, devido à falta de nível teórico e político, manifestavam-se em questões práticas e secundárias da atividade, atingindo claramente a essência da política vanguardista da $\mathrm{AV}^{925}$.

\footnotetext{
${ }^{923}$ PARTIDO COMUNISTA DO BRASIL - ALA VERMELHA. Autocrítica, cit., p. 56-57.

${ }^{924}$ PARTIDO COMUNISTA DO BRASIL - ALA VERMELHA. Autocrítica, cit., p. 57.

${ }^{925}$ PARTIDO COMUNISTA DO BRASIL - ALA VERMELHA. Autocrítica, cit., p. 57.
} 
Os rumos cada vez mais extremistas que o vanguardismo passa a assumir na organização, notadamente o caso do "Grupo Especial" e a atividade do Regional de São Paulo, cria um clima de dúvida e insegurança na direção nacional e nos quadros, mostrando que algo estava errado com a política e a prática da $\mathrm{AV}^{926}$.

A reflexão sobre estes fatos, "e não uma compreensão madura da teoria marxistaleninista", que vai produzir a necessidade de uma mudança na "fisionomia política" da $\operatorname{organização~}^{927}$.

A Autocrítica passa a abordar o documento dos "16 Pontos", afirmando que ele "propôs de fato, uma profunda mudança na orientação do trabalho da $A V$ ”, mas, na medida em que ele não identificava os verdadeiros desvios de nossas concepções, nem põe a nu suas causas, conserva as mesmas características ideológicas não proletárias do Documento de Crítica. Isto é, na medida em que não identifica autocriticamente o dogmatismo, o subjetivismo e o voluntarismo de nossas concepções ele representa uma continuidade do "radicalismo" pequeno-burguês que orienta nossa organização. Na verdade, "a autocrítica dos "16 Pontos" se centra no militarismo" — e apenas nele — "sem chegar a localizar as determinações ideológicas das quais o militarismo é simples manifestação”, sem conseguir romper radicalmente com essa concepção vanguardista extremada. Assim que, embora chegue a falar em vanguardismo, ainda o faz com uma visão nitidamente unilateral ${ }^{928}$.

Segundo o Doc. Autocrítica o "16 Pontos" passou “de leve pela apreensão correta de que vanguardismo, continuamos a não apreender o papel ideológico da vanguarda, destacando apenas o seu papel dirigente". Mesmo em se considerando essa limitação básica, mesmo levando em conta que os "16 Pontos" ainda é "o documento radical pequeno-burguês, necessário é constatar a importância da transformação que ele inaugura" na AV. Em seus aspectos essenciais, tal importância está em que ele compreende que "a revolução é feita pelas massas e não pela vanguarda - e que a prática isolada das massas só levaria derrota”. Nesse sentido, já fez uma crítica enérgica à concepção de foco, ao desligamento das massas e aquilo que chama de "ações armadas de vanguarda". Reconhecendo a importância de um trabalho sistemático de agitação, propaganda e organização das "massas básicas" (proletariado e campesinato), "ressaltou a

\footnotetext{
${ }^{926}$ PARTIDO COMUNISTA DO BRASIL - ALA VERMELHA. Autocrítica, cit., p. 58.

${ }^{927}$ PARTIDO COMUNISTA DO BRASIL - ALA VERMELHA. Autocrítica, cit., p. 58.

${ }^{928}$ PARTIDO COMUNISTA DO BRASIL - ALA VERMELHA. Autocrítica, cit., p. 59.
} 
necessidade da ligação com o proletariado nas grandes concentrações da cidade e do campo ${ }^{929}$.

Em resumo, os "16 pontos", na medida em que conserva os desvios fundamentais das concepções anteriores, salienta "a necessidade de uma linha de massas que leve à luta armada a curto prazo”. A partir dessa compreensão, a reformulação básica consistia em definir onde realizar o investimento das forças partidárias, "onde concentrar o trabalho". Como resposta a estas questões surgem as "diretivas e resoluções" que acompanham o documento - são elas que dão indicações práticas que deveriam guiar a reestruturação interna da AV e a orientação básica das tarefas junto às massas. São elas, portanto, as responsáveis no plano da ação concreta pela mudança da "fisionomia política" da organização ${ }^{930}$.

Como se tratam de orientações extremamente elementares - na verdade, indicações genéricas de como ligar às massas uma organização que até aquele momento estivera delas isolada - as "diretivas e resoluções" contêm diversas verdades, válidas ainda hoje - na mesma medida em que "ainda hoje continua a existir uma situação de isolamento em relação às massas". Entretanto, como o pensamento no qual elas estão inseridas continuava a ser um pensamento "radical" pequeno-burguês, sua visão geral revela uma orientação errônea ${ }^{931}$.

Assim é que elas definem a necessidade de concentrar as principais forças da AV junto à classe operária, nos principais centros industriais, lançando nessa tarefa o maior número possível de militantes; insistem na necessidade de lutar pelo soerguimento da luta de classe operária, destacando a importância da agitação e propaganda das lutas econômicas; por fim preconizam uma reformulação interna que visa dar unidade à organização e fortalecer o órgão dirigente, bem como reorientar a política de finanças, transformando-a num instrumento de educação e numa resultante do trabalho político entre as $\operatorname{massas}^{932}$.

As principais manifestações de permanência dos desvios encontram-se nas "constantes referências à luta armada imediata": "tomar como ponto de partida (...) e mostrar o caminho armado" (diretriz 2, ponto 2); "greves, piquetes, auto-defesa, sabotagens, grupos de propaganda armada" (diretriz 2, ponto 4); "Deslocar quadros (...) objetivando a guerrilha rural “ (diretriz 3, ponto 1). Mesmo em orientações que não fazem

\footnotetext{
${ }^{929}$ PARTIDO COMUNISTA DO BRASIL - ALA VERMELHA. Autocrítica, cit., p. 59-60.

${ }^{930}$ PARTIDO COMUNISTA DO BRASIL - ALA VERMELHA. Autocrítica, cit., p. 63.

${ }^{931}$ PARTIDO COMUNISTA DO BRASIL - ALA VERMELHA. Autocrítica, cit., p. 63-64.

${ }^{932}$ PARTIDO COMUNISTA DO BRASIL - ALA VERMELHA. Autocrítica, cit., p. 64.
} 
referência direta à luta armada, "os ecos do nosso voluntarismo e vanguardismo continuam soando" 933 .

Para aplicação dos "16 Pontos" - e de acordo com uma de suas resoluções — a AV se submeteu a uma reestruturação orgânica, buscando uma estrutura partidária leninista. Empreendemos a reorganização de cima para baixo, fortalecendo a direção central. A unidade política conseguida em torno dos "16 Pontos" e a reestruturação orgânica puseram fim, no fundamental, ao "autonomismo" dos Regionais. Porém, essa reestruturação aplicada ainda nos marcos do vanguardismo fez com que "se criassem organismos $e$ comissões artificiais", sem apoio nas reais necessidades do trabalho de massas ${ }^{934}$.

O Doc. Autocrítica enfoca neste ponto as conseqüências de "Nossa Prática", quando afirma que "não foi fácil, porém - e nem se completou —, a passagem de uma prática política isolada para a de ligação com as massas, dada a permanência de concepções voluntaristas e de práticas vanguardistas". Sobretudo nas condições de uma organização cujos militantes estavam em grande parte na clandestinidade ou profissionalizados, alguns em decorrência da repressão conseqüente o AI-5, mas principalmente por causa da política anterior da AV, "voltada para a preparação da infraestrutura como base de apoio à ação de grupos isolados”. Além das dificuldades naturais impostas pelas condições objetivas — vigilância e repressão da ditadura - a "desprofissionalização" e a conseqüente ligação à produção "se dá de modo lento $e$ encontra resistências, algumas por oposição às diretivas”, a maioria pela falta de consciência em relação ao seu significado. Deformados pela prática anterior em que os recursos da organização não eram frutos do trabalho e da influência política entre as massas, "muitos perduraram por longo tempo dependendo materialmente da organização" ${ }^{935}$.

As principais dificuldades vão surgir, entretanto, “da própria limitação e visão errônea dos '16 Pontos'”. Ao se lançar no trabalho entre as massas, a AV vai com uma visão estreita sobre as formas de organização das massas, não compreendendo a necessidade de aproveitar todas as formas de organização legais existentes, como ponto de apoio para o trabalho clandestino e para as organizações ilegais. Conseqüentemente, se propunha como forma principal a organização em grupos de "Unidade Operária", isto é, uma organização clandestina em torno deste jornal. A idéia que estava por trás de tal

\footnotetext{
${ }^{933}$ PARTIDO COMUNISTA DO BRASIL - ALA VERMELHA. Autocrítica, cit., p. 64.

${ }^{934}$ PARTIDO COMUNISTA DO BRASIL - ALA VERMELHA. Autocrítica, cit., p. 64-65.

${ }^{935}$ PARTIDO COMUNISTA DO BRASIL - ALA VERMELHA. Autocrítica, cit., p. 65.
} 
proposta era a de fazer a "Unidade Operária" representar o mesmo papel que na Rússia fora desempenhado pelo "Iskra" - idéia essa que decorria de uma leitura mal assimilada de uma transposição mecânica da obra de Lênin "Por onde começar". Confundíamos, pois, a organização parapartidária com as organizações amplas das massas - por isso mesmo, não sabíamos aproveitar as organizações legais e nelas fazer um trabalho paciente de elevação de consciência de classe. Não atuávamos no sentido do soerguimento do movimento de massas: limitávamo-nos a organizar os elementos próximos da AV (com perspectivas de recrutamento), não sabendo o que fazer em termos da organização das massas não partidárias. Em suma, não compreendíamos a relação que existe entre o movimento de massas e a construção do Partido ${ }^{936}$.

As quedas em dois Regionais no final de 1970 e as de 1971, na direção nacional, revelam toda a debilidade orgânica e ideológica que ainda persiste na organização, a concepção vanguardista de ligação com as massas e o conteúdo claro da política da época iniciada com a aplicação dos '16 Pontos","937.

Essa política conduziu à instalação de uma aparelhagem voltada para a realização de "grandes" tarefas de apoio ao trabalho de ligação com as massas e de divulgação da organização. Essa aparelhagem, centralizada e vulnerável, era desproporcional às forças da organização e em desacordo com o volume de nosso trabalho e de nossa penetração nas massas. Não só foi desmantelada rapidamente pela repressão, como multiplicou os seus golpes, permitindo atingir através dessa estrutura (aparelhagem de direção nacional) os Regionais e o trabalho de base do Partido. Deixou claro, ainda, de forma brutal, a insuficiência ideológica da organização, que se refletiu em diversos comportamentos débeis, chegando alguns ao nível da traição.

O balanço dessa trajetória da AV indica que, até então, suas ligações com as massas permaneciam precárias, sua composição social não se modificara e o artificialismo na sua política de organização ainda se refletia numa aparelhagem não assentada na fusão com a luta de classe concreta. É necessário destacar que, devido a todos esses fatores e devido ao reduzido tamanho da organização, a AV "não desempenhou um papel significativo ao processo político do período”. Sua importância na sociedade foi — e ainda é extremamente reduzida, uma vez que é praticamente nula sua influência na política entre as massas, e muito pequena sua capacidade de manter estreitos laços com a classe operária. $\mathrm{O}$

\footnotetext{
${ }^{936}$ PARTIDO COMUNISTA DO BRASIL - ALA VERMELHA. Autocrítica, cit., p. 66.

${ }^{937}$ PARTIDO COMUNISTA DO BRASIL - ALA VERMELHA. Autocrítica, cit., p. 67.
} 
reconhecimento dessa debilidade deve servir de estímulo para que todos os quadros e militantes da organização ${ }^{938}$.

Autocrítica passa agora a enfocar a situação da Ala Vermelha em 1974 e suas tarefas, inicialmente salientando que com os golpes sofridos em 71, a organização teve "seus principais dirigentes presos, todos os seus segredos desvendados, sua infra-estrutura destruída e seus organismos desmantelados"939.

A principal tarefa de então era "impedir o colapso total, resguardando $e$ rearticulando o restante da organização". Todas as medidas tomadas na época visam este objetivo, o que "obrigou a um recuo no trabalho revolucionário"

No entanto, a própria sobrevivência política da organização não dependia somente dessas medidas, mas sim de uma "profunda transformação política e ideológica que retificasse o conjunto de erros e desvios que eram a base” dos reveses sofridos.

O cumprimento desta tarefa pesada teria de ser feito a partir de uma "organização extremamente enfraquecida". O contingente da AV, reduziu-se mais ainda caracterizandose "por apresentar um despreparo político e ideológico muito grande", mais claramente revelado em condições adversas. Soma-se a isto a perda de apoio da maioria dos aliados e simpatizantes que, devidos aos acontecimentos, "mostravam-se receosos e sem confiança na organização”. Essa situação gera uma confusão político-ideológica interna, onde se desenvolvem posições errôneas diversas: negação da necessidade do partido — desde o liquidacionismo até o obreirismo praticista - e o "teoricismo" - que nega a possibilidade da realização do trabalho entre as massas sem uma linha política acabada - o que implicava em parar a atividade prática para aprofundar o conhecimento teórico ${ }^{941}$.

Segue-se um período de desagregação com o afastamento de militantes e aliados. A direção, por sua vez, denotando fraqueza política em condições precárias de funcionamento coletivo, foi incapaz de sustar em tempo mais curto este processo de desagregação interna ${ }^{942}$.

Não obstante tudo isto, a AV sobreviveu não só pela compreensão global adquirida da origem dos erros e desvios mas principalmente pelas medidas práticas que tomou:

\footnotetext{
${ }^{938}$ PARTIDO COMUNISTA DO BRASIL - ALA VERMELHA. Autocrítica, cit., p. 67.

${ }^{939}$ PARTIDO COMUNISTA DO BRASIL - ALA VERMELHA. Autocrítica, cit., p. 68.

${ }^{940}$ PARTIDO COMUNISTA DO BRASIL - ALA VERMELHA. Autocrítica, cit., p. 68.

${ }^{941}$ PARTIDO COMUNISTA DO BRASIL - ALA VERMELHA. Autocrítica, cit., p. 68.

${ }^{942}$ PARTIDO COMUNISTA DO BRASIL - ALA VERMELHA. Autocrítica, cit., p. 68.
} 
"orientação de integração nas fábricas e bairros proletários, mudança da política de infraestrutura, abandono dos métodos vanguardistas na ligação com as massas" "943.

Já se processa um encaminhamento — por meio das "circulares" de diretivas centrais e na discussão em toda a organização - através da qual se "abandona, efetivamente, no plano teórico, as concepções vanguardistas e espontaneístas, bom como o dogmatismo, as pretensões futurológicas" de definir cabalmente um programa, uma estratégia e uma tática que correspondem, hoje, "a todos os problemas da revolução, além da visão dogmática sobre a própria questão do partido"944.

A mudança do modo pelo qual a AV enfoca o movimento revolucionário tem base na "mudança de visão em relação à sociedade brasileira". Anteriormente se deslocava o centro de interesse da organização para a questão do campo, uma vez que este era considerado o palco principal da luta e o campesinato o contingente principal da revolução.Hoje, entretanto, a análise da sociedade brasileira - livre das transposições mecânicas - nos indica o papel preponderante do movimento operário em nossa revolução. Preponderante não apenas devido ao peso que esta classe adquire na "sociedade brasileira enquanto sociedade capitalista" - mas também devido à compreensão da necessidade ideológica de um partido enraizado na classe. Em outras palavras: compreende-se que o proletariado não é apenas o fator dirigente do processo. Além do dirigente, ele desempenha papel decisivo como participante da luta revolucionária.

Nos "16 Pontos" já ocorre uma mudança na orientação da AV nesse sentido, mas sem ir ao fundo do problema nem fazer uma autocrítica da posição anterior. Agora completamos a reformulação de nossa visão, colocando de fato — na teoria e na prática — a classe operária e o movimento operário como o centro de nossas preocupações e atividades. No entanto, essas mudanças são apenas o primeiro passo para que nos situemos corretamente diante da sociedade, do movimento revolucionário e das massas, e para que definamos as tarefas que, na situação atual, o que permitirá superar o impasse em que se encontra a revolução brasileira. Para traçar as indicações gerais dessas tarefas, dizia o Doc. Autocrítica, torna-se necessário apreciar a conjuntura atual da sociedade e do movimento revolucionário no Brasil ${ }^{945}$.

A conjuntura atual - fruto de um desenvolvimento capitalista acelerado e dependente (sob a condição política de intenso acirramento da ditadura) —, se caracteriza

\footnotetext{
${ }^{943}$ PARTIDO COMUNISTA DO BRASIL - ALA VERMELHA. Autocrítica, cit., p. 69.

${ }^{944}$ PARTIDO COMUNISTA DO BRASIL - ALA VERMELHA. Autocrítica, cit., p. 69.

${ }^{945}$ PARTIDO COMUNISTA DO BRASIL - ALA VERMELHA. Autocrítica, cit., p. 69.
} 
pela "inexistência de lutas significativas das massas e pelo esfacelamento das organizações de esquerda"946.

$\mathrm{O}$ aspecto conjuntural que nos interessa mais de perto e como elemento central de nossas preocupações é a situação da classe operária e de seu movimento - "uma vez que este é o aspecto decisivo para a definição das tarefas que se impõem ao movimento revolucionário”. Atualmente o movimento operário se encontra num estado de acentuada apatia. Os últimos movimentos de algum vulto data de 1968 - as greves de Osasco e Contagem -, compondo um quadro de "profundo refluxo que vem desde 1964". Particularmente nos últimos anos, a inexistência de mobilizações é a regra - observam-se apenas esporádicos e reduzidos movimentos tolerados e legais, "nos quadros permitidos pela legislação da ditadura”. Mais recentemente têm surgido erupções em alguns centros de grandes concentração industrial, lutas espontâneas e isoladas umas das outras, de pequena envergadura (paralisações parciais, operações tartaruga) que "buscam formas que não se enquadram na legislação repressiva da ditadura”. Essas lutas, de significado restrito, não mudam o quadro geral da apatia da classe refletindo entretanto, o alto grau de exploração a que ela está submetida e uma situação particular do desenvolvimento capitalista do país. O quadro geral é de uma classe operária inerte, incapaz de movimentos mais vigorosos, ainda que ao nível da luta econômica. Os motivos mais imediatos dessa situação encontram-se no baixíssimo nível de consciência e organização da classe, ao lado da eficiente política repressiva da ditadura. A classe operária no Brasil hoje em dia, não dispõe sequer de uma consciência sindicalista; e isto está relacionado com a inexistência prática de qualquer nível de organização independente desta classe. Os próprios "sindicatos oficiais, controlados pela ditadura" — e naturalmente a serviço da burguesia —, têm pouca penetração na classe operária, o que se reflete no baixo grau de sindicalização. Tudo isto nos dá a visão de uma classe, na prática, quase totalmente desorganizada ${ }^{947}$.

A fraqueza do movimento operário no Brasil tem causas inerentes a seu próprio processo de formação. Cabe destacar nesse sentido, como aspectos mais marcantes, a estrutura organizativa do sindicalismo populista, a correspondente orientação "nacionaldesenvolvimentista" e a incorreta atuação do PCB. O sindicalismo oficial afirmou-se como principal forma de organização da classe operária. Sua estrutura vertical tende a dificultar as trocas de experiência e a unidade entre as várias categorias profissionais. A

\footnotetext{
${ }_{946}$ PARTIDO COMUNISTA DO BRASIL - ALA VERMELHA. Autocrítica, cit., p. 70.

${ }^{947}$ PARTIDO COMUNISTA DO BRASIL - ALA VERMELHA. Autocrítica, cit., p. 71.
} 
existência do imposto sindical representa a pedra de toque da dependência dos sindicatos oficiais do Estado - e explica em parte a falta de dinamismo desses próprios sindicatos. $\mathrm{Na}$ medida em que recebem verbas referentes a toda sua categoria profissional, independentemente do número de sindicalizados, os sindicatos oficiais tendem a se mostrar mais solidários ao Estado — via Ministério do Trabalho — , que a seus associados, desinteressando-se mesmo em incentivar a sindicalização. Por outro lado, a orientação "nacional desenvolvimentista" que prevaleceu até 64 imprimiu ao movimento operário uma forte tendência a se solidarizar com os interesses da burguesia nacional, entravando a formação de uma consciência de classe ${ }^{948}$.

Motivados de cima para baixo pelos sindicatos oficiais em torno de interesses alheios aos de sua classe, lutando também por reivindicações econômicas, mas "sem com isso identificar nos sindicatos oficiais os instrumentos de defesa de seus interesses" - os operários não chegam sequer a desenvolver uma consciência "sindicalista" consistente ${ }^{949}$.

É necessário observar que estas características do movimento operário encontram plenas condições para se desenvolver entre uma classe operária jovem, isto é, cuja composição se renova rapidamente, devido ao aumento de seu contingente, provocado pela industrialização acelerada, e também jovem pelo pouco tempo de industrialização no país. Além disso, há a questão da "origem camponesa que contribui para rarefazer a possibilidade do desenvolvimento de uma consciência de classe”. Esses fatores objetivos favorecem a fluidez do mundo subjetivo do proletariado, criando um terreno fértil para a penetração das deformações da ideologia burguesa, particularmente aquelas instrumentadas por um sindicalismo oficial que atende aos interesses das classes dominantes. Por outro lado, o fator que poderia se contrapor a essas tendências - uma educação ideológica realizada pela intelectualidade socialista militante — simplesmente não existe. O PCB, através de suas políticas concretas, reforçou efeitos negativos do populismo. Não levou à classe a ideologia socialista - e pior que isso, nem mesmo combateu o sindicalismo oficial, buscando criar um movimento operário independente. Mesmo que em certos momentos possa ter conseguido alguma penetração na massa operária, o PCB falhou ao longo de toda sua história como vanguarda da classe, não conseguindo subtraí-la à influência da burguesia.Tentativas pouco conseqüentes, como a dos "sindicatos paralelos" não forneceram alternativas de organização autônoma para o proletariado. O que nos permite afirmar que, falando como educador ideológico e como

\footnotetext{
${ }^{948}$ PARTIDO COMUNISTA DO BRASIL - ALA VERMELHA. Autocrítica, cit., p. 71-72.

${ }^{949}$ PARTIDO COMUNISTA DO BRASIL — ALA VERMELHA. Autocrítica, cit., p. 72.
} 
dirigente político, o PCB não foi — nem é — o partido de vanguarda da classe operária. Como nenhuma outra tendência de esquerda, até hoje, se aproximou do cumprimento desse papel, podemos registrar como um dos fatores fundamentais para a situação atual de atraso do movimento operário, justamente a inexistência do partido de vanguarda da classe operária em nosso país ${ }^{950}$.

O surgimento de outras organizações de esquerda além do PCB, através da fragmentação iniciada já antes de 64, não mudou a situação. Em certo sentido, agravou-a, pois além de não dar origem a qualquer partido que assumisse o papel de vanguarda da classe operária, deu surgimento a tendências que se afastaram ainda mais daquela classe: as que negaram a necessidade do Partido, como a "Ação Libertadora Nacional" e a "Vanguarda Popular Revolucionária", substituindo-o pela ação isolada de pequenos grupos mantiveram-se voluntariamente distantes das massas. Outras como o Partido Comunista do Brasil, vendo no campesinato o verdadeiro sujeito da revolução, não exerceram influência política na classe da qual, curiosamente, se proclamavam vanguardas; e, ainda, as que se voltam para o proletariado mas, devido aos desvios de suas orientações, falham em se aproximar dele. A “Ação Popular”, por exemplo, levou uma política voluntarista, agitando questões que resultaram muitas vezes em erupções imediatas e momentâneas, mas que nunca chegaram a modificar a consciência da massa que atingiam e não organizaram, e por fim, acabou perdendo cada um dos vínculos que conseguira estabelecer. A organização Partidária Marxista-Leninista Política Operária, por sua vez, tentou realizar uma propaganda socialista calcada apenas no doutrinarismo teórico. Esse voluntarismo teoricista não logra, é claro, estabelecer laços com a massa; ele só tem condições de ser razoavelmente aceito entre os setores intelectualizados da pequena-burguesia. Por fim a $\mathrm{AV}$ "que oscila entre o militarismo e o agitacionismo vanguardista", permanecendo distante das massas ${ }^{951}$.

Assim, desligadas das massas, as organizações de esquerda não combateram as tendências ideológicas burguesas do populismo e do revisionismo, deixando as massas proletárias sob a influência dessas tendências. Além disso, nos anos mais recentes, " $a$ esquerda foi profundamente golpeada pela repressão": várias organizações foram aniquiladas, outras sofreram golpes bastante sérios para, na prática, perderem sua capacidade de atuação. Os marxistas-leninistas e outros revolucionários encontram-se hoje isolados com poucos laços organizativos entre si e mergulhados em profunda confusão

\footnotetext{
${ }^{950}$ PARTIDO COMUNISTA DO BRASIL - ALA VERMELHA. Autocrítica, cit., p. 72.

${ }^{951}$ PARTIDO COMUNISTA DO BRASIL - ALA VERMELHA. Autocrítica, cit., p. 73.
} 
relativamente aos passos que devem ser dados para retirar o processo revolucionário de seu refluxo. Registram-se tão somente algumas tentativas de rearticulação, bem como o surgimento de círculos independentes que buscam estudar o marxismo-leninismo e/ou realizar algum trabalho de ligação com a massa ${ }^{952}$.

É fácil definir, a partir da análise precedente, os principais elementos que comprovam o baixo nível das condições subjetivas da classe operária: "desorganização, falta de uma consciência de classe, inexistência de seu partido de vanguarda" - e, paralelamente — "desligamento dos marxistas-leninistas em relação às massas e a presença de diversas tendências ideológicas não proletárias no seio da esquerda”. Observando os entraves que o sindicalismo oficial, a repressão e o bombardeio ideológico da burguesia colocam para o desenvolvimento do movimento operário torna-se clara a necessidade, para os revolucionários, da realização de tarefas que auxiliem no soerguimento do movimento operário e a ele imprimam uma orientação revolucionária. Com isso não se quer cair no voluntarismo de afirmar que o movimento operário dependa exclusivamente da ação dos revolucionários de vanguarda para realizar quaisquer movimentos. O agravamento das condições objetivas deverá levar à intensificação da luta espontânea. Trata-se, isto sim, de não cair no espontaneísmo de esperar o surgimento de movimentos, para então atuar, praticamente a reboque deles. As tarefas que cabem, hoje, aos revolucionários, são aquelas que acelerando a formação das condições subjetivas das massas, permitirão romper os entraves contra-revolucionários e preparar o surgimento de um movimento "verdadeiramente de massas e verdadeiramente revolucionário" — Lênin em "Doença Infantil". Nesse sentido, salta à vista que uma das tarefas é “a da ligação dos marxistas-leninistas às massas, particularmente à classe operária, sua fusão com a luta de classes concreta”. Ligação que visa educá-las política e ideologicamente e junto a elas e com elas descobrir as formas de luta e de organização capazes de superar o atual refluxo ${ }^{953}$.

No curso desse processo e na medida em que os marxistas-leninistas se fundam à luta de classes concreta, coloca-se " a tarefa de construir o partido de vanguarda do proletariado" - garantia de que todo o movimento se orientará no sentido do cumprimento do papel histórico da classe operária. Finalmente, para que estas tarefas possam ser levadas a bom termo torna-se imprescindível empreender uma "vigorosa luta

\footnotetext{
952 PARTIDO COMUNISTA DO BRASIL - ALA VERMELHA. Autocrítica, cit., p. 73-74.

${ }^{953}$ PARTIDO COMUNISTA DO BRASIL - ALA VERMELHA. Autocrítica, cit., p. 74-75.
} 
ideológica contra todas as tendências não proletária existentes não só na própria classe operária, como no seio da esquerda"954.

A partir deste ponto a Autocrítica passa a analisaro Desenvolvimento Capitalista Acelerado e as condições objetivas da classe operária, registrando inicialmente que o "grande atraso das condições subjetivas da classe operária" coloca como principal tarefa hoje o trabalho de organização e educação das grandes massas proletárias. A realização desse trabalho encontra condições objetivas favoráveis - superexploração e deterioramento das condições de vida dos trabalhadores - decorrentes da política de desenvolvimento capitalista acelerado adotada pela burguesia integrada como solução para a crise que afetou o sistema na primeira metade da década de 60.

Os aspectos exteriores dessa nova orientação traduzem-se nas altas taxas de crescimento do Produto Nacional Bruto nos últimos cinco anos e no relativo controle da inflação. Esse crescimento da economia se tornou possível, a partir de opções tomadas desde 64, dirigindo-a para um mercado consumidor de altas rendas e para a exportação. A presença crescente do capital imperialista e de sua tecnologia avançada — aplicada em setores já voltados para um mercado de altas rendas - condicionava tais opções, na mesma medida em que tornava a economia brasileira mais dependente em relação aos monopólios estrangeiros. A penetração do capital imperialista garantiu-lhe o controle dos setores fundamentais da produção, inclusive através do capitalismo de Estado - empresas estatais - , na medida em que este é colocado a serviço da classe que detém a hegemonia do poder. Esse processo de desenvolvimento não só se dirige para um mercado consumidor de altas rendas já existente, mas também o cria - amplia — e reforça. A tendência de concentração de rendas já existia na economia brasileira desde há muito, particularmente devido à estrutura de propriedade rural. A partir de 64, tal tendência é reforçada por uma política dirigida expressamente nesse sentido. A política de reconcentração de rendas determina, ao mesmo tempo, um reforço do processo de monopolização da economia e o fortalecimento de um mercado interno de alto poder aquisitivo, ainda que restrito como área social. Dele vão participar, além da própria grande burguesia e dos outros setores burgueses, as camadas superiores e ascendentes da classe média —que somam aproximadamente $10 \%$ da população —, cujo poder aquisitivo é artificialmente ampliado por mecanismos de crédito direto ${ }^{955}$.

\footnotetext{
${ }^{954}$ PARTIDO COMUNISTA DO BRASIL - ALA VERMELHA. Autocrítica, cit., p. 75.

${ }^{955}$ PARTIDO COMUNISTA DO BRASIL — ALA VERMELHA. Autocrítica, cit., p. 76.
} 
Ao voltar-se para a exportação, a política econômica visa não apenas encontrar novos mercados para os produtos manufaturados — garantindo a colocação de uma produção em crescimento-, como também a "obtenção de divisas que garantam a capacidade de importar" - sobretudo bens de produção e matérias prima ${ }^{956}$.

Para que a economia crescesse de forma acelerada, ampliou-se a capacidade de investir. A entrada do capital imperialista não bastaria - na verdade, de acordo com os interesses do imperialismo, essa entrada de capitais objetiva fundamentalmente controlar a economia. No que diz respeito à capacidade de investir, o capital imperialista, além de contribuir decisivamente - enquanto investimento direto - para a "arrancada inicial" de importantes setores do atual desenvolvimento, participa, sob a forma de empréstimos, da formação do capital necessário à expansão, como "poupança externa" complementar "a "poupança interna" considerada insuficiente para manter sozinha taxas de crescimento de 9 a $10 \%$ anuais. Como ocorre nas economias de desenvolvimento capitalista acelerado (a exemplo da Alemanha Ocidental e Japão), "a base da acumulação necessária de capital — a "poupança interna - é a superexploração do proletariado", isto é, trata-se de extrair da classe operária altas taxas de mais valia super-dimensionadas, muito além da exploração capitalista "normal”. A base evidentemente é a compressão salarial, o "arrocho". Mas a ele se somam inúmeras outras formas de aumentar a parcela de trabalho não pago. A inflação é uma delas, e a inflação se torna necessária num processo de desenvolvimento acelerado: o propalado controle da inflação, fora a evidente carga demagógica que o acompanha, visa tão somente mantê-la em níveis previsíveis, que possam ser computados nos cálculos empresariais, mas nunca a acabar com ela ${ }^{957}$.

Outros recursos como o Programa de Integração Social e o Fundo de Garantia por Tempo de Serviço realizam uma poupança aplicável como investimento pelo grande capital. Ainda que de forma indireta, os incentivos fiscais operam no mesmo sentido. Se ainda acrescermos a tudo isto o aumento da produtividade não acompanhado pelo aumento do salário, a extensão real da jornada do trabalho através do recurso às horas extras e o aumento da intensidade do trabalho (técnicas de racionalização), teremos uma idéia aproximada do volume de trabalho não pago extraído do operário brasileiro e localizaremos a verdadeira fonte da capacidade de investir que permitiu à grande burguesia industrial impulsionar o desenvolvimento acelerado ${ }^{958}$.

\footnotetext{
${ }^{956}$ PARTIDO COMUNISTA DO BRASIL - ALA VERMELHA. Autocrítica, cit., p. 77.

${ }^{957}$ PARTIDO COMUNISTA DO BRASIL - ALA VERMELHA. Autocrítica, cit., p. 77.

${ }^{958}$ PARTIDO COMUNISTA DO BRASIL - ALA VERMELHA. Autocrítica, cit., p. 78.
} 
A superexploração do operário é acompanhada, também, por um emprego mais intenso de mão-de-obra feminina e do menor (sub-remuneradas) e por péssimas condições de trabalho: as empresas, visando baixar custos de produção, não instalam equipamentos de proteção ao trabalhador; não cumprem a legislação e estimulam, através dos chamados prêmios de produção, o desrespeito, pelos próprios operários, das normas mais elementares de segurança pessoal em função de minguados aumentos de salário. Daí o índice de acidentes de trabalho e doenças profissionais no Brasil estar entre os mais altos. Por outro lado, devido ao baixo nível de consciência e organização, as empresas agem discricionariamente em relação aos operários: mudanças no ritmo de trabalho, dispensas, etc. são questões resolvidas pelas direções das empresas sem a mínima possibilidade de interferência dos trabalhadores. Além disso, "o próprio crescimento industrial, aumentando seu contingente de operários, sua concentração e seu poder de barganha”sobretudo devido à demanda crescente de operários especializados —, cria continuamente melhores condições objetivas para o desencadeamento de lutas ${ }^{959}$.

Finaliza seu apanhado o Doc. Autocrítica salientando que todas as condições expostas agem nesse sentido na medida em que criam tensões cada vez maiores. A manutenção da situação só é possível através da permanente vigilância repressiva, que interfere nas manifestações mais elementares de descontentamento dos operários, e devido à falta de condições subjetivas da classe. $\mathrm{O}$ que nos traz de volta à questão da falta de consciência e organização que permitam aproveitar as condições objetivas existentes. $\mathrm{O}$ proletariado necessita partir das reivindicações mais elementares, com as formas de luta e de organização que estiverem de acordo com o seu próprio nível, a cada momento; é necessário que os revolucionários saibam aproveitar cada situação dessas para educar as massas, passando pela experiência concreta da luta para os níveis mais elevados"960.

Neste ponto o Doc. Autocrítica passa examinar criticamente a situação no campo sob o desenvolvimento capitalista acelarado, ressaltando que ele também implementa a rápida penetração do capitalismo no campo. A grande burguesia industrial e financeira realiza grandes investimentos na agricultura e na pecuária. Configuram-se "empresas capitalistas no campo" que, tanto pela racionalização da produção quanto pelas relações de produção que estabelecem, modificam a estrutura agrária tradicional. A oligarquia latifundiária, nas regiões onde se registra este desenvolvimento, associa-se ao grande capital, "perdendo expressão como classe social diferenciada". Os novos

\footnotetext{
${ }^{959}$ PARTIDO COMUNISTA DO BRASIL - ALA VERMELHA. Autocrítica, cit., p. 78.

${ }^{960}$ PARTIDO COMUNISTA DO BRASIL - ALA VERMELHA. Autocrítica, cit., p. 79.
} 
empreendimentos se dirigem tanto para o abastecimento do mercado interno quanto para a exportação, e a presença do capital estrangeiro é significativa. Importa assinalar que esse fenômeno determina o deslocamento do controle da economia rural para a área do grande capital monopolista, tornando paulatinamente de menor importância, no conjunto da economia, o capital da burguesia agro-exportadora "tradicional" 961.

Diz a Autocrítica que a penetração das grandes empresas capitalistas no campo "aumenta a concentração de assalariados agrícolas", ao mesmo tempo em que determina um "crescimento impressionante do contingente de camponeses sem terra e sem trabalho certo". O Doc. Autocrítica destaca que as principais modificações introduzidas pela penetração capitalista no campo, que cria, por outro lado, concentrações de proletariado rural e outros assalariados agrícolas e, por outro lado, expulsa os camponeses da terra me ritmo mais acelerado do que o faziam os setores agrários "tradicionais". Os camponeses sem terra geralmente vão aumentar o número de marginalizados que gravitam na periferia de alguns centros urbanos sem se integrarem à economia urbana, constituem uma massa flutuante de assalariados temporários de empreendimentos agrícolas — os trabalhadores volantes ou "bóias frias". Todos esses fenômenos no campo dão origem a tensões sociais que, com relativa freqüência, explodem em conflitos isolados e espontâneos. Entretanto, as condições subjetivas das massas rurais encontram-se num nível ainda mais baixo que os da classe operária. No campo, nem mesmo a experiência sindical-populista adquiriu significância. As massas rurais sempre estiveram marginalizadas dos processos políticos da sociedade brasileira. Todas as transformações que caracterizaram o desenvolvimento capitalista e a revolução burguesa no país não contavam com sua participação. A reação espontânea às condições da miséria, opressão e exploração não encontrou no campo formas políticas de expressão, manifestando-se muitas vezes no terreno do banditismo e do misticismo. A isso corresponde uma igual incapacidade do PCB para organizar e dirigir as lutas rurais. Embora falasse, em seus programas, do campesinato desde a época de sua fundação, só na década de 50 é que alguma atividade prática vai se dirigir nesse sentido. Mesmo assim o PCB não conseguiu ligar a luta dos camponeses ao conjunto da luta revolucionária. $\mathrm{O}$ único período em que há um início de incorporação dessas massas no processo político é aquela que vai dos últimos anos da década de 50 até 64 . por um lado, a burguesia nacional começava a se interessar em atrair as massas rurais para a economia do mercado, por outro, a agitação no campo contava com um mínimo de organização

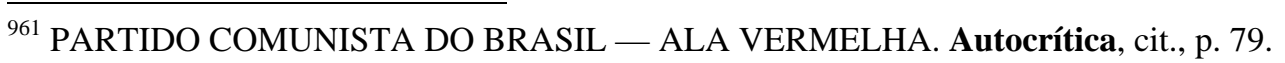


construída tanto pelo PCB quanto pelas Ligas. A experiência das Ligas e as tentativas de sindicalização rural vão constituir o único momento significativo da política revolucionária no campo. Mesmo sem levar em conta os erros ideológicos e políticos que caracterizaram estas experiências, sua vida foi "demasiado curta criar condições subjetivas necessárias ao desenvolvimento da luta revolucionária”.

O golpe de 64 "reprime radicalmente a agitação rural e leva as massas camponesas a retornarem a uma situação de apatia e desorganização - choques que posteriormente ainda se verificam até hoje - "são o produto espontâneo de condições de exploração e opressão insuportáveis". Muito embora a grande maioria das organizações de esquerda surgidas das cisões do velho partido tenham colocado o campo — a guerrilha rural — como eixo de seus programas -inclusive a AV, praticamente nenhuma delas consegue sequer dar os primeiros passos nesse sentido. Quase única e lamentável exceção é o PC do B: "o desencadeamento da guerrilha na região do Araguaia leva à prática uma concepção voluntarista similar à do foco ainda que disfarçada verbalmente de 'guerra popular"”. A ação armada numa “região de população extremamente rarefeita, distante de qualquer zona agrária econômica ou socialmente vital”, além de permitir seu isolamento estratégico pela repressão, não tem o menor efeito sobre a consciência e a organização das massas rurais. Acresça-se a tudo isso o fato de o surgimento dessa guerrilha se dar extemporaneamente, em condições de refluxo da revolução ${ }^{962}$.

Hoje em dia se torna claro que o trabalho dos marxistas-leninistas no campo se deve dirigir para as regiões onde existem "grandes concentrações de camponeses elou assalariados rurais, determinadas pelo desenvolvimento capitalista do campo e áreas de tensão social" e não como preconizam as orientações militaristas, para as regiões "estrategicamente" favoráveis do ponto de vista militar. Em cada região específica, em face das condições objetivas existentes, os marxistas-leninistas devem lutar pela organização dos camponeses e assalariados rurais —assumindo particular importância a questão dos sindicatos rurais. A questão do campo exige particular atenção dos marxistasleninistas porque lá, mais que em qualquer outro lugar, o abismo entre a rápida maturação das condições subjetivas pode levar a aventuras espontaneístas, trazendo situações prejudiciais para a revolução dirigida pelo proletariado ${ }^{963}$.

\footnotetext{
${ }^{962}$ PARTIDO COMUNISTA DO BRASIL - ALA VERMELHA. Autocrítica, cit., p. 80-81.

${ }^{963}$ PARTIDO COMUNISTA DO BRASIL — ALA VERMELHA. Autocrítica, cit., p. 81.
} 
O Doc. Autocrítica se lança agora para realçar a importância e a necessidade da luta pelas liberdades políticas, destacando que mesmo considerando a difícil situação das suas camadas inferiores, não se pode falar hoje — como se poderia em 1967 ou 1968 —, de pauperização da pequena burguesia, ao menos nas camadas médias e superiores. Entretanto, existem tensões latentes: setores prejudicados pela monopolização buscam ter voz política para protestar, os setores ascendentes também o fazem, na medida em que toda camada que passa a desempenhar um certo papel econômico, procura influir politicamente nos centros de decisão ${ }^{964}$.

É necessário destacar, no caso das camadas médias, o aspecto determinado pelo acesso à cultura que, criando certa consciência política, cria igualmente uma tendência à participação. Intelectuais e estudantes assumem, quase sempre, "a postura de oposição à ditadura", principalmente por motivos políticos, "em face das restrições às liberdades democráticas”. O movimento estudantil, além de lutar por suas reivindicações específicas, "tende a assumir a luta contra a ditadura, pelas liberdades políticas",965.

O proletariado, por sua vez, tem necessidade vital de liberdade política que lhe garanta melhores condições de expressão, organização e mobilização. Embora as grandes massas proletárias não tenham ainda consciência dessa necessidade, e por isso mesmo, cabe aos revolucionários despertá-las para isso, "tornando a luta por liberdade política parte integrante de suas reivindicações imediatas e concretas" "966.

Somente quando o proletariado "assumir sua liderança é que a luta por liberdades políticas tornar-se-á um amplo e sólido movimento de todos os setores oprimidos contra a ditadura",967.

Embora reconhecendo a tendência dominante no momento - capitalismo acelerado e manutenção da ditadura —, "é necessário aos marxistas-leninistas observar o movimento das forças que ocorre no interior da sociedade” - inclusive entre as classes dominantes —, para empreender as perspectivas de mudanças ${ }^{968}$.

Nesse sentido é possível que "os atritos entre as classes dominantes levem a um 'afrouxamento das tensões políticas' circunstancial". Mais remota é a "possibilidade de uma 'redemocratização', de uma volta à democracia burguesa, com a revogação dos instrumentos de exceção", mesmo sem afastar a grande burguesia integrada de sua posição

\footnotetext{
${ }^{964}$ PARTIDO COMUNISTA DO BRASIL - ALA VERMELHA. Autocrítica, cit., p. 82.

${ }^{965}$ PARTIDO COMUNISTA DO BRASIL - ALA VERMELHA. Autocrítica, cit., p. 82.

${ }^{966}$ PARTIDO COMUNISTA DO BRASIL - ALA VERMELHA. Autocrítica, cit., p. 82-83.

${ }^{967}$ PARTIDO COMUNISTA DO BRASIL - ALA VERMELHA. Autocrítica, cit., p. 83.

${ }^{968}$ PARTIDO COMUNISTA DO BRASIL - ALA VERMELHA. Autocrítica, cit., p. 83.
} 
hegemônica. Tal possibilidade estaria relacionada com a ocorrência de fatores tais como a configuração de uma crise na situação internacional, que levaria o capital imperialista a pressionar a ditadura no sentido de 'aberturas democráticas'”. Entretanto, ainda que atritos entre as classes dominantes ou abalos internacionais possa, eventualmente, imprimir mudanças no sentido de "'abrandamento" da ditadura", somente a mobilização e lutas das massas pode manter e elevar as liberdades políticas alcançadas numa situação desse tipo ${ }^{969}$.

Após a vasta investigação que efetuou, o Doc. Autocrítica trata, finalmente, das tarefas atuais que se colocavam para superar o atraso político das massas e o distanciamento dos revolucionários da luta de classes concreta. Caberia aos marxistasleninistas construir as forças da revolução, ou seja, realizar as tarefas já determinadas no curso desta autocrítica: "ligar-se à luta de classes concreta, construir o partido de vanguarda do proletariado e travar a luta ideológica”. A ordem em que enunciamos, no entanto, não implica em "qualquer hierarquia de uma sobre as outras". Pelo contrário, "estas três tarefas são absolutamente interdependentes", o que significa que "a realização de cada uma implica a realização das demais e é por elas determinada" 970 .

Os marxistas-leninistas, organizados em seus partidos, organizações, agrupamentos ou círculos, devem "buscar a ligação com as massas a fim de levar a elas a ideologia socialista”. Dessa forma, e somente dessa forma, será possível fazer com que o proletariado e as massas saiam da atual situação de refluxo e desencadeiem movimentos significativos $^{971}$.

Objetivando a criação desse "movimento verdadeiramente de massas e verdadeiramente revolucionário", mas tendo a clareza das limitações impostas pela conjuntura atual e pela situação da esquerda, os marxistas leninistas precisam entender que a tarefa de ligação com as massas, particularmente com o proletariado, "implica num trabalho miúdo e paciente". Nesse trabalho é preciso "apoiar-se nas atividades legais para camuflar a atividade clandestina"; "aproveitar todas as formas de luta”, desde as mais atrasadas, mais simples e elementares, e descobrir, criar e adaptar as formas de organização; localizar a liderança espontânea da classe, seja na fábrica, nas escolas, nos sindicatos e nos bairros, para educá-las na ideologia socialista, aplicando o princípio da linha de massas de "organizar os mais avançados, apoiar-se nos intermediários, para dirigir os mais atrasados". O movimento verdadeiramente revolucionário de massas será resultado

\footnotetext{
${ }^{969}$ PARTIDO COMUNISTA DO BRASIL - ALA VERMELHA. Autocrítica, cit., p. 83.

${ }^{970}$ PARTIDO COMUNISTA DO BRASIL - ALA VERMELHA. Autocrítica, cit., p. 84.

${ }^{971}$ PARTIDO COMUNISTA DO BRASIL - ALA VERMELHA. Autocrítica, cit., p. 84.
} 
da educação ideológica de sua liderança e da organização da classe, dialeticamente relacionada com o próprio movimento e com as condições objetivas existentes. Cabe ainda ressaltar que, no trabalho de ligação com as massas não se pode cair no desvio vanguardista de provocar movimentações imediatas, não sustentadas pela educação e organização de pelo menos, uma parcela da massa. Esse tipo de atuação realizada em diversas oportunidades pela Ação Popular e, em menor escala pela AV, provoca uma erupção momentânea, mas que esvazia em seguida sem deixar saldo em termos de consciência e organização da massa ${ }^{972}$.

No seio de um "movimento verdadeiramente de massas e verdadeiramente revolucionário" é que se torna possível construir o Partido da classe operária, através da fusão da ideologia socialista com a luta de classes. Por isso além de estar ligado à luta de classes concreta é preciso ter a compreensão da necessidade histórica do Partido, particularmente no que diz respeito a seu conteúdo ideológico, o que precede suas demais caracterizações e tarefas. Historicamente, o Partido é necessário porque nenhuma outra forma menos avançada de organização tem condições de levar a consciência de classe à classe e dirigi-la conseqüentemente. $\mathrm{O}$ ponto de partida para esse entendimento é a compreensão do papel histórico da classe operária, como a única capaz de levar a revolução até as últimas consequiências, isto é, até seu próprio desaparecimento como classe na sociedade sem classes. Dito de outro modo, o proletariado é a única classe cuja libertação implica na libertação de todas as outras, através da extinção de todas elas. Entretanto, a compreensão desse papel histórico, como se sabe, não surge espontaneamente da própria classe. A ideologia socialista, que o define cientificamente, surge fora da classe, elaborada pela intelectualidade socialista —capaz de acesso à ciência. A consciência espontânea da classe operária só atinge o "trade-unionismo", a luta pela melhoria das condições em que vende a força de trabalho, sem questionar o sistema que a submete a esta venda. Torna-se pois, necessário levar a consciência socialista à classe e isso é tarefa dos marxistas-leninistas organizados em seus partidos, organizações, agrupamentos ou círculos — quando ainda não existe o Partido da classe operária, como é o caso de nosso país. Essa tarefa de educação, entretanto, tem duplo significado: os intelectuais socialistas vão às massas para educá-las no conhecimento do marxismo-leninismo e, ao mesmo tempo, para se educarem na luta de classes concreta. No momento em que a organização, orientada pela ideologia socialista, influa sobre as massas operárias, educando seus elementos mais avançados no conhecimento do marxismo-leninismo, permite e cria as condições para seu

\footnotetext{
${ }^{972}$ PARTIDO COMUNISTA DO BRASIL — ALA VERMELHA. Autocrítica, cit., p. 84-85.
} 
próprio crescimento e transformação. Só com a assimilação dos melhores e mais combativos elementos, será possível mudar o conteúdo da organização e capacitá-la a atuar de forma mais direta e proveitosa, ou seja, como partido proletário. Percebe-se que o partido só pode se construir na luta de classes concreta e que, inversamente, a luta de massas, particularmente a do proletariado, só ganha consequiência com a existência do Partido. Isto é, "só com Partido é que se dará conseqüência à construção das forças da revolução, conduzindo-as para as lutas futuras pela tomada do poder político e pelo socialismo" ${ }^{, 973}$.

Por outro lado, essas tarefas só serão possíveis através de uma "intensa luta ideológica que faça prevalecer a ideologia proletária” sobre as outras ideologias que desviam a classe de seus objetivos ${ }^{974}$.

A luta ideológica se dirige contra as principais tendências que entrava o desenvolvimento da revolução. Atualmente, no Brasil, essas tendências são: entre as massas do proletariado, o populismo, a visão "nacional desenvolvimentista", o reboquismo em relação à burguesia, ainda uma vez o revisionismo, o "radicalismo" pequeno burguês, o voluntarismo, e nos últimos tempos o economicismo - em sua forma obreirista —, negando a necessidade da luta política e, em última instância, do Partido. Deve ficar claro que a luta ideológica não é um simples debate esotérico entre organizações de esquerda: ela é "um processo complexo, permanente", que implica na luta entre as massas contra todas as tendências não proletárias, na luta contra as diversas correntes que se pretendem marxistas-leninistas e na luta dentro de cada uma destas. Tanto ao nível de ligação com as massas quanto da construção do Partido será a luta ideológica que garantirá aos marxistasleninistas fazer prevalecer a ideologia proletária na realização daquelas $\operatorname{tarefas}^{975}$.

Nas condições atuais da revolução brasileira, "tais tarefas cabem a tosos os marxistas-leninistas agrupados em suas organizações, partidos ou círculos: é imprescindivel a organização para obter a ligação com as massas "976.

Salienta o Doc. Autocrítica que deve ficar claro que nas circunstâncias atuais a tarefa de construção do Partido não as embasará na fusão orgânica (reorganização) das organizações, grupos ou círculos existentes, mas sim no encontro no trabalho de base (no seio das massas) das diversas tendências, na luta ideológica na base, na construção de novas forças ideologicamente proletárias no interior da classe, enfim, na aproximação pela

\footnotetext{
${ }^{973}$ PARTIDO COMUNISTA DO BRASIL - ALA VERMELHA. Autocrítica, cit., p. 85-86.

${ }^{974}$ PARTIDO COMUNISTA DO BRASIL - ALA VERMELHA. Autocrítica, cit., p. 86.

${ }^{975}$ PARTIDO COMUNISTA DO BRASIL - ALA VERMELHA. Autocrítica, cit., p. 86.

${ }^{976}$ PARTIDO COMUNISTA DO BRASIL - ALA VERMELHA. Autocrítica, cit., p. 86-87.
} 
base dentro do movimento de massas onde se manifestam essas tendências. O que vale dizer que a luta ideológica deve ser entre as organizações, grupos ou círculos, principalmente através da imprensa. Assim, "qualquer fusão de organizações que não derive da fusão com base ideológica e promovida no trabalho revolucionário concreto é artificial" e tende a formar grupos internamente fracionados em tendências inconciliáveis ${ }^{977}$.

A AV se insere no quadro de esquerda e a ela cabe também como aos demais, marxistas-leninistas, desenvolver as três tarefas fundamentais. Para isso deve levar em conta "sua situação particular atual, suas limitações e suas potencialidades"

Definindo-se como uma organização partidária leninista, que se orienta pelo marxismo-leninismo e luta pela construção do partido de vanguarda de classe operária, a AV necessita, antes de mais nada, "superar suas próprias limitações, retificar sua orientação, eliminando os erros e desvios apontados nesta autocrítica". Trata-se portanto de se voltar decisivamente par as massas e se lançar na tarefa de educá-las e organizá-las, tomando como base a necessidade de eliminar o "radicalismo" pequeno burguês, o voluntarismo, o vanguardismo, o dogmatismo e o subjetivismo de suas concepções e de sua prática, através de uma intensa luta ideológica interna. Não se trata apenas de substituir determinadas orientações por outras, mas sim de instrumentar um profundo debate capaz de chegar à raiz ideológica dos desvios de cada militante e do conjunto da organização. Partindo daí, elaborar e adotar diretivas que lhe permitam realizar corretamente as tarefas que hoje São apresentadas como tarefas de todos os marxistas-leninistas. Cabe-lhe ainda para chegar a isso, instrumentar sua própria transformação numa organização sólida e eficaz, através da retificação e aperfeiçoamento dos métodos de direção, de formação de quadros, dando um caráter científico à militância, transformando cada militante num educador, organizador e dirigente político das massas ${ }^{979}$.

Objetivando a realização das três tarefas e buscando a unidade de todos os marxistas-leninistas do país, o PC do B - AV "apresenta sua autocrítica ao conjunto do movimento revolucionário”. Espera que como primeiro passo de uma luta ideológica conseqüente, "as demais organizações, agrupamentos e partidos assumam também uma atitude autocrítica, além de criticar as concepções expostas neste trabalho"980.

\footnotetext{
${ }^{977}$ PARTIDO COMUNISTA DO BRASIL - ALA VERMELHA. Autocrítica, cit., p. 87.

${ }^{978}$ PARTIDO COMUNISTA DO BRASIL — ALA VERMELHA. Autocrítica, cit., p. 87.

${ }^{979}$ PARTIDO COMUNISTA DO BRASIL - ALA VERMELHA. Autocrítica, cit., p. 87-88.

${ }^{980}$ PARTIDO COMUNISTA DO BRASIL - ALA VERMELHA. Autocrítica, cit., p. 88.
} 


\section{CONSIDERAÇÕES FINAIS}

A degeneração das matrizes ideológicas dos antigos partidos comunistas no Brasil motivou a inação imediata destas organizações, que não souberam responder de modo coerente com a realidade advinda com o Golpe de 64. Este quadro foi sendo paulatinamente agravado com o surgimento da "nova esquerda" ou "esquerda revolucionária”, a qual encarnava o espírito renovador e libertário que grassava o mundo nos meados dos anos 60. Incapazes de cooptá-la, estas organizações seriam por ela alteradas de maneira mais gravosa: aconteceriam em seu interior variadas cisões, inspiradas no "mundo da revolução" no qual a "nova esquerda" havia sido gerada. Preconizando a derrubada dos militares e seus aliados civis do poder, estes novos militantes propugnavam uma ofensiva revolucionária, que aconteceria por meio da luta armada ou insurreições de massa, para posterior implantação de um regime socialista no Brasil.

Como reflexo deste contexto é que surge a Ala Vermelha. O retorno de vários estagiários das Academias Políticas e Militares chinesas vieram imbuídos dos ideais da Revolução Cultural, e entraram em choque com concepções e posições expressadas pelo PC do B, e iniciaram um processo de luta interna visando uma ampla discussão ideológica de todas as questões fundamentais da revolução brasileira e do próprio partido. Todavia, os ventos das novas idéias foi rechaçado por aquele partido, e não restou outro caminho aos dissidentes - que haviam angariado respeitável apoio dos militantes do $\mathrm{PC}$ do $\mathrm{B}$ - senão o de buscar a ruptura com aquela organização.

A Ala Vermelha nasce, assim, sob o signo da livre discussão de idéias, de um permanente debate, e conseqüentemente, de revisão de suas próprias idéias por meio de um incessante processo autocrítico - inicialmente para procurar fugir do que entendia ser o "oportunismo" e "mandonismo" da direção do PC do B.

O discurso da Ala divisava, a centralidade partidária e a subordinação da luta armada ao partido - o que a distinguiria de outras organizações que privilegiavam a ação militar em detrimento do papel do partido. Inicialmente instituiu o Grupo Especial Nacional (GEN), um agrupamento guerrilheiro que teria uma estrutura fixa que responderia diretamente à Direção Nacional Provisória. Após a dissolução do 
GEN, a Direção Nacional não mais autorizou a criação de organismos fixos de luta armada no partido, passou a convocar militantes de modo a formar um grupo especial para as imprescindíveis ações de expropriação, assim como de atividades que envolvessem ações de propaganda revolucionária, seriam os grupos especiais.

Importante destacar que a Ala Vermelha não considerava a expropriação como uma ação política, ao contrário de outras organizações que a viam como um fim político em si. Apenas praticou atividade de expropriação premida pela necessidade de levar adiante os objetivos do partido, ou seja, conseguir recursos para sua própria subsistência e a de seus militantes que foram obrigados a optarem pela vida clandestina em função de suas atividades - já que eram objeto dos órgãos de repressão do Regime Autoritário brasileiro.

$\mathrm{O}$ aspecto singular dessa organização e que a distingue dos demais grupos guerrilheiros que atuavam naquela época no Brasil foi o fato de que em pleno processo de luta armada, a Ala Vermelha haver iniciado um processo autocrítico com relação à própria luta armada, que começou em 1969, para culminar em 1974.

Em 1969 lançou os "16 Pontos”, onde faz uma avaliação crítica sobre a luta armada e propõe um profundo trabalho com as massas fundamentais da revolução: o proletariado e o campesinato. Através da permanente revisão e debate sobre os caminhos escolhidos pelo partido, o refluxo dado pelos "16 Pontos" impede o massacre da organização, garantido a sobrevivência da Ala Vermelha. Este início de processo autocrítico consegue atravessar a fase mais dura da repressão o que permite a sua reorganização na linha do trabalho de massa.

A organização elaborou, em 1974, uma resolução denominada de “Autocrítica 1967-1974". Nesse documento, avaliou seu isolamento dos movimentos sociais, o equívoco da opção pela luta armada imediata em detrimento ao trabalho político de massas entre as classes trabalhadoras.

Neste documento se trata de localizar os erros, identificar suas causas mais profundas e apontar o caminho para a superação, sustentado no princípio de que a crítica e a autocrítica sejam precedidas pela firme decisão de levar avante a revolução através dos estudos do marxismo-leninismo. Para isto determinaram as tarefas de se ligarem à luta de classes concreta, de construção do partido de vanguarda do proletariado e o de travar a luta ideológica sustentada na fusão da ideologia socialista com a luta de classes, considerando o papel histórico da classe operária. 
O documento de Autocrítica, ao analisar a situação do Brasil naquele momento se posiciona frente a uma particular visão sobre o economicismo (em sua forma obreirista), negando a necessidade da luta política e, em última instância, do Partido. Isto reflete a preocupação com os novos rumos do país. O que na realidade acabou por acontecer com o processo globalizador que se instalou em nosso país como um fenômeno de várias faces, não ficando restrita à economia.

O documento autocrítico passou a ser considerado pela maioria das demais organizações que atuaram contra o Estado autoritário brasileiro, como um documento essencial para o procedimento autocrítico de todo o processo de luta armada no Brasil, o que demonstra a relevância da organização Ala Vermelha para a História da esquerda armada brasileira.

A Ala Vermelha continuou sua trajetória mesmo depois de iniciada a "abertura" do regime, efetivando trabalho de massas que privilegiava a atuação política junto à classe operária e nos bairros populares, quer com inserção em sindicatos, quer com a criação de centros culturais, trabalho junto ao movimento de mulheres, da Anistia, além de cuidar de uma ampla gama de publicações na imprensa, com a manutenção de vários jornais não clandestinos em diversas cidades do Brasil. No final dos anos 70 participou do debate existente no seio da esquerda brasileira sobre a construção de um partido de massas, fazendo a opção pelo Partido dos Trabalhadores, e passou a integrar essa agremiação desde seus encontros preliminares em diversos Estados, que culminariam na fundação nacional do PT. 


\section{FONTES DOCUMENTAIS}

\section{Documentos do Partido Comunista do Brasil — Ala Vermelha.}

A LUTA contra o oportunismo: a origem da luta interna. [S. 1.], ago./set. 1967. ARQUIVO PÚBLICO DO ESTADO DO RIO DE JANEIRO. Coleção particular Daniel Aarão Reis Filho. SÉRIE: Ala Vermelha. Dossiê 05 , doc. 87.

CONVOCAÇÃO. [S. 1.], 1967. Coleção particular Daniel Aarão Reis Filho. SÉRIE: Ala Vermelha. Dossiê 05, doc. 86, Arquivo Público do Estado do Rio de Janeiro.

CONVOCAÇÃO. São Paulo, jul., 1967. Coleção particular Daniel Aarão Reis Filho. SÉRIE: Ala Vermelha. Dossiê 09, doc. 238, Arquivo Público do Estado do Rio de Janeiro.

PARTIDO COMUNISTA DO BRASIL - ALA VERMELHA. A luta contra o oportunismo: a origem da luta interna. [S. 1.], ago./set. 1967. Coleção particular Daniel Aarão Reis Filho. SÉRIE: Ala Vermelha. Dossiê 05, doc. 87, Arquivo Público do Estado do Rio de Janeiro.

PARTIDO COMUNISTA DO BRASIL - ALA VERMELHA. Aos estudantes e trabalhadores revolucionários. [S. 1.], jul. 1968. Coleção particular Daniel Aarão Reis Filho. SÉRIE: Ala Vermelha. Dossiê 05, doc. 95, Arquivo Público do Estado do Rio de Janeiro.

PARTIDO COMUNISTA DO BRASIL - ALA VERMELHA. Autocrítica. 1967-1973. [S. 1.], jan., 1974. Coleção particular Daniel Aarão Reis Filho. SÉRIE: Ala Vermelha. Dossiê 05, doc. 150. Arquivo Público do Estado do Rio de Janeiro.

PARTIDO COMUNISTA DO BRASIL - ALA VERMELHA. BIRÔ ESTUDANTIL DO PC DO B - ALA VERMELHA. Desencadear uma revolução cultural dentro do partido. [S. 1.], set., 1967. Coleção particular Daniel Aarão Reis Filho. SÉRIE: Ala Vermelha. Dossiê 05, doc. 88, Arquivo Público do Estado do Rio de Janeiro. 
PARTIDO COMUNISTA DO BRASIL - ALA VERMELHA. COMitê Regional de SÃo PAUlo. Organizar um Partido de Novo Tipo em função da Luta Armada. [S. 1.], mar. 1968. Coleção particular Daniel Aarão Reis Filho. SÉRIE: Ala Vermelha. Dossiê 05, doc. 91, Arquivo Público do Estado do Rio de Janeiro.

PARTIDO COMUNISTA DO BRASIL - ALA VERMELHA. COMITÊ REGIONAL DE SÃO PAULO. Organizar um Partido de Novo Tipo em função da Luta Armada. [S. 1.], mar. 1968. Coleção particular Daniel Aarão Reis Filho. SÉRIE: Ala Vermelha. Dossiê 05, doc. 91. Arquivo Público do Estado do Rio de Janeiro.

PARTIDO COMUNISTA DO BRASIL - ALA VERMELHA. Crítica ao oportunismo e subjetivismo do documento "União dos Patriotas para livrar o País da Crise, da Ditadura, da Ameaça Neocolonial”. [S. 1.], dez., 1967. Coleção particular Daniel Aarão Reis Filho. SÉRIE: Ala Vermelha. Dossiê 05, doc. 90, Arquivo Público do Estado do Rio de Janeiro.

PARTIDO COMUNISTA DO BRASIL - ALA VERMELHA. Guerra Popular. [S. 1.] ano 1, nº 1, 25 de out., 1967. Coleção particular Daniel Aarão Reis Filho. SÉRIE: Ala Vermelha. Dossiê 09, doc. 238, Arquivo Público do Estado do Rio de Janeiro.

PARTIDO COMUNISTA DO BRASIL - ALA VERMELHA. Os 16 Pontos. [S. 1.], nov., 1969. Coleção particular Daniel Aarão Reis Filho. SÉRIE: Ala Vermelha. Dossiê 05, doc. 103.

PARTIDO COMUNISTA DO BRASIL - ALA VERMELHA. Os 16 Pontos. [S. 1.], nov., 1969. Coleção particular Daniel Aarão Reis Filho. SÉRIE: Ala Vermelha. Dossiê 05, doc. 103. Arquivo Público do Estado do Rio de Janeiro.

PARTIDO COMUNISTA DO BRASIL - ALA VERMELHA. Popular. Guanabara, ano I, nº. 1, nov. 1967. Coleção particular Daniel Aarão Reis Filho. SÉRIE: Ala Vermelha. Dossiê 09, doc. 239, Arquivo Público do Estado do Rio de Janeiro. 
PARTIDO COMUNISTA DO BRASIL - ALA VERMELHA. Sobre o relacionamento do Partido com outras Organizações Revolucionárias. São Paulo, abr. 1968. Coleção particular Daniel Aarão Reis Filho. SÉRIE: Ala Vermelha. Dossiê 05, doc. 92, Arquivo Público do Estado do Rio de Janeiro.

PARTIDO COMUNISTA DO BRASIL. COMITÊ DISTRITAL DO ABC et al. Resolução do Comitê Distrital do ABC. São Bernardo do Campo, jun., 1967. Coleção particular Daniel Aarão Reis Filho. SÉRIE: Ala Vermelha. Dossiê 05, doc. 85.1, Arquivo Público do Estado do Rio de Janeiro.

POR UM GRANDE debate revolucionário em nosso Partido. [S. 1.], 1966. Coleção particular Daniel Aarão Reis Filho. SÉRIE: Ala Vermelha. Dossiê 05, doc. 85, Arquivo Público do Estado do Rio de Janeiro.

REFORMEMOS nossos métodos de trabalho e nossas concepções de mundo. Nova Iguaçu. 20 nov., 1967. Coleção particular Daniel Aarão Reis Filho. SÉRIE: Ala Vermelha. Dossiê 05, doc. 89, Arquivo Público do Estado do Rio de Janeiro.

\title{
Processos
}

BNM 119, BNM 180, BNM 269, BNM 294, BNM 334, BNM 403, BNM 406, BNM 436, BNM 589, BNM 599, BNM 602, BNM 682.

\section{Entrevistas concedidas ao autor do trabalho por antigos militantes da Ala Vermelha em São Paulo.}

\author{
Alípio Raimundo Viana Freire \\ Delmar Mattes \\ Derly José de Carvalho \\ Élio Cabral de Souza \\ Felipe José Lindoso \\ Gerôncio Albuquerque Rocha \\ Renato Carvalho Tapajós \\ Tarzan de Castro \\ Vicente Eduardo Gómez Roig
}


Entrevistas concedidas ao autor do trabalho por juristas que atuaram nos processos BNM.

\author{
Idebal Piveta \\ José Carlos Dias \\ Marcos Antonio Nahum \\ Mário Simas
}

\title{
Bibliografia
}

AFFONSO, Almino. Raízes do golpe. Da crise da legalidade ao parlamentarismo (1961-1963). São Paulo: Marco Zero, 1988.

AGUIAR, Roberto A. R. de. Direito, Poder e Opressão. São Paulo: AlfaÔmega, 1980.

AGUIAR, Roberto A. R. de. O que é justiça - Uma abordagem dialética. São Paulo: Alfa-Ômega, 1982.

ALIA, Ramiz. Uma Linha de Luta de Vitória contra o Revisionismo Krutchevista. In: HOXHA, Enver; ALIA, Ramiz. Uma Linha de Luta de Vitória contra o Revisionismo Krutchevista. Lisboa: Maria da Fonte, 1976, p. 11-32.

ALVES, Maria Helena Moreira. Estado e Oposição no Brasil (1964-1984). Petrópolis: Vozes, 1989.

ALVIM, João Carlos. A revolução sem rumo. Rio de Janeiro: Val, 1964.

AMAZONAS, João. João Amazonas, Secretário geral do PC do B, analisa o momento político nacional e internacional e promete voltar ao Brasil até o fim do ano. Entrevista concedida a Alberto Villas e Manoel Domingos Neto. Movimento, São Paulo, n. 215, ago. 1979, p. 11-13. 
ANTUNES, Ricardo. Os comunistas no Brasil: As Repercussões do VI Congresso da Internacional Comunista e a Primeira Inflexão Stalinista no Partido Comunista do Brasil (PCB). Cadernos AEL. Comunistas e Comunismo, Campinas, n. 2, 1995, p. 11-34.

AQUINO, Maria Aparecida de. A especificidade do regime militar brasileiro: abordagem teórica e exercício empírico. In: REIS FILHO, Daniel Aarão (org.). Intelectuais, história e política (séculos XIX e XX). Rio de Janeiro: 7 Letras, 2000, p. 219-227.

AQUINO, Maria Aparecida de. Caminhos Cruzados. Imprensa e Estado Autoritário no Brasil (1964-80). 1994. 310 f. Tese (Doutorado em História) Universidade de São Paulo, 1994.

AQUINO, Maria Aparecida de. Censura, Imprensa, Estado Autoritário (1968-1978). Bauru, Edusc, 1999.

AQUINO, Maria Aparecida de. MATTOS, Marco Aurélio Vannucchi Leme de. SWENSSON JR, Walter Cruz. No Coração das Trevas: o DEOPS/SP visto por dentro. São Paulo: Arquivo do Estado- Imprensa Oficial, 2001.

ARENDT, Hannah. A condição humana. Forense: Rio de Janeiro, 1995.

ARENDT, Hannah. Eichmann em Jerusalém. Um relato sobre a banalidade do mal. São Paulo: Companhia da Letras, 2000.

ARENDT, Hannah. Origens do Totalitarismo. Anti-semitismo, imperialismo, totalitarismo. São Paulo; Companhia das Letras, 2004.

ARNS, D. Paulo Evaristo. Da esperança à utopia: testemunho de uma vida. Rio de Janeiro: Sextante, 2001.

ARROYO, Ângelo. Relatório sobre a Luta no Araguaia. In: POMAR, Wladimir. Araguaia: o Partido e a guerrilha. São Paulo: Global, 1980, p. 249-274.

ARROYO, Ângelo. Um grande acontecimento na vida do país e do Partido. In: POMAR, Wladimir. Araguaia: o Partido e a guerrilha. São Paulo: Global, 1980, p. $275-290$.

ASÚA, Jiménez de. Tratado de Derecho Penal. Vol. II. Buenos Aires: Losada, 1950. 
AYERBE, Luis Fernando. A Revolução Cubana. São Paulo: Unesp, 2004.

AZEVEDO, Fernando Antonio. As Ligas Camponesas. Petrópolis: Vozes, 1982.

BABY, Jean. As Grandes Divergências do Mundo Socialista. São Paulo: Senzala, [19- -].

BANDEIRA, Luiz Alberto Moniz. O Governo João Goulart. As lutas sociais no Brasil: 1961-1964. Rio de Janeiro: UnB-Revan, 2001.

BARATTA, Alessandro. Criminologia Crítica y Crítica del Derecho Penal. Ciudad de México: Siglo Veinteuno, 1993.

BARATTA, Alessandro. Criminología y Dogmática Penal. Pasado y futuro del modelo integral de la ciencia penal. In:MIR PUIG, Santiago (org.). Política Criminal y Reforma del Derecho Penal. Bogotá: Colombia, 1982.

BARROSO, Luís Roberto. A superação da ideologia da segurança nacional e a tipificação dos crimes contra o Estado Democrático de Direito. Revista de Estudos Criminais, Porto Alegre, f. 9, v. 2, p. 71-79, 2003.

BATISTA, Nilo. Considerações em torno dos crimes de insurreição e conspiração no direito brasileiro. Revista de Direito Penal e Criminologia, Rio de Janeiro, $n^{\circ} .5$, jan.-mar., 1972, p. 49-70.

BATISTA, Nilo. Lei de Segurança Nacional: o direito da tortura e da morte. Revista de Direito Penal e Criminologia, Rio de Janeiro, ${ }^{\circ}{ }^{\circ} .34$, jul./dez., 1982, p. 48-62.

BECCARIA, Marquês de (Césare Bonesana). Dei Delitti e Delle Pene. Florença: Monnier, 1992.

BEIGUElMAN, Paula. O Pingo de Azeite: a instauração da ditadura. São Paulo: Perspectiva, 1994.

BERARDO, João Batista. Guerrilhas e guerrilheiros no drama da América Latina. São Paulo: Edições Populares, 1981.

BETTO, Frei. Batismo de Sangue. São Paulo: Casa Amarela, 2001. 
BICALHO, Luiz de Carvalho. PCB: processo de cassação de registro (1947). Belo Horizonte, Aldeia Global, 1980.

BICUDO, Hélio. Segurança nacional ou submissão. Rio de Janeiro: Paz e Terra, 1984.

BOAS, Marco Antonio Vilas. Processo Penal. Saraiva: São Paulo, 2001.

BORBA, Marco Aurélio. Cabo Anselmo: a luta armada ferida por dentro. São Paulo: Global, 1984.

BOSCHI, José Antonio Paganella. Persecução Penal. Rio de Janeiro: Aide, 1987.

BRANCO, Carlos Castello. Introdução à revolução de 1964 - agonia do poder civil. $1^{\circ}$ Tomo. Rio de Janeiro: Artenova, 1975.

BRANCO, Eurico Castello. Dos Crimes contra a Segurança Nacional. Rio de Janeiro: José Konfino, 1971.

BRASIL. Ato Institucional (n. 1), de 9 de abril de 1964. Brasília: Senado Federal, 1964.

BRASIL. Ato Institucional $\mathbf{n}^{\mathbf{0}}$. 14, de 5 de setembro de 1969. Brasília: Senado Federal, 1969.

BRASIL. Ato Institucional no . 2, de 27 de outubro de 1965. Brasília: Senado Federal, 1965.

BRASIL. Ato Institucional no . 4, de 7 de dezembro de 1966. Brasília: Senado Federal, 1966.

BRASIL. Ato Institucional $\mathbf{n}^{\mathbf{0}}$. 5, de 13 de dezembro de 1968. Brasília: Senado Federal, 1968.

BRASIL. Código Criminal do Império do Brazil. Annotado por Antônio Luiz Tinôco. Brasília: Senado Federal, 2003.

BRASIL. Código da Justiça Militar, de 2 de dezembro de 1938. Organizado por Reinaldo Calil. São Paulo: Sugestões Literárias, 1967.

BRASIL. Código de Processo Penal Militar. São Paulo: Sugestões Literárias, 1970. 
BRASIL. Código Penal (1890). Código Penal dos Estados Unidos do Brazil. In: PIERANGELI, José Henrique. Códigos Penais do Brasil. Evolução histórica. São Paulo: Revista dos Tribunais, 2001.

BRASIL. Código Penal Brasileiro (1940). Código Penal Brasileiro. São Paulo: Saraiva, 1945.

BRASIL. Código Penal Militar (1969). Brasília: Senado Federal, 1969.

BRASIL. Constituição (1824) Constituição Política do Império do Brazil. Seguida do Acto Adiccional e Lei de Interpretação. Rio de Janeiro: Nicolau-Alves, 1884 .

BRASIL. Constituição (1891) Constituição da República dos Estados Unidos do Brazil. Brasília, Senado Federal.

BRASIL. Constituição (1934) Constituição dos Estados Unidos do Brasil. Rio de Janeiro: Assembléia Nacional Constituinte, 1934.

BRASIL. Constituição (1937) Constituição dos Estados Unidos do Brasil. Rio de Janeiro: [S. 1.], 1937.

BRASIL. Constituição (1946) Constituição dos Estados Unidos do Brasil. Promulgada em 18 de setembro de 1946. São Paulo: Saraiva, 1946.

BRASIL. Constituição (1967). Constituição do Brasil. Brasília: Senado Federal, 1967.

BRASIL. Constituição (1988) Constituição da República Federativa do Brasil. São Paulo: Saraiva: 2006.

BRASIL. Constituição. Emenda Constitucional (1969). Constituição da República Federativa do Brasil. Organização, remissão e índices por Juarez de Oliveira e Marcus Cláudio Acquaviva. São Paulo: Saraiva: 1974.

BRASIL. Decreto n. 4.269, de 17 de janeiro de 1921. Regula a Repressão do Anarchismo. Rio de Janeiro: Senado Federal, 1921.

BRASIL. Decreto n. 7, de 3 de agosto de 1935. Modifica a denominação do Conselho de Defesa Nacional e de seus órgãos componentes. Rio de Janeiro: Senado Federal, 1935. 
BRASIL. Decreto-lei n. 428, de 16 de maio de 1938. Dispõe sobre o processo dos crimes definidos nas leis ns. 38 e 136, de 4 de abril e 14 de dezembro de 1935. Rio de Janeiro: Senado Federal, 1938.

BRASIL. Decreto-lei n. 88, de 20 de dezembro de 1937. Modifica a Lei 244, de 11 de setembro de 1936, que instituiu o Tribunal de Segurança Nacional e dá outras providências. Rio de Janeiro: Senado Federal, 1937.

BRASIL. Lei de Organização Judiciária Militar. Decreto-lei $\mathrm{n}^{\circ}$. 1.003, de 21 de outubro de 1969. São Paulo: Sugestões Literárias, 1971.

BRASIL. Lei n. 1.802, de 5 de janeiro de 1953. Define os crimes contra o Estado e a Ordem Política e Social, e dá outras providências. Rio de Janeiro: Senado Federal, 1953.

BRASIL. Lei n. 136, de 14 de dezembro de 1935. Modifica vários dispositivos da Lei n. 38, de 4 de abril de 1935, e define novos crimes contra a ordem política e social. Rio de Janeiro: Senado Federal, 1935.

BRASIL. Lei n. 244, de 11 de setembro de 1936. Institui o Tribunal de Segurança Nacional e dá outras providências. Rio de Janeiro: Senado Federal, 1936.

BRASIL. Lei n. 38, de 4 de abril de 1935. Define crimes contra a ordem política e social. Rio de Janeiro: Senado Federal, 1935.

BRASIL. Nova Lei de Segurança Nacional. Decreto-lei 898, de 29 de setembro de 1969. Define os crimes contra a segurança nacional, a ordem política e social, estabelece seu processo e julgamento e dá outras providências. São Paulo: Sugestões Literárias, 1970.

BRASIL. Nova Lei de Segurança Nacional. Decreto-lei $n^{\circ}$. 314, de 13 de março de 1967 alterado pelo Decreto-lei nº. 510, de 20 de março de 1969. São Paulo: Sugestões Literárias, 1969.

BRUNO, Aníbal. Direito Penal. Parte Geral. Tomo I. Rio de Janeiro: Forense, 1978. 
BUSTOS RAMÍRES, Juan. Estado y control: la ideologia del control y el control de la ideologia. In:BERGALLI, Roberto; BUSTOS RAMÍRES, Juan (org.). El Pensamiento Criminológico. II. Estado y Control. Barcelona: Península, 1983, p. 11-36.

BUSTOS RAMÍRES, Juan; HOMAZÁBAL MALARÉE, Hernán. Lecciones de Derecho Penal. Volumen I. Madri: Trotta, 1997.

CABRAL, Reinaldo e LAPA, Ronaldo. Desaparecidos políticos. Rio de Janeiro: Edições Opções/CBA, 1979.

CALDAS, Álvaro. Tirando o Capuz. Rio de Janeiro: Codecri, 1981.

CALLADO, Antonio. Tempo de Arraes - padres e comunistas na revolução sem violência. Rio de Janeiro: José Álvaro, 1965.

CAMARGO, Aspásia; GÓES, Walder de. Meio século de combate: diálogo com Cordeiro de Farias. Rio de Janeiro: Nova Fronteira, 1981.

CAPELlETTI, Mauro. Proceso, ideologias, sociedad. Buenos Aires: Juridicas Europa-America, s.d.

CAPITANI, Avelino Biden. A Rebelião dos Marinheiros. Porto Alegre: Artes \& Ofícios, 1997.

CARDOSO, Irene. Memória de 68: terror e interdição do passado. Tempo social; Rev. Sociologia da USP, São Paulo, 2 (2), 2ºm 1990, p. . 101-112.

CARDOSO, Rosa Maria. O conceito e histórico do crime político. In: MARTINS FILHO, João Roberto, SWENSSON JÚNIOR, Walter Cruz, CARDOSO, Rosa. Crime político: conceito, histórico e conseqüências. São Paulo: IBCCRIM, 2001. (Seminário práticas repressivas e crime político no regime militar). 2 Fitas VHS.

CARNOY, Martin. Estado e Teoria Política. Campinas: Papirus, 1986.

CARONE, Edgard. Movimento operário no Brasil (1964-1984). São Paulo: DIFEL, 1984.

CARONE, Edgard. O PCB: 1943 a 1964. Vol. 2. São Paulo: Difel, 1982. 
CARRARA, Francesco. Programa de Derecho Criminal. Vol. 5. Bogotá: Temis, 1973.

CARVALHO, Apolonio de. Vale a pena sonhar. Rio de Janeiro: Rocco, 1997.

CARVALHO, General Ferdinando de. Lembrai-vos de 35! Rio de Janeiro: Biblioteca do Exército, 1981.

CARVALHO, José Murili de. Forças armadas e política no Brasil. Rio de Janeiro: Jorge Zahar Ed., 2005.

CARVALHO, Luiz Maklouf. Mulheres que foram à luta armada. Rio de Janeiro: Globo, 1998.

CARVALHO, Luiz Maklouf. Pesquisa biográfica. In: POMAR, Pedro et al. Pedro Pomar. São Paulo: Brasil Debates, 1980, p. 25-63.

CARVAlHO, Péricles de; ALMEIDA, Francisco. PC do B. A sobrevivência de um erro. São Paulo: Novos Rumos, 1985.

CASTRO, Celso; D’ARAUJO, Maria Celina. Dossiê Geisel. Rio de Janeiro: FGV, 2002.

CASTRO, Celso; D’ARAUJO, Maria Celina. Militares e política na Nova República. Rio de Janeiro: FGV, 2001.

CASTRO, Fidel. Hoy somos un pueblo entero conquistando el porvenir. México: Siglo Veintiuno, 1973.

CHACON, Vamireh. História das idéias socialistas no Brasil. Rio de Janeiro: Civilização Brasileira, 1981.

CHARF, Clara. Duas histórias de luta, uma historia de amor. Revista Teoria e Debate. São Paulo, nº. 8, out./nov./dez., 1989, p. 32-42.

CHOMSKY, Noam. Poder e terrorismo. Rio de Janeiro: Record, 2005.

CLAUSEWITZ, Karl Von. Da Guerra. Mem Martins: Europa-América, 1997.

COGAN, Arthur. Crimes contra a Segurança Nacional. São Paulo: Revista dos Tribunais, 1976. 
COIMBRA, Cecília. Guardiães da Ordem - uma viagem pelas práticas psi no Brasil do "Milagre". Rio de Janeiro: Oficina do Autor, 1995.

COLES, Harry L. Guerra total e guerra fria. Rio de Janeiro: GRD, 1964.

COLLIER, David. O novo autoritarismo na América Latina. Rio de Janeiro: Paz e Terra, 1982.

COMBLIN, Joseph. A ideologia de segurança nacional: o poder militar na América Latina. Rio de Janeiro: Civilização Brasileira, 1978.

COMISSÃO DE FAMILIARES DE MORTOS E DESAPARECIDOS POLÍTICOS. Dossiê dos mortos e desaparecidos políticos a partir de 1964. São Paulo: IMESP, 1996.

COSTA, Albertina Oliveira (org.) Memórias das mulheres do exílio. Rio de Janeiro: Paz e Terra, 1980.

COUTO, Ronaldo Costa. História Indiscreta da Ditadura e da Abertura. Brasil: (1964-1985). Rio de Janeiro: Record, 1998.

COUTO, Ronaldo Costa. Memória viva do regime militar - Brasil: 19641985. Rio de Janeiro: Record, 1999.

CURY, Enrique. Orientación para el estudio de la teoria del delito. Santiago de Chile: Nueva Universidad, 1973.

D’ARAúJO, Maria Celina et al (org.) Os Anos de chumbo. A Memória militar sobre a repressão. Rio de Janeiro: Relume-Dumará, 1994.

D’ARAÚJO, Maria Celina et al (org.). A volta aos quartéis. A Memória militar sobre a abertura. Rio de Janeiro: Relume-Dumará, 1995.

D'ARAÚJO, Maria Celina et al (org.). Visões do golpe. A Memória militar sobre 1964. Rio de Janeiro: Relume-Dumará, 1994.

D’ARAUJO, Maria Celina; CASTRO, Celso. Ernesto Geisel. Rio de Janeiro: FGV, 1997.

D’ARAÚJO, Maria Celina. O Estado Novo. Rio de Janeiro: Jorge Zahar, 2000. 
D’ARAUJO, Maria Celina; SOARES, Gláucio Ary Dillon; CASTRO, Celso. Visões do Golpe - A memória militar de 1964. Rio de Janeiro: Ediouro, 2004.

DELGADO, Lucília de Almeida Neves, 1964: temporalidade e interpretações. Em: REIS, Daniel Aarão; RIDENTI, Marcelo; MOTTA, Rodrigo Patto Sá. (org.). O golpe e a ditadura militar: quarenta anos depois (1964-2004). Bauru, Edusc, 2004, p. 15-28.

DEBRAY, Regis. ¿Revolucion en la revolucion? Havana: Casa de las Americas, 1967.

DEBRAY, Regis. A Guerrilla do Che. São Paulo: Populares, 1980.

DEBRAY, Regis. America Latina: algunos prolemas de estrategia revolucionaria. Montevidéu: La Banda Oriental, 1967.

DEBRAY, Regis. A neve queima. Belo Horizonte: Vega, 1978.

DIAS, Luzimar Nogueira. Esquerda armada: testemunho dos presos políticos do Presídio Milton Dias Moreira, no Rio de Janeiro. Vitória: Leitor, 1979.

DÍAZ, Elías. Estado de Derecho y sociedad democrática. Madri: Taurus, 1992.

DINGES, John. The Condor Years: How Pinochet and His Allies Brought Terrorism to Three Continents. Nova Iorque: New Press, 2004.

DOCUMENTOS Programáticos de Luta pela Paz, a Democracia e o Socialismo. Moscou: Politizdat, 1963.

DREIFUSS, René Armand. 1964: A Conquista do Estado. Ação política, poder e golpe de classe. Petrópolis: Vozes, 1981.

DULLES, John W. F. Anarquistas e comunistas no Brasil. Rio de Janeiro: Nova Fronteira, 1977.

EIRAnOVA EnCINAS, Emilio. Código Penal Aleman (StGB). Madri: Marcial Pons, 2000.

ESCOLA SUPERIOR DE GUERRA. Fundamentos Doutrinários da Escola Superior de Guerra. Rio de Janeiro: ESG, 1985. 
ESCOLA SUPERIOR DE GUERRA. Manual Básico. Rio de Janeiro: ESG, 1982.

ESPÍRITO SANTO, José do. Estudos de Direito Penal e processual Penal Militar. Belo Horizonte: Imprensa Oficial, 1985.

FARIA, José Eduardo (org.). Direito e Justiça. A Função social do Judiciário. São Paulo: Ática, 1989.

FAUSTO, Boris. O pensamento nacionalista autoritário (1920-1940). Rio de Janeiro: Jorge Zahar Ed., 2001.

FERREIRA FILHO, Manoel Gonçalves. A democracia possível. São Paulo: Saraiva, 1978.

FERREIRA FILHO, Manoel Gonçalves. Estado de Direito e Constituição. São Paulo: Saraiva, 1988.

FICO, Carlos. Além do golpe: a tomada do poder em 31 de março de 1964 e a ditadura militar. Rio de Janeiro: Record, 2004.

FICO, Carlos. Como eles agiam - Os subterrâneos da ditadura militar: espionagem e polícia política. Rio de Janeiro: Record, 2001.

FIDELIS, Guido. Lei de Segurança Nacional e Censura (comentários). São Paulo: Sugestões Literárias, 1979.

FIORIN, José Luiz. O regime de 1964, discurso e ideologia. São Paulo: Atual, 1988.

FON, Antônio Carlos. Tortura. A História da repressão política no Brasil. São Paulo: Global, 1979.

FOUCAULT, Michel. Em defesa da sociedade. São Paulo: Martins Fontes, 2002.

FOUCAULT, Michel. A verdade e as formas jurídicas. Rio de Janeiro: Nau, 2005 .

FOUCAULT, Michel. Ditos \& Escritos IV. Estratégia, Poder-Saber. São Paulo: Forense, 2003. 
FOUCAULT, Michel. História da sexualidade I. A vontade de saber. Rio de Janeiro: Graal, 1997.

FOUCAULT, Michel. Microfísica do Poder. São Paulo: Graal, 1995.

FOUCAULT, Michel. Vigiar e punir. Nascimento da prisão. Petrópolis: Vozes, 1995.

FRAGOSO, Heleno Cláudio. A Nova Lei de Segurança Nacional. Revista de Direito Penal e Criminologia. Rio de Janeiro, n. 35, jan./jun., 1983, p. 61-69.

FRAGOSO, Heleno Cláudio. Advocacia da Liberdade. Rio de Janeiro: Forense, 1984.

FRAGOSO, Heleno Cláudio. Assalto a banco sem motivação política. Crime contra a segurança nacional. Conceito de Segurança Nacional. Revista de Direito Penal, Rio de Janeiro, no. 2, abr./jun., 1971, p. 146-156.

FRAGOSO, Heleno Cláudio. Jurisprudência Criminal. Rio de Janeiro: Forense, 1982.

FRAGOSO, Heleno Cláudio. Lei de Segurança Nacional. Uma experiência antidemocrática. Porto Alegre: Sergio Fabris, 1980.

FRAGOSO, Heleno Cláudio. Nova definição jurídica do fato. Lei de Segurança Nacional. Revista de Direito Penal, Rio de Janeiro, n. 13/14, jan.-jun., 1974, p. 156-159.

FRAGOSO, Heleno Cláudio. Sobre a Lei de Segurança Nacional. Revista de Direito Penal e Criminologia. Rio de Janeiro, n. 30, jul./dez., 1980, p. 5-10.

FRAGOSO, Heleno Cláudio. Terrorismo e Criminalidade Política. Rio de Janeiro: Forense, 1981.

FRANCA, Antonio. Anos de Resistência. Rio de Janeiro: Casa do Estudante, 1950.

FRANCO, Alberto Silva. Da aplicação da lei penal. In: FRANCO, Alberto Silva; STOCO, Rui (org.). Código Penal e sua interpretação jurisprudencial. São Paulo: Revista dos Tribunais, 2001. 
FREIRE, Alípio; ALMADA, Izaías; PONCE, J. A. de Granville. (org.). Tiradentes: um presídio da ditadura. São Paulo: Scipione Cultural, 1997.

FREIRE, Alípio. Anotações sobre uma tragédia. A quebra do militante revolucionário Edgar de Almeida Martins - o Matias. Campinas: Trabalho inédito, jan., 2005.

FREITAS, Lena Castello Branco Ferreira de. As elites brasileiras e a Escola Superior de Guerra. 1986. Tese (Doutorado em História) - Universidade de São Paulo, 1986.

FROTA, Silvio. Ideais Traídos. A mais grave crise dos governos militares narrada por um de seus protagonistas. Rio de Janeiro: Jorge Zahar, 2006.

GABEIRA, Fernando Nagle. O que é isso, companheiro. Rio de Janeiro: Codecri, 1979.

GARCÍA-PABLOS DE MOLINA, Antonio. Criminologia. Una introducción a sus fundamentos teóricos. Valência: Tirant Lo Blanch, 1996.

GASPARI, Elio. A Ditadura Derrotada. São Paulo: Companhia das Letras, 2003.

GASPARI, Elio. A Ditadura Encurralada. São Paulo: Companhia das Letras, 2004.

GASPARI, Elio. A Ditadura Envergonhada. São Paulo: Companhia das Letras, 2002.

GASPARI, Elio. A Ditadura Escancarada. São Paulo: Companhia das Letras, 2002.

GIAP, Vo Nguyen. Exército do Povo e Armamento das Massas Revolucionárias. Lisboa: Ulmeiro, 1976.

GIAP, Vo Nguyen. Guerra del Pueblo, Ejército del Pueblo. Havana: Política, 1964.

GOMES, João Paulo. Las entrañas del “milagro" brasileño. Buenos Aires: Actualidad, 1976. 
GORENDER, Jacob. Combate nas trevas. A Esquerda brasileira: das ilusões perdidas à luta armada. São Paulo: Ática, 2003.

GRECO FILHO, Vicente. Manual de Processo Penal. Saraiva: São Paulo: 1999, p. 95.

GRINOVER, Ada Pellegrini; FERNANDES, Antonio Scarance; GOMES FILHO, Antonio Magalhães. As nulidades no processo penal. São Paulo: Revista dos Tribunais, 2001.

GUEDES, Carlos Luís. Tinha que ser Minas. Rio de Janeiro: Nova Fronteira, 1979.

GURGEL, José Alfredo Amaral. Segurança e democracia: uma reflexão política. Rio de Janeiro: J. Olympio, 1978.

HOBSBAWN, Eric. Era dos Extremos. O breve século XX. São Paulo: Companhia das Letras, 1998.

HUNGRIA, Nelson. Comentários ao Código Penal. Vol. IX. Rio de Janeiro: Forense, 1959.

HUNGRIA, Nelson. Comentários ao Código Penal. Volume V. Rio de Janeiro: Forense, 1981.

HUNGRIA, Nelson. Comentários ao Código Penal. Volume VIII. Rio de Janeiro: Forense, 1954.

IANNI, Octavio, O colapso do populismo no Brasil. Rio de Janeiro: Civilização brasileira, 1971.

IANNI, Octavio. A ditadura do grande capital. Rio de Janeiro: Civilização Brasileira, 1981.

JOSÉ, Emiliano. Carlos Marighella. O inimigo número um da ditadura militar. São Paulo: Sol \& Chuva, 1997.

JOSÉ, Emiliano; MIRANDA, Oldack. Lamarca. O capitão da guerrilha. São Paulo: Global, 1980.

KELSEN, Hans. Teoria Pura do Direito. São Paulo: Martins Fontes, 1995. 
KLEIN, Fritz. Da natureza do Fascismo Hitleriano. In: KLEIN, F. et al. As origens do fascismo. São Paulo: Fatos e Documentos, [19--], p. 119-170.

KURLANSKY, Mark. 1968. O ano que abalou o mundo. Rio de Janeiro: José Olympio, 2005.

LAFER, Celso. A reconstrução dos direitos humanos. Um diálogo com o pensamento de Hannah Arendt. São Paulo: Companhia das Letras, 1991.

LANGGUTH, A. J. A face oculta do terror. Rio de Janeiro: Civilização Brasileira, 1979.

LÊNIN, Vladmir Ilich Ulianov. El Marxismo y la insurrección. Carta al Comité Central del POSD(b) de Rusia. Moscou: Progresso [19- -].

LÊNIN, Vladmir Ilich Ulianov. La enfermedad infantil del 'izquierdismo' en el comunismo. Pequim: Lenguas Estranjeras, 1971.

LÊNIN, Vladmir Ilich Ulianov. Obras Escogidas. Tomo V. 1913-1916. Moscou: Progresso, 1976.

LEVY, Nelson. O PC do B, continuidade e ruptura. Teoria \& Política, São Paulo, no. 1, 1980, p. 22-59.

LIMA, Haroldo; ARANTES, Aldo. História da Ação Popular. Da JUC ao PCdoB. São Paulo: Alfa-Ômega, 1984.

LOBO, Amílcar. A hora do lobo, a hora do carneiro. Petrópolis: Vozes, 1989.

LUDWIG, Antonio Carlos Will. Democracia e Ensino Militar. São Paulo: Cortez, 1998.

LYRA FILHO, Roberto. A Filosofia Jurídica nos Estados Unidos da América. Revisão Crítica. Porto Alegre: Fabris, 1977.

LYRA FILHO, Roberto. Carta aberta a um jovem criminólogo: teoria, práxis e táticas atuais. Revista de Direito Penal, Rio de Janeiro, fasc. 28, jul./dez., 1979, p. $5-25$. 
LYRA FILHO, Roberto. Criminologia Dialética. Rio de Janeiro: Borsoi, 1972.

LYRA FILHO, Roberto. Criminologia e dialética (2. parte). Revista de Direito Penal. Rio de Janeiro, fasc. 2, abr./jun., 1971, p. 29-57.

LYRA FILHO, Roberto. Criminologia e dialética: estudo comemorativo do bicentenário de Hegel (1770-1970) - 1. parte. Revista de Direito Penal, Rio de Janeiro, fasc. 1, jan./mar., 1971, p. 7-31.

LYRA FILHO, Roberto. Desordem e Processo: Um Posfácio Explicativo. In: LYRA, Doreodo Araujo (org.). Desordem e Processo. Estudos sobre o Direito em Homenagem a Roberto Lyra Filho na Ocasião do seu $60^{\circ}$ Aniversário com um Posfácio Explicativo. Porto Alegre, Sergio Fabris Editor, 1986.

LYRA FILHO, Roberto. Direito e Lei. In: SOUZA JÚNIOR, José Geraldo de (org.). O Direito achado na rua. Brasília: Universidade de Brasía, 1988, p. 35-37.

LYRA FILHO, Roberto. Humanismo Dialético. Direito e Avesso, Brasília, Ano II, nº 3, jan./jun., 1983, p. 15-103.

LYRA FILHO, Roberto. Normas jurídicas e outras normas sociais. In: SOUZA JÚNIOR, José Geraldo de (org.). O Direito achado na rua. Brasília: Universidade de Brasía, 1988, p. 55-59.

LYRA FILHO, Roberto. O Que é Direito? São Paulo: Brasiliense, 1982.

LYRA FILHO, Roberto. Panorama Atual da Criminologia. Revista Brasileira de Criminologia e Direito Penal, Rio de Janeiro, Vol. 4, fasc. 15, out./dez., 1966, p. $37-52$.

LYRA FILHO, Roberto. Para um Direito sem Dogmas. Porto Alegre: Sergio Antonio Fabris Editor, 1980.

LYRA FILHO, Roberto. Por que estudar direito, hoje? In: SOUZA JÚNIOR, José Geraldo de (org.). O Direito achado na rua. Brasília: Universidade de Brasía, 1988, p. 26-30.

MACIEL, Wilma Antunes. O Capitão Lamarca e a VPR na Justiça Militar: repressão judicial no Brasil. Versão para publicação. 2005. $181 \mathrm{f}$. Dissertação (Mestrado em História) - Universidade de São Paulo, 2005. 
MAGNOLI, Demetrio. Da guerra fria à détente. Campinas: Papirus, 1988.

MAIA, Andréas. O que foi o Partido Operário Revolucionário. Em Tempo, São Paulo, no. 104, 17 a 30 de abril, 1980, p. 16-19.

MAREGA, Marisa. A Nicarágua Sandinista. São Paulo: Brasiliense, 1981.

MARIANO, Nilson. As Garras do Condor. Como as ditaduras militares da Argentina, Chile, Uruguai, Brasil, Bolívia, Paraguai se associaram para eliminar adversários políticos. Petrópolis: Vozes, 2003.

MARQUES, José de Frederico. Tratado de Direito Penal. Volume I. São Paulo: Saraiva, 1964.

MARTENS, Ludo. Stalin. Um novo olhar. Rio de Janeiro: Revan, 2003.

MARTINS, Roberto R. A Repressão e a liberdade no Brasil. Cinco séculos de luta. Revista OAB, Rio de Janeiro, nº. 21. 1984.

MARTINS, Roberto R. Segurança Nacional. São Paulo: Brasiliense: 1986.

MARX, Karl; ENGELS, Friedrich. Obras Escogidas de Marx y Engels. Tomo I. Madri: Fundamentos, 1977.

MATTOS, Marco Aurélio Vannucchi L. de. JR. SWENSSON, Walter Cruz. Contra os inimigos da ordem - a repressão política do regime militar brasileiro (1964-1985). Rio de Janeiro: DP\&A, 2003.

MATTOS, Marco Aurélio Vannucchi Leme de. Em nome da segurança nacional: os processos da Justiça Militar contra a Ação Libertadora Nacional (ALN), 1969-1979. 2002. 172 f. Dissertação (Mestrado em História) - Universidade de São Paulo, 2002.

MATTSON, Kevin. Intellectuals in Action: The Origins of the New Left and Radical Liberalism, 1945-1970. Filadélfia: Pennsylvania State University, 2002.

MÉDICI, Emílio Garrastazu. Nova consciência de Brasil. Brasília: Imprensa Nacional, 1970.

MELLO, Lydio Machado Bandeira de. Diretrizes Gerais da Ação Penal. Belo Horizonte: Faculdade de Direito da Universidade de Minas Gerais, 1958. 
MENDONÇA, Sonia Regina de. FONTES, Virginia Maria. História do Brasil recente 1964-1980. São Paulo: Ática, 1988.

MENEZES, Geraldo Bezerra de. O comunismo: crítica doutrinária. São Paulo: Ibrasa/MEC, 1978.

MESSUTI, Ana. El tercero: una interpretación. In: MESSUTI, Ana; SANPEDRO ARRUBLA, Julio Andrés (org.). La Administración de Justicia en los Albores del Tercer Milenio. Buenos Aires: Universidad, 2001, p. 175-187.

MESSUTI, Ana. O Tempo como Pena. São Paulo: Revista dos Tribunais, 2003.

MESSUTI, Ana. Reflexiones sobre el pensamiento penal. In: MESSUTI, Ana (org.). Perpectivas Criminologicas en el Umbral del Tercer Milenio. Montevideo: FCU, 1998, p. 113-129.

MILBAND, Ralph; POULANTZAS, Nicos; LACLAU, Ernesto. Debate sobre el Estado Capitalista. Buenos Aires: Imago Mundi, 1991.

MIRABETE, Julio Fabbrini. Processo Penal. São Paulo: Atlas, 2001.

MIRANDA, Nilmário; TIBÚRCIO, Carlos. Dos filhos deste solo. Mortos e desaparecidos políticos durante a ditadura militar: a responsabilidade do Estado. São Paulo: Fundação Perseu Abramo-Boitempo, 1999.

MIRANDA, Pontes de. Comentários à Constituição de 1946. Vol. IV (Arts. 141-156). São Paulo: Max Limonad, 1953.

MIRANDA, Pontes de. Comentários à Constituição de 1967 com a Emenda n. 1 de 1969. Volume III. São Paulo: Revista dos Tribunais, 1970.

MONTESQUIEU, Barão de (Charles-Louis de Secondat). Lo spirito delle leggi. Vol. 2. Turim: UTET, 2005.

MORAES FILHO, Evaristo de. Lei de Segurança Nacional: um atentado à liberdade. Rio de Janeiro: Zahar, 1982..

MORAES, Denis de. A Esquerda e o golpe de 64. Rio de Janeiro: Espaço e Tempo, 1989 
MORAES, João Quartim de. COSTA, Wilma Peres. OLIVEIRA, Eliézer Rizzo de. A tutela militar. São Paulo: Vértice-Revista dos Tribunais, 1987.

MORAES, João Quartim de. DEL ROIO, Marcos. (org.). História do Marxismo no Brasil - Visões do Brasil. Volume IV. Campinas: Unicamp, 2000.

MORAES, João Quartim. La Guérilla Urbanine au Brésil. Les Temps Modernes, $\mathrm{n}^{\circ}$ 292, Nov., 1970.

MORAES, João Quartim. (org.). História do Marxismo no Brasil - os influxos teóricos. Vol. II. Campinas: Unicamp, 1995.

MORAES, Maria Lygia Quartim de. O golpe de 1964: testemunho de uma geração. In: REIS FILHO, Daniel Aarão; RIDENTI, Marcelo; MOTTA, Rodrigo Patto Sá. O golpe e a ditadura militar: 40 anos depois (1964-2004). Bauru SP: Edusc, 2004, p. 297-314.

MORAIS, Clodomiro Santos de. História das Ligas Camponesas do Brasil. v. 1. Brasília: Iattermund, , 1997.

MORAIS, Taís; SILVA, Eumano. Operação Araguaia. Os arquivos secretos da guerrilha. São Paulo: Geração, 2005.

MUÑOZ CONDE, Francisco. Derecho Penal. Parte Especial. Valência: Tirant Lo Blanch, 2004.

MUÑOZ CONDE, Francisco. Edmund Mezger y el Derecho Penal de su Tiempo. Valência: Tirant Lo Blanch, 2003.

MUÑOZ CONDE, Francisco; MUÑOZ AUNIÓN, Marta. ¿Vencedores o vencidos? Tirant Lo Blanch, 2003.

NUVOLONE, Pietro. Le problème de la Peine de Mort em Italie. In: FACUlDADE DE DIREITO DA UNIVERSIDADE DE COIMBRA. Pena de Morte. Colóquio Internacional comemorativo do Centenário da Abolição da Pena de Morte em Portugal. I. Comunicações. Coimbra: Faculdade de Direito de Coimbra, 1967, p. 189-198. 
OLIVEIRA, Eliézer Rizzo de. As Forças Armadas: política e ideologia no Brasil (1964-1969). Petrópolis: Vozes, 1976.

OLIVEIRA, Eliézer Rizzo de. Militares: pensamento e ação política. Campinas: Papirus, 1987.

OLIVEIRA, Franklin de. Revolução e Contra-revolução no Brasil. Rio de Janeiro: Civilização brasileira, 1962.

ORDEM DOS ADVOGADOS DO BRASIL. Declaração de Curitiba. $6^{\circ}$. Encontro da Diretoria do Conselho Federal com os presidentes dos Conselhos Seccionais. Curitiba, 31 de maio a $1^{\circ}$ de junho de 1972.

ORGANIZAÇÃO DAS NAÇÕES UNIDAS (ONU). Declaração Universal dos Direitos Humanos. In: Carta das Nações Unidas e Declaração Universal dos Direitos do Homem. Campinas: Julex, [196-], p. 39-40.

PAES, Maria Helena Simões. Em nome da segurança nacional. São Paulo: Atual, 1995.

PALMAR, Aluízio. Onde foi que vocês enterraram nossos mortos? Curitiba: Travessa, 2005.

PARTIDO COMUNISTA DO BRASIL. A Linha Política Revolucionária do Partido Comunista do Brasil (M-L). Lisboa: Maria da Fonte, 1974.

PARTIDO COMUNISTA DO BRASIL. Cinqüenta anos de Luta. Lisboa: Maria da Fonte, 1975.

PARTIDO COMUNISTA DO BRASIL. Guerra Popular - Caminho da Luta Armada no Brasil. Lisboa: Maria da Fonte, 1974.

PARTIDO COMUNISTA VIETNAMITA. História do Partido dos Trabalhadores do Vietname. Lisboa: Maria da Fonte, 1975.

PAZ, Carlos Eugênio. Nas Trilhas da ALN. Rio de Janeiro: Bertrand Brasil, 1997.

PAZ, Carlos Eugênio. Viagem à Luta Armada. Rio de Janeiro: Civilização Brasileira, 1996. 
PCB: Vinte Anos de Política. 1958-1979 (documentos). São Paulo: Ciências Humanas, 1979.

PEREIRA, Osny Duarte. Quem faz as leis no Brasil? Rio de Janeiro: Civilização Brasileira, 1963.

PERI, Marcos. Perspectiva da revolução brasileira. Autores Reunidos, 1962.

PESSOA, Mário. Da Aplicação da Lei de Segurança Nacional. São Paulo: Saraiva, 1978.

PESSOA, Mário. Direito da Segurança Nacional. Guanabara: Biblioteca do Exército/Revista dos Tribunais, 1971.

PIERANGELI, José Henrique. Códigos Penais do Brasil. Evolução histórica. São Paulo: Revista dos Tribunais, 2001.

PIETROCOLlA, Luci Gatti. Anos 60/70: o viver entre parênteses - a perseguição política aos revolucionários e suas famílias. Tese de Doutorado em Sociologia. Universidade de São Paulo. São Paulo, 1995.

POLARI, Alex. Em busca do tesouro. Rio de Janeiro: Codecri, 1982.

POMAR, Pedro Estevam da Rocha. Massacre na Lapa. Como o Exército liquidou o Comitê Central do PcdoB. São Paulo: Scritta, 1996.

POMAR, Pedro. Sobre o Araguaia. (Intervenção no debate do Comitê Central do Partido Comunista do Brasil. Julho de 1976). In: POMAR, Pedro et al. Pedro Pomar. São Paulo: Debates, 1980, p. 194-207.

POMAR, Wladimir. A Revolução Chinesa. São Paulo: Unesp, 2003.

POMAR, Wladimir. Araguaia: o Partido e a guerrilha. São Paulo: Global, 1980.

PORTELA, Fernando. Guerra de Guerrilhas no Brasil. São Paulo: Global, 1979.

PORTUGAL. Das Ordenações do Reino. Código Felipino. In: PIERANGELI, José Henrique. Códigos Penais do Brasil. Evolução histórica. São Paulo: Revista dos Tribunais, 2001, p. 97-217. 
POUlantZAS, Nicos. As Classes Sociais no Capitalismo de Hoje. Rio de Janeiro: Zahar, 1978.

POULANTZAS, Nicos. Fascismo e Ditadura. São Paulo: Martins Fontes, 1978.

POULANTZAS, Nicos. O Estado, o poder, o socialismo. São Paulo: Graal, 2000.

PRADO JÚNIOR, Caio. A Revolução Brasileira. Perspectivas em 1977. São Paulo: Brasiliense, 1978.

PRATS CANUT, Josep Miguel. Título XXIII. In: QUINTERO OLIVARES, Gonzalo; MORALES PRATS, Firmín. Comentarios a la Parte Especial del Derecho Penal. Cizur Menor: Thompson-Aranzadi, 2004, p. 1825-1990.

PROJETO "BRASIL: NUNCA MAIS". As Leis Repressivas. Projeto "A"Tomo IV. São Paulo: Arquidiocese de São Paulo, 1985.

PROJETO "BRASIL: NUNCA MAIS". O Regime Militar. Projeto “A”Tomo I. São Paulo: Arquidiocese de São Paulo, 1985.

PROJETO "BRASIL: NUNCA MAIS". Os Atingidos. Projeto “A”- Tomo II, Volume 2. São Paulo: Arquidiocese de São Paulo, 1985.

PROJETO "BRASIL: NUNCA MAIS". Os Instrumentos da Pesquisa e a Fonte. Projeto "A"- Tomo II, Volume 1. São Paulo: Arquidiocese de São Paulo, 1985.

PROJETO "BRASIL: NUNCA MAIS". Perfil dos Atingidos. Projeto “A”Tomo III. São Paulo: Arquidiocese de São Paulo, 1985.

QUINTANO RIPOLlÉS, Antonio. Tratado de Derecho Penal Internacional e Internacional Penal. Tomo II. Madri: Instituto Francisco de Vitoria, 1955.

QUINTERO OLIVARES, Gonzalo; MORALES PRATS, Fermín. Comentarios a la Parte Especial del Derecho Penal. Cizur Menor: ThomsonAranzadi, 2004. 
RAMONET, Ignacio. Piensamiento único y nuevos amos del mundo. In: CHOMSKY, Noam; RAMONET, Ignacio. Cómo nos venden la moto. Barcelona: Icaria, 1997, p. 7-54.

RAMOS, Guerreiro. Ideologias e Segurança Nacional. Rio de Janeiro: Instituto Superior de Estudos Brasileiros, 1957.

RANCIÈRE, Jaques. A partilha do sensível. São Paulo: 34, 2005.

RANCIÈRE, Jaques. Os Nomes da História. Um ensaio de Poética do Saber. São Paulo: Educ-Pontes, 1994.

RANCIÈRE, Jaques. Políticas da Escrita. São Paulo: 34, 1995.

REBELlo, Gilson. A Guerrilha de Caparó. São Paulo: Alfa-Ômega, 1980.

REIS FILHO, Daniel Aarão et al. Versões e Ficções: o seqüestro da história. São Paulo: Perseu Abramo, 1997.

REIS FILHO, Daniel Aarão. 1968: a paixão de uma utopia. Rio de Janeiro: Espaço e Tempo, 1988.

REIS FILHO, Daniel Aarão. A aventura socialista no século XX. São Paulo: Atual, 1999.

REIS FILHO, Daniel Aarão. A Revolução faltou ao encontro. Os comunistas no Brasil. São Paulo: Brasiliense, 1990.

REIS FILHO, Daniel Aarão. As organizações comunistas e a luta de classes. 1987. 1235 f. Tese (Doutorado em História) - Universidade de São Paulo, São Paulo, 1987.

REIS FILHO, Daniel Aarão. As revoluções russas e o socialismo soviético. São Paulo: Unesp, 2003.

REIS FILHO, Daniel Aarão. COUTINHO, Carlos Nelson et. al. O manifesto comunista 150 anos depois: Karl Marx, Friedrich Engels. Rio de Janeiro: Contraponto; São Paulo: Fundação Perseu Abramo, 1998. 
REIS FILHO, Daniel Aarão. Ditadura e sociedade: a reconstrução da memória. In: REIS FILHO, Daniel Aarão; RIDENTI, Marcelo; MOTTA, Rodrigo Patto Sá. O golpe e a ditadura militar: 40 anos depois (1964-2004). Bauru SP: Edusc, 2004, p. 29-52.

REIS FILHO, Daniel Aarão. Ditadura militar, esquerdas e sociedade. Rio de Janeiro: Jorge Zahar, 2000.

REIS FILHO, Daniel Aarão. O maoísmo e a trajetória dos marxistas brasileiros. In: REIS FILHO, Daniel Aarão et al. História do Marxismo no Brasil. O impacto das revoluções. São Paulo: Paz e Terra, 1991, p. 105-132.

REIS FILHO, Daniel Aarão; RIDENTI, Marcelo; MOTTA, Rodrigo Patto Sá. O golpe e a ditadura militar: 40 anos depois (1964-2004). Bauru SP: Edusc, 2004.

REIS FILHO, Daniel Aarão; SÁ, Jair Ferreira de. Imagens da Revolução. Documentos políticos das organizações clandestinas de esquerda dos anos 19611971. Rio de Janeiro: Marco Zero, 1985.

REZENDE, José Roberto. Ousar Lutar. Memórias da guerrilha que vivi. São Paulo: Viramundo, 2000.

REZNIK, Luís. Democracia e Segurança Nacional. A polícia política no pós-guerra. Rio de Janeiro: FGV, 2004.

RIBEIRO, Darcy. Confissões. São Paulo: Schwarcz, 2002.

RIDENTI, Marcelo Siqueira. O Fantasma da revolução brasileira: raízes sociais das esquerdas armadas, 1964-1974. 1989. 529 f. Tese (Doutorado em Sociologia) - Universidade de São Paulo, São Paulo, 1989.

RIDENTI, Marcelo. O Fantasma da Revolução Brasileira. São Paulo: Unesp, 1993.

RIDENTI, Marcelo. REIS FILHO, Daniel Aarão. (org.). História do Marxismo no Brasil - Partidos e organizações dos anos 20 aos 60. Volume V. Campinas: Unicamp, 2002.

ROJO, Ricardo. Meu amigo Che. Rio de Janeiro: Civilização Brasileira, 1968. 
Rollemberg, Denise. O Apoio de Cuba à Luta Armada no Brasil: o treinamento guerrilheiro. Rio de Janeiro: Mauad, 2001.

SANTOS, Maria Cecília L. dos (org.) Maria Antonia, uma rua na contramão. São Paulo: Nobel, 1988.

SÁTYRO, Ernani. Direito Penal Militar e Segurança Nacional. Brasília : Senado Federal , 1977.

SCARTEZINI, Antonio Carlos. Segredos de Médici. São Paulo: Marco Zero, 1985.

SCHUR, Edwin M. A Sociologist's View. In: SCHUR, Edwin M.; BEDAU, Hugo Adam. Victimless crimes. Two side of a controversy. Engelwood Cliffs: Prentice-Hall, 1974.

SCHUR, Edwin M. Crimes Without Victims: Deviant Behavior and Public Policy. Upper Saddle River: Prentice-Hall, 1965.

SEGATTO, José Antonio et al. PCB: 1922-1982. São Paulo: Brasiliense, 1982.

SELSER, Gregório. Sandino. General de homens livres. São Paulo: Global, 1979.

SHECAIRA, Sérgio Salomão. Criminologia. São Paulo: Revista dos Tribunais, 2004.

SHECAIRA, Sérgio Salomão. Responsabilidade Penal da Pessoa Jurídica. São Paulo: Revista dos Tribunais, 1998.

SHECAIRA, Sérgio Salomão; CORRÊA JÚNIOR, Alceu. Teoria da Pena. São Paulo: Revista dos Tribunais, 2002.

SHILING, Paulo. Como se coloca a direita no poder. São Paulo: Global, 1979.

SILVA, Carlos A. Canedo Gonçalves. Crimes Políticos. Belo Horizonte: Del Rey, 1993.

SILVA, Golbery do Couto e. Aspectos geopolíticos do Brasil. Rio de Janeiro: Biblioteca do Exército, 1957. 
SILVA, Golbery do Couto e. Geopolítica do Brasil. Rio de Janeiro: José Olympio, 1967.

SILVA, Golbery do Couto e. Planejamento estratégico. Brasília: Universidade de Brasília, 1981.

SILVA, Hélio. 1935. A Revolta Vermelha. Rio de Janeiro: Civilização Brasileira, 1969.

SILVA, Hélio. 1939: Véspera de Guerra. Rio de Janeiro: Civilização Brasileira, 1972.

SILVA, Hélio. 1964: golpe ou contragolpe? Porto Alegre: L\&PM, 1978.

SILVA, Hélio. A Ameaça Vermelha. O Plano Cohen. Porto Alegra: L\&PM, 1980.

SILVA, Hélio. O Estado Novo. 1937-1938. Rio de Janeiro: Três, 1975.

SILVA, Hélio. O poder militar. Porto Alegre: L\&PM, 1985.

SILVA, Hélio. Os Governos Militares. 1969-1974. São Paulo: Três, 1975.

SILVA, Hélio. Vez e a voz dos vencidos. Petrópolis: Vozes, 1988.

SILVA, José Afonso da. Curso de Direito Constitucional Positivo. São Paulo: Malheiros, 1998.

SILVA, Paulo Napoleão Nogueira. Autoritarismo e Impunidade. Um perfil do democratismo brasileiro. São Paulo: Alfa-Ômega, 1988.

SILVA, Tadeu Antônio Dix. Liberdade de Expressão e Direito Penal no Estado Democrático de Direito. São Paulo: IBCCRIM, 2000.

SILVA, Tadeu Antônio Dix; DANTAS, Alexandre; TOLEDO, Maria Clara Veronesi de. Violência e criminalidade na sala de estar. Revista Brasileira de Ciências Criminais, São Paulo, vol. 13, fasc. 57, nov./dez., 2005, p. 248-327.

SIMAS, Mário. Gritos de justiça. Brasil: 1963-1979. São Paulo: FTD, 1986.

SIQUEIRA, Galdino. Direito Penal Brazileiro. Parte Especial. Vol. II. Rio de Janeiro: Jacyntho, 1932. 
SKIDMORE, Thomas. De Castelo a Tancredo: 1964-1985. Rio de Janeiro: Paz e Terra, 1994.

SODRÉ, Roberto de Abreu. No Espelho do Tempo. Meio Século de Política. São Paulo: Best Seller, 1995.

SODRÉ, Nelson Werneck. A História militar do Brasil. Rio de Janeiro: Civilização Brasileira, 1979.

SODRÉ, Nelson Werneck. A verdade sobre o ISEB. Rio de Janeiro: Avenir, 1978.

SODRÉ, Nelson Werneck. O Governo Militar Secreto. Rio de Janeiro: Bertrand Brasil, 1987.

SODRÉ, Nelson Werneck. Vida e Morte da Ditadura: 20 anos de autoritarismo no Brasil. Petrópolis: Vozes, 1984.

SODRÉ, Roberto de Abreu. No espelho do tempo: meio século de política. São Paulo: Best Seller, 1995.

SOUZA, Percival de. Autópsia do Medo - vida e morte do delegado Sérgio Paranhos Fleury. São Paulo: Global, 2000.

SOUZA, Percival de. Eu, Cabo Anselmo. Rio de Janeiro: Globo, 1999.

SPINDEL, Arnaldo. O Partido Comunista na Gênese do Populismo. São Paulo: Símbolo, 1980.

STARLING, Heloisa Maria Murgel. Os Senhores das Gerais - Os novos inconfidentes e o golpe de 1964. Petrópolis: Vozes, 1986.

STEPAN, Alfred. Os Militares na política. Rio de Janeiro: Artenova, 1975.

STEPAN, Alfred. Os Militares: da Abertura a Nova República. Rio de Janeiro: Paz e Terra, 1986.

SYRKIS, Alfredo. Os Carbonários. São Paulo: Global, 1980.

TAPAJÓS, Renato. Em câmara lenta. São Paulo: Alfa-Ômega, 1979.

TAVARES, A. de Lyra. O Brasil de minha geração - Mais dois decênios de lutas - 1956-1976. Rio de Janeiro: Editora Biblioteca do Exército, 1977. 
TAVARES, A. de Lyra. Segurança Nacional: Antagonismos e Vulnerabilidades. Rio de Janeiro: Biblioteca do Exército, 1958.

TAVARES, Flávio. Memórias do Esquecimento. São Paulo: Globo, 1999.

TAVARES, José Antônio Giusti. A estrutura do autoritarismo brasileiro. Porto Alegre: Mercado aberto, 1982.

THERBORN, Göran. La ideologia del poder y el poder de la ideología. Madrid: Siglo Veintiuno, 1987.

THOMPSON, Edward P. A Formação da Classe Operária Inglesa. I. A árvore da liberdade. Rio de Janeiro: Paz e Terra, 2004.

THOMPSON, Edward P. A miséria da teoria ou um planetário de erros. Rio de Janeiro: Zahar, 1981.

THOMPSON, Edward P. As peculiaridades dos ingleses e outros escritos. Campinas: UNICAMP, 2001.

THOMPSON, Edward P. Senhores \& Caçadores. A origem da lei negra. Rio de Janeiro: Paz e Terra, 1997.

TORINHO FILHO, Fernando da Costa. Código de Processo Penal Comentado. 1 (arts. 1º A 393). São Paulo: Saraiva, 1999.

TOURINHO FILHO, Fernando da Costa. Prática de Processo Penal. São Paulo: Saraiva, 2002.

TOURINHO FILHO, Fernando da Costa. Processo Penal - Volume 2. São Paulo: Saraiva, 2005.

TOURINHO FILHO, Fernando da Costa. Processo Penal - Volume 4. São Paulo: Saraiva, 2005.

TSÉ-TUNG, Mao. Obras. Tomo I. Buenos Aires: La Paloma, [196-].

TSÉ-TUNG, Mao. Escritos Militares Selecionados. Línguas Estrangeiras, Pequim, 1963.

TSÉ-TUNG, Mao. Obras Escogidas de Mao Tsetung. Tomo V. Pequim: Lenguas Estrangeras, 1975. 
UCHÔA, Pedro Celso, RAMOS, Jovelino (orgs.). Memórias do exílio. Brasil 1964-19??. São Paulo: Livramento, 1978.

USTRA, Carlos Alberto Brilhante. A Verdade Sufocada. A história que a esquerda não quer que o Brasil conheça. Rio de Janeiro: Brilhante Ustra, 2006.

USTRA, Carlos Alberto Brilhante. Rompendo o silêncio. Brasília: Editerra, 1987.

VALE, Oswaldo Trigueiro. O Supremo Tribunal Federal e a instabilidade político-institucional. Rio de Janeiro: Civilização Brasileira, 1976.

VAlLE FILHO, Oswaldo Trigueiro. A Ilicitude da prova - Teoria do testemunho de ouvir dizer. São Paulo: Revista dos Tribunais, 2004.

VARGAS, Índio. Guerra é Guerra, dizia o torturador. Rio de Janeiro: Codecri, 1980.

VASCONCELOS, José Gerardo. Memórias do Silêncio: Militantes de esquerda no Brasil autoritário. Fortaleza: UFC Edições, 1998.

VELHO, Gilberto. Individualismo e Cultura. Notas para uma Antropologia da Sociedade Contemporânea. Rio de Janeiro: Jorge Zahar, 2004.

VELHO, Gilberto. Subjetividade e Sociedade. Uma experiência de geração. Rio de Janeiro: Jorge Zahar, 2002.

VIANA, Gilney A., CIPRIANO, Perly. Fome de Liberdade: Relato dos Presos Políticos. Vitória: Fundação Ceciliano A. de Almeida da Universidade Federal do Espírito Santo, 1992.

VICÁRIO, Guido. Militares e Política na América Latina. Rio de Janeiro: Civilização Brasileira, 1979.

VILA, Marco Antonio. Jango: um perfil (1945-1964). São Paulo: Globo, 2003.

VIÑAR, Maren; VIÑAR, Marcelo. Exílio e tortura. São Paulo: Escuta, 1992. 
VIVES ANTÓN, Tomás S.; CARBONELL MATEU, Juan Carlos. Delitos de traición y contra la paz o la independencia del Estado y relativos a la Defesensa Nacional. In: VIVES ANTÓN, T.S.; BOIX REIG, Javier. et al. Derecho Penal. Parte Especial. Valência: Tirant Lo Blanch, 1999, p. 871-881.

WESCHLER, Lawrence. Um Milagre, um universo. O Acerto de contas com os torturadores. São Paulo: Companhia das Letras, 1990.

ZAFFARONi, Eugenio Raúl. En Busca de las Penas Perdidas. Buenos Aires: Ediar, 1989.

ZAFFARONI, Eugenio Raúl. Globalización y sistema penal en America Latina : de la seguridad nacional a la urbana. Revista Brasileira de Ciências Criminais. São Paulo, fasc. 20, out./dez., 1997, p. 13-23.

ZAFFARONI, Eugenio Raúl. Manual de Derecho Penal. Parte General. Buenos Aires: Ediar, 1987.

ZAFFARONI, Eugenio Raúl; BATISTA, Nilo; ALAGIA, Alejandro; SLOKAR, Alejandro. Direito Penal Brasileiro - I. Rio de Janeiro: Revan, 2003.

ZAVERUCHA, Jorge. Rumor de sabres: controle civil ou tutela militar? São Paulo: Ática,1994.

ZUlgadía ESPINAR, José Miguel. Fundamentos de Derecho Penal. Valência: Tirant Lo Blanch, 1993. 
This document was created with Win2PDF available at http://www.win2pdf.com.

The unregistered version of Win2PDF is for evaluation or non-commercial use only. This page will not be added after purchasing Win2PDF. 